
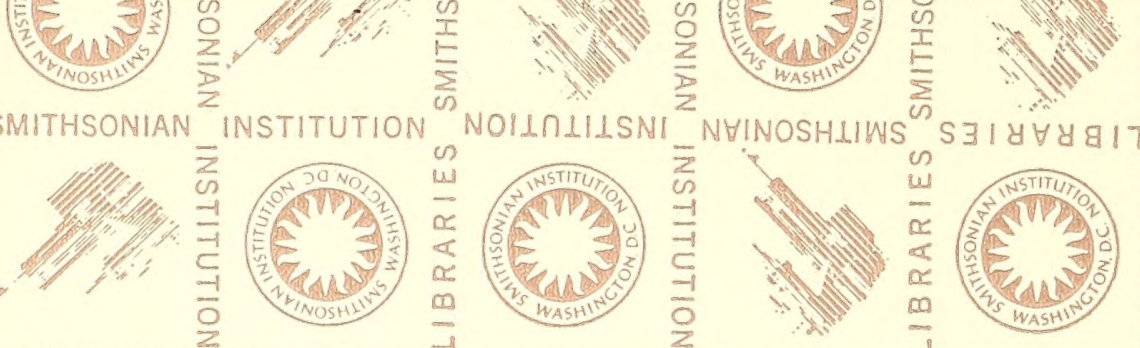

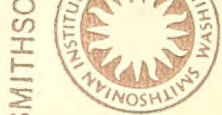

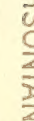

NHINOSHLIWS ${ }^{2}$ SZI\&Y\&G17 LIBRARIES SMITHSONIAN
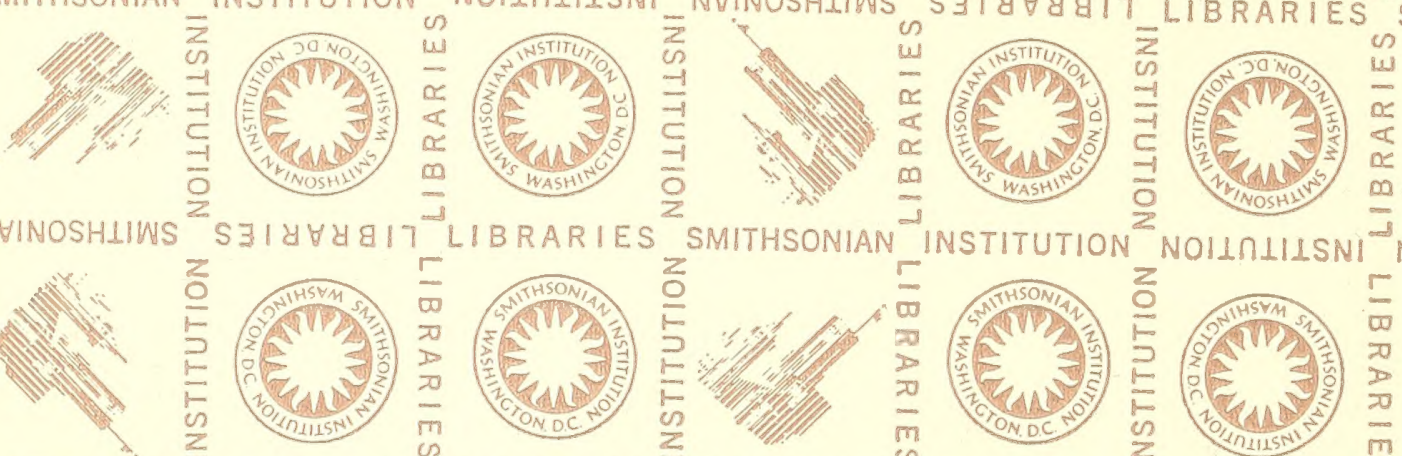

SMITHSONIAN

$\frac{2}{2}$ NOI1R1IISNI NHINOSHHIWS
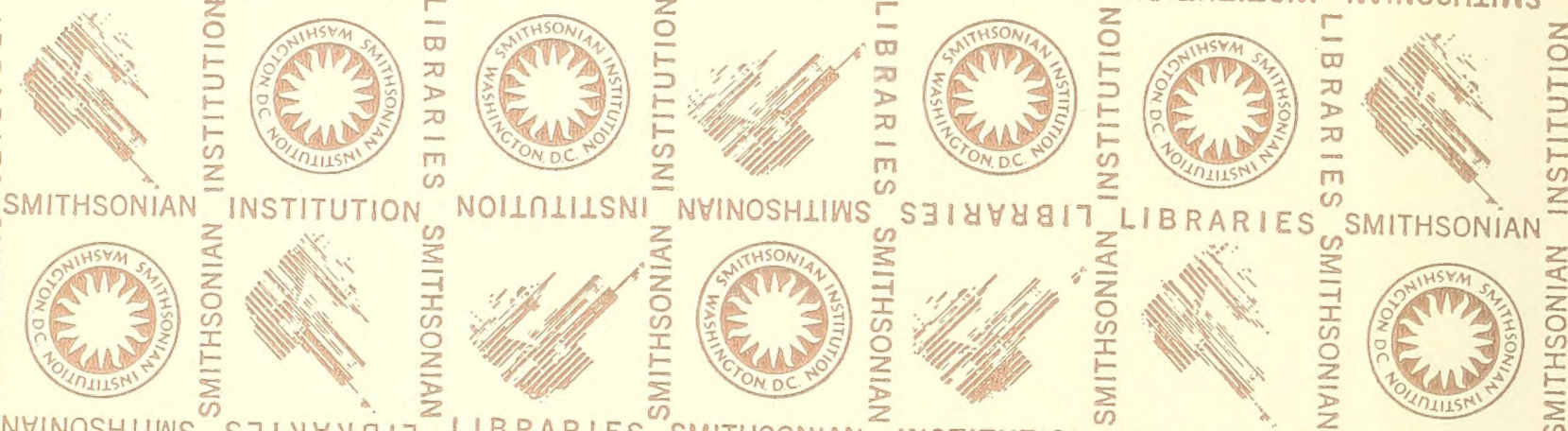

긍
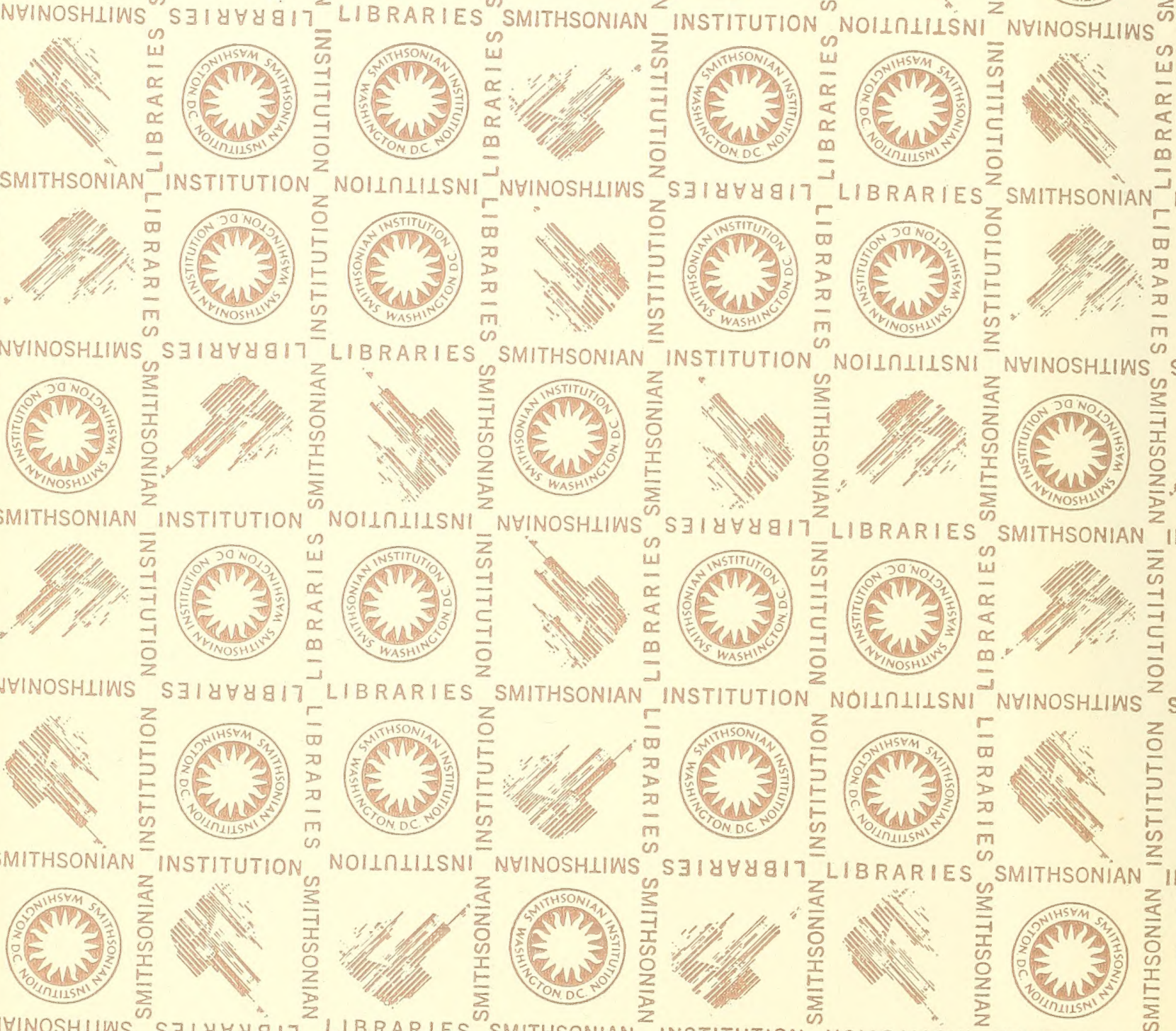

$5 \exists 14 \forall 4817$
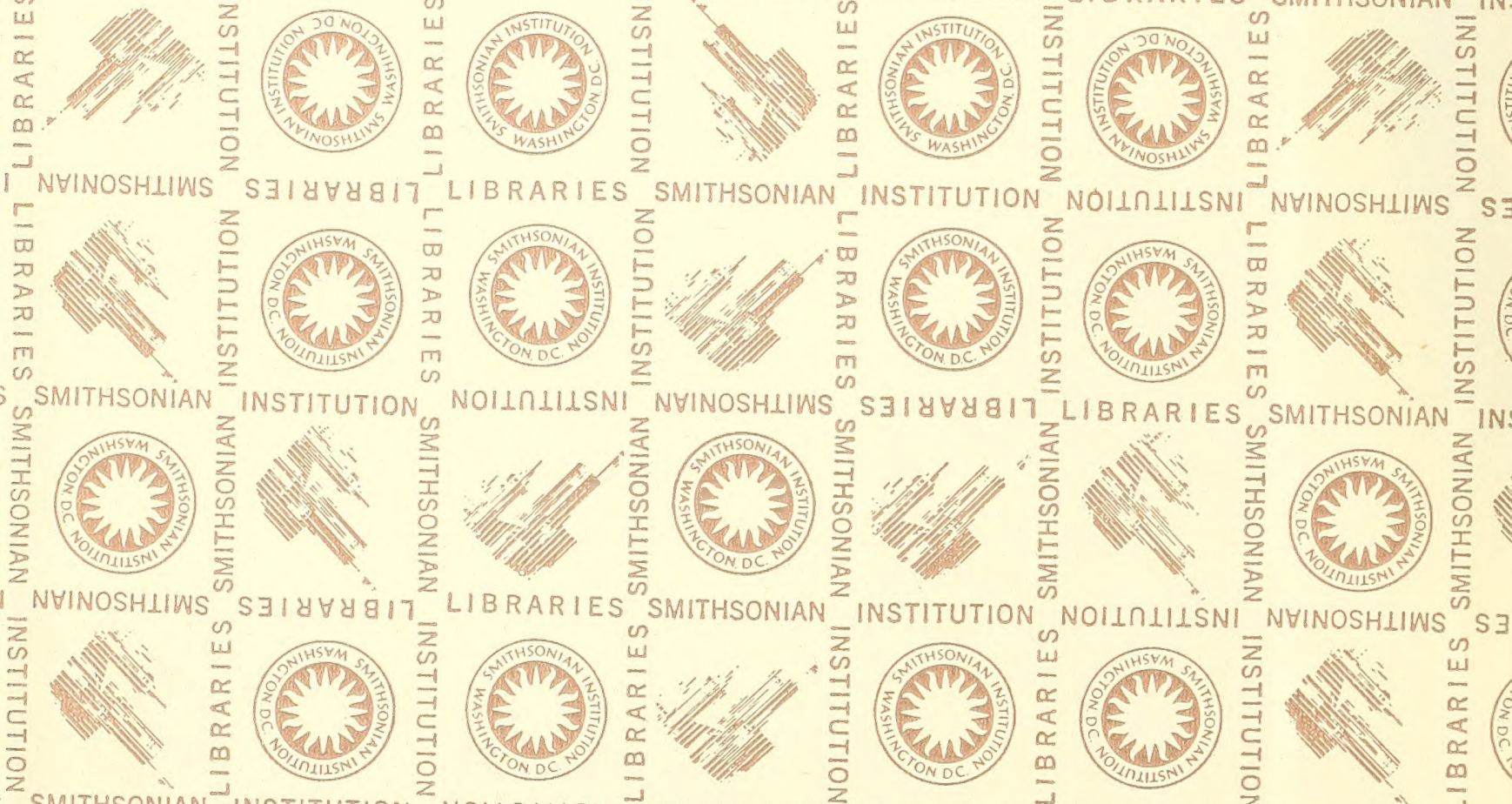

$z_{0}$
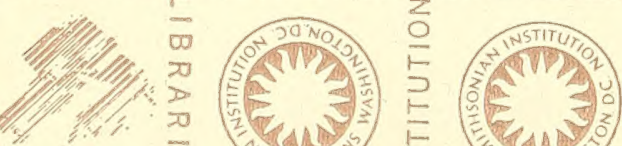

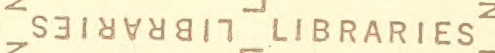





W. I. Jtay.

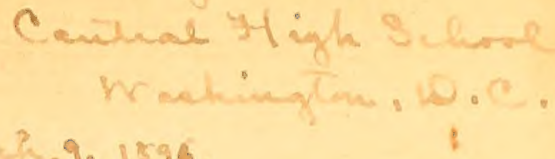

Mul. 9, 1896.

W. P. HAI COLLECIOH

世

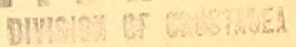





\title{
THE AMERICAN LOBSTER:
}

\author{
A STUDY OF ITS HABITS AND DEVELOPYENT.
}

BY

FRANCIS HOBAR'T HERRICK, PH. D.,

PROFESSOR OF BTOLOGY IN ADELBERT COLLEGE OF WESTERN RESERVE UNIVERSITY

WASHINGTON:

GOVERNMET PRINTING OFFICE.

1895.

$\varepsilon$ 



\section{THE AMERICAN LOBSTER:}

A STUDY OF ITS HABITS AND DEVELOPMENT.

BYY

FRANCIS HOBART HERRICK, Ph. D.,

Projessor of Biology in Adelbert College of Western Reserve University. 


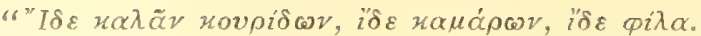
$\Theta \alpha ั \sigma \alpha \imath \mu \dot{\alpha} v$ ف่

"Behold the dainty courides, my frieud, And see these lobsters; see how red they are,

How smooth and glossy are their hair and coats." Sophron, quoted by Athenous.

"La Nature a ton̂jours de quoi payer les soins de ceux qui l'examinent; il n'est point de si petit côté oì elle ne soit inépuisable."

Réaumur.

"Wir finden zwar bey allen Scribenten der natiirlichen Historie eine Beschreibung des Fluskrebses, wenn man aber alles was sie rou selbigem gesaget zusammnimmt, so kommt so wenig heraus, dass anch hier das Sprichwort, Quotidiana vilescunt, was wir täglich vor Augen haben, achten wir nicht, allerdings einzutreffen scheinet."

Roesel von Rosenhof. 


\section{CONTENTS.}

Page

INTKOM ION . . . . . .

Chapter I. Habits and Enviromment ........... 14-32

Distribution of the Lobster .................. 14-16

Character of the Enviromment ............... 17

Intelligence of the Lobster................... 17-18

The Lobster's Powers of Morement ......... 18-20

Periodical Migrations and their Relation to Changes in the Environment - $\cdots=20-27$

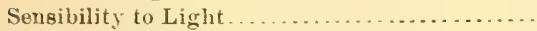

Digging and Burrowing Habits ..

The Food of the Iolveter and how it is procured.

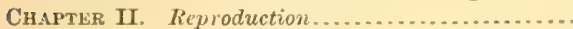

The Reproductive Organs ....................

Pairing of the Lobster and of other Crustacea..

The Laying of Eggs

Summer Eggs in Vineyard Sound ...........

Summer Eggs on the Coast of Maine.......

Fall and Winter Eggs at Woods Hole.......

Fall and $W$ inter Eggs in other places.......

Laying of the Eggs and Absorption of Ovarian (1) ra . . . . . . . . . . . . . . . . . . . . .

Number of Eggs Laid and Law of Production.

Period of Incubation at Woods Hole and Rate of

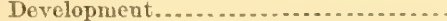

The Hatehing of the Eggs .......................

Time of Hatching of Lobsters at Woods Hole. . . .

Jispersal of the Young..................

Tariations in the Time of Tatching

Destruction of the Egg-Lobster and its Spawn..

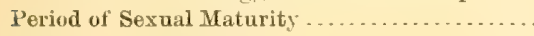

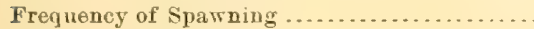

Relative Abundance of the Sexes.............. $73-7$

Chapter III. Molting and Growth............ . 75-99

Earlier Observations...................... $75-77$

Structure and Growth of the Shell ........... $77-78$

The Shedding of the Shell in the Lobster......

Molting Period

Molting Process.........................

Habits of Molting Lobsters ..............

Casting of the Shell.

Withdrawal of the Large Claws. ..........

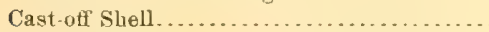

The Gastroliths

Gastroliths in the Lobster; Their Structure

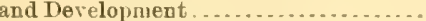

History of the Gastrolitbs: Their Probable Function.

Chemical Analysis of the Shell and Gastro.

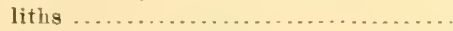

Hardening of the New Shell..................

Rate of Growth
C'HALTER IV. Defensive Mrutilation and Regenera. tion of Lost Parts .................... 100-108 Alitotomy in the Young and Adult. . ... . . . . . . 100-103 Regeneration of Appendages.................. 103-10 Regeneration of the Large Chelipeds..... . 104-105 Regeneration of the Antennes and Other Appendages......................... 105-107 Internal Changes in Regeneration. . . . . . . . . 107-108 CHAPTER V. Large Lobsters ..................... 109-120 The Greatest Size Attained by the Lobster ... . 109-117 The Relation of Weight to Length of Boly ..... 118-120

CHAPTER VI. Enemies of the Lobster.............. 120-124 Animals which prey upon the Lobster. ....... . 120-122 Parasites, Messmates, and Diseases... ......... . 122-124 Chapter TII. The Tegumental Glands, and their Relation to Sense Organs .............. 125-133 General Structure of the Tegumental Gland... . 125-126 The Cement Glands .....................

Immediately before Ovulation . . . . . . . . . . . 126

Immediately after Ovulation .............. 126-127

Historieal Sketch of the Cement Gland..... 127-128 Tegumental Glands in other Parts of the Body............................ 128-129 Experiments apon the Sensory Areas of the Body aud A ppendages................. . . 129-133

Chapter VIII. Tariations in Colop . . ............ 134-148

Normal Coloration..................... 134-135

Variations in Color........................ 135-137

Color of the Eggs.................... 137

Blue Lobsters.......... 137-138

Red Lobsters. . . . . . . . . . . . . . . . . . 138139

Cream-colored Lobsters. ............... 139-140

Variations in Color Patterus ........ . . . . . . . . . . 140

Spottexl Lolusters...................... 140

Parti-colorerl Lobsters . . . . . . . . . . . . . . . . . . . . 141-142

CHAPTER IX. Variations in Strueture........... 143-149

Normal Variations in the Large Claws......... . . 143

Abnormal Variations in the Claws............- 14

Similar Claws dereloper on Both Sides of the Body ......................... 14; 14

Division and Repetition of Appendages... 144-148

Variations in Other Organs................... 149

Rostrun ............................ 149

Ovaxy ............................... 149

Hermaphroditism ...................... 149

Chapter X. Structure and Development of the Re productive Organs................... 150-160

The Female Reproductive Organs............. . 150

The Ovary . . . . . . . . . . . . . . . . . . . . . . . . 150

The Ripe Ovary . . . . . . . . . . . . . . . . . . . . 150-151

The Ovary after Ovulation .............. 151-152 
Page.

CHAPTER $X$. Structure and Development of the Reproductive Organs-Continued.

The Female Reproductive Organs-Continued.

The Structure of the Ovary at the Time of Hatching of External Eggs. ........... 152-153

Origin of the Ova....................... 153

The Metamorphosis of the Germinal Vesicle... . 153-154 Movements of the Nucleolus through the Action of Gravity . . . . . . . . . . . . 154-155

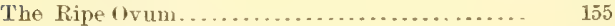

Development of the Reproductive Organs ...... 156 General Development.................... 156

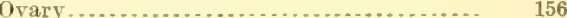

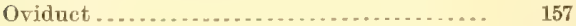

Seminal Receptacle....................... 157

Development of the Seminal Receptacle... 158

The Male Reproductive Organs............... 158

Testis................................... 158

Vas deferens............................ 158-159

Spermatophores. . . . . . . . . . . . . . . . . . . 159-160

Sperm Cells ........................... $\quad 160$

CHAPTER XI. Habits of the Lobster from time of Hatching until the period of Maturity ... 161-166

ChAPTER XT. History of the Larval andearly A dolescent Periods ............................ 167-201

Historical Notes . . . . . . . . . . . . . . . . . . . . . . . . 167-168

Methods of Studying the Xoung. . ............ 168-169

The Embryo in Late Stages of Development.... 169-170

The Hatehing of the Larva .................. 170

The First Stage ...................... 171-172

The Second stage ...................... 172-173

The Third Stage ......................... 173-174

The Fourth Stage.......................... 174-176

The Fifth Stage. . . . . . . . . . . . . . . . . . . 176-177

The Sixth Stage.......................... 177-178

The Seventh Stage........................... 178

Description of Small Lobster's (Nos. 1-6, table 35 ; No. 1, table 33) ................... 179-162

Molting of the Embryo and Larva . . . . . . . . . . . . . 182-184

Color Variations in the Young Lobster.......... 184
CHAPTER XII. History of the Larval and carly Ado. lescent Periods-Continued.

The Death-feigning Fibit. . . . . . . . . . . . . . . . . . . 184-186

The Food of the Larva. . . . . . . . . . . . . . . . . . . . 186 186

Heliotropism of Larval Lobsters . . . ........... . 187-189

Mortality of Larvæ ......................... 190

Effect of increased Temperature upon the Rate of Development of Larvæ ............. . 190-19]

Development and Morphology of the Body and

Appendages ...................... 191

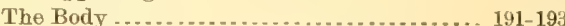

The Visual Organs and Appendages...... 193-197

Development of the First Pair of Pleopods.. 197-200

The Metamorphosis of the European lobster,

Homarus gammarus...................

The Shortening of the Metamorphosis of the

Lobster ............................ 200-201 Chapter XIII. Embryology of the Lobster....... 202-217

Normal Develomment .......................... 208

The Maturation and Segmentation of the Egg .............................. 202-203

External Phenomena of Serrmentation ..... 203-205

Internal Changes in Segmentation. . . . . . . 205-206

The Invagination Stage . . . . . . . . . . . . . . . . 206-209

Later Stages in Embryonic Development ... 209-210

History of Xolk.Cells. . . . . . . . . . . . . . . . . 210-211

Degeneration of Cells . . . .................. 211-213

Abnormal Development. ..................... 213

segmentation of the Egg................... 213-214

Invagination and Egg-Nauplius Stages.... 214-216

Double Monsters in Ovum and Larva ..... . . 216-217

Note on the Development of Cambarus ..... 217-218 CHAPTER XIV, Summany of Obscrvations . . ...... 219-225 APPENDIX I. Preparation of the Eggs ............ 226-227 APPENDIX II. Composition of the Shell and Gastroliths of the Lobster. By Professor Al bert W. Smith..................... 227-228 APPENDIX III. Bibliography................ 229-237

A PPENDIX IV. Description of Plates.............. 238-252 


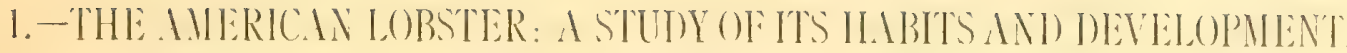

\author{
BY FRANCYS IIOBART HERRICK, \\ Professor of Biology in Adclberi College of Westem Reserve University.
}

\section{INTPODUCTION.}

\section{I.}

While working on the embryology of Alphens several years ago, I decided to study the development of the lobster for the purpose of comparison. An opportunity was offered in the summer of 1889 , which I spent at the laboratory of the United States Fish Commission at Woods Hole, Massachusetts. In the spring of that year I had also received, through the kindness of Dr. G. H. Parker, a considerable quantity of embryological material of the lobster, represeuting particularly its later stages of development.

In the spring of 1890 I was invited by Hon. Marshall MeDonald, United States Commissioner of Fisheries, to prepare as complete a work as possible upon the habits and development or general biology of the lobster. Accordingly during the past five years I have devoted all the time which conld be spared from professional duties to this research. For a part of each summer, from June to the latter part of August, I have enjoyed the excellent facilities for study which the laboratory of the Fish Com. mission at Woods Hole affords, and in the autnmu of 1893 I was enabled to carry my observations into the field by a jouruey along the coasts of Massachusetts and Maine and into the Province of New Brunswick.

The materials, therefore, upou which this work is based have been gathered from a large number of different points, although the most systematic and prolonged observations have been made at Woods Hole. In this pleasant task I lave been aided by the friendly efforts of many who have nade collections, particularly of eggs, at widely separated parts of the coast and at different times of the year. These I have gratefully acknowledged in the pages of this work.

To everyone at the Woods Hole station I am indebted for many kindnesses, but particularly to Hon. Marshall MeDonald, whose aid and encouragement I have constantly received, and to Mr. Richard Rathbun, of the United States Fish Commissiou, who has forwarded my plans in every possible way.

II.

During the course of this study I have published several papers embod cing the results of my researches (91-93, 96-101), ${ }^{1}$ but these should not be consulted witlont reference to this final revision of my work. Whatever errors this may contain I must leave for other naturalists to rectify.

I Italic figures in parentheses refer to the uumbers of publications in the Bibliography at the end of this paper. 
The lobster, though it may be rightfully ealled the King of the Crustacea, in consideration of both its size and strength, its abundance and economic value, had, until recently, been singularly neglected by naturalists. Even its breeding habits were not understood, and so little was our knowledge of many phases of its general biology that I determined from the first to devote ample time to this important subject.

Rathbun, who brought together what was known concerning the habits of the lobster in a contribution to the Natural History of Useful Aquatic Animals, published in 1887 (155), spoke as follows:

Although the lobster is one of the most important of our food invertebrates, careful observations regarding its natural history, and especially its breeding habits, rate of growth, etc, have been strangely neglected. This fact is greatly to be deplored, considering that the lobster has recently become the subject of important legislation by the several States which it inlabits and that its cultivation by artificial means has been frequently attempted. * * * The success attending the artificial breeding of several of our food-fishes has inspired the hope that similar methods might succeed with regard to the lobster, and many persons are now awaiting with interest the results of experiment in that direction. It is very certain, however, that the breeding of lobsters can never be successfully carried on until we have become acquainted with at least the main features of their natural history. The artificial cultivation of animals can only progress through the fultillment of natural laws, which must be thoroughly uuderstood before they can be properly applied. As it is, however, the would-be experimenters in the matter of lobster breering must still follow a very uncertain pathway, meeting with numerous failures which previous studies might have arrested ( $p .781$ ).

Many facts relating more particularly to the larval development and reproduction have important economic bearings, and for the benefit of those who have neither the time nor inclination to read the details of this paper I have added a careful summary of the principal observations and conclusions at the end (Chapter XIV).

Under the subjects diseussed in the various chapters I have given all the important historical references, and have added a full bibliography. There has grown up around every well-known animal like the lobster a considerable mass of popular pseudo-scientific literature, which is of no value either as literature or science. and may well be ignored.

III.

The lobster is singularly free from common names, in this country at least. It is rarely confused with any other animal unless it be with the Palinurus of the Pacific Coast and the West Indies, and with some of the larger species of crayfish, all of which, however, are very distinct, the latter being inhabitants of fresh water.

Patrick Brown tells us in his "History of Jamaica," published in 1789 , that the Palinurus was then commonly called the "horned lobster or great crayfish." The terms rock lobster and spiny lobster are still applied to it in this country and in Europe, but the entire lack of large claws-one of the most striking characteristies of the lobster-its spines, brilliant coloring, and enormous antennæ, should prevent the most inubservant person from confusing it with so distinct a form.

The lobster, as I have explained in Chapters II and III (pp. 55, 82), has acquired numerous epithets while carrying eggs or passing through the various phases of the noolt.

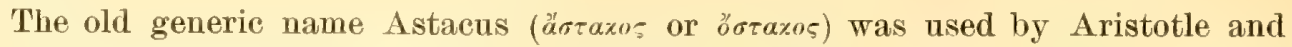
the older naturalists down to the present century to embrace the crayfishes and the lobsters proper. Aristotle thus speaks in the fourth book of his History of Animals 
of "the small astaci, which are bred in the rivers" 1 showing that the reference is undoubtedly to the erayfish.

Athenieus frequently mentions the Astacus in the third book of The Deipnosophists, where, as in the passage quoted below, he undoubtedly had in mind the lobster: This is from a famous poem of Archestratus, wherein, as Athenxus remarks, he never

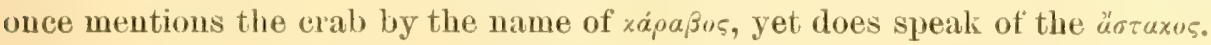

\begin{abstract}
But passing our trifles, buy an astacus, Which has long hands and heavy, too, but feet Of delicate smallness, and which slowly walks Over the earth's face. A goodly troop there are Of such, and those of finest flavor where The isles of Lipara do gem the ocean: And many lie deep in the broad Hellespont.
\end{abstract}

(The Deipnosophists; Bk. nI, tr. by C. D. Yonge, 1854.)

Athenieus then quotes from another anthor, Epicharmus, to show that the "̈otuxos mentioned by Archestratus is the same as the zajo $\alpha_{\beta}$ :

'There are astaci and colybdxene, both equipped

With little feet and long hands, both coming under

The name of кápaßos.

The English word lobster is from the old English lopystre, ${ }^{2}$ which is probably a corruption of the Latin locusta-English, locust-a name used by Pliny in speaking of the lobster in his Natural History. Thus, in the ninth book, he says: "The lobsters, being of that kind which want blood, are protected by a weak shell." ${ }^{3}$ In the next section of the same chapter there is a sentence, ${ }^{4}$ in which the astaci are mentioned as one of the genera of crabs. It is possible that lobsters are here referred to, but the meaning is doubtful.

Gesuer, whose remarkable History of Animals was published at Ziirich between 1551 and 1587, speaks of the lobster under the Aristotlean name of Astacus, and adds a very interesting synonymy. He says:

The English call the Astacus a cremyse of the sea, ${ }^{5}$ for the lopstar of the English is the locust, not the ustacus; although Eliot in different places has translaterl astacus, locust, and leo as a lopster. ${ }^{5}$

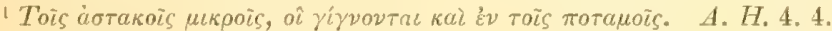

2Longusta or langusta, le langouste of the French, the Palinurus, probably has the same origin. This was corrupted to "Iong oyster" in the West Indies. (See The Natural History of Jamaica, by IIans Sloane, vol. II, p. 271.)

${ }^{3}$ Lncustre erusta fragile muniuntur in eo genere quod earet sanguine. Latent mensibus quinis, similiter cancri qui eodem tempore oceultantur, et ambo veris principio senectutem anguinm nore exnernut renovatione tergorum. Lib. 1x, Cap. xxx, sec. 50. sec. 51 .

千 Cancrorum genera carabi, astaci maeae, paguri, heracleotici, leones et alia ignobiliora. Ibid.,

"Creuyse according to Skeat, is probably a variation in the spelling of the Midale English for crayfish (crayf-ish), _— crevis, creves, crevise, or creveys; Old French, crevisse, or eserevisse; Modern French, écrevisse; Old High German, crebez; Middle High German, krebez; German, Krebs, allierl to Krabbe.

"Anglis astacns est a creuyse of the sea, nam lopstar Anglorum, locusta est, non astacus; quamquam Eliota diversis locis astacum locustam et leonem interpretatus a Lopster (75, De Astaco. ply. 113-121). [Eliota is Sir Thomas Elyot, who published a Latin-English dictionary in 15:38.] 
Some light is thrown upon this passage by the German translation of Gesner's Historia Animalium, published at Frankfort in 1598, where the lobster is spoken of as Humer oder grossen Meerkrebs. The Latin name Astacus is also given to it. A paragraph, which I did not find in the original, is as follows:

These sea-crabs mentioned above, are called by Pliny sea-elephants, on account of their size and strength. They are also regarded by some as sea-lions, and by such names are commonly known at Montpelier.

The lobster was also called by the Greeks $\alpha \dot{\alpha} \mu \mu \alpha \rho \varsigma$, Latin gammarus, probably from its arched back, from which Spanish, camaron, and the Italian gambaro are derived. Gesner tells us that the crayfish, was often called simply gambaro, to distinguish it from the lobster gambaro di mari; that to the French and Normans the lobster was known as Homar; to the Germans as Humer. In Norway, Sweden, Denmark, and Germany it is now called Hummer. ${ }^{2}$ This in French became Homard (Homar, Latinized form Homarus). It has been suggested by Boeck that the name may possibly have come from the Norse verb homa, meaning to go backward.

Gesner adds that the lobster was called by the Venetiaus astase vecari andio; by the Illyrians, larantola (or caranthola), and by the Swiss, langroit or escrevice de mer. The Dutch call the lobster Zeekruft or sea-crayfish, while it is known to the Turks of Constantinople as liczuda or lichuda.

According to Boeck there are numerous poetical allusions to the lobster in the Eddas and Sagas. Thus the sea is described as "the path of the lobster" in Olaf der Heilige's Saga, and in Olaf Tryggvason's Saga it is said that "the wave-horses run over the fields of the lobster," meaning the ships that sail on the waves. "To be at the bottom with the lobster" is to drown, as in the song of Snigly Holle. "In the Selkolle Songs of Einar Gilson, in Bishop Gudmund's Saga, the term "the light of the lobster," equivalent to the fire of the sea or gold, is used. In the same place the expression, "the horse of the lobster mountain," meaning the ship, is used. Finally there is found in the poem Liknar-brant, the expression "land lobster," meaning a serpent or dragon. $\quad(20$, p. 224.)

IV.

Excluding from our consideration the Palinurus or langouste and the Norwegian lobster, Nephrops novvegicus, two species belonging to this genus are now known, namely:

Homarus, Milne Edwards.

(1) Homarus gammarus (Linn.); = = Cancer gammarus (Linn.);

$=$ Homarus vulgaris (M. Edw.) European Lobster.

(2) Homarus americanus (M. Edw.) American Lobster.

A third form, H. capensis, has been imperfectly described from the Cape of Good Hope, but it is doubtful if it belongs in this genus. (See 102, p. 754, note 4.)

'Diese obgenandte Meerkrebsz nennet Plinius Meerhelffant von wegen irer grösse und stärcke werden sonst auch von etlichen Meerlöwen geachtet sind mit solchem Namen von menniglichen zu Mompelier genenut worden . . . . Fischbuch; translated from the original of Conrad Gesner into German by Conrad Forer; p. 125; Franckfurt, 1598.

The animal described and figured on the next page of this work and ealled the Small Lobster or Small Sea-crab-Astacus marinus parvus-is probably a species of Galatea. Palinurus is described as the Meerstöffel. Synonyms are: A Species of Lobster; A Kind of Large Sea-crab; Locusta; Carabus.

${ }^{2}$ The old Norwegian and Danish writers, Pantoppidans (1752, 152), Ström (1762), Bomares (1767), and Leems (1767) speak of the lobster as Hummer, while by Olafssens and Povelsens (1772) it is ealled Humar, according to Fabricius. These dates refer to works. For bibliography see Otho anel J. C. Fabricius $(68-64)$. 
V.

Although the lobster has a place in the literature of the Old World, it is seldom mentioned by American writers. Rathbun, who was the first to give a history of the American lobster fisheries, says that the great abundance and rare flavor of the lobster "are uot infrequently mentioned in the early anuals of New England, and it probably formed an important element in the food-supply of the seacoast inhabitants of colonial times. As a separate industry, however, the lobster fishery does not date back much, if any, beyond the beginning of the present century, and it appears to have been first developed on the Massachusetts coast, in the region of Cape Cod and Boston, although some fishing was done as early as 1810 among the Elizabeth Islands and on the coast of Connecticut. Strangely enough this industry was not extended to the coast of Maine, where it subsequently attained its greatest proportions, until about 1840." (156.)

In an account of marketing in Boston in 1740, among various kinds of meats and game, "oysters and lobsters" are mentioned "in course, the latter in large size at 3 half-pence each." (200, vol. II, p. 540.)

Kalm, the Swedish traveler, writing in 1771, thus speaks of the abundance of sea food on the shores of Long Island:

The soil of the southern part of the island is very poor; but this deficiency is made up by a vast quantity of oysters, lobsters, crals, several kiads of fish, aud numbers of water fowl, all of which are there far more abundant than on the northern shores of the island. Therefore the Indians formerly chose the southern part to live in, because they subsisted ou oysters and other prodnctions of the sea. (1ns, vol. 2, pp. 226-227.)

The older writers had little to say of the sea and its products in New England, yet many interesting facts could probably be gathered by a careful examination of all available sources.

VI.

Lobsters are caught in pots or traps made of laths, nailed to a wooden frame, with a funnel-shaped opening at each end. The traps are commonly 4 feet long, 2 feet wide, and 18 inches high. The funnels are usually netted out of manila twine. The pots are weighted with stones or bricks, and set either in single warps or in trawls of from 8 to 40 pots each. Each pot has a buoy line to which a wooden spindle-shaped buoy is attached. The latter bears the owner's mark or stamp, and shows the position of the trap. The traps are baited with fish, such as herrings, sculpins, or flounders, and the lobster, when once induced to come inside the pot, seldom eseapes, unless small enough to erawl between the slats. It has been estimated that half a million lobster traps have been in use in the Maritime Provinces during a single year.

The old-fashioned hoop nets formerly in use consisted of a single iron ring or hoop to which a net with cord was attached. When baited they bad to be closely watehed and pulled up from time to time, in order to secure the lobster before he could get out of the net.

The lobster fishery is conducted chiefly in the spring and summer months. The pots are tended from small boats, and the eateh is kept in floating cars moored in some protected spot near the shore. Welled fishing smacks, or more rarely welled steamers, gather up the lobsters from the fishermen and carry them to the canneries and to the markets in the large distributing centers, such as Portland, Boston, and New York. Lobsters are shipped alive in barrels, with ice in summer, to many parts of 
the country. The winter shipment is also very considerable. Large numbers are immediately boiled for home consumption, while many are kept alive in floaring cars at the market until required. The impounding of lobsters, ol placing them in large inclosures of salt water, called pounds, where they can be kept during the winter, is now successfully practiced on a large scale.

VII.

We have witnessed in the lobster fishery for many years past the anomaly of a declining industry with a yearly increasing yield, but with the gradual diminutiou in the size of the lobsters caught and an undue increase in the number of traps and fishermen. "How much longer," writes the inspector of fisheries of New Brunswick, " "an increased catch can be made out of a liminishing supply is a problem of some interest to those who have watched the rise, progress, and decay of this industry." 1

In 1886 fully 90,000,000 lobsters were captured in Canada, ${ }^{2}$ principally in Nova Scotia, New Brunswick, Prince Edward Island, and Quebee. Out of this vast number nearly 34,000,000 were taken in New Brunswick alone, and 22,000,000 in Prince Edward Island. These numbers are extraordinary, when we consider, as in the last instance, the small extent of the coast and the narrow limits of the fishing season.

In regard to the catch of lobsters in New Brunswick for 1856, the inspector of fisheries says in his report ${ }^{3}$ that the average size is diminishing, and "6to fill a pound can now requires rather more than an average of six lobsters-about $2 \frac{1}{2}$ ounces of meat per tish. The returus show 4,661,812 cans preserved, and 4,290 tous of fresh lobsters. In order to fill these cans, $28,000,000$ lobsters were killed. If to these we ard the number exported fresh, allowing 15 jounds to each, which is a large average, the number killed during the season will be $33,720,000 .{ }^{94}$

In 1887 about 70,000,000 lobsters were taken in Canada, and in 1892 upward of $68,000,000$ lobsters (estimated as above) were captured, valued at nearly $\$-, 000,000.5$

In 1884 the catch of lobsters in New Brunswick amounted to 5,662,072 caus and 1,709 tons, valued at \$900,580, the number of traps in use being 105,984. In 1892 the number of traps had increased to 172,022, an increase of over 60 per cent, while the product had decreased by nearly the same anount, being 3,204,3:0 cans and 1,132 tous, valued at only $\$ 493,804{ }^{6}$

The average annual yield of the Norwegian lobster fishery from 1879 to 1884 is estimated to have been $1,175,000$ lobsters, valued at $\$ 107,465$, the greater number

1 IV. H. Venning, inspector of fisheries of New Brumswiek. (Annual Report of the I)epartment. of Fisheries, Dominion of Canada, 1886, p. 146.)

'This estimate is based upon the official statistical returu of the lobster fishery, allowing five lobsters to a pound ean of meat, and a trifle over 2 pounds in weight to each lobster. 'The yield in 1892 was $16,434,431$ pounds in cans, and 8,662 tous of fresh lobsters, valued at $\$ 2,638,394$. (Report on the Lobster Industry of Canada for 1892. Supplement to the Twenty-fiftl Annual Report of the Department of Marine and Fisheries, No. 10d, Ottawa, 1893.)

${ }^{3}$ Annual Report of the Department of Fisheries of the Dominion of Canada, 1886.

+ Ibid.

5It should be remembered that these estimates, large as they seem, are based npon statistics which are generally reliable, and probably fall far below the number of animals anmually killer; for they do not include the number of undersized lobsters illegally used for canning, nor those user as food by fishermen and their families. Then there is, besides, the vast number of lolstrrs which annually fall a prey to other enemies than man.

"Report on the Lobster Industry of Canada, 1892, Supplement to thi' Twenty-filth Annul Report of the Department of Marine and Fisheries, No. 10d, ()ttawa, 189:3. 
being shipped to England. ${ }^{3}$ About 3,000,000 lobsters are said to be taken in the British Isles in a year, while the total number captured on the North Atlantic coast of America has undoubtedly in some years reached close to $100,000,000$.

The total quantity of lobsters taken in the United States in 1880 was 20,238,683 pounds, valued at $\$ 488,432$; of this quantity, $19,946,733$ pounds, worth $\$ 477,484$, were taken in the New England States, and 291,950 pounds, valued at \$10,948, in the Middle Atlantic States. In 1887 the United States lobster eatch was 28,882,180 pounds, with a market value of $\$ 799,717$, of which $28,627,600$ pounds, worth $\$ 784,238$, were eanght in New England and 254,580 pounds, valued at \$15,479, in the Middle Atlantic region. The output of the New England lobster fishery in 1889 was $30,449,603$ pounds, valued at $\$ 833,736$; of this catch, $25,001,351$ pounds, worth $\$ 574,165$, were taken in Maine.

The division of the United States Fish Commission concerned with statistics and methods of fisheries took a complete census of the lobster fishery of New York, New Jersey, and Delaware in $1892,{ }^{2}$ and in 1893 canvassed the lobster fishery of the New England States. Through the courtesy of Dr. H. M. Smith, the assistant in charge of the division, I am able to present in the following table the results of these inquiries.

The total number of persons engaged in the lobster fishery of the United States in 1892 was 3,766; of these, 2,628 were in Maine and 616 in Massachusetts. The vessels employed in lobster fishing numbered 58 , valued at nearly $\$ 75,000$. The number of boats used was 3,976 , having a value of $\$ 325,000$. Over 200,000 traps, worth $\$ 221,000$, were operated. The total investment in the fishery, including the value of live cars $(\$ 25,835)$, was $\$ 648,065$, distributed among the different States as shown in the table. The quantity of lobsters taken and sold by United States fishermen in 1892 was $23,724,525$ pounds, for which $\$ 1,062,392$ was received. Of this output, $17,642,677$ pounds, valued at $\$ 663,043$. were eaught in Maine and $3,182,270$ pounds, worth $\$ 205,638$, in Massachusetts.

Table showing the extent of the lobster fishery of the United States in 189\%.

\begin{tabular}{|c|c|c|c|c|c|c|c|c|c|}
\hline \multirow{3}{*}{ States. } & \multirow{3}{*}{$\begin{array}{l}\text { Number } \\
\text { of fisher- } \\
\text { men em- } \\
\text { ployed. }\end{array}$} & \multicolumn{6}{|c|}{ Vessels, boats, and traps used. } & \multirow{2}{*}{\multicolumn{2}{|c|}{ Lobsters taken. }} \\
\hline & & \multicolumn{2}{|c|}{ Vessels. } & \multicolumn{2}{|c|}{ Boats. } & \multicolumn{2}{|c|}{ Traps or pots. } & & \\
\hline & & No. & Value. & No. & Value. & No. & Value. & Pounds. & Value. \\
\hline 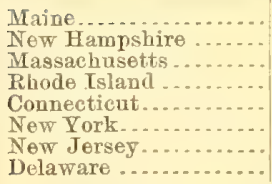 & $\begin{array}{r}2,628 \\
26 \\
616 \\
145 \\
258 \\
55 \\
36 \\
2\end{array}$ & $\begin{array}{r}7 \\
2 \\
12 \\
34 \\
2 \\
1\end{array}$ & $\begin{array}{r}\$ 7,050 \\
1,710 \\
8,455 \\
46,265 \\
9,880 \\
1,475 \\
-\end{array}$ & $\begin{array}{r}2,888 \\
29 \\
739 \\
86 \\
183 \\
34 \\
16 \\
1\end{array}$ & $\begin{array}{r}\$ 242,629 \\
594 \\
47,162 \\
15,320 \\
17,585 \\
1,140 \\
1,062 \\
40\end{array}$ & $\begin{array}{r}153,043 \\
1,393 \\
26,192 \\
6,341 \\
10,105 \\
2,240 \\
678 \\
21\end{array}$ & $\begin{array}{r}\$ 143,709 \\
2,786 \\
38,479 \\
10,090 \\
22,178 \\
3,469 \\
1,099 \\
53\end{array}$ & $\begin{array}{r}17,642,677 \\
196,350 \\
3,182,270 \\
774,100 \\
1,614,530 \\
165,093 \\
143,905 \\
5,600\end{array}$ & $\begin{array}{r}\$ 663,043 \\
11,790 \\
205,638 \\
53,762 \\
101,358 \\
15,655 \\
10,861 \\
285\end{array}$ \\
\hline Total ............. & 3,766 & 58 & 74,835 & 3,976 & 325,532 & 200,013 & 221,863 & $23,724,525$ & $1,062,392$ \\
\hline
\end{tabular}

Between 1887 and 1892 the decline in the lobster fishery of the United States was over $5,000,000$ pounds, although the value of the catch was more than $\$ 260,000$ greater in the latter year. When the yield and value of the fishery in the New England States in 1892 are compared with the results of the fishery in 1889, we find a falling

'Bulletin of the United States Fish Commission, vol. vI; also Report of the United States Fish Commissioner for 1889.

2 See a Statistical Report on the Fisheries of the Middle Atlantic States, by Hugh M. Smith, M. D., Bulletin of the United States Fish Commission for 1894, jage 455. 
off of more than 7,000,000 pounds, or over 23 per cent, but an increase in the market value of the output of over $\$ 200,000$, or nearly 25 per cent. These figures illustrate very forribly the decline which, unless speedily checked, threatens to destroy this valuable fishery.

Five attempts to transport lobsters alive across the continent and plant them in the Pacific Ocean have been male by the Juited States Fish Commission (1.y), in 1875-1889, and all but the first have proved successful. No evidence has, however, yot appeared to show that the lobster has multiplied and thriven in its new environ. ment. INore recently attempts have been made, with some degree of success, to ship) lobsters across the Atlantic, and deliver them alivo in the markets of London and Paris.

England, France, and Germany are the principal markets for the export trade outside of the United stites, but, like other preserved meats, the cauned lobster is shipped to all parts of the world.

\section{VIII.}

Civilized man is sweeping off the face of the earth one after another some of its most interesting and valuable animals, by a lark of foresight and selfish zeal unworthy of the savage. If man had as ready access to the submarine fields as to the forests and plains, it is easy to imagine how much havor he would spread. The ocean indeed seems to be as inexhaustible in its animal life as it is apparently limitless in extent and fathomless in depth, but we are apt to forget that marine animals may be as restricted in their distribution as terrestrial forms, and as nicely adjusted to their environment. Thus, as we shall see, the American lobster occupies only a narrow strip along a part of the North Atantic coast, and while it is probably not possible to exterminate such an amimal, it is possible to so rerluce its numbers that its fishing hecomes unprofitable, as has already been done in many places.

The only ways open to secure an increase in the lobster are to protect the spawnlobsters, or to protect the immature until they are able to reproduce, or to take the eggs from the lobsters themselves and hatch them artiticially. The latter is the method which has been adopted and is now in use in the British Naritime Provinces, and less extensively in the United States.

In an earlier paper, published in the United states Fish Commission Bulletin for 1893 (pp. 75-86), I have discusserl the question of the artificial propagation of the lobster, and have called attention to what seem to me the weakest points in the present method and what the most promising field for future experiments.

Adelbert College, Cleveland, Ohio, 


\title{
Chapter I.-HABITS AND ENVIRONMENT.
}

\author{
DISTRIBUTION OF THE LOBSTER.
}

The American lobster inhabits the coastal waters of the Atlantic Ocean from Labrador to Delaware, and occurs in depths of from less than 1 to more than 100 fathoms. It is thus confined to a strip of the Atlantic Ocean about 1,300 miles long, and at some points (as on the coast of Maine, where there is an extensive fishery in the outward islands) from 30 to upward of 50 miles wide. Its geographical range covers about 20 degrees of north latitude, from the thirty-fifth to the fifty-second parallel; but owing to the extreme irregularity of the coast the actual area of distribution is much greater. At present the lobster is most abundant and attains the largest size in the northern half of its range, that is upon the coasts of Maine and the British Maritime Provinces.

The lobster was recorded from Labrador by Packard in 1863. "The rocky shores," he says, "exposed to surf from the gulf, did not seem to harbor any animal life, but a narrow, interrupted belt of sand and mud flats in Salmon Bay" (near Caribou Island) supports a feeble assemblage of littoral forms (144). Under the rocks and seaweed the lobster was occasionally seen. At Henley Harbor, a little above the Straits of Belle Isle, it is mentioned as "rare." This seems to be the northeru limit of the lobster. At Hopedale, 200 miles above this point, he showed a picture of the lobster to one of the native Eskimos, who signified that it was not found there (148).

The lobster was common at Anticosti and Mingan islands (145), where collections were made by Verrill, Hyatt, and Shaler in 1861. Stearns (185), who asserts that "Jobsters were found everywhere along the coast of Labrador," is doubtless in error. He probably had in mind the "Gulf coast," or "Inner Labrador," as the territory of the Province of Quebec which stretches southwesterly from the Straits of Belle Isle is often erroneously called.

In speaking of the habits of lobsters in "Labrador," Stearns says:

Very often the beach is covered with rocks, large and small, interspersed with holes and pits filled with water at low tide. The seaweed grows over these places, thus affording capital hidingplaces. One can often procure 100 lobsters in au afternoon from a strip of the beach hardly as many yards long. The small boys hunt them with long poles on the ends of which are tied large cod hooks. With these the boys reach in and feel abont in the holes and under the rocks until they feel the shell of a lobster, when a smart or careful haul, as the case may require, generally brings the animal out of Its snug quarters. [These lobsters] are seldom very large, while the very young ones appear not to come inshore among the rocks to any great extent (185).

Dr. W. Wakeham, to whose kindness I am indebted for much interesting information on the northerly range of the lobster, writes as follows:

My own experience of the Labrador coast does not go beyond Chatean Bay at the northeastern entrance to the straits of Belle Isle. From this point west along the Labrador and north shore of Quebec, I have found the lobster everywhere fairly abundant up to Maniconagan in the river St. 
Lawrence. I have inquired of Gaspes whalers who are in the habit of going as far as Capo Harrison, on the coast of Labralor, but they all tell me that they havo never taken a lohster below st. Charlesthat is, a few miles north of Chatean Bay. Wost of Chateau Bay, as I have said, they are found all along the coast, but not in paying quantities. Several attempts have been mado to operato canneries on this coast, but they have one after another been abandoned. The lobstr rs seem to give out surldeuly. They are all canght up when the traps are fixst set. Of course the water is too teep for any general fishery, and it is only in shoal bays and harbors that traps can be used.

In reply to a letter of inquiry from Dr. Wakeham, Mr. P. M. McKenzie, one of the chief fitetors of the Inudson Bay Gompany, says that he has been on the Labrador coast and entrance of Hudson Straits for fourteen years, and has "never seen a Lobster ol heard of any being caught between Graly Harbor (longitude W. 56 25'. latitude 53 $4 i^{\prime}$ ) and (ape Chudleigh." Шe says further, that he does not think they occur between Grady Harbor and the straits of Belle Isle, but "all along the Gulf from Seven Islands to St. Angustine there are a great many at certain points."

Mr. W. H. Whitely, overseer of fisheries at the straits, writes to the same effect:

Lobsters are not found below [i. e, east of] the narrow's of the straits of Belle Isle [the lowest point, a place called Broclore Bay]. Some are found on the sonthern or Newfoundland side of the straits. They are not plenty at any place within 100 miles west of the north side of the straits of Belle Isle, but a ferv are found in places sheltered from rough water and drifting ice. I have never heard of any lobsters being seen at any point on the Labrador east of the straits.

From the character and abundance of this testimony we may safely conclude that the lobster is not found on the coast of Labrador very far beyond the straits of Belle Isle, or not many miles north of Heuley Harbor (about $52^{\circ}$ north latitude). From the straits northward the temperature is said to fall rapidly, owing to the aretic current which flows sonth, and the presence of ice, which is carried along with it close to the land. We should not, therefore, expect to meet with the lobster, except as a very rare stragg'Ter, north of the straits.

It is interesting to fuld, on the other hand, that Fabricius (63) includes the lobster (Cancer gummarus L.) in his Fauna Groenlandica. He is particular to state, however, that he does so upon the authority of others, as he had never seen the lobster in Greeuland himself. He says that the lobster is found under the name of Pekkuk in the Greenlandish dictionary. He had heard the natives distinguish the smaller Squillas by the name of P'elkungoit, from a much larger form (Cuncris), called Pek. kuit or Pekkurksoit, and very similar to the "Gammari." This name may have been derived from the Esquimanx of the southern Labrador coast or from Iceland, where, according to Mohr's "Islandske Naturhistorie." the Furopean lobster "has been found by Dr. Ponlsen in Gröndevig, but it does not extend to Greenland or Spitzbergen" (20).

De Kay, writing in 1844, remarks that while the lobster was taken in comparatively small quantities ou the New Jersey coast, "two years after building the breakwater in Delaware Bay, lobsters made their appearance there in great quantities." He also says that in about the year 1814 General Pinckney "caused a car full of lobsters to be emptied into the harbor of Charleston, South Carolina. A few of their survivors, or their descendants, were captured about ten years since, but, as I am. informed, they were the last." (51, p. 25.)

The stonewrok of Delaware Breakwater, says Rathbun (155), may be considered the sonthern boundary of the lobster, although he has recorded several instances of its occurrence south of this point. Thus it has been said that lobsters have been seen along the beach in the surf near Indian River Inlet, Delaware. Two or three have 
been recorded at Johnstown, in the northeastern corner of Virginia, "and in October 1s8t, the United States Fish Commission steamer Albatross obtained a single specimen of good size off Cape Hatteras, North Carolina, from a depth of about 30 fathoms, by means of the beam trawl" (155). Coues (49) also records the capture of a single lobster at Beaufort, North Carolina, in the summer of 1870.

Dr. Wakeham writes that lobsters are abundant around the island of Anticosti and that a large number of canneries have been in operation on this island for some years. He says that lobsters are more abundant on the southern side of the island, and concludes that this is "due to the fact that the water deepens gradually on the southern side, while on the north side of the island you go abruptly into deep water. The lobsters taken at Anticosti and on the north shore of the Gulf are of large size. This may be explained by the fact that they have not been overfished to the same extent there as elsewhere. At any rate we do not find any small lobsters in the traps. The largest lobster that I have seen taken on the north shore weighed 18 pounds."

Sars (176) considers it remarkable that lobsters on the southern coast of Norway never become as large as those farther north. It seems to me that the explanation of this fact is simple, and applies to both European and American species. The northern parts of the range of the lobster have been the last to be fished, and consequently the average size is greater than in the south, where the fishery began.

The bathymetrical range varies with the season and is influenced largely by the temperature of the water. It may be also governed in some measure by the abundance of food and by the reproductive and molting periods.

Lobsters are occasionally seen close to the shore in very shallow water and they are sometimes even stranded on the beach. This was the case with the large lobster, weighing upward of 20 pounds, the mutilated shell of which is now preserved in the land office of Boothbay Harbor Village, Maine (see p. 114). This great lobster was discovered on the beach of Boothbay Harbor, at low tide, about twenty-five years ago.

Professor Verrill related to me his experience with a large lobster at Grand Manan, Maine, in 1859. This lobster, which he thinks must have weighed at least 20 pounds, had established himself so securely under the projecting side of a large bowlder that it was not an easy matter to dislodge him, even at low tide; but with the aid of a boat-hook this giant was at last drawn out and captured. When it was finally taken to the set:lement it attracted very little interest, the fishermen saying that it was worth only a penny, 2 cents being then the regular price of lobsters, whether of 5 or 20 pounds weight. In those days lobsters were never weighed and sold by the pound.

Lobsters, on the other hand, stray out to great distances from the shore, and have been recorded on the fishing-banks of Nova Scotia "flom the fishing-banks and ledges of the Gult' of Maine, such as Jeffrey's Ledge and Cashe's Ledge, and from the more souther'n offshore bauks. They have also been taken from the stomachs of cod caught on George's Banks." (Rathbun, 155, p. 787.)

Lobsters are also sometimes driven by severe storms on the beach, where they perish in great numbers. In March, 1888, thousands of lobsters were washed ashore on the south side of Marthas Vineyard during a south and southwest gale. 


\section{CHARACTER OF THE ENVIRONMENT.}

Where there is great diversity of natural conditions throughout the geographical range of an animal we may expect to find its habits varying in a proportionate degree. From Labrador to Maine the Atlantic coast is rocky, and often precipitous, with deep bays and harbor's, and with large islands, some like Grand Manan presenting sheer perpendicular walls to the sea. The coast of Maine, in its middle and eastern sections, is essentially bold and rocky, and diversified to an extraordinary degree by chamels eut by large fresh-water rivers, by long deep inlets, studded with islands large and small. by bold rocky promontories, and by groups of larger islands farther from shore, such as the Viual Haven or Fox islands. These are masses of gray granite, scarred and ent up by glacial forces into an archipelago of smaller islands, abounding in long granite basins and inlets, into which pure sea water is driven with every tide. Thus are formed the most admirable breeding grounds for the lobster, for fish, and other marine animals. In the region of Cape Cod we meet with extensive shoals, which resemble on a smaller seale those of North Carolina. The northern part of the Massachusetts coast is rocky, while the southern section is greatly diversified, abounding in submerged ledges, sandy and weedy bottom, and a great variety of bays and channels in the vicinity of the Elizabeth Islands, where lobsters used to abound until their numbers were depleted by overfishing.

Under the variety of conditions which I have hinted at, we shonld not only expect to find lobsters larger and more abundant in some localities than elsewhere, a condition greatly influenced by the number and persistence of fishermen, but also to meet with variations in the time of laying and hatching of the eggs, in the season of molting, in the time when the semiannual movements are undertaken, in color, and in a variety of other details.

The habits of the lobster as affected by the chauges of season and other causes in the various stages of its life will be described, as we have been able to interpret them, in different parts of this work. Certain habits, however, are often so closely interrelated that the mere mention of one requires a consideration of others also.

\section{INTELLIGENCE OF THE LOBSTER.}

Since the lobster belougs to a less specialized class than the erab, it is not surprising to find that its intelligence is of a lower order. Sluggish as it often appears when out of water and partially exhansted, it is quite a different animal when free to move at will in its natural enviroument on the sea bottom. It is very cautious and cumning, capturing its prey by stealth, and with weapons which it knows how to conceal. Lying hidden in a bunch of seaweed, in a crevice among the rocks or in its burrow in the mud, it waits until its victim is within reach of its claws, before striking the fatal blow. The senses of sight and hearing are probably far from acute, but it possesses a keen sense of touch, and of smell, and probably also a sense of taste. We have, moreover, seen that it is quite sensitive to changes in temperature.

All animals which play the part of scavengers have strong powers of scent, and the lobster is no exception to the rule. This is illustrated by the way in which it can be enticed into the traps. Thus it is asserted that where traps are set on a trawl placed across the tide, the catch is greater than when the trawl is set in the direction 
of the current, since in the former case the scent, or fiue particles coming from the bait, is more widely diffused. Lobsters are sometimes wary and shy of entering the trap, and have been seen to crawl abont it several times and examine it cautiously on all sides before, too weak or too hungry to resist temptation, they finally enter. When the pots are hauled, lobsters sometimes escape by darting backward through the narrow opening of one of the funiels, but this seldom happens and may be set dow $n$ to accident.

Many facts will be given in the course of this work which illustrate either directly or indirectly the intelligence of the lobster. I will add here only the following account of a lobster which was kept at the Rothsay aquarium, in England (Nature, xv, p. 415, March 8, 1875). A flounder was unintentionally left in one of the aquaria, in which three lobsters were placed. The largest lobster immediately appropriated the fish, which was then dead, and buried it beneath a heap of shingle, on which he mounted guard. Five times within two hours was the fish unearthed, and as often did the lobster shovel the gravel over it with his huge claws, each time ascending the pile and turning his bold, defensive front to his companions.

\section{THE LOBSTER'S POWERS OF MOVEMENT.}

The adult lobster lives and feeds exclusively upon the sea bottom, which it never leaves of its own accord in any considerable degree. In traveling over the bottom in search of its prey, the lobster walks nimbly upon the tips of its slender legs. The large claws are extended forward in front of the head, a position which offers the least resistance to the water, while the two hinder pairs of walking legs, which end in hard spur-like joints, serve as picks to steady the movements of the animal.. In thus going about it has the constant aid of the delicate swimmerets, attached vertically to the under surface of the "tail," each of which consists of a short stalk and two very flexible blades. By the movements of the swimmerets the lobster is impelled slowly forward without the aid of the walking legs. The branches of the swimming feet are garnished with long, chitinous setre or hairs, to which, as is well known, the eggs in the female are attached. Thus these appendages are not only natatory, but play an important part in reproduction, and by their almost incessant beating movements serve to keep the developing eggs well aerated and clean.

When taken out of the water the lobster can only erawl, in its vain attempts to walk, owing to the heavy weight of the body and claws, which the slender walking legs are now unable to sustain. If turned over on its back the animal is usually able to right itself when out of the water, but not without great effort. If placed near the salt water and left to its own devices, it will almost immediately strike out by the nearest path for the sea with as keen a sense of direction as the sea turtle will show when upon land. Its power of crawling on land is, however, limited to short distances, and the lobster never forsakes the salt water of its own accord and, as has been said, never willingly leaves the sea bottom.

In exploring its feeding-grounds, where an enemy is likely to be encountered, the legs which carry the long claws are extended forward in frout of the head, or earried somewhat obliquely, their tips resting on the bottom, and the long sensitive "feelers" are waved constantly back and forth to give warning of any foe or other objects which the eye may fail to detect. These are exclusively orgaus of touch. If the anticipated 
enemy makes his appearance or if the animal is surprised, as wheu it is surdenly touched with the blade of an oar or cornered, it will immerliately strike an attitude of defense. It now raises itself on the tips of its walking legs, and lifts its powerful claws over the head after the manner of a boxer, and strikes with one of its claws at the offending object, trying to crush it or tear it in pieces. I have several times pulled lobsters partially or completely out of their burrows with an oar. You have only to thrust the oar-blade into their holes, when, if a lobster is present, it will immediately seize it with a firm grip; but it often shows its intelligence by relaxing its hold before becoming completely exposed. By far the most powerful organ of locomotion in the lobster is its "tail." By the Hexion of this, aided by the extended tail-fan, the animal is able to shoot backward throngh the water with astonishing rapidity, sometimes going, according to one observer, 25 feet in less than a second. If tossed into the water back or head first, the animal, unless exhansted, immediately rights itself and, with one or two vigorous flexions of the tail, shoots off obliquely toward the bottom, as if sliding down an inclined plane.

The lobster, though less active and keen-witted than the higher crabs, can not be regarded as a sluggish animal in any sense. In the water its movements are graceful; it is wary, resourceful, pugnacious, capable of defending itself against enemies which are often larger than itself, aud, if the oceasion requires it, of rumning about with the greatest agility and speed.

On calm evenings in summer at about sundown I have seen lobsters very close to shore lying on little patches of sand, surrounded by eelgrass, probably waiting their opportunity to seize a passing fish or erab. If approached in a boat on such an occasion, they soon become aware of your presence and put themselves in an attitude of defense, but press them too close, or attempt to pin them down with an oar, they immediately dart backward into deeper water among the seaweed. If still pursued, the lobster rises and flies in another direction, thus zigzagging its way over the bottom until it finds safety in some denser tangle or rocky erevice.

Of the English lobster, Travis remarks:

In the water they can rum nimbly upon their legs or small claws and, if alarmed, can spring tail forward to a surprising distauce as swift as a bircl can fly. The fisbermen seo them pass about 30 feet, and by the swiftness of their motion suppose that they go much farther. Athenwus remarks this cirenwstance, and says that incurvated lobsters will spring with the activity of dolphins. When frightened they will spring from a considerable distance to their hole in the rock, and, what is not less surprising than true, will throw themselves into their hole in that manner, through an entrance barely sufficient for their bodies to pass; as is frequently seen by the people who endeavor to take them at Filey-bridge (191).

When a lobster is surprised it seems to disappear with a single leap or bound as a locust or grasshopper might do. This habit, added to their appearance, explains why lobsters were called by Pliny and the ancient writers locuste, or "locusts of the sea." The lobster, however, never rises more than a few inches or at most a few feet above the bottom, and it is evident that swimming at the surface wouid be impossible on account of the great weight of the body. The "traveling lobsters," or ford-hummer, which Norwegian fishermen, as Sars tells us (176), have described as swimming at the surface of the ocean in large schools, often many miles from the coast, were, without doubt, some large species of surface-feerling shrimp.

Lobsters kept in an aquarium often thrive well, and will live for a long period if they are properly cared for. In the hatchery of the United States Fish Commission 
at Woods Hole, Massachusetts, sea water is kept running through the tanks, in the larger of which we have kept lobsters and watehed their habits for several months at a time. If the tank is provided with a pile of stones the lobster very soon investigates this with care, seeking out the most attractive holes. If several individuals are placed in the same aquarium, each will select its own hole or corner over which it establishes a sort of proprietary right. In these they lie during the greater part of the day with their antennæ and a part of the body and large claws projecting, ready when a good chance offers to strike at a fish, or if an enemy should approach, to retire at a safer distance into their retreats. If the occupants of the same aquarium are of about equal size, and if they show no weakness, they usually live in peace; but if one has been disabled in any way, as by the loss of a claw, he is attacked by the strong and forthwith destroyed.

As the lobster lies in its corner of the aquarium-always with its tail folded, if a female "in berry"-it slowly sweeps the water with its long, sensitive antennæ, which it now holds erect, now lowers until they lie horizontal and extend almost directly in front of the body. The sualler pair of antennæ are elevated, while the larger outer branch of each is constantly beating with a slight up-and-down movement; this branch supports the delicate filaments which have been regarded as the terminal organs of the sense of smell. If one watches this lobster he may see it deliberately lower the branches of the first pair of autennæ and clean them by drawing them through the bunches of stiff bristles of the third pair of maxillipeds, the large prominent appendages which project forward at the sides of the mouth immediately in front of the chelipeds. The large claws are held in readiness for use, their tips resting close together on the bottom and their opposite ends raised obliquely upward.

\section{PERIODICAL MIGRATIONS AND THEIR RELATION TO CHANGES IN THE ENVIRONMENT.}

The adult lobster never moves up and down the coast like the migratory fishes, but is of a far more sedentary disposition. In the spring months of April and May, however, large numbers appear to move from deeper water toward the shore. In the fall they retire to deeper water agaiu.

The movements of such anadromous fish as the mackerel and the menhaden are influenced by the spawning period, by the temperature conditions, and by the abundance of food. The mackerel is said to thrive in a water-temperature as low as $40^{\circ} \mathrm{F}$. or even less. The same causes, of which the influence of temperature may sometimes be the most potent, probably determine the migration of both fish and crustacean.

When the question of food is paramount, the lobster will remain in considerable numbers in the relatively shallow water of harbors, but only on a rocky bottom, where food is most abundant. The extent of the migration is also naturally influenced by the depth of the water and the general character of the bottom, being more extended on a gradually sloping bottom where deep water is less readily accessible. The exact period at which the semiannual migrations of the lobster occur varies at different points on the coast and also at the same point for different seasons.

In the vicinity of Rockland, Maine, and to the eastward as far as Eastport, the summer fishery begins in the latter part of May and lasts until the first of November. 
During this time, lobsters are canght in from 3 to 10 fathoms of water. For the rest of the year the winter fishing is conclucted in 35 to 40 fathoms. In general, the spring migration along the entire coast of Mane and in the Maritime Provinces is accomplished in April and May, and the fall movement into deeper water in October and November.

When the spring is late and the water cold, the lobster keeps away from the shore. Thus the spring of 1884 was a month later than usual in Prince Edward Island, says the inspector of fisherios in his anmual report (56), "and the ice hung long about the coast." The first lobster was caught on the 3d of Jume. "The hands about the factories had been idle for fully four weeks, but the first batch or run of lobsters came in fuite as fast as they conld be utilized. I have noticed this to have been the case in previous years, as if when ice remained long the lobster congregated in large bodies on the outer edge of the frozen belt ready to run for the shore as soon as it was elear and the temperature suited. Subsequently the batches fell off to a little less than the average." Ice is said to remain so long on this coast that few lobster fishermen begin work until the first or second week in May. In 1892 the ice left early, and some lobsters were landed on the north side of the island the 29th of April. Packing was begun as early as the 10th of May. (Fishery Statements, 1891, p. 97.)

At Cape Breton, in late seasons, very little lobster fishing is done before the 1st of June, or even later. Lobsters probably do not, as a rule, move in schools, but approach and leave the shores gradually with the change of temperature, yet a suddeu cold smap seems to cause them to disappear promptly from auy locality. It is probable that their disappearance muder such cincumstances may be explained by their burrowing in the mud. (See pp. 26 aud 29.) Mr. M. B. Spinney, of Cliftistone, Maine, informed me that in May or .June in 1869, at Prince Edward Island, while sailing in a small boat from Georgetown into Grand River, lobsters were seen for the distance of several miles crawling over the bottom in very large numbers and often very close together, the water being 10 or 12 feet deep.

Mr. Adolph Nielsen writes, in reply to certain questions, that as the coast of Newfoundland is affected by the polar current, a spurt of northeast and easterly winds often brings down the temperatme of the rater, and this canses the lobsters to move off into deeper water or bury themselves in the sand or mud in the midst of the season. At such times the fishermen can not take them in their traps.

The sudden appearance of lobsters in the spring in relatively shallow water lends color to the supposition that they sometimes move in large numbers together. Thus, Mr. A. C. Smith says that in 1884 the proprietor of a lobster factory in New Brunswick "set his traps on the 20th of April, keeping them baited, but eanght nothing till the night of the 5th of May, when the lobsters suddenly 'struck in' as pleutiful as at any time of the season."

It is certain that lobsters do not indulge in any considerable northward or southward migrations. This is proved, as Rathbun has pointed ont (158), by the depletion of the lobster fishery at certain points on the coast, as at Provincetown, Cape Cod, Massachusetts. He states that the fishery was begun here in 1800, and that between 1845 and 1850 New York City received nearly its entire supply of these crustaceans from the Provincetown region. A marked decrease in their abundance was noticed in 1865, and this was followed by a gradual ammal diminution, until in 1880 there were but eight wen engaged in the business. If there were any considerable coastwise 
migration, it is evident that regions once depleted would in time be restored naturally by accessions from neighboring sections. This does not appear to be the case, and we may look upon each geographical region on the coast as in habited by a distinct school of lobsters, which hold their ground fairly constantly, so that if their uumbers are depleted by overfishing they would under natural conditions be stocked but slowly. If this argument is sound, and it certaiuly looks as if the Cape Cod region were a case in point, it must follow that the young are not widely distributed, but $\mathbf{I}$ can hardly accept this as probable. It would seem as if the young, which, to be sure, have little powers of locomotion, would always tend to find an extra local distribution by tides, winds, and currents. Furthermore, if this were the case, it would follow that restocking under natural conditions is a slow process at best. Writing iu December, 1885, Rathbun says (158):

The Cape Corl lobster fishery has been at a low standing for many years and, although but few men have engaged in the fishery of that region for a long time, there are, as yet, no signs of improvement.

That lobsters move up and down the coast to some extent is inevitable, althongh such a migration may be regarded as accidental rather than deliberate or instinctive. They may also return suddenly, as some believe, to places where they have not been seen for years. Thus a correspondent wrote to the United States Fish Commission from South Amboy, New Jersey, February 15, 1886, that lobsters had made an appearance there after an absence of about twelve years. "I discovered them late in October, and captured a hundred before the cold weather set in, after which I could not catch auy." (Bull. U. S. F. C., vol. VI, p. 407.) Statements of this kind must, however, be received with much caution, since what appears to be a sudden arrival may be due to desultory observatious.

The subject of the schooling of lobsters is one about which it is very difficult to get accurate information, and we need to use much eaution in drawing conclusions from too sleuder data. The only region which I have been able to study for a number of consecutive seasons is that about Woods Hole, Massachusetts, including Marthas Tineyard, No Man's Land, and the Elizabeth Islands, and I will give in some detail the observations which I have been able to make in this limited area, believing that they will shed some light upon this interesting and perplexing question.

The fishermen of a part of this region set their traps from the last of April to the middle or last of June on rocky bottom in the vicinity of Gay Head and No Man's Land, while from the middle or last of June until September they generally fish upon the sandy bottom of the Sound in much shallower water. A few lobstermen fish during September upon the rocks. They distinguish "rock lobsters" from what they call "school lobsters." The latter are also called "sand" or "June lobsters," aud are considered more migratory than the "rock lobsters" or "ground-holders." "School lobsters" are most abundant in summer from the middle of June to the middle or last of July on a sandy bottom in Vineyard Sound in 5 to 10 fathoms of water.

On June 28, 1890, I found the fishermen at Menemsha ${ }^{1}$ setting their traps both off Gay Head on a rock bottom and on the sandy bottom of the Sound. The difference

${ }^{1}$ Menemsha is a small fishing settlement in the town of Chilmark, Marthas Vineyard, about 2 miles due east from Gay Head, on Vineyard Sound. Gay Head, the remarkable promontory forming the western extremity of Marthas Vineyard, is 14 miles southwest of Woods Hole Hurbor and 6 miles north of No Man's Land. 
in the lobsters canght at the same time under these couditions was sufficiently marked to attract attention. The lobsters captured on the rocks had hard shells and frequently bore old eggs, while those taken in the Sound had in no single instance, up to this time during the season, borne extermal eggs, either old or new, and a large number of them had soft shells. These are ofteu called "paper shells," or "buckle shells," the shell being relatively soft, so that it is easily compressible with the thumb and finger, and the colors are very bright, showing that they have molted within four or five weeks. Special care was taken to save all egg lobsters caught, since the Inited States Fish Commission purchased them for use in its hatchery. These "buckle shells" or "school lobsters" were said to appear rather suddenly about the middle of June or" first of July, and to retreat into deeper water during the first half of September.

On the 9th of July I again visited Menemsha, and found that since the first of the month only six lobsters with old eggs had been obtained. These were eaught in the Sound, where the majority of all lobsters now taken had soft shells. On the 16th and 2Sth of July, when I made further visits to the locality, the fishery was conducted almost wholly in the Sound. At the later period the fishermen had begun to shift their traps to slightly deeper water, following up the lobster's in their retreat from the shore. On the 11th of August they were fishing both in Vineyard Sound and off Gay Head in 8 to 15 fathoms. A large proportion of these lobsters taken in the Sound had soft shells, but an examination of the ovaries of the soft-shell females proved beyond a doubt that they had hatched their old eggs and molted during the present season.

Some very interesting facts have been brought out by the record of the fishery at No Man's Land during the months of May and June, 1894. Mr. Vinal Edwards foum that egg-lobsters of large size conld be taken there in abundance, and accordingly the Fish Commission drew the supply of eggs for its hatchery from that place. Mr. Edwards carefully recorded the catches of the smackmen, examining nearly every lobster himself. The result is given in table 1. The traps were set on ledges of rock, 15 miles from land, in about 15 fathoms of water. Besides the extraordinary disproportion of the sexes-only 6.4 per cent of males being obtained out of a total of 1,318 lobsters captured in May-we notice the equally remarkable and probably correlated fact that 63.7 per cent of the total number are females with egg's soon to be hatched.

TABLE 1.-Record of Tobster's caught off To Man's Land in May, 1894.

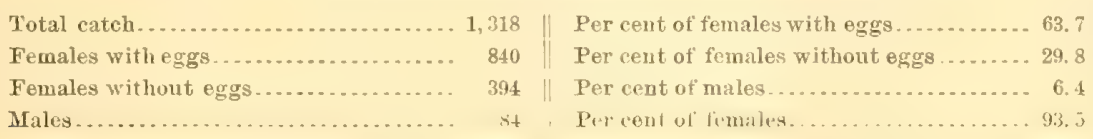

Another striking fact which the fishermen noticed was the persistence with which the lobsters at this time of the year clung to the rocky areas. When set on a rock bottom the traps were certain to catch lobsters in abundance, but when sunk upon a sandy or muddy bottom, though but a few feet away, not a lobster was trapped. In fishing on trawls, where a long line of traps was put out, it sometimes happened that some of these would strike a sand bottom, often not more than a narrow streak or bar, but they were always found empty. Mr. Edwards systematically fished for lobsters in Woods Hole Harbor from Necember, 1893, to the June following. Ile found them 
in the winter months abundant on the rocks, but when the traps were placed on the mud not a lobster was taken. ${ }^{1}$

The disproportion of the sexes noticed at No Man's Land is due, I believe, to the fact that the females find it more advantageous to remain on a rocky bottom while they are encumbered with their old eggs. As soon as these hatch, the female lobsters press on in large numbers toward the shore, coming up into the sounds and bays and on to sandy bottoms during the summer. The lobster can probably protect herself and eggs better while on the rocks, but almost immediately after the hatching of the eggs the molt occurs, for some time after which the female is helpless. Now the molting lobster seems to prefer the sandy bottom while in this critical state, probably because it can slield itself better from its enemies. On the sand the molting lobster may hide in tangles of seaweed, or scratch a hole and partially bury itself, as it often does, and remain tolerably secure, but let the soft lobster try to conceal itself among the rocks, and what is the result? There are hosts of bottom-feeding fish which lount the rock-piles, none of which are probably more troublesome than the cunner, which can goalmost anywhere, and would soon surround the soft lobster in its retreat and nibble at its legs, or snip off its eyes, which means death. The cumners, eels, and other fish may attempt to pick off the eggs, but these are on the under side of the body and except in extraordinary cases, where the ova are excessively numerous, the lobster can fold them between the segments of its tail and thus rest tolerably secure (see p. 34). This theory is supported by the fact that the "school lobsters" caught on the sand bottom of Vineyard Sound rarely have old eggs and very commonly possess soft shells. Rocky bottoms furnish food in greater abundance, at certain seasons, which explains their preference for these areas in winter. Where on the other hand, as in the region abont Provincetown, Cape Cod, the bottom is uniformly sandy, the lobster has little or no choice of environment.

To sum up the preceding observations, what seems to take place at the western end of Vineyard Sound during the season of migration is as follows: The general movement of lobsters toward the shore is here modified by the fact that lobsters with old eggs find it advantageous to remain on the rocky ledges until the young are hatched, while the males press on in their inward movement. After the hatching period the females make their appearance in large numbers in the Sound toward the last of Jume or first of July, and form a large part of what fishermen call "school lobsters" or "buckle shells." Their appearance is probably not as sudden as it often seems. Fishermen, as a rule, work only one set of traps, putting them down now here, now there. In order to follow the movements of these animals systematically, it would be necessary to set traps simultaneously in different places and on different bottoms, and to keep them there for a considerable time.

Some females with old eggs come into the Sound before the young are hatched, but the majority do not. It must be borne in mind also that many lobsters remain in the Sound and harbors the year round, and that these observations refer only to the movements of the larger number. Toward the latter part of August the pendulum begins

ISpeaking of the lobsters captured in February, Mr. Edwards says: "The Iobsters taken this month have been caught on rocky bottom in fire lobster pots. I have set five others in deep water on sandy bottom, and also on the mud, but find none. I have tried in shoal water in eelgrass, but there are none there. I also tried for them in the middle of Vineyard Sound and in Buzzards Bay, but found none." 
to swing the other way, and the lobsters move into deeper water or to a rocky bottom. This outbound movement is continued during the months of September and Oetober, but, as alrealy pointed out, it is by no means general and is probably more pronounced in cold than in mild seasons.

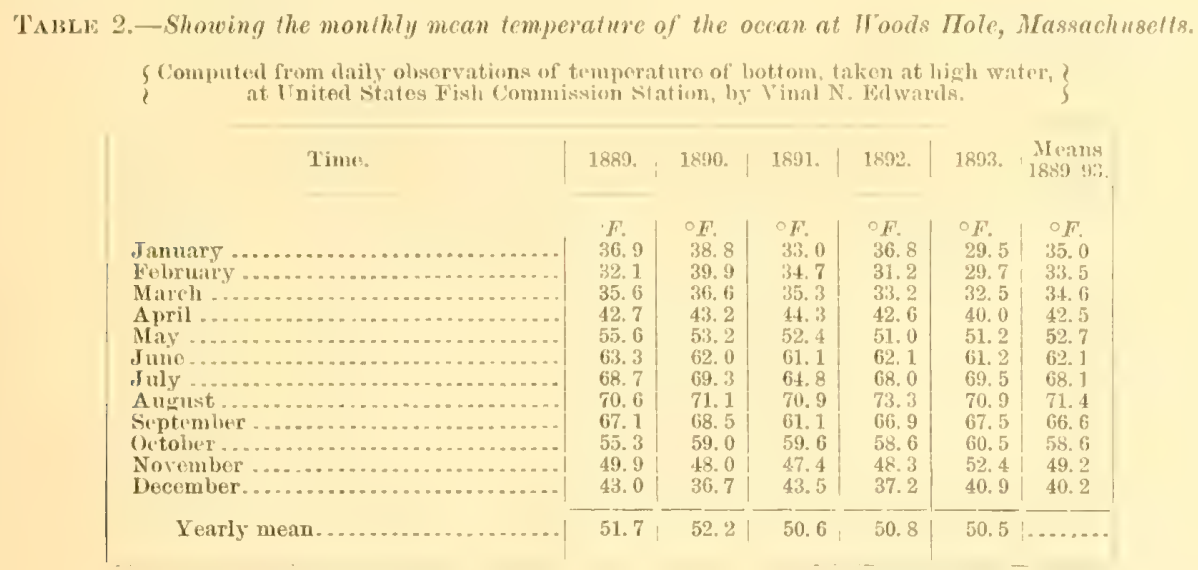

The mean temperature of the water at Woods Hole, Massachusetts, was $52.680 \mathrm{~F}$. for May, from 1889 to 1893 ( $v$. table 2), the extremes of monthly averages varying from. $51^{\circ}$ in May, 1892, to 55.6 in May, 1889, and the range was similar for the latter part of October during the same period. The greatest heat is reacher in August (70.60, 1889, to $\left.73.3^{\circ}, 1892\right)$, while the temperature of the water in September is but little lower than that of July. In the latter part of October the water becomes cooled to about the same degree it had reached dluring the latter half of May. We may therefore conclnde that the optimum temperature for the lobster lies between $50^{\circ}$ and $60^{\circ} \mathrm{F}$. When the temperature of the sea water marks $50^{\circ}$ to $55^{\circ}$ in spring large numbers of these animals bave already begun to creep nearer the shores into shallower and warmer places, and again in the fall, when the temperature has fallen to this point, many have alrearly been impelled to recede to greater depths. Many lobsters, however, remain in the relatively shallow water of harbors all winter, a fact which has already been emphasized; so it is certain that temperature is not the only influence at work in directing these semiannual movements. The question of food may be of equal or even greater importance.

The winter catch of lobsters in relatively shallow water is often considerable. Thus, on December 13, 1888, Mr. Edwards set two lobster pots ${ }^{1}$ in the harbor of Woods Hole, in abont 25 feet of water, and hauled them fifteen times during the month, taking an average of 15 lobsters to a haul, or $223 \mathrm{in}$ all. Iu December, 1889, 54 lobsters were taken in a fyke net at the head of the harbor, 36 were captured in January, while none were caught in February.

In December, 1893, Mr. Edwards began to collect more systematically facts relating to the winter habits of the lobster, the results of which are discussed in another place (see pp. 30,31, 44, 45, 79, 80). Five trajss were set in the harbor of Woods Hole in 25 to 29 feet of water on rocky bottom (it being impossible to get any lobsters on the mud); 224 were taken in December, 501 in January, 246 in February, and 318 in

In these and all other traps used, the space between the laths varied from 1 to 18 inches. 
March. Only 6.1 per cent of the total catch were egg lobsters, and while this number would have been increased if the traps had been scattered instead of kept in definite spots, it would contrast markedly with the results at No Man's Land, where more than half of the total catch were lobsters with external eggs (table 1).

In severe winters lobsters are driven into deeper water or forced to protect themselves by burrowing in the mud. The effect of sudden or extreme cold upon these auimals may be witnessed in lobster pounds, where they are kept in large numbers to supply the winter market. On the Vinal Haven Islands, near Rockland, Maine, there is a large pound belonging to Messrs. Johnson and Young, of Boston, of 12 to 15 acres in area. It is said to have an average depth of 18 feet at low water. In January, 1893, during a cold snap, ice was formed over this pool to the thickness of 31 inches. At this time many of the lobsters died. All the pollock also, which had been placed in the pond, were killed, some of them being $2 \frac{1}{2}$ feet long, and large numbers of hake at the same time succumbed.

Lieut. W. M. Wood (207), while transporting live lobsters from New York City to Chesapeake Bay, tried some experiments upon the effect of reducing the temperature of the water. Lobsters placed in water at the freezing point were just alive after one hour's immersion. He was of the opinion that lobsters could be kept alive for a number of days in a cold chest, with a temperature of from $40^{\circ}$ to $50^{\circ} \mathrm{F}$. The practice of transporting lobsters by the aid of ice is now generally adopted.

The annual range of temperature thronghout the stretch of coast inhabited by the lobster is less than might be supposed. The temperature of the surface water of Winter Quarter Shoal, Virginia, ranges from $35^{\circ}$ to $76^{\circ} \mathrm{F}$; at Five Fathom Bank, New Jersey, the range is $37^{\circ}$ to $76^{\circ}$. Delaware Breakwater, which is practically the southern limit of the lobster, is situated between the light-ships anchored upon these two shoals. At Sandy Hook light-ship, north of the Five Fathom Bank, New Jersey, we have an anuual range of $33^{\circ}$ to $74^{\circ}$; at Bartlett Reef and Hartford Shoal lightships, on Long Island Sound, it is $33^{\circ}$ to $70^{\circ}$. The middle portion of Vineyard Sound, farther east, has a similar range, while at the Brenton Reef and Vineyard Sound light-ships, the region of Block Island, the Elizabeth Islands, and Marthas Vineyard, the temperature varies from about $32^{\circ}$ to $69^{\circ}$. The range at Woods Hole (see table 2) is about 290 to $73 \circ$, taking the means for each month, while the actual extremes are greater. At Pollock Rip light-ship, at the southern end of Cape Cod, the mean range is $32^{\circ}$ to $62^{\circ}$; in the Gulf of Maine the same range is obtained by combining the results of observations at all stations. In some places the maximum is ouly 54․ The preceding data are extracted from a paper by Mr. Rathbun (157).

Mr. J. H. Duvar says that from 1878 to 1880 the average temperature on the north shore of Prince Edward Island was 56.56 in June, $63.40^{\circ}$ in July, and $62.27 \circ$ in August. The temperature of the water at bottom in 6 to 8 fathoms he estimated roughly at 55०. Lobsters spawn in July on the north shore; in August on the south

${ }^{1}$ The inspector of fisheries of Prince Edward Island has an interesting note on the capture of lobsters through the ice in his annual report for 1882 (210). He says that on March 10 of that year there were brought to him "a number of lobsters of a uniform length of body [probably meaning carapace or shell of the back] of 4 inches, and one weighing 3 pounds that had been taken through the ice by the scoop of a mud-digging machine in a ereek off Cascumpeque Bay. They seemed rather sluggish, but not torpid." It is evident that these lobsters preferred to burrow in the mud rather thau migrate into deeper water. 
shore. This is explained, he thinks, by the curent and by the rise of the tides in the straits of Northumberlaud, which make the southeru water cooler, and hence delay the spawning (209, p. 2233).

Nielsen finds that the temperature of the water along the coast of Labrador ranges very low and does not exceed $46.050 \mathrm{~F}$. on the wal'mest summer days. 'The lobstel is thus debarred from this coast north of Henley Harbor, where it comes more directly under the influence of ice and the arctic curent (see p. 15).

\section{SENSIBILITY TO LIGHT.}

The lolster is essentially a nocturnal animal, exploring the bottom in the quest of food mainly in the night, when it is far more active than during the day. 'Lhis can be proved by anyone who watehes their habits in aquaria or in lobster ponds or cars. It is true that they show some activity in the daytime, especially if they are fed, but at night they become very restless. Moving nimbly about, they explore every par't of the car or investigate anew the resources of the aquarium. I believe that the eggs are laid and that the paring takes place at that time, and this inference is strengthened by the fact that this is the common habit of shrimp and many other crustacea. The craytish, according to Chantran (37), usually lays its eggs in the night.

According to Forel, light can not penetrate in the ocean below a depth of 400 meters of tolerably clear water, but even in 50 fathoms off the Atlantic coast the difference between day and night can not be very considerable. This is not the case in shallow bays or sounds with sandy bottom, which lobster's frequent in summer, and where we may expect to find the greatest difference between their diumal and nocturnal habits. The lobster, like many other marine invertebrates, is very seusitive to the extremes of heat and cold. If exposed to direct suulight out of the water, or to the nipping air of a winter's day, it weakens and succumbs in a short time.

The large floating cars in which lobsters are generally stored alive, in readiness for market, are always kept closed. When they are particularly shallow and the lobsters are exposed to the glare of the sun they always suffer and sometimes die in consequence. The majority of lobsters probably spend the greater part of the year' in depths where the effect of sunlight is but very slight, and during the course of its evolution the eye of this animal has become sensitive to a minimum quantity of light For this reason alone we should expect that the adults would avoid intense sunlight The effect of light mpon the colors of the shell is considered in another place. (See 1). 135, 136.)

\section{DIGGING AND BURROWING HABITS OF THE LOBSTER.}

The louster not only digs up the sea bottom in its search for shellfish and covers itself with mud in cold weather, but burrows, under some conditions at least, as extensively as the muskrat. I have observed this interesting habit only in lobster's contined in pounds where they are obliged to adapt themselves to new couditions, it is true, but since they burrow while in these inclosures in summer as well as in winter, we may infer that the habit is one which is ofteu practiced when the auimal is free to roam at will. This has been observed, moreover, by fishermen who have fretgently' taken lobsters from their holes. 
The lobster pound at the Vinal Haven Islands is a granite basin with a clay or mud bottom, and with low mud banks in certain parts of the shore. At low tide it has an average depth of 3 fathoms, while the difference between tides is 10 feet. On the 26th of August, 1893, I explored this pound in a boat, in company with Mr. Thomas Barton, an intelligent lobster fisherwan, and lad an excellent opportunity to observe how lobsters behave under such conditions on a bright summer afternoon. It was quite common to see these animals partially buried in the mud in shallow water, their antennx, eyes, and part of the shell projecting from the muddy surface. We could rely upon finding lobsters in the holes which they excavate beneath stones, and rarely failed to discover one or more individuals in every good-sized chink among the rocks. Others lay at the months of burrows which they had dug straight into the banks. Comparatively few lobsters were seen lying upon the bottom or erawling actively over it. Occasionally two or three lobsters could be dislodged from a common place of retreat, and Mr. Barton said that in the spring, when the ice was breaking up, he had taken five lobsters from a single hole in the mud. Some years ago the lobsters made their way out of this pound, as I was told by an old fisherman formerly employed there, by excavating a submarine passage beneath the dam. In order to effect their escape, they harl dug down beneath the stones to a depth of from 2 to 3 feet.

At one of the pounds in Southport, Maine, I had a still better opportunity to study the burrowing habits of the lobster. The larger pound at this island is under the charge of Mr. A. P. Greenleaf, a man of much experience in fishing the lobster and a very intelligent observer of its habits. ${ }^{1}$ He finds that the lobster burrows most extensively in winter, when it is far less active in the pounds than at other times. When the water is drawn off from the pound in winter the lobsters often remain in their holes, the mouths of which are then exposed along the banks, but in summer they are more careful under these conditions to forsake their burrows and crawl into deeper water.

In digging, lobsters probably make use of their large claws and walking legs, and possibly the tail-fan may be brought into service as a scoop or shovel, but I have no observation in support of this latter supposition. In some cases, however, I have noticed the under side of the tail-fan to be scratched and scarified and the marginal fringe of hairs worn down in such a way as to suggest the probability of such a use. ${ }^{2}$

That lobsters transport stones with their large claws, Mr. Greenleaf had the opportunity to observe, while watching a lobster one day in the pound. The animal was maneuvering about a hole, in 3 feet of water. It was seen to crawl up to the burrow, possibly one which had been dug by another lobster, and cantiously put in first one claw and then the other. Finally it went in so as to conceal about half the length of

'Mr. Greenleaf is the only fisherman whom I have met who has independently determined the period during which the female lobster regularly carries her eggs.

${ }^{2}$ The process by which the hole is said to be excavated solely by means of the tail has been described by a writer on the habits of the lobster (181). This paper abounds in errors, and leads one to suspect that the author has drawn too largely upon the accounts of others; still, this fact need not discredit this particular observation. He says: "The tail is slowly drawn up at first, taking as much of the mud as possible on its under side; then, when well under the body, a final powerful jerk sends the mud or sand from out in front, and at the same time draws the lobster farther back into the cavity thus made, enabling him to get a better grasp for repeating the process over and over again, till by degrees he disappears from sight." The statement that "these holes are for the shelter of the lobster during the period of exuviation," however plausible it may be, is contrary to observed facts. 
its body and bronght out in its large "chub claw" a small stone, which it deposited near the month of the burrow. Ilaving thus removed this obstruction, it faced about and "backed," tail first, into its newly acquired shelter.

The east pound at this place has 18 feet of water at half tide and an average depth of about 8 feet. On one side are low rocky cliff's, the talus of which gives shelter to many lobsters, while the low clay banks of the opposite shore are so completely undermined by their burrows as to afford, in some places, a very insecure foothold. I examined these banks carefully from a boat, and had the opportunity of satisfying myself of the extent to which the tunneling operations had been carried on. The holes were driven horizontally into the mud bank to a distance of from 1 to 5 feet, and in each a lobster could either be seen, the tips of its large claws and its antenna standing out, or conld be felt by inserting the end of an oar, the lobster tixing its large claws on the blade and sometimes allowing itself to be dragged out clear.

The holes had sometimes a relatively large opening of 8 to 10 inches in diameter, which allowed of their being readily probed and measured with an oar blade. I did not observe that they ever had an upward or downward eurve, but they sometimes swerve to the right or left, which is explained, perhaps, by the presence of some obstacle in the path. In some cases the holes were made beneath rocks, and the entrauce was often much larger than that described, owing, perhaps, to the union of the mouths of two originally distinct burrows. The pile of dirt and the brokeu clam shells which are sometimes seen near the hole of the lobster recall the excavations of the muskrat. It is exceptional to see a lobster with its tail projecting from the burrow. I saw one or two under these circumstances, and when touched they immediately disappeared. I thonght that possibly they might be engaged in digging while in this position, but this was evidently not the case, as the water about the hole was very clear. These ponnds are often much roiled, so energetically do the lobsters turn over the bottom and dig into the banks. On this account it is not easy to wateh the process of excavation, which in all probability is carried on at night.

I was informed by one fisherman, who had hunted lobsters quite extensively along the north Atlantic coast, that he had frerpently taken lobsters out of holes in the mud and eelgrass, while wading in shallow water. It has been observed in pounds that a cold snap in winter will cause the lobsters to burrow suddenly in the mud, so that they can not be taken in traps for several days. We have already noticed the probable oceurrence of the same thing in Newfoundland, when the temperature of the water is abruptly lowered. (See pp. 21, and 26, note 1.)

The burrowing habits of certain species of crayfish are well known, while those of the Stomatopods, which have been described by Professor Brooks, (261 $)$ are equally characteristic. We meet with the same habit in many shrimp, such as Alpheus, expressed in a greater or less degree; in crabs, and in a great number of the lower crustacea.

\section{THE FOOD OF THE LOBSTER AND HOW IT IS PROCURED.}

The food of the lobster consists principally of fish, alive or dead, aud of inverte. brates which inhabit the bottom and come within its reach. It is not unusual to find bits of alga, such as the common eelgrass, in its stomach, and sometimes in such quantities as to show that it is not an accidental occurrence. Vegetable matter, however, forms, at most, but a small part of its rliet. Fragments of dead shells are 
frequently met with, and in lobsters from 3 to 4 inches long, under very peculiar circumstances. (See pp. 89 and 90.) Coarse sand and gravel-stones, occasionally as large as duck shot, may also be found in the stomach, but with no marked regularity. These are not necessary for grinding the food, as in the gizzards of fowls, since the walls of the lobster's stomach are furnished with an admirable masticatory apparatus; still, whether of accidental occurrence or not, they can hardly fail to serve a useful purpose.

In the course of this investigation of the habits of the lobster, the stomachs of large numbers of these animals were earefully preserved during a period of seven months (December to June). They were all captured in the harbor of Woods Hole, Massachusetts, under the couditions described on p. 25. A considerable number of these stomachs were empty; more than half contained remnants of recently devoured fish, a mass of scales and bones, mixed with fragments of the indigestible parts of other organisms. In many cases it was quite evident that the bait of the traps formed the only food found in their stomachs.

The lobster undoubtedly regurgitates the insoluble and indigestible parts of its food. That the crayfish possesses this power was shown by the experiments of Lemoine (118). When the buccal cavity was stimulated by electricity, autiperistaltic movements were set up in the remaining parts, until the contents of the stomach escaped by the mouth. It was thus proved that the cesophagus was capable of two kiuds of movements-peristaltic and antiperistaltic. Some such outlet for waste matter is absolutely necessary in an animal where the fluid or finely divided and digestible parts of the food only can pass into the delicate intestine. The hard parts of fish, mollusks, and erustacea appear to be retained until they have given up a good deal of their lime, thus contributing to the calcareous supply of the exoskeleton.

The stomachs examined contained remnants of the following organisms placed in the order of their relative abundance: fish (procured independently of the traps); crustacea, embracing chiefly isopods and decapods; mollusca, consisting largely of small univalves; algæ; echinoderms aud hydroids. The bones of fish showed them to belong, as a rule, to small individuals or species. Among the crustacean remains parts of the small mud-crab, Panopaus ( $P$. sayi and $P$. depressus, the common species in Vineyard Sound) were almost invariably recognized, and it was not unusual to find parts of the skeletors of small lobsters. The isopod, Civolana concharum, is frequently eaten by the lobster, often in large numbers. This species is a scavenger, and devours the bait used in the traps, which explains its common occurrence in the stomachs of lobsters recently caught. In one case, that of a female captured in January, the stomach was filled with fresh lobster eggs in an advanced stage of development. These were not taken from any lobsters in the trap, but under what circumstances they were obtained one can easily conjecture. The egg-lobster is undoubtedly a shining mark, not only for outside enemies, but even for members of its own species. The larger mollusks are eaten by crushing the shells and picking out the soft parts, while many of the smaller species are swallowed entire, and afterwards pulverized in the gastric mill. Echinoderms probably enter largely into the diet of the lobster, wherever they abound. Parts of the common starfish (Asterias forbesii) and rarely a few spines of the sea-urehin (Arbacia punctulata) were detected, but it might be that the latter were swallowed together with other calcareous fragments. Very little change 
in the food was noticed during the winter and spring months, and there was liftle evidence that the appetites of these animals sensibly abated during the cold weather, yet it is probable that food is less abundant and less necessary in winter. (See pr. 24 , note 1 , and 25.$)$

That lobsters eateh fish alive there is no donbt, but few have ever seen this feat performed. Fish which inhabit the bottom, like the flounder, would naturally fall an easy prey to their powerful claws. They are said to catch the sculpin, and I have known a lobster which was confined in an aquarium at the United States Fish Commission station in the summer to seize and devour the sea-robin (Prionotus evolans).

The common blie crab (Callinectes hastatus) is said to capture fish, and fishermen report having taken haddock on trawls with the heads almost nipped off', as if cut by the claws of the lobster.

The smaller of the large claws is essentially a pair of toothed nippers, the hard tips of which are incurved so as to enable the animal to secme and hold every object which it can fairly seize. This is sometimes called the "fish claw" or the "quick claw" by fisbermen in Maine, while the heavy crushing-claw is called the "club claw," and according to Travis (191) it was known in England in the last century as the "knobbed" or "numb claw."

While lobsters are great seavengers, it is probable that they always prefer fresh food to stale. Some fishermen maiutain that there is no better bait than fresh herring.? Fresh codfish-heads, flatfish, sculpins, sea-robins, menhaden, and haddock are also used, as well as salted fish. The flesh of the shark is occasionally utilized by the Gay Head fishermen on account of its firmness and lasting qualities.

In the lobster pound at Southport, Maine, the lobsters are fed chiefly upon herring and sculpin. The fish are scattered around the shore and over the pond. They stop feeding them after the 1st of December, and the fall stock is taken out for the winter market in January, February, and Mareh.

In the large lobster pound at the Vinal Haven Islands $I$ have seen the muddy bottom scored in all directions-the work of lobsters in their search for clans. One is there remiuded of a pasture in which the soil has been rooted up by pigs. As a fisherman remarked, if you put lobsters in a pound and do not feed them, they will soon turn over the bottom as effectively as it could be done with a plow. Some of the holes which the lobsters had made in digging clams were 2 feet in diameter and 6 inches or more in depth. Here they had dug up the eelgrass, or loosened it so that it had floated to the surface, and cartloads of it had been cast ashore. We have already seen that lobsters sometimes eat parts of this plaut, ${ }^{2}$ but they had plainly rooted it up in this case with another object in view. The broken and often comminuted shells of the long-necked clam (Mya arenaria) could be seen strewn everywhere about their excavations.

The lobster probably attacks such large aud powerful mollusks as the conchs, which live upon hard bottom, in deep water, and devours their soft parts. Anillustra-

'I an told by Mr. M. B. Spinner, of Cliffstone, Maine, that many years ago, when lobsters were very abundant, he and his father userl "wash bait" in taking them. Fish, such as the mackerel, were minced up and put overboard. Then, as lobsters came flocking from all directions about the boat, they would gaff them.

:The grass-wrack, or eelgrass (Zostera marina), belonging to the pond-weed family (Vaiadacen), is, with one or two exceptions. the only flowering plant found growing submerged in salt water on the Now England coast. 
tion of this was afforded in an aquarium at Woods Hole in the summer of 1892, when a conch (Sycotypus canaliculatus) was placed in the same tank with a female lobster which was nearly 10 inches long aud which had been in captivity about eight weeks. The conch, which was of the average size, was not molested for several days, but at last, when hard pressed by hunger, the lobster attacked it, broke off its shell, piece by piece, and made quick work of the soft meat.

On many parts of the coast the lobster does not find any lack of dead fish for food. This is notoriously the case where seining is conducted on a large scale, as on the coast of Maine. One of the great evils attending this method of taking fish is the destruction wrought upon the young. In seining mackerel the catch is hoisted upon deck, where the fish are sorted, the larger, which are marketable, being saved while the smaller fry are thrown overboard. Owing to the rough treatment which they receive, and especially the exposure to the sum, the smaller fish are thus said to be destroyed by thousands. The lobsters in the vicinity profit by this evil, playing the part of scavengers.

If a lobster which has fasted for a number of hours is fed with a little fresh meat, such as a piece of clam or fish, the process of feeding will be found to be one of no little interest. The lobster eagerly seizes a piece of food with the chelæ of the third and fourth pairs of walking legs, and passes it up to the third pair of maxillipeds, which are held close together, each being bent at the fourth joint and folded on itself. With the third maxillipeds thus pressing against the mouth, the food is kept in contact with the other mouth parts, all of which are in motion, and their action is thus brought to bear upon it. By meaus of the cutting spines of the appendages external to the mandibles-maxillæ and first and second pairs of maxillipeds-the meat is as finely divided as in a sausage machine, and a stream of fine particles is passed constantly into the mouth, being previously submitted to the action of the inandibles.

If one wishes to watch the movements of the complicated mouth parts more closely, he has only to take a lobster out of the water, place the animal upon its back, and when it has become sufficiently quiet stimulate the mandibles or the broad plate of the large maxillipeds with the juice of a clam or the vapor of ammonia, which can be squirted with a pipette. Masticatory movements are immediately set up in the appendages, those belonging to the side stimulated usually working independently. The two small chelate legs are also drawn up rapidly to the mouth, as if to hand up pieces of food.

When stimulated in this way the plates of the first pair of maxillæ come together over the lower posterior half of the mandibles. The movements of the masticatory parts of the second maxillæ are synchronous with the beating of the scaphognathite. These project somewhat obliquely over the convex surfaces of the appendages in front, inward, and slightly upward. The large plates of the first maxillipeds work up and down, and at the same time inward toward the middle line, describing an ellipse. The second pair of maxillipeds move alternately or together, inward and outward, with slight up-and-down movement. The large maxillipeds move together, the toothed margins meeting like the edges of a nutcracker (compare fig. $68, \mathrm{pl} .30$ ), while the three terminal joints are bent inward and somewhat downward, as in the case of the second maxillipeds, so as to meet on the middle line below and hold the food up to the mouth. 


\section{Chapter II.-REPRODUCTION.}

\section{THE REPRODUCTIVE ORGANS.}

The breeding habits of an animal are not only of great scieutific interest, but of the utmost practical importance, in view of any experiments which we may undertake in its artificial propagation. When this work was begun the breeding habits of the lobster were very imperfectly understood, and until now no exhaustive study of the subject has been attempted. In questions of this kind, one may be led to draw conclusions from too slender data, since an abundance of carefully attested facts gathered from a sufticiently wide area can be attained only with great difficulty.

In the summer of 1891 I made as full a study as the time would allow of the reprodnctive organs aud habits of the lobster at Woods Hole, Massachusetts, and in the sunmer and fall of $1893 \mathrm{I}$ was able to add to my knowledge of this subject by materials gathered at different points along the northern Atlantic coast.

The reproductive organs will now be briefly considered, reserving a description of their structure and development for another part of this paper. (See Chapter X.)

The ovaries, or "coral" as they are sometimes called, consist of two cylindrical rods of tissue united by a transverse bridge in the upper part of the body, and are immeriately exposen upon opening the dorsal body wall. The uniting bridge of tissue probably represents the first trace of a fusion, which is expressed in various degrees in different Decapods. The ovarian lobes extend over about two-thirds the length of the animal, from behiud the head to the third, fourth, or fifth segments of the "tail," aud when approaching maturity are of a rich, dark-green color (plate 36, fig. 123; sea. also plate 38 ). The ripe ovaries are so much swollen that they fill all the available space in the upper parts of the body-cavity. The bead-like eggs are clearly seen through the thin ovarian wall, and when this is cut they flow out, if perfectly ripe, in an uninterrupted stream. When the congested ovary is not mature the loosened eggs stick together aud can not be easily disengaged withont injury. A fenale with egg's approaching maturity can be readily distinguished by extending the translucent membraue between the "tail" and carapace, through which the deep-green color of the ovary is at once apparent, but since the eggs can not be presised from the unyielding body of the auimal, there is no way of telling when these are ripe short of actual dissection.

The secondary organs of reproduction in the female are: (a) The oviducts, two short membranous tubes, which lead from the ovaries to the exterior, and open; one on each side, upon the basal segments of the second pair of walking legs; $(b)$ the copulatory pouch or seminal receptacle, for storage of spermato\%oa (plate 7 , and plate 38, fig. 130), situated between the bases of the thind pair of walking legs: $(c)$ cement glands, which secrete the material by which the egg's are fixed to the swimming legs (plate 40, fig: 144, and plate 49, figs. 211,212$):(d)$ the first pair of abdominal appendages, which are so reduced in size and modified as to be useless for swimming. 
The male reproductive organs are the testes (plate 36 , fig. 120), the ducts of which open at the base of the last pair of walking legs. The sperm which is inclosed in gelatinous capsules or spermatophores, the secretion of the seminal ducts, is thus ejected in packets. There is no penis or tubular extension of the integument from the opening of the duct, as is the case with the Brachyura.

The first pair of legs of the tail are also modified in a peculiar way in the male, as if. they served for conducting the spermatophores through the elastic, slit-like orifice of the seminal receptacle.

There are numerous secondary sexual distinctions, the most striking of which is seen in the abdomen. The latter is conspicuonsly broader in the female, a variation which is correlated with the greater size of the ovary as compared with the testis; its lateral plates are deeper and it is more conspicuously hollowed below to form an incubatory pouch for the ova. A discriminative fisherman can thus distinguish the sex at a glance. (Compare plates 4 and 6.) The large claws are more voluminous in the male than in the female, and the male attains the greatest size. This wonld imply that the male molts oftener than the female, which, according to the observations of Brook (26), is actually the case.

In addition to these distinctions Gouriet (82) found that in the crayfish the antennæ were longer in the males than in the females; that while the length of the abdomen of the male was relatively shorter, it was heavier than in the female. He found the length of the abdomen, compared with that of the carapace, to be in the proportion of 7 to 6 in the female, while in the male this difference in leugth did not exceed $\frac{1}{15}$ inch.

In the male lobster the second pair of swimmerets carries a small spur on its inner blade, the function of which is obseure. The reduction of the first pair of abdomiual appendages in the female is in all probability correlated with their use in reproduction. If they were of the normal size they would eatch so many eggs at the time of oviposition that it would be next to impossible for the fernale to completely flex the abdomen. Locomotion would thus be interfered with, and the eggs would be constantly exposed. As it is, it sometimes happens in very large females, where the ova are excessively abundant, that it is impossible to completely fold the abdomen. (See p. 54.)

Each testis consists of a slender, grayish-white, sacculated tube filled with developing sperm cells (fig. 120, plate 36), and its coiled duct usually contains sperm in abundance. The spermatophore can be easily pressed from the duct, when the latter is dissected out. The sperm cells have a characteristic shape (fig. 129, plate 37) and are absolutely immobile in the conditions under which they are ordinarily observed, but it is impossible to suppose that this is always the case. Their complicated form, recalling that of the bell-shaped medusa, leads one to suspect that under the influence of some subtle and unknown stimulus, possibly of a chemical nature and coming from the cement glands or some other organ, they are able to execute independent and rapid movements through the water. ${ }^{1}$

${ }^{1}$ Cano states that he once detected amæboid movements in the rayed sperm-cells of the crab Maia. See observations quoted on p. 49. 
THE PAIRING OF THE LOBSTER AND OF OTHER CRUSTACEA.

The copulation of the lobster has never been seen, as far as I am aware, in any of the species, but we know that it takes place in spring aud summer at least, if not at other times of the year. If ripe fenales, or females even with newly laid eggs, are examined in . Inte of oluly at Woods Hole, the seminal receptacle is found to be almost. invariably charged with spermatozoa, and it is evident that copulation takes place, certainly in many cases, withont immediate reference to the condition of the animal. Thus on August 19 I examined a female lobster. which was 9 inches long and found her seminal receptacle loaded with sperm. The ovaries were of a light, greenish-yellow color, and in a very immature condition. This lobster had been impregnated at least two years before leer eggs would be ripe.

I was surprised to find the seminal ponch of another lobster, which was examined about the same time, to be charged with freshly deposited sperm, although it had just hatched a brood and was preparing to molt. It therefore seems probable that the male lobster has no means of discriminating the sexual condition of the female. This lobster, in the ordinary course of nature, would soon have lost in the molt the sperm with which she had been so recently supplien. The first copulation, which had occurred either before or shortly after the hatching of the brood, must have been followed by a second union in order to secure the fertilization of the next batch of eggs. These would not be due, moreover, until one year from this time. It is thus evident that the female lobster is not impregnated once for all and compelled to take the chances of fertilizing her eggs, but is approached more than once by the male. The molting of these animals, although subject to less variation in the adult female than in the male, renders this necessary. Females usually molt shortly after the hatching of a brood. Where the molting is accomplished just before the eggs are laid, which happens very rarely -I have noticed ouly two cases in the lobster-(see p. 80), copulation can precerle the act of extrusion by a fer days at the most.

A lobster which liad been kept in an aquarium for upward of two months in the summer, without access to the male, laid eggs which were normally fertilized. This and other facts which have just been mentioned show that the female lobster must in some cases be impregnated more than once before each reprodnctive period, and also that the spermato\%oa retain their vital activities for a long time, perhaps, as Bumpus suggests (30), from one to two years. This is not so remarkable, when w: onsider the lougevity of spermatozoa recorded by Sir John Lubbock (Weismanu's Essays, vol, 1, p. 52), who succeeded in keeping a queen ant until she was 15 years old, during which time she continued to lay fertile eggs. Fertilization must have taken place at the latest in the season when the insect was captured. "There has been no male in the nest since then," writes Lubbock, "and, moreover, it is, I believe, well establisher that queen ants and queen bees are fertilized once for all. Hence, the spermatozoa of 1874 must have retained their life and energy for thirteen years, a fact, I believe, unparalleled in physiology."

Observations on the copalation of the crayfish (Potamobius fluviatilis) have been made by Gerbe (4.3), Chantran, and other naturalists. The latest and most detailed account of Chantran, published in 1872 (39), is as follows: ${ }^{1}$

${ }^{I}$ In quotations from works in foreign languages, I shall give, for convenience, the English translation. The extract can be verified by reference to the original. 
The male crayfish deposits its fertilizing matter in the form of spermatophores upon the plates of the tail-fan and upon the plastron of the female. The time of egg-laying varies from two to forty-five days after copulation. When the time comes for the extrusion of the eggs, the female raises herself upon her feet, and then the abdominal appendages secrete for a number of hours a grayish, somewhat viscous mucus. She thereupon lies upon her back, bends her "tail" toward the opening of the oviducts, so as to form a kind of cistern or chamber, as deseribed by Lereboullet, into which during the following night the eggs are received as fast as they are expelled from the genital organs. This expulsion lasts from one to several hours. These eggs, which are always turned so as to present their whitish spot or cicatricula uppermost, in order to be fertilized the more readily, are thus found engulfed in the grayish mucus which fastens, in some degree, the swimmerets and the borders and extremity of the "tail" to the thorax. This also helps to bound the pocket or chamber, in which there is a certain amount of water inclosed with eggs and mucus. Immediately after egg-laying we can find in the water and mucus spermatozoids exactly like those contained in the spermatophores which are attached to the plastron, and from which, in fact, the sperm-cells proceed. The spermatozoids are thus in direct contact with the eggs and are in the presence of a vehicle which assists them to penetrate the ova. Fecundation is effected in this chamber, that is, outside of the genital organs of the female.

The spermatozoids found mixed with the eggs and mucus in the egg-chamber are like those found in the spermacophores and male sexual organs. In the course of the first three days after egg-laying these spermatozoids become spherical, pale, and continue immobile. After this they wither and become smaller, darker, and more irregular. Finally, when, after the fixation of the eggs, the excess of mucus has completely disappeared by means of pressure exerted by the incessant contractions of the abdomen, which takes place in from six to eight days after egg-extrusion, those spermatophores which still remain attached to the plastron consist of small white coriaceous filaments. The latter are either isolated or composed of several adhering together. They have nothing to show but a central cavity, in which the microscope can detect nothing but a few spermatozoids, more or less withered. The wall of the spermatophores preserves its thickness and remains, as before, composed of a hard, striated, tenacious mucus.

On the 10th of Oetober a small species of Cambarus copulated in an aquarium, in the following manner: The animals lay on their sides, aud the sternal surface of the thorax of the male was pressed closely against that of the female. The abdomen of the female was folded beneath that of the male. The male grasped with bis great claws the large pincers of the female, and thus held her securely, bringing also into service the walking legs. According to Andrews (Johns Hopkins Univ. Circ, vol. XIV, p. 74), the spermatophores, which I did not observe, are deposited in the annulus of the female, and the animals are firmly adherent by means of definite hooks and ridges on the appendages of the male and female respectively.

The following notes are interesting as showing how popular errors in regard to the breeding habits of lobsters have arisen. Some of these statements, mixed with a minimum of accurate observation, have been repeated so many times that they have almost assumed the semblance of truth.

Travis (191) writes to Thomas Pennant, in a letter on the habits of Homarus gammarus, published in $\mathbf{1 7 7 7}$, that lobsters "begin to breed in the spring and continue breeding most of the summer; they propagate more humano and are extremely prolific. Dr. Baster says he counted 12,444 eggs under the tail, besides those that remained in the body unprotruded. They deposit these eggs in the sand, where they are soon hatched." This curious contradictory statement is repeated by Herbst (88), who says that "they lay their eggs in the sand, where they are hatched by the sun." 1

'The same notion existed in regard to the breeding habits of crabs. Thus, Herbst says: "The sea crabs do not show so much care for their young as the crayfish. They try to deposit their eggs either on the shore in the sand or they commit them to the sea, which washes these eggs thus extruded in on the beach, where they are soon hatched by the sun, and the young seek again their proper element." Of the land crabs, he says: "They carry their eggs to the sea, where the females wash them off from their tails. They are then cast up by the sea on the beach, where they are hatched by the sun." 
Boeck asserts (20) in his history of the Norwegian lobster fishery, that a real act of copulation takes place, the male placing its double male member (moditied ajpendages of the first abdominal somite) into the onter genital openings of the female, and that the eggs are impreguated while they are yet in the ovary.

Fraiche $(\tilde{V} 0)$ says that the union of the sexes takes place in the fall of the year (October and November) for the common and Norwegian lobsters, and in the case of the former species extends into winter:

As with the crayfish, the sexual aet is accomplished belly to belly, and so closely and firmly do they clasp each other, that, if taken from the water at this period, it is with difficulty that they "an be separated.

He thinks that the seminal fluid is introduced directly into the oviducts, and says that the sides of the abdomen secrete a viscous substance which incloses the eggs and attaches them to the body of the female.

The question, How is the fertilization of the eggs effected in crustacea? is one which has been asked by naturalists from the days of Aristotle down to the present century, and it has received the most varied and contradictory answers. A brief account of the history of opinion on this subject has been given by Brocchi in his thesis on the male organs of the decapor crustacea, published in 1875 (25). One source of difficulty lay, as recent studies have proved, in supposing that the process was essentially the same in both Macrura and Brachyura.

Porzio ${ }^{1}$ and Cavolini $(36),{ }^{1}$ among the older writers, as Brocehi shows, had clearer ideas upon this question than their immediate successors. Thus the Neapolitan physician, Porzio, says, in his study on the lobster:

Organa autem propagationis et generationis sic constructa sunt, ut facilem non inveniam rationem qua maris semen, in femina corpus ejaculari, infundi, vel introiri possit.

\section{Cavolini also remarks in his memoir on generation, published in 1787, that-}

The crustacea copulate face to face, with the penis on the outside of the body; there is no intromission, for the papilla which we have shown to be present on the base of the last pair of legs ean scarcely serve to make a passage for the semen; the eggs are glued to the hairs of the female and are bathed in the semen (36).

Milne Edwards (58) in his Histoire Naturelle des Crustacés, publisher in 1834, expressed some true ideas upon the reproductive processes in the crustacea which were not comprehended by many subsequent writers. At the same time he falls into errors in regard to certain organs and their functions. He says that the first two pairs of abdominal appendages in the male, which are often so different from the following pairs, seem to serve as exciting organs in the act of reproduction, but that uaturalist. have been mistaken in regarding them as representing the penis. In many cases, as in Gegarcinus, their size would make it impossible for them to penetrate into the vulva, and he says "we have proved, by direct observation, that in others it is the lower end of the efferent canal which is alone introduced into the body of the temale." These appendages apparently assist in directing the penis towar the vulva, and possibly in exciting the latter. (See note 1, p.39.) He calls attention to the important fact that in the Anomura aud Macrura there is no copulatory pouch such as he had discovered

II have been unable to consult the original works of these writers, and give the culotations from them on the authority of Brocehi and Cano. 
in the Brachyura. In the Brachyura he found that a trne copulation took place: "The wands of the male penetrate into the copulatory pouches situated below the vulva of the female, and deposit there the semen, which is so held and preserved in that part that it may be turned over the eggs as fast as they pass ont." On the coasts of Brittany Milne Edwards found a female Cancer pagurus, which was fertilized, "and in which the extremities of the wands of the male were broken off after copulation, as happens in many insects; these organs remained inclosed in the copulatory pouches." As Brocehi (25) observes, Milne Edwards seems to have foreseen the presence of spermatophores, for in a subsequent work (59) he says, in reference to this observation, that since his attention has been directed to spermatophores it has seemed possible "that the sort of stopper in question left in the vulva may have beeu a body of that nature rather than a fragment of the penis."

In regard to the reproduction of the Macrura, where there is no internal seminal receptacle, the fecundation of the eggs, says Milne Edwards (58), is less easily understood:

It is generally admitted that in all these animals there is a true copulation, in consequence of which the seminal flaid is introduced into the interior of the generative organs of the female. If it were not so, it would be difficult to understand how the eggs, which fill the entire ovary, the first of which are laid a Iong time before the last are developed, come in contact with this fluid, as a necessary condition of their fertilization. But there is not, so far as I know, any direct observation which proves the existence of such a copulation, and the absence of a copulatory pouch leads us to suppose that in these animals the eggs are fertilized as in the cricket, or very shortly after they have left the bodv of the mother. After being received into the cavity of the ovary, the egg is directed little by little toward the external orifice of one of the oviducts, the walls of which secrete in spring a rather thick, albuminous liquid, which, hardening after the eggs are laid, forms a second external envelope.

This error of attributing the viscous secretion to the oviducts has been repeated by subsequent writers, notwithstanding the fact that it was corrected by Milne: Edwards $(60)$ in a subsequent work. He says in a note following a recapitulation of the observations of Lereboullet, that the glue by which the eggs are attached does not come from the walls of the oviduct, but is secreted by subcutaneous glands situated on the under side of the abdomen, between the bases of the appendages. A membranous penis is said to be formed by the subdermal portion of the seminal tube, which is here enlarged and has thickened walls. This dilated portion of the canal, the "vecteur" of the sperm, "is capable of evaginating and passing outside beyond the genital opening, to the borders of which it is inserted. It thus forms a tubular appendix, having the function of a penis."

Milue Edwards was undonbtedly mistaken in supposing that the large glandular segment of the vas deferens of the Macrura was evaginated in copulation. This, as Grobben remarked, would be mechanically impossible (83).

Duvernoy (57) in 1850 again raised the question whether fertilization in Decapod Crustacea took place at the moment the eggs were laid, and comes to the conclusion that in Macrura and some Brachyura, where there is no seminal reservoir, fecundation takes place without a true copulation. He says:

The way in which the oviducts are stuffed like sausages with large numbers of eggs arranged in line, when they have reached maturity, would not admit of an internal fertilization, except for those eggs which were brought near the orifice, unless there was a copulatory pouch or a seminal reservoir, before the mouth of which they must successively pass at the time of egg-extrusion, in order to be fertilized, as is the case with insects.

He supposed that in all cases where internal fecundation was impossible, the eggs were fertilized at the moment they were laid, as occurs in the tailless Batrachians; he 
had also the notion that the male helped the female to place her eggs under the abdomen and glue them to the swimmerets.

Apart from the physical imposibility of an internal (oppulation and fertilization, in the way which many have conjectured, the absence in the Michura of two important aceessory reprodnctive organs, the vagina and internal seminal receptacle, points at once to the fact that the eggs are fertilized ontside of the body. With the discovery of an external seminal pouch in the lobster, the function of which hat been curiously overlooker or misunderstood until Bumpus adled attention to it in 1891 (30), this is still further emphasized.

As Brochi and, more recently, Cano (32) have pointed out, the vagina and internal seminal reeptacle always ocenr in the biachyma in relation to the presence of a male penis (the terminal portion of the etterent durt which is sail to be capable of evagination), and imply a different method of copulation.

The common green crab (Carcinus monas), the pairing of which has been repeat edly observed, illustrates this process among the Brachyura. A pair of these crabs was brought into the laboratory at the United States Fish Commission at Woorls Hole on the 27 th of July. They were allierent solely by the intromittent organs of the male, which were introduced into the orifices of the oviducts of the female. The male had a hard shell; the female, which was smaller, a soft shell, conditions which seem to be necessary for copulation, as Cavolini (36) long ago showed, and as Bouchard-Chantraux (21) and Lafresnaye (111) independently observed. (25).

Cano gives the following account of the copulation of Maia (33):

The male crab runs to meet the female, lifts her up and places her beneath him, embraces her closely with his feet, and his claws hold her by the margin of the orbits or in the regiou of the antenno. In other cases the male turns upon its back, catehes hold of the female and draws her upon his belly. The whole action lasts about an hour.

It is undoubtedly true, as Cano has remarked, that in all the Macrura and Anomura, which have no internal receptaculum seminis, penis or vagina, there is no internal copulation and the sperm is never found in the ovary or its ducts.

\section{THE LAYING OF EGGS.}

In order to determine the time and limits of the breerling season of the lobster, it is necessary to collect and examine a large number of their egg's at different plitces and at different times of the year. The examination of the riuter or summer egg's alone will not suffice to solve the problem, as I have learned by my owu experience, and this explains why the question has been the subject of so many contlicting statements and has remained uusettled down to the present day. (For a review of this question see Nos. 98 and 101 of Bibliography.)

The following quotations illustrate the confusion which has surrounded this important subject. Verrill (196) remarks:

There is a great difference in the breeding season on different parts of the coast. The lolsters from New London and Stonington often lay their eggs as early as the last of April or first of May; while at Halifax Mr. Smith found females with recently laid eggs in September. At Eastport, Maine, the females carry their eggs in midsummer.

'The only intromittent organs noticed in this case were the slender wand-like appendages of the first abdoninal somite. The penis is probably introduces after the former have been withirawn. (Compare p. 37.) 
At the time this was written it was not known that the lobster usually carries her eggs for a period of ten or eleven months. It was, therefore, quite natural that Verrill should misconstrue the discriminative statement of Smith (182), who says:

The season at which the female lobsters carry eggs varies very much on different parts of the coast. Lobsters from New London and Stonington, Connecticut, are with eggs in April and May, while at Halifax, Nova Scotia, I found them with eggs, in which the embryos were just beginning to develop, early in September. A corresponding variation is noticed in the lobster of the European coast.

Verrill further says $(196$, p. 745$)$ :

Subsequent observations have shown that the breeding season of the lobster extends over a large part of the year. * * * Mr. Vinal N. Edwards has forwarded two living females, of medium size, taken in Vineyard Sound, December 12, both carrying an abundance of freshly laid eggs. He states that he finds about one in twenty carrying eggs at that season.

Wheildon says, in a paper published in 1875 (202), that the assumption that the lobster has a definite annual spawning season is an error, and that in February of that year he had obtained "spawn in several stages of development from newly laid eggs to the swimming larvæ."

The following statement of a member of the local government of Prince Edward Island expresses an opinion upon the breeding habits of the lobster, which is as misleading as it is common:

I feel certain that the close season has not and can not accomplish anything toward the first olject [protection for lobsters while spawning], as it is now admitted by everyone who has har any experience in packing, that lobsters in spawn are caught at all seasons of the year and that they have no particular season for spawning.

Bumpus concludes that-

The eggs are normally deposited during the months of July and August, and develop rapidly so long as the water is relatively warm. *** Large numbers of eggs collected during the winter months, both from the colder waters of Nahant as well as from the warmer waters of Woods Hole, were almost invariably in the same advanced stage of development-the eyes large and bright, the appendages well outlined, and the yolk occupying but a fraction, perhaps one-third of the surface exposure.

Out of hundreds of lobsters found "in berry" in May, 1890, at Woods Hole, "not a single one had eggs in early stages of development." (30)

After fluctuating from one view to another, I came to the conclusion that the breeding season was limited as defined in the paragraph just quoted, but as my obser. vatious had been restricted to the summer months and to the region about Woods Hole, I determined to extend them to other points of the coast and to other seasons of the year. The results of these inquiries I will now give in detail. They may be summarized as follows:

For the majority of lobsters there is a definite breeding season, which is the summer, July and August being the months in which the greatest number of eggs are laid. A minority, on the other hand, perhaps 20 to 25 per cent of the entire number of spawners, lay their eggs at other times of the year, in the fall and winter at least, if not also in the spring. The fall and winter eggs are normally extruded, and do not appear to be necessarily the product of the first reproductive period. A glance at table 12 shows that while the average size of the females is small, it is fully up to the average of all females captured during the same time.

I received an "egg-lobster," which is not recorded in the following tables, from Woods Hole early in December. It was 121 inches long, and its eggs were just past the egg-nauplius stage. If laid in July or August, they would have reached this stage in about 18 days. 
SUMUER EGGS IN VINEYARD SOLND.

The following tables illustrate the time of spawning of the lobster in the vicinity of Woods Hole, in Vineyand Sound, and about Gay llead. The date of the extrusion of the eggs is, of course, only approximately determinable. It is estimated fiom obser. vations ou the rate of development of embryos at Woods Hole. The parent lobsters were contined in tloating latticed boxes, which were exposed to the wash of the waves, in one instance, for nearly a year. (See table 18, p. 56.)

TABLE 3. - Time of spawning of the lobster in Fineyard Sound and vicinity in 188?.

\begin{tabular}{|c|c|c|c|c|c|}
\hline No. & Locality. & $\begin{array}{l}\text { Date of } \\
\text { capture. }\end{array}$ & Stage of development. & Age of embryo. & $\begin{array}{l}\text { Date of } \\
\text { "xtrusion } \\
\text { of eggss. }\end{array}$ \\
\hline I & Woods Hole Harbor.. & July 10 & Thoracic abdominal plate well marked ... & 8 to 9 days.... & July 1 \\
\hline 2 & Menemsha........... & July 11 & $\begin{array}{l}\text { At least four pairs of appendages behind } \\
\text { mandibles. }\end{array}$ & 20 to 21 days. & June 20 \\
\hline 3 & .... do. & ... do .... & Egg nauplius: second antenor bilobed.. & 14 to 15 dajs... & June 26 \\
\hline 4 & ivodo Hole Har & .. do ..... & do do & .... do .......... & Do. \\
\hline $\begin{array}{l}5 \\
6\end{array}$ & $\begin{array}{l}\text { Woods Hole Harbor. } \\
\text {.... do ................ }\end{array}$ & $\begin{array}{ll}\text {... do } \\
\ldots \text { do.... }\end{array}$ & Close of yolk segmentation. . . . . & 3 days .... & $\begin{array}{l}\text { Do. } \\
\text { July } 8\end{array}$ \\
\hline 8 & Menemisha...... & $\ldots$ do ..... & Yolk segmentation: 60 to 100 segments... & $1 \frac{1}{2}$ days ... & July 9 \\
\hline 9 & (jo do & ... do ..... & , do & ..... do .... & Do. \\
\hline 10 & W vods Hole Harbor. & ... do .... & .... do ... & & I1). \\
\hline 11 & ... do $\ldots \ldots \ldots . . .6$. & ...do .... & . do & .... do & Do. \\
\hline 12 & .... do & $\ldots$ do .... & $\begin{array}{l}\text { Early egg nauplius: second antennæ not } \\
\text { bilobed. }\end{array}$ & 10 days. & July 1 \\
\hline 13 & ..... do & July 16 & $\begin{array}{l}\text { Egg nauplius, later stage: secoud anten- } \\
\text { wæ bilobed. }\end{array}$ & 14 to 15 elays.. & Do. \\
\hline 14 & .... do & ... do & Close of yolk segmentation................ & 3 days & July 13 \\
\hline 15 & ..... do & ...do & $\begin{array}{l}\text { Thoracic abdominal plate becomiug prom- } \\
\text { inent. }\end{array}$ & $6 \mathrm{da}$ & July 10 \\
\hline 16 & ....do do & do .... & Yolk segmentation: 50 to 100 segments... & $1 \frac{1}{2}$ days .... & July 14 \\
\hline 17 & & July 18 & $\begin{array}{l}\text { Large thoracic abdominal plate. Pit ob- } \\
\text { scured. }\end{array}$ & & July 9 \\
\hline 18 & $\ldots$......... & July 20 & $\begin{array}{l}\text { Very slight in ragination: nuclei close to } \\
\text { surface. }\end{array}$ & 4 days... & July 16 \\
\hline $\begin{array}{l}19 \\
20\end{array}$ & .... do do..... & $\begin{array}{l}\text { July } 28 \\
\text { Aug. } 3\end{array}$ & 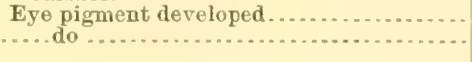 & $\begin{array}{l}27 \text { days } \ldots . \\
\ldots . \text { do } \ldots . . .\end{array}$ & $\begin{array}{ll}\text { July } & 1 \\
\text { July } & 7\end{array}$ \\
\hline
\end{tabular}

TABLE 4.-Time of spawning of the lobster in Vineyard Sound and vicinity in 1890.

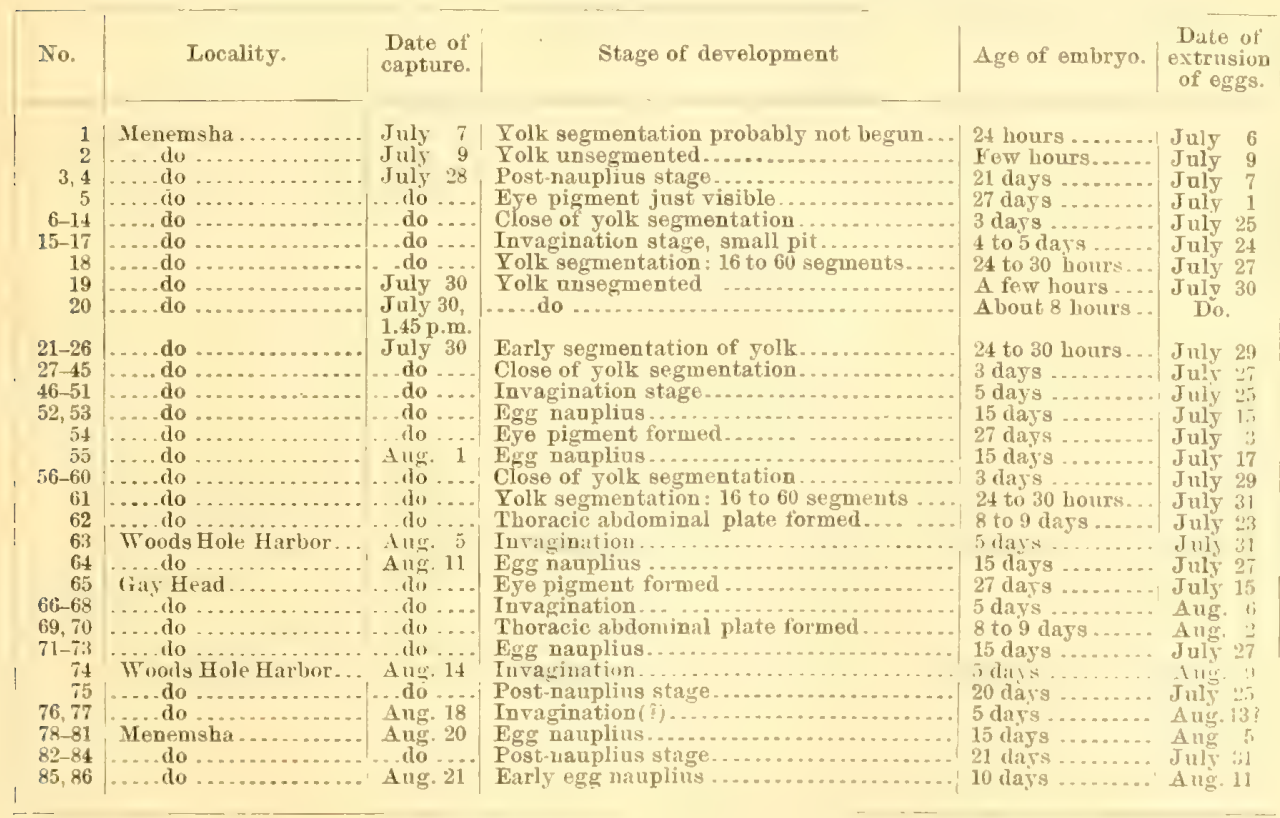


TABLE 5.-Time of spawning of the Tobster in Fineyard Sound and vicinity in 1891.

\begin{tabular}{|c|c|c|c|c|c|}
\hline No. & Locality. & $\begin{array}{l}\text { Date of } \\
\text { capture. }\end{array}$ & Stage of development. & Age of embryo. & $\begin{array}{l}\text { Date of } \\
\text { extrusion } \\
\text { of eggs. }\end{array}$ \\
\hline $\begin{array}{r}1 \\
2 \\
3 \\
4 \\
5 \\
6 \\
7 \\
8 \\
9,10 \\
11-13 \\
14-16 \\
17-21 \\
22 \\
23 \\
24 \\
25,26 \\
37 \\
28 \\
28 \\
29,30 \\
31 \\
32 \\
: 33 \\
: 34 \\
37,36 \\
37,38\end{array}$ & 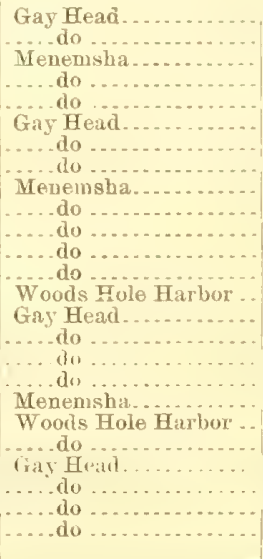 & 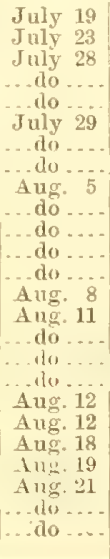 & 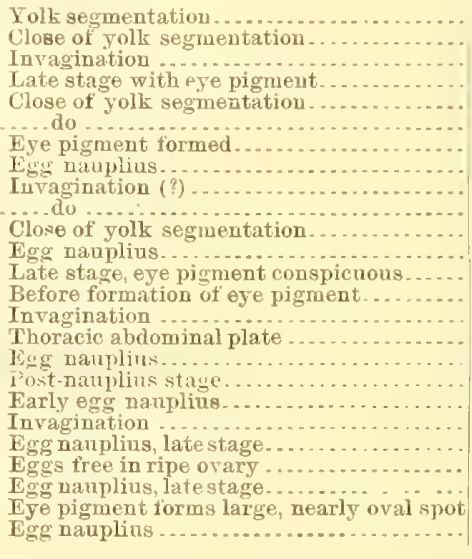 & 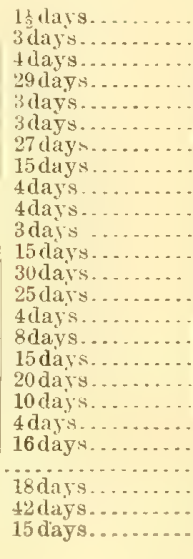 & $\begin{array}{l}\text { July } 17 \\
\text { July } 20 \\
\text { July } 24 \\
\text { June } 29 \\
\text { July } 25 \\
\text { July } 26 \\
\text { July } 2 \\
\text { July } 14 \\
\text { Aug. } 1 \\
\text { Do. } \\
\text { Aug. } 2 \\
\text { July } 21 \\
\text { July } 6 \\
\text { July } 14 \\
\text { Aug. } 7 \\
\text { Aug. } 3 \\
\text { July } 27 \\
\text { July } 22 \\
\text { Aug. } 2 \\
\text { Aug. } 8 \\
\text { Aug. } 2 \\
\text { Aug. } 3 \\
\text { July } 10 \\
\text { Aug. } 6\end{array}$ \\
\hline
\end{tabular}

TABLE 6.-Time of spawning of the Tobster in Vineyard Sound in 1892 and 1893.

\begin{tabular}{|c|c|c|c|c|c|}
\hline No. & Locality. & $\begin{array}{c}\text { Date of } \\
\text { capture. }\end{array}$ & Stage of development. & A ge of embryo. & $\begin{array}{c}\text { Date of } \\
\text { extrusion } \\
\text { of eggs. }\end{array}$ \\
\hline $\begin{array}{r}1 \\
2 \\
3 \\
4 \\
5 \\
6 \\
7 \\
8 \\
1-3 \\
4 \\
5 \\
6\end{array}$ & 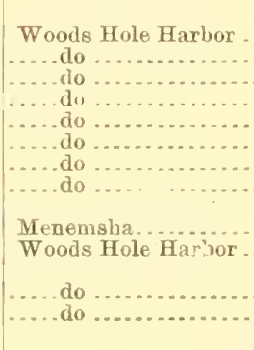 & $\begin{array}{l}1892 . \\
\text { July } 29 \\
\text { July } 30 \\
\text { Aug. } 1 \\
\text { dug. } 1 \\
\text { Aug. } 3 \\
\text { do do... } \\
\text { Aug. } 6 \\
1893 . \\
\text { Jult } 25 \\
\text { Aug. } 11 \\
\text { Aug. } 15 \\
\text {. do }\end{array}$ & 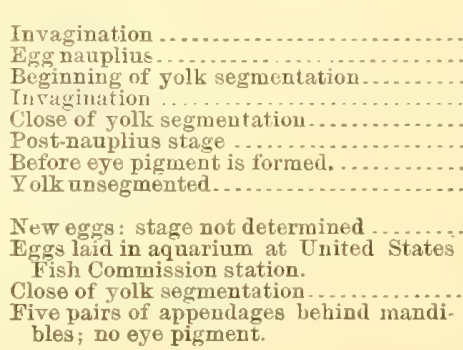 & 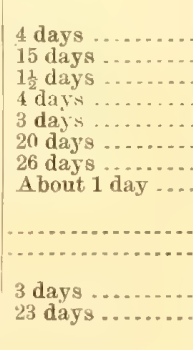 & \begin{tabular}{|} 
July 25 \\
July 15 \\
July 31 \\
July 28 \\
Jaly 31 \\
July 14 \\
July 8 \\
Aug. 5 \\
\\
About \\
Aug. 10 \\
Aug. 12 \\
July 23
\end{tabular} \\
\hline
\end{tabular}

TABLE 7.- Tariation in time of spawning of lobsters in Vineyard Sound and vicinity in the years 1889-93.

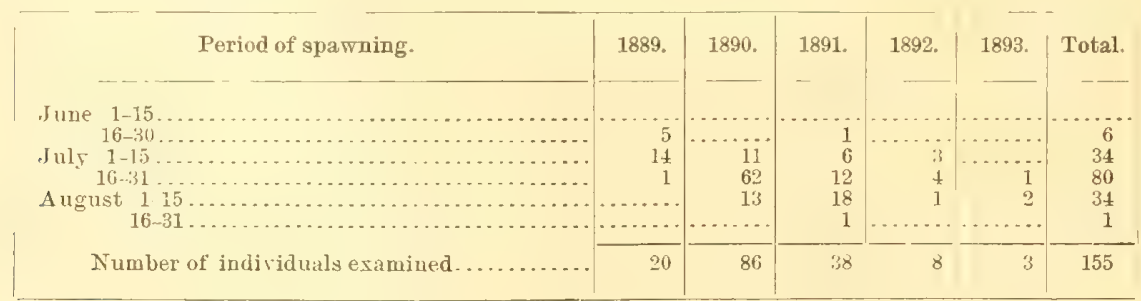

The data afforded by the preceding tables lead us to conclude that the summer eggs are produced in this region during a period of about nine weeks, extending from the middle of June to the middle or last of Angust, the largest number being laid 
during the latter half of July and the first two weeks of August. The summer spawning of each year lasts about six weeks, but may fluctuate from year to year, backward or forward through an interval of a fortnight.

The observations for the years 1890 and 1891 only, are large enongh to make a comparison of much value. Of the 86 lobsters with new eggs examined in July and Angust, 1890, 85 per cent extruded eggs in July and 15 per cent in August, while in the following year, out of 38 females, one-half had laid in July and half in August. In 1890, however, 72 per cent of the eggs were laid in the latter half of July and 15 per cent in the first half of August, while in 189147 per cent were extruded in the first part of August and 31 per cent in the latter half of July. The season of 1891 thus appears to have been somewhat later than that of the former year.

The record of ocean temperatures given in table $2(p .25)$ shows that the water was cooler in 1891 than in the precerling year, the difference of the mean annual temperatures being 1.6\%. This difference is slightly raised by eliminating the month of June, when the smallest number of lobsters carry eggs. It is possible that so small a variatiou as is here recorded in the mean annual temperature of the sea water would sensibly affect the rate of development, yet a larger number of observations would be required before this could be satisfactorily shown.

There are undoubtedly other causes than the temperature changes which influence the growth of the ovarian eggs, which it must be remembered require at least two years to reach maturity. Anything which affects the individual during this interval may affect also the time of spawning, and this affords a partial explanation of the fact that eggs are sometimes produced at other seasons of the year than the summer.

\section{SUMMER EGGS ON THE COAST OF MAINE.}

Tables 8, 9, and 10 throw more light on the time of spawning upon the coast of Iaine, where the water is somewhat cooler than at Woors Hole. The range of temperature in the Gulf of Maine is about the same as that obtained at Pollock Rip light-ship, off the southern end of Cape Cod, namely, $32^{\circ}$ to $62^{\circ} \mathrm{F}$.

TABLE 8.-Time of spawning at Southport, Maine.

[A[any of the lobsters were captured in Nova Scotia and brought to Southport before laying their eggs.]

\begin{tabular}{|c|c|c|c|c|c|}
\hline No. & Place of spawning. & $\begin{array}{c}\text { Date of } \\
\text { exami- } \\
\text { nation of } \\
\text { eggs. }\end{array}$ & Stage of development. & $\begin{array}{c}\text { Age } \\
\text { of em- } \\
\text { bryo. }\end{array}$ & $\begin{array}{l}\text { Date of } \\
\text { extrusion } \\
\text { of eggs. }\end{array}$ \\
\hline 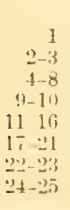 & 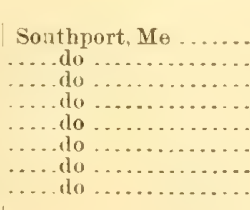 & 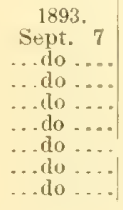 & 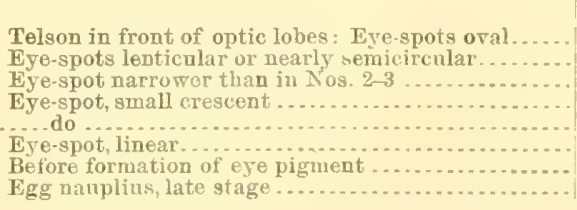 & $\begin{array}{l}\text { Days. } \\
61 \\
35 \\
33 \\
30 \\
29 \\
27 \\
25 \\
18\end{array}$ & $\begin{array}{l}\text { July } 8 \\
\text { Aug. } 3 \\
\text { Ang. } 5 \\
\text { Aug. } 8 \\
\text { Aug. 9 } \\
\text { Aug. } 11 \\
\text { Aug. 13 } \\
\text { Aug. } 20\end{array}$ \\
\hline
\end{tabular}


TABLE 9.-Time of spawning of the lobster at different points on the coast of Maine."

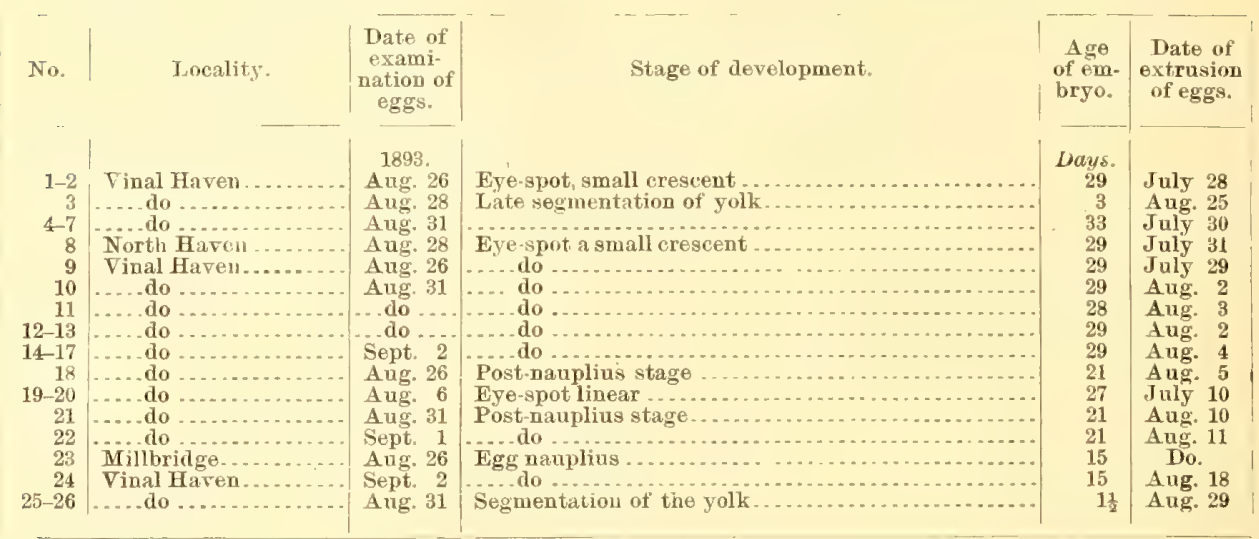

The results given in tables 8 and 9 are combined in table 10 , which may be compared with table 7 . In the first column, taken from table 8 (in which some of the lobsters were brought from Nova Scotia to Southport, Maine), all but three individuals extruded eggs during the first half of August. In the second column 46 per cent laid eggs during the same period. Combining the results of the observations at Woods Hole for five years, 1889-1893 (table 7), we find that 52 per cent of egg-bearing lobsters, in all cases observed, laid in the latter half of July, while about 21 per cent spawned during the first half of July and an equal unmber in the first half of August. We find that 66 per eent of the individuals recorded in table 10 laid eggs during the first half of August. These results tend to show that the summer spawning season in the middle and eastern districts of Maine is about two weeks later than in Vineyard Sound.

TABLF 10.-Time of spawning of the lobster on the coast of Maine for the summer of 189.3.

\begin{tabular}{|c|c|c|c|}
\hline Spawning period. & $\begin{array}{c}\text { Data from } \\
\text { table } 8 .\end{array}$ & $\begin{array}{c}\text { Data from } \\
\text { table } 9 .\end{array}$ & Totals. \\
\hline $\begin{array}{l}\text { July } 1-15 \ldots \ldots \\
\text { July } 16-31 \\
\text { August } 1-15 \ldots \ldots \\
\text { Angust } 16-31 \ldots \ldots\end{array}$ & $\begin{array}{r}1 \\
0 \\
22 \\
2\end{array}$ & $\begin{array}{r}2 \\
8 \\
12 \\
4\end{array}$ & $\begin{array}{r}3 \\
8 \\
34 \\
6\end{array}$ \\
\hline Number examined... & 25 & 26 & 51 \\
\hline
\end{tabular}

FALL AND WINTER EGGS AT WOODS HOLE.

The catch of egg-bearing lobsters in the harbor of Woods Hole for seven consecutive months is given in table 11 . Out of a total of 168 captured, 21 per cent were taken in January, 6 per cent in February, and 20 per cent in April. Of the entire number, 25.5 per cent bore eggs which had been laid during the fall and winter months. This fact was determined in the following way. Some of the eggs of every lobster captured were preserved and carefully examined. Where no eye pigment was present it was at once evident that the eggs bad been laid at a comparatively recent date. In all other cases the pigmented areas of the eyes were drawn to scale and compared with

${ }^{1}$ For the collection of eggs at various points on the coast aud islands north of Massachusetts I am particularly indebted to Messrs. F. W. Collins of Rockland, M. B. Spinney of Cliffstone, J. W. Fisher of Eastport, and also to Mr. Greenleaf of Vinal Haven, Maine. 
a series of similar drawings of embryos developing undex normal conditions from summer eggs.

The eye pigment furnishes the most convenient scale for the measurement of the rate of development of the embryo as a whole, since it appears early, is clearly defined, and since the development of the eye is correlated with that of the other organs of the body. Where the ocular pigment forms a thin crescent in eggs taken in January, the embryo will be found in a stage of development similar to that reached in the summer eggs four weeks after fertilization. In such a case, it is a safe inference that the ova have been laid in the fall. Again, when in May or early June the area of ocular pigment is not greater or is less than that observed in summer eggs by the first of September (cut 36, pl. J), we may be confident that such eggs were extruded later than the previous summer.

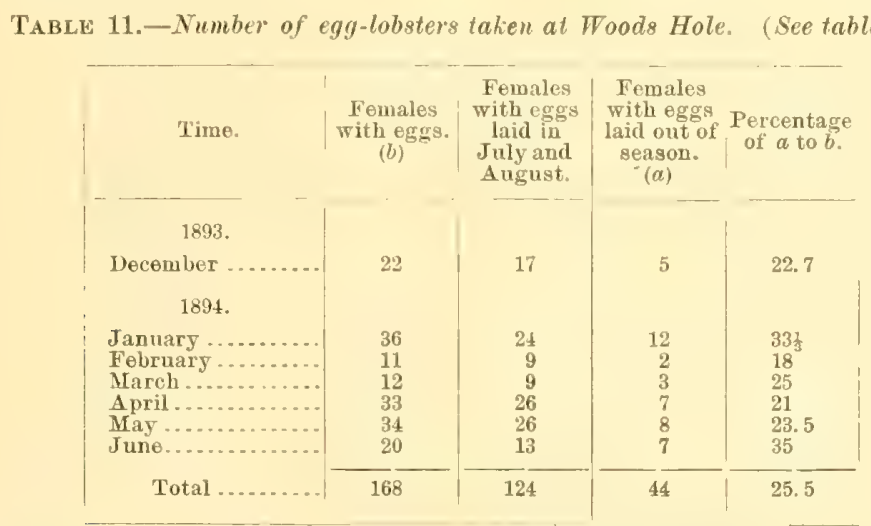

Table 12 shows the stage of development of the eggs of 44 lobsters taken under the conditions described (1).25) and compared with the normal coudition of summer eggs shown in table 18, lobster No.3 (1) to (20). These comparisons are rendered clearer by a series of drawings (euts 23-38) made from the eggs of this lobster.

TABLE 12.-Stage of development of eggs laid in fall and winter at Woods Hole.

\begin{tabular}{|c|c|c|c|c|c|c|c|}
\hline No. & Date. & $\begin{array}{l}\text { Leugtl } \\
\text { in } \\
\text { inches. }\end{array}$ & Stage of development. & No. & Date. & $\begin{array}{l}\text { Length } \\
\text { in } \\
\text { inches. }\end{array}$ & Stage of development. \\
\hline 1 & $\begin{array}{c}1893 . \\
\text { Dec. } 20\end{array}$ & $10 \frac{1}{4}$ & No eyo pigment. Like stage 3 & 22 & $\begin{array}{c}1894 . \\
\text { Mar. } 15\end{array}$ & $9 \frac{1}{2}$ & Like 3 (11), table 18 \\
\hline & & & (7), table 18 & 23 & Apr. 16 & $10^{2}$ & Little earlier than $3(10)$, table 18. \\
\hline 2 & Dec. 23 & $9 \frac{1}{2}$ & Forked telson overlaps brain. & 24 & Apr. 17 & 10 & Like 3 (9), table 18 \\
\hline 3 & & & Like preceding. & 25 & Apr. 17 & 10 & Little earlier thau $3(10)$, table 18 . \\
\hline 4 & Dee, 26 & ${ }_{10}^{8}$ & Like 3 (11), table 18 . & $\begin{array}{l}26 \\
27\end{array}$ & Apr. 18 & $\operatorname{li}_{81}$ & Little earlier than $3(9)$, table 18. \\
\hline 5 & Dec. 27 & 8 & Trifle later than $3(9)$, table 18. & 28 & Apr. 20 & $10 \frac{2}{2}$ & $\begin{array}{l}\text { Like } 3 \text { (9), table } 18 . \\
\text { Like } 3 \text { (10), table } 18 .\end{array}$ \\
\hline & $\operatorname{Jan}_{1}^{1894}$ & 114 & & $\begin{array}{l}29 \\
30\end{array}$ & $\frac{\text { Apr. } 21}{\text { Mav }}$ & $\begin{array}{r}9 \\
102\end{array}$ & Little earlier than 3 (9), table 18. \\
\hline$\frac{6}{7}$ & $\begin{array}{ll}\text { Jan. } & 1 \\
\text { Jan. } & 2\end{array}$ & $\begin{aligned} 11 \frac{1}{2} \\
9 \frac{1}{5}\end{aligned}$ & $\begin{array}{l}\text { Like } 3(9) \text {, tablo } 18 . \\
\text { Like } 3(10) \text { table } 18 .\end{array}$ & 30 & May 1 & $10 \frac{1}{2}$ & Little earlier than $3(10)$, table 18. \\
\hline 8 & Jar. 3 & $11 \frac{2}{3}$ & $\begin{array}{l}\text { Like } 3(10) \text {, table } 18 . \\
\text { Like } 3(9) \text { table } 18 .\end{array}$ & $\begin{array}{l}51 \\
32\end{array}$ & May & $10^{3}$ & Like 3 (10), table 18 . \\
\hline 9 & Jau. & $9 \frac{1}{2}$ & Like 3 (11), table 18 . & 33 & May & 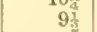 & Like $3(9)$ table 18 . \\
\hline 10 & Jan. 4 & $9^{2}$ & Eye pigment just isible. & 34 & $\overline{\mathrm{M}} \mathrm{aJ} \quad 9$ & $10^{-3}$ & Like 3 (9), table 18. \\
\hline 11 & Jan. 9 & 10 & Like 3 (6), table 18 & 35 & May 10 & 10 & Little later than 3 (9), table 18. \\
\hline 12 & Jan. 11 & $10 \frac{x}{4}$ & Like $3(10)$, table 18. & 36 & May 11 & 7 & Little later than $3(9)$, table 18 \\
\hline 13 & Jan. 12 & $10^{4}$ & Like $3(10)$, table 18. & 37 & May 12 & 9 & Little earlier than $3(9)$, table 18 . \\
\hline 14 & Jan. 13 & 10 & Like 3 (9), table 18. & 38 & June 7 & 9 & Like 3 (11), table 18. \\
\hline 15 & Jan. 20 & 9 & Like 3 (10), table 18 & 39 & June $i$ & 11 & Like 3 (11), table 18. \\
\hline 16 & Jan. 27 & 10 & Like $3(10)$, table 18. & 40 & June 9 & $8 \frac{1}{2}$ & Like 3 (11), table 18. \\
\hline 17 & Jan. 31 & 10 & Like 3 (9), table 18 & 41 & June 8 & $11^{2}$ & Lit tle earlier than (11), table 18. \\
\hline 18 & Feb. 19 & 93 & Like 3 (11), table 18. & 42 & June 11 & $10 \frac{1}{3}$ & Like 3 (11), table 18 \\
\hline 19 & Feb. 5 & 9 & Like $3(9)$, table 18 & 43 & Jane 12 & $10^{-}$ & Like 3 (11), table 18 . \\
\hline 20 & Mar. 10 & $10 \frac{3}{5}$ & Like 3 (11), table 18 & 44 & June 14 & 91 & Like 3 (11), table 18. \\
\hline 21 & Mar. 13 & $10 \frac{1}{2}$ & Like 3 (11), table 18. & & & & \\
\hline
\end{tabular}


FALL AND WINTER EGGS IN O'PHER PLACES.

The conclusion that the production of eggs in the fall and winter is of general occurrence throughout the entire range of the lobster is supported by the obserrations recorded in table 13. Here are eggs, none of them laid during the summer months, coming from a wide area from the middle and eastern parts of the Maine coast, from the outward islands, and from the province of New Brunswick. They are compared, as before, with the rate of development of summer eggs observed at Woods Hole [lobster No. 3 (1) to (20), table 18]. In one instance, No. 20, the yolk is unsegmented, though taken in February; in others the egg nauplius, which in summer appears at about the fourteenth day, is barely outlined.

TABLF 13. - Stage of development of eggs laid in fall and winter on the coasts of Maine and Province of New Brunswick.

\begin{tabular}{|c|c|c|c|c|c|c|c|}
\hline No. & Date. & Locality. & $\begin{array}{c}\text { Stage of } \\
\text { development. }\end{array}$ & No. & Date. & Locality. & $\begin{array}{l}\text { Stage of } \\
\text { development. }\end{array}$ \\
\hline & 1893. & & & & 1894 & & \\
\hline 1 & Not. 10 & Isle au Haute. & Like 3 (9). & 21 & Feb. 5 & Matinicus Island & Like $3(10)$. \\
\hline 2 & Noy. 15 & York Island . & $\begin{array}{l}\text { Late segmen- } \\
\text { tation of }\end{array}$ & $\begin{array}{r}22 \\
23 \\
24\end{array}$ & $\begin{array}{l}\text { Feb. } 8 \\
\text { Feb. } 10\end{array}$ & Ragged Island... & $\begin{array}{l}\text { Like } 3(8) \text {. } \\
\text { Like } 3(10) \text {. }\end{array}$ \\
\hline 3 & Nox. 25 & Cranberry Isle.. & $\begin{array}{l}\text { Egg nanplius. } \\
\text { Earlier thau }\end{array}$ & $\begin{array}{l}24 \\
25 \\
26\end{array}$ & $\begin{array}{l}\text { Feb. } 14 \\
\text { Feb. } 17\end{array}$ & $\begin{array}{l}\text { Long Island ........... } \\
\text { Matinieus Island.... }\end{array}$ & $\begin{array}{l}\text { Like } 3(4) \text {. } \\
\text { Like } 3(10) .\end{array}$ \\
\hline & & & $4(3)$ & 27 & Feb. 21 & Mount Desert. . . . . . . . & Like 3 (8). \\
\hline 4 & $\begin{array}{c}\text { Dec. } 11 \\
\text { 1894. }\end{array}$ & Matinicus Island & $\operatorname{Lik} \theta 3(9)$ & $\begin{array}{l}28 \\
29\end{array}$ & Feb. 22 & Cranberry Isle. - & Like 3 (9), \\
\hline 5 & Jan. 11 & $\begin{array}{l}\text { Beaver Harbor, Bay } \\
\text { of Fundy. }\end{array}$ & Like 3 (10). & $\begin{array}{l}30 \\
31\end{array}$ & $\begin{array}{ll}\text { Mar. } & 1 \\
\text { Mar. } 10 & \end{array}$ & $\begin{array}{l}\text { North Haven... } \\
\text { Isle au Haute... }\end{array}$ & $\begin{array}{l}\text { Like } 3 \text { (5). } \\
\text { Like } 3(10) \text {. }\end{array}$ \\
\hline 6 & Jan. 13 & Monnt Desert ....... & I ike $3(9)$. & 32 & Mar. 13 & Matinicus Island & Like 3 (9). \\
\hline$i$ & Jax. 15 & Cranberry Isle. & Jike 3 (10). & 33 & Mar. 15 & Fork Island.... & Like 3 (9). \\
\hline 8 & Jan. 17 & Isle au Haute.. & Like 3 (9). & 34 & Mar. 20 & Cranberry Isle & Like 3 (9). \\
\hline 9 & Jau. 18 & Eastport................... & Like $3(10)$. & 35 & Mar. 22 & Ragged Island. . & Like 3 (9). \\
\hline 10 & Jan. 18 & $\begin{array}{l}\text { Musquash Bay, } 35 \mathrm{~m} \text {. } \\
\text { east of Eastport. }\end{array}$ & Like 3 (9). & $\begin{array}{l}36 \\
37\end{array}$ & $\begin{array}{l}\text { Mar. } 27 \\
\text { Mar. } 29\end{array}$ & $\begin{array}{l}\text { Fox Island } \\
\text { Matinieus Island }\end{array}$ & $\begin{array}{l}\text { Like } 3 \text { (9). } \\
\text { Like } 3 \text { (9). }\end{array}$ \\
\hline 11 & Jan. 19 & $\begin{array}{l}\text { Seeley Basin, } 24 \mathrm{~m} . \\
\text { from Eastport. }\end{array}$ & Like $3(10)$. & $\begin{array}{l}38 \\
39\end{array}$ & $\begin{array}{l}\text { Mar. } 30 \\
\text { AnT. } 1\end{array}$ & $\begin{array}{l}\text { Brimstone Island } \\
\text { Swan lsland.... }\end{array}$ & $\begin{array}{l}\text { Like } 3 \text { (11). } \\
\text { Like } 3(9) .\end{array}$ \\
\hline 12 & Jan. 20 & Baker Island ........ . . & Like $3(10)$. & 40 & A pr. 5 & Fox Island.. & Like 3 (10). \\
\hline 13 & Јап, 20 & Otter Creek....... & Like 3 (9). & 41 & Apr. 10 & Eastport.... & Like $3(10)$. \\
\hline 14 & Jan. 21 & Eastport.................... & $\begin{array}{l}\text { Eye pigment } \\
\text { just visible. }\end{array}$ & $\begin{array}{l}42 \\
43\end{array}$ & $\begin{array}{l}\text { Apr. } 15 \\
\text { Apr. } 24\end{array}$ & 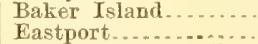 & $\begin{array}{l}\text { Like } 3(10) . \\
\text { Like } 3(10) .\end{array}$ \\
\hline 15 & Jan. 22 & $\begin{array}{l}10 \text { miles from st. } \\
\text { John, N. } \mathrm{B} \text {. }\end{array}$ & Like $3(10)$. & 44 & Apr. 26 & $\begin{array}{l}\text { Deer Island, } 4 \text { miles } \\
\text { from Eastport. }\end{array}$ & Like 3 (11). \\
\hline 16 & Jan. 24 & $\begin{array}{l}18 \text { miles from st. } \\
\text { John. N.B. }\end{array}$ & Like $3(10)$ & $\begin{array}{l}45 \\
46\end{array}$ & $\begin{array}{l}\text { Apr. } 30 \\
\text { A pr. } 30\end{array}$ & $\begin{array}{l}\text { Eastport } \\
\text { Islesboro }\end{array}$ & $\begin{array}{l}\text { Like } 3 \text { (11). } \\
\text { Like ? (11). }\end{array}$ \\
\hline 17 & Jan. 27 & Brimstone Isle... & $\begin{array}{l}\text { Like3(4). Late } \\
\text { egg nauplius. }\end{array}$ & $\begin{array}{l}47 \\
48\end{array}$ & $\begin{array}{l}\text { May } 1 \\
\text { June } 10\end{array}$ & $\begin{array}{l}\text { Green Island... } \\
\text { Matinicus Island }\end{array}$ & $\begin{array}{l}\text { Like } 3(11) . \\
\text { Like } 3(9) .\end{array}$ \\
\hline 18 & Јаม. 29 & Isle au Haute.... & Like $3(6)$ & 49 & June 8 & York Island .... . & Like $3(9)$. \\
\hline 19 & Jan. 17 & Spoon Island .... & Like $3(9)$ & 50 & June 13 & Vinal Haven. - & Like 3 (10). \\
\hline 20 & Feb. 4 & Matinicus Island .... & $\begin{array}{l}\text { Yolk unseg- } \\
\text { mented. }\end{array}$ & 51 & June 20 & High Island... & Like 3 (11). \\
\hline
\end{tabular}

Mr. N. F. Trefethen, of Portland, who deals extensively in lobsters, and who has a lobster pound in South Bristol, 35 miles east of Portland, believes that some lobster's in that vicinity spawn in June. In support of this view he cited the following case: In the latter part of May, 1893, he placed 20,000 lobsters in his pound and took them all out at intervals in the month of July, beginuing the first of the month. All the lobsters had been examined before they were placed in the pound, and none of them were kuown to be with spawn. At the most only a relatively few egg-lobsters could have been put into the pound by accident. When taken out about one-third of the lobsters had spawn attached to the body. It is thus evident that some of these females must have laid their eggs in June or in the first part of July. No tally was kept of the proportion of $\mathrm{gg}^{\circ}$-lobsters taken out during the first part, the middle, and the Jatter part of July, and it is possible that the great number of egg-lobsters, which 
caused surprise, may have laid their eges during the last half of July, and that very few in reality extruded their eggs during the first part of this month. It is not probable that any eggs were laid in June.

In the second week of August, 1893, a vessel came into P'ortland, Maine, bringing lobsters from Seguin Island and Georgetown. Very few lobsters were at this time (Angust 13 to 20 ) with spawn.

I have been told by fishermen and others that lobsters are sometimes taken ouc of the wells of smacks in winter with very dark, external eggs, when it had been the rule to carefully exclude every egg-lobster in loading the boat, the inference being that lobsters had laid while in the well. Allowing a wide loophole for error in such cases, it is very evident from the facts already recorded that this is quite likely to happen.

Mr. Nielsen gives the spawning period for lobsters in Newfoundland as extending fiom the 20th of July to the 20th of August (Annual Report of the Newfoundland Fisheries Commission, 1892), but also states, in reply to certain questions which I endeavored to have answered, that lobsters were taken with newly laid eggs up to the latter part of September.

The spawning mouths for the lobster in Prince Edward Island are said to be July and August. We have no data whatever upon the spawning habits of the lobster on the coast of Labrador, or in the extreme southern parts of its range.

Considering the fact that the lobster is distributed through 20 degrees of latitude. there is less variation in the time of spawning than might be expected.

THE LAYING OF THE EGGS AND THE ABSORPTION OF OVARIAN OVA.

I have not seen the process of egg extrusion and consequently have no direct observations to record. It has, however, been witnessed in other crustacea where it is undoubtedly similar. In two instances lobsters bave laid eggs while kept in small aquaria in the laboratory of the United States Fish Commission. Since these animals were under constant surveillance during the day, it is almost certain that the eggs were deposited in the night or early morning, as is the well-kuown habit of many decapods. In each case the mother lobster scratched off nearly all of her egg's in the course of a few days. In other attempts to obserre this proress, where the eggs seemerl to be overdue, I dissected the mimals and fomm that the ova were retained and partially. absorbed. This led to other attempts with similar results.

Two "ripe" female lobsters, measuring 11.5 and 9 inches, respectively, were captured July 30 in Woods Hole Harbor, and placed in a large floating car, which was kept covered so that the lobsters were not exposed to direct sunlight. Fifteen days later, August 14, their ovaries were examined. In the smaller individual more than half the ovarian eggs, which were overdne, were in various stages of degeneration, thus giving the ovary a remarkable appearance. Instead of the uniform dark green hue, it was of a light yellow or straw color flecked with darker green areas, where

'Ehrenbaum (61, p. 287), who mentions a single case of a female lobster which was found lying on its back shortly after the eggs had been extruded from the hody, says: "The mass of eggs lay in the mold formed by the folded abdomen without being fixerl, since the cement had not as yet hardenerl. When the animal, in cousequence of a disturbance, soon made movements and tried to get upon its feet, most of the egge were left at the bottom of the aquirium, and only a small uumber were already so firmly fixed that they clung to the swimming feet." 
the eggs had not yet broken down. The ovary of the larger lobster was similar to this, but the process of histolysis had not advanced quite so far.

The eggs are sometimes absorbed under natural conditions, but why this happens is not understood. A very interesting illustration of this fact came to hand on July 16,1894 , when, on account of its very dark color, my attention was directed to a hard-shell female lobster, about 11 inches long. The membranes of the joints of the limbs and under surface of the body were of a dull-green color, very unlike the appearance which these parts assume in a molting lobster. Examinatiou showed that the ovarian eggs were almost completely absorbed and that the blood of the animal had a very distinct greenish tinge. The ovary was of a bright lemon-yellow tint, the color of the degenerated eggs, flecked lightly with green, where an egg had not lost its normal appearance. The ovarian lobe had shrunken to less than one-half its former size. The green pigment which was dissolved in the blood had undoubtedly come from the eggs, and had been taken up into the blood faster than it could be eliminated from it. I was told by Professor. Ryder that the ovarian eggs of the sturgeon are sometimes absorbed in a similar way, and the same phenomenon is probably met with throughout the animal series.

In the lobster there are always a few ripe ovarian eggs which fail of extrusion at the proper time, which are invariably absorbed and give to the mature ovary at the next reproductive period a characteristic appearance. (See p. 69 and plate 38, fig. 136.)

One of the females which laid eggs had been kept by herself for several weeks. When discovered, on August 24, the ova were in an advanced stage of yolk segmentation. They were somewhat undersized and of a peculiar light-grayish color. The eggs were fertile, although the segmentation was generally abnormal. The lobster, which was placed in an aquarium on July 30, was found to have external eggs on the 11th of August, in a very early stage of development. They had probably been extruded during the previous night. These eggs were rapidly attacked by fungi and their development was retarded in consequence. Long fungoid filaments grew over the surface of the eggs, and diatoms attached themselves in great numbers to the egg-capsule. The eggs of lobsters taken under natural conditions are always clean and, so far as I have observed, free from vegetable growths of every kind.

The eggs are fertilized after ejection from the oviducts by the spermatozoa, a supply of which is always stored up in the seminal receptacle of the female. There is no internal copulation, and no possibility of an internal fertilization in either the ovaries or their ducts, as already explained (p.39). The ova are probably immersed as soon as they are extruded, in a liquid cement substance, which is secreted in special glands situated in the swimmerets of the female. The "tail" is folded so as to form a closed pouch or chamber, as has been observed in the crayfish and other decapods (see note $1, \mathrm{p} .47$ ), and the eggs received within it are mixed with the liquid cement and sea water. Fixation to the hairs of the swimmerets is finally effected by means of the cement, which gradually hardens. How the sperm cells are conveyed from their receptacle to the eggs, whether through the medinm of the sea water or the glue, or whether or not by a motion of their own, is not definitely known. (Page 34, note 1.)

That the cement is incapable of fixing and holding the eggs until after exposure to sea water for some time (perhaps a few hours) was shown in the case of a lobster 
taken from the well of a lishing smake, after extrusion had been partially acemplisherl, at Rockland, Maine, August 6, 1893. The lobster, I was told, was taken out and laid on the deck, when the soft. dark-green mass of egges began to flow away from the horly from their own weight. (Compare note 1, p. 47.)

Cano (32) gives the following detailed account of the laying of the eggs in the crab Mlaia:

The time that intervenes between copulation and the deposit of the eggs inay be eight, ten, fifteen days, or even longer, and can not be fixed, since copulation happens before the eggs mature in the ovary. The eggs, at the time of ovulation, pass the opening of the receptaculun seminis, and are here invested with a coat of cement, which is secreted and beld in the receptacle. The eggs then revolve on their axes in the vaginal canal, aud are expelled, one at a time, by means of the valvular apparatus. This is formed by a prolapsus of the vaginal canal. * * * Besides the proper muscles of this canal there exist special muscles which, by lowering the membranous covering, provoke the expulsion of the eggs through the valvular orifice. The eggs thus ejected fall into the abdominal chamber. The female beats them about with repeated blows of the tail, while the pleopods, keeping them in continued agitation, make them converge toward the center of the abdominal pouch. The deposition of eggs is effected in Maia in the course of twenty-four hours, but sometimes in Lissa it takes a longer time. On the next day all the eggs alhere in groups, by means of one or two peduncles, to the hairs of the internal branches of the pleopods, while the external branch agitates them continuously. This movement, besikes renewing the surrounding water, probably assists in rupturing the egg shell, when the embryos are ready to hatch. Fixation could not be explained without the interaction of the sea water. The cement at first becomes more viscous, then hardens and forms a very thin pellicle, which, with the growth of the embryo, becomes quite hard and resistant. It would seem that the sea water might explain the chemical change which the cement undergoes, a change analogous to that which is observed in the exoskeleton after the molt. The cement may be regarderl as a substance very like chitin, both being of ectodermie origin. The cement serves not only for fixation, but unquestionably as the vehicle of the seminal elements toward the eggs.

If we examine the zone of cement which invests the eggs at the moment the latter traverse the short vaginal canal, there is seen a large quantity of seminal corpuscles, some of these still in the spermatophoral envelope, others free and swimming in the homogeneous mucus. These vary both in shape and dimensions. All the elements are immobile, but once I noticed that some of these cells, especially those with radial prolongations, were endowed with amœboid movements. Whether these movements are the same as those which impel the sperm into the egg I can not say from direct observation. The question then remains open as to when and how the spermatozoa pass into the eggs, which are unprovided with a micropyle. If they are able to penetrate through the poral canals of the chorion, and if this penetration can happen during the very brief passage of the egg through the raginal canal or at the moment of deposition of the eggs, as in the Macrura, then the sea water must exert unknown physico-chemical actions on the cement, which makes the egg itself adhere later to the hairs of the pleopods.

The typical phenomena of fecundation-the expulsion of the polar bodies and formation of pronuclei-I have not been able to observe directly.

When the eggs have reached the receptaculum seminis the pucleus has become invisible. The first segmentation nuclei are found in the central part of the eggs and move toward the periphery. Segmentation begins almost as soon as the eggs are fixed.

Cano (33) observed cases in Carcinus and Portunus where the eggs were laid at different periods, one-third of the eggs being in the mornla stage and the rest ready to hatch. Again, it was rarely found that the eggs were laid just before the molt, in which ease they were cast off and destroyed. This anomalous condition was first noticed by Lo Bianco in Palinurus (18). 


\section{NUMBER OF EGGS LAID AND THE LAW OF PRODUCTION.}

The production of ova among animals is directly correlated with the condition of the young at the time of hatching. Where eggs are very small and present in large numbers, as in some of the crabs, we may look for a long larval period; when the ova attain a much greater size and are at the same time very abundant, as in the lobster, we find the larval period abbreviated; in other cases, as in some shrimps, where eggs are relatively very large and few, the young hatch with the external characteristics of the adult.

The production of a large number of eggs always means great destruction under natural conditions. In such cases, however, the opportunity is afforded of increasing the supply of adults, provided we are able to tide the larvæ over their earlier stages of development. The number of eggs produced by the lobster is thus a subject which deserves careful attention in view of its economic bearings alone.

The numbers here recorded are based upon the records kept at the United States Fish Commission station. The eggs of each individual were carefully removed from the "tail" of the female lobster and measured in a graduate (having sloping sides), and the whole number of ova was estimated on the basis of the number contained in a fluid ounce. .Mr. Edwards found the number of new eggs in one fluid onnce to be about 6,440 (in one ounce 6,461 , in another 6,419), and the number of old or well-developed eggs in an ounce to be 6,090 . This is a relatively rough method of determination, aud the results are of course only approximately accurate.

I estimated by weight the number of fresh eggs carried by a Iobster 13 inches long to be 17,623 ; total weight of eggs, 54.9 grams; number of living eggs to the gram, 321 . These eggs were in an early stage of development.

The number of eggs borne by a large and a small lobster, carefully determined both by the wet and dry methods by my assistant, Mr. F. C. Waite, is given in the following table:

TABLE 14.-The production of eggs determined by different methods.

\begin{tabular}{|c|c|c|}
\hline Observations. & $\begin{array}{c}\text { Lobster No. } 51 \text {, } \\
\text { table } 20 \text {; from } \\
\text { Gay Head. }\end{array}$ & $\begin{array}{c}\text { Lobster No. } 69, \\
\text { table } 20 \text {; from } \\
\text { Woods Hole } \\
\text { Harbor. }\end{array}$ \\
\hline Stage of development of eggs.... & $\begin{array}{l}\text { Late segmen- } \\
\text { tation. }\end{array}$ & $\begin{array}{l}\text { Post-nauplius; } \\
\text { about three } \\
\text { weeks old. }\end{array}$ \\
\hline 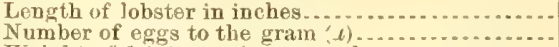 & 815 & $1,009^{9 \frac{1}{2}}$ \\
\hline Weight of 1,000 eggs in grams $(b) \ldots \ldots \ldots \ldots \ldots$ & 1. 2255 & 0.9893 \\
\hline 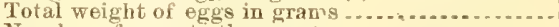 & 68.8092 & 10.4029 \\
\hline 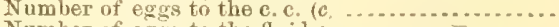 & 220 & 211 \\
\hline Number of eggs to the fluid ounce .................... & 6,248 & $\begin{array}{r}5,992 \\
10,07\end{array}$ \\
\hline $\begin{array}{l}\text { Number of eggs determined by the dry method }(a) \text {. } \\
\text { Number of eggs determined by the dry method }(b) \text {. }\end{array}$ & 56,079 & $\begin{array}{l}10,07 \\
10,514\end{array}$ \\
\hline Number of eggs determined by the wet method (c). & 58,500 & 10,919 \\
\hline
\end{tabular}

Mr. Waite estimated the number of eggs in a fluid ounce (on the basis of 2,110 to 10 c.c., the number obtained by count) to be 5,992. These eggs had been in stroug alcohol for upwards of three years. They were about three weeks old when preserved, and in alcohol had an average diameter of $1.625 \mathrm{~mm}$. $(1.56,1.69 \mathrm{~mm}$.)

In the wet method (c) employed, the number of eggs was estimated upon the actual number, obtained by counting, in $10 \mathrm{c}$, c. In the dry method the number was 
determined either (1) on the basis of the number of eggs to the gram, or (b) by the weight of 1,000 eggs. The numbers obtained by the last two methods agree very closely, and it is plain that the dry method is the nost reliable. The wet method gives a number which is from 3 to 4 per cent greater than that obtained by the dry method. There is probably a constant error of this amount in the wet method, ${ }^{\prime}$ and this slight error is due to the presence of the stalk of the secondary ogg membrane, which has a tendency to keep the wet eggs apart, but which shrivels ambleracks off when dry. It increases the buoyancy of the fresh eggs and is the cause of the bunching commonly observed. The excess due to the bunching of the eggs is about 0.3 per cent. This source of error was eliminated in No. 69 of the table, where the eggs were separated with needles before measuring.

\section{THE LAW OF PRODUCTION.}

In table 15 I have reduced the results of a very large number of observations made upon lobsters varying from 8 to 19 inches in length. The total number examinerl is 4,645 . Of these, 1,678 were taken on the ledges 15 miles south west of No Man's Land Island from April 20 to June 16, 1894. The remaining 2,967 were captured in Vineyard Sound and in the vicinity of the Elizabeth Islands from April to June, 1889-94. A smaller number were taken in February during the same year's. The eggs went to supply the hatchery of the United States Fish Commission.

TABLE 15.-Production of eggs.

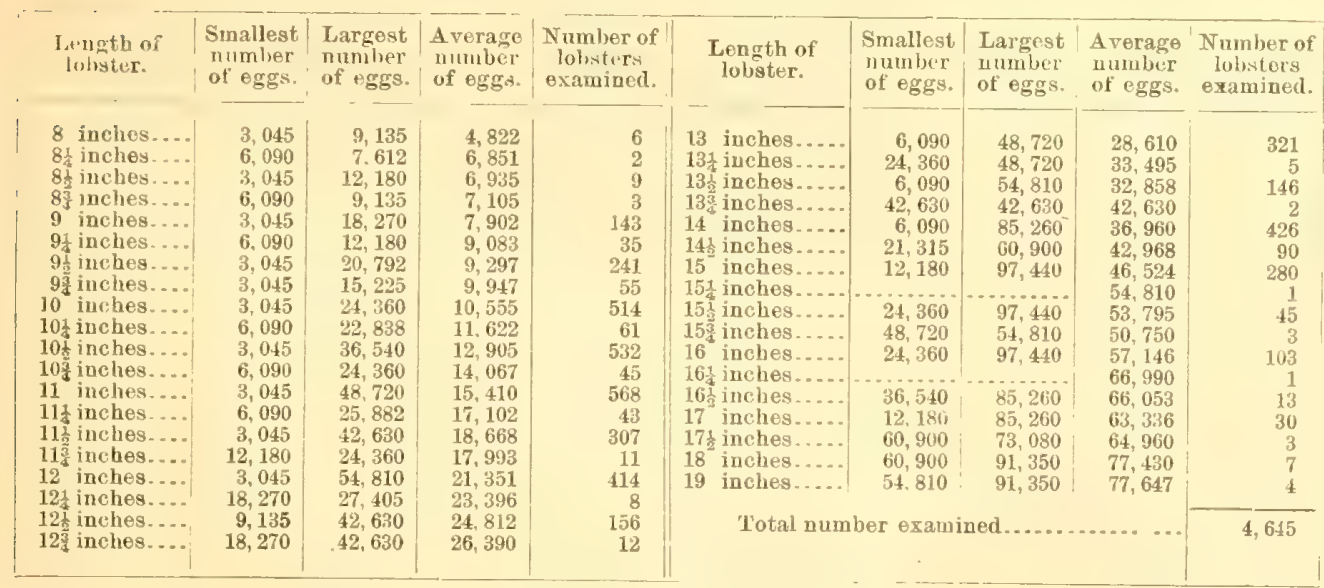

The average number of egg's of a lobster of a given length has little value unless obtained from a large number of individuals. While the small number of eggs occasionally recorded for lobsters over 12 inches loug may be the result of loss, in lobsters under this size it is probably. more often dne to belated sexual maturity.

'This excess will probably about offset the slight loss of eggs which must always occur. The numbers given in table 15 do not therefore require correction on this account. 
In casting the eye down the column of averages ${ }^{1}$ in table 15 , we are immediately struck by the fact that a 10-inch lobster bears about twice as many eggs as one 8 inches long, and that a 12-inch lobster has double the number borne by one which measures 10 inches.

It is therefore suggested that in the early years of sexual vigor there is a general law of fecundity or production which may be formulated in this way: The numbers of eggs produced by female lobsters at each reproductive period vary in a geometrical series, while the lengths of the lobsters producing these eggs vary in an arithmetical series. It is safe to assume that the avearge number of eggs laid by a lobster 8 inches long is not above 5,000. If such a law prevails we would have the following:

\begin{tabular}{|c|r|r|r|r|r|r|} 
Terms. & (1) & (2) & (3) & (4) & (5) & (6) \\
\hline Series of lengths in inches. & 8 & 10 & 12 & 14 & 16 & 18 \\
Series of eggs .............. & 5,000 & 10,000 & 20,000 & 40,000 & 80,000 & 160,000 \\
\hline
\end{tabular}

An examination of table 15 shows how closely the first four terms of this series are represented in nature, and that when the 14 to 16 inch limit is reached, there is a decline in sexual vigor. Yet the largest number of eggs recorded for lobsters of

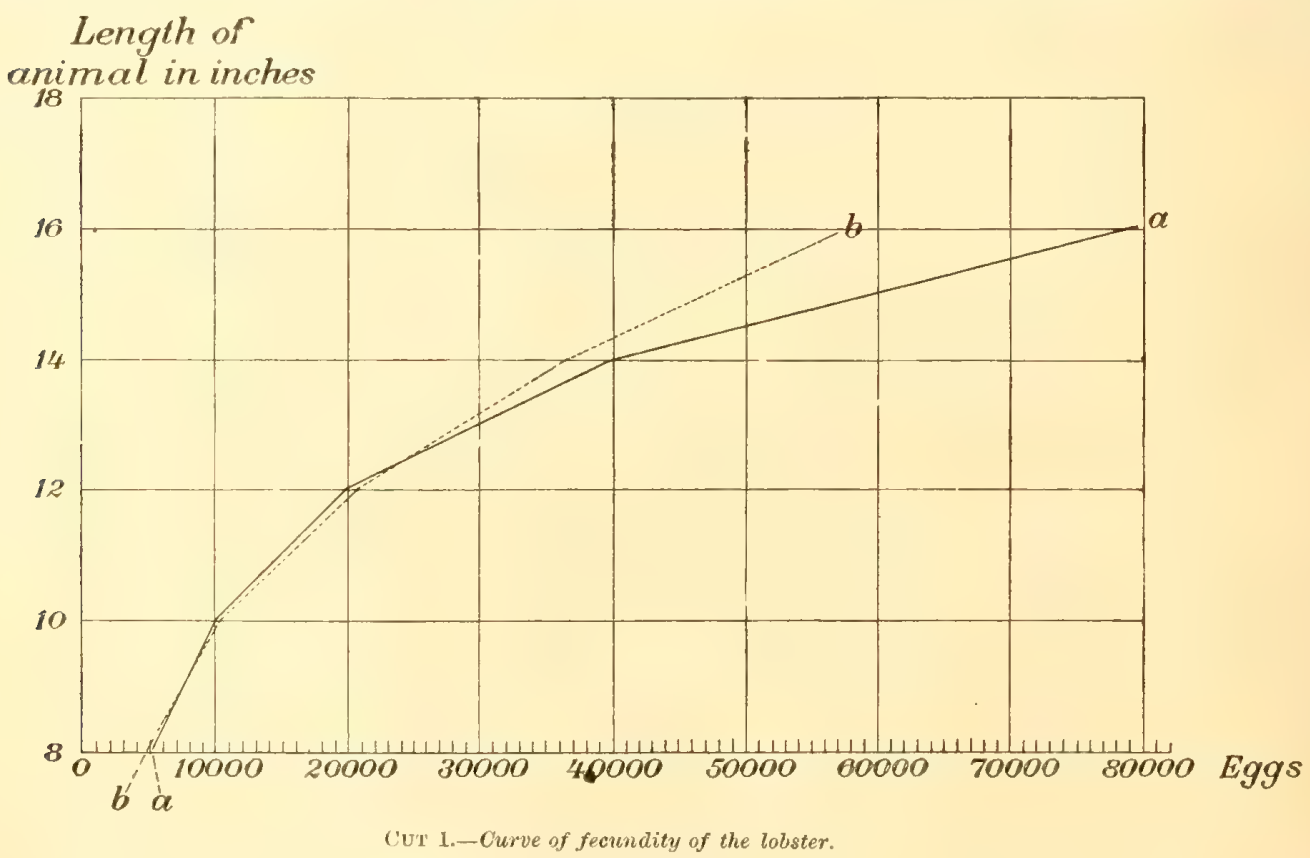

1 division on ordinate corresponds to 2 inches in length of lobster. 1 smaller diviaion on abscissa represents 1,000 eggs, $a a_{1}$ carve deduced from law of production as theoretically stated.

$b b$, curve of fecundity deduced from observations recorded in table 15 , for lobsters $8,10,12,14$, and 16 inches long.

this size shows that there is a tendency to maintain this high standard of production even at an advanced stage of sexual life.

'It is a conspicuous fact that in the fifth column of table 15 the largest numbers refer to individuals whose length is expressed in even inches or half inches. This is of course the result of inaccuracy in taking measurements: the quarters have been somewhat neglected. 
A graphic representation of the fecundity of the lobster tells more forcibly than words or figures can how closely it is in conformity with the law just enunciated. If a curve is constructed in accordance with the latter, we obtain, as in cut 1 , the curve al, which is the wing of a parabola. Neglecting for the present all data in table 1 in but those corresponding to the arithmetical sexies of lengths, $8,10,12,14,16$ inches, we obtain the curve of fecundity representer by the dotted line $b b$, cut 1 . This curve is parabolic and follows the curve a with remarkable uniformity up to the region of the fourth term, where the ratio of production is distinctly lessened. This becomes still more marked in the fifth and sixth terms.

In cut 2 the details of the curve $b b$ are given, including all the data of the table. We see in the line $b b^{1}$ the same remarkable conformity to the parabolic curve required by the law. Beyond the fourth term (length 14 inches) the irregularities in the curve become greatest, owing to the small number of individuals represented.

I believe the law above formulated expresses the propagative powers of the lobster during the height of its sexual activity, although it must not be supposed that the latter conforms uniformly to any arithmetical standard.

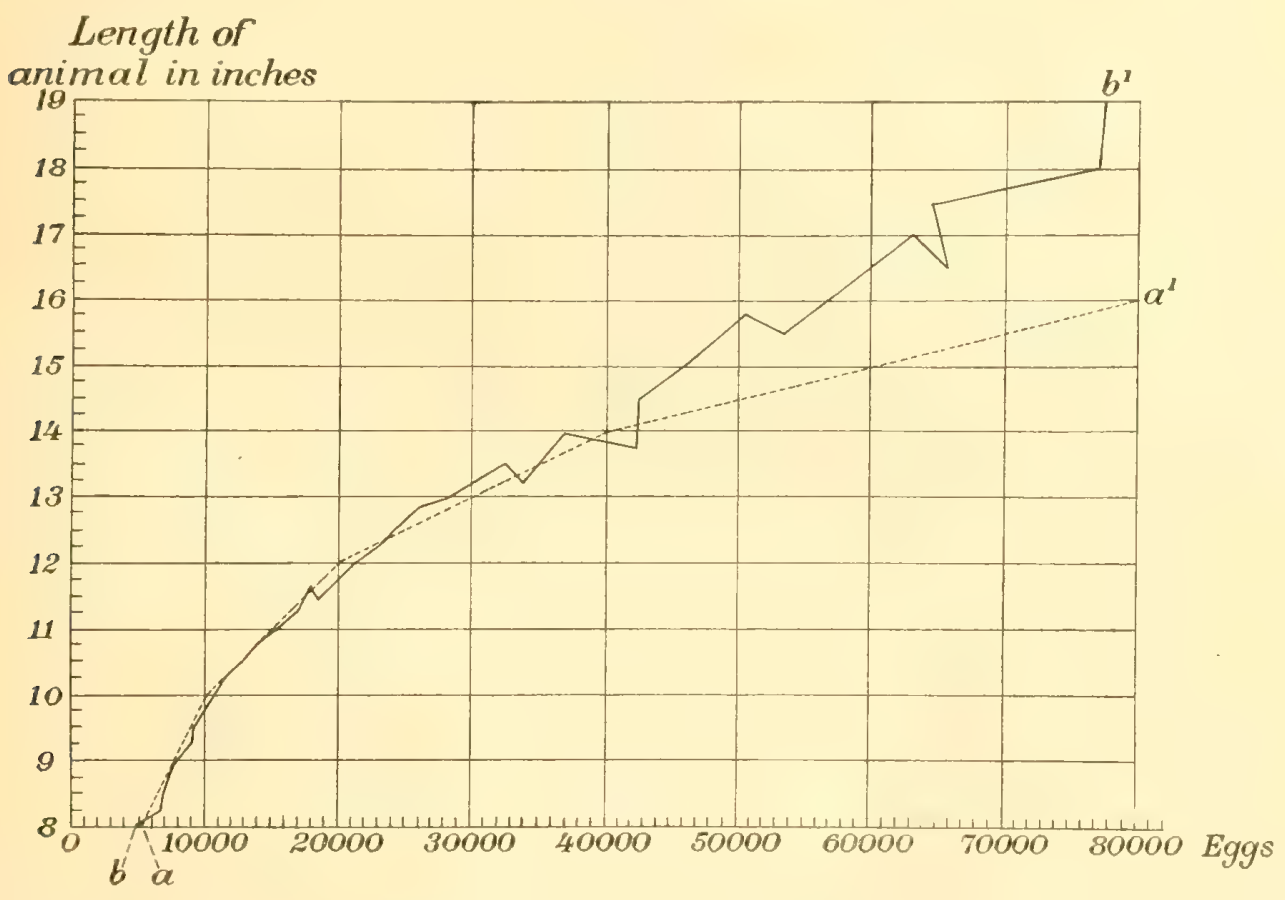

Cot 2.-Curve of fecundity of the lobster.

4 smaller divisions on ordinate correspond to 1 inch iu length of lobster. 1 smaller division on abscissa represents 1,000 eggs.

$a a^{1}$, curve deduced from law of production as theoretically stated.

$b b^{1}$, curve of fecundity deduced from all the data contained in table 15 , or from number of eggs produced by 4,645 lobsters.

After the lobster has reached a certain age, determined ly its early or late sexual maturity, its reproductive energy tends to decline, as is the case with the higher animals, and the ratio of increase, maintained at an earlier period, begins to fall, Whether the highest point of production is ever reached at 14 or 16 inches it is 
difficult to say, and whether the sexual decline is gradual or not it is impossible to decide from the data at hand. In this connection, however, it is interesting to recall the fact that the male lobster attains greater size than the female. The large lobsters, weighing upward of 20 pounds and measuring upward of 20 inches in length, are invariably males, so far as my observation extends.

The largest egg-bearing lobsters of which I have any record were taken 15 miles southwest of No Man's Land, Jine 9, 1894, and examined by Vinal N. Edwards. One 19 inches long, carried 91,350 eggs, which weighed 15 ounces; another, 16 inches in length, bore 97,440 eggs, which measured 16 fluid ounces and weighed nearly a pound. Mr. Edwards said that the mass of eggs was in these cases so great that the animals were unable to completely fold their "tails." (See p. 34.) A lobster with exterual eggs was taken at Green Island, Maine, in November, 1892, which, according to Mr. F. W. Collins, weighed $18 \frac{1}{2}$ pounds.

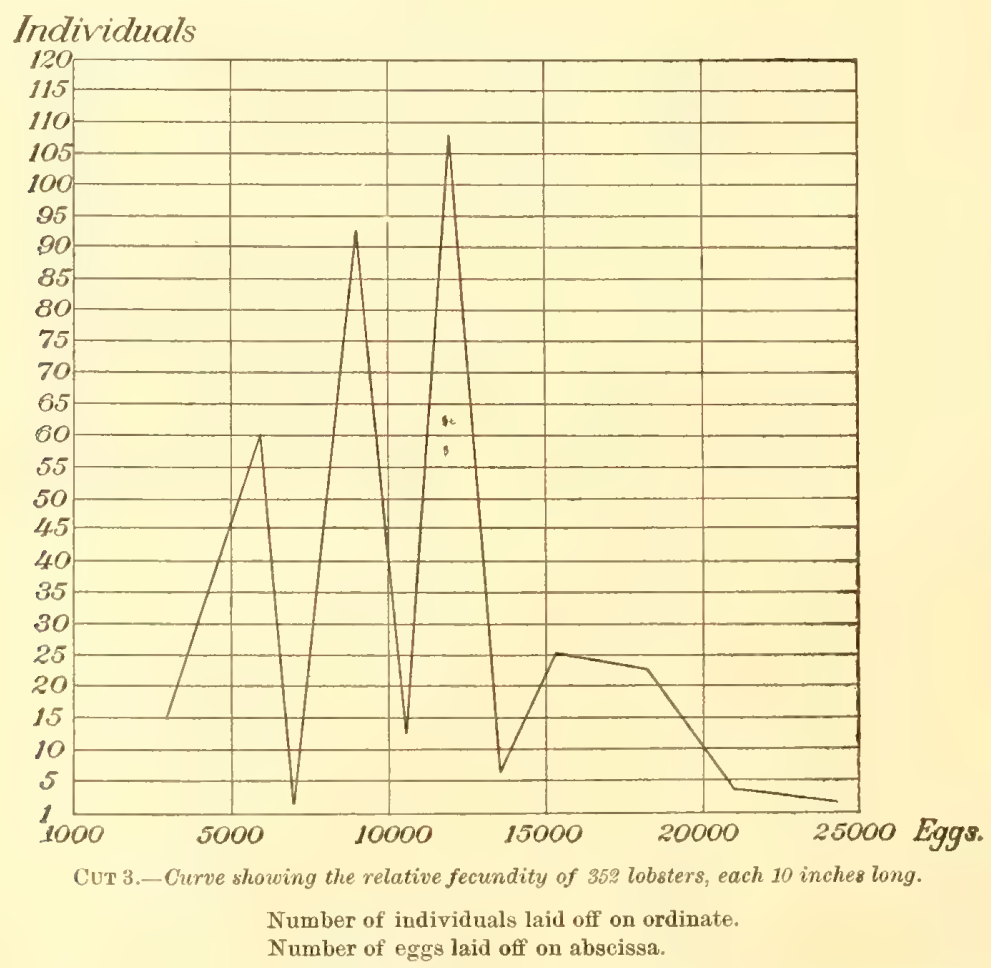

The No Man's Land lobsters seemed to carry rather more eggs than those of the same length captured elsewhere. Thus 234 lobsters, 13 inches long, from No Man's Land produced on the average 29,526 eggs (extremes 6,090-48,720), while for 79 lobsters caught elsewhere the average production was 26,518 (extremes as above). The small number examined in the last instance shows, however, that the comparison has little or no value.

The variation in the number of eggs borne by lobsters of the same length is often very great, and is as marked in large as in small individuals. Thus in 152 cases the average production of $10 \frac{1}{2}$-inch lobsters was about 11,000 eggs (the average in 532 cases, table 15 , is nearly 13,000$)$; 32 yer cent of this number bore fiom 12,000 to 13,000 
eggs; 15 per cent carried from 15,000 to 16,000 ; (i per cent had 18,000 to 19,000 ; 011 ( individual carried upwad of 21,000 , while 4.6 per cent bure only 3,000 to 1,000 . This is further illustrated by cut 3, which shows the variation in fecundity of 35: lobsters each 10 inches long. In this case 26 per vent laid 9,000 eggs, 30 per cent 12,000 , not ruite 1 per cent 18,000. The curve drops and keeps well down after the 12,000 limit is reached, which possibly implies a loss of eggs in those lobsters having more than the average number.

TaBLE 16.-Production of eggs by volume.

\begin{tabular}{|c|c|c|c|c|c|c|c|c|c|}
\hline $\begin{array}{c}\text { Length } \\
\text { of lobster. }\end{array}$ & $\begin{array}{l}\text { Smallest } \\
\text { number } \\
\text { of tluid } \\
\text { ounces. }\end{array}$ & $\begin{array}{l}\text { Largest } \\
\text { number } \\
\text { of tluid } \\
\text { onnces. }\end{array}$ & $\begin{array}{l}\text { Average } \\
\text { utubber } \\
\text { ot fluid } \\
\text { onuces. }\end{array}$ & $\begin{array}{l}\text { Number } \\
\text { of lobsters } \\
\text { examined. }\end{array}$ & $\begin{array}{l}\text { Lingth } \\
\text { of lobster. }\end{array}$ & $\begin{array}{l}\text { Smallest } \\
\text { number } \\
\text { of fluid } \\
\text { ounces. }\end{array}$ & $\begin{array}{l}\text { Largest } \\
\text { number } \\
\text { of fluid } \\
\text { ounces. }\end{array}$ & $\begin{array}{l}\text { A verage } \\
\text { mumber } \\
\text { of thuid } \\
\text { ounces. }\end{array}$ & $\begin{array}{l}\text { Number } \\
\text { of lobsters } \\
\text { eramined. }\end{array}$ \\
\hline 8 inches.... & & $1 \frac{1}{8}$ & .78 & 6 & 13 inches... & 1 & 8 & 4.70 & 321 \\
\hline 8 inches.... & $1^{5}$ & $1 \frac{1}{4}$ & 1. 12 & 2 & 132 inches.... & 4 & 8 & 5. 50 & 5 \\
\hline 8 inches... & $\frac{1}{2}$ & 2 & 1. 14 & 9 & 131 inches.... & 1 & 9 & 5.39 & 146 \\
\hline 83 iuches ... & $1^{2}$ & $1 \frac{1}{2}$ & 1.17 & 3 & $13_{4}^{3}$ inches..... & 7 & 7 & 7.00 & 2 \\
\hline 9 inches... & $\frac{1}{2}$ & $3^{2}$ & 1. 30 & 143 & 14 inclies.... & 1 & 14 & 6.07 & 426 \\
\hline 94 inches.... & $1^{2}$ & 2 & 1. 50 & 35 & 142 inches ..... & $3 \frac{1}{2}$ & 10 & 7.05 & 90 \\
\hline 91 inches.... & $\frac{1}{2}$ & $3 \frac{1}{4}$ & 1.53 & 241 & 15 inches.... & 2 & 16 & 7.64 & 280 \\
\hline 93 inches.... & $\frac{2}{8}$ & $2 \frac{4}{2}$ & 1.63 & 55 & $15 \frac{1}{4}$ inches.... & & & 9.00 & 1 \\
\hline 10 inches... & $\frac{1}{2}$ & $4^{2}$ & 1.73 & 514 & 151 inches.... & 4 & 16 & 8.83 & 45 \\
\hline 10 inches... & $1^{2}$ & $3 \frac{3}{4}$ & 1.91 & 61 & $15^{3}$ inches.... & 8 & 9 & 8.41 & 3 \\
\hline $10 \frac{1}{\text { inches... }}$ & $\frac{1}{2}$ & 6 & 2.12 & 532 & 16 inches.... & 4 & 16 & 9. 38 & 103 \\
\hline $10_{3}^{3}$ inchos.... & $1^{2}$ & 4 & 2.31 & 45 & 161 inches... & & & 11.00 & 1 \\
\hline 11 inches... & $\frac{1}{2}$ & 8 & 2.53 & 568 & $16 \frac{1}{2}$ inches.... & 6 & 14 & 10.85 & 13 \\
\hline $11 \frac{1}{4}$ inches... & $1^{2}$ & 4 & 2. 79 & 43 & 17 inches... & 2 & 14 & 10.40 & 30 \\
\hline 11 inches.... & $\frac{1}{5}$ & $7^{2}$ & 3. 06 & 307 & $17 \frac{1}{2}$ inches.... & 10 & 12 & 10.67 & 3 \\
\hline $11 \frac{3}{4}$ inches.... & $2^{2}$ & 4 & 2.95 & 11 & 18 inches.... & 10 & 15 & 12.71 & 7 \\
\hline 12 inches.... & $\frac{1}{2}$ & 9 & 3.51 & 414 & 19 inches... & 9 & 15 & 12.75 & 4 \\
\hline $\begin{array}{l}12 \frac{1}{6} \text { inches..... } \\
12 \text { inches.... }\end{array}$ & $\begin{array}{l}3 \\
1 \frac{1}{3}\end{array}$ & $7^{\frac{4}{2}}$ & $\begin{array}{l}3.84 \\
4.07\end{array}$ & $\begin{array}{r}8 \\
156\end{array}$ & \multirow{2}{*}{\multicolumn{4}{|c|}{ Total number examined. ................ }} & 4,645 \\
\hline $12 \frac{3}{6}$ inches.... & $3^{2}$ & 7 & 4.34 & 12 & & & & & \\
\hline
\end{tabular}

The data collected in table 16 will show in still another way the variation in the quantity of eggs produced by lobsters of different sizes. The average weight of a 10.1 -inch female lobster with eggs is $1 \frac{3}{4}$ pounds (table 31 ), the eggs weighing about 2 ounces. A 15-inch lobster which weighs upward of 4 pounds (table 31), sometimes carries a burden of a pound of eggs. As already remarked, a thid ounce of fresh eggs weighs about 1 ounce avoirdupois.

\section{PERIOD OF INCUBATION AT WOODS HOLE AND RATE OF DEVELOPMENT.}

The freshly laid eggs are somewhat irregular in shape, but soon plump out and become nearly spherical. Some, however, have the form of elongated spheroids (plate 17, fig. 24). They measure approximately $\frac{1}{16}$ inch in diameter, or 1.5 to $1.7 \mathrm{~mm}$. In color they are dark olive-green, ${ }^{1}$ sometimes almost black, hence the use of the term "black egg-lobster," common among fishermen, to distinguish the "new egg-lobster" from the "old" or the "light egg-lobster," in which the dark-green food yolk has been more or less absorbed by the growing embryo. In England the female lobster with exterual egg's is spoken of as being "in berry," or is sometimes called a "berried hen."

The rate of development of the summer eggs at Woods Hole is illustrated by tables 17 and 18, and by cuts 23-38 (plates $\mathrm{G}$ to $\mathbf{J}$ ).

${ }^{2}$ For variation in the color of the egg, see p. 137, and plate 17, figs, 23 and 24. 
TABLE 17. - The rate of derelopment of the embryo at Toods Hole.

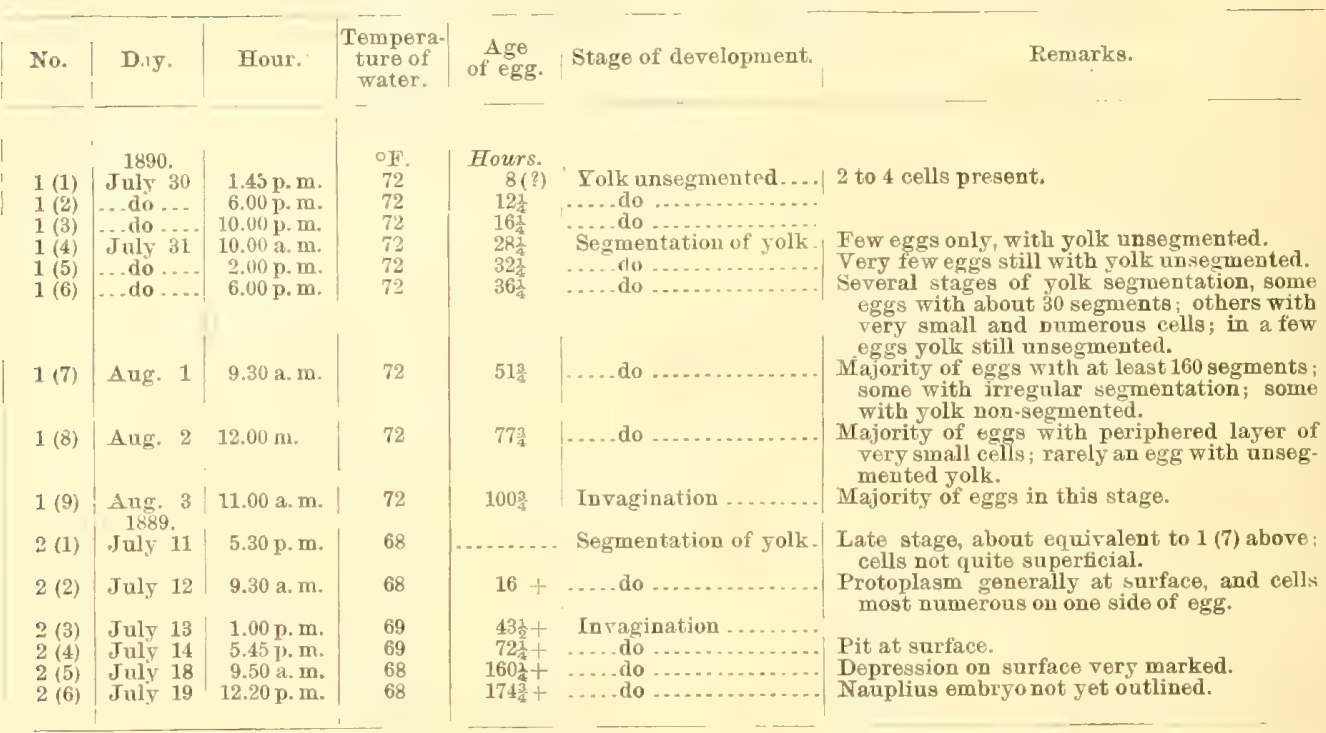

TABLE 18.-Rate of development of the embryo at Woods Hole.

\begin{tabular}{|c|c|c|c|c|c|c|c|}
\hline No. & Day. & Hour. & $\begin{array}{l}\text { Tempera- } \\
\text { ture of } \\
\text { water. }\end{array}$ & Age ot & f egg. & $\begin{array}{l}\text { Stage of develop- } \\
\text { ment. }\end{array}$ & Remarks. \\
\hline & 1890. & $3.45 \mathrm{p}, \mathrm{m}$. & ${ }^{\circ} \mathbf{F}$. & Days. & Hrs. & Jncagination & Pit at surface rerv conspicnons. See cut 25. \\
\hline $\begin{array}{ll}3 & (1) \\
3 & (2)\end{array}$ & July $1 \overrightarrow{1}$ & $12.45 \mathrm{p} . \mathrm{m}$. & 69 & 10 & & Egq-nauplius. & [n some eggs, second antennæe not budded. \\
\hline 3 (3) & July 15 & 10.30 a. m. & 69 & 14 & $2 \frac{1}{4}$ & do & $\begin{array}{l}\text { Second antenns bifid; thoracic abdominal } \\
\text { fold formed. See cut } 31 \text {. }\end{array}$ \\
\hline (4) & July 17 & $12 \mathrm{~m}$. & 70 & 16 & $3 \frac{3}{3}$ & $\ldots$ do ........... & Late egg-nauplius. See cut 32. \\
\hline $3(5)$ & July 22 & $12 \mathrm{~m}$. & 70 & 21 & $3 \frac{1}{4}$ & Post-rianplius & $\begin{array}{l}4 \text { to } 5 \text { pairs of post-mandibular appendages; } \\
\text { tip of "tail" conspicuously forked; optic } \\
\text { disks lobular. Cut } 34 \text {. }\end{array}$ \\
\hline $3(7)$ & ...do ... & $10.30 \mathrm{a} . \mathrm{m}$. & 69 & 24 & $2 \frac{1}{4}$ & & $\begin{array}{l}\text { Optic lobes very large; telson overlaps } \\
\text { brain; } 6 \text { or } 7 \text { pairs of post-nandibular } \\
\text { appendages; antenna and telson tipped } \\
\text { with rudimentary setæ. } \\
\text { Telson reaches base of optic lobes. }\end{array}$ \\
\hline $3(8)$ & July 29 & 5 p. n. & 71 & 28 & 8 & & $\begin{array}{l}\text { Eye pigment present for about } 24 \text { hours. } \\
\text { Cut } 35 \text {. }\end{array}$ \\
\hline $3 \quad(9)$ & Aug. 3 & $10.30 \mathrm{a} . \mathrm{s}$. & 72 & 33 & $2 \frac{1}{2}$ & & $\begin{array}{l}\text { Eye-spots crescentic or semicircular; telson } \\
\text { overlaps bases of optic lobes. }\end{array}$ \\
\hline Sิ (10) & Aug. 12 & 12.30 p. m. & 72 & 42 & $16 \frac{1}{4}$ & & $\begin{array}{l}\text { Eye-spots oval; telson considerably behind } \\
\text { optic lobes. }\end{array}$ \\
\hline $3(11)$ & Sept. 1 & & & 61 & & & Seo drawing, cut 36 \\
\hline $\begin{array}{l}3(12) \\
3(13)\end{array}$ & $\begin{array}{ll}\text { Uet. } & 1 \\
\text { Nor. } & 1\end{array}$ & & & $\begin{array}{r}31 \\
122\end{array}$ & & & See drawing, cut 37 . \\
\hline $3(14)$ & $\begin{array}{l}\text { Dee. } \\
1891 .\end{array}$ & & & 132 & & & \\
\hline $\begin{array}{l}3(15) \\
3(16) \\
3(17) \\
3(18) \\
3(19) \\
3(20)\end{array}$ & $\begin{array}{ll}\text { Jan. } & 1 \\
\text { Feb. } & 1 \\
\text { Mar. } & 1 \\
\text { Apr. } & 1 \\
\text { May } & 1 \\
\text { June } & 1\end{array}$ & $\begin{array}{l}\cdots \\
\cdots \\
\cdots\end{array}$ & $\cdots$ & $\begin{array}{l}183 \\
211 \\
242 \\
273 \\
3013 \\
334\end{array}$ & & & Larvæ hatching out. \\
\hline
\end{tabular}

The lobster (No. 3, table 18) which laid eggs about July 1, 1890, was kept under observation at the Fish Commission station at Woods Hole for a period of 11 months or 334 days, until June, 1891, when, as we see, the eggs had begun to hatch. Under natural conditions the period of incubation of the summer eggs at Woods Hole is nearer 10 months-(from July 16th-August 15 to May 15-June 15). 
The very fresh eggs can be usually detected by examination with a hand lens. The transparent egg capsule closely invests the yolk, which then presents a miform, finely granular texture. The external segmentation of the yolk follows in twenty to twenty-five hours after oviposition, and the large yolk-segments can be easily distinguished by the naked eye. At the close of this process, or after the invagination has begun, the living egg, when examined with a low power, resembles the fresh egg, excepting that the yolk has now a coarser and more irregular texture. The embryo is distinctly marked off in the egg-nauplius stage in about ten days, and when from twenty-six to twenty-eight days old the eye pigment can be seen at the surface.

THE HATCHING OF THE EGGS.

\section{THE HATCHING OF LOBSTERS AT WOODS HOLE.}

We have seen that the period of incubation or fosterage lasts from ten to elever months in the case of the summer eggs. As yet nothing is known about the hatching of the fall and winter eggs. The bulk of the eggs which are taken for the Woods Hole hatchery complete their development in the MeDonald jars in June, as shown in the following table:

TABLE 19.-Time of collection and hatching of the eggs of the lobster at the United States Fish Commission station, Toods Hole, Massachusetts; compiled from records of the station.

\begin{tabular}{|c|c|c|c|}
\hline Time of collection of the eggs. & Hatching begun. & $\begin{array}{c}\text { Hatching } \\
\text { ended. }\end{array}$ & $\begin{array}{l}\text { Time of hatehing of } \\
\text { majority of eggs. }\end{array}$ \\
\hline 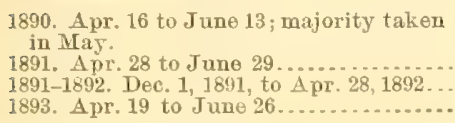 & 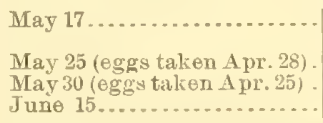 & $\begin{array}{l}\text { June } 23 \\
\text { June } 15 \\
\text { June } 29 \\
\text { July } 15\end{array}$ & $\begin{array}{l}\text { June. } \\
\text { June. } \\
\text { June. } \\
\text { June } 15 \text { to } 30 .\end{array}$ \\
\hline
\end{tabular}

These results agree with what takes place in nature when the lobster is permitted to keep her eggs for the full time. The eggs from several lobsters are usually placed in a single jar, and the jar's are replenished while the hatching goes on. ${ }^{1}$ The dates in the second and third columus of table 19 therefore indicate the general range of the hatching period, not that of the hatching of a single brood.

Lobsters with light eggs, or eggs of the previous summer, were last caught in Vineyard Sound and vicinity in the summers of 1890 to 1893 , at the following dates:

1890, July 9. One female lobster taken in Woods Hole Harbor with eggs hatching; several hundred eggs not yet hatched.

1891, Jnly 16. Six female lobsters, with nine-tenths of the eggs hatched, taken at Menemsha. On July 11 a lobster was taken at that place with eggs in process of hatching, and on June 30 two lobsters with old eggs were canght in Woods Hole Harbor. In one of these the eggs had begun to hatch; in the eggs of the other there was still conaiderable unabsorbed solk.

1892, June 28. Four lobsters with old eggs were taken.

1893, June 30. No lobsters with old eggs were taken at Menemsha after June 30. At this time they had in the past few days obtained 16 lobsters with old e ggs, and in half of these the eggs hark meantime hatched.

1844, July 14. A lobster was brought from Menemsha, having been canght some time before, with eggs ahout four-fifths hateher out.

${ }_{1}^{1}$ The temperature of the water in the hatching. jars in summer is about one degree ligher than that of the water outside. 
The last lobsters with light eggs were taken by the Gay Head lobstermen in 1890, July 7. This was also the date of the capture, at that point, of the first lobster with new eggs.

The time occupied by the hatching of a single brood was upward of a week, in the following case: On June 30, 1891, a lobster with old eggs, taken in Woods Hole Harbor, was stripped, and the spawn was placed in a "HcDonald" jar. On July 3 one larva had appeared; by July 5 a dozen larvæ had been hatched; on the 13th of the month hatching was still progressing slowly, and some of the young had molted and were in the second stage.

In another lobster taken at Menemsha, July 11, 1891, with young just hatehing out, the eggs, treated in the same way, were nearly all hatched in one week's time. On July 12 a large number of the first larvæ were swimming about the jar, and on July 18 the eggs were mostly hatched and many of the young were in the second larval stage.

In July and August, 1892, Mr. A. P. Greenleaf placed 300 egg-lobsters from Nova Scotia with newly laid eggs in one of the lobster pounds at Southport, Maine. In A pril, 1893, he seined, and found the females still bearing eggs. He seined the pond again in June, when it was evident that the larger part of the eggs had hatched.

Mr. Thomas Garrett, who began to fish for lobsters in the Vinal Haven Islands over forty years ago, caught in July a large, old egg-lobster, which weighed about 6 pounds, in the "Basin" near the present lobster park. He returned it to the water, caught it a second time, liberated it again, and about the 1st of August caught it for the third time, when the eggs had all hatched out

\section{THE DISPERSAL OF THE YOUNG.}

With the hatching of the young the period of fosterage comes to an end. ${ }^{1}$ By the fanning movements of her swimmerets the young are driven away from the body of the mother as soon as the egg-membranes have burst and are immediately dispersed; thenceforth they lead a free and independent existence.

The hatching of the eggs of the lobster has been often witnessed by smackmen and keepers of lobster pounds. In May, June, and July "the surface of the water in the wells of the smacks often becomes perfectly alive with the young, and they may be

${ }^{i}$ Nothing very definite seems to be known about the ovulation and hatching of the young in the European lobster, Astacus gammarus. Rathke's observations in 1840 did not settle the question (see p. 167), and Sars's paper (175), published over thirty jears later, left it still in doubt. Sars says that "the reproduction of the lobster does not appear, as is generally held, to be confined to any definite period of the year, yet the young are mostly hatched in summer. It is not unusual, however, to find the lobster with external eggs at other times of the year." Mayer (138) remarks that there is no definite breeding season, but that Homarus (Astacus gammarus) and Palinurus extrude their eggs mostly in November and December. These conflicting statements show that the European lobster carries her external eggs for a long period, and I have no doubt that when this subject is carefully investigaterl it will be found that the breeding habits of Astacus gammarus are very similar to those of the American species.

When this work was in press and after the preceding note was written I received Dr. Ehrenbaum's paper, to which I have already referred (61). He says that the eggs are laid and the young are hatched from about the middle of July to the middle of September. In one of two cases observed the eggs were laid Angust 1, 1893, and the first larvæ hatched July 20, 1894; in the other, the eggs were extruded August 28, 1893, and the larvw hatehed July 21, 1894. The period of incubation is thus about 11 months, as in the American form, and the times of the laying and hatching of the eggs in the two species very nearly agree. 
scooped np by the humdleds of thousands," and, as Rathbun says (154, p. 3"'), "a solt of" transplanting of young lobsters las been going on along the New England coast, and especially the southern portion of it, ever since the well-smack lobster trade began." As the vessels sail along, the newly hatched lobsters "work ont through the holes in the bottom of the well, and are thus constantly adding to the supply of the regions through which the smacks pass."

Peter Kalm relates in his Travels, under date of October, 1748, the following interesting anecdote of the transplanting of lobsters around New York by the New England fishing boats, which it seems carried wells:

Lobsters are likewise plentifully canght hereabouts, pickled much in the same way as oysters, and sent to several places. I was told a very remarkable circumstance about these lobsters, and I have afterwards frequently heard it mentioned. The coast of New York had already European inhabitants for a considerable time, jet no lobsters were to be met with on that coast; and though the people fished ever so often, they could never find any signs of lobsters being in this part of the sea. They were, therefore, continually brought in great well boats from New England, where they are plentiful; but it happened that one of these well boats broke in pieces near Hell Gate, about 10 English miles from New York, and all the lobsters in it got off. Since that time they have so multiplied in this part of the sea that they are now eanght in the greatest abundance. (108, vol. 1, pp. 240-241.)

It is well known that the crayfish protects her young after they are hatched and carries them about under her tail, as Roesel so well described over a hundred years ago. He says:

If the mother of these little crayfish, after they begin to stir about, becomes quiet with her foot at any time, or for some other reason sits still, they begin to move away from her somewhat and to crawl about her, but if they spy out the slightest danger, or there is any unusual movement in the water, it seems as if the mother called them back by a signal, for they all at once quickly return under her tail and gather into a clnster again, and the mother hurries off with them to a place of safety as fast as she can. After a few days, however, they gradually leave her. (169, p. 336.)

Huxley was the first to observe that the ends of the forceps or large claws of the young crayfish are bent into "abruptly incurved hooks," by means of which the young cling to the mother. He says:

Immediately after the young are set free, they must instinctively bury the ends of their forceps in the hardened egg glue which is smeared over the swimmerets, for they are all found to be holding on in this manner. They exhibit very little movement, and they bear rough shaking or handling without becoming detached, in consequence, I suppose, of the interlocking of the hooked ends of the chelæe embedded in the egg glue. Even after the female has been plunged into alcohol the young remain attached. I have had a female, with young affixed in this manner, under observation for five days, but none of them showed any signs of detaching themselves; and I am inelined to think that they are set free only at the first molt. After this it would appear that the adhesion to the parent is only temporary. (103, pp. 43-44.)

The young lobster has no organs for attaching itself to the mother. Its large claws do not end in sharp hooks (fig. 33, plate 20), as in the craytish, aud when once set fiee, it never again finds shelter under the body of the parent. I have noticed that the young of Pontonia domestica (a delicate West Indian prawn, which lives as a commensal in the shell of the Pinua), when hatched in an aryurium, ustally keep together in a ball or cluster, like a swarm of gnats, a habit which is doubtless shared by many of the prawns, but they never seek protection from the mother, who lives in the mantie chamber of the mollusk. Young lobsters which are hatched and kept in the aquarium swarm up to the surface or go to the bottom of the jar when closely confined, but if given greater liberty they teud to scatter. A swarming or gregarious liabit would be fatal to this species, on accomt of its inborn pugacity and camnibalism. 
Bell (14, pp. 248-249) has given the following account, furnished him by Mr. Peach, of the way in which lobsters were supposed by fishermen to protect their young. Hardly a word of it is true, but it is a good example of the psendo-scientific literature to which $I$ have referred, and on this account is worth quoting:

I have heard the fishermen of Goram Haven say that they have seen in the summer, frequently, the old lobsters with their young ores around them. Some of the young have been noticed six inches long. One man noticed the old lobster with her head peeping from under a rock, the young ones playing around her: she appeared to rattle her claws on the approach of the fisherman, and herself and young took shelter under the roek; this rattling, no doubt, was to give the alarm. I have heard this from several, some very old men, who all speak to this without concert, and as a matter of course; and they are men I can readily believe.

Young lobsters 6 inches long hardly require protection; smaller ones (an inch long) are rarely seen by fishermen, and old and young separate as soon as the latter are hatched.

The writer of a popular magazine article, in quoting a fisherman, thus speaks of the habits of young lobsters:

The mother is often seen surrounderl by baby lobsters a few inches in length, who take refuge under her tail in case of danger. (The Lobster at Home, by William R. Bishop, Scribmer's Monthly, vol. XXII, 1881, p. 212.)

Erdl (62) says of the green crab (Carcinus monas), that it often appears to play with small, round stones and with empty snail shells, just as cats play with balls. ("Manchmal scheint mit kleinen runden steinen, mit leeren Schneckenhäusen wie die Katzen mit den kugeln zu spielen.") Here, doubtless, the writer was misled by his imagination: in the former instance we have a popular error which seems to have crossed the Atlantic Ocean with emigrants to the New World.

Of the hatching of the eggs of the European lobster, which were thought to be laid in the sand by some of the older naturalists (see p. 36), Travis (191) euriously remarks:

Though the ova are cast at all times of the year, they seem only to come to life during the warm summer months of July and Angust. Great numbers of them may then be found, under the appearance of tadpoles, swimming about the little ponls left by the tides among the rocks, and many also under their proper form, from half an inch to 4 inches in length.

\section{VARIATIONS IN THE TIME OF HATCHING.}

Accordirg to Mr. Nielsen, the hatching period of the lobster in Newfoundland begins about the first week in July and continues until the 15th or 20th of August, the majority of the eggs hatching from the 15th or 20th of July to the 20th of August. It is thus from three to six weeks later than at Woods Hole, which is what we might expect from the difference in the temperature of the ocean at these points. It is not yet known to what extent the time of hatching and period of embryonic development varies from the normal course at the most divergent points on the coast; but it would not be surprising if young were hatched at almost any time from late summer until spring, owing to the irregularity in the production of eggs already pointed out.

Mr. Nielsen hatehed a number of lobsters in floating incubators during November in Newfoundland, and Mr. Rathbun (158) gives the following account of the hatehing of some lobsters at the Wroods Hole station by Capt. H. C. Chester, in November, 1885:

The eggs were aetached from the lobster and placed in the "MeDonald" jar November 5. They began to hatch November 8 , three iays afterwarls, and continned hatching for a fow days longer, but 
oniy about 50 young ones wore observed. The remainder of the eggs are still in jars in good condition. A few of the embryos were transferred to an acpuarium with running water, and others to a small vessel in which there was no change of water. The former lived about 24 hours, the latter about 36 hours. The temperature of the water in the hatching jar November 5 was $54.3^{\circ} \mathrm{F}$.; on the 6 th, $55^{\circ}$; and on the 7 th and 8 th, $56^{\circ}$. *** The conditions under which the eggs were kept wero perfectly normal, the water being of about the same temperature as that of the harbor outside.

I have learned of another very interesting case of the artificial hatching of the eggs of the lobster out of the regular season. This happened during the latter part of January and the first ten days of February, 1889, at the hatehery of the United Stater Fish Commission at Ten Pound Islaud, Culoncester, Massachusetts. Mr. M. M. Robiuson, to whom I am indebted for these facts, was at that time superintendent of the station. He says that the eggs were clipped from the lobster at about Christmas time, and suspended in aquaria through which sea water was constantly running. The temperature of the water was very low, at least as low as $36^{\circ} \mathrm{F}$., and as many as 10,000 lobster's were hatched under these conditions.

Mr. Nielsen, who visited the station at that time, corroborates this account, so far as the actual hatching of young lobsters is concerned. He writes that he examined with the microscope a young lobster which had been hatched on the day of his visit. The larva had perished in breaking out of the egg and in passing its first molt, but was perfectly developed in every way.

These facts clearly show that the hatching period varies in the same way that the time of egg-laying varies. The one must be correlated with the other.

William H. Wheildon gives some interesting facts about the lobster in a short paper published in 1875 (202), already referred to. He says:

In February of the present jear we exhibited spawn in several stages of development from newly laid eggs to the swimming larvæ.

The fact that the lobsters are with eggs in every month of the year, and that young sometimes make their appearance in winter and fall, does not prove, however, as this writer, like so many others, inferred, that the animal has no particular breeding season. but from these facts alone it would never have been possible to have arrived at a clear understanding of the reproductive habits. To the cireumstance that egg-lobsters are taken at all seasons and often with eggs in very different stages of development is due, more than to anything else, the confusion which had settled down upon this most important phase in the life-history of this animal.

In the case of the lobsters hatched at Woods Hole in early November, 1885, the eggs were probably laid in the late winter or spring of the same year. I have the record of a lobster which had in all probability spawned as early as June 20 (table 3, No. 2). Supposing these ova to have been extruded by the first week in June, they would have had fire months, including the warmest perior of the year, for their development. For five months, from the first of December to the first of May, the eggs are subjected under natural conditions to a relatively low temperature, and their development is greatly retarded. Consequently a batch of eggs which is extruded at the first or middle of August and hatched in May or June following is not, in all probability, subjected to a greater number of heat units than eggs which are laid in June and hatched in November. The embryos grow very slowly during the winter months, but the advancement may be sufticient, when development has already procederi far enongh in the fall, to bring the embryo to the point of hatching under favorable circumstances in winter. 


\section{DESTRUCTION OF THE EGG-LOBSTER AND ITS SPAWN.}

The berried lobster has many enemies, of which man is the chief, but if we except the latter, she seems to avoid them with remarkable skill. At least it is true that during the long period in which the ova are carried the losses are relatively slight. You detect but rarely a bad egg in the whole lot, and when, after ten months, the mother's fostering care is about to end, one is surprised to see how healthy every egg appears and how few seem to have been torn off. I have found that lobsters will scratch off and devour their own eggs when confined in aquaria; and we often see the spider crab (Libinia canaliculata) industriously picking off its eggs, as if for its own amusement, when it seems to have no lack of other food. The eel has a decided partiality for the eggs of the lobster, but the eautious way in which she keeps her tail folded up when crawling over the bottom, and the lightning-like speed with which she can dart about when disturbed, must often circumvent her most wily adversary. On July 5, 1890, I placed three egg-lobsters, from which I wished to obtain embryos in progressive stages of development, in a small floating car. One of these was a large perfect female, a second was a small perfect female, and a third was disabled by the loss of its claws. The next morning I found that the smaller female lobster had been killed and eaten. The large one had cut its body in two, at the junction of the "back" and "tail," and eels had eaten out the flesh and picked off nearly every egg, only two or three being left. I afterwards found that lobsters kept in a similar way were liable to lose their eggs while still active, and the aggressor was undoubtedly the eel.

Fishermen have maintained $(28, \mathrm{p} .11)$ that egg-lobsters, if put together, devour each other's eggs, but this is not true. At least $I$ am certain that this never occurs unless the lobster is first killed by its companions.

At Small Point, Maine, "berry" lobsters used to be considered the best kind of bait for certain fish. The "tail" of the lobster was eut off", a part of the upper shell removed, and the eggs left clinging to the under side. This practice was probably not confined to a single locality.

The pernicious destruction of the egg or spawn-lobsters is wisely prohibited in most of the States, and it is to be regretted that an attempt to enforce such a law has not been made in the Maritime Provinces and in Europe. This should certainly be done even if the law is often evaded, owing to the ease with which the eggs can be scraped off with a mitten or brush.

Ignorance of the fact that the lobster carries her eggs for a long period has been an element of confusion in the establishment of close seasons. Thus in Connecticut the law of 1878 forbade the destruction of females with spawn from July 1 to July $\mathbf{1 5 .}$ In Massachusetts, in 1880, the sale of females with eggs was prohibited during July. In 1883 the Maine legislature made a close time for egg-bearing females from April 1 to August 1; this was changed in 1885 to from October 1 to August 15. In both Maine and Massachusetts it is now, as it should be, illegal to take spawn-lobsters at any time.

The destruction of the spawn of lobsters is a terrible waste of life, and this is of itself sufficient reason for the adoption of any measure which may tend to lessen the evil. In certain parts of England lobsters in berry have been considered as in the very best condition for eating, and the eggs are highly prized for salad. On this account and because it was thought too great a hardship to compel the fishermen to throw back the "berried hens," the eommissioners were not inclined to recommend 
any legistation on this point. 'lloe following extrats from the testimony relating to this subject is interesting. A witness from Londou says (28):

There is a difficulty in throwing back the berried hens. They are generally worth twice as mueh as any other lobsters. The spawn is bruised and put into sauce, and makes better sauce than tho lobster itself. In salads it is boilod, and sprinkled over tho salad. It is a capital article of food. The spawuing hens are of value to the cooks, who won't have lobsters withont spawn. The sale of herried hens must not be prohibited, as it would be preventing the fishermen from taking the most fish. The production of the lobster is so enormous that if' a gange were fixed the taking of a few berried hens would make no appreciable difference. Berried hens are in the best possible condition as food. They form fresh spawn immediately after they have cast their spawn. If they have no spawn outside, they are full of red coral inside.

\section{In his Report on the Fisheries of Norfolk, Buckland (29) says:}

The lobster is never so good as when in the condition of a berried hen. Berried hens occur most frequently in April, May, and June. They begin to lose their berries about July, but still many berried hens occur in July. The use of the berries is almost entirely devoted to cooking; they are used in many preparations by the West End chefs, especially for coloring and exriching sauces. The "chefs" are also fond of coral out of the body of the lobster.

The evidence of a manager of a shellfish factory in the Haymarket is quoted as follows (29):

Mr. Sheppard, who boils lobsters for Scotts', at the top of the Haymarket, informs me that he has taken from one lobster (weighing 3 to $3 \frac{3}{2}$ pounds) 6 ounces of berries in the month of May. In August, out of 100 lobsters he would not be able to get 6 ounces of eggs from the whole. On the 5th of August he had 26 crabs, not one of which carried any spawn. In the month of May a great proportion of these 26 hen crabs would be full of sp iwn. The eggs from the berried hens are used for coloring various sauces; the berries are often mashed up in the sance, a little anchory added, and then it is called "lobster sauce." In order to supply these eggs for sauce to the cooks, Mr. Sheppard has collecter in April and May from 14 to 18 pounds of lobster spawn. I find that there are 6,720 [eggs] in an ounce of lobster spawn. Here, then, we have destroyed eggs which might have represented, say, in 16 pounds of eggs, no less than 1,720,320 lobsters. A very good substitute for lobster spawn could be made by boiling logwood (!). He considers that all berried hens should be returned to the water all the year round.

The number of eggs borne by the female lobster is considered on pp. 50-55. A 15-inch lobster sometimes carries nearly $100,000 \mathrm{eggs}$, which weigh a pound.

The reasous urged by the commissioners for not indorsing the recommendation to prohibit the sale of herried lobsters are remarkable as examples of logic. Thus, they said "if it were illegal to take berried lobsters it would not pay the fishermen in many cases to pursue the lobster fishery. In the next place, the lobster, when berried, is in the very best possible condition for food; and it would be as illogical, therefore, to prohibit its eapture as to prohibit the taking of full herrings." Furthermore, it is said that if the sale of berried lobsters were marte illegal "the fishermen wouid probably remove the berries. The berries would no longer be seen in the market, but berried lobsters would be killed as much as ever. Berried lobsters are, it must be remembered, especially valuable; the berries are in great demant for sance and for garnish for fish and salad." (28, p. XVI.) "Accordingly," says a writer in the Quarterly Review (213), "we must run the risk of exterminating a valuable animal to please our cooks."

Mr. Buckland says again, in his Report on the Fisheries of Norfolk:

There are, I regret to say, many difficulties in the way of preventing berried hens being destroyed, the principal one being that, unlike the salmon, lobsters when carrying eggs are at their very best for human food. Notwithstanding this, it must be evident that the destruction of so many lobsters in the form of eggs must of necessity greatly tend to produce that scarcity of lobsters which is now being felt in the London and other markets. 
The concession to the cooks container in the previous extracts is no more defensible than the idea that the lobster when in berry is necessarily at its best as an article of food. The reviewer just referred to, thus speaks upon the latter point:

We were under the impression--a common one, we believe-that as the spawning season began to come on all the food eaten went chiefly to aid the growth of the innumerable eggs in the female or of the soft roe in the male.

Travis (191), writing in 1768 from Scarborough-a place which still abounds in lobsters-says:

It is a common mistake that a berried hen is always in perfection for the table. When her berries appear large and brownish she will always be found exhausted, watery, and poor. *** Cock lobsters are in general better than hens in winter.

It should be borne in mind that there is no organic connection between the external eggs, which are carried under the "tail," of the lobster, any more than there is between a plaster and the skin to which it is made to adhere by an adhesive substance.

The case of the berried lobster and of the roe-herring are not strictly analogous, since the lobster is carrying her eggs which have been extruded, perhaps months before, while the herring is yet in the active process of producing the spawn within the body.

One would suppose that the only time when the lobster could be compared as to the effects of spawning with fish like the salmon would be for a short period after the eggs were laid. But this is not exactly the case, and Travis was nearer right than his suecessors, when he maintained that the egg-lobster was an inferior article of food. The fact is that the egg-lobster is in poorer condition or weighs relatively less than the female of the same length without eggs. This point is illustrated more fully in another part of this work (see p.119).

The lobster at the time of egg-laying is not in as poor condition, however, as the shotted herring or the salnon, which at this period is worthless as food, and the reason is plain. The ovary of the lobster ripens slowly during a period of at least two years, and the production and emission of the eggs is not so severe a drain upon its vitality as in the case of the fish. After the eggs have been laid for some time, the lobster gains in flesh; the ovary resumes its slow growth, but it is a year before the "coral" becomes very conspicuous. The testes, corresponding to the "soft roe" of fishes, are always very small, and produce sperm, not at a particular period, as is the case with many species of fish, but probably throughout the entire year. The time when the adult lobster is in the poorest condition for food is when the animal is getting ready to cast its shell, and for a few weeks after the molt while the new shell is still soft.

The destruction of a few hundred thousand eggs, or even a few millions, would have no appreciable effect upon the supply of lobsters at any point on the coast; but where the practice of taking lobsters with eggs is general throughout the range of the fishery, the total amount of ova or embryos which are thus killed is prodigious, and can not fail to lessen the number of adults. 
PERIOD OF SEXUAL MATURITY.

To determine the size which is usually attainer by the sexually mature lobster is of the first importance in studying the economy of this animal. If the female lobster is not allowed to reproduce at least once before she is caught and destroyed, a depletion of the fishery must imevitably result.

In some of the States and in the Maritime Provinces of Great Britain, where lobsters still abound, or were abundant in the past, potective laws have been enacted, prescribing a definite limit to the length of marlictable lobsters. In Newfoundland this limit is set at 9 inches. (The Royal Gazette, May 27, 1893.) In Maine the limit is placed at 9 inches for the months of May and June, and $10 \%$ inches for the remainder of the year.' In Massachusetts, New Hampshire, and New York the limit is fixed at 10. $\frac{1}{2}$ inches; in Rhode Island at 10, and in Connecticut at 6 inches. It is thus evident that very uncertain and contrary opinions have been entertained in regard to the size which is reached by the sexually mature lobster. In order to settle this question upon the solid ground of anatomy, and at the same time work out a number of other problems relating to the reproductive organs, I made in the summer of 1890 a large number of dissections, and have embodied some of the results in table 20.

TABLE 20.-General condition of the sexual organs, of the external and internal eggs, and of the shell in lobsters, chiefly females, ranging from 2 to 16 inches in length, in June, July, and August.

\begin{tabular}{|c|c|c|c|c|c|c|c|}
\hline No. & Sex. & Length. & $\begin{array}{l}\text { Date of } \\
\text { capture. }\end{array}$ & Locality. & $\begin{array}{c}\text { Condition of sexual } \\
\text { organs. }\end{array}$ & $\begin{array}{c}\text { Condition of swim. } \\
\text { merets. }\end{array}$ & Remarks. \\
\hline 1 & Female & $\begin{array}{r}\text { Inches. } \\
10 \frac{12}{16}\end{array}$ & $\begin{array}{l}1890 \\
\text { June } 28\end{array}$ & $\begin{array}{l}\text { Gay Head, } \\
\text { rock bot- } \\
\text { tom. }\end{array}$ & $\begin{array}{l}\text { Ovary pea-groen color; } \\
\text { extends nearly to end } \\
\text { of third abdominal } \\
\text { segment. }\end{array}$ & $\begin{array}{l}\text { With old eggs, } \\
\text { now hatching. }\end{array}$ & $\begin{array}{l}\text { Shell hard. Compare } \\
\text { fig. } 138, \text { pl. } 38 \text {. }\end{array}$ \\
\hline 2 & ...do .... & $11 \frac{1}{2}$ & ... do .. & .... do . ...... & $\begin{array}{l}\text { Ovary nearly ripe; ex. } \\
\text { tends to end of third } \\
\text { aludominal segment. }\end{array}$ & & $\begin{array}{l}\text { Oviducts not distended } \\
\text { with eggs. }\end{array}$ \\
\hline 3 & Male... & $81 \frac{1}{16}$ & ...to & 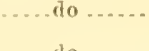 & $\begin{array}{l}\text { Dnets of testes charged } \\
\text { with ripe sperm. }\end{array}$ & & \\
\hline $4-10$ & Fenale & & ... do & ... dlo & $\begin{array}{l}\text { Ovaries pea-green color. } \\
\text { Compare fig. } 138, \mathrm{pl} \\
38 \text {. }\end{array}$ & $\begin{array}{l}\text { All with old eggs, } \\
\text { hatched this } \\
\text { year. }\end{array}$ & $\begin{array}{l}\text { The glue threads still } \\
\text { attached to the hairs } \\
\text { of the swimmerets } \\
\text { show conclusively } \\
\text { that jounghave been }\end{array}$ \\
\hline $11-17$ & ... dlo ... & & $\ldots$. 10 & $\ldots$ do ...... & $\begin{array}{l}\text { Ovaries approaching } \\
\text { maturity. }\end{array}$ & Clean... & $\begin{array}{l}\text { All about to extrude } \\
\text { eggs tbis season. In } \\
\text { one case eggs nearly } \\
\text { ripe. Sizeofinternal } \\
\text { egg. } 1.33 \text { mm. }\end{array}$ \\
\hline $18-21$ & Male.... & $81 \frac{2}{6}$ & ...do.. & $\ldots$... do ....... & $\begin{array}{l}\text { Testes filled with solid } \\
\text { masses of ripe sper- } \\
\text { matozoa, which are } \\
\text { surrounded by a gela- } \\
\text { timons secretion. }\end{array}$ & & $\begin{array}{l}\text { Spermat op hor } \mathrm{B} s-\text { or } \\
\text { packages of sperm. } \\
\text { wrapped in a gelati- } \\
\text { nous substance-can } \\
\text { be pressed out of the } \\
\text { ducts. }\end{array}$ \\
\hline 22 & Female & $11 \frac{3}{6}$ & July & $\begin{array}{l}\text { Meuemsha, } \\
\text { sand bot- } \\
\text { tom. }\end{array}$ & $\begin{array}{l}\text { Oraries dirty, y ellow } \\
\text { color; very immature. }\end{array}$ & Clean... & $\begin{array}{l}\text { dpparent'y no young } \\
\text { hatehed this year. } \\
\text { Probably never sexu } \\
\text { ally mature. }\end{array}$ \\
\hline 23 & .. do .... & 12 & .. do ... & . . do ...... & $\begin{array}{c}\text { Oraries dark green } \\
\text { nearly ripe. }\end{array}$ & ..... do ........... & Hard shell. \\
\hline 24 & do & 11 & ...do . & ....do ....... & Oraries immature; & ..... do .... & Do. \\
\hline 25 & $\ldots$ do & $10 \frac{1}{2}$ & ... do .. & ... do ...... & Ovaries dark green; & .....do... & Do. \\
\hline 26 & .. do... & 10 & . do... & & $\begin{array}{l}\text { Ovary straw color ; very } \\
\text { immature. }\end{array}$ & .... do ............ & $\begin{array}{l}\text { Animal not reached } \\
\text { sexual maturity. }\end{array}$ \\
\hline
\end{tabular}

I The legislature amended this law in 1895 , so that it is now illegal to destroy lobsters measuring less than $10 \frac{1}{2}$ inches in length at any time of the year. 
TABLE 20.-General condition of the sexual organs, of the external and internal eggs, etc.-Continued.

\begin{tabular}{|c|c|c|c|c|c|c|c|}
\hline No. & Sex. & Length. & $\begin{array}{l}\text { Date of } \\
\text { capture. }\end{array}$ & Locality. & $\begin{array}{c}\text { Condition of sexual } \\
\text { organs. }\end{array}$ & $\begin{array}{c}\text { Condition of swim- } \\
\text { merets. }\end{array}$ & Remarks. \\
\hline 27 & Female - & $\begin{array}{r}\text { Inches. } \\
11 \frac{1}{2}\end{array}$ & $\begin{array}{l}\text { 1890. } \\
\text { July } 9\end{array}$ & $\begin{array}{l}\text { Menemsha, } \\
\text { sand bot }\end{array}$ & Ovary nearly mature... & & Soft shell. \\
\hline 28 & ...do.... & $10 \underline{1}$ & ...do.. & $\begin{array}{l}\text { tom. } \\
\text {.... do ... }\end{array}$ & $\begin{array}{l}\text { Ovary straw color; like } \\
\text { No. } 26 \text {. }\end{array}$ & & $\begin{array}{l}\text { Has probably molted } \\
\text { this season. }\end{array}$ \\
\hline 29 & ... do .... & $11 \frac{1}{2}$ & ...do.... & .....do .... & Ovary very light green. & Old eggs, hatched & \\
\hline 30 & ... do . & $10 \frac{1}{2}$ & ...do ... & do & .....do . & $\begin{array}{l}\text { this year. } \\
\text { Clean .............. }\end{array}$ & Soft shell. Hatched \\
\hline $\begin{array}{r}31-32 \\
33\end{array}$ & ... do ..... & $105,10 \frac{1}{2}$ & .... do . .... & (3) & ..... do ........... & Gluev ............ & $\begin{array}{l}\text { Do. } \\
\text { Sheil hard. Hatched }\end{array}$ \\
\hline $\begin{array}{l}34 \\
35\end{array}$ & 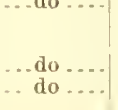 & $\begin{aligned} 92 \\
10 \frac{1}{2}\end{aligned}$ & $\begin{array}{l}\text {.. do ... } \\
\ldots \text { do } . . .\end{array}$ & $\begin{array}{l}\text { do } \\
\text { do... }\end{array}$ & $\begin{array}{l}\text { Ovary nearly ripe......- } \\
\text { Ovary light green; im- }\end{array}$ & Old eggs, just & $\begin{array}{l}\text { young, but has not } \\
\text { yet molted. } \\
\text { Hard shell. } \\
\text { Do. }\end{array}$ \\
\hline 36 & ...do ... & $10 \frac{1}{2}$ & ...do.... & ... do & $\begin{array}{l}\text { Ovary straw color; very } \\
\text { immature. }\end{array}$ & clean ............ & $\begin{array}{l}\text { Fairly hard shell. An- } \\
\text { imal never sexually } \\
\text { mature. }\end{array}$ \\
\hline 37 & $\ldots$ do $\ldots .$. & $11 \frac{1}{2}$ & ... do .... & .... do .. & Ovary pea-green color- & Old eggs, hatched & Fairly hard shell. \\
\hline 38 & ... do .... & $10 \mathrm{~g}$ & ... do .. & ....do ... & $\begin{array}{l}\text { Ovary light green; im- } \\
\text { mature. }\end{array}$ & $\begin{array}{l}\text { this year. } \\
\text { Clean............ }\end{array}$ & $\begin{array}{l}\text { Soft shell; probably } \\
\text { hatched old eggs and }\end{array}$ \\
\hline 39 & . do .... & 16 & July 22 & $\begin{array}{l}\text { Gay Head, } \\
\text { rock bot- } \\
\text { tom. }\end{array}$ & $\begin{array}{l}\text { Ovary nearly ripe; ex- } \\
\text { tends to end of third } \\
\text { abdominal segment. }\end{array}$ & $\ldots d o \ldots . .$. & $\begin{array}{l}\text { Hard shell. Ovary } \\
\text { flecked with yellow } \\
\text { spots, the remains of } \\
\text { degenerated eggs be- } \\
\text { longing to last sexual } \\
\text { period. }\end{array}$ \\
\hline 40 & $\therefore$ do $\ldots$... & 15 & ... do ..... & ..... do ... & Ovary pea-green color. & $\begin{array}{l}\text { Gluey: old exgs, } \\
\text { hatehed this } \\
\text { year. }\end{array}$ & $\begin{array}{l}\text { Hard shell. Degener. } \\
\text { ated old eggs in ovary } \\
\text { and oviduct. }\end{array}$ \\
\hline 41 & Male.... & $10 \frac{\pi}{4}$ & do & do & & & Soft shell. Molted in \\
\hline 42 & Female. & $4 \frac{3}{16}$ & ... do ... & $\ldots$ do .... & $\begin{array}{l}\text { Oxary vory small; } \\
\text { opaque white. }\end{array}$ & Smontl..... & Hard shell. \\
\hline 43 & Male.... & $3 \frac{\pi}{g}$ & . do & ....do & $\begin{array}{l}\text { Testes not found in } \\
\text { gross dissection. }\end{array}$ & & \\
\hline 44 & ... do .... & $9 \frac{3}{8}$ & .. do & & & & $\begin{array}{l}\text { See drawing of repro- } \\
\text { ductive organs, fig. } \\
120 \text {, pl. } 36 \text {. }\end{array}$ \\
\hline 45 & Female & $7 \overline{r \sigma}$. & $\ldots$. do .... & ....do & $\begin{array}{l}\text { Ovary light yellowish } \\
\text { white; extends to } \\
\text { middle of second ab- } \\
\text { dominal segment. }\end{array}$ & & $\begin{array}{l}\text { Hard shell; immature. } \\
\text { Ovarian lobe, } 3 \text { mm. } \\
\text { in diameter. }\end{array}$ \\
\hline 46 & $\ldots$ do .... & $4 \frac{1}{4}$ & ...do . - & ....do . & $\begin{array}{l}\text { Ovary opaque white; } \\
\text { extends into third } \\
\text { abdominal segment. }\end{array}$ & & $\begin{array}{l}\text { Hard shell. Ovarian } \\
\text { lobe } 0.8 \text { mm. in diam- } \\
\text { eter. }\end{array}$ \\
\hline 47 & $\ldots$ do ... & $9 \frac{5}{16}$ & ... do .... & .....do do & $\begin{array}{l}\text { Orary light flesh color; } \\
\text { extends to end of } \\
\text { third abdominal seg. } \\
\text { ment. }\end{array}$ & & Hard shell. \\
\hline 48 & $\ldots$. do .... & 57 & ...do .... & Jo & $\begin{array}{l}\text { Ovary opaque white; } \\
\text { very immature; ex- } \\
\text { tends to end of third } \\
\text { abdominal segment. }\end{array}$ & & \\
\hline 50 & ... do .... & $12 \frac{8}{8}$ & July 29 & . & $\begin{array}{l}\text { Ovary light greenish } \\
\text { white, flecked with } \\
\text { orange. }\end{array}$ & $\begin{array}{l}\text { External oggs; } \\
\text { embryos with } \\
\text { eve pigment. }\end{array}$ & $\begin{array}{l}\text { Hard shell. Degener- } \\
\text { ated old eggs in ovary } \\
\text { and oviduct. }\end{array}$ \\
\hline 51 & $\ldots$ do .... & $15 \frac{1}{2}$ & ...do. & .... . do ... & $\begin{array}{l}\text { Ovary opaque whitish, } \\
\text { with many mature } \\
\text { unextruded eggs. }\end{array}$ & $\begin{array}{l}\text { External eggs in } \\
\text { late segmenta- } \\
\text { tion stage; laid } \\
\text { about } 3 \text { days. }\end{array}$ & $\begin{array}{l}\text { Oviducts filled up to } \\
\text { external opening } \\
\text { with ripe, unex- } \\
\text { truded eggs. For } \\
\text { number of eggs see }\end{array}$ \\
\hline 52 & $\ldots$ do $\ldots . .$. & $12 \mid$. & ...do .... & .....do .... & $\begin{array}{l}\text { Ovary soft, jelly-like; } \\
\text { opaque dirty-wlite } \\
\text { color, flecked with } \\
\text { yellow and orange. }\end{array}$ & $\begin{array}{l}\text { External eggs in } \\
\text { early segnenta- } \\
\text { tion; about } 36 \\
\text { hours old. }\end{array}$ & $\begin{array}{l}\text { Hard shell. A few un- } \\
\text { extruded eggs, with } \\
\text { remains of degener- } \\
\text { ated ova of last sex- } \\
\text { ualperiod. Figs. 134, } \\
136 \text {, pl. } 38 \text {, and fig. } \\
139 \text { pl. } 39 \text {. }\end{array}$ \\
\hline 53 & ... do .... & $11 \frac{1}{2}$ & Aug: 11 & ..... do .... & $\begin{array}{l}\text { Orary light pea green, } \\
\text { flecked with yellow. }\end{array}$ & Smooth.. & $\begin{array}{l}\text { Soft shell. Has proba- } \\
\text { bly hatehed and }\end{array}$ \\
\hline
\end{tabular}


TABLe 20.-General condition of the sexual organs, of the external and internal eggs, elc.-Continued.

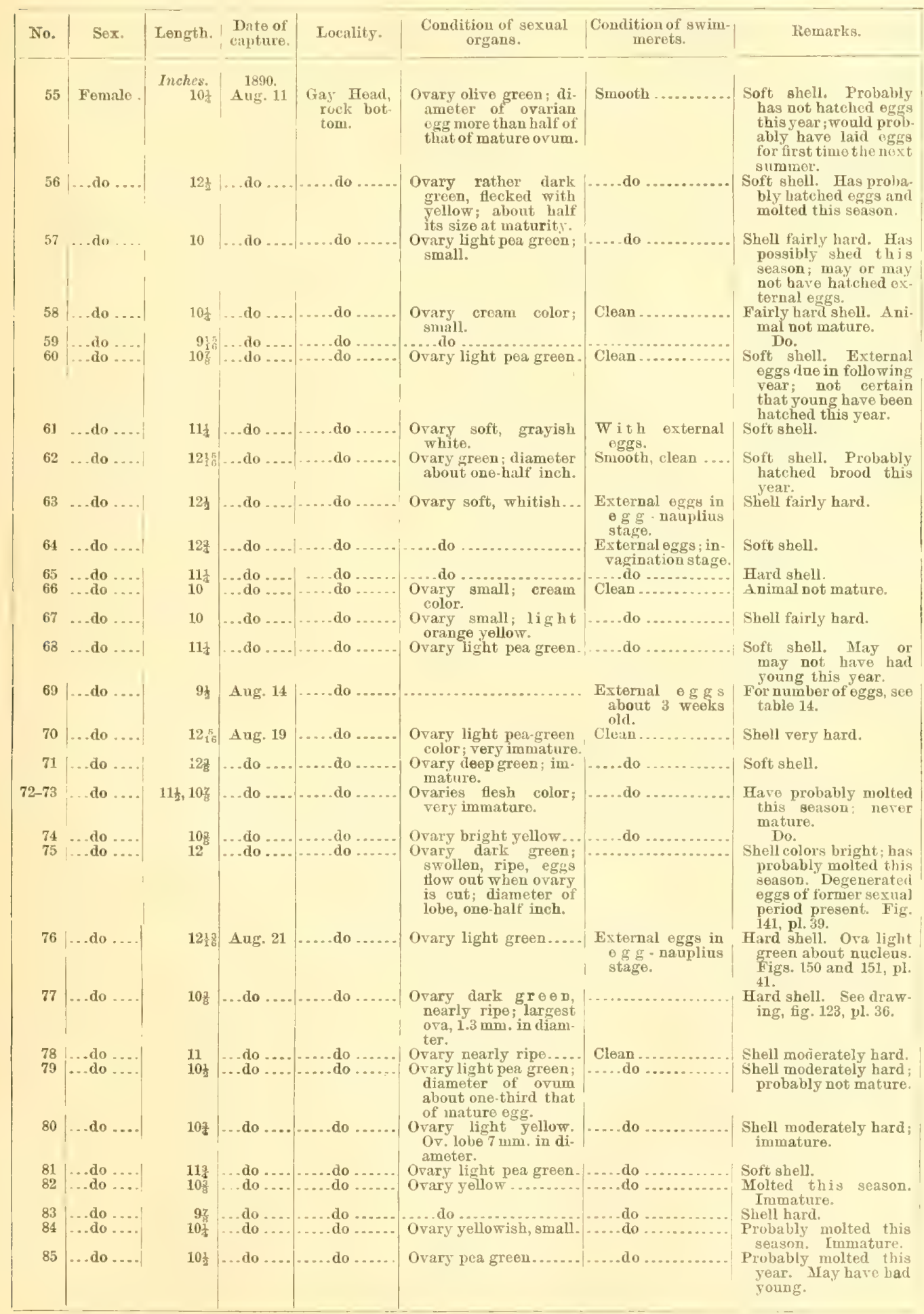


TABLE 20.-General condition of the sexual organs, of the external and internal eggs, etc.-Continued.

\begin{tabular}{|c|c|c|c|c|c|c|c|}
\hline No. & Sex. & Length. & $\begin{array}{l}\text { Date of } \\
\text { capture. }\end{array}$ & Locality. & $\begin{array}{c}\text { Conditiou of sexual } \\
\text { organs. }\end{array}$ & $\begin{array}{c}\text { Condition of swim- } \\
\text { merets. }\end{array}$ & Remarks. \\
\hline 86 & Female & $\begin{array}{r}\text { Inches. } \\
11\end{array}$ & $\begin{array}{l}1890 . \\
\text { A ug. } 21\end{array}$ & $\begin{array}{l}\text { Gray Head, } \\
\text { rock bot- }\end{array}$ & Ovary eream color..... & Clean ... & Immature. \\
\hline 87 & ado. & $9 \frac{1}{3}$ & ado & $\begin{array}{l}\text { tom. } \\
\ldots \text { do } \ldots . . . .\end{array}$ & $\begin{array}{l}\text { Ovary light green, } \\
\text { flecked with yellow } \\
\text { (degenerating eggs) } \\
\text { and white (yonng } \\
\text { eggs). }\end{array}$ & $\begin{array}{l}\text { External eggs } \\
\text { about sixweeks } \\
\text { old, extruded } \\
\text { about July } 10 .\end{array}$ & $\begin{array}{l}\text { Very lard shell. See } \\
\text { ctrawing of ovary and } \\
\text { ova, figs. } 137 \text { and } 135, \\
\text { plate } 38 .\end{array}$ \\
\hline 88 & ... do .... & 12 & ... do & ...... (1) ... & $\begin{array}{l}\text { Ovary whitish, flecked } \\
\text { with yellow spots, } \\
\text { and dark green un- } \\
\text { extruded eggs. }\end{array}$ & $\begin{array}{l}\text { External eggs in } \\
\text { egg-nauplius } \\
\text { stage, Iaidabont } \\
\text { August } 6 .\end{array}$ & Soft shell. \\
\hline $\begin{array}{l}89 \\
90\end{array}$ & ...do - & $10 y_{i}^{2}$ & $\begin{array}{l}\text { he } \\
\ldots \text { do }\end{array}$ & $\begin{array}{l}\ldots . \text { do } \\
\ldots . . . \\
\ldots \text { do }\end{array}$ & Ovary same as in No.87. & .... do . . . . . . . . & $\begin{array}{l}\text { Silell fairly hard. } \\
\text { Do. }\end{array}$ \\
\hline 91 & ... do .... & 55 & July 22 & $\begin{array}{l}\text { Wouds } \mathbf{H o l e} \\
\text { Harbor. }\end{array}$ & $\begin{array}{l}\text { O)ary white, 15nim. in } \\
\text { diameter. }\end{array}$ & & \\
\hline 92 & $\ldots d o$ & $7 n$ & ... dio ... & $\ldots . . d 0 . . .$. & $\begin{array}{l}\text { 'Jvary whitish, with } \\
\text { tinge of pink, } 3 \mathrm{~mm} \text {. } \\
\text { in diameter. }\end{array}$ & & Do. \\
\hline 93 & ...do .... & $7 \frac{15}{16}$ & July 24 & ..... do ....... & $\begin{array}{l}\text { 9vary white, about } \\
\text { 3mm. in diameter. }\end{array}$ & & \\
\hline 94 & . do .... & $9 \frac{1}{2}$ & July 30 & .... do & $\begin{array}{l}\text { Oraries nearly ripe; } \\
\text { seminal receptacle } \\
\text { charged with sperm. }\end{array}$ & & $\begin{array}{l}\text { Hard shell. For sec- } \\
\text { tion of ovary, see tig. } \\
140 \text {. }\end{array}$ \\
\hline 95 & . do .... & $9 \frac{1}{2}$ & July 30 & $\ldots . . . d 0 \ldots . .$. & $\begin{array}{l}\text { Light green. Ora light } \\
\text { yellowish green. No } \\
\text { sperm in semiual re- } \\
\text { ceptacle. }\end{array}$ & 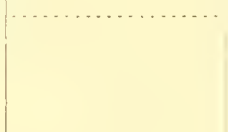 & $\begin{array}{l}\text { Shell hard; to molt } \\
\text { soon; e g gs hatched } \\
\text { this s e a s on. Se } \\
\text { drawing of ovary and } \\
\text { ovum, figs. } 138 \text { a nd } \\
\text { 133, pl. } 38 \text {. }\end{array}$ \\
\hline 96 & . do do... & $9 \frac{3}{4}$ & Aug. 4 & do & $\begin{array}{c}\text { Ovary nearly ripe. Fe- } \\
\text { male impregnated. }\end{array}$ & & \\
\hline 97 & .. do .... & 12 & Aug. 5 & Menemsha.. & $\begin{array}{l}\text { Ovary light pea green. } \\
\text { Female }\end{array}$ & Clean...... & \\
\hline 99 & . do .... & $\begin{array}{l}2 \frac{15}{15} \\
2 q^{2}\end{array}$ & June 30 & $\begin{array}{l}\text { Woods Hole } \\
\text { Harbor. }\end{array}$ & $\begin{array}{l}\text { Ovary white; length } 1 \frac{5}{8} \\
\text { in.; diameter of in. }\end{array}$ & & $\begin{array}{l}\text { Hard shell. See draw. } \\
\text { ing of ovary, fig. 132, } \\
\text { pl. } 38 \text {. }\end{array}$ \\
\hline 100 & $\ldots d \sigma \ldots$ & $11 \frac{1}{4}$ & July 18 & Menemsha.. & & $\begin{array}{l}\text { External eggs in } \\
\text { late segmenta. } \\
\text { tion. }\end{array}$ & Eggs laid about July 25. \\
\hline
\end{tabular}

These results, with those given in table 15 , show very elearly that on the coast of Massachusetts female lobsters become sexually mature and produce eggs for the first time when they have attained the length of from 8 to 12 inches. Very few lobsters under 9 inches in length have exterual eggs, while only few have attained the length of $10 \frac{1}{2}$ inches without having them. The limits of 9 and 10 inches, which have been variously adopted, are therefore too small, and should be increased if the lobster is to receive the benefit which is intended by this form of legislation. It is clearly illogical to protect the very small lobster and not to extend protection to the lobster which is about to spawn, in view of the natural increase of the species, since the latter has the greater chance of survival. It is highly probable that the majority of female lobsters 10.1 inches long are sexually mature. It is possible that the limit is sometimes extended at both extremes and that very rarely a lobster produces eggs before it is 8 or even $7 \frac{1}{2}$ inches long or fails to produce them until it is over 12 inches in length. Out of over a thousand egg-bearing lobsters which have been examined at the Woods Hole station during the past four years there have been found only 20 lobsters measuring from 8 to $8 \frac{3}{4}$ inches, or less than 2 per cent of the total number with external eggs. (For statistics of the majority of these, see table 1.5.) The hundred lobsters, the dissections of which are tabulated above. were not, however, taken at haphazard, but were selected in many cases to illustrate the development of the ovary and its growth between two successive sexual periods. 
Culling from table 20 all lobsters 9 inches long and upward which are inmature or have not as yet spawned, the record is as follows:

\begin{tabular}{|c|c|}
\hline Number in table 20. & $\begin{array}{l}\text { Length in } \\
\text { inches. }\end{array}$ \\
\hline $47 \ldots . .$. & $9_{\text {iti }}$ \\
\hline $8: 3 \ldots \ldots$. & $9_{i t ;}^{i}$ \\
\hline $59 \ldots \ldots \ldots \ldots \ldots, \quad \ldots \ldots \ldots \ldots$ & $9 \frac{15}{10}$ \\
\hline $26,66,67 \ldots \ldots \ldots \ldots$ & 10 \\
\hline $58,84 \ldots \ldots \ldots \ldots$ & $10 \frac{2}{4}$ \\
\hline $74,82 \ldots \ldots \ldots \ldots \ldots \ldots \ldots$ & $10 \mathrm{~g}$ \\
\hline $28,36 \ldots \ldots \ldots \ldots \ldots \ldots \ldots$ & $10 \frac{1}{13}$ \\
\hline $80 \ldots \ldots \ldots \ldots$ & $10_{4}^{3}$ \\
\hline $73 \ldots \ldots \ldots$ & $10 z$ \\
\hline $86 \ldots \ldots \ldots \ldots \ldots \ldots$ & 11 \\
\hline $7 \because \ldots \ldots \ldots \ldots$ & $11 \frac{1}{2}$ \\
\hline $22 \ldots \ldots \ldots \ldots \ldots \ldots \ldots$ & 113 \\
\hline
\end{tabular}

The following would have laid eggs during the eurrent season-that is, they were within a few days or a few weeks of their first spawning:

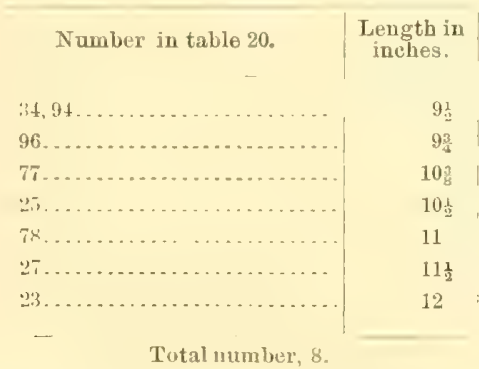

We thus find that 25 females, a large number out of the entire list, varying from $9 \frac{5}{16}$ to 12 inches in length, had either never reached maturity or were mature for the first time. Of the 17 immature females, 6 are $10 \frac{1}{2}$ inches or upward in length, and the ovaries in most cases would not have matured for at least two years. In order to be on the safe side I have purposely omitted from the enumeration all doubtful cases.

It may be asked, How can you be certain that a lobster has never spawned? The answer to this question is easily found by examining the ovary. If the surface or interior of the ovaries or their ducts are flecked with small yellow or yellowish orange spots, in however slight a degree (see fig. 136), it is an infallible sign that external eggs have already been carried. If these specks are examined under the microscope. (fig. 150, plate 41), it will be seen that they are the remnants of old eggs which failed of extrusion at the last sexual period. At every such season of egg-laying there are always, as we have already seen, a few residual eggs, out of the thousands which are laid, which stick fast in the ovary or in its ducts, or for some cause are not driven outside of the body. These remain in the organs and undergo degeneration in situ. It is, perhaps, not surprising that traces of these egg's persist in the ovary for up warl of two years without being completely absorbed, when it is remembered that the semifluid contents of the egg are surrounded by a tough bag of chitin, the primary egg membraue.

A nother means of determining the sexual condition of the female, which, I consicter to be also infallible, is the color of the ovaries. The ovary immediately after egg-laying 
is always of an opaque grayish-white tint (plate 38, fig. 136). The ovary of a lobster taken at the time of the hatehing of the brood (plate 38, fig. 138), or several weeks after it, is invariably, so far as my observation goes, of a light pea-green color, and possesses definite histological characteristics which will be considered in another place.

The ovary of a female which is approaching maturity for the first time (see Nos. 22, $26,47,58,67,74,83$, etc., table 20 ), on the other hand, is variable in color. It may have a flesh or almost salmon tint, a eream color, a dirty yellow, bright light-yellow, light olive-green color, or one of many intermediate tints.

The interesting fact has already been pointed out that the percentage variation in the numbers of eggs produced by lobsters from 8 to 12 inches is excessively great. This points to the conclusion, which is confirmed by anatomical evidence, that the period at which lobsters reach sexual maturity is a variable one, extending over several years, over a period, at least, in which lobsters vary from 8 inches, or slightly under, to 12 inches, or slightly over, in length.

\section{THE FREQUENCY OF SPAWNING.}

Is the lobster an annual spawner, or, to put the question in another way, what percentage of mature female lobsters produce external eggs each year? These questions, although of much importance, have generally received erroneous answers.

In the summer of 1890 I first demonstrated, upon the ground of anatomy, that the lobster did not and could not breed aunually, as had been commonly supposed. This is proved, first, by the growth of the ovarian eggs, and confirmed by the relatively small percentage of females with external eggs captured during the winter and spring.

The growth of the ovarian eggs was followed from the time of hatching of the brood until the ova of the next generation were ripe and ready for extrusion. (See note, p. 152.) These results are embodied in table 20. In some notes published in May, 1s91, I pointed out that three-fourths of the whole number of egg-lobsters examined in the summer of 1890 in Vineyard Sound had extruded eggs during the latter part of July (see table 7). It was also shown that the eggs which are then laid are "carried by the female throughout the fall, winter, and spring, and are not hatched under natural conditions until the following summer" (92). The hatching period was given as extending over a period of about eight weeks, from May 15 to July $\mathbf{1 5 .}$ This agrees, for the most part, with the experience of recent years.

Bumpus (30) gives correctly the periods of spawning-with the exceptions I have noted-of incubation, and hatching of the young. Garman (72), in a report upon the lobster to the fishery commissioner of Massachusetts, summarizes his results as follows:

(1) The female lobster lays eggs but once in two years, the laying periods being two years apart.

(2) The normal time of laying is when the water has reached its summer temperature, varying in different seasons and places, the period extending from about the middle of June till about the 1st of September.

(3) The eggs do not hatch before the summer following that in which they were laid, the time of hatching varying with the temperature, and the period extending from the middle of May till about the lst of August.

These conclusions-subject to the corrections which I have pointed out-are essentially a repetition and confirmation of facts which were already known.

Mather emphasizes $(135,136)$ the facts that the lobster carries its summer eggs all winter and that it breeds once in two years.

In order to prove with certainty that the lobster can not breed every ycar, we have only to dissect a female which has recently produced a brood, or has external eggs nearly ready to hatch, in June, July, or August. In table 20 records of over 
twenty-one such dissections are given (Nos. 1, 4 to 10,29 to $33,35,37,38,40,53,50$, (52, 95) which illustrate the condition of the ovary before the eggs hatch, up to about the middle of Angust, or from six to eight reeks after hatching. The ovarian egres have had, in all these cases, from ten months" to a year's growth, this interval having elapsed since the last sexual period, when eggs were extruded.

The colored drawing, fig. 138, plate 38, represents, in natural size, the ovary of a lobster (No.95, table 20 ) forr to six weeks after the hatching of its eggs. In figs. 136, 137, and 1:35 I have given representations of the ovaries of the lobster as they appear thirty-six hours, six weeks, and one year after egg-laying. Figs. 134, 135, and 133 show the arelage size and form of the ovarian egsis, drawn to the same scale, at these various periods. The ovarian eggs are in about the same condition of immaturity in figs. 133 and 13i, and it would seem that immediately after egg-laying the ovary grows very rapidly, and then enters upon a long period of rest. In the following summer, wheu the exterual eggs have hatched, another period of rapid glowth is experienced in theovily, and at the beginning of the third summer after ovulation there is a thind period of active growth which continues mutil the new ova of the next generation are ripe. That the spawning periods are thus two years apart is a valid inference drawn from the study of the anatomy of the reproductive organs. (See note, p. 152, and in particular the description of fig. 138, p. 246.)

If the spawning perion of the lobster is a biennial one, and if the sexes are equally divided, we should expect to find half of the adult females carrying eges each year. In other rords, one in every four mature lobsters (of both sexes) captured would rarry external eggs. Since lobsters do not mature at a uniform period, or when of a uniform size, it is impossible to get perfectly accurate data upon this point. It would be impossible, furthermore, to trust any data, unless we could be certain that the egg bearing lobsters were uniformly distributed. The fucts which we have, relating to this point, are however, worth considering.

In April, 1889, a number of lobster pots were set in the harbor of Woods Hole by Vinal N. Edwards, and a daily record of the catch was made. A total of 3,230 lobsters were captured, as described in table 21. About one in every seven bore eggs. The percentage of females with external eggs to the whole number of females taken was 40 in April, while it dropped to 36 in May. This slight fall might or might not be owing to the hatching of some of the eggs, while it is evident that the drop to 9 per cent in June is due to this cause, by far the larger part of the eggs being hatched in this month.

It is seen that in the total catch of 2,657 lobsters, from December 1,1893 , to June 30, 1894, the seres are very mearly equally divicled, and that about one in every fifteen lobsters eaptured bore external eggs. Neither this nor the percentage of females with eggs to the whole number of females has any special signiticance, since both mature and immature are included. Striking out the months of May and June, when the eggs are mostly hatched, and eliminating the smaller lobsters, we find the percentage of egg-bearing lobsters 10 inches long or over to the whole number of females of the same length with or withont egos (that is, mature female lobsters), to be 21.79. If the limit is taken at 9 inches, we find the percentage to be 19.81. In other words, about one-fifth of the females 9 inches or more in length bore eggs.

The catch off No Man's Land in May, 1894 (table 1), illustrates very well how the conditions are affected by the locality. Out of 1,318 lobsters taken 9:3.) per cent were females, and 63.7 per cent carried eggs; moreover, 6 s per cent of the total number of females bore eggs. 
TABLE 21.-Percentage of male to female lobsters and the percentage of egg-bearing females taken in I'oods Hole Harbor.

\begin{tabular}{|c|c|c|c|c|c|c|c|c|c|c|c|}
\hline & \multicolumn{10}{|c|}{ Time of capture. } & \multirow[b]{2}{*}{$\begin{array}{c}\text { For } \\
\text { whole } \\
\text { period. }\end{array}$} \\
\hline & $\begin{array}{c}1889 \\
\text { Apr. } 24 \\
\text { to } 30 .\end{array}$ & $\begin{array}{l}1889 \\
\text { May. }\end{array}$ & $\begin{array}{l}1889 \\
\text { June. }\end{array}$ & $\begin{array}{l}\text { 1893, } \\
\text { Dec. }\end{array}$ & $\begin{array}{l}1894, \\
\text { Jan. }\end{array}$ & $\begin{array}{l}1894 \\
\text { Feb. }\end{array}$ & $\begin{array}{c}1894 \\
\text { March. }\end{array}$ & $\begin{array}{l}1894 \\
\text { April. }\end{array}$ & $\begin{array}{l}1894 \\
\text { May. }\end{array}$ & $\begin{array}{l}\text { 1894, } \\
\text { June. }\end{array}$ & \\
\hline Total catch ............................. & 104 & 912 & 2,184 & 224 & 501 & 246 & 348 & 457 & 434 & 447 & 5,887 \\
\hline Males... & 49 & 440 & 1,009 & 123 & 250 & 116 & 161 & 247 & $\begin{array}{l}454 \\
197\end{array}$ & 219 & $\begin{array}{l}5,881 \\
2,811\end{array}$ \\
\hline 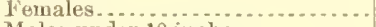 & 55 & 502 & 1,175 & 101 & 251 & 130 & 187 & 210 & 237 & 228 & 3,076 \\
\hline Males under 10 inches.. & 49 & & & & & & & & & & 49 \\
\hline Males under $10 x$ incbes. & -.... & 418 & 976 & 97 & 215 & 107 & 137 & 210 & 173 & 196 & 2,529 \\
\hline Males over $10 \frac{1}{2}$ inches... & 55 & 22 & 33 & 26 & 35 & 9 & 24 & 37 & 24 & 23 & 233 \\
\hline $\begin{array}{l}\text { Females under } 10 \text { inches } . . . . . . . \\
\text { Females under } 10 \frac{1}{2} \text { inches ......... }\end{array}$ & & 439 & 1,099 & 78 & 194 & 106 & $147^{\circ}$ & 163 & 207 & 192 & $\begin{array}{r}55 \\
2,625\end{array}$ \\
\hline Females over $10 \frac{1}{2}$ unches......... & & 63 & 76 & 23 & 57 & 24 & 40 & 47 & 30 & 36 & 396 \\
\hline Females with eggs ............... & 22 & 185 & 108 & 22 & 36 & 11 & 12 & 33 & 34 & 20 & 483 \\
\hline Females without eggs............ & 33 & 317 & 1,067 & 79 & 215 & 119 & 175 & 177 & 203 & 208 & 2,593 \\
\hline $\begin{array}{l}\text { Females under } 10 \text { inches with } \\
\text { egrgs }\end{array}$ & 22 & & & & & & & & & & \\
\hline $\begin{array}{l}\text { Females under } 10 \frac{1}{2} \text { incles with } \\
\text { eggs. }\end{array}$ & & 131 & 63 & & & & & & & & \\
\hline Fomales over $10 \frac{1}{2}$ inches witl & & 5 & 45 & & & & & & & & \\
\hline Percentage of females with eggs & & & & & & & & & & & \\
\hline $\begin{array}{l}\text { to total number of females...... } \\
\text { Percentage of femalps with eggs }\end{array}$ & 40 & 36 & 9 & 21.78 & 14.34 & 8.46 & 6.42 & 15.71 & 14.35 & 8.77 & 17.48 \\
\hline to whole catch...................... & 31 & 19.6 & 4.9 & 9.82 & 7. 18 & 4.47 & 3.45 & 7.22 & 7.83 & 4.47 & 8.99 \\
\hline Percentage of females to males... & 112.2 & 114.3 & 116.4 & 82.1 & 100.4 & 112.07 & 116.15 & 85.02 & 120.30 & 104.11 & 106. 30 \\
\hline
\end{tabular}

The inspector of fisheries for the Province of Prince Edward Island says:

In 1879 returns from almost all the factories then in operation gave, for the whole catch, only from 3 to 10 per cent in spawn, much the larger portion being in July.

This agrees closely with the results obtained at Woods Hole, but it does not follow, as Mr. Duvar supposes, "that one-fifth of the females carry ova each year," or that "there are four times as many young breeders coming forward as there are egg-bearers", and "that one-fourth of the number come into breeding year after year" (209, p. 234), since the artult lobster does not breed annually, as he erroneously supposes.

From December 1, 1893, to May 1, 1894, 358 female lobsters measuring 10 inches or more in length were taken in the harbor of Woods Hole, and 1,234 were captured during the same period at No Man's Land, in all 1,592 lobsters, 57 per cent of which bore external eggs. If we include the 9 -inch lobsters, we find that the total number of females taken at both places is 1,779 , and that 53 per cent carried eggs. This supports the conclusion already reached from the study of anatomy, that the lobster breeds once in two years, in which case 50 per cent, or fully one-half, of all sexually mature female lobsters spawn in some part of each year. It also shows very forcibly that valid inferences respecting the breeding habits can not be drawn from observatious made in a restricted area. Thus, had our attention been confined to Woods Hole it would have appeared that only one-fifth of adult females bore eggs (from December to May), or that the lobster spawned only once in five years. ${ }^{1}$

${ }^{1}$ Ehrenbaum (61) found that only 25.4 per cent of females supposed to be of adnlt age canght at Heligoland carry eggs, and hence concluded that the European lobster becomes productive onls once in four years. Besides the objection that the data are derived from one locality, which, as table 21 shows, is a serious one, there is the further difficulty that over 10 per cent of these female lobsters were captured during the months of July, August, and September, when, according to Ehrenbaum, both the laying and the hatching of the eggs occur. This alone might vitiate the result. The best way to test this question by experiment would be to take a female which had recently hatched a brood and keep her alive until the following summer, when the next batch of eggs would be due, in case the spawuing period is a biennial one. So far as I know, this has never been done. 
It shonld be borne in mind that, as we have already seen, a certain number of lobsters from 9 to 12 inches long have never borne eggs. Thus the chances for error in making estimates of this kind are further increased.

The percentages given in table 21 must therefore be greatly increased to express the ratio between the actual spawners of the current year and those which have reached the spawning age, sinee in the total number of females there were undoubtedly included many which were not mature. While the perceutage of egg-lobster's taken in the same locality may vary considerably from year to year or from month to month it seems probable that if we could average the results taken from many different localities along the coast we should find that the number of spawners each year represents about half the total number of mature females.

\section{RELATIVE ABUNDANCE OF THE SEXES.}

Some species of crustacea are strictly monogamous, such as the beautiful tropical shrimp, Stenopus hispidus, which is always seen swimming in pairs, the male and female being rarely separated. This is also true of another delicate shrimp, Pontonic domestica, which lives in the mantle chamber of the mollusk Pinna. In such cases the sexes are of necessity about equally divided. But in the lobster there seems to be no attachment of this kind. It is probable that a given male fecundates more than one female, and it is certain that the sexes are distributed with great irregularity, at certain seasons of the year at least, as I shall presently show. Nevertheless, if an extended census could be taken, at different points on the coast, it is very probable that but little difference would be found in the numbers of the sexes.

The following table shows the relative abundance of male and female lobsters found in Woods Hole Harbor and at No Man's Land:

TABLE 22.-Relative abundance of male and female lubsters at Woods Hole and To Man's Land.

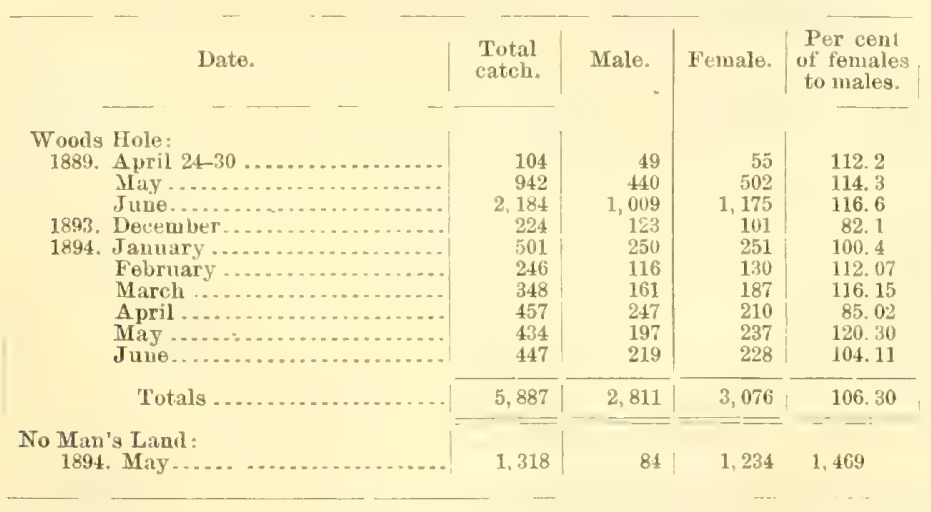

In the monthly eatches at Woods Hole in 1889 the females preponderated by 12 to 16 per cent, while in the total catch for 1893-1894 the sexes are very mearly evenly divided. During this period the percentage of females to males fluctuated from 82.1 minus to 120.30 plus, a variation of abont 38 per cent. The traps were stationary, but the lobsters were constantly moving about over the bottom; yet there was no segregation of the sexes, and such variation as we find in the monthly catches has no special significance. 
When, however, we glance at the data from No Man's Land, it is evident that something besides chance has caused the overwhelming preponderance of females, 1,469 per cent. It seems almost certain that this condition of things is only temporary, and it may be explained, as I have suggested in another place (see pp. 23,24), in relation with the inshore migration and the hatehing of the eggs.

Regarding the relative abundance of the sexes of the lobster, Verrill (196) remarks:

Among those which I have examined from New London, Waterford, and Stonington, Connecticut, in our markets, I have not noticed any marked inequality in the number of the sexes. Mr. Smith examined the lobsters in the market at Provincetown on two occasions, in August and September, without finding any decided differences in the number of males and females. He also repeatedly examined those in the fish-markets at Eastport, Maine, in sumamer, with the same result.

Capt. N. E. Atwood published in 1866 a paper on the habits of the Jobster in the proceedings of the Boston Society of Natural History (5), in which he makes the following remarks:

From Plymouth northward and eastward [lobsters] are caught in deep water in the months of February and March, bnt not in large quantities; as the season advances they come near the shore and remain through the spring, summer, and antumn, and are very plentiful. Along this range of coast three-quarters at least are males at all seasons of the year. At Cape Cod (Provincetown) their habits differ very much from the babits of the lobsters on the north shore. They do not come there until June and remain until October, when they disappear and go to parts unknown. One very singular fact I have noticed is, that the lobsters which visit Cape Cod are nearly all females; they appear to come near the shore for the purpose of depositing their young, after which they pass away and others in turn take their places, as is indicated by the change that is constantly taking place, for when the fishermen are catching great quantities of large, good hard-shelled lobsters-and they are unusually abundant-perhaps the next day there will be a new kind, smaller and not of so good quality, the former ones having passed away and others come to take their places.

In Boston the number of lobsters sold annually can not be much short of a million. The male lobster is preferred and is the most salable, as this city has always been supplied from the northern shore of Massachusetts and coast of Maine, where the males are most plentiful. It is a great advantage to the fishermen that the people prefer males. In New York it is very different in this particular, the city being supplied from Cape Cod after June, and the female lobsters thus considered much the best. I have sold many lobsters in Now York, and males sell at only about half price. The male is much poorer than the female in meat.

I have quoted the foregoing passages at some length, not because they are free from error, but because they were written by an intelligent fisherman at a time when scarcely anything was known of the habits and general biology of the American lobster. If such a preponderance of females actually occurred on the shores of Cape Cod it may have been a seasonal phenomenon, similar to that observed at No Man's Land. It did not exist in August and September, when the observations of Professor Smith were made at a later period.

The statement that males are more plentiful than females on the northern shore of Massachusetts and the coast of Maine is without doubt an unsupported generalization. Conflicting statements in regard to this subject are often given by fishermen, who, as Verrill suggests, probably do not often discriminate the sexes when the females are without eggs. The only detailed facts which we possess on this subject are those recorded in tables 21 and 22 , and they seem to point to the conclusions already drawn. 


\section{Chapter III.-MOLTING AND GROWTH.}

\section{EARLIER OBSERVATIONS}

The process of molting, which makes growth possible to the arthropod, is of such interest and importance that it deserves very careful attention. There is much to be added to onr knowledge of this subject in the lobster, and I shall deal with it at full length. Aristotle knew very well that erabs and lobsters shed their shells (The History of Animals, Book VII, e. XIx), althongh his observations were not accurate; but the fact was forgotten and finally denied altogether.

It is only necessary to go back to the beginning of the last century (in 1712) to find Réaumur (161) demonstrating that the river cray fish periodically cast its shell, yet in the early part of the seventeenth century, a hundred years before, Olaus Wormius, according to Couch ( 17 ), speaks of the molting of crabs as a thing not to be doubted.

The regeneration of the lining of the stomach of the crayfish was reported by Van Helmont, but this writer's reputation did not lend much weight to the statement until it was confirmed in 1709 by Geoffroy (74).

To that marvelously acute observer, Riaumur, we are indebted for the best account of the exuviation of the crayfish. He took crayfishes which appeared to be ready to molt and placed them in jars of water in his museum and watehed them carefully. Others he put into boxes, the bottoms of which were pierced with holes, and moored them in the river Marne, which flowed past his garden. The erayfishes in the river were under more favorable conditions than those kept in the house, and molted more frequently in consequence. He gives a very circumstantial account of the external process of molting in the crayfish, which took place in June, July, and August. The time occupied in the final act of casting the shell by crayfishes kept in the river was from seven to fifteen minutes, while those in the house often struggled for several hours before they were free. Sometimes they died in the operation, especially the young ones. Some would lie on their sides, some on their bellies or backs, and in the latter case he observed that they frequently died.

However, as Couch remarked, Réaumur's paper produced so little effect that when, many years later (1756), Peter Collinson communicated some cursory remarks on this subject to the lioyal Society, his account of the molting of the rrab was received with so much doubt that his second paper was chiefly employed in furnishing evidence of the fact.

Observations on the molting of the higher crustacea have since been made by Couch (45, 46, 47), Gosse (81), Chantran (37), Max Braun (22), Vitzou (197), Sars (176), Hyatt (104), Brook (26), and others. The histological rhanges involved in the molting 
process have been studied by Max Braun (22), and more recently by Vitzou (197). As so often happens, there are many observations on this subject which either ignore the earlier and often better ones, or add nothing of value to our knowledge of the process. Hyatt, in remarking that, while the molting of the lobster had been previously described several times, "no professional naturalist" had "actually seen the process and recorded his observations," appears to have overlooked the account of Sars (176), which, however, is not particularly circumstantial.

Sars saw a lobster in the act of molting in July near Tananger, in Norway. He says:

It had just been taken out of a lobster box, and could be handled. without its offering the slightest resistance. The shell on its back was burst in the middle, and the tail and the feet were nearly ont of the old shell, while the largest elaw strek ont only half its length. This latter portion of the change is evidently very dangerous, and, although I observed it for quite a while, I could see little or no progress.

This lobster was not a good exponent of the molting process. As soon as the larger claws begin to be withdrawn from the old shell the exuviation, under normal conditions, is speedily brought to a close. Nor is it true that the lobster "only reaches its former size after a considerable time las elapsed." According to Sars, the lobster on the Norwegian coast molts chiefly in July.

Both Couch (45) and Salter (14) have given accounts, at secondhand, of the molting of the European lobster. Couch, writing in 1837, says that the newly molted lobster shows great activity in effecting its escape, which is undoubtedly true in some cases, but not in all. The lobster whose cast shell is described escaped "through an aperture too narrow to have allowed it to pass if its new covering had possessed a very moderate degree of firmness." He supposed that escape was effected by the cracking open of the shell, in the middle line, where he noticed that in life a faint stripe was perceptible. He observed in a lobster prepariug to molt that absorption took place along this area, and inferred that the two halves of the shell were completely separated when the critical moment came. Of the molting, he further says that "it is not improbable that the general opinion is correct which limits the exuviation of the adult animals to once in the year," and "general opinion" does not seem to have made much progress in clearing up this matter during the last fifty years.

Salter's account, published in 1860, is interesting on account of some extraordinary statements, such as that in molting the legs are extracted pair by pair, which of course is a physical impossibility, as Hyatt pointed out, and that the abdomen is the part first withdrawn from the old shell. This latter statement expresses exactly the reverse of what has since been found to occur.

Wheildon (202) published in 1875 a short paper containing some interesting facts on the molting habits of the American lobster, which will be referred to again.

The work of Vitzou, which appeared in 1882, is the best yet done on this subject. He treats of the histology of the old and new shell, and of the organic and "inorganic reserves," which are supposed to be laid down in certain tissues with reference to the molting period.

Hyatt's paper (104), appearing in 1883, gave an accurate account of some of the phenomena of exuviation in this species.

Packard in 1886 published some notes (147) in which very little is added to our knowledge of the subject. He says that "the integument of the legs is molted last, and when, owing to rough handling, the process is delayed, the extremities of the legs 



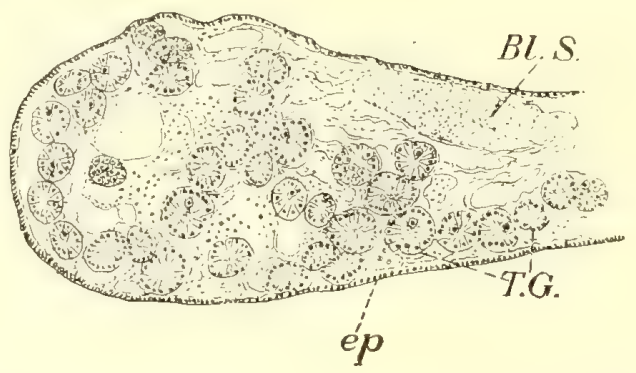

Cot 4.-Part of transverse section of exopodite of pleopod of femalo lobster (the cuticle removed), showing the dis tribution of the cement glands. July 19, 1891.

Bl. $S$, blood sinus. ep, chitinogenous epithelium. T. G, tegumental gland.

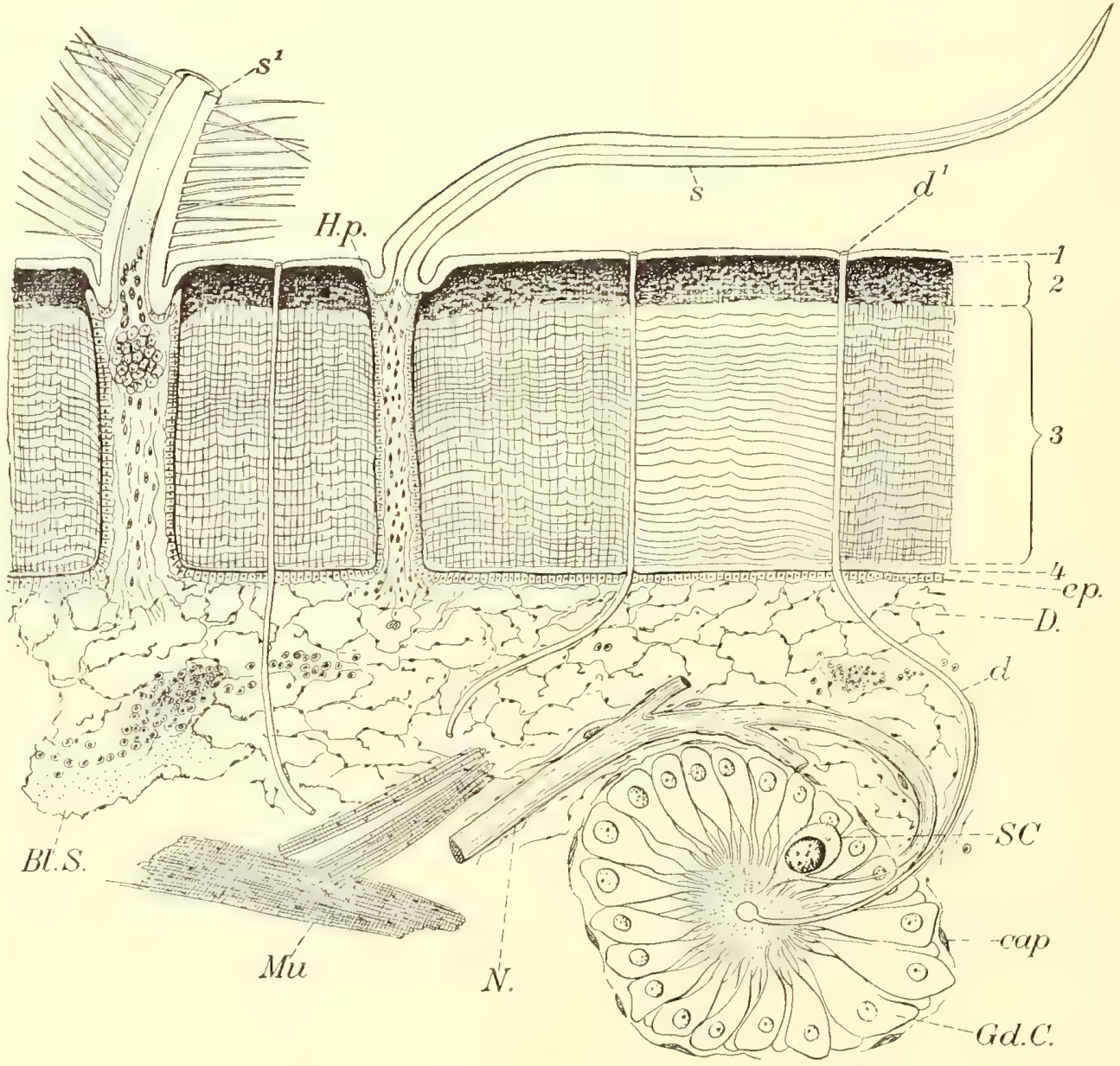

CUT 5.-Diagram of vertical section through skin, showing a tegumental gland (relatively much smaller than representer) in section and it duct opening to the exterior, also hair pores perforating the cuticle, with the superimposed hairs or set: The structure of the cuticle or shell is diagrammatically shown.

BL. $S$, blood sinus. cap, capsule of tegumental gland. $D$, dernis. d, duct of gland. $d^{1}$, mouth of duct. ep, chitinogenous epithelium. Gd. $C$, gland cell. $H . p$, hair pore. Mu, muscle. $N$ nerve, supplying gland. SC, central nerve cell. $s^{\prime}$, plumose hair. s, simple hair. 1, enamel layer of shell. 2, calcified pigmental layer of shell. 3, calcified non-pigmented layer. 4, inner non-calcified layer of shell. 
slough off." The remarkable statement that "the abdominal legs are molted before the thoracic ones" would imply that the hinder part of the body is first withdrawn from the old shell, which is not true.

The statement that the lobster "remains inactive for nearly or quite a week, until the new crust beeomes hard," can not be accepted without modifieation, since the soft lobster is frequently caught in traps, and the newly molted lobster often displays surprising agility, and besides it requires more than one week for the shell to become hard.

Brook (26), writing in 1857 on the reproduction of the lost parts of the lobster, has some interesting notes on the growth of the European lobster which he kept and observed in an aquarium for nearly a year and a half in one instance, during which period the animal molted four times. The ecdysis usually occurred at night, and the exuvium was buried.

No one, strange to say, has ever examined the cast-off shell and observed with sufficient care the areas of absorption. This has resulted in much useless discussion as to whether the carapace splits along the middle line when it is cast off. I shall refer to this hereafter.

We are now concerned with the adult animal only. The molting of the embryo and larva will be considered in Chapter XII.

\section{THE STRUCTURE AND GROWTH OF THE SHELL.}

The phenomena of the molt are unintelligible withont a knowledge of the structure of the skin or integument. The histology of the shell in the crustacea has been studied with varying degrees of success by a number of naturalists-by Carpenter (34), Lavalle (116), Williamson (205), and Tullberg (191 $\left.\frac{1}{2}\right)$. The most accurate statement is in the paper by Vitzou (19\%), on which I shall mainly rely in giving the following account.

The skin as a whole is composed of dermis and epidermis, and consists of the various parts shown in the diagram (ent 5). The epidermis is made up of a single iayer of chitinogenous epithelial cells, and of the shell which they secrete; the dermis is composed of connective tissue, blood vessels, nerves, pigment cells, and glands. The shell consists of four layers, namely: (1) the thin outermost layer, which I shall call the enamel layer, apparently structureless; (2) the pigment layer, composed of parallel lamellæ, traversed by canaliculi and filled with pigment and lime salts; (3) the calcified layer, devoid of pigment but otherwise like the last, forming the greater part of the carapace; (4) a noncalcified imer layer, composed of very thin lamellæ.

The chitinogenous epithelium corresponds to the Malpighian layer of the epidermis of the vertebrate, while the layers of chitin represent its horny cuticle.

The vertical canalicnli correspond, as Vitzou has shown, in certain decapods, to the boundaries of the chitinogenous cells; but this is not the case in the lobster, where they are close together and very numerous.

During the molting period the cells of the chitinogenous epithelium undergo a great change. They grow out, vertical to the surface, into very slender aud exceedingly long rods. (Compare Cut 11, and figs. 171, 173, plate 43.) The epithelium formed over the surface of a budding limb is of the same character. The chitinous layers of the new shell are formed by discontimnous thickenings of what, according to Vitzou, may be regarded as the upper wall of the epithelial cell. Thus are formed parallel lamelle of varying density, which fiuse with those of adjoining cells and make a continuous shelly erust. 
At the time the shell is ready to be cast the tegumentary covering consists of (1) the old shell; (2) the new shell; (3) an intermediate structureless membrane, besides the chitinogenous epithelinm, and (4) the dermis. The new carapace, according to Vitzou, is composed of the enamel and pigment layers only. The calcified layer is not formed until after the molt.

The connective-tissue cells are now of large size and contain granules of glycogen. Claude Bernard first demonstrated the presence of glycogen below the carapace in crustacea. Glycogen was extracted by Vitzou from the connective tissue, liver, lymph, and ovaries, duxing the molting period. Besides acting as a pancreas, the liver was found to be a great producer of glycogen during the molt. Glycogen is thus an organic reserve, which furnishes material for the growth of the new shell and tissues. According to Vitzou, Schmidt aud Berthelot have shown that the chitin of the crustacea contains a principle belonging to the same group as cellulose and lignin. This substance, under the influence of sulphuric acid, may be transformed into a body analogous to glucose. Hence the remark of Claude Bernard, that "without forcing the metaphor one may say that the crustacea are enveloped in a carapace of wood." (Leçons sur les phénomènes de la vie, 1879, t. 2, 1. 113.-19\%.)

The enamel is plainly the first product of the secretions of the skin which goes into the new shell, and when once laid down can not be competely removed except by a molt. The enamel is often partially removed by friction, as is seen in the abrasions on the shells of old lobsters or those about to molt.

The surface of the shell, particularly that of the carapace, has a decided punctate appearance, due to the hair pores. These mark the points where setæ either penetrate the shell now or did so at an earlier stage of development. In the adult lobster the setre of the carapace have disappeared or are worn down except upon its margins and in the orbital regions. In the fourth larva, however, the whole carapace is seen to be studded with hairs (fig. 113, 115, plate 35 ).

If the carapace-better one without pigment-is examined with a hand lens, the surface is seen to have a beautiful though somewhat irregular mosaic appearance. It is divided into polygonal areas which inclose the hair pores. These markings are probably due, as Professor Patten has shown to be the case in Limulus, to shallow depressions in the enamel, dependent upon a peculiar bending together or clustering of the outer ends of the canaliculi. The hair pores open on the inner side of the shell in small blister-like elevations.

A very minute pore of another character is scattered amoug the hair pores on the inner side of the shell. It has the appearance of a symmetrical crater with a minute tube issuing from it. This is the duct and opening of the tegumental gland. The distribution of these two kinds of pores would probably repay careful study. But few parts of the carapace, such as the white tendon marks (see p. 135), are wholly free from them. Toward the lateral margius of the carapace they become exceedingly small and numerous. Some of the superficial pits in the dorsal region, on the other hand, are very large.

We thus see that the dense shell is a veritable strainer, being perforated by hundreds of thousands of minute passages, which lead from the surface to the parts below it, to the tegumental glands on the one hand, or to the sensory cells which lie at the roots of the hairs, on the other. The bearing of these facts will be better appreciated when we discuss hereafter the function of the tegumental glands themselves. 
THE SHEDDING OF THE SHELL IN THE LOBSTER.

THE MOL'TING PERIOD.

The hard-shell lobster is heaviest, has the firmest flesh, is hardiest, standing transportation best, and therefore most valuable for the market. A large percentage of all lobsters taken during the fall and winter months are of this character, and all or nearly all lobsters canght in March, April, and May belong also to this class. Shedders and soft-shell lobsters are taken in greater or less abundance from June to October, varying somewhat with the season and locality and surrounding conditions, such as the nature of the sea bottom and the temperature of the water. By far the greater number of lobsters in all seasons, and in all places, east their shells duriug the months of July, August, and September. However, the time of shedding varies considerably on different parts of the coast, being from four to six weeks earlier in some seasons in western Maine than in the extreme eastern section. Shedders are not fit for the market, being lean and watery, and soft lobsters are in a similar condition and will not bear much handling or transportation. Until the shell becomes tolerably hard the soft lobster is in constant danger of attack from its companions, and is easily wounded and killed. Lobsters with very soft shells and those which have been mutilated are often kept in the lobster preserves or pounds until the shell is hardened or the injury repaired.

No systematic data have hitherto been gathered at any point along our coast upon the molting habits of the lobster. I am therefore glad to be able to give the results of a series of daily observations made at Woods Hole, Massachusetts, during the space of seven months, from December 1 to June 30, 1894. During this interval 2,657 lobsters were captured in traps set at fixed points in the harbor. As shown in table 23, ' there was no month in which either shedders or soft lobsters were not caught.

TABLE 23.-The molting of the lobster.

\begin{tabular}{|c|c|c|c|c|c|c|c|c|c|c|c|c|}
\hline \multirow{2}{*}{ Months. } & \multirow{2}{*}{$\begin{array}{c}\text { Tempera } \\
\text { ture of } \\
\text { water in } \\
\text { harbor. }\end{array}$} & \multirow{2}{*}{$\begin{array}{l}\text { No. of } \\
\text { days for } \\
\text { which } \\
\text { average } \\
\text { tempera. } \\
\text { ture is } \\
\text { given. }\end{array}$} & \multirow{2}{*}{$\begin{array}{l}\text { Nature of } \\
\text { bottom. }\end{array}$} & \multicolumn{3}{|c|}{ Catch } & \multicolumn{2}{|c|}{$\begin{array}{l}\text { Shell hard } \\
\text { and bright. }\end{array}$} & \multicolumn{2}{|c|}{$\begin{array}{l}\text { Shell hard } \\
\text { and dull. }\end{array}$} & \multicolumn{2}{|c|}{ Shell soft. } \\
\hline & & & & Male. & Fem. & Total. & Male. & Fem. & Male. & Fern. & Male. & Fem. \\
\hline 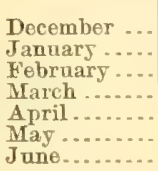 & \begin{tabular}{l|} 
F. \\
37.71 \\
35.48 \\
32.54 \\
37.40 \\
42.52 \\
53.65 \\
62.20
\end{tabular} & $\begin{array}{l}14 \\
27 \\
24 \\
27 \\
25 \\
26 \\
25\end{array}$ & $\begin{array}{l}\text { Rocky .... } \\
\ldots \text {. do .... } \\
\ldots \text { do } \\
\ldots \text {... do } \\
\ldots \text { do }\end{array}$ & $\begin{array}{l}123 \\
250 \\
116 \\
161 \\
247 \\
197 \\
219\end{array}$ & $\begin{array}{l}101 \\
251 \\
130 \\
187 \\
210 \\
237 \\
228\end{array}$ & $\begin{array}{l}224 \\
501 \\
246 \\
348 \\
457 \\
434 \\
447\end{array}$ & $\begin{array}{l}117 \\
239 \\
115 \\
154 \\
232 \\
194 \\
185\end{array}$ & $\begin{array}{l}101 \\
250 \\
130 \\
186 \\
206 \\
236 \\
202\end{array}$ & $\begin{array}{r}2 \\
7 \\
0 \\
7 \\
14 \\
3 \\
0\end{array}$ & $\begin{array}{l}0 \\
0 \\
0 \\
0 \\
4 \\
1 \\
2\end{array}$ & $\begin{array}{r}4 \\
4 \\
1 \\
0 \\
1 \\
0 \\
34\end{array}$ & $\begin{array}{r}0 \\
1 \\
0 \\
1 \\
0 \\
0 \\
0 \\
24\end{array}$ \\
\hline
\end{tabular}

Only one soft-shell lobster was taken in February out of a total catch of 246 , and 110 "shedders" (shell hard and dull) were captured during this month. Again, one soft-shell lobster only was observed in March and April, and none in May. In June,

${ }^{1}$ Lobsters with shells "hard and dull" are nearing the molting period; those with "soft shells" have recently shed, and in those with "hard and bright" shells the molting time is most distant. See p. 82. 
on the other hand, the number of lobsters which have recently shed jumps suddenly to 58. These observations may be summed up for the whole period as follows:

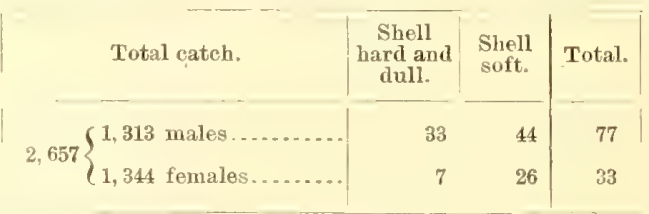

Of the entire catch, 110 have either recently molted or are preparing to molt; 77 of them are males, 33 females. The total number of males is smaller, yet the number of soft shells among them is nearly twice as great as in the other sex. 'This fact implies that the males molt oftener than the females, which would be an a priori deduction from the greater size which the male attains (see p.34), or that they molt more frequently during those months. It is interesting to recall in this connection the observation of Chantran (37) that the male crayfish molts twice in the year, while the female molts but once. Females molt, as a rule, shortly after the young are hatched, and very rarely just before the eggs are laid (see p. 35).

When I was in Portland, Maine, on the 24th of August, 1893, soft-shelled lobsters were being caught in that region, while fishing suacks were bringing hard-shelled lobsters from Jonesport, near the eastern border of the State. Soft-shelled lobsters are still taken in the Portland district, as I was informed by Mr. N. F. Trefethen, for four or five weeks before they are received in large numbers from Jonesport.

Mr. F. W. Collins, of Rockland, thinks that lobsters shed earlier in the shoal mud coves, which are full of eelgrass, than on rocky bottoms. The shedding commonly oceurs there on muddy bottoms in the latter part of July and the first part of August.

Shedders in small numbers are occasionally taken in Rockland in January and February, and sometimes shed in cars at this time. In deep water outside, as at Seal Island, Matinieus, Green, and Ragged islands, where lobsters are caught in winter in 40 to 50 fathoms, and in shoal places in summer in 3 to 10 fathoms, very few soft-shell lobsters or shedders were taken in the summer of 1893, np to the 26th of August, not more than a dozen among thousands examined each week. The majority of the softshell lobsters from these localities come later in the season, from the last of September to the middle of October.

Mr. A.P. Greenleaf said he had rarely seen soft-shell lobsters at Southport, Maine, but that in the winter of 1893 (in January and February) he had taken dozens of them.

At West Jonesport, Maine, on September 4, 1893, I was told by a fisherman at Beal Island that hard-shell lobsters had prevailed up to that time, but that soft-shells were becoming common. He thought that the shedding was rather later than usual. This confirms the reports made at Rockland and Portland.

Molting lobsters were very common at Woods Hole in October and November, 1890, particularly in the latter month, when Mr. Vinal N. Edwards says that more were caught than during the earlier part of the season. In December, 1891, Mr. Edwards found lobsters in all stages of shedding, some that appeared as if they would be ready to molt in a few weeks, and others as if they might shed in a few days. Thus it was probable that the lobsters continued to molt to some extent in winter, which is shown by table 23 to be the case.

The abundance of shedders which was noticed in the late fall of 1890 at Woods Hole has not since been observerl, and it seems clear that there is considerable variation in the molting of lobsters in a single locality at this season of the year. 
It is stated in the annual report of the inspector of fisheries of Prince Edward Island (20\%, 1. 236i) for 1850 that soft-shell lobsters "are seldom seen on the north sirle of the island, while on the south side almost all that are caught in the month of July are soft and unfit for eamning." A canner in Queens County says that scarcely a lobster can be canght before the zoth of 11 ay. Soft-shell lobster's begin to abound by the 1st of August and continue abundant during this month. One-third of the lobsters ('anght during August are said to be soft-shelled. The fishery officer for Cape Breton states in his report for $18 s 8$ (210) that no soft-shell lobsters were captured during the fishing season which closed July 28.

\section{THE MOLTING PROCESS.}

Next to reproducing its kind, the act of molting is the most important in the life of this mimal. The whole body is covered, as we have seen, by a chitinous shell, in which salts of lime are deposited, giving to parts of it the hardness of stone. Molting consists of two distiuct phenomena: (1) the formation of a new shell and (2) the rejection of the old. When once formed the shell admits of no increase in size, since it is a dead structure, excreted by the skin below it, and when it is outgrown it must be cast off and replaced by a new and larger shell. The new shell is gradually excreted under the old one, and when the latter is discarded the new shell is soft and flexible and is easily disteuded to meet the requirements of growth. The growth of the lobster, and of every arthropod, thus aplrarently takes place, from infancy to old age, by a series of stages characterized by the growth of a mew shell under the old, by the shedding of the outgrown old shell, a sudden increase in size, and the gradual hardening of the shell newly formed. Not only is the external skeleton cast off in the molt and the linings of the masticatory stomach, the cesophagus and intestine, but also the internal skeletou, which consists for the most part of a complicated linkwork of hard tendons. This is rendered possible from the fact that these structures are derived from infolded portions of the skin, and in molting they are simply drawn ont of their original folds or pockets. It is thus easy to see why the molting process is eritical.

The frequency of the molting period depends directly upon the physiological condition of the animal, which varies with its environment. The molting process is both an expensive and dangerous operation, and calls for a considerable excess of energy. Since it is largels dependent upon the condition of the individual, which is subject to wide variation, the molt does not take place at any stated time, but may occur in any month of the year, though but rarely in the spring. Warmer weather, a more active life, and a more vigorous appetite, which are characteristic of the lobster during the warmest part of the year, are most favorable, as we have seen, to the renewal of the shell. The lobster, though a carnivorous and voracious animal, feeds less in winter, when its habits are relatively sluggish. Broken limbs and injuries to the shell are then but slowly repaired, and there is less energy to be drawn upon in molting.

The growth of the crustacean takes place during the period of the molt, while the new shell is being formed, and not immediately after the ecdysis, as is commonly believed. It was elearly shown by Vitzou that the old shell is gradually thrown off in consequence of the growth during the molting period, when the animal tends to become larger than its envelope. The rapid swelling out of the body after the old shell is gotten rid of is due to the absorption of water through the new shell into the blood and tissues, not to cellular growth.

$$
\text { F. C. B. } 1895-6
$$


Before the molt takes place the lobster has been for a long time preparing for it, while growth has been going on. After molting, it is several weeks before the new shell is as hard as the old one, so that the lobster is, for a large part of its life, either preparing for a molt or recovering from one. It is therefore not remarkable that lobsters bave acquired many popular names among fishermen, such as "hard shell" or "old shell" Iobster; "shedder," "black shell," or "crack back" (lobsters preparing to molt); "soft shell," "new shell," "shadow," "rubber shell," "paper shell," "buckle shell" lobster, ete. (lobsters which have recently molted).

\section{HABITS OF MOLTING LOBSTERS.}

Shedders can be readily distinguished by the dark, dull colors of the old shell hence the common name of "black lobster," and by the deep reddish tint of the membranes at the joints, where the flesh is now seen through the old and new cuticle. The lobster is now naturally sluggish, though not too inactive to enter a trap. When in this condition they very commonly haunt shallow water with a sandy, muddy, or weedy bottom, and at low tide have been taken out of bunches of eelgrass in a few iuches of water. When in this condition they frequently dig a shallow hole in the mud under stones, where they can await the coming change with greater security from enemies. Fishermen frequently see a shed shell lying on the bottom and a soft lobster close by under a rock or bunch of kelp.

It is well known that many prawns habitualiy molt in the early morning while it is yet dark. The lobster when kept in an aquarium molts either by day or night, and it probably does the same in nature. In those which Brook observed (26) the shells were cast off in the night and partially buried.

Shedders and soft lobsters used to be a favorite bait with fishermen who knew where to look for them and could then find them in abundance. The shell of the black louster was peeled off, and the soft, pulpy flesh formed a tempting bait which fish found difficult to resist. Mr. Vinal N. Edwards says that in 1869 or 1870 he used to take moltiug lobsters for bat at Menemsha, in Vineyard Sound, in October, sometimes a barrel of them at a time. He says that he never found a molting lobster buried in the sand, but they were usually under bunches of seaweed, such as the common kelp (Fucus vesiculosus) with their bodies only partially surrounded by the sand, and in 5 to 9 feet of water. It was not uncommon formerly to catch shedders in fyke nets, but he has taken none in recent years. He used to take them occasionally with hook and line. The lobster probably requires greater freedom in getting free from its old shell than could be found in the most carefully constructed burrow.

While at the Vinal Haven Islands, August 26, 1893, I saw in the pound at that place a number of soft lobsters which had molted but a few hours before. One was found lying in the eelgrass; another, a male, was exposed on the mud bottom in 2 feet of water. A shedder, weighing upward of 10 pounds, was eanght by Mr. M. B. Spinuey in Seal Cove, Small Point, Maine, in the month of August, in very shallow water; and in Sagadahoc Bay, near the mouth of the Kennebec River, a large soft lobster was once found and close beside it its cast-off shell. The lobster lay buried under roots of eelgrass and was out of water, when discovered, at low tide.

In the Peabody Academy of Science, at Salem, Massachusetts, there is a crushing. claw of a lobster said to have come from Gloucester and to have weighed 39 pounds. An outline drawing of this claw is given in plate 15 (see p. 115). This lobster probably 
weigherl not over as pounds. The shell of the last three joints of the claw-bearing limb (the parts represented in fig. 20 ), weighed 10:3 ounces. It has the thickness of thin pasteboard, excepting at the tips of the claw, where it is deuser, and probably belonged to a lobster which had molted within three months of the time of its capture.

Putnam (15i) recoids some interesting facts in regard to the molting habits of the blind craytish, Cambarus pellucidus, and of the eyed craytish, Combarus bartonii, captured in Mammoth Cave November 13. The blind species was of a milk white color. One molted on Jauuary 29 and a second time April 20. Another specinen of this species, exposed to the light over nime months, had eaten little and molted once. One of the specimens of $C$. burtonii molted about February 20, and when observed was eating its own shell. It had devoured about half of it. This habit of eating the remains of the old shell is rery interesting, and is undoubtedly induced by the need of lime. It was noticed in the crayfish by Baker (7) over a hundred years ago, but it is so seldom recorded that it would hardly seem to be a fixed habit. It is probably occasionally practiced by the lobster and all the higher crustacea, especially when in confinement. Warrington (199) estimated that the molting period of prawns (Pulcmon scrratus), which he kept in aquaria, varied from twelve to twenty.four days, depending upon food, the temperature, and other conditions. When the cast skins were not removed the prawns devoured all the soft parts. Young lobsters, immediately after molting, fill their stomachs with any calcareons matter at hand, such as the fragments of the shells of mollusks and crustacea. Pieces of the integument of the lobster are commonly found in the stomach-bag, so that it is not at all improbable that the young lobster sometimes devours its cast.off skeleton. Brook (26) thus speaks of a lobster the day after ecdysis:

It had partially buried its cast shell under the gravel. During the previous fortnight this specimen has shown great irritability and pugnacity, and when offered food seized it savagely, but instead of eating proceeded immediately to bury it.

Spence Bate (9), who tried without success to observe the common green crab (Carcinus monas) in the act of molting, concluded that this animal had the power of inhibiting the process until a favorable time arrived.

THE CASTING OF THE SHELL.

A male "shedder" was eaught in the harbor of Woods Hole July 13, 1891, and placed in an aquarium. At exactly $2.48 \mathrm{p} . \mathrm{m}$. this lobster began to molt and in six minutes was out of its shell.

When the lobster is approaching the critical point the carapace or shell of the back gapes away a quarter of an inch or more from the tail. Through the wide chink thus former the flesh can be seen glistening through the old and new cuticle, giving it a decidedly pinkish tinge. Take the lobster up in the hand now and the tail drops down as in death, the strong muscles which bind the pleon to the carapace being completely relaxed. When this stage is reached the time of exuviation is at hand and the process becomes purely automatic, the animal having lost all control over its own movements. There are other sigus, though not equally infallible, which point to the same conclusion-the dull, faded color's of the old shell, scratehed and marred often with the marks of many conflicts. The shell is frequently of a dark, dinty green color, the mottled tints having become very much obscured. The contrast in color is very great if the shedder happens to be among a lot of new-shell lobsters, and the 
term "black lobster," used by the fishermen on the coast of Maine, is not altogether inappropriate. The old shell is also brittle, owing to the absorption of organic matter, and if the carapace or large shield wnich covers the anterior half of the body is pressed between the fingers, it will sometimes split down the back in the longitudinal median furrow. In most cases the shell does not crack in this place unless artificially compressed. In the course of the preparation for the molt the lime salts of the shell are absorbed along the middle line of the carapace, leaving a narrow perfectly straight gutter, extending from the spine or rostrum to the posterior margin of the shield. The chitinous portion of the cuticle still remains, forming an inelastic hinge, on which the lateral halves of the carapace bend without breaking asunder. In the molted shell there is also a linear nembranous area on either side of the rostrum. Absorption of the hard matter of the shell at these points teads to give greater latitude to the movements of the two halves of the carapace. If you examine a hard-shell lobster you will find in place of the median furrow a blue line, drawn as if with a fine pen and rule. Below this line the epidermic cells of the skin become so modified as to bring about the total absorption of the lime salts of the cuticle. In sections of the skin, however, it is difficult to detect any histological change in this linear area. Other areas of absorption, to be described hereafter, occur, which are of even greater importance to the success with which the lobster comes out of his old covering alive and whole.

The period of uneasiness, which foreshadowed the molt and was very marked, ended in this lobster by its rolling over on its side, agitating its appendages, and bending its body in the shape of the letter $V$, the angle of the $V$ coinciding with the gaping chink between the dorsal shield and "tail." Presently the old cuticle, holding these parts together and through which the new shell is seen, began to stretch, the wall of the body pressing against it with considerable force, and the hinder end of the shell being slowly lifted up, while its anterior part remained attached to the rest of the skeleton. The slow but sure pressure of the parts within cause an increasing tension in the yielding cuticular nembrane, which finally bursts, revealing the brilliant colors of the new shell. The legs and other appendages are occasionally moved, but no marked convulsive movements are to be seen. The carapace has now become raised upward to an elevation of perhaps 2 inches behind, in consequence of which, the anterior end being fixed, the rostrum is bent downward and the animal now has a very singular appearance.

When this much has been achieved the lobster becomes quiet for a few seconds and then resumes its task with renewed vigor. From this time on until free its muscles work intermittently. 'T'he doubled-up fore part of the body is with each effort of the animal more and more withdrawn from the old shell, and this implies the separation of the skin from the complicated linkwork of the internal skeleton and the freeing of the twenty-eight separate appendages, which are attached to this portion of the body, from their old cases, and at the same time the release of the muscles from the internal tendons of the large claws and other parts. The cuticular part of every ectodermic structure is stripped off. This exoskeleton folded up to fit such a complicated mold is in reaiity a continuous structure, and from the method of its regeneration the sloughing of one part necessitates the shedding of the whole.

The carapace is now elevated to such an extent behind that the rostrum is directed obliquely downward and backward. The lobster is still lying in comparative 
quiet upon its side, but the muscles of all its appendages are undergoing violent contraction as the animal tugs and wrestles violently as if to free itself from ropes which bind it down firmly on every side. The carapace is unbroken, yet the two halves bend as upon a hinge along the median furror. Presently the pressed-down bases of the antenure, the eyestalks, and the bent-down rostrum of the new shell can just be seen. No part of the covering of the large claws or of any of the legs has been split or cracked. The muscular masses of the powerful claws have been withdrawn through their narrow openings without a rent. Finally a few kicks free the entire anterior half of the body, the antenne, chelipeds, and various other parts, which now lie above or to one side of the old covering". The "tail" has been gradually breaking away from its old case, and as soon as the forward part of the body is withdrawn the lobster gives one or two final switches and is free. The newly molted lobster has a very sleek and. fresh appearance, and its colors were never brighter or more attractive. Try to take it up in the hand, after some time has elapsed, and it feels as limp as wet paper; but immediately after casting the shell the muscles of the crustacean are hard and tense, probably from being in a state of cramp or tetanus. Every part of the old shell down to a microseopic hair has been reproduced in the new one, but in the latter the fringes of stiff setæe are as soft as silk, the strong ends of the claws, the rostrum, and every spine of the body so soft as to easily bend beneath the finger. The large claws are considerably distorted, as well as some of the other parts, being squeezed and drawn out to an unnatural length. After getting clear of the old shell the animal is not inclined to activity. It soon orients itself, however, resting in the usual way, and is capable of moving about with some degree of agility by the flexure of the tail. Fishermen who have had lobsters shed in cars and traps have often been surprised by the ease with which they sometimes slip through their fingers.

The length of the cast shell of this lobster was $11 \frac{1}{4}$ inches. Shortly after the molt the lobster was 12 inches long. On July 17, four days after molting, the length was a little short of $12 \frac{1}{2}$ inches. The increase in length was thus very nearly $1 \frac{1}{4}$ inches. The actual increase in size of the different parts of the body can be best appreciated by comparisons of plates $45 a$, and $45 b$, which represent life-size drawings of a lobster before and several hours after the molt. The measurements in this case were $5 \frac{1}{2}$ and $6 \frac{1}{2}$ inches, the increase in leugth being just 1 inch.

Réaumur remarked on the hardness of the flesh of the crayfish immediately after exuviation, and, as Huxley says (103):

In the absence of the hard skeleton there is nothing to bring the contracted museles at once back into position, and it must be some time before the pressure of the internal fluids is so distributed as to stretch them out.

Hyatt (104) said of the large claws of a molted lobster:

They were exceedingly hard and firm, and I have no doubt would have been extremely good eating if we had dared to indulge in such extravagance. This is entirely contrary to the usual accounts, but it agrees with my former observations on the common blue crab, of which I have seen hundreds directly after molting, and they are always firm and delicions eating if taken at this time. In fact, the watery aspect usually attributed to the newly molted crustacean did not appear until some time after the lobster was placed in our live tank.

Very soon after molting the lobster is ready to take food, the body, owing to the absorption of water, plumps out to its natural shape, and the limit of increase in the volume of the body is reached. 
The interesting observations of Hyatt on the molting of a lobster were made at Matimicus Island, Maine, July 21, 1880. The ecdysis was accomplished at 9.30 a. m., and the lobster lived forty hours, when the shell had become but little hardened, being still papery and pliable. In twenty-four hours after shedding the claws had swelled out and assumed a transparent, watery aspect. An under tint of green was observed in the shell. The crowns and points of the spines and teeth of the large claws had become whitened. The ratio of increase in buik was found to be 1.211 ; the ratio of increase in breadth, 1.192; the ratio of increase in length, 1.010. This lobster came out of its shell without splitting the carapace, and the "tail" was the last part to be set free.

Vitzou describes the molting of a lobster which he watehed in the marine laboratory at Roscoff on the 21st of July. He speaks of the membrane between the carapace as being early ruptured, and points to this as a sigu that the animal is about to molt, but this can not be a normal occurrence.

\section{WITHDRAWAL OF THE LARGE CLAWS.}

The shell of the large claws is molted entire without a rupture in any part. This means that the great mass of muscles which fills the terminal joints must undergo distension and compression to an extraordinary degree. This will be better appreciated by an examination of cuts 6 and 7 , plate B. Cut 6 represents the cast shell of the left cheliped of the lobster (No. 7, table 24) which molted on July 13, and cut 7 cross-sections of the shell with their plotted areas, in the planes indicated in eut 6 . The flesh which fills the area I $a$ is drawn through the opening of the joint II (plotted area shown in II $a$ ), and later through III, the smallest part of the claw. The shell is here distensible, however, owing to the absorption of lime from the upper surface, so that probably in this part the area of the cross-section is increased until it equals that of II $a$. Finally the compressed and distorted limb is drawn through the quadrilateral opening at the base IV (plotted area, IVa), as Salter says, much as a wire is drawn through the contracting holes of a draw-plate. The latter is somewhat larger than the opening of the subterminal joint II. The area of the section of the largest part of the claw (I, I $a$ ) is more than four times that of the opening II $a$, through which all the tissues of the claw must pass. The muscles appear to be stretched out like a stick of candy, but, apart from their elasticity, they are probably aided in accomplishing. this by the removal of water from the blood. The parts are very much distorted immediately after they are free, and are quite hard, but they soon take up water and assume their natural form, with a proportional increase in size.

The areas of absorption in the three basal joints of the limb are easily distinguished, though less plainly circumscribed, in the hard-shell lobster. The shell of the basal joint becomes a slender ring, which is not broken, as has been inferred, but remains intact, as Salter (174) has already observed.

In the crayfish, on the contrary, Réaumur (161) maintained that in molting the shell of the "second and third" joints (meaning, as shown by his figure, the meros and carpus - fourth and fifth joints) opens by a longitudinal tissure on the outer side.

The two pieces are so perfeetly adjusted to each other that they appear as one, but at the time of the molt, when the erayfish subjects them to strain, these tubes gape apart and thus permit the passage of the extremity of the limb.

After the molt the crack closes up and appears to be glued together again, as if no rent had been made. This explanation of the withdrawal of the large claws is 


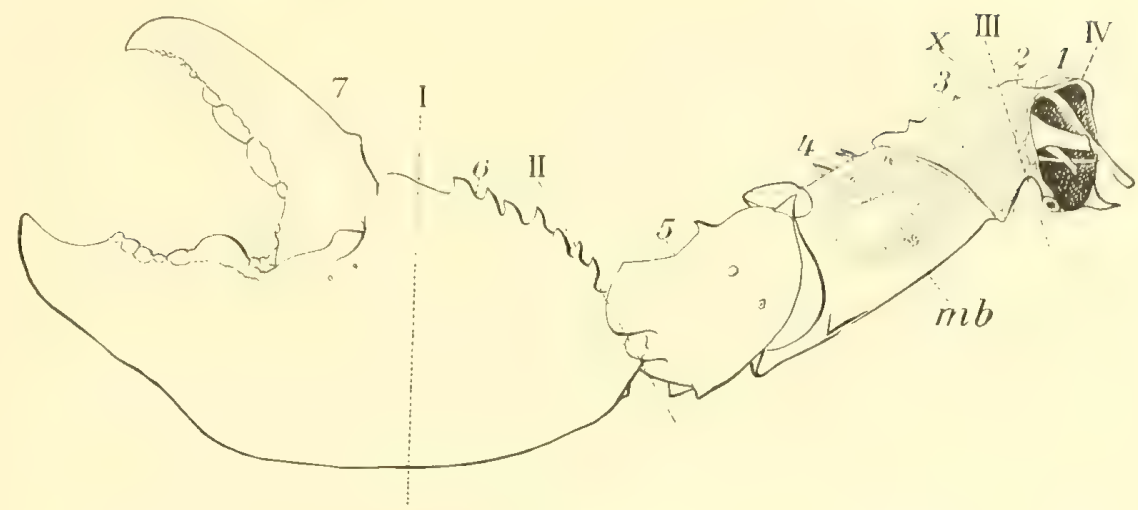

Cot 6,-Left cheliped of lobster seen from thedorsal side. From specimen which molted in an aquarium July 13, 1891, and which is described in Chapter III, pp. 83 to 85 . See No. 7, table 24. One-half nat. ural size.

The Roman numerals I-IV correspond to the planes of section illustrated in eut 7; Arabie num. erals 1-7 to segments of limb. mb, area of absorption, on upper surface of third and fourth, joints. $x$, plane of fracture.

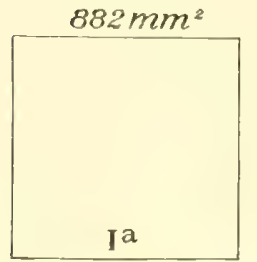

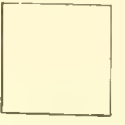

I ${ }^{\mathrm{a}}$

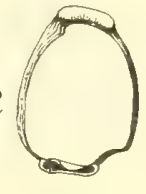

II

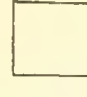

III ${ }^{a}$

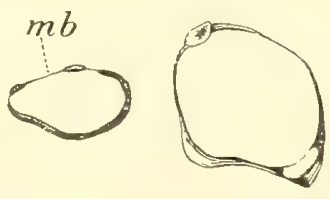

III

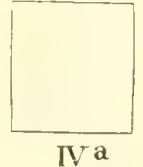

IV

CuT 7.-I-IV represent transverse sections of cheliped shown in cut 6 in the planes indi. cated by corresponding numerals, II and IV showing the nat ural openings at the proximal ends of the sixthand tirst seguents respectively. I $x-I V a$ represent the areas of the respective sectious expressed graphically and numerically. (The plotted areas are two-thirds natural size; tho numerical expressions above them refer to actual areas.) At $m b$, cuts 6 and 7 (III), the lime salts of the shell have been absorbed, so that the cuticle is capable of distention, aud the area of the transverse section is thereby slightly increased. The muscles and other tissues which fill the transverse section $I \alpha$ must be drawn through an opening the size of $I I a$, then through one but little larger than $I I I a$ (allowing for the distention of the membrane), and finally through the small ring, IV, $I F a$ at the base of the limb, since there is no rupture of any of these parts. Drawings two-thirds natural size. 

repeated by Rymer Jones $(106)$ and others. It is, wichout doubt, erroneous, but possibly based originally upon an exceptional occurrence.

At the time of the casting of the shell the large claws must be practically free from blood, since, as Vitzon hats pointed ont, if the claw were to be increased in siz. it would be next to impossible for it to be withdrawn without rupture. The older naturalists used to explain the withdrawal of the large claws by a wasting of the tissues. The lobster was supposed to become sick and emaciated, which, of course, was in error. The most significant fact in this process is the displacement of the liquids which normally belong to these appendages.

Conch (47), in his account of the exuviation of the common edible crab of Great Britain, Cancer payneres, maintains that the membranes in the areas of absorption at the base of the ehelipeds split along the edges and open like hinges, thus freeing the limb from its constraint. This does not happen in the lobster, as Conch inferred, and even if it did no benefit would arise, since there is the unbroken ring of the coxopodite, through which the tissues must still pass. Spence Bate (10) thought that the splittiug of" the walls of the cheliped, alluded to by Couch, might be to enable "the auimal to withdraw the great osseous tendon." It is diflicult to understand what is here meant. The great osseous tendons are never withdrawn at all (past the absorption areas at the base of the limb), but remain attached to the old shell, of which they form a part.

\section{THE CAST-OFF SHELL.}

At the time of the molt there is an intermediate membrane which makes its appearance between the new and oll shells. It is non-cellular, has a gelatinous appearance, is very transparent, aud may be found adherent to the old shell after the molt is past. When examined microscopically it has the appearance shown in fig. 177, pl. 44. It bears the impress of a mosaic of cells, which can be none other than the cells of the chitinogenous epithelium. Vitzou is thus in error in supposing that this substance is a secretion of the chitinogemous epithelium underlying the new carapare, which it traverses by endosmosis. It must be either the first secreted product of the new shell or the innermost layer of the old shell modified by absorption.

In this cuticular nembrane the parts which correspond to the cell boundaries (of the chitinogenous epithelium) have the form of elevated ridges on the under side, and in the center of each polygonal area there is a slight thickening. Réaumur (162) had in view a similar structure in the crayfish when he spoke of a glairy matter, "as transparent as water, which separated the parts which the craytish was soon to cast off from the rest of the body, and which allowed these to glide smoothly over one another."

There is normally no rupturing of the shell in any part in the course of the molt. The entire exoskeleton, with the linings of the oesophagus, stomach, and intestine, comes off as a whole, ${ }^{1}$ and the animal leaves it by drawing the anterior parts of the body backward, and the abrlomen and its appeudages forward, through an opening made by the elevation of the carapace. When the old carapace falls back into its

'The lining of the alimentary tract is of course ruptured. In small lobsters, at the fifth or sixth molt, I have noticed that the break takes place not far behind the stomach-bag, and that while the linings of the masticatory stomach and oesophagus come out by way of the mouth, as in the adult, the lining of the intestine is withdrawn from the anus. 
natural position one might, at the first glance, as Réaumur said of the crayfish, mistake the empty shell for another lobster.

In old lobsters, where the membranes are thick, a rupture of the carapace may arise possibly from want of complete absorption of the lime, but this rarely happens, and the lobster gains nothing from the complete dehiscence of the parts.

It has been stated so many times that it has come to be generally believed-the result of the reiteration of error-that the carapace of the lobster is ruptured along the middle line to assist ecdysis. A careful examination of the east-off shell, which would have settled in short order the disputes over this subject, is the very thing which apparently has not occurred to anyone to make. When this is done, we find that rupture of the shell is guarded against in the most ingenious way. The areas of absorption of lime salts in the carapace, which we have only to consider in this connection, are as follows: (1) The wide lateral margins of the branchiostegites, including what in life appears as a light blue area, about three-eighths of an inch wide in a lobster 10 inches long; (2) a narrow median stripe extending from near the apex of the rostrum to the posterior margin of the carapace; (3) the endotergites (three small teeth like projections from the under side of the carapace, on which muscles are inserted); (4) a linear area on each side of the rostrum; (5) two small round areas in front of the endotergites-not always noticeable. The linear area (2) extending down the back acts as a hinge, rupture in the rostral region being provided against by the narrow absorption areas on each side of it (4), while the softening of the margins of the carapace makes the lifting of this from the body an easy matter during the molt. The result of such areas of absorption is plainly to prevent the rupture of the shell, which, however, does accidentally occur from other causes. The softening of the endotergites is also necessary to prevent injury to the soft tissues.

THE GASTROLITHS.

\section{THE GASTROLITHS OF THE LOBSTER; THEIR STRUCTURE AND DEVELOPMENT.}

The gastroliths, though often called crabs' eyes, are found only in the crayfish and lobster, so far as is known. Discovered first in the river crayfishes, they early figured in the old pharmacopœia as oculi seu lapides cancrorum, and have excited the interest of naturalists from early times. Owing, however, to their very transitory nature, they have been generally overlooked in the lobster. A satisfactory explanation of the function of the gastroliths has, in my opinion, never been given, and in the following section I shall offer one which I think is iu harmony with the facts.

The first reference to these bodies, which I have found, is by Greoffroy the younger, in 1709 (74), who says, in his paper on the molting of the crayfish:

Although I have spoken only of the stones which are found in the river crayfish, there is, moreover, a kind of crayfish, called Astacus marinus, in French Homar, in which they also occur.

More particular reference was made to them in 1874 by Chantran (41), and they are mentioned for the first time in the American lobster by Wheildon in 1875 (202), who says that "just before shedding a white substance, the size of a 5-cent coin, is found on either side of the stomach. These bodies harden into limestone and are absorbed in the process of forming the new shell." They are described by Vitzou (197) as an inorganic reserve composed of small truncated rods, free or delicately bound together. 



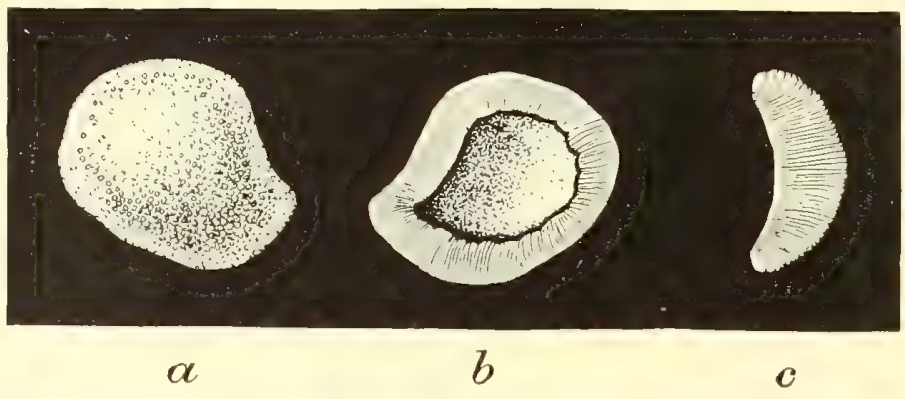

CuT 8.- The gastrolith of a lobster nearly ready to molt, removed from the wall of the stomach.

$a$, seen from the outside; $b$, from the inside (toward cavity of stomach), and $b$, in transverse section. From adult male, lobster No.2, table 24. For chemical analysis of this gastrolith, see Appendix II, No. $4 a$ of table. Natural size.

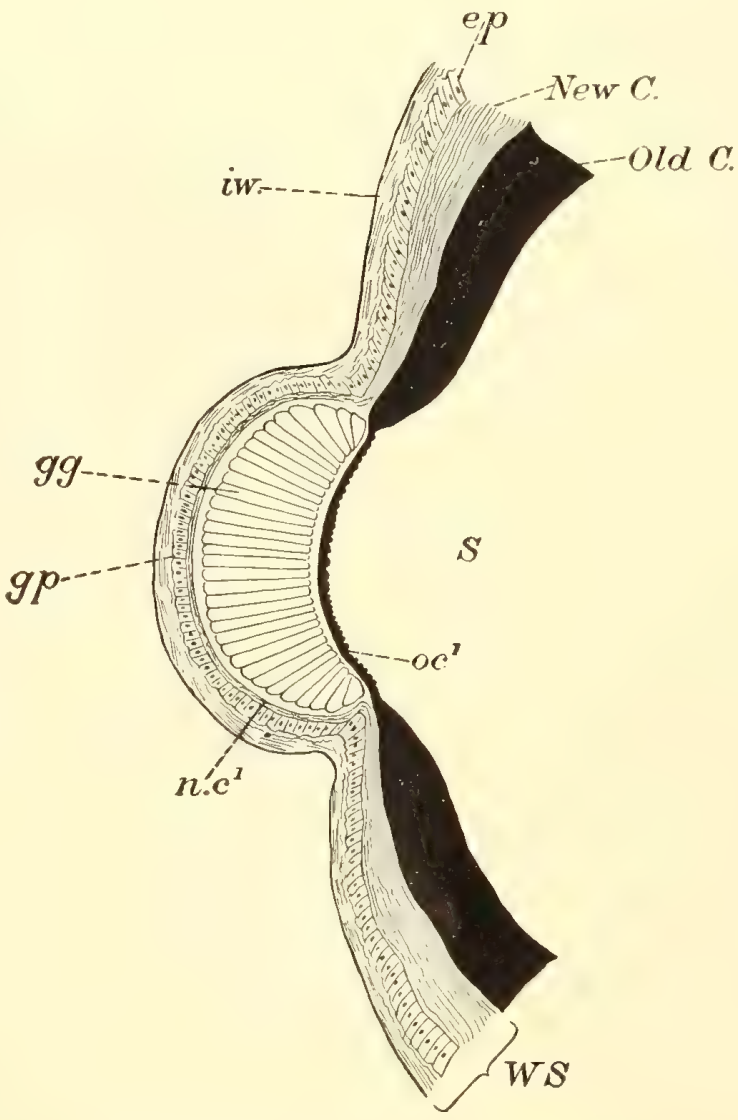

CuT 9.-Diagrammatic section through the wall of the stomach of a molting lobster, cutting gastrolitb.

$e p$, chitinogenous epithelium. $g g$, gastrolith, a differ entiated part of the old cuticle. gp, gastrolithic sac. $n$ $c^{1}$, new cuticle of gastrolithic sac. iw, outer side of stomach-wall next body-cavity. New $O$, new cuticle $O c^{1}$, the deciduous part of cuticle overlying gastrolith. old $O$, old cuticle. $S$, interior of stomach. WS, wall of stomach.

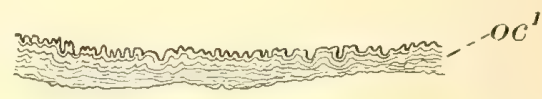

CUT 10.-Section of the deciduous portion of old cutieular lining of stomach overlying gastrolith. See cut $9, o c^{3}$ 89 diameters.

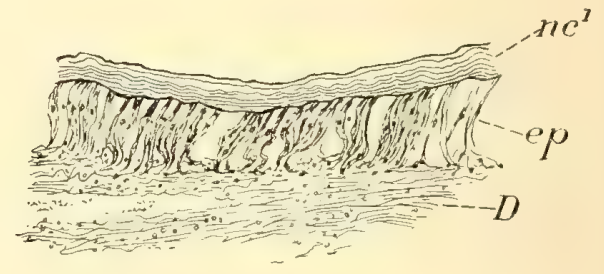

CUT 11.-Section of gastrolithic sae from wall of stomach underlying gastrolith, as it appears while the latter is still in place in the stomach. From a lobster nearly ready to molt. August 2,1894 . See cut 9, gp. 89 diam eters.

$D$, connective tissue of dermis. ep, chitinogenous epithelium. $n c^{1}$, new euticle. 
If the shell of a lobster which is nearly ready to nolt is carefully removed, there will be seeu two glistening snow.white masses, one on either side of the stomach (fig. 184, pl. 44, and cut 9, pl. C). The shape and dimensions of the gastrolith are shown in ent $8 a-c, p l$. O. This particular one, from a lobster 11 inches in length (No. 2, table 24), was au inch long, three-quarters of an inch wide, and a quarter of an inch thick. Its onter, convex side is applied to the sae in which it lies, while its concave surface is separated from the cavity of the stomach by the old cuticular lining of this organ ('ut 9. pl. C). When the stomach is raised the gastroliths almost break through its delicate outer wall by their own weight. They lie between the old cuticular lining of the stomach, which may be stripped off, and its delicate onter wall, next the boly cavity. The impression of the gastrolithic plate is seen on the new enticular lining only $\left(n . c^{1}{ }^{1}\right)$ If the saes in which they are formed are eut open, each mass separates into a large number-a thousand or more-of ossicles or columns. The majority of these are sleuder, truncated prisms of irregular shapes, and $5 \mathrm{~mm}$. or more long. Each ossicle resembles a piece of milk-white glass, with transparent edges, and is faintly marked with transverse and longitudinal striations, like those seen in the cuticle (fig. 165, plate 42).

On August 2, 1894, I examined a lobster which was very nearly ready to molt. The old shell came off easily. The gastroliths were fully formed. We can detect npon the new cuticular wall of the stomach the gastrolithic plate, from which the next gastrolith will be formed. When the old cuticular lining of the stomach is removed the new teeth appear of the same brown color and nearly of the same hardness as the old. The supporting calcareous parts are, however, quite soft. (For analysis of these gastroliths, see No. $3 a$ of table, Appendix II.)

The gastrolith shown in its natural position in the sac (fig. 184, pl. 44) was from a male lobster 7.5 inches long. This is the smallest animal in which I have found these structures, and it is possible that they are not developed until the lobster is several years old, although I have not obtained enough material to establish the time of their first appearance with definiteness. A female lobster $3 \frac{1}{1} \frac{1}{6}$ inches long, which was taken in Small I'oint Harbor, Maine, by Mr. M. B. Spinney, was as soft as wet paper, and had apparently just molted. Upon dissecting this animal I was surprised to find the stomach stuffed full of fragments of calcareous matter, consisting chiefly of waterworn pieces of the shells of dead mollusks, such as are commonly thrown upon a beach. The largest of these fragments was a quarter of an inch long. Many of the shells were softened or corroded and were easily broken by needles. There were, besides, a considerable number of small mollusks, sueh as the young stages of Mytilus edulis. Some of these shells, when devoured, were undoubterly alive. No trace of gastroliths conld be seen. The old enticular skeleton of the stomach had been discarded, and the new "teeth" were but little hardened, save upon their brown, horny surfaces.

Another small lobster, a male, $4 \frac{9}{6}$ inches long, taken at the same place and at about the same time, had recently molted, probably within a few days. The shell was very delicate and fragile. In this case, also, the stomach was loaded with fiagments of the dead shells of mollnsks, crabs, and small lobsters. The hardest parts of the shells of the latter seem to have been chosen, such as the stony mandibles, spines, and teeth of the large claws. There was no fleshy substance which might serve as food in this stomach. It is possible that these shells are swallowed by the yomg lobster, after Gach molt, to furuish lime for the hardening of the cuticular skeleton. The absence of 
gastroliths may have no significance in these cases, but in order to determine this oue should examine the stomachs of larger animals which have recently molted under natural conditions.

The gastroliths, though a part of the cuticle, are not cast off during the molt, but are retained in the stomach. When the old lining of this organ is withdrawn, the gastroliths are soon set free, and breaking up into their constituent parts are speedily dissolved.

In the lobster referred to above (No. 2, table 24), which was preserved immediately after the old shell was shed, the gastroliths were still in place in the stomach, and unchanged. (For chemical analysis of these, see table, Appendix II, No. 4a.) The horny parts of the gastric ossicles agree closely with those of the cast shell, having the same light-brown color and approximately the same hardness. The supporting calcareous parts are, however, quite soft. In every case which I have examined, the old teeth are expelled from the stomach at the time of ecdysis, and not left with the gastroliths, as Réaumur (161) said was true of the crayfish.

Experiments upon the crayfish have seemed to show that the gastroliths are necessary for the hardening of the new shell, but this is undoubtedly an error.

The length of time required for the development of the gastroliths of the lobster has not been determined. It is probable, however, that the latter part of their development is rapid, and that they are conspicuous objects for a few days only before the shell is cast off.

A female lobster which was examined August 10, 1893, had a very hard, dullcolored shell, which one might infer would be shed before many weeks. In place of the gastrolith there was a very thin gastrolithic plate in the lateral wall of the stomach (fig. 183, pl. 44). A section through this plate (fig. 171, pl. 43) shows how the gastrolith is developed. The cuticular epithelium is columnar, consisting of very long, slender cells. The thick excreted cuticular product is traversed by undulatory striations, which mark off the columnar ossicles, the separation of which begins at the outer surface.

The inner section of the gastrolithic plate $(G P)$ appears much more homogeneous than the outer portion, although the demarcation is not quite so sharp as appears in the figure. The striations in the inmer part are only conventionally represented. The undulatory striæ extend inward, and with the deposition of lime the ossicles are developed and completely separated. When the gastroliths are fully formed (cut 9, plate () the deciduous cuticle of the gastrolithic sac is differentiated into two parts, the gastrolith $(g g)$ and a thin outer layer (oc), cuts 9 and 10) corresponding to the outermost part of the cuticle shown in figure 171 and in continnity with the old lining of the stomach $($ Old $C)$. The new cuticle of the stomach (New $C)$ is represented in the gastrolithic sae by a thin stratified layer $\left(n c^{1}\right.$, cuts 9,11$)$, from which the next gastrolith will be developed.

The condition of the gastrolith at this stage bears a resemblance to that which is finally reached in the crayfish, where, according to Huxley (10:3):

It is a solid body which, in vertical section, is seen to be composed of thin superimposed layers, the densest of which form the hard projections of the outer surface next the epithelial substratum.

The outer side of the gastrolith in the crayfish is roughened with irregular prominences, so that it resembles a "brainstone" coral. When from any cause the stones are not dissolved, they lose their normal blue or white color and become brown or green; the shell remains soft and the animal, according to Chantran, soon dies. When the 
formation of the stones is allested, as Chantran had often observed in October and November, the crayfish was unable to molt, and died.

Chantran (42) presented to the Acadeny of Sciences of Paris a paper, giving an account of the natural concretions, called "crayfishes" eyes," produced from the time of birth in this crustacean up to the age of six years-that is, during 22 successive molts. It was found that the stones are not absorbed at the moment they become free in the stomach, but that they are gradually worn down by reciprocal rubbing and contractions of the stomach. The plane faces of the stones are thus lubbed together until they are gradually worn down, and at the tenth hour after ecdysis they are reduced to pellicles of 1 to $2 \mathrm{~mm}$. in diameter. The destruction of the concretions may be complete at this time, or they may persist up to the eightieth hour.

According to Chantran $(41,42)$, the number and succession of molts in the European cray tish are as follows: First year, 8 ; secoud year, 5016 ; thirl year, 3 . Atter the tind year the males molt twice aud the females once annually. He fiuther believed that every molt involved the formation of calcareous masses in the stomach, and that these numbers consequently show how often the gastroliths have been formed and used up. The time occupied in their formation increases with age, being 10 days the first year, 15 days the second, 25 days the third, and 40 days in subsequent year's. The time which elapses after the molt before the stones are reabsorbed also varies with the age of the individual, from 24 to 30 hours in the young, which have not molted more than twice, to from 70 to 80 hours in adults.

\section{HISTORY OF THE GASTROLITHS-THEIR PROBABLE FUNCTION.}

The gastroliths were the subject of much curious speculation among the older naturalists-Gesner, Bellonius, and Agricola-who, according to Herbst, assigned to them a position in the brain. Vau Helmont, who first describer their true position, was not far from right in thinking that they were formed by a milky secretion which was poured out between the old and new linings of the stomach. Geoffroy's observations (74), published in 1709 , were the best made up to his time.

I have opened [Geoffroy says] vigorous crayfishes which had entered upon the process of molting and have found in the place of each stone a scale or white plate, which $\$$ wims in the middle of a mucus, aud which was apparentls the undeveloped condition of the stone. This stone and the glairy liquor were enveloped in a small, nuembranous, and very delicate sac.

In crayfishes which have recently molted the stones are not in their usual places, but lie in the stomach, joined together by theix concave parts. No vestige of a stone was found in the stomachs of erayfish in which the shell had hardened after molting. He concludes however that the stones play no part in the formation of the new shell, although they appeared to serve as food after the molt.

Réamur (162), besides repeating Geoffroy's observations, added much that was new to the subject, and placed the general facts of the molting of crustacea beyond the doubts which had existed up to his time. By dissecting crayfishes which had molted he found that the stones gradually dwindled and disappeared. He says:

Is it not natural to suppose that these stones are dissolved, and that their substance is then carried and laid down in the interstices of the fibers of which the skin is composed?

Roesel (168), in his beautiful Insecten Belustigung, published in 1755, discusses at some length the function of the gastroliths, coming to the conclusion that they are useless material which is formed during the molt, to be afterwards expelled from the 
œsophagus. According to Mayer, whom Roesel quotes with some reserve, it was the eustom of the inhabitants of Asiatic Tartary and Ukrania to collect crayfish at the time of the year in which they were in the best condition and place them in large pits in the ground. Here they were broken up and allowed to remain all winter, during which time the evil odor kept everybody away. In the spring the owners would return, wash out the remnants of the crayfish in water, and sift out the stones with a sieve which they used for this purpose. It was formerly the custom also in Poland and Russia, on the River Don, to collect crayfish in large quantities and allow them to rot in the fields or in pits. The stones were afterwards carefully collected and sent to market to be used as medicine.

Mr. Baker (7) communicated to the Royal Society on February 25, 1748, an interesting letter on "crabs' eyes" from Dr. James Mounsey, a Russian physician. He noticed the seal-shaped spots on the wall of the stomach, which mark the position of the developing gastroliths, and concluded that the latter helped to form the new shell, which, he says, "does not greatly recommend the opinion that these stones have a dissolving quality of service against the stone in the human kidneys and bladder." "The price comes to a groat or sixpence a pound. All the apothecary shops throughout the whole Russian Empire are furnished with them, and great quantities are exported." Notwithstanding their cheapness, "fictitious bodies, made of chalk" and "tobacco-pipe clay" were cast in molds and substituted for real "crabs" eyes." In this case the counterfeit undoubtedly possessed all the virtues of the genuine article.

K. E. von Baer (6) thought that the gastroliths were salivary stones, developed in the lumen of a salivary gland, an idea which was not destined to bear much fruit. Some writers even pretended that they were cast out through a fissure in the walls of the stomach and body.

Van der Hoeven (195) seems to have been one of the first in the present century to protest against the theory that the sole function of the gastroliths was to provide lime for the new shell. In his Handbook of Zoology, a translation of which was published in 1834, he says:

The part, however, which the crabs' eyes take in the secretion [of the hard shell] can not be great when we compare their weight with that of the calcareous matter of the shell. During the time that the shell is still iucreasing in hardness no new crabs' eyes are produced; but ouly after the shell has attained its greatest hardness is ealcareous matter again secreted on the walls of the stomach, and new crabs' eyes again appear. Thus the production of crabs' eyes would seem to be a vicarious secretion of such constituents of the blood as, if too abundant, would be injurious to the organs, like the secretion of urine for instance, but with this difference, that the calcareous matter is not set at liberty shortly after its secretion, but remains accumulated for a long time in continuance.

Max Braun, in his work on the molting of the crayfish (22), concluded that the gastroliths were cuticular products analogous to the integument, but paid no attention to their function or growth.

Vitzon (197) says that shortly after the molt in the lobster the gastroliths are dissolved in the acids of the stomach and, entering the lymph, form an inorganic reserve comparable to the phosphatic plaques which are found in the membranes of the fotus in ruminants.

The problem of the gastroliths has recently been attacked by Irvine and Woodhead (105) in one of their valuable communications on the secretion of carbonate of lime in animals. They conclude that, if the gastroliths play any part at all, they must be converted into phosphates and thus carried in the lymph. If the brachyura have 
a lime reserve, it must be in the lymph, in the form of ealcium phosphate, since they have no gastroliths. "We think," they say, "that this theory [of the gastroliths contributing to the formation of the new shell may be clismissed as of "omparatively little importance, since, even if the teeth and whole calcareous structure could be absorbed by the animals, the amount of carbonate of lime at their disposal from this source is so small (a very small fraction of the outer covering) that it could not account for any considerable part of the new structure. Consequently such an explauation must be abandoned."

These writers are undoubtedly right in attributing little importance to the gastroliths as a source of lime for the new shell. Lime is usually at hand in abundance in the form of the dead skeletons of mollusks and other animals, and, as we have seen (see p. 89), young lobsters make free use of it at the time of the molt. The fact that the brachyura have no gastroliths should also possess some significauce.

I have already shown that there are considerable areas in the shell where the lime is completely absorbed preparatory to the molt. What becomes of the lime thus removed? So far as known, there is no means of eliminating it directly from the body, and it is not likely that this amonnt of lime can be retained in the blood in adrition to that which the latter is constantly receiving from the food. It seems to me much more probable that the gastroliths in the lobster represent the lime which has been removed by absorption from the old shell preparatory to the molt, as well as, possibly, a small amount which may have entered the blood from the food during the molting period. The blood probably contains a maximum quantity of lime at this time, so that very little can be absorbed from the food. Upon this hypothesis the absorption of the gastroliths is a purely secondary phenomenon and of comparatively little importance in the vital economy. In the brachyura, where no gastroliths are developed, we should expect to find the absorption of lime from the shell to be relatively much less, which, so far as I can ascertain, is the case. It seems to be a fact also that the absorption of lime from the old shell proceeds pari passu with the growth of the gastroliths.

Chantran observed (see p. 90) that when the formation of the stones was arrested in the craytish the animal died. This might be true of the lobster, and would not conflict with the theory proposed. When once formed, the question of the subsequent absorption of the gastroliths is not of vital importance. Vitzou speaks of a lobster which died six days after the molt, without absorption of the gastroliths having occurred. It would, of course, be very illogical to conclude that the gastroliths were necessarily in any way concerned with the death of this animal.

In an interesting letter from Dr. Irvine, describing some of his recent experiments, he says in reference to a former attempt to determine the proportionate quantities of carbonate of lime in the exoskeleton: "But as these experiments were made with the common shore crabs, containing much less carbonate of lime proportionately to a full grown animal, I have repeated the determination, using a full-sized lobster which weighed 15,000 grains. On carefnlly separating the stomach, and freeing it from merely fleshy appendages and drying it, I find it to weigh about 50 grains or To ${ }^{3}$ of the whole animal, while the gastroliths weighed only 20 grains or $\frac{1}{760}$ of the whole. I then carefully dried the outer calcareons structure and found it to weigh 3,720 grains, the proportion between the carbonate of lime in the gastroliths and in the outer structure being 20 grains to 3,720 gr ains The $\mathrm{CaCo}_{3}$ in the gastroliths thus stood in proportion to the $\mathrm{CaCo}_{3}$ in the exoskeleton as 1 part in 186, an amount too trifling to be of any practical service in providing calcareous matter for it." 


\section{CHEMICAL ANALYSIS OF THE SHELL AND GASTROLITHS.}

It seemed to me that a chemical analysis of the shell of the lobster in its different conditions imposed by the molting habit might prove of interest, especially when compared with the composition of the gastroliths, and I am fortunate in being able to add as an appendix of this work the results of several analyses made by my friend, Professor Albert W. Smith.

The most striking facts brought out by Professor Smith's work are, first, that lime salts, carbonates and phosphates, form about half the constituents of the hard shell, there being from three to five times as much carbonate as phosphate. We also find that in the cast shell of the lobster, the brittleness of which we have already noticed, the proportion of organic matter present is considerably less than under other conditions. An absorption of organic matter thus takes place during the period in which the new shell is formed, and this fact explains the fragility of the cast-off shell.

It is also interesting to notice that small quantities of alumina and silica are normally present in both the shell and gastrolith.

The composition of the gastroliths is very like that of the shell, a conclusion which we would be led to draw from the fact that the gastrolith is but a specialized part of the dead chitinous integument. The same substances are found in both, but in different proportions. The gastroliths are far richer in lime, chiefly in the form of carbonate $\left(\mathrm{CaCO}_{3}\right)$, than is the shell, and the amounts of magnesium carbonate $\left(\mathrm{MgCO}_{3}\right)$, alumina $\left(\mathrm{Al}_{2} \mathrm{O}_{3}\right)$, ferric oxide $\left(\mathrm{Fe}_{2} \mathrm{O}_{3}\right)$, aud silica $\left(\mathrm{SiO}_{2}\right)$ are more or less reduced.

Lime estimated as carbonate $\left(\mathrm{CaCO}_{3}\right)$ constitutes about three-fourths of the gastrolith, but less than two-fifths of the carapace. Lime reckoned as phosphate $\left(\mathrm{Ca}_{3}\left(\mathrm{PO}_{4}\right)_{2}\right)$ forms about 10 per cent of the gastrolith and but little less in the case of the shell; about 10 per cent of the gastrolith is water and organic matter, probably mainly chitin, and the rest is made up of the various salts and oxides given in the table. In the only molted shell analyzed about 38 per cent was water aud organic matter, while in two hard-shell lobsters this percentage was considerably greater, 42.21 in one case and 51.80 in the other.

The gastroliths of the crayfish were analyzed by Dulk (54) in $1834,{ }^{1}$ but apart from this rough determination no later work has been done ou this subject.

He also analyzed the contents of the stomach of a crab newly moited, and found a free volatile acid, probably hydrochloric, present, besides lime salts (53).

THE HARDENING OF THE NEW SHELL.

Since the total quantity of lime contained in the gastroliths is insignificant compared with the amount necessary for building up the hard crust, the rapidity with which the new shell hardens depends, in some measure, upon the individual, and particularly upon the quality of its food. We have seen that the adolescent lobster, under 4 inches long, after molting swallows fragments of shells aud other calcareous materials, which are dissolved in the stomach and help in strengthening the new shell. It is possible that older lobsters have the same habit.

\footnotetext{
1 The results of Dulk's work were as follows:

Animal matter soluble in water . ......... 11.43)

Animal matter insoluble in water (probably chitin-Huxley) ............ . 4.33

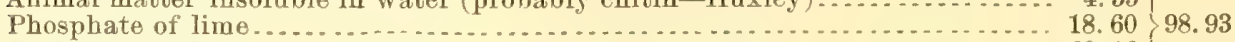

Carbonate of lime

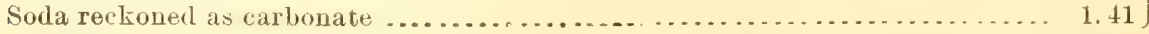


According to the researches of Irvine and Woodhead lime salts, in whatever condition absorbed, are changed during digestion into acid phosphates, and in this state are carried by the blood to the protoplasm of the chitinogenous cells. The nascent carbon dioxide gas, which the active protoplasm of these cells throws off, precipitates calcium carbonate $\left(\mathrm{CaCO}_{3}\right)$ and calcium phosphate $\left(\mathrm{Ca}_{3}\left(\mathrm{PO}_{4}\right)_{2}\right)$. These salts are then dialyzed into the dead chitinous matrix, where they are finally laid down. Lime is deposited in an insoluble coudition only in vitally inactive tissues. They found that crabs which began to shed late in the season were retarded by the cold. Heat thus seems to be a necessary factor in the assimilation of lime salts from seawater by these animals. They also found that the crabs died in water containing only sodium chloride ( $\mathrm{NaCl}$ ), but lived without molting in water containing NaCl and magnesium chloride $\left(\mathrm{MgCl}_{2}\right)$; they lived and molted in water which contained $\mathrm{NaCl}, \mathrm{MgCl}_{2}$, and calcium chloride $\left(\mathrm{CaCl}_{2}\right)$, the latter in the amount equivalent to the lime in normal sea water.

A lobster which molted while under observation (No. 7, table 24) was watched particularly with reference to the hardening of the shell. One hour after the molt the cuticle seemed to the touch of the finger to be perceptibly hardened, but this may have been partially due to the turgescence of the tissues. Eighteen hours after shedding the cuticle had a leathery consisteney, and the tubercles and spines had hardened slightly. The shape of all the parts was perfectly normal. Four days after the molt, when the animal dierl, the cuticle was still coriaceous, and but slight increase in the stiffness of any parts had occurred.

A lobster which also molted in confinement (No.6, table 24) was kept for a period of twenty-five days. The carapace at the end of this time was easily compressible between the thumb and finger. The large claws could be made to yield in the same way, but not without using considerable force. It was in the state which the fishermen call "paper shell" or "rubber shell." If sent to market it would be classed as a soft-shell lobster. It is possible, of course, that in this space of time a lobster under natural conditions would have become harder. It is safe to conclude, nowever, that from six to eight weeks are necessary, under ordinary conditions, to produce a shell which is as hard as that cast off; and if the lobsters were destmed for the market they would probably be in a still better condition in ten weeks or three months. Many lobsters are eaught and shipped to dealers a few weeks after they have molted, but their meat is then soft and of inferior quality, as we have already remarked. According to the opinion of a canner of lobsters in Maine, 7 pounds of soft-shelled lobsters in summer or fall will yield no more than 4 pounds in spriug, when the flesh is more solid.

Réanmur says of the crayfish (162) that he has seen the new shell become as hard as the old in 24 hours, but that it usually takes from two to three days. This observation is confirmed by Chantran (37), who says:

Twelve hours after the molt, the nippers are already hard enough to pinch sharply, and in 24 hours they are completely hardened. The sides of the back remain flexible for a much longer time, but at the end of 48 hours they have attained a degree of consistency which is almost normal.

Vitzou remarks that the carapace of the crabs has perceptibly hardened after 24 hours, but is not completely hardened until after 72 to 80 hours.

It has been stated that the shell of the newly molted lobster becomes as hard as formerly in the space of 24 hours. This and many similar coujectures which have been made upon this subject are entirely erroneous, as proved by the statisties of the fishery during the summer mouths. It is probable, however, that under exceptioual conditions this process is subject to much variation. 
THE RATE OF GROWTH.

The question often asked is, How long does it take an adult marketable lobster to grow? It is impossible to answer this with certainty, since complete data for solving the problem have not been gathered. We can, however, give a tentative answer which is probably not far from the truth.

In order to ascertain the average age of a lobster $10 \frac{1}{2}$ inches long (weight, $1 \frac{3}{4}$ pounds), it would be necessary to know, first, the number of molts which the animal had passed through, and, secondly, the time interval between each molt. The number of molts can be approximately determiner by means which I shall presently discuss. The time interval can only be ascertained by keeping the animals alive for a period of years and carefully recording their growth. Both factors are very variable quantities, as I have already shown. The leugth of one yearling lobster which was raised from the egg was only $36 \mathrm{~mm}$., while three other lobsters measured from $35 \mathrm{~mm}$. to $51.8 \mathrm{~mm}$. when not over five months old. Lobsters which live in harbors where they find abundant food undoubtedly grow much faster than those farther from shore. It would hardly be expected, moreover, that lobsters kept under artificial conditions would grow as rapidly as when free in the ocean. ${ }^{1}$

In table 24 I have recorded the molts of eight lobsters varying from $5 \frac{1}{2}$ to $11 \frac{1}{4}$ inches in leugth. The actual increase in leugth varied from 1 inch to $1 \frac{1}{2}$ inches, and the increase percentage (that is, the ratio which the increase bears to the total length before molting) from 6.66 to 18.18. The average percentage of increase in all these cases is 12.01 .

TABLE 24.-Increase in the length of lobsters at the time of molting.

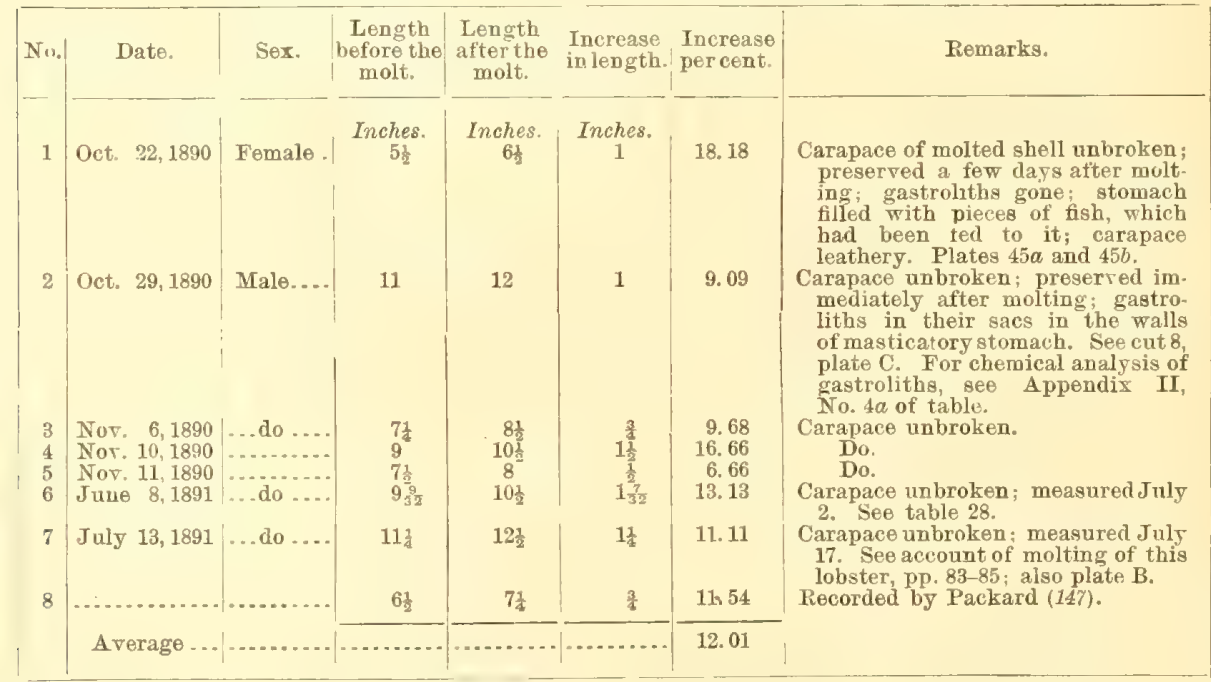

'The best way to ascertain the growth of the lobster would be to fence in securely with wire netting a convenient area in a lobster pound, place a few lobsters in the inclosure, and feed them regularly. They should be examined every week and carefully measured. They could be distinguished by branding the tail-fan. By selecting lobsters of different sizes $(3,5,8,10$ inches long), the rate of growth at different periods of life could be gradually determined. 
The increase per cent in the gxowth of larvæ is recorded in table 34. Sixty-six molts belonging to more than half as many individuals are tabulated. The average increase per cent in length in stages 2 to 10 varied from 11 to 15.84 . The average for stages is 13.67; for individuals, 13.89. These facts seem to warrant the conclusion that the increase percentage in the young is very similar to that of the adult, a result of consilerable interest. The average length of the young lobster dning its first ten molts is given in the following table. The data are taken partly from table 34:

'TABLE 25.- Actual length of lobsters during the first ten molts.

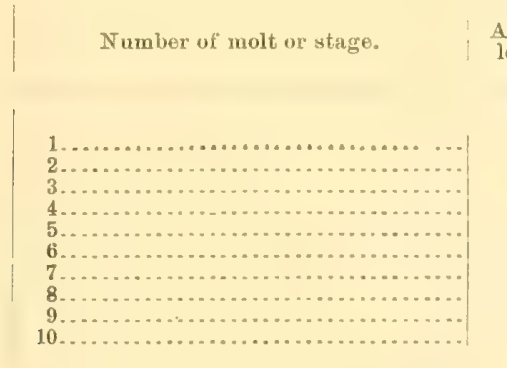

\begin{tabular}{c|cc|c|}
$\begin{array}{c}\text { Average } \\
\text { length. }\end{array}$ & $\begin{array}{c}\text { Extremes in } \\
\text { length. }\end{array}$ & $\begin{array}{c}\text { Number of } \\
\text { lobsters } \\
\text { examined. }\end{array}$ \\
mm. & \multicolumn{3}{|c|}{ mm. } \\
7.84 & 7.50 to $8.03^{*}$ & 15 \\
9.20 & 8.3 & 10.2 & 47 \\
11.1 & 10 & 12 & 79 \\
12.6 & 11 & 14 & 64 \\
14.2 & 13.4 & 15 & 15 \\
16.1 & 15 & 17 & 12 \\
18.6 & 18 & 19.5 & 4 \\
21.03 & 19.75 & 22 & 5 \\
24.5 & 24 & 25 & 2 \\
28.03 & 26.6 & 29.5 & 3 \\
& & &
\end{tabular}

The rate of growth expressed by the average of lengths in the second column of table 25 implies an increase per cent of about 15.3 instear of 13.67 (the average increase in stages recorded in table 34). Assuming the average length of the first larva to be 7.84 (the average of 15 individuals, table 25 ), and allowing the increase in length at each molt to be 15.3 per cent of the length before molting, we would have the following series of lengths attained during the first thirty stages.

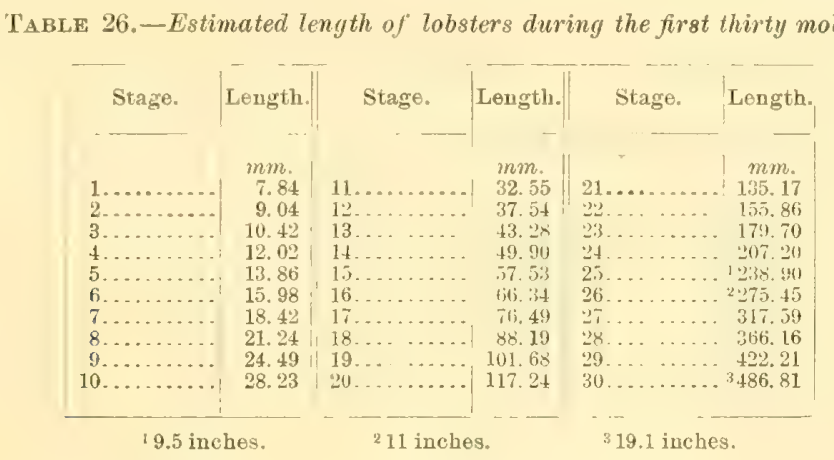

According to this estimate a lobster 2 inches long has molted 14 times; a lobster 5 inches in length, from 20 to 21 times; an adult from 10 to 11 inches long, 25 to 26 times, and a 19-inch lobster 30 times. These estimates do not, I believe, go very far astray. We see them practically verified up to the tenth molt by comparing the figures given above with those in the second column of table 25 .

The time interval between successive molts is the next point to consider. The yearling lobster undoubtedly varies greatly in size. A young female lobster already mentioned reached the length of $51.8 \mathrm{~mm}$. by December 10 , or when from five to six months old (No. 19, table 33). On the 28th of January 16 small lobsters, measuring from 39 to $83.7 \mathrm{~mm}$. in length, were driven ashore at Woods $\amalg$ ole during a storm, It is 
certain that some and possibly all were hatched in the preceding summer. Allowing the lobster (No. 19, table 33) whose length was $51.8 \mathrm{~mm}$. long on the 10th of December to have molted, in case it had lived, three times before the following June, and this is well within the bounds of probability, it would then have attained a length of a little over 3 inches. During the first year the young lobster probably molts from 14 to 17 times and attaius a length of from 2 to 3 inches, but it is likely that the length reached often exceeds these limits.

Of the young lobsters recorded in table 32 a few may be the young of the year (Nos.1-4), that is hatched in the previous June, but the majority are probably from one to two years old. It is further possible that some of these were hatched at other times of the year than June.

Brook appears to be the only one who has given a trustworthy account ${ }^{1}$ of the successive molts of individual lobsters. He succeeded in keeping a lobster (female, length $6 \frac{15}{16}$ inches) alive in an aquarium 506 days, from July 1, 1883, until November 19, 1884, during which time the animal molted four times (on July 1 and December 25, 1883, July 25 and November 19, 1884) and increased in length $2 \frac{7}{16}$ inches. During the first year of its eaptivity it molted twice, in summer and early winter; again it molted in summer and late fall. The lengths at successive stages were as follows: $6 \frac{15}{16}, 7 \frac{3}{16}, 8,8 \frac{14}{16}, 9 \frac{6}{16}$ inches.

In another captive lobster (a male, length $7 \frac{3}{16}$ inches) four molts were also passed, one in the spring and fall of two successive years (May 19, September 20, May 13, October 13). The lengths at successive stages were as follows: $7 \frac{3}{16}, 7 \frac{15}{16}, 8 \frac{15}{16}, 9 \frac{6}{16}, 9 \frac{12}{16}$ inches. There was an increase here in length of $2 \frac{9}{16}$ inches in 414 days.

These experiments are instructive in showing that in the unfavorable conditions of life in an aquarium a lobster from 6 to 7 inches long will make a gain in length of $2 \frac{1}{2}$ inches in 14 to 17 months. It is therefore extremely likely that in nature a 6 -inch lobster will often attain the length of from 9 to 10 inches in two years.

How long a time is the 3-inch yearling lobster growing to become 6 inches in length? Reference to the series of molts given in table 26 , deduced from study of the young, leads us to expect five molts (Nos. 18 to 22) between the 3 and 6 inch stages. It is certain that these do not embrace more than two years, and it is probable that they require somewhat less. We may therefore eonelude that a 10-inch lobster is between four and a half and five years old, the higher degree of probability favoring the smaller number. ${ }^{2}$ The reader is reminded that this is only an estimate, based, it is true, upon rather slender data, but upon the only facts which we possess. In future years some experiments will be made by which this result can be tested.

'Buekland (29) says that "according to some careful observations made at the marine laboratory, Concarnealz, it appears that the first year the lobster sheds his shell six times, the second year six times, the third year four times, and the fourth year three times." If this were amended so as to read careless instead of "careful" observations, no complaint could be made. We have seen that the American lobster molts ten times in the space of three or four months, and it is not probable that the record is very different for the English species. No crustacean is known in which the molts are as numerous during the second year of its life as during the first. A table is also given by Buckland showing the rate of growth during successive molts, but it seems to be based upon error. At the eighth molt the lobster is said to be 2 inches long, whereas the American lobster is less than 1 inch in length at the eighth molt ( $21 \mathrm{~mm}$., see table 25 ), and there is no reason to believe that the European species is more than twice as large as its near ally at this stage.

${ }^{2}$ Coste maintained that the European lobster was about 5 years old (length $24 \mathrm{~cm}$.) before becoming sexually mature, and this supposition, though unsupported at the time by any detailed facts, seems to be very near the truth. (See 61, p. 285.) 
Vitzou records the following observations (197) upon the increase in size and reight of moltiug lobsters. In a lobster which was measured immediately belore and after the molt it was foond that the carapace had gained $11 \mathrm{~mm}$. in length and the abdomen $8 \mathrm{~mm}$. The last joint of the right claw was smaller by $3 \mathrm{~mm}$., which is explained, first, by the thickness of the chitinous layer in this joint, and, secondly, by the almost complete absence of blood in the claw at this time. This is a forced condition, since if the last joint of the claw were inereased in size it would be next to impossible for it to be withdrawn (see p1. 86-87). The same lobster 17 hours after the molt showed no increase in size of carapace or abdomen, but the claws had gained from 12 to $15 \mathrm{~mm}$. in length. No increase in any of these parts was noticed on the third to the sixth days following the molt, but there was a gain in weight.

TABLE 27.

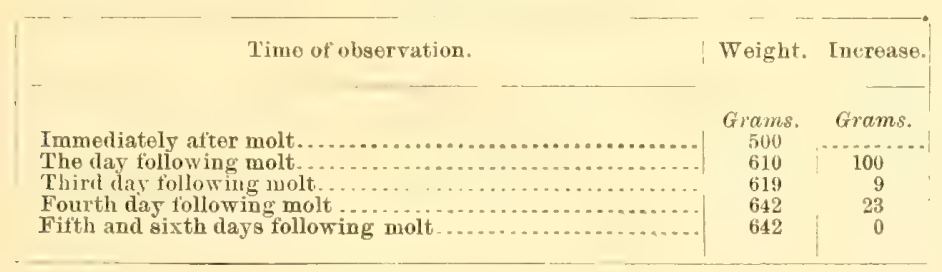

The following measurements show the increase in various parts of the body after the molt. They refer to lobster No. 6, table 24 (compare plates $45 a$ and 45b):

TABLE 28.

\begin{tabular}{|c|c|c|c|}
\hline Measurements. & $\begin{array}{l}\text { Before } \\
\text { molt. }\end{array}$ & $\begin{array}{l}\text { Five days } \\
\text { after molt. }\end{array}$ & Increase. \\
\hline 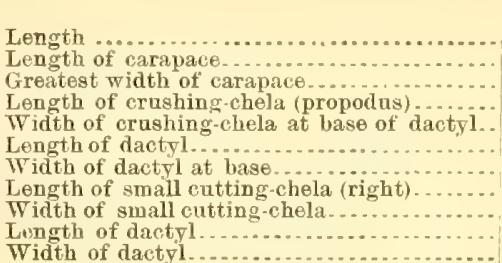 & $\begin{array}{c}\text { Inches. } \\
9.28 \\
4.33 \\
2.2 \\
4.12 \\
2.06 \\
1.90 \\
.72 \\
4.53 \\
1.53 \\
2.53 \\
.56\end{array}$ & $\begin{array}{r}\text { Inches. } \\
10.50 \\
5.03 \\
2.33 \\
5.62 \\
2.56 \\
2.25 \\
1.00 \\
5.53 \\
1.47 \\
3.06 \\
.65\end{array}$ & $\begin{array}{c}\text { Inches. } \\
1.22 \\
.70 \\
.13 \\
1.50 \\
.50 \\
.35 \\
.28 \\
1.00 \\
.06 \\
.53 \\
.09\end{array}$ \\
\hline
\end{tabular}




\title{
Chapter IV.-DEFENSIVE MUTILATION AND REGENERATION OF LOST PARTS.
}

\author{
AUTOTOMY IN THE YOUNG AND ADULT.
}

It is well known that among the invertebrates the crustacea possess, in a remarkable degree, the power of reproducing parts of their bodies which have been lost. This is most pronounced in those Decapods, such as the crab and lobster, which practice defensive mutilation or autotomy. Thus, if one catches a land crab and holds it by the carapace it brandishes its chelipeds in its vain attempts to get free, but once seize it by the claws, the crab immediately scuttles off, leaving you in possession of its only effectual weapons. The leg is broken off at a definite place near its base; there is very little bleeding from the old stump, and a new limb soon sprouts and grows again. This power of thus detaching a limb at the right time is a valuable means of defense, which, as Père Du Tertre remarked, would be very useful for pickpockets. The lobster has the power of casting off its legs, but those which carry the "nippers" are the most commonly sacrificed.

The limb (cut 6, plate B) consists of seven joints, two basal ones-coxopodite (1) and basipodite (2)-and five succeeding joints, the last two of which form the claw (6 and 7, cut 6). In autotomy the five terminal joints are always cast off; that is, fracture takes place between the second and third segments. In the large chelipeds of the lobster the second and third joints-basipodite (2) and ischiopodite (3)-are fused together. This is the case in all the pereiopods of the crab. There is a distinct groove which marks the union of the two fused joints, and it is always in this groove that disjunction occurs ( $\mathbf{x}$, cut 13 , plate $\mathbf{D})$. This fact was noticed by Réaumur (161) at the beginning of the last century, but he did not offer an explanation. He noticed that it was not at the functional articulation that the limb was broken, and that the shell of the "second joint" (second and third, cut 13) was "composed of several different pieces. The evidence of this was found in the presence of two and sometimes three sutures, which occur in this part. It is in the middle suture, moreover, that the leg is broken." He noticed also that the leg could be broken off by exerting very little force. The interesting fact did not escape his attention that if you cut off the leg at or near the terminal joint you will find after a time that the nutilated limb is always thrown off at the suture between the secoud and third joints.

Fredericq (71) has published several papers on the defensive mutilation of the crab, and has given a physiological explanation of this phenomenon. I will now add a brief abstract of some of his experiments, which were performed chiefly upon the common green crab, Carcinus monas.

The breaking off of a leg, which so often happens when we handle these animals, is not due to their fragility, for experiment proves that the limbs of a dead crab are very resistant and that they will support a weight of $3 \frac{1}{2}$ to 5 kilograms ( 7.7 to 11 pounds), which represents about one hundred times the weight of the entire body of the animal. If one breaks off a leg of a dead crab, it separates either between the cephalothorax and first joint, or between the first and second joints, and a mass of muscles is usually drawn out of the body with it. The fracture of the leg of a living crab occurs, as we 100 


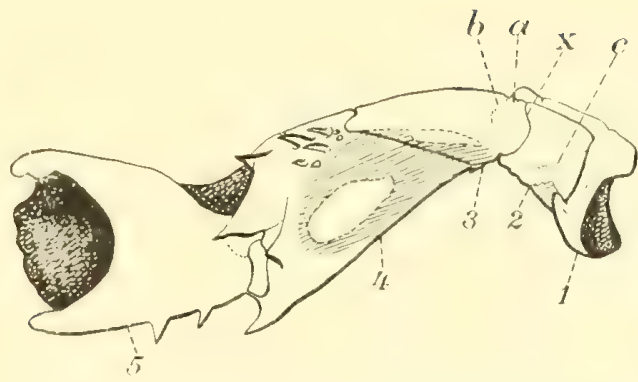

Cur 12.-First left pereiopod of adult lobster, seen from in front, showing anterior bordor at base of limb. Twothirds natural size.

$a, b$, constrictions in cuticle of third joint. $c$, oblique linear impression upon upper surface of secomd joint. $x$, plane of fracture. $1-\bar{y}$, segments of linb.

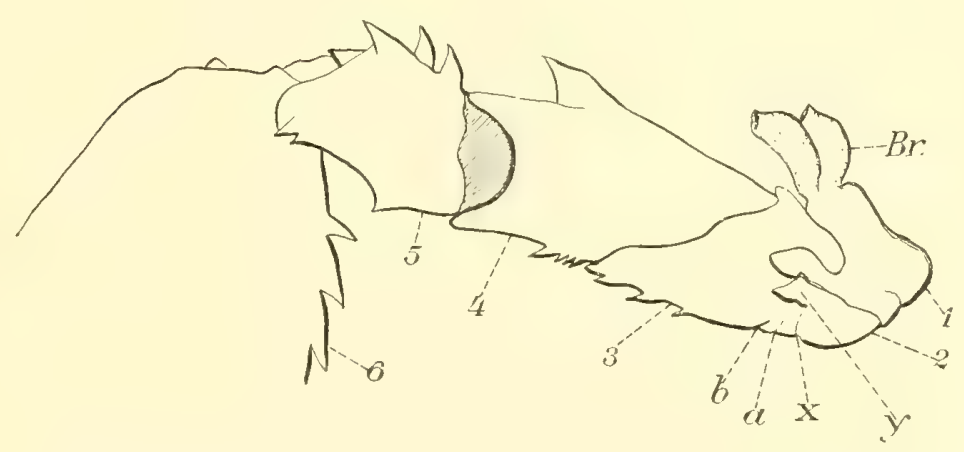

Cut 13.--Basal portion of first left pereiopol of adult lobster from under side. Two thirds natural size.

$a, b, g r o o v e s$ on surface of third joint external to $x . B r$, podobranchia. $x$, plane of fracture. $y_{1}$ spur of second joint. 1-6, segnents of appendage.

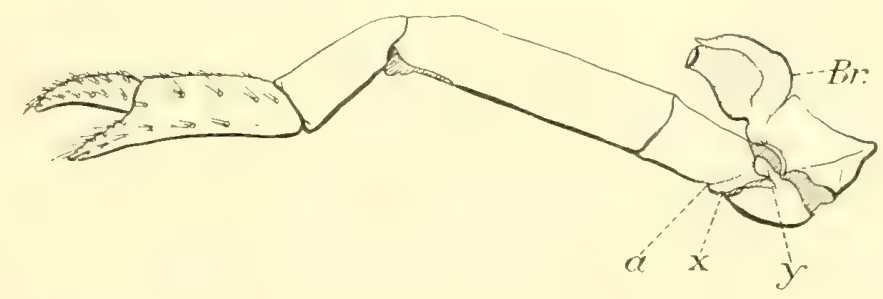

Cuт 14.-Second left pereiopod of female, 10 inches long, seen from under side. Two-thirds natural side.

$\alpha$, coustriction upon second joint immediately in front of $x . B r$, podobranchia. $x_{1}$ articulation between second and third joints, correspouding to plane of fracture in cuts 12 and $13 . y$, spur on second joint. 

bave seen in the large cheliped of the lobster, in a definite plane. It involves only the nerves and blood ressels of the soft tissues, and is provoked by a vigorous muscular "ontraction, which oceurs whenever the nerve of the leo is stimulated violently, whether by a mechanical stimulus, as by smipping oft the terminal joints, or by electricity, heat, or chemical action. The nervous mechamism is reflex, and thus beyond the control of the animal. Autotomy occurs when the whole of the dorsal and cephalic regions of the body, including the supra. cesophageal ganglion or brain, is removed. The reflex nerve center is found to lie in the thoracic ganglionic mass of the crab, or ventral nervechain of the Macrura.

The secoud compound joint is moved by two muscles, a flexor and an extensor, of which the last only is essential to autotomy. Fracture of the limb was produced so long as the extensor muscle and its tendon were mimpaired, but when these were sectioned autotomy was suppressed.

The mechanism of the crustacean limb has been explained by Milne Edwards (58, vol. 1, p. 152). The leg consists, as we have already seen in Derapods, of seven joints, each of which is a lever of the third order. Any two joints are articulated like a hinge, touching at only two points, and axe capable of simple extension and flexion only. The whole limb, however, is capable of executing complicated movements, since the axes of articulation of the several segments are not parallel, but nearly at right angles to each other. Each segment possseses two or more cuticular tendons at its proximal extremity, upon which its flexor and extensor muscles are inserted, the fibers of the latter being fixed upon the imner surface of the next proximal joint.

Fredericq has shown that the distal extremity of the second joint, or basipodite, is separated from the third joint, or ischiopodite, by a diaphragm, perforated near its center only, for the passage of the nerves and blood vessels; and Andrews (3) has pointed out that "in the spider crab, Libinia canaliculata, there extends from the plane of rupture" a distinct membranous fold, "from the epidermis to the central nerve and blood ressels." With the rupture of the limb the outer half of the membrane is torn away, leaving a clean stump. This double membraue possibly represents, as Andrews suggests, the invagination of the body wall, like that seen at an ordinary movable joint. This membrane has thus experienced a complete change of function, and has become modified so as to prevent excessive hemorrhage.

In order that autotomy may occur it is necessary that the peripheral portion of the limb should offer a greater resistance than the traction of the extensor muscle is able to overcome, allowing the traction of the muscle to be equivalent to a weight of 250 grams. Ordinarily the sides of the carapace, the hard parts of an adjoining leg or the clutch of an enemy afford the necessary resistance.

If the compound-second and third-joint of the cheliped of the lobster be examined. a fine hair line is seen leading from the small spur next to the articular facet on the under side, round the anterior border to the mpper side of the joint. It then bends forward and abruptly backward, crossing the small proximal end of the joint, to near its point of departure ( $\mathrm{x}$, cuts 12,13 , plate I)). There are incomplete grooves in front of this line (cut 12, $a, b$, ) and a more oblique one behiud it (cut 12, c). On the upper side of the second joint of the small walking legs of the lobster a delicate hair liue is also scen, which turns abruptly forward at the anterior horler of the appendage and joins the arthrodial membrane. This groove looks as if it micht mark the piane of rupture in 
a part of the joint, but it does not correspond to the intersegmental groove (cuts $13,14, x)$ of the cheliped.

I have never observed the casting of a claw at any time before the fourth larval stage. Autotomy seems to be occasionally practiced at this period, and in the fitth and following stages it is common. This is illustrated by the history of larva No. 23, table 34. When this lobster in the fourth stage was placed under observation, July 25 , it was $13 \mathrm{~mm}$. long and had lost both its large chelipeds and its right fifth and left fourth pereiopods. When, fifteen days later, August 9, it molted to the fifth stage (length, $15 \mathrm{~mm}$ ), the large left cheliped (figs. 92, 96, plate 33) and the fourth and fiftli walking legs were regenerated; the right cheliped appeared as a rudimentary stump. Eight days later, August 21, it had molted to the sixth stage $(17 \mathrm{~mm}$. long), when its large right cheliped appeared regenerated. The animal was placed in a flat glass dish, and in disturbing it, upon changing the water, it shot off its large left cheliped again and died two days after.

In the first larva there is a free articulation between the second and third joints of the great chelipeds (fig. 66, plate 30 ), and there is no true fusion of the segments until after the fifth stage. In the fourth stage the articulation is distinct, as representer in cut 15. This not only shows that the plane of rupture in the large chelipeds

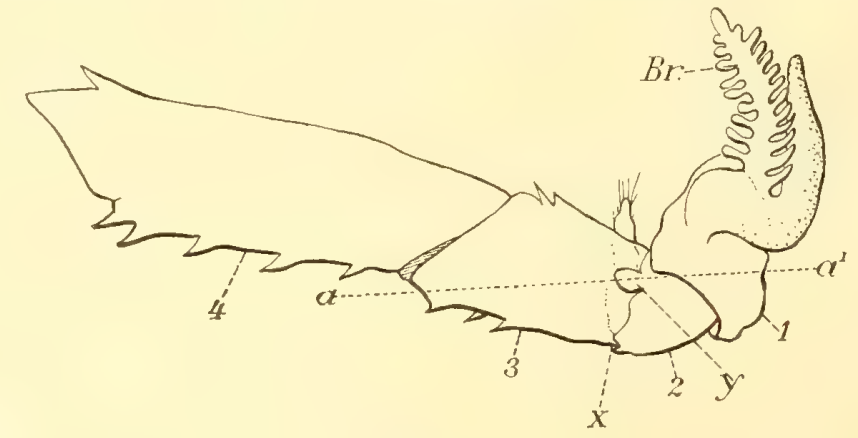

CUT 15.-Part of first cheliped of fourth larva, showing the base of the limb and distinet articulation between the second and third joints.

$a-a^{3}$, plane of section shown in fig. 169 , plate $43 ; b r$, podobranchia; $x$, articulation between second and third joints, corresponding to plane of fracture in adult appendage; $y$, articular process in second joint; $1-4$, segments of limb. Drawn from molted shell.

corresponds to what was formerly a free articulation, but also that this autotomy is a comparatively recent acquisition. It may have been acquired independently in the Macrura and Brachyura. Autotomy of a pronounced character occurs only in limbs where fusion of two neighboring joints has been effected, and was probably produced as a result of natural selection while the fusion was taking place.

The habit of "casting a claw" being of a purely reflex character, and therefore not subject to the will of the animal, there is needed only the proper stimulus to call it into play. Unintentional experiments in autotomy have often been made by tethering a lobster or crab by its large claws. The animal, of course, escapes, leaving only its members behind. When lobsters are drawn out of the water by the claws, or when a claw is pinched by another lobster, or while they are handled in packing, especially for the winter market, they often "cast a elaw;" and the transportation of lobsters at this season is said to be attended with considerable loss in consequence. The old custom of plugging lobsters, which consisted in driving a wooden wedge between the 
joints of the claws, to prevent them from injuring each other, has been gonerally abandoned. Mutilated lobsters are now often placed in pounds, where they are allowed to repair their injuries.

One has only to examine a lot of freshly captured lobsters to be assared of how common the practice of casting the claw is. "Out of a hundred specimens," says Rathbun (155), "collected for natural-history purposes in Narragansett liay in 1880, fully 25 per cent had lost a claw each, and a few both claws." In a total of 725 lobsters captured at Woods Hole in Jecember and Jamaly, 189:3-94, 54 or 5 per cent had thrown off one or both claws.

It is often stated that lobsters sometimes cast their claws during thunder storms, but until some proof of the truth of this statement is afforder it must be regarded as a fable. One of the earliest versions of this idea which I have seen is that of Travis (191), who wrote to Pennant in 1777 that-

Lobsters fear thunder, and are apt to cast their claws on a great clap. I am told they will do the same on firing a great gun, and that when men-of-war meet a lobster boat a jocular threat is used, that if the master does not sell them good lobsters they will salute him.

Since autotomy is the result of a reflex nervous impulse, and has been acquired by the animal as a means of defense, we should expect to find that the reflex center would always be aroused into activity by stimuli comng through the nerves of the limb, as is always the case in experiment, and not through a higher center like the brain. When an anmal is frightened by lond noises it is impelled to flee, and it would manifestly be of no advantage to the animal to immediately drop its legs.

\section{REGENERATION OF APPENDAGES}

The regeneration of lost limbs in crustacea has been studied by Réaumur (161) Goodsir (80), Chantran (38, 40), and Brook (26).

Réaumur's general account of the process in the crayfish is one of the best which has been written. He quotes Du Tertre (55), who had "made similar observations on the crabs of Guadeloupe, of which he has given a very curious history." Réaumur began his experiments on the searoast, but the sea broke and carried away his boxes or filled them with sand. He then experimented with erayfishes with more success. He says:

I took several of them, from which I broke off a leg; placed them in one of the covered boats which the fishermen call "Boutiques," in which they keep fish alive. As I did not allow them any food, I had reason to suppose that a reproduction would occur in them like that which I had attempted to prove. My expectation was not in vaim. At the end of some month $I$ saw, and this withont surprise, since I had expected it-I saw, I say, new legs, which took the place of the old ones, which I had removed; except in size they were exactly like them; they had the same form in all their parts, the same joints, the same movements. A kind of regeneration like this hardly less excites our envy than our imagiuation; if, in the place of a lost leg or arm, another would grow out again, one wonld be more willing to adopt the profession of the soldier.

He noticed that the time necessary for the production of new legs was indeterminate, depending upon a variety of conditions:

These limbs arise and grow more or less rapidly, like plants, according as the season is more or less favorable; the warmer days are those which hasten the more their formation and growth.

Sometimes new legs sprout out in three weeks; sometimes not until after six, and when the legs are broken off in winter they do not grow again until summer. 
Réaumur cut off the "tails" of erayfishes in various places, but there was never any reproduction of these parts, and the animals invariably died after a few days. It sometimes happens that a lobster loses a part of its "tail," and the accident probably results fatally in most cases, but not always, according to the statement of Mr. Thomas Barton, who is employed at the lobster pound at Vinal H aven, Maine. He says that in the winter of 1892-93 he caught several lobsters with the tail-fan and the last one or two joints of the "tail" gone, apparently bitten off. There was a scar where the wound had healed, but no sign of a regenerated tail.

Chantran (38) says of the crayfish that the antenna are regenerated in the period between two successive molts, while three molts are required to restore the other appendages. In the first year of life, seventy days, according to this observer, are necessary for the generation of new limbs. The adult female requires 3 to 4 years, the male $1 \frac{1}{2}$ to 2 years to repair its limbs, and we are told that the adult male molts twice and the female but once in the year.

Chantrau has also some interesting notes on the regeneration of the eyes in the crayfish $(40)$. This process takes place more or less normally and rapidly according to the age of the animal. When the eyes are cut off in October, at the end of the season of molting, there is no new growth apparent until the following May. At that time a series of molts is begun, and by July, nime months after excision, the eyes are regenerated. If the eyes are operated on in the molting season, the regenerative processes are disturbed. In his experiments about one-half of the optic peduncle was cut away; with total excision of the peduncle the eye was never regenerated.

Goodsir $(80)$ explains the production of new limbs from the basipodite in the following way:

A small glaudular like body exists at this spot in each of the limbs, which supplies the germs of future legs. This body completely fills up the cavity of the shell for the extent of about half an inch in length. The microscopic structure of this glandular-like borly is very peculiar, consisting of a great number of large nucleated cells, which are interspersed throughout a fibro-gelatinous mass. A single branch of each of the great vessels, accompanied by a branch of nerve, runs through a small foramen near the center of this body, but there is no vestige either of muscle or tendon, the attachments of which are at each extremity. In fact, this body is perfectly defined and can be turned out of the shell without being much injured. When the limb is thrown oft the blood vessels and nerve retract, thus leaving a small cavity in the new-made surface. [See the account given by Fredericq.] It is from this cavity that the germ of the future leg springs, and it is first seen as a nucleated cell.

These statements, some of which-as the existence of a glandular body and the origin of the limb from a nucleated cell-are entirely erroneous, will be diseussed hereafter (see pp. 107, 108).

\section{REGENERATION OF LARGE CHELIPEDS.}

The regeneration of the large chelipeds in the fourth and fifth larval stages is essentially the same as in the adults. The external changes are illustrated by figs. 176, 182, and may be described as follows: At the moment the limb is broken off blood immediately oozes out and coagulates, forming a dense crust over the stump. In a short time a sinall white papilla which represents the rudiment of the new limb appears in the midst of the brown, hardened clot, fig. 176, plate 44. This papilla continues to grow, independently of the molting process, though covered with a cuticular membrane, until a miniature appendage is formed. The papilla lengtheus, and gradually the constrictions which mark the future joints of the new limb make their appearance. At first colorless, the new appendage becomes bright, transparent red, with 
bluish pigment at the constrictions of the joints (fig.182). In this stage the limb is surrounded by a thickening cuticle and soon reases to increase until after the next molt. It may, according to Brook, attain a length in yonng lobsters of $1 \frac{1}{4}$ to $1 \frac{1}{2}$ inches. If autotomy occurs just after a molt, the appendage will reach a much greater size than if it happens a short time before. When the molt finally takes place the new stump becomes very much larger and now resembles the normal appendage in all respects except size. With each succeeling molt the normal size is gradually attained.

Two stages in the regeneration of the large cheliped of the larva alrearly referred to (No. 23, table 34) are illustrated in figs. 92, 96. After a period of 15 days, during which time two molts had occurred, this limb had become completely regenerated. It was reproduced in 12 days after the emergence of the papillary bud.

A larva in the fifth stage, length $15 \mathrm{~mm}$., was placed under observation July 28, when the first right cheliped was clipped off. On August 12, 15 days after the injury, the animal molted and the cheliped appeared restored. The lobster was now $17 \mathrm{~mm}$. long. The length of the sixth joint-propodus-of this rudiment at the time of the molt was $2 \mathrm{~mm}$., while the length of the same joint of the limb after ecdysis was $4 \frac{1}{2} \mathrm{~mm}$., and the length of the corresponding joint of the unimpaired limb was 5 mm. In this case the new limb had been developed during a single molting period to nearly its normal size.

A similar result was obtained in the following experiment: A fifth larva, length 15 millimeters, was placed under observation on July 28, and the first right cheliped was clipped. The right antennary flagellum had been previously cropped close to the stalk, from which a new bud was growing; 6 days later, on August 3, the sprouting antennary flagellum was coiled, and a very small bud represented the right cheliped. August 12, 15 days after the first observation, the flagellum of the second antenna on the right side was nearly normal in appearance and size. The rudiment of the right cheliped was segmented, and about $3 \mathrm{~mm}$. long. This larva molted on or near August 15, or 18 days after mutilation, to the sixth stage, when it attained the length of $18 \mathrm{~mm}$. The right cheliped was regenerated, but, as in the other case, it was somewhat smaller than the other. The measurements are as follows:

Regenerated right first cheliped: Length of propodus, $5 \mathrm{~mm}$.; greatest width, $1.3 \mathrm{~mm}$.

Unimpaired left first cheliped: Length of propodus, $6 \mathrm{~mm}$.; greatest width, $1.5 \mathrm{~mm}$.

On the one hand, the large cheliped of the young lobster may be regenerated in from 15 to 18 days, and after a single ecrlysis, and on the other it may require a month's time, during which the animal has molted twice.

The time required for the renewal of a limb thus depends upon the time at which an injury occurs with reference to the molt, and also upou the physiological condition of the animal. If the tips of the large chelipeds are clipped off, autotomy does not always or usually occur, and the limb is completely repaired after one molt. If the limb is injured below the sixth joint (propodus or large joint of claw in cheliped), it is usually cast off at the plane of fracture.

\section{REGENERATION OF ANTENNA AND OTHER APPENDAGES}

The autennæ are very liable to injury, particularly the delicate, sensitive flagella. Antotomy does not occur in these appendages, so far as is known, but regeneration may take place at any articulation in the flagellum or stalk. 
In the young the flagellum of the second antenna may be completely restored without a molt taking place; in the adult one molt at least appears to be necessary for complete restoration. In the fifth stage already mentioned, the antennary flagellum was restored in about fifteen days. The flagellum appears first as a papilla or bud, which becomes sickle-shaped and finally coiled (figs. 100, 179).

Fig. 100 is from the molted shell of a lobster $18 \mathrm{~mm}$. long (No. 34, table 34). It lost its right antennary flagellum in molting, July '25, and molted again in two weeks' time. The drawing shows the condition which the regenerating appendage had reached in the interval between the molts. After the last molt it was completely restored. This figure illustrates the stage which the appendage usually reaches before its complete renewal with the next molt. The flagellum then resembles a small, spirally coiled, red-wax taper. In fig. 179 this appendage is being renewed from the first joint.

The cuticle of the limbs in process of restoration must be elastic or capable of considerable distension, although the limit of this distensibility is, in most cases, soon reached.

In the isopod crustacea the antennæ are regenerated in a somewhat different manner. In the case of the large Ligea oceanica, illustrated in figs. 180, 181, plate 44, the rent is repaired, and the new bud does not grow out from the stump, but coils up within it. The cuticular wall of the stump serves as a sort of brood chamber for the growing part, until it is set free at the next molt.

Autotomy often occurs in the second to fifth pereiopods, but is much feebler than in the large chelipedn. Two stages in the regeneration of these appendages are shown in figs. 175, 178. The fourth pereiopod of a fourth larva, drawn from the molted skin, is illustrated in fig. 99, plate 33 .

Réaumur (161) was one of the first to attempt to give a philosophical explanation of regeneration in erustacea. He says:

We may suppose that these little limbs which we see grow out were each inclosed in a little egg, and that when a limb was broken off the same juices which nourished this part were used to develop and bring to the birth the little germ of a limb inclosed in this egg. Moreover, according to this theory, we should have to suppose that there was no spot in a leg of the erayfish where there was not an egg which incloses another limb or, what is more marvellous still, a part of a limb like that near the point where the egg is situated at the end of the limb; in short, at any point in the leg which you may name there must be one of these eggs, which contains another part of the limb. The eggs which are at the origin of each claw, for example, would contain only a claw: but one egg would not be sufficient, since if a new leg is cut off another comes.

How many times this process could be repeated without exhausting the supply of "eggs" he did not determine, but Spallanzani, according to Weismann, "observed in the case of a young Triton, that the four limbs and tail when they were cut off grew again six times in the space of three summer months." (The Germ-Plasm, p. 120.) Réaumur believea that each new limb must contain an infiuite number of eggs, and in conclusion says:

It would seem that the reproduction of the legs of the crayfishes is a matter where we can scarcely hope to see clearly; besides its peculiar difficulties, it has all those which envelop the generation of the foetus.

It is over eighty years since these words were written, and the solution of the problem of regeneration seems to some as far away as ever. The new limb is not formed from a definite cell or cell-mass recognizable before the time of injury, but from a budding growth very much as in the embryo. 
'The power of regenerating a lost part varies in both vertebrates aud invertebrates in direct proportion to the physiological importance of the part, as Weismann luas clearly shown. Just as the enemies of the lizard seize it by its long trailing tail, so the lobster is almost invariably caught by a claw, and the life of the animal is often saved in either case by the breaking off of the nember. The plane of fracture in the limb, as in the large cheliped of the lobster and in the five paics of pereiopods of the crab, is a secondary structure which coincides with the plane of articulation of two coalescer joints, yet Leydig has shown, according to Weismann, that the tail of the lizard is specially adapted for breaking off, "the borlies of the caudal vertebre from the seventh onward being provided with a special plane of fracture, so that they easily break into two transversely." (The Germ-Plasm, p. 116.) The regenerative power is probably a secondary characteristic which has been acquired by natural selection, for the good of the species, while autotomy is a much more recent acquisition. As Weismann says, "there is no such thing as a general power of regeneration" among animals as with crystals, but "in each kind of animal this power" is graduated according" to the need of regeneration in the part under consideration."

Weismann rejects the idea of a spiritus rector, or external directing agency, and assumes that the nisus formativus is situated in the "idioplasm" of the cell, and "that each cell capable of regeneration contains an accessory idioplasm, consisting of the determinants of the parts which can be regenerated by it in addition to its primary idioplasm." He furthermore infers that the general capacity of all the parts for regen eration may have been acquired by natural selection in the lower and simpler forms, aud that it is gradually decreased in the comrse of phylogeny in correspoudence with the increase in complexity of organization.

Weismann attempts, in a very ingenious way, to harmonize the facts of regeneratiou in animal embryos with the "mosaic theory" of develojment of Ronx, but, as E. B. Wilson (206) remarks, the two fundamental postulates of this hypothesis, "namely, qualitative nuclear division and accessory latent idioplasm, are purely imaginary." The theory of Roux and Weismann has its counterpart in the view advocated by Whitman (204), that "in the development of the germ, in the repair of injured parts, and in the regeneration of lost parts the organism as a whole controls the formative processes going on in each part."

While no final explanation of the process of regeneration can now be given, and the idea of a formative power is, as Whitman says, one of profound mystery, the solution of which appears to lie as far beyond our grasp to-day as at any time in the past, yet we are in a better position to-day, if not to give answers to these questions, at least to point out the probable direction in which they should be songht.

I shall consider the question of regeneration again in connection with the origin and perpetuation of deformities in the lobster.

\section{IN'TERNAL CHANGES IN REGENERATION.}

The histogenesis of the new limb is not easy to understand, althongh it can be followed without much difficulty after the papilla stage.

I am unable to find any trace of "glandular-like" bodies such as Goodsir described (80) as furnishing germs of the new limb. On the contrary, the new limb appears to arise mainly by growth of the connective tissue cells already present in the stump.

After the blood has elotted over the wound and has produced a hard crust, the cuticular cells, in response to the stmulus thus received, grow over the wound and 
produce a new cuticle which has a certain degree of elasticity. My material was insufficient to trace with certainty the origin of the reticulated tissue which soon appears under the new skin.

A minute papilla grows out, having the general structure shown in fig. 173. It is a spongy network of fibers, containing the potential elements of muscles, nerves, connective tissue, and blood vessels. Blood flows in an irregular system of large and small sinuses. The epidermis of the new skin, which is relatively much thinner than the old, is composed of a single stratum of very tall, slender cells, the chitinogenous epithelium, and of an elastic cuticula. The epidermis of the papilla is thus structurally similar to that which covers all parts of the body when a new shell is being formed under the old. (See p. 77.)

As the papilla grows out the fibrous tissue becomes gradually differentiated into the muscles, blood vessels, and nerves (fig. 172), as in an embryo, and constrictions in the cuticle arise, which mark with absolute precision the limitation of the future joints. The cuticle at this stage appears to be destitute of hairs, but it contains pores. In the stump at the base of the appendage a great mass of large oval bodies is seen. These appear as thin solid dises, and when compressed break like starch grains (fig. 121, pl. 36). They represent connective tissue cells in a certain stage of metamorphosis, and in all probability contain glycogen, which furnishes material for the growth of the epidermis-that is, of the chitimogenous cells and the shell which they secrete. (See p. 78.) They seem to be the same structures which Leydig has described in the integument of crabs, under the name of liune concretions (Kalkconeremente), and which Hoeck calls "Krystall Plattchen" (121-122). Mayer (137) has also figured and deseribed what are probably similar bodies in the indurated shell of certain swellings which are found in the large claws of the male Heterograpsus lucasii. These he desig. nates as "amyl-like chitinous inclusions."

In the lobster these bodies stain very diffusely, and sometimes a central figure, possibly the impression or remains of the original nucleus, may be detected. The histogenesis of these structures and the changes which they undergo have apparently never been studied. Their origin is elearly demonstrated by fig. 122 , plate 36 , from a preparation of the maxilliped. It is evident that the large granular mass is the product of the parent mesoblastic cell, the protoplasm of which is reduced to a thin enveloping shell.

Fig. 169 represents one of a series of sections cut in a longitudinal plane through the first three joints of the right large cheliped of the lobster (sixth stage, length 18 mm.), the history of which has been already given (p. 105). The appendage of this larva had been cut off July 28, and had grown to nearly its full size by August 17, when the animal was preserved. Since autotomy occurs in the very young animal as well as in the adult, we should be able to determine from this specimen whether there is any preformed organ or store of embryonic cells for the supply of the new limb at this time. The examination of serial sections through this part of the limb reveals nothing but normal tissue cells. Embryonic cells may be present but are not discernible. The opening between the basipodite and ischiopodite is reduced to a narrow passage by the ingrowth of cuticular cells, to form ectodermic pillars like those seen in the earapace of the embryo. The several tissues are bathed in blood, which is here confined to no definite channels. Some circumscription of the passage leading from the second to the third joint is thus necessary. 


\section{Chapter V.-LARGE LOBSTERS. \\ THE GREATEST SIZE ATTAINED BY THE LOBSTER.}

Stories of gigantic lobsters made their appearance at a very early periorl, and one could probably gather as many exaggerated accounts of this animal now as in the days of Olaus Magnus. Time, however, has narrowed the bounds of credulity, even among the ignorant, and we no longer hear some of the interesting legeuds which the old witers have "arefully handed down. Thus (Mans Magnus tells us in his description of northern lands and seas, ${ }^{1}$ published in 1555 , that between the Orkneys and Hebrides there lived lobsters so lunge that they could eatch a strong swimmer and squeeze him to death in their claws. His curious figures are copied by Gesner (75), who has many others equal to any which are described in the old mythologies.

Giants are met with in all the higher groups of animals. They interest us not only on account of their actual size, but also in showing to what degree individuals may surpass the mean average of the race. It may be a question whether lobsters which weigh from 20 to 25 pounds are to be regarded as giants in the technical sense, or simply as sound and vigorous individuals on whose side fortme has always fought in the struggle for life. I am inclined to the latter view, and to look upon the mam. moth lobster simply as a favorite of nature, who is larger than his fellows because he is their senior; good luck has never deserted him until at last he is stranded on the beach or becomes entangled in some fisherman's gear.

Gesner gives a very poor figure of a lobster, but a very good drawing of the large crushing-claw of one which he had preserved in his collection on account of its great size. The length of this claw is $8 \frac{3}{4}$ inches, and its breadth at the junction of the dactyl abont 4 inches, so that it must have belonged to a lobster which weighed not far from 8 pounds.

Pontoppidans (152) relates a fable, which is repeated by Herbst (88) and others, of the Störjer, or lobsters of huge size which fishermen reported having seen in Utvaer in the Bay of Erien, Norway. One of these was so large a ud terrible that no one dared to attack it, and it measured between its claws at least a fathom. This, says Herbst, probably belongs with the Kracken, the natural products of Norwegian superstition.

Boeck says that he had seen the claw ${ }^{2}$ of a lobster which must have been about 18 inches long, and Sir John Graham Dalyell (jo), according to Boeck, tells us, in The Powers of the Creator, published in 1827, that he had seen a joint of the left claw of a lobster which measured 9 inches in length. It does not follow, however, as Boeck infers, that "the whole claw" must have measured 18 to 24 inches, and the whole animal 3 to 4 feet."

The European lobster of to-day seldom attains so great size as the American species, and its average weight is considerably less. Buckland (28) gives the following account of large lobsters from the British Islands:

The Skye and Orkney lobsters are probably the largest in the British Islands. At St. Mawes we heard of two lobsters, oue 10 pounds and the other 9: pounds; and at Durgan and Sennen of one of 13 pounds. A large lobster was caught in a large earthen ware pot at Gosport in 1870 which weighed.

Historia de Gentibus Septentrionalibus, Rome, 1555.

The word claw is here inaccurately used to mean the entire claw-bearing limb (cheliped). 
8 pounds 10 ounces. In May, 1875, a lobster, weight 12 pounds, was found at Saints Bay, Guernsey. I find a record of a lobster exhibited at Billingsgate July 30,1842 , which measured 2 feet $5 \frac{1}{2}$ inches; the size of the body was 16 inches; the claws measured upward of 14 inches. In August, 1873, a lobster weighing $11 \frac{1}{4}$ pounds, caught in Guernsey. was exhibited by Messrs. Grove, of Bond street. In July, 1874, a lobster, weight $7 \frac{1}{2}$ pounds, was caught on the Fife Banks of the Forth. The lobsters from the Lizard ground are one-third heavier than those in Falmouth Bay, but crabs are smaller.

The largest lobsters that have come under nay individual notice are, first, a lobster weighing $10 \frac{1}{8}$ pounds, sent me from Tenby and now in my musenm; secondly, a lobster presented to me by John Byatt, of Messrs. Winder's, Haymarket, measuring 8 inches in the barrel [that is shell of back or carapace], the total length being $19 \frac{1}{2}$ inches and the weight $9 \frac{3}{4}$ pounds. In the York Museum there is a magnificent specimen of a lobster, of which the following are the dimensions: Barrel, 91 inches; tip of beak to tail, $19 \frac{1}{2}$ inches;' left claw, the erusher, length $10 \frac{1}{2}$ inches; right claw, cutting, length $10 \frac{1}{2}$ inches; left elaw at widest part, 5 inches. This was an American specimen.

Another very large lobster we came across in our inquiry was a grand specimen which we examined in the house of Mr. Scovell, at Hamble, near Southampton. The following are the dimensions: Length of barrel to tip of horu, $9 \frac{1}{4}$ inches; length of tail turned under the body, 12 inches; total length, 2 feet, all but three-quarters of an inch. Right claw, $19 \frac{1}{2}$ inches ${ }^{2}$ long; girth, $12 \frac{1}{4}$ inches; weight when killed, 14 pounds. This lobster, Mr. Scovell informs me, was caught in a trammel net on the coast of Cornwall.

Fourteen pounds is the greatest weight recorded in the notes just quoted, and European lobsters of this size are undoubtedly very rare.

In the museum of the Academy of Natural Sciences of Philadelphia there is preserved a large lobster, Astacus vulgaris, for the particulars concerning which I am indebted to the kinduess of Professor Ryder. Unfortunately it is not known where or when it was captured, nor what its living weight was; but from the measurements given below (table 29, No. 1 a) I conclude that it weighed from 21 to 22 pounds. If these measurements are compared with those given in table $30, N_{0} .1$, it will become evideut that this specimen could not have weighed less than 20, and not more than 23 pounds. This specimen has been carefully examined by Professor Ryder, who writes that there is no doubt of its belonging to the European species; that it was normal in every respect, and that the skeleton is in an admirable state of preservation.

TABLE 29

\begin{tabular}{|c|c|c|}
\hline Measurements. & $\begin{array}{l}\text { No. } 1 \text { a.-Male; } \\
20 \text { to } 23 \text { pounds; } \\
\text { obtained from: } \\
\text { Europe; pre- } \\
\text { served in the } \\
\text { museum of the } \\
\text { University of } \\
\text { Pennsylvania. }\end{array}$ & $\begin{array}{l}\text { No. } 2 \text { a.-Male; } \\
10 \text { pounds; cap } \\
\text { tured on coast of } \\
\text { Norway some } \\
\text { time between } 1850 \\
\text { and } 1865 \text {; pre- } \\
\text { served in muse. } \\
\text { um of Bergen, } \\
\text { Norway. }\end{array}$ \\
\hline $\begin{array}{l}\text { Total length, rostrum to end of telson (not including hairs).......inches.. } \\
\text { Le.ngth of carapace (rostrum to posterior margin)................. . do.... }\end{array}$ & $\begin{array}{c}19.4 \\
9.29\end{array}$ & $\begin{array}{r}18.73 \\
8.58\end{array}$ \\
\hline 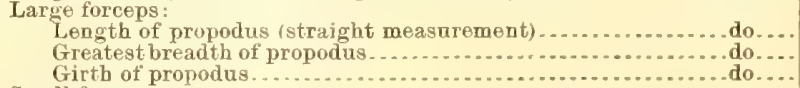 & $\begin{array}{r}13.1 \\
6.8 \\
16.8\end{array}$ & $\begin{array}{r}10.23 \\
4.32 \\
10.62\end{array}$ \\
\hline 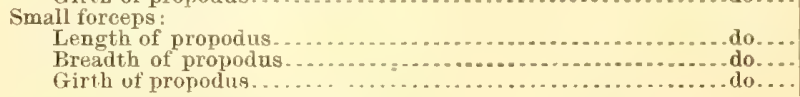 & $\begin{array}{c}12.4 \\
4.8 \\
10.15\end{array}$ & $\begin{array}{r}10.03 \\
3.30 \\
8.07\end{array}$ \\
\hline
\end{tabular}

${ }^{1}$ The elaws of this specimen were considerably undersized (compare tables 29 and 30 ).

${ }^{2}$ This is intended for the measurement of the entire right claw-bearing limb or cheliped; by "total length" is probably meant, as above, the distance measured from the tips of the extenderl chelipeds to the end of the tail. 
In speaking of the size attained by the European lobster, Sars says:

It is a remarkable fact that the lobsters on onr southern coast never get as large as those farther north. I have never seeu an urusually large specimen among the many lobsters which I examined at the different fishing stations. The lobsters which are occasionally caught farther north are generally much larger, and to judge from their appearance much older. At Florö I once saw a lobster which was not much smaller than the immense specimen in the Bergen Museum. This specimen, as far as I remember, comes from a still more northerly point of our western coast. (176.)

I am able to give some comparative measurements of the "immense specimen" to which siars refers in the passage just quoted, throngh the kindness of my friend, 1)r. Einar Lönuberg, of the University of Upsala. If the length of this lobster aud the measurements of its large claws (No. 2 ", table "29) are compared with the ofirer specimen (No. 1 a), and with lobster No. 7, table 30, we shall see that in all probability the Bergen specimen did not weigh above 10 pounds. It is nearly an inch longer than lobster No.7, which weighed after preservation in alcohol a little less than 10 pounds. On the other hand, the claws of this American lobster are larger than those of the Norwegian specimeu, and the claws constitute in old lobsters more than one-half the weight of the entire animal. (See table 31 a.) The latter probably weighed when alive not over 10 pounds.

In reference to my questions about the Bergen lobster, Dr. Lönnberg writes:

The specimen is now dry, and, as we never weigh any lobsters in our country, the weight is not recorded.

He says the date of capture is doubtful, but it was probably between 1850 and 1865 .

It has been an accepted belief that the American lobster attains a greater size than its European counterpart, but it seems to be a fact that the maximum size of each species is nearly the same. The lobster fishery is much older in Europe than in this country, and the average size has there been long reduced to a minimum by overfishing. At the tme when Sars's paper was written (about twenty years ago) it would not have occurred to one familiar with the American species to look upon a 10-pound lobster as an "Immense specimen," though at present there are comparatively few of this size which find their way to markets. In fact the same gradual falling oft in size, due to the same cause, has been experienced in recent years on the coast of Maine and in the Maritime Provinces. It is probable, however, that the American lobster is stockler than the European, and that length for length the American species will weigh the more.

Buckland (29) speaks of a "breed" of lobsters caught at Boguor which are always smail. They are called "chicken Iobsters", and it takes 14 to 20 to weigh a pound. This merely illustrates how the size inay be kept down by the persistency of fishermen.

Rathbun (155), in speaking of the occurrence of large lobsters in American waters, says:

A dealer at New Haven states that twenty years ago 12 to 16 pound lobsters were common, but during the past ten years a lobster weighing 10 pounds has been rarely seen. A Boston dealer writes that during the past season (1880) he had received and sold lobsters weighing from 12 to 15 pounds each. - * * A specimen taken at Boothbay, Maine, and said to weigh between 30 and 40 pounds, had such claws that the meat from one of them was equal to that of an ordinary-sized lobster.

I have examined and carefully measured a lobster taken at Boothbay which is probably the one here referred to, and will describe it presently. The actual weight of this lobster was probably not over 22 pounds.

A lobster "shipped from Eastport in 1875 " is said to have weighed 19 pounds aud to have "measured 3 feet 5 inches in length (measurement from tips of' extended 
claws to end of tail), the claws being 18 inches long and 8 inches across." (155.) If the weight is given correctly, the measurements are certainly at fault, as I shall presently show.

There can be nothing in literature more unreliable than accounts of the size and weights of animals, gathered at random. The first estimate is often a guess, which immediately acquires an air of accuracy by being expressed in figures. It does not usually get into print until it has been rolled over many tongues, and during the process it increases in size like the snowball which is rolled along the ground. But it undoubtedly comes hardest for a man who has a large lobster for sale to resist temptation. In describing a few very large lobsters I shall therefore limit myself to those which I have actually seen and measured or weighed.

I will now give the history of a lobster which came into my possession in August, 1893. It is probably one of the largest lobsters ever taken on the Atlantic coast. Its history has been carefully authenticated, and I have obtained some excellent photographs of it, which are reproduced in plates 1 and 2. This mammoth specimen was captured in Penobscot Bay, southeast of Moose Point, in line with Brigadier Island, near Belfast, Maine, May 6, 1891, in about $3 \frac{1}{2}$ fathoms of water, by Mr. John Jondon. Its capture was accidental, since it was brought to the surface on the end of a lobster pot, the "tail" of the lobster resting in the funnel of the trap, while the huge claws hung down at the sides. The animal, attracted by the bait, had doubtless been making fruitless attempts to euter the trap. A dealer in fish at Belfast soon came into the possession of this lobster while it was still alive. The shell was then very dark in color, almost black on the upper surface, and supported a number of prosperous colonies of marine animals. The common barnacle (Balanus balanoides) was growing on the shell of the back and also on the upper surface of the crushing-claw, near the joint of the thumb or dactyl, where it may be seen in the plate. Several species of mollusks, particularly the common mussel (Mytilus edulis), were fixed to various parts of the shell, and hydroids (Pennaria or Eudendrium) were flourishing at the articulations of some of the legs. The presence of these messmates pointed to a rather sluggish habit of life, which the animal may have possessed. The entire upper surface of the shell and both the upper and lower surfaces of the claws are scarred, scraped, and gonged like the side of a cliff over which a glacier has passed, and present a graphic record of the struggle for life which this animal had so long and so successfully fought.

When laid on its back the lobster could move but little, but when in its normal position it would crawl over the floor, and if worried with a stick it seized it savagely and crushed it with its claws. It was weighed on a Fairbanks scale in the presence of a number of people. Its living weight was found to be a little over 23 pounds. ${ }^{2}$

This lobster was finally killed by boiling in the usual way, the membranes being first cut at the articulations to let out the blood and admit the water. It was afterwards placed in a large kettle of water to which a bushel of salt was added, and was boiled in this brine for more than an hour. ${ }^{3}$ After it was boiled, the meat of the

${ }^{1}$ This lobster is now preserved, in excellent condition, in the museum of Adelbert College, Cleveland, Ohio.

${ }^{2}$ When I first saw this lobster I was assured that the animal was not weighed until after it had been boiled. Allowing a shrinkage of 20 per cent in boiling, I estimated the living weight to have been about 28 pounds. (See 99.) The first statement was not true. I have since ascertained that the facts are as given above.

${ }^{3}$ Old-shell lobsters are said to shrink 20 per cent and new-shell lobsters 25 per cent in woight after boiling. 
"tail" was of a pink color and very tough. The skeleton was perfectly preserved by removing the muscles of the abdomen and the "tomally" or "liver," and some of the other organs of the body. This lobster was a male, and it is a noticeable fact that all very large lobsters which I have records of or have examiued belong to the male sex. I have never heard of a female lobster which exceeded $18 \frac{1}{2}$ pounds being caught.

The total length of this lobster, whose history I have just given, is only 20 inches (measured, as in all cases, from the end of the spine or rostrum to the end of the tail. fan), but would have been nearly 21 inches liad the rostrum been perfect. The body seems surprisingly short for so powerful an animal, and it is in fact in the large claws that the greater part of its weight and strength resides. This may be seen by a comparison of the plates (see also table 31 a), and may be possibly explained by the fact that as age advances the increase in length at each molt becomes less, while there is a corresponding gain in the size of the claws. Thus Ehrenbaum (61) mentions a lobster $42.2 \mathrm{~cm}$. long, which showed an increase in length of scarcely $1 \mathrm{~mm}$. on molting The length of the crushing-claw of the Belfast lobster is nearly 14 inclres, and its greatest girth is $16 \frac{1}{2}$ inches. It was probably powerful enough to crush a man's arm at the wrist.

\section{TABLE 30}

General descriptions: No. 1 was a male, 23 pounds, captured at Belfast, Maine, May 6, 1891. No, 2 was a male, 20 to 22 pounds, captured at Boothbay, Maine, about 1856. No.3 was a male, 20 to 22 pounds, captured at Salem, Massachusetts, in 1850. No. 4, 23 to 25 pounds, was captured at Gloucester, Massachusetts. No. 5 was a male, 20 to 22 pounds, captured on the Delaware const. No. 6 was a male, 20 to 22 pounds, captured at Lubec. Maine, September, 1892 . No. 7 was a male, 97 pounds, in alcohol.

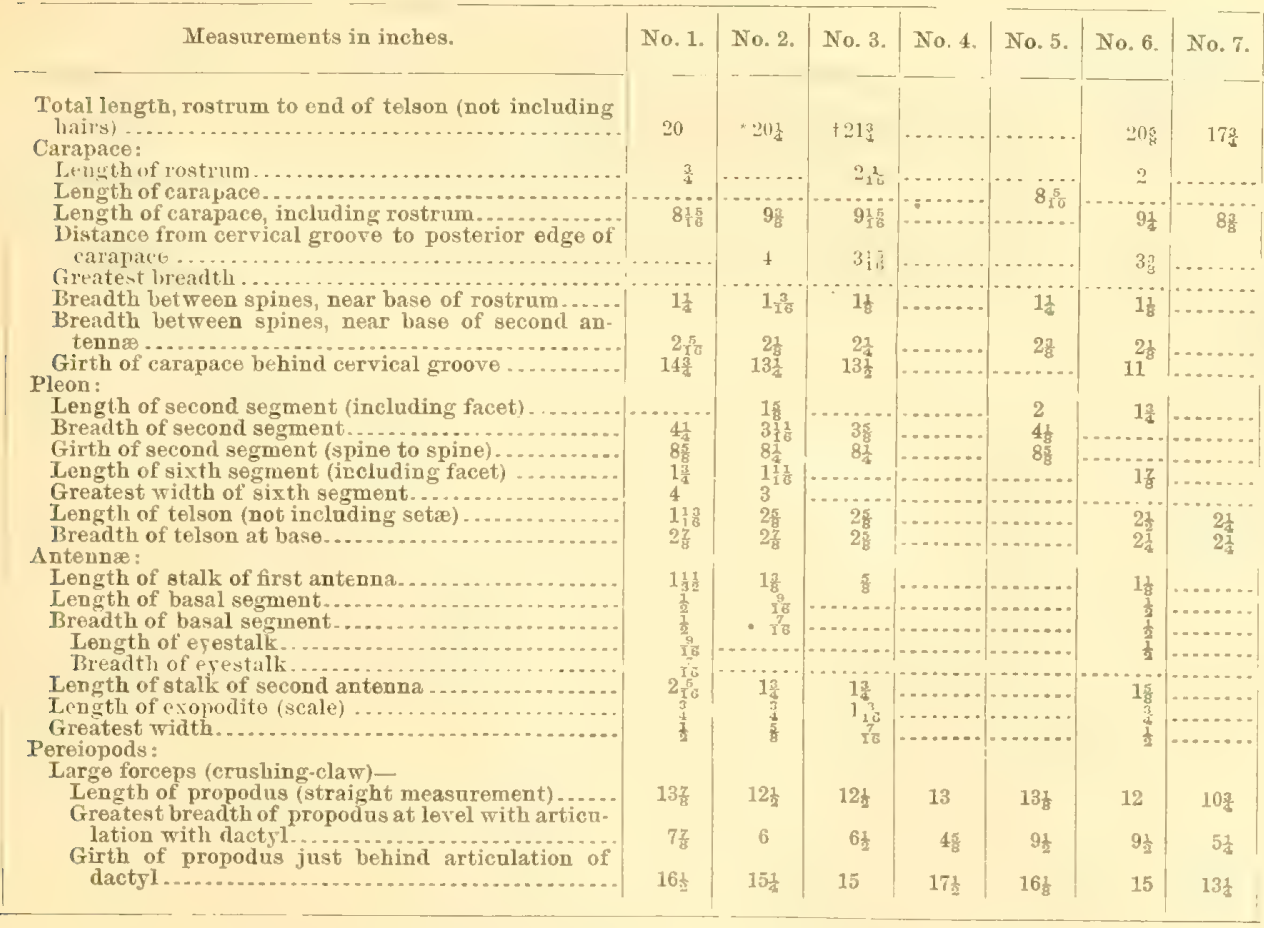

* Body"nearly straight. 
TABLE 30-Continued.

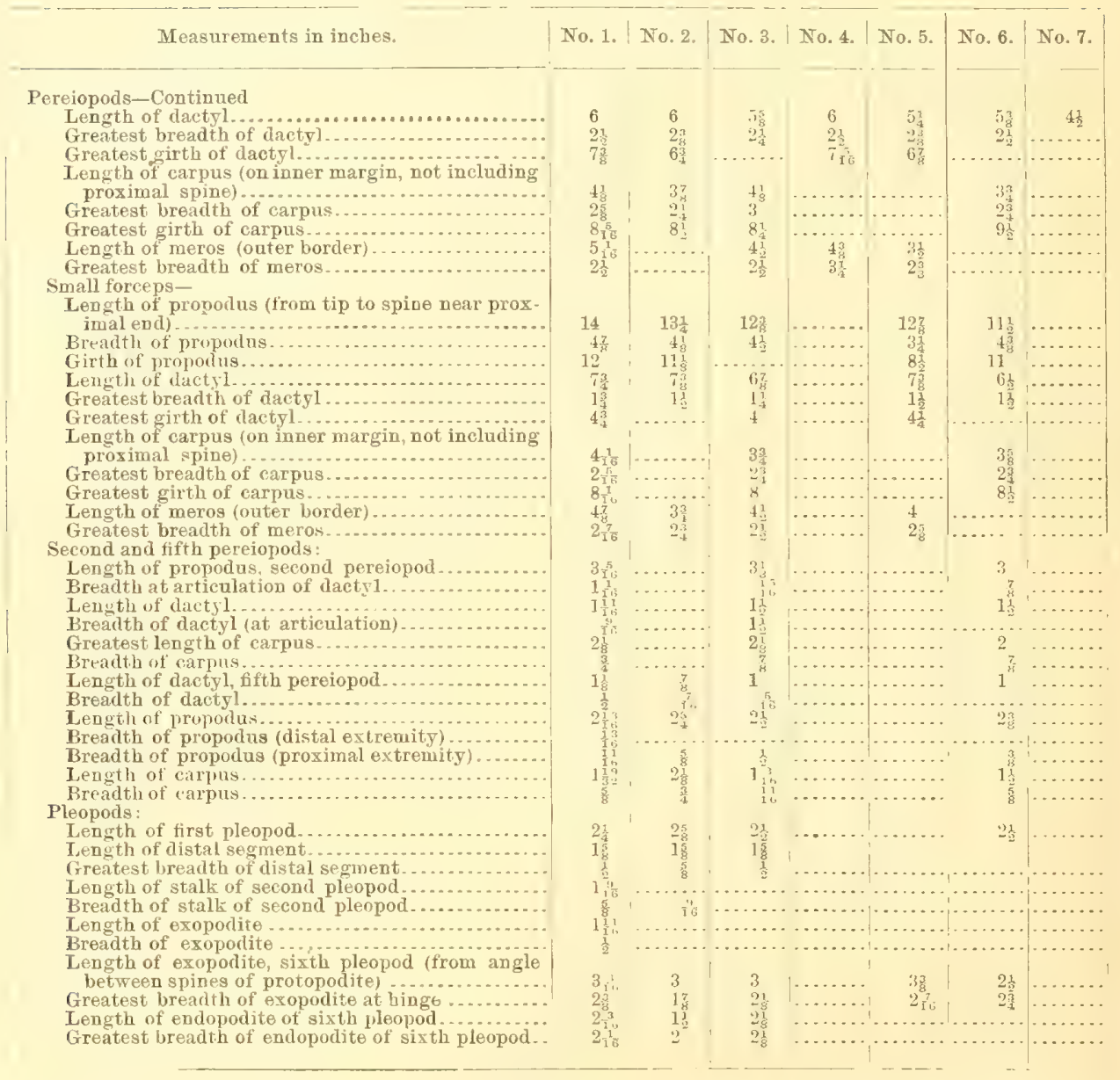

The detailed measurements of this animal are given in table $30, \mathrm{No} .1$, where they may be compared with those of the small lobster, seen on plate 2 , and with those of the large specimens which I have recorded above.

The large Boothbay lobster, which has already been referred to (p. 16), is reported to have weighed as much as 40 pounds. I was told that it tipped a scale which weighed up to 25 pounds, and would have weighed somewhat more. Its measurement, however (table 30, No. 2), proves it to have weighed less than the Belfast specimen, and a comparison of its length and the dimensions of its claws with the large European lobster (No. 1 a, table 29) show that it could have exceeded this in weight very slightly, if at all. Its true living weight was probably between 20 and 22 pounds. The shell of this lobster was eleaned by placing it in an ant-hill, and it is now in a bad state of preservation. The claws are furrowed, pitted, and scarred, and the carapace is scratched, as is apt to be the case with large old-shell lobsters.

In the museum of the Peabody Academy of Science at Salem, Massachusetts, there is a perfect specimen of a lobster (No.3, table 30), said to have been taken at Salem 
in 1850, and to have weighed, when alive, 25 pounds. The body is a little longer than the two first mentioned, but it is also slenderer, and the large claws, which count so much in the weight of this animal, are, upon the whole, smaller and weigh less. The greater length of the Salem specimen is due largely to the long, perfect rostrum. The large claws correspond closely in size with those of the Boothbay lobster, and we may be almost certain that its living weight did not exceed 22 pounds.

A lobster but little under the Salem specimen in size is in the possession of Mr. George R. Batson, of Campobello Island, New Brunswick. This lobster weighed, when alive, according to the somewhat wavering memory of the man who weighed it, $24 \frac{1}{2}$ pounds. The measurements fail to corroborate this statement. (No. 6, table 30.) The dimensions of the large elaws and the girth of the carapace prove conclusively that it weighed less than 23 pounds, the anthenticated weight of the Belfast lobster (No. 1, table 30). It was captured in a hoop pot, a few of which are said to be still in use, in South Bay, near Lubec, Maine, in 15 fathoms of water, September, 1892. This lobster is a very shapely and perfect specimen. It had a hard shell, and showed great activity when alive.

In the museum of the Peabody Academy of Science there is also the right large claw of a lobster markerl, "From a lobster weighing 39 pounds; from Moses H. Shaw, Gloucester." This is said to have been in the museum for over fifty years. Measurements of this claw (No. 4, table 30), supposing the animal to have been normally developed, show that it could have been but little larger than the Belfast specimen. The only available comparisons lie between the large claw and the fifth joint the only parts preserved. A full-sized drawing of this huge claw is produced on plate 15. The erushing claw of the Belfast lobster was nearly an inch longer and much broader than the specimen figured, but less by one inch in girth. The claws of these two animals must thus have been of nearly equal weight, and I think it a safe conclusion that the Gloucester giant did not weigh above 25 pounds. The shell of the claw was very light for so large an animal, weighing only $16 \frac{3}{4}$ ounces, including the fifth joint. (See chapter III, pp. 82, 83.)

In the museum of the Smithsonian Institution there are fragments of the skeleton of a lobster which was captured with hook and line on the coast of Delaware, and is said to have weighed over 25 pounds. Measurements of these parts show that its weight was probably somewhat less, certainly not much over 22 pounds. (No. 5, table 27.) The shell of the large elaw of this lobster weighs $1 \frac{1}{2}$ pounds.

In 1863 a large lobster was caught on a hand line at Bald Head Sands, near Small Point, Maine, which I was assured by a fisherman weighed 38 pounds. I afterwards had the opportunity of examining the large arushing claw, all that has been preserved of this lobster, at the market house of Mr. Lewis McDonald, Portland, Maine. The claw is $12 \frac{1}{2}$ inches long, has a breadth of $6 \frac{1}{2}$ inches, and a girth of $15 \frac{1}{2}$ inches just behind the terminal joint. It was thus of about the same size as the crushing-clan of the Salem lobster (No. 3, table 30), and the animal probably did not exceed 22 pounds in entire weight. I mention this as an example of how the weight of the lobster, though dead, increases with the lapse of time.

There may be seen at the St. Nicholas Hotel in Boston, Massachusetts, the sleetetou of a male lobster said to have weighed 35 to 40 pounds. It ras captured off Provincetown, in August, 1894. When I examined this specimen, June 25, 1895, it was mounted in a glass case in a very perfect state of preservation. Though not allowed to take careful measurements, I could see that its weight had been greatly exag- 
gerated. The total length of the body, measured from the rostral spine to the end of the tail-fan, when the tail was naturally articulated with the thorax, was not far from 20 inches, and not over 21 inches. The length of the large crushing-claw is from 12 to 13 inches. The cutting-claw is relatively smaller than in any of the large lobsters which I have examined, and it seems fairly certain that the living weight of the animal could not have much exceeded 20 pounds.

I am indebted to the kindness of Professor Leslie A. Lee for the measurements of the large crushing-claw of a lobster which is preserved in the museum of Bowdoin College, Maine. It was taken from an animal which came from Cape Breton, which is said to have weighed 33 pounds 11 ounces. The length of this claw is $13 \frac{1}{16}$ inches, its breadth $6 \frac{7}{8}$ inches, and its girth (measured just behind the first joint) is 16 inches. In this case the weight is specifically given, yet it is certainly erroneous. ${ }^{1}$ If normally formed, this animal probably did not weigh over 23 pounds. I base this opinion upon the fact that the Belfast lobster (No.1, table 30) has a somewhat larger crushing-claw, is normally formed, has a hard shell, and therefore could not, in all probability, have weighed less and nay have weighed more than the specimen from Cape Breton.

In the museum of Yale University there is preserved the large crushing-elaw of a lobster, which is said to have weighed 39 pounds. ${ }^{2}$ The length of the elaw is $12 \frac{9}{16}$ inches, the greatest width 6.9 inches, and the greatest girth $16 \frac{3}{4}$ inches. It is shorter by half an uch than the Cape Breton specimen, and but little larger in circumference. The length of the crushing chela falls short of the Belfast lobster (No. 1, table 30) by one inch. Its weight probably did not much exceed 23 pounds, if at all.

In the collections of the Smithsonian Institution there is a lobster which weighed, after preservation in alcohol, 9 pounds 14 ounces (No. 7, table 30$){ }^{3}$ The entting-claw on the right side was undersized. A few measurements of this specimen are given for purposes of comparison. There is far less difference between some of these and corresponding measurements of larger lobsters than one might expect. Thus the telson in this ease has the same dimensions as in lobster No. 6 (table 30), which weighed more than twice as much.

I was informed by Mr. F. W. Collins that a male lobster which weighed nearly 25 pounds was taken on a trawl below Monro Island, 5 miles east of Rockland, Maine, in the summer of 1890 . The large claw is said to have measured 16 inches in girth.

I heard through Mr. Vinal Edwards of a lobster, said to have weighed 27 pounds, which was caught off Breton Reef, Newport, Rhode Island, in June, 1894. This was taken by accident, one of its claws having been entangled in a lobster-pot, in 10 to 12 fathoms of water. It was a male, and its shell was freely sprinkled with barnacles. ${ }^{4}$

I will add a few notes on the occurrence of large lobsters, which I gathered on the coast of Maine, in August and September, 1893. I give them upon the testimony of others, but believe them trustworthy.

Mr. J. W. Savage stated that he received from the region of Eastport, Maine, in

'Professor Lee writes as follows concerning this specimen: "The large lobster's claw in our museum was obtained many years ago in Cape Breton. It came into our possession in 1881. The weight of this animal is not well authenticated on our records."

${ }^{2}$ I am indebted to Prof. A. E. Verrill for the opportunity of examining this specimen. The inscription upon it, which is almost illegible, is as follows: "Boston, Mass., March, 1823; 39 1bs."

"The weight of this lobster was kindly determined by Mr. James E. Benedict of the Smithsonian Institution.

${ }^{4}$ I was unable to obtain any direct information about this lobster, or to verify its weight, which I do not consider authentic. 
June, 1893, a large male lobster which weighed 20 pounds. In the same lot was one weighing 16 pounds.

In May, 1892, Mr. N. F. Trefethen obtained a lobster from the vicinity of Eastport, Maine, which weighed $15 \frac{1}{2}$ pounds. He weighed it himself, and sent it to market. It had a very hard shell and had lost its smaller claw; if it had been perfect it would have weighed considerably more.

In Angust, 1891, according to Mr. F. W. Collins, a lobster (sex undetermined) was taken at Blue Hill Falls, 40 miles east of Rockland, which weighed $18 \frac{1}{2}$ pounds, and in November, 1892, a perfect female lobster was taken at Green Island, Maine, which weighed 18 pounds. This outer island is noted for its fine lobster fishing. Mr. Collins states that in August, 1891, he had fifty lobsters at one time in his establish. ment which would weigh from 10 to $18 \frac{1}{2}$ pounds. About half of these came from Castiue and the remainder from Blue Hill Falls, Maine. All of these were "new shell lobsters" - that is, they had shed that year, probably in July.

Mr. Thomas Garrett, who was one of three men who first engaged in lobster fishing at Vinal Haven, Maine, over forty years ago, and has been engaged in this pursuit most of the time siuce, says that he has taken a great many lobsters which would weigh from 15 to 20 pounds. He says that a perfect male lobster weighing 30 pounds ${ }^{1}$ was taken in a hoop-net in Golden Cove, in Vinal Haven Harbor, in about the year 1858 , and that in 1887 a lobster was canght in the basin (near the site of the present lobster pound on Vinal Haven Island) which weighed 11 pounds and had only one Jarge claw.

The mouth of the Skillings River is said to have furnished large lobsters in plenty in the fall of 1888. It was very common to take lobsters there weighing 15 pounds. The place had not been previously fished with regularity, but it soon became the resort of fishermen and the lobsters were rapidly reduced in numbers and size.

Fishermen in Rockland, Maine, have gaffed lobsters in the harbor in the past two years weighiug from 8 to 9 pounds. I heard of a large lobster which was caught on a trawl, the hook catehing in a joint of the shell, in June, 1892, on White Island grounds, near Vinal Haven. It was said to have weighed over 20 pounds.

Mr. F. W. Collins informs me that he received at Rockland, in 1893, a larger number of lobsters than usual measuring about 15 inches in length and weighing about 5 pounds.

These notes furnish evidence, if any were needed, that very large lobsters, weighing 20 pounds or more, are even now occasionally taken, but I have never obtained any reliable evidence that lobsters weighing over 25 pounds have ever been caught. Where lobsters are said to have attained a greater weight, measurements of the parts of the skeleton which have been preserved invariably prove that the figures have been exaggerated. I do not maintain that the American lobster does not reach a greater weight than 25 pounds, but that I have been unable, up to the present time, to discover any well-authenticated evidence that this is the case.

Many points on the coast of Maine and the Maritime Provinces still furnish large lobsters weighing 10 pounds or more, but not in any considerable number, and lobster's of 5 pounds weight are frequently common; yet it is at the same time true that the size of the lobster lias been declining for many years, until the average weight has, in most places, fallen below 2 pounds.

I The weight of this large lobster may have been unintentionally exaggerated. One can harrlly avoid such an inference from the evidence already given. 


\section{THE RELATION OF WEIGHT TO LENGTH.}

The weights and leugths ${ }^{1}$ of 2,657 lobsters captured at Woods Hole under the conditious already described $($ p. 25) are recorded in table 31 . The weight does not bear a constant relation to the length, but is very variable owing to the loss of the appendages, particularly the large claw-bearing legs. These alone constitute from one quarter to one-half the entire weight of the animal, and probably in the Belfast lobster (plate 1), and in all giants of similar size, the weight of the large chelipeds is more than two-thirds that of the entire body (see table 31a). The lost limbs are regenerated, as we have seen, but never completely so without the intervention of one or more molts, so that a lobster with an undersized claw is a common occurrence.

The weight also is subject to great variation in consequence of the molt, when a dense heavy armor or cuticle is exchanged for a much lighter though larger one. In the soft lobster the specific gravity of the solids and fluids of the body is considerably reduced. Very few soft lobsters, however, were taken during the period of these observations, only about 3 per cent (see table 23), so we may ascribe the great variations shown in the table below chrefly to disparity in the size of the large claws. This is particularly noticeable in smaller individuals, as in the 9-inch lobsters, where out of 170 males the smallest weighed only 10 ounces and the largest three times as much.

TABLE 31.-Relation between the lengths and weights of male and female lobsters, taken in Woods Hole Harbor, December to June, 1893-94.

\begin{tabular}{|c|c|c|c|c|c|c|c|c|c|c|c|}
\hline $\begin{array}{l}\text { Length } \\
\text { in } \\
\text { inches. }\end{array}$ & $\begin{array}{l}\text { No. of } \\
\text { males } \\
\text { exam. } \\
\text { ined. }\end{array}$ & $\begin{array}{l}\text { Arerige } \\
\text { weight } \\
\text { of males. }\end{array}$ & $\begin{array}{l}\text { Extrenes } \\
\text { of weight } \\
\text { of males }\end{array}$ & $\begin{array}{l}\text { No. of } \\
\text { fermales } \\
\text { without } \\
\text { eggs Bx- } \\
\text { amined. }\end{array}$ & $\begin{array}{l}\text { Average } \\
\text { weight of } \\
\text { females } \\
\text { without } \\
\text { eggs. }\end{array}$ & $\begin{array}{c}\text { Extremes } \\
\text { of weight } \\
\text { of females } \\
\text { without } \\
\text { eggs. }\end{array}$ & $\begin{array}{l}\text { No. of } \\
\text { females } \\
\text { with } \\
\text { eggs ex. } \\
\text { amined. }\end{array}$ & $\begin{array}{c}\text { Average } \\
\text { weight of } \\
\text { females } \\
\text { with } \\
\text { eggs. }\end{array}$ & $\begin{array}{l}\text { Extremes } \\
\text { of witight } \\
\text { of females } \\
\text { with } \\
\text { eggs. }\end{array}$ & $\begin{array}{c}\text { Total } \\
\text { number } \\
\text { of males } \\
\text { and } \\
\text { females } \\
\text { examined. }\end{array}$ & $\begin{array}{l}\text { Arerage } \\
\text { weight } \\
\text { of all } \\
\text { themales } \\
\text { and } \\
\text { females. }\end{array}$ \\
\hline 6 & 3 & $\begin{array}{l}\text { oz. } \\
5.33\end{array}$ & 4 to 6 & 4 & $8 z .75$ & 8 to 10 & & oz. & $o z$. & 7 & $\begin{array}{l}\text { 0z. } \\
7.29\end{array}$ \\
\hline $6 \frac{1}{2}$ & 1 & & & & & & & & & 1 & \\
\hline $\begin{array}{l}6 \frac{1}{2} \\
6 \frac{3}{4}\end{array}$ & $\begin{array}{l}3 \\
5\end{array}$ & $\begin{array}{l}8 \\
7.60\end{array}$ & $\begin{array}{lr}8 & 8 \\
6 & 10\end{array}$ & 4 & 7.25 & 6 & & & & 7 & 7.57 \\
\hline $\begin{array}{l}7 \\
7 \\
78\end{array}$ & 45 & 10.18 & $\begin{array}{ll}7 & 13\end{array}$ & $\begin{array}{r}46 \\
1\end{array}$ & $\begin{array}{l}10.76 \\
10\end{array}$ & $\begin{array}{ll}9 & 13\end{array}$ & 1 & 12.00 & & $\begin{array}{r}5 \\
92 \\
1\end{array}$ & 10.49 \\
\hline $7 \frac{8}{4}$ & 10 & 1). 40 & 13 & $\begin{array}{l}1 \\
4\end{array}$ & 10.25 & 13 & & & & $\begin{array}{r}1 \\
14\end{array}$ & $\begin{array}{l}10 \\
10.36\end{array}$ \\
\hline $7 \frac{1}{2}$ & 66 & 1.86 & 15 & 47 & 11.43 & 15 & & 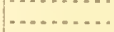 & & 113 & 11. 68 \\
\hline $7 \frac{3}{\frac{3}{4}}$ & 20 & 75 & 10 & 9 & 12.44 & 16 & & & & 29 & 12.66 \\
\hline 8 & 168 & 15.16 & 18 & 138 & 15.30 & 11 & 2 & 12.50 & 12 to 13 & 308 & 15.21 \\
\hline $\begin{array}{l}8 \frac{1}{8} \\
8 \frac{1}{6}\end{array}$ & 44 & 30 & $11^{20}$ & $\begin{array}{r}1 \\
29\end{array}$ & $\begin{array}{l}14 \\
15.24\end{array}$ & $12 \quad 18$ & & 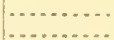 & $\ldots \ldots$ & $\begin{array}{r}1 \\
73\end{array}$ & $\begin{array}{l}14 \\
15.27\end{array}$ \\
\hline $8 \frac{1}{2}$ & 143 & 61 & 22 & 108 & 16. 36 & $\begin{array}{ll}12 & 19\end{array}$ & 7 & 16.14 & $15 \quad 17$ & 258 & 16.50 \\
\hline $8 \frac{3}{4}$ & 26 & 46 & 13 & 26 & & 13 & 1 & & & 53 & 17. 23 \\
\hline 9 & 170 & 18.96 & 10 & 153 & 18.61 & .... & 13 & 18.69 & 15 & 336 & 18.79 \\
\hline $9 \frac{1}{8}$ & & & & & & & 1 & & & 1 & 16 \\
\hline $9 \frac{1}{4}$ & 32 & 19.91 & 11 & 34 & 19. 32 & 16 & 4 & 20 & 17 & 70 & 19. 63 \\
\hline $9 \frac{1}{2}$ & 148 & 1. 24 & 16 & 145 & 0.51 & 16 & 24 & 20.42 & 18 & 317 & 20.84 \\
\hline $9 \frac{3}{6}$ & 27 & & 18 & 26 & 21.19 & 18 & 3 & 20.67 & 19 & 56 & 22.52 \\
\hline 10 & 167 & 24.41 & 19 & 148 & 23.76 & 32 & 36 & 23.86 & 20 & 351 & 24.08 \\
\hline $10 \frac{1}{4}$ & 62 & & 20 & 54 & & 21 & $\frac{1}{17}$ & $\begin{array}{l}28 \\
23.12\end{array}$ & & $\begin{array}{r}1 \\
133\end{array}$ & $\begin{array}{l}28 \\
25.76\end{array}$ \\
\hline $10 \frac{2}{2}$ & 79 & 28.89 & 22 & 75 & 27.52 & 23 & 28 & 28.11 & 23 & $\begin{array}{l}100 \\
182\end{array}$ & $\begin{array}{l}25.66 \\
27.66\end{array}$ \\
\hline 105 & 1 & & & & & & & & & 1 & \\
\hline $10 \frac{8}{3}$ & 18 & 29.94 & 25 & 16 & 24.19 & 24 & 2 & 26.50 & 25 & 36 & 27. 19 \\
\hline 11 & 31 & 4.65 & 30 & 42 & 30. & 23 & 20 & 32.10 & 29 & 93 & 32.22 \\
\hline $11 \frac{1}{4}$ & 10 & 7.20 & 32 & 11 & & 37 & & & & 21 & 34.52 \\
\hline $11 \frac{1}{2}$ & 11 & 42.36 & 34 & 26 & 34.46 & 30 & 4 & 32.25 & 30 & 41 & 36.37 \\
\hline $11 \frac{3}{4}$ & 2 & & 32 & 2 & 34.50 & 35 & & & & 4 & 35.25 \\
\hline 12 & 9 & 43. 78 & 34 & 11 & 42 & 54 & 3 & 43.67 & $\begin{array}{ll}37 & 48\end{array}$ & 23 & 42.91 \\
\hline 123 & 1 & & & & & & & & ……... & 1 & \\
\hline $12 \frac{1}{2}$ & 4 & 50.25 & 52 & 7 & 42.71 & 36 & & & set & 11 & 45.45 \\
\hline 13 & 4 & 51.80 & $44 \quad 60$ & 4 & & & & 45 & & $\frac{1}{8}$ & \\
\hline $13 \frac{1}{2}$ & $i$ & 68 & $7 \pm \quad 00$ & 4 & 47.25 & 40 & & ..... & ...... & 8 & 49.75 \\
\hline $14^{2}$ & 1 & 88 & & & & 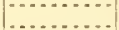 & & . & & 1 & 88 \\
\hline $14 \frac{1}{2}$ & 1 & 74 & & 2 & & 64 & & & & 3 & 68 \\
\hline $15^{-}$ & & & & 3 & 69.33 & 66 & & & & 3 & 69.33 \\
\hline & 1,313 & & & 1,176 & & .... & 168 & & & 2,657 & \\
\hline
\end{tabular}

'The length of the lobster is measured from the apex of the rostral spine to the end of the telson, not including the terminal fringe of hairs. 
The fact that the male is heavier than the female of the same length is very clearly brought out by the observations recorded above. In passing the eye down the columns to the left only three cases will be discovered where this is not true, namely, in the 6, 7, and 8 inch lobsters. The difference here in favor of the females, where a sufficient number of observations were made to entitle them to much confidence, is only a question of fractions of an onuce in average weights. After passing the 8 -inch limit the balance is in faror of the male. The 10 -inch males are about half an ounce heavier thau the females of the same length. From this stage the excess in favor of the male becomes very marked. The 11 -inch male exceeds the female of the same length by a full quarter of a pound. In the lobster $12 \frac{1}{2}$ inches long there is a greater difference in favor of the male, $7 \frac{1}{2}$ ounces in the cases cited in the table.

It is evident from the facts here recorded that the greater size of the male, which is a sexual characteristic, does not appear until the animal has passed the 8-inch limit. At this period the sexes are of about equal weight, but from this point the male surpasses the female in weight, owing chietly to the greater development of the large clams.

The average weight of females withont and with eggs recorded in columns 6 and 9 of table 31 brings to the surface a rather unexpected fact, namely, that females with spawn are in a poorer condition or weigh relatively less than females without. In one-third of the cases here recorded the weight of females with eggs was actually less than that of females of the same length without eggs. In the 10-inch series, 184 females were examined; 36 of them had eggs, and weighed on the average but one-tenth ounce more than those without eggs. Turning to table 16, we find that the average quantity of eggs borne by a 10 -inch lobster is 1.73 fluid ounces, and since a Hluid ounce of lobster eggs weighs very nearly an ounce avoirdupois, the average weight of the 10-inch female deprived of her eggs is 22.13 ounces, as compared with 23.76 ounces, the average weight of non-egg-bearing females of this size. There is a difference of 1.63 ounces in favor of the female without eggs. In the case of the 92-inch lobsters, where 169 in all and 24 bearing eggs were examined, the average weight of the spawuers is less by 0.09 ounce than that of the corresponding females without eggs.

The facts which have just been stated do not support the conclusion of Buckland and his associates on the fisheries work in Great Britain, that "the lobster, when berried, is in the very best possible condition for food." (28, p. xvi. See p. 64.)

In the last column of table 31 the average weights of lobsters corresponding to definite lengths are given. A lobster of the minimum length at which it can be legally sold, 10: iuches, weighs on the average $1 \frac{3}{4}$ pounds, while a 12 -inch lobster attains a weight of 2 pounds 11 ounces, and a lobster 15 inches long weighs from 4 to $1 \frac{1}{2}$ pounds, and probably more in some cases.

Lobster No. 7, table 30,173 inches long, weighed nearly 10 pounds (though in this case the cutting-claw was undersized), and the mammoth specimens recorded in this table, weighing from 20 to 23 pounds, varied only from 20 to $21 \frac{3}{4}$ inches in length (pp. 113-116).

In the early part of this chapter I mentioned the fact that the disparity in weight between lobsters of the same length was due largely to the difference in the size of the large claws. This is illustraterl by the following table, which is compiled from the observations made by Vinal N. Edwards. 
TABLE 31a._- Variation in the weights of lobsters with and withous the great claws.

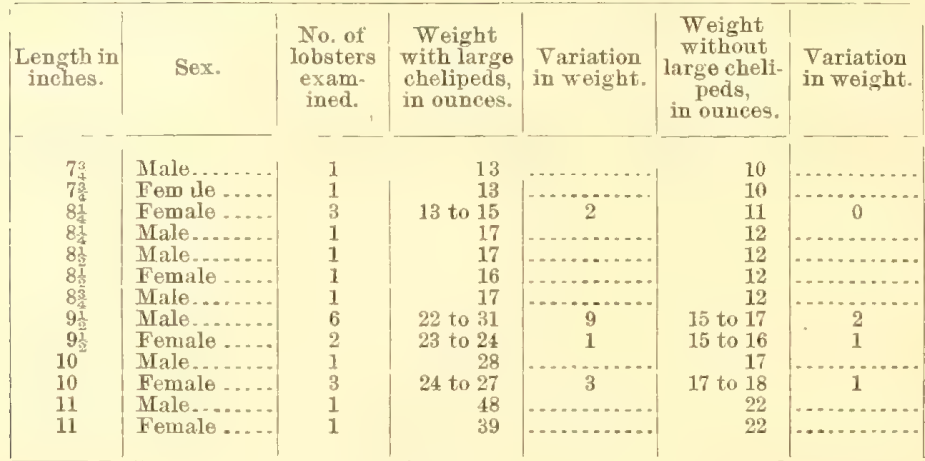

\section{Chapter VI.-ENEMIES OF THE LOBSTER.}

\section{ANIMALS WHICH PREY UPON THE LOBSTER.}

The adult lobster, whether with eggs attached to the body or not, is the prey of numerous fish which feed upon the sea bottom, like the sharks, skates, and rays. When of considerable size or in soft condition it is also devoured by the cod, pollock, striped bass, sea bass, tantog, and probably by many other species. In fact every predaceous tish which feeds upon the bottom may be looked upon in general as an enemy of the lobster.

A fisherman at Beal Island, West Jonesport, Maine, stated that he had eaught cod on trawls 10 to 15 miles from shore with lobsters 4 to 6 inches long in their stomachs. Cod were also eaught at Grand Manan, in summer, in 20 fathoms of water, by Mr. J. W. Fisher, of Eastport, with very smail lobsters, ${ }^{1} 1$ to 2 jnches long, in their stomachs. Lobsters an iuch long have also been taken from the stomachs of codfish on the shores of Prince Edward Islaud (209, p. 232), and soft lobsters 3 to 8 inches long have also been found in the stomachs of these fish taken in deep water off shore.

The observations of Mr. Vinal N. Edwards are quoted by Mr. Rathbun (156, p. 782) to show the great destruetion of lobsters in the Edgartown district, Marthas Vineyard. Out of hundreds of cod caught about No Mau's Land and examined by Mr. Edwards, nearly every fish "contained one or more young lobsters, and in many cases the stomachs were almost entirely filled with them." So great did the destruction wrought upon the lobster by the cod impress one fisherman $(156$, p. 728) that he thought the cod a greater enemy than the lobstermen, and said: "I bave caught one hundred cod in one day that I knew had the amount of one thousand lobsters and shadows in their entrails." 
The cod has an equally bad reputation among English fishermen. Frank Buck. land says $(28, \mathrm{pp} .14,15)$ :

Among the animate enemies the principal enemy [of the lobsters] I believe are cod. $\Lambda$ witness at Burghead stated that codfish are great enemies to lobsters; he hardly ever opens a cod without finding joung lobsters in the stomach, particularly in February and March. He has seen cod throwing up lobsters on the deck of a ressel, as many as five or six lobsters in one cod. These lobsters wonld be 3 or 4 inches in length or even smaller. Cod eat lobster's all the season. In the spring and in January, February, and Mareh there aте many cod abont. Skates and congers, and codling and haddock also eat crabs and lobsters.

On July 16, 1894, Dr. J. I. Peck showed me the "tail" of a soft lobster which he had taken from the stomach of the weakfish or squeteague (Cynoscion regale). The lobster had been out of its shell but a few hours when it was snapped up by this fish.

Verrill (196) records the finding of lobsters in the following fish: Dusky shark (Eulamir obscura), Woods Hole, in July and August; dogtish (.lustelus canis), Woods Mole, in August; sand shark (Eugomphodus littoralis), Woods Hole, July and Angust; peaked-nose skate (Raia levis), Menemsha, July; long-tailed stingray (Myliobatis freminvillei), Vineyard Sound, July; rabbit-fish (Chilomycterus geometricns), Woods IIole, July; striped bass (Rocens lineutus), Woods Hole, August, 1871; tautog (Tautogr onitis), "two caught July \& and 15 contained small lobsters."

Mr. Mosher, who had prepared striped bass for market for upward of thirty years, said:

Striped bass do not feed upon live menhaden, but upon erabs and lobsters. * * * I have always observed that bass fishing was best where lobsters and erabs were most plentifu]. (Bull. U. S. F. C., vol. 11, p. 410.)

Small lobsters are probably to some extent the prey of sea-roving birds, such as the gulls and terns, but in regard to this nothing is known. According to Boeck (20,pp. 227-228), the Norwegian lobster is sometimes attacked by crows. His account is as follows:

An interesting scene may be witnessed near Bukkenö, north of Stavanger, where an Englishman has constructed a large pund betweon some small islands for keeping live lobsters. Whenever the pond becomes too full of lobsters, so that they do not find sufficient food, they leave the water and crawl about, seeking to reach the sea, but during their wanderings they fall an easy prey to large numbers of crows hovering round, which take them in their claws, fly high up, and let the unfortunate lobster drop down on the rocks, where their shells are broken, so that the erows can eat them in eomfort. The crows are not easily scared away, but show a remarkable degree of sense, only flying away when anyone approaches with firearms, and later they carry on their depredations in the early morning, when they have less to fear.

That lobsters ever leave the water and attempt to crawl upon the land can not be credited, and it is likely that this story passed through several hands before rearhing its present form. Herbst (88) says that the lobsters have a great enemy in the Steinbeisser. ${ }^{1}$

If the lobster is thus attacked and destroyed in large numbers by fish after it has acquired the habits of the adult and has many devices to avoid its enemies, what shall we say of the destruction which is wrought on the young during the first eight or ten weeks of their life? From the time of hatching up to the sixth stage the young lobster swims at the surface and becomes an rasy prey to all surface-feeding

' It is uncertain what fish is here meant. The name is applied to the fresh-water genera Cobitis and Lota. 
fish, some of which, like the menhaden, ${ }^{1}$ roam about in vast schools, straining the water as effectively as the towing net. During this period the lobster measures from one-third to two-thirds of an inch in length, and is not only helpless in the hauds of its animate enemies, but is subject to a vast amount of indiscriminate destruction from the forces of inanimate nature.' (For the further consideration of this subject see pp. 187-189.)

\section{PARASITES, MESSMATES, AND DISEASES OF THE LOBSTER.}

One of the two parasites known to infest the lobster is a trematode (Stichocotyle nethropis). This was first described by Cunningham, who found it in the intestine of the Norwegian lobster. It has recently been discovered in the American lobster by Dr. Nickerson, to whom I am indebted for the following particulars. The larva of this singular parasite, which is from 3 to 7 millimeters long, is found sometimes to the number of 70 or more embedded in the mucous coat of the intestine about the coecum. It is relatively rare, hardly more than 2 per cent of the lobsters which Dr. Nickerson examined being infested by it. Its position at the hinder end of the alimentary tract seems to argue that it comes in by way of the anus rather than through the mouth. Its final host is probably some species of fish which feeds upon the lobster, but the adult trematode is unknown. It may prove to be of a different species from the larva discovered by Cunningham.

The only other strict parasite which the lobster is known to possess is the large Gregarine (G. gigantea), which was discovered in the intestine of the European lobster by Van Beneden. (194)

In 1853 Van Beneden (69) called attention to a small green worm which he found on the eggs of the lobster, and which he supposed was a larva of Serpula. Later, in 1858 , he concluded that the animal was not a larva, but a fully developed individual, which he called Histriobdella homari, placing it amoug the Hirudinex (69). Foettinger, a later student of this form (69), proposes to change its name to Histriodrilus benedeni, and concludes that is is an Enterocoelian, allied to Polygordius. It is not a parasite in the strict sense.

Although parasites are rare, the lobster is encumbered with a great variety of messmates, which attach themselves to the external shell.

Whenever the lobster is confined in inclosures, or compelled for any reason to lead a sluggish life, the common barnacle fixes itself to the arched carapace and begins to secrete its tent-like covering as securely as it might upon a stone; mussels of various kinds insinuate themselves in convenient angles of the shell and joints, small tunicates sometimes becoming attached firmly to the under side of the shell between the legs. Tube-forming annelids, lace-like bryozoa, form incrustations in various parts, and red, brown, and green algæ often decorate the antennæ and carapace with long streamers which are waved with every movement of the animal. At each molt the lobster of course frees itself completely from these troublesome companions.

${ }^{1}$ Regarding the menhaden as an enemy of the larval lobster, I have consulted with my friend, Professor J. I. Peck, who has made a very careful study of the habits of these remarkable fish. He writes as follows: "I have never found lobster larvæ in the stomachs of menhaden, and yet it must be remembered that the localities whence my material was nearly all secured were brackish-water inlets. Copepods in all stages of growth are abundant and shrimp of the smallest size were common at New Bedford, but in the material trom Buzzards Bay I have never seen lobster larvæ." He thinks that the evidence can not be conclusive until menhaden are exammed which have fed both day and night in localities which abound in lobsters. 
At the lobster pound in Vinal Haven, Maine, which I visited on August 26, 1893, I examined a number of lobsters whose bodies and free appendages supported a surprisingly varied flora. A hard-shelled female which I took out of the mud in very shallow water was decorated with algie in a very striking fashion upon the upper' part of the body, the big claws, and antenna. The long whip-like "feelers" were weighed down with fronds of the brown laminaria, or devil's apron, as shown in fig. 118, plate 36. The common green lettuce (Ulva latuca) was sprinkled freely over various parts, and baruacles had gained also a foothold upon the shell. A frond of laminaria, which was fixed to the side of the abdomen, was 7 inches long and 2 to 3 inches in width. Besides the larger frouds, there was a matted undergrowth upon the antennæ, composed of several species of algx and attached fungi. One of the men employed at this pound said that he had taken hard-shell lobsters with "kelp" 2 feet long growing upon the shell.

A lobster now in the Peabody Museum of Yale University was incrusted with Nullipores, when it was captured in Nantucket in April, 1880. This specimen was a male and weighed about 10 pounds.

Mussels sometimes glue themselves in extraordinary numbers to the under sides of the bodies of living Iobsters, in places where the animal is unable to scratch them off. A good illustration of this may be seen in the museum of the Peabody Academy of Science at Salem, Massachusetts, where there is a male bard-shelled lobster about 12 inches long with fifty or more shells of the common Mytilus edulis attached to its body. The shells of some of these bivalves are $1 \frac{1}{2}$ inches long. They have wedged themselves between the bases of the thoracic legs, the plates of the tail-fan, and have fastened themselves even to the head between the antennæ and about the eyes.

It is not nucommon to find the barnacle (Balanus balanoides), as we have already seen, attached to the shell of both very old and relatively young lobsters (fig. 1, plate 1). The large Belfast lobster carried about with it several species of mollusks, as well as barnacles and hydroids.

On July 15, 1894, I found a lobster which had been kept for several days, or perhaps for a longer time, in a floating ear, with one of its eyes completely hooded by a colony of bryozoa. When set free, the eye appeared perfectly uormal.

The messmates of the young lobster consist chiefly of fungi (of which bacteria are the most characteristic) and of diatoms. Young lobsters captured at sea seem to be peculiarly free from foreigu matter of every kind, but when the young of almost any of the crustacea are confined they soon become clogged with solid organic or inorganic floating particles and bacteria with which such material is invariably associated. The hairs which garnish the body and appendages of crustacean larvæ serve to gather up and hold solid particles from the water, so that one of the first considerations in the artificial rearing of crustacea is to give them as clean a water supply as possible.

I have seen larvæ in the fifth stage of development literally covered with a mass of diatoms (Tabelaria, Navicula, etc.) like those found in the brown sediment at the bottom of the jar in which they lived and in the undigested food contained in their stomachs. Old lobsters, in which the molting period has become very infrequent, are commonly the worst sufferers from enemies of this kind, but the physiological condition of the animal is, as we have seen, the most important consideration.

The crayfish, which is devoured eagerly by numerous species of fish in fresh-water lakes and rivers, both in this conntry and in Enrope, is infested by Trematode worms, which become encysted in the tissues of the auimal. Distomum nodulosum lias beeu 
described from Cambarus propinquus by Wright and Linton, and Ward (198) has found in the same crustacean still another species, Distoma opacum. "The cysts occupied the space in the cephalothorax above the heart and sexual organs."

The "tomally" or liver of the lobster is free, so far as is known, from parasites of all kinds, yet this is not the case with all the decapod crustacea. In June, 1885, while dissecting the southern shrimp (Penceus setiferus), I found numerous stages in the development of a cestode worm, Tetrarhynchus (species undetermined), in the liver of this prawn. The youngest were oval, about $\frac{1}{1} \frac{1}{7}$ inch in loug diameter; the oldest larvæ measured $\frac{1}{15}$ inch; they had a round, flattened body, an anterior segment or neek, with four well-developed proboscides, and a "tail" of about equal length, and unsegmented. Two pairs of bright red pigment spots were borne on the upper anterior part of the body.

\section{DISEASES OF THE LOBSTER.}

There are no specific diseases to which lobsters are subject, so far as known, yet they sometimes die off so rapidly as to lead one to suspect that they may have fallen a prey to some contagious disease.

Mr. N. F. Trefethen, of Portland, Maine, who owns a lobster pound in South Bristol, 35 miles east of Portland, relates the following experience: In May, 1s93, he placed 100,000 lobsters in this pound, the area of which is about 3 acres. Very soon they began to die, and in a few days all of them were dead. There were 12 to 13 feet of water in this pound at flood tide and not less than " feet at low water. The pound was probably very much overstocked, but it is difficult to understand why these lobsters should have all died so suddenly, unless they were either poisoned or attacked by disease.

In the summer of 1889 a lobster with a large bunch on the side of the carapace was eaptured in Vineyard Sound. On the top of this tumoid growth was a craterlike depression covered with a membrane. This was probably a sore resulting from a wound which the animal had received in the back, and which had failed to heal. A similar case is mentioned by Rathbun (155). 


\section{Chapter VII.-THE TEGUMENTAL GLANDS.}

The shell of the lobster, as lias been seen already (pp.77, 78), is not a solid armor, but is everywhere perforated by capillary canals which open by minute pores at the surface. One set of these ducts is called the hair pores. These lie immediately beneath the hairs or setae of the shell. The other set constitutes the ducts of the tegumental glauds.

The tegmental glands are very generally found in the decapod crustacea, and they are more widely distributed over the body of the individual than almost any othex organ. Nevertheless their structure has never been accurately determined, and almost nothing is known of their function. They lie in the dermis or in the connective tissue and adjoining muscles immediately below the cuticular epithelium. They are opaque, subspherical or oblong, not usually over $\frac{1}{8} \mathrm{~mm}$. in longest diameter, and each communicates with the exterior by means of a capillary duct, the entire length of which-not including the part which traverses the cuticle-is probably not more than $\frac{1}{10}$ mm. (cuts 4 and 5, pl. A, and fig. 208, pl. 49) and its diameter only $-\frac{1}{2} 5 \mathrm{~mm}$. These minute organs are scattered all over the body and appendages; they are particularly abundaut about the mouth and in the o'sophagus, and Vitzou has found them in the walls of the intestine of Palinurus (197). As he remarks, "one may stuly these organs indifferently in a macruran or brachyuran, for they have the same structure in both."

\section{GENERAL STRUCTURE OF THE TEGUMENTAL GLAND.}

The tegumental gland, wherever found, whether in the appendages or beneath the skin of the body proper, has the structure shown in cut 5. It consists of a central reticulate body or rosette, the exact nature of which is unknown. In the midst of this there is a small cavity, which is continued into a short capillary duct. The latter perforates the cuticle and thus places the organ in direct communication with the exterior. Gromped about the rosette is a cluster of gland cells of various shapes and sizes. Each has a broad base and tapering central end, which is united to a process of the rosette. Each organ is supplied with a nerve and contains an eccentric, bipolar cell, which resembles a ganglionic cell. One of the processes of the latter joins the rosette, while the other unites with the nerve. Rarely two such cells appear in the same organ. The duct and nerve usually issue from the gland together, the former possessing apparently, for at least a part of its course, a thin sheath. Each organ is usually surrounded with a delicate capsule, probably of connective tissue, though it is not always possible to detect such an envelope.

I have seen no branching of ducts, each organ opening independently at the surface, and I bave not suceeder in determining with any degree of satisfaction the relation which the nerve fibers bear to the glaud cells.

1 Similar structures have been called dermal glands, salivary glands, and cement glands. While it is probable that they originate in the epidermis, it may be better to classify them under the generic term of tegumental glands.

In the work of this chapter, relating to histology and technique, I wish to acknowledge my indebteduess to Professors Patten and Watase for valuable suggestions. 
What is the function of these organs which are distributed so widely over the surface of the body? It has been found that glands of a similar character play a part in excretion. (Text-book of Comparative Anatomy, Lang, part I, p. 330.) Those found in the resophagus were regarded as salivary glauds until the embarrassing fact was discovered that they were also found in the walls of the intestine. When oceurring in the swimmerets and ventral abdominal region of the female these organs have been considered responsible for the liquid glue or chitin-like cement which is poured over the eggs at ovulation, and have been accordingly called cement glands. It seems probable that they have such a function, and I shall proceed to deseribe them in detail as they occur in the lobster.

\section{THE CEMENT GLANDS.}

If we strip off the hard cuticle from the pleopod of a female lobster just before the eggs are laid (fig. 144, plate 40), we will see thousauds of opaque whitish bodies lying upon the strands of muscular tissue. Each is a gland not more than an eighth of a millimeter in diameter, and each opens to the exterior by a capillary duct which pierces the cuticle. The grounds for attributing a cement-producing function to these organs lie chiefly in their periodical changes coincident with the sexual condition of the female, and in their absence or restricted occurrence in the pleopods of the male. Their position upon the swimmerets also favors such a view. We can not look elsewhere for such an organ, unless it is to the oviducts, and I know at present of no evidence showing that the latter possess this function in the macrura.

CEAIENT GLANDS IMMEDIATELY BEFORE OVULATION.

As the time of oviposition draws near, the swimmerets of the female become more and more opaque, especially along the free margins of their branches. At this time a milky-white substance can be pressed out, upon removing the cuticle. This is analogous to what Lereboullet observed in the crayfish (120), and is composed of the glandular tissue.

At this perior the glands have the appearance shown in plate 49, fig. 212. Stained with the Ehrlich-Biondi auilin mixture the cells have a cloudy, granular appearance. Their peripheral ends contain a coarser material, which takes a deeper red than the central parts; the latter appear much lighter, and select and hold some of the green. The distribution and appearauce of the zymogen granules may be compared to that seen in the pancreas of a well-fed dog, or the resting cells of the submaxillary gland.

An attempt to get a secretion from these giands while in this condition by stimulating the nerve cord by induction currents was not successful, possibly owing to the fact that these organs had not quite reached the stage of their periodical activity.

THE CEMENT GLAND IMMEDIATELY AFTER OVULATION.

The structure of the exhausted gland, taken shortly after the eggs are laid, is illustrater by fig. 211, plate 49. If this is compared with fig. 212, which is treated in the same way, we will find a marked difference in its cytological condition. A very conspicuous zone of deeply stained zymogen granules surrounds the central rosette, while the outer parts of the gland cells are poor in zymogen and stain but feebly. This central darker zone is very variable in breadth, being' sometimes reduced to a thin circle, involving only the apices of the cells, and is often very sharply marked 
off from the rest of the cells. It should be remarked, however, that in two or three days atter ovalation (external eggs with segmented yolk) there is a striking lack of unifonmity in he condition of the glands, in many the central zymogen zone being entirely absent. This may be due to the fact either that some of the glands recover from exhaustion raster than others, or that they secrete unequally, or that some are not roused to activity at all.

Fig. 210, plate 49, is from the swimmeret of a female which had probably recently hatched a brood and was close upon the point of shedding. As may be seen, the glands are much shrunken in size, the cells transparent and uon-granular, as if they were completely exhausted. This seems to be a perfectly normal case, but whether it has any significance in respect to the molt I am not able to say.

\section{HISTORICAL SKETCH OF THE CEMENT GLANDS.}

Cement glands have been described in numerous species of macrurous crustacea, but their structure seems to have been imperfectly made out.

Cavolini, ${ }^{1}$ according to Cauo (32), maintained that the cement came from the oviduct, and liathke (160) regarded the genital organs as the probable source of this secretion. Erdl (62), in 1843, described three membranes in the egg of the lobster, and considered the outermost of these to be the secreted product of the oviduct.

Lereboullet (120) barely escaped the discovery of the cement glands of the crayfish in 1860 , but correctly stated that the cement substance came from beneath the skin of the under side of the abdomen. He had indeed communicated this discovery to the Natural History Society of Strasbourg in 1852 (published in a note in L'Institut, in 1853. See ref. 120.) As he says, zoologists had up to this time been almost mute upon this subject, some explaining the attachment of the ova to au extension of the primary egg menbrane, others, like Milne Edwards (58), to an albuminous secretion from the epithelium of the oviduct. Lereboullet described a milky-white matter rich in fat and utclei, which is present in the epimeral regions of the abdomen of the female crayfish at the time of oviposition, but is not found in the male at auy period of the year. He supposed that this substance oozed through pores in the cuticle, coagulated in the water after fixing the eggs, and that all trace of it subsequently disappeared until the next reproductive period.

The true source of this secretion was first recognized by Bram (22), who, in 1875, described cement glands in the crayfish. He showed that they consisted of clusters of cells, which open to the surface of the abdominal appendages by narrow ducts penetrating the cuticle-a single duct to each cluster. A little later (23) he figued aud described these glands in the six species of decapods. Similar strurtures were found in the carapace aud $\alpha^{2}$ sophagus. Gsophageal glauds (Speicheldrisen) had been already seen in several species of crabs, such as Grapsus and Eriphia spinifions, and analogous structures were found in the labrum and maxille.

Vitzou, whose work was published in 1882 (197), found glands gemerally present in the cesophagus of all the crustaced examined, and they appear in mauy of his drawings, but no attempt seems to have been made to study theix histology. The oesophageal glands were extremely abundant in the lobster and Palinurus. The ducts are said to

Memoria sulla generazıone der peser e dei granchi. Napoli, 1787. I have not had access to this work, and quote it upon the authority of Cano. 
be sometmes united into groups of five or six, and in the intervals small hairs ${ }^{1}$ occur upon the surface of the cuticular lining.

Cano (32) devotes considerable attention to this subject, in a paper published in 1891, describing the distribution and structure of the cement glands in a large number of decapods. Bumpus attributes the "varnish-like layer" which surrounds the ovum of the lobster after oviposition to a secretion which is supposed to come from the columnar cells lining the oviducts $(30)$.

In 1893 I gave a short and incomplete account of the cement glauds of the lobster (96). See also $9 \%$, note p. 79 .

\section{TEGUMENTAL GLANDS IN OTHER PARTS OF THE BODY.}

I am not able to map the entire distributionn of the tegumental glands, but have found them in many parts. The labrum and metastoma are packed almost full (fig. 208, plate 49). In the latter the ducts open for the most part upon the side next the mandible. We find them also in the basal stalk (protopodite) and respiratory plates of the maxillæ and maxillipeds, where they are already developed in the larval stages (plate 29, figs. 59,62), and in the flagella of the antennx. ${ }^{2}$ The skin of the carapace and abdomen abound in these organs, and they are clustered in large numbers about the auterior lower margins of the former, just below the cervical groove, where the surface of the shell is raised into prominences like a grater. The ducts of many of these glands open into the respiratory cavity. I have also found a few of the organs in the walls of the seminal receptacle.

In sections through the dorsal posterior surface of the carapace of a lobster nearly ready to molt I find glands in precisely the same condition as shown in fig. 211, plate 49, where there is an inver deeply staining granular zone. Figure 208, plate 49, represents an organ from the metastoma, after maceration for three days in Béla Haller mixture and staining in methylen blue. The duct, running in the nerve bundle, shows very clearly and can be readily traced to the surface of the gland. By focusing with care I was able to follow the tubular duct into the central lumen or space, so characteristic of these organs. The relative number and distribution of glands in auy part can be determined from macerated portions of the shell, as in fig. 170, which represents the inner surface of the first maxilla.

By maceration and pressure the structure of the gland can be made out in most of its details. In fig. 203 , plate 49 , the eccentric "ganglion" cell (s.c.) is seen to give off two branches, one of which joins the rosette $(R)$, while the other passes into the nerve bundle, not shown in this drawing. A single gland cell is still joined to a process of the rosette by its attenuated central end. By rolling this specimen under the cover slip I was able to confirm the relations here pointed out. In fig. 214, drawn from a similar preparation, fewer glandular cells are detached, and but one process of the "ganglion" cell is shown. In many instances I have noticed that the inner ends of the gland cells have a very refractive, tubular appearance where they join the central rosette (figs. 209, 213, etc., plate 49), as if they had been snapped off at this point of delicate union. Figs. 206, 207 show a single gland cell drawn from opposite sides, from a cement gland of a female with nearly ripe ovaries. Besides the promi-

I think it probable that the ducts of the glands really open upon these "hairs," as they do in the labrum. (See p. 133.)

${ }^{2}$ I have seen them in the outer flagellum only of the first antenna. 
nent numeus at the peripheral end of this cell, there are two other borlies-one mear the tubular neck-which take up the stain like nuclei and are considerably refractive. From the larger end of the cell (fig. 206) a sleuder process is given oft (compare figs. 201,204 from the maxill: ${ }^{P}$, which snggests a nerve fiber. All that I can say definitely is that this process is in continuity with the cell, probably with its wall. I did not see many cases of a similar character.

\section{EXPERIMENTS UPON THE SENSORY AREAS OF THE BODY AND APPENDAGES.}

Before discussing the function of the tegumental organs in general, I will record some experiments which were matle to determine how the lobster reacts to stimuli directed against the dead shell or enticle.

The lobsters experimented upon were taken from the sea, placed on their backs on a table, and allowed to remain in this position until quiet. At first they move their appendages vigorously in trying to right themselves, but soon come to rest. $\mathrm{By}$ sprinkling them with sea water they may be kept fresh for experiment for a cousider. able time.

Various stimuli, such as electricity, heat, weak acetic acid, ammonia gas, clam juice, were applied to different parts of the body, with a view to ascertain the most seusitive areas where the quickest and most vigorous responses were given.

The degree of sensibility to external stimuli is surprisingly great in many cases, where the skin of the lobster with its shelly covering seems quite as sensitive as that of the frog. In other cases, however, the animal is much less responsive, a fact which we may attribute in some degree to the thickness of the shell.

To sum up the experiments in a general way, all or nearly all the a!pendages react strongly to chemical stimuli, and in many cases the surface of the body is capable of receiring and responding to stimuli of various kinds. If a jet of ammonia gas is injected against the intersegmental membranes or appendages of the "tail," the pleopods may be set in very lively motion and violent flexion of the whole abdomen may follow. Direct the jet upon the anterior swimmerets, and the last three pairs of walking legs are drawn backward and make scratching movements to remove the offending object, reminding one of the motions of a "reflex frog" when its skin is stimulated in a similar way.

The reaction is more violent when the stimulus is applied to the swimmerets than when directed against the intersternal membranes. The seminal receptacle is very sensitive, and when stimulated the walking legs make violent scratching movements toward it. If the jet of gas is directed along the surface of the walking legs, the reaction is usually greatest at their tips.

If the extremities of the large chelr, especially the propodus, are tonched by the gas the claw opens and shuts. The first pair of antennæe are much more sensitive to the stimuli than the second pair. If the jet is directed over the region of the mouth, very violent chewing movements are set up.

If the ammonium vapors be squirted on the dorsal surface of the carapace or abdomen, a vigorous response is sometimes seen by the immediate movements of the legs. Both males and females respond to the ammonia stimulus on the abdominal appendages and intersegmental membranes.

Very similar reactious are obtained if a small piece of blotting paper wet with weak acetic acid is used. In some cases no response is obtained if the wet paper is 
placed on the intersternal membranes of the abdomen, but if laid upon either the inner sides of the pleura or upon the surfaces of the pleopods the reaction is more marked

If clam juice is placed on the mouth parts, as upon the flattened basal segments of the second maxillæ or first pair of maxillipeds, vigorous chewing movements are immediately begun, and are continted for several minutes. If the stimulus is applied to one side, the movements are at first restricted to that side only, but eventually, in some cases, the appendages of the opposite side begin to move also.

If clam juice is dropped upon the swimmerets of the female, a response is usually forthcoming, and the same is true if this stimulus be applied to the terminal segments of the walking legs. In the case of the large chelæ the respouse may be very slight. In one instance, where three females and one male were experimented upon, the abdominal appendages gave no response to clam juice, but the mouth parts were always extremely sensitive. In this case the pleopods gave a marked reaction when touched with weak acetic acid.

As a rule, the pleopods of the female were more sensitive to the various stimuli than those of the male. The abdominal appendages of the body give no reaction when breathed upon, and show but slight sensitiveness to heat. Weak electrical currents from an induction coil produce marked responses in the maxillæ and first pair of maxillipeds, and if the swimmerets are touched by the electrodes, violent contractions of the flexor muscles of the abdomen speedily follow.

The preceding experiments would lead us to suppose either that certain areas of the skin of the body and appendages are very sensitive to a variety of stimuli or that the skin or parts below it possess special sense-organs. In either case, excepting electrical stimuli, the organs must be reached by means of the canals which penetrate the inert cuticle.

Since there are only two possible roads for the entrance of chemical stimuli-the hair pores and the pores of the glandular ducts-the question is therefore raised whether the glands possess a subsidiary sensory function. If it could be shown that the setæ of the carapace were not perforated at their tips, it would be certain that ammonia vapor could not enter them ${ }^{1}$ and extremely probable that the reaction from this chemical stimulus had its seat in the gland. I believe that these organs do possess such a subsidiary function, and that this is shown to be the case by a study of the sensitive labrum, in which hair pores and their corresponding setæ are entirely absent.

The function of the tegumental glands in various parts of the body has been a subject of much embarrassment. Max Braun (2\%) thought that the œosophageal glands of the crayfish were salivary organs. Vitzou inclines to acquiesce in this opinion, but admits that the presence of organs of exactly the same structure in the walls of the intestine (in Palinurus) is puzzling, to say the least.

Professor Patten (150) has recently discovered certain organs in Limulus to which he attributes a sensory function. They have essentially the same structure as the tegumental glands of the decapod crustacea. There occurs in front of the mouth of Limulus, on the middle line, a wart-like swelling, which Patten regards as the cuticular portion of an olfactory organ. "Directly beneath the ectoderm", he says, there "are a great many-at a rough estimate, from 1,500 to 2,000-clear, flask-shaped sense buds, each of which is connected by a narrow neck with a cuticular canal." The structure

${ }^{1}$ Where the setre are moist it might be possible for ammonium vapor or any other chemical stimulus to reach the sensory cells by diffusion through the thin chitinous wall of the tubular hair. 
of these "olfactory buds," their cuticular canal, gland-like cells, and large eccentric, in this case multipolar, ganglion, prove conclusively that these organs are essentially similar to the glands which 1 have deseribed in the lobster. In discussing this subject with P'rofessor Patten we have always been mutually agreed upon this point. What the function of these organs in all cases really is, may well be an open question. In Limulus the lumen of the organ varied much in appearance, being more sharply ciremuseribed in the young than in the adult, where it might be reduced or even absent. The tubule was sometimes coiled and very brittle. It is "undonbtedly composed of chitin, for, as with the gustatory tubules, it can still be seen in the cast-off shells of immature specimens and in the fresh shells cleaned with potash." The same is true of the cuticular cauals of the glands of the lobster, except that the tubule is always apparently straight and is never effacerl.

Lang (114) mentions some of the many cases in which glands have been described in the body and appendages of varions crustacea, attributing to some of these "dermal" structures an excretory function, a fact which, he says, may be proved by feeding with carmine.

Unicellular glands of a remarkable character have been described in the append ages of various amphipods by Nebenski (140), Claus, and others. Here they are found in both sexes, but are confined in Orchestia to terrestrial species. Nebenski thinks that in the latter they may serve a respiratory function by keeping the gills moist.

The glands situated in the month parts, when stained in Ehrlich-Biondi anilin mixture, select the green with more regularity, the nuclei taking up the red. This, however, may be due to slightly different methods of treatment in washing out the stain.

The differences between what appear to be the resting and active gland, illustrated in figs. 212, 211, which are fairly characteristic of the swimmerets, immediately before and after orulation, respectively, should not be given undue importance, since these conditions are met with, though less commonly, in other parts of the body.

Micro-chemical reactions point clearly to the glandular nature of the large peripheral cells of which these organs in certain places are composed. It is probable that in the pleopods they are concerned with the secretion of cement, for the reasons already given. What, then, is the function of the eccentric bipolar cell? Is it a reflex center for the glaud, or is this a sensory cell which conveys impulses received from withont to a reflex center in the central nervous system governing the secretory activity of the glandular cells? If the former supposition were correct, another question would remain to be answered: What are the organs of the sense of taste? The remarkably quick responses which are obtained upon stimulating the mouth parts immediately suggest the presence of gustatory organs. Such animals as the lobster and crab undoubtedly possess the sense of taste, but no organs have yet been described to which this function could be ascribed. Huxley says:

It is probable that the crayfish possesses something analogous to taste, and a very likely seat for the organ of this funetion is in the upper lip and the metastoma; but if the organ exists it possesses no structural peculiarities by which it can be identified.

The labrum of the crayfish, so far as I could ascertaiu from a single specimen which I sectioned, contains no such glandular organs as occur in the lobster.

If it is inadmissible to regard any of the tegumental "glands" as gustatory organs, we must conclude that no distinct organs of taste can be detected in this animal, which has the power of discriminating its food. Is it possible, as Lemoine suggested (118), that the sense of taste is in some species bleuded with that of smell 
and touch? Lemoine, who experimented with the crayfish, found that even the thickest parts of the carapace were seusitive, and that the parts which abounded in hairs were the most sensitive. Tonching the hairs determined the movement of the claws and thoracic legs.

Milne Edwards considered the buccal cavity as the seat of the sense of taste, but although the experiments made by Audonin and himself convinced him that the sense was developed, he failed to find any special organs. (58, I, pp. 112-113.)

Lemoine experimented upon the buccal cavity, and especially the labrum, using a great variety of stimulants, such as salt, pepper, tobacco, ammonia, and electricity. He describes the labrum of the lobster, but, strauge to say, did not discover the orgaus, with which it is packed full. He found that the inner face of this body was extremeiy sensitive. A nerve enters the labrum on exch side. This gives off lateral twigs near the point of entry and numerous terminal branches toward the median plane. He supposed that these termiual filaments supplied the short hairs which were erroneously supposed to cover the surface.

The setæ of crustacea have tactile, auditory, and probably olfactory functions. The sensory seta is hollow and stands over a canal, which penetrates the integument, and a nerve fiber passes up into the lower part of the canal. (84.)

The organs of taste in insects, according to Lubbock, are modified hairs, situated either in the mouth or on the organs immediately surrounding it. Nine different antennal organs have been described in the Hymenoptera. Some of these antennal hairs serve as organs of touch and smell, and possibly for hearing also.

I have already called attention to the fact that while the pleopods are studded with thousands of microscopic glands, these appendages in the male are almost devoid of them. Their occurrence in the brachyura, where indeed they were first described by Braun (23), might support the theory that they had, in such cases, a function to perform independent of the production of cement, since it has been shown that the crabs possess a special cement-forming organ in the epithelial lining of the glandular receptaculum seminis. We must therefore conclude that in the brachyura the work of the glandular receptaculum seminis is supplemented by that of the pleopodal glands, or that the latter possess another function.

On the other hand, Leydig (122) has maintained that there is a close relation between gland cells and sensory cells, the two kinds of cells resembling each other in general structure and in the disposition of the cell contents. He found in the sensory cells of the skin of some vertebrates what seemed to correspond to cuticular secretions in gland cells. ${ }^{3}$

The gland of the type which we have been considering is undoubtedly a very primitive organ in Arthropods. It has probably been modified to perform different functions, with a minimal change of gross anatomical structure. What the function in every case is we can not for the present say with any degree of certainty. While the question is a puzzling one, it seems to me safer to regard all such structures, wherever they oceur, in resophagus, the intestine, the labrum, pleopods, or outer integument of the body, whether in Decapods, Limulus, or in other forms, where they will doubtless be discovered, primarily as glands. We may add that in the labrum, and perhaps in other parts of the exterual integument of the lobster, and in Limulus, they may have

${ }^{1}$ Jickeli, according to Leydig, believes that in certain Hydropolyps which he studied sensory cells are converted into gland cells. (12\%.) 
a secondary sensory function. I have not examined the glands which occur in the alimentary tract, and can not say whether they possess a precisely similar structure.

Upon the supposition that the tegumentary organs are never sensory in function, we would have to conchde that the reactions which were obtained upon stimulating the dead shell had their seat in sensory elements in the vicinity of hair pores, and that the sensory hairs themselves are open at the tip, or at least have thin walls. I have usually found sensitive areas covered with setie, ${ }^{1}$ and while these do not normally open at the tip, the cuticle is so thin at this point that chemical stimuli might be readily conducted through them.

There is, however, one organ which is very sensitive to chemical stimuli, and which is entirely devoid of true setie in the adult animal. This is the labrum or upper lip. Its structure certainly favors the view that the peculiar tegumental organs which it contains in such abundance may be the seat of the sense of taste.

There can be no doubt that the labrum is very sensitive to various stimuli, as Lemoine clearly showed many years ago. In the specimens which I examined with particular care no setie of the ordinary kind were present on either the upper or lower sides, and the only direct chanuel for the passage of chemical stimuli from the surface of the dearl cuticle to sensitive structures below it were the ducts of the tegumental glands. After the labrum had been cleaned by boiling it in a strong solution of potas. sium hydrate, the cutieular structures were clearly demonstrated. The only setre present lie in four small rounded clusters of 12 to 15 each, near the base of the labrum and on its upper surface, where the cuticle has been reenforced by deposits of lime. These setze are microscopic, measuring only one-tenth millimeter in length. Moreover, each is traversed by a duct which apparently opens at the surface and without doubt belongs to a tegumental gland. The upper surface of the labrum is abundantly sprinkled in other places, especially abont the tip, with the minute pores of glands. These are sometimes in elusters, and their aggregate number is very great. When we examine the inner surface of the labrum we see it covered with sieve-like patches, each siere containing sometimes as many as 60 or 70 holes, the openings of tegumental glauds. At the auterior end these merge together so that the openings are exceedingly numerous. (Compare figure by Lemoine, 118.)

Lemoine evidently mistook the ducts in the sieve-like areas for hairs, and has figured them incorrectly. The ducts project from the inner surface of the cuticle, (compare fig. 170) and in no instance were true setæ or hairs present on any part of the adult labrum.

Experimental evidence seems thus to point to the possession of a subsidiary gustatory function on the part of tegumental organs of the labrum, and possibly of other appendages about the mouth. This would imply that the stimulating particles are conveyed to the lumen of the organ, and thence to the central rosette. It would of course be absurd to suppose that the apparently similar organs in many other parts of the body, as in the carapace, possessed a similar function. While such a conclusion is not perfectly satisfactory, it is at least worthy of consideration.

'The walls of the seminal receptacle contain very few glands, but are copiously supplied with clusters of set:e. As I have already shown, they are very sensitive to chemical stimuli. 


\section{Chapter VIII.-VARIATIONS IN COLOR.}

In the study of the color of animals we must distinguish between $(a)$ variations in colors themselves and $(b)$ variations in color patterus. The variation in colors, which Bateson calls "substantive variation," may be the result of a physical or chemical change and has no vital significance, like the change of yellow phosphorus to the red variety, of blue to red litmus, or of green to red pigments in autumn leaves and in the shell of the living lobster when the latter is boiled. "Different colors," says Bateson," "are liable to different discontinuous variations; as instances may be mentioned black and tan in dogs, olive brown or green and yellow in birds, red and blue in the eggs of many Copejoda," ete. "Discontinuous color variation of this kind is one of the commonest phenomena in nature." The dark green and golden yellow in the eggs of several species of Alpheus and many other macrura is a characteristic example (94). Such changes can have no protective or adaptive significance.

The color of the lobster ${ }^{2}$ is primarily due to the presence of pigments, either in solution in the blood or in the form of granules in the protoplasm of certain cells, particularly the chromatoblasts, which lie beneath the euticular epithelium. The chromatoblasts are richly supplied with blood, which flows in a system of irregular sinuses through the spongy tissues underlying the epidermis.

In the aduit lobster the shell is an opaque, dead substance, and the pigments which give it color are excreted by the chromatoblasts lying in the soft skin which is exposed upon removing the shell. This skin is flecked and mottled with scarlet, and it takes only a simple magnifying glass to see that its color is due to the branching pigment cells, accumulations of which correspond to the blotches of pigment on the shell. The excreted pigments undergo physical and probably chemical changes in the shell, and become of a very different color from that of the ehromatoblasts.

Since the colors of the adult lobster reside in a dead body-the pigment layer of the shell (see pp. 77-78) - it is evident that no changes of a vital nature can take place after this is definitively formed. A young male, 10 inches long, drawn and colored from life, is represented on plate 16, fig. 22. This may be taken to represent the average color in lobsters with moderately hard shells.

\section{NORMAL COLORATION.}

There is no apparent sexual variation in the color of the lobster. The following detailed description is drawn from a female 105 inches long, with elastic or "buckle" shell and with nearly ripe ovaries.

The general cast of color of the upper parts is dark bluish-green, mottled and speckled with very dark greenish-b lack spots; tail-fan light greenish-olive; sides of carapace brownish-olive, conspicuously spotted with small greenish-black spots; sides of abdomen marked in the same way, spots not as numerons; no spots on upper surface of uropods; large chelæe above dark bluish-green, almost black, with suffusions of orange on propodus; tubercles and spines bright red; spines of rostrum, antennæ,

Materials for the study of variation, treated with especial regard to discontinuity in the origin of species, by William Bateson. 1894.

${ }^{2}$ The color variations in the young are discussed on p. 184. 
pleura of third to sixth abdominal segments, and of appendages generally, vermilion; worn points of spines or worn surfaces of tubercles whitish; orange area of crushing chela (on propodus) mottled with dark green; walking legs bluish-green; bright sky. blue on basal joints, and tufts of setæ reddish.

Tendon marks: (1) A large porcelain-like whitish spot at junction of the cervical and branchio-cardiac grooves. Passing down the cervical groove are ( 2 ) numerous white or greenish white spots; (3) a large irregular yellowish-white spot occurs in a depression which lies about an inch behind the first antenna, and one-half inch from the dorsal surface, measured vertically; (4) a small white spot is seen about five-eighths inch behind the second antenua and five-sixteenths inch above the cervical groove. These spots are very characteristic, and are more prominent in the young than in the adults. They first become conspicuous in the fifth stage. (Compare plates 24, 25.)

The edge of the carapace is scalloped opposite the appendages, probably an adaptation for the movement of the legs: ${ }^{2}$ largest scallops opposite the large chelipeds; a wide seam-like border, disappearing behind, forms part of the lateral area of absorp. tion (see p. 8S); color of absorption area light blue; yellowish spots on either side of second to sixth terga of pleon, most marked on second, third, and fourth segments.

Lower surface of large chelae reddish orange; bright red at the tips; bluish-green at edges, and on hinder parts of the propodus, aud on the other joints; basal joints of smaller legs sky-blue varied with brownish-olive; wing-like pieces of seminal receptacle bright blue; swimmerets flesh color, edged with reddish; intersegmental membranes of abdomen nearly colorless; lower side of tail-fan brownish-olive; telson and uropods edged reddish-brown; fringes of silky hairs of the same color.

There is generally an under tint of olive on the body verging into a greenish-blue on the one hand or light reddish-brown on the other, the whole upper and lateral surfaces being spotted or mottled with dark greenish-blue or blue-black, the spots often confluent on the upper surface.

\section{VARIATIONS IN COLOR.}

The coloration is uniform in plan, but exceedingly variable in details, much more so than we see in the case of the intricate color patterns of many insects. The brilliancy and purity of the shell pigments depend largely upon the age of the shell or its condition with respect to the molting period. The pigments are usually most brilliant immediately after the molt, when the cuticle is thin and translucent, and dullest just before ecdysis begins, when the old shell encumbers the body.

The pigment cells themselves, which, as we have seen, reside in the skin or immediately below it, are subject to vital changes, but when the shell is once hardened the color of the animal is fixed. It is certain, however, that under the action of light, or from other causes, the shell pigments undergo molecular or chemical changes. Men who handle lobsters have frequently observed that when they are exposed in shallow cars to unusually intense light they become decidedly bluer in color. I recently witnessed a very interesting demonstration of this fact. The fishermen at Menemsha, at the western end of Vineyard Sound, saved all the egg-bearing lobsters which they caught in June, 1894, for the hatchery of the Fish Commission, placing them in a floating skiff, covered only with netting and thus exposed to the full glare of the sun. Toward the last of the hatching season, when operations in the hatchery had

${ }^{1}$ The development of the earapace shows that these notches have nothing to do with the primitive segmentation of the body. 
ceased, I made no visits to Menemsha from June 22 until July 16, when I found about a dozen lobsters in the car, where they had been imprisoned from two to three weeks. They were without exception of a brilliant blue color, and were very conspicuous when placed with other lobsters recently taken in the Sound. They were all old-shell females, most of which had hatched their eggs and were approaching their molting time. All the green pigment of the shell had become light cobalt-blue, which, interspersed with the usual Naples yellow tints, gave them a very striking appearance.

According to the observations of MacMunn (132), the coloring of the skin of the lobster (Astacus gammarus) and crayfish (Potamobius fluviatilis) is due to the presence of chromogens, which are converted on very slight provocation, as by dehydration, oxidation, or some molecular change, into a red lipochrome, resembling rhodophan. Everyone is familiar with the wonderful change of color which the adult lobster undergoes when boiled, ${ }^{1}$ and according to Mac Munn the beautiful blue pigment of the larval lobster is converted by alcohol into a true lipochrome.

Alcohol quickly converts the chromogens in the lobster's shell into lipochromes, and dissolves them at the same time. This is well seen in recently molted lobsters, where the colors are very brilliant. When placed in alcohol, the soft-shelled lobster is first reddened, and then in a short time completely bleached, while a lobster with a hard shell treated in the same way will retain some of its color for a long time, if not indefinitely. The same changes are seen when the dark-green eggs are treated with alcohol or boiling water.

The lipochromes are pigments of a very wide distribution in the living world, oceurring in green leaves, in yellow flowers and fruits, and it is said that the vertebrate retina, "egg-yolks of different species of animals, the yellow, green, or red pigmented integuments of various invertebrates and vertebrates from tishes to birds, owe their coloration, with few exceptions, to dissolved, granular, or diffusely distributed lipochromes." (132, p. 95.)

Lipochromogens are found in a natural state in the gastric glands, blood, soft skin (as the blue prismatic cyano-crystals, which are reddened by alcohol or by boiling), and in the exoskeleton of crustacea. MacMunn 'is of the opinion that they are "built up in the digestive gland and carried in the blood current to be deposited in other parts of the body." (132, p. 62.) If this is true, it would not be remarkable if the color of the animal were affected by the nature of its food, yet this does not seem to be often the case.

The following substantive variations have been met with: (1) Blue lobsters, in which the prevailing color is blue; (2) red lobsters, which are pure red or reddish-yellow; (3) cream-colored lobsters, characterized by the almost entire absence of color; (4) we should also add black lobsters, to include possible cases of melanism, where the colors are extremely dark. A specimen of this kind was reported to me at Beal Island, near West Jonesport, Maine, where a fisherman recently captured, in 3 fathoms of water among the eelgrass, a lobster about 6 or 7 inches long with moderately hard shell and almost jet-black. He supposed at first that it was covered with coal tar. It did not appear to be preparing to molt. Malard (133) speaks of meeting with cases of melanism in erabs, where in consequence of a lesion of the skin the crab becomes entirely black"charbonné," as the sailors describe it.

${ }^{1}$ In France the lobster, Astacus gammarus, is said to be called. the "red cardinal of the sea," and the Norwegian lobster, Nethrops norvegicus, I am informed by Dr. Lönnberg, is called by the fishermen in Sweden Kejsar hummer, or emperor lobster, on account of its color and spines. 
Changes in color pattern are more elusive. There is (1) the normal variety, in which the upper part of the body is mottled with green, blue, and cream color; (2) spotted or "calico" lobsters, the coloration of which is a bold pattern of green and light-yellowish or cream-colored spots; (3) pied or parti-colored varieties, in which the contrast of tints is abuormally pronounced. This may perbaps be better classed under substantive variation. The changes are dne apparently to vital or physiological causes, which have at least no adaptational significance.

We will presently cousider in more detail the variations which have just been enumerated, but must first speak of the egg's.

\section{COLOR OF THE EGGS.}

The eggs of the lobster furnish a good example of substantive variation. The body of the animal is opaque, so that it is affected but little by the color of the ovaries, aud not at all when seen from above, by that of the external eggs.

The freshly laid ovum is of a dark green (fig. 24, pl. 17), sometimes almost black, color, due to the presence of a dissolved lipochromogen. The golden-yellow varlation, which is often associated with dark green, as in the egg's of Alpheus heterochelis and A. saulcyi $(94$, p. 375), has never been observed, but occasionally the ova are of a light, almost pea-green color, or some tint between this and very dark green. Rarely the new eggs are light grayish green. I received a lobster from Woods Hole in December, with external eggs of a very light greenish straw-color. (See fig. 23, pl, 17.) These were in an early stage of development, and had been laid but a few weeks. It was the most striking color variation in the ova which I have yet seen. Such changes as these can not be interpreted as having any adaptational significance.

If the eggs are treated with hot water, alcohol, or other killing reagents the green lipochromogen is quickly converted into red lipochrome. When the water is heated gradually the red color appears slowly, and it is interesting to observe that if these red eggs are now plunged into cold water the green color is restored. This change may be somewhat analogons to the breaking np and reconstruction of the blue compound of starch and iodine upon the successive application of heat and cold, and to the variation in color which sometimes appears in the living animal at the time of the molt. Soon after the water has been bronght to the boiling point the red color becomes permaneut.

\section{BLUE LOBSTERS.}

Lobsters of a deep, almost uniform ultramarine color are sometimes met with and never fail to attract attention. ${ }^{\text {. }}$ The color, which is often of a rich indigo along the middle of the upper part of the body, shades off into a brighter and clearer tint on the sides and extremities. The upper surface of the large claws is blue and purple, faintly mottled with darker shades, while underneath is a delicate cream tint. The under parts of the body tend also to melt into a light eream color, and this is also true of the spines and tubercles of the shell and appendages, which are usually bright red.

A lobster of the foregoing description was caught off Hurricane Island by Thomas Garrett, in April, 1874. It was a female, had a hard shell, and weighed about '2 pounds. A very bright blue lobster was taken at Grand Manan, Maine, in August, 1893.

'DeKay (51) speaks of a variety of lobsters called Bluebacks, but his impressious that they are derived from one part of the coast, that they have thin shells, and that they are chiefly seeu im early May, were all erroneous. He also remarked that they were highly prized by epicures. 
I have never seen a blue lobster of perfectly uniform tint or without markings on the shell; yet lobsters which very nearly answer this description are occasionally taken, according to abundant testimony. Passing from this condition, there is a graded series of colors, from the decidedly blue to the distinctly blackish or bluish green.

There is a well-preserved skeleton of a blue lobster in the museum of the Peabody Academy of Science at Salem, Massachusetts. ${ }^{1}$ This specimen is a male, $11 \frac{7}{8}$ inches long, and has a hard shell. The carapace is deep indigo above, but lighter on the sides with rather faint spots of light blue. The "tail" is of a purplish cast, with fine spots or marbling of dark blue. The large claws are purplish above, with abundant darker blotches, while they are eream-colored below, with some fine blue spots. The other legs are eream-colored, washed or speckled with blue.

Mr. J. W. Savage received at Boston, in June, 1893, about a hundred exceptionally blue lobsters from Nova Scotia. They had "hard shells," and would average $1 \frac{3}{4}$ pounds each in weight. As he expressed it, "they were as blue as bluejays." In April of the same year Mr. A. P. Greenleaf, of Boothbay, Maine, received also from Nova Scotia, as he informed me, two thousand or more very blue lobsters. He says that the usual spots and other markiugs of the shell were not conspicuous, and that the colors were so bright that he was almost afraid to ship them to market. A female egg-bearing lobster from Nova Scotia, which I examined in September, was of a dull leaden blue color over the whole upper part of the body. The lateral edges of the carapace were sky-blue, the claws very dark, almost black, above, and dull red below. I bave already referred to the bluing of lobsters (p. 135), which is due to either a physical or chemical ('hange in the shell pigments and has no adaptational significance.

Blue crayfishes described by Lereboullet (119) were "of an azure or cobalt color more or less intense; the claws deeply colored; the legs paler, and the lower parts of the body of a pale red." He thought that the shell contained three kiuds of pigmentred, blue, and green, and that in the red and blue varieties one of these pigments was excessively developed.

\section{RED LOBSTERS.}

Occasionally red living lobsters are seen, which are very rarely as bright in color as those which have been boiled. Mr. F. W. Collins, of Rockland, Maine, had a lobster of this variety in September, 1890. It was taken in Dyers Bay, near Jonesport, Maine. It had a hard shell, and when in the floating ear with other lobsters was very conspicuous for its bright color.

Mr. S. M. Johnson informs me that lobsters of this interesting color variety are met with "more or less frequently." Speaking of one which was obtained in 1892, he says that "although taken by itself the color was somewhat paler than the ordinary boiled lobster, yet if put with others that had been boiled it would have been hard to distinguish the difference."

Through the kindness of Messrs. Johnson and Young I received on April 9, 1894, a remarkably perfect specimen of a red lobster, of which I have made a drawing colored as accurately as possible from life (plate 16, fig. 21). It was alive and active when it reached. Cleveland, had a fairly hard shell, was without external eggs, and measured 113 inches. Except in color, it was perfectly normal. It was caught in the vicinity of Mount Desert, Maine. The ovaries, which were immature, were of a light-

I had the privilege of examining this and other specimens in the nuseum through the courtesy of Mr. John Robinson, treasurer of the Peabody Academy of Science. 
green color. Messrs. Johnson and Young consider this variety very rare, since they have seen but one other in which the red color was so bright and uniform in life.

The color of this animal, as shown on plate 16, was very brilliant. There was not the slightest trate of any blue or green pigment about any part of it, except at some of the articulations, nor of any other color except a light-reddish russet or orange. The eyes, however, possessed the usual black pigment, and on this account were exceptionally prominent. The Hagella of the antenne, the tips of the walking legs, and posterıor margins of the tail-fan were brilliant ved. The color on the upper surface of the large claws was rather brighter red than on the lower. A good idea of the natural color of this lobster may be had by imagining the color of the whole animal to be of the orange-red tint which is uormally seen on the under side of the large claws.

The spines were not brighter red than the other parts, but were worn white at the tips, as is usually the case. The setæ over the various parts were of the usual reddish-brown color. The color of the carapace may be described as light orange-red, corered with a reticulate or very delicately lined pattern of darker red, and mottled with white. The light spot which is seen midway between the roots of the second pair of antenna and the cervical groove was very large, as were also the whitish tendon-marks of the cervical groove itself.

The sternal calcified portions of the animal were snow-white, washed faintly with orange-red. The seminal receptacle, which is usually bright blue, was pure white; the swimmerets very translucent and faintly tinged with red; under side of tail-fan a muiform pale reddish orange.

This seems to be a remarkable case of a discontinuous color variation, which is the result of a chemical change simlar, in all probability, to that which occurs after death, as when the animal is boiled.

Lereboullet (119) says that a red variety of the crayfish was found in certain streams in the Rhine valley. It was usually small, though sometimes of the average size. "They are all of a uniform brick-red color, without spots, and resemble cooked craytishes perfectly; the legs and lower parts of the body are always very pale."

\section{CREAM-COLORED LOBSTERS.}

A light cream-colored lobster, without any darker spots visible upon it, was captured at North Waldoboro, Maine, about 188:. It was between 10 and 11 inches long. I saw this specimen, but not until it had been preserved in alcohol.

Mr. J. W. Fisher, of Eastport, Maine, informed me that in the winter of 1893 a lobster was eaught at Deer Island, Maine, which was 11 inches long and of a light cream-color. It appeared very white in the water. There were no visible spots or markings upon it. A lobster of similar appearance was taken in Boston Harbor by Mr. J. W. Savage, in August, 1892. The under side of the claws was light red, which was not intensified upon boiling.

Perfect albino lobsters, without trace of natural pigment in the eyes, or parts of the exoskeleton, have never been captured. "Albinism," or the various stages of an approach toward this condition met with among crustacea, are, according to Malard (133), in all probability but particular cases of adaptive coloration. It seems to me far more likely that such eases are primarily non-adaptive. In the lobster there has been a degeneration, and in some cases a final loss of pigment. This may be the last of a series of changes which we see begun in the live red lobster. The latter is no more or less protectively colored than the former. 
A specimen of a gray lobster (Astacus gammarus) was described at a meeting of the Société Philomathique of Paris, on December 12, 1891, by M. Martiu. It was captured at St. Vaast-la-Hougue, in a trap with several perfectly normal lobsters. The dorsal part of the carapace of the abnormal specimen was of a dark yellowishgreen color, with greenish-black spots. The green color disappeared rapidly on either side of the dorsal median line, the yellow remaining, and passing into almost pure white on the sides. There was not the least trace of marbling and none of the pronounced blue color of the average lobster. The pleon was yellowish-green above, and yellow on the sides. Large irregular spots of a deep bluish-black color ornamented each segment, even in the dorsal parts, but without forming the usual marbled pattern.

Martin rejects the hypothesis that this deficiency of color may be due to the absence of light, supposing the lobster to have lived in a dark erevice in very deep water, and regards this variation as adaptive, a conclusion which seems to me gratuitous. He says, in a note, that M. Biétrix, of Concarneau, had a white lobster, kept in a poud, which recovered its blue color at the next molt. A young male of Alpheus saulcyi, which I once kept for several days in an aquarium, molted and lost completely the bright vermilion color of its claws. (94, p. 381.)

Casual or temporary decoloration occurs in many species of crustacea, as in Cancer pagarus, of which Malard (133) says that he has met with many cases of young individuals living under stones in old oyster parks in the island of Tatihou, while the permanent absence of pigment is characteristic of certain well-kuown burrowing crustacea which live in the sand, such as Hippa, Callianassa, and Gebia. It is doubtful if the entire absence of pigment in such a form as Callianassa can be regarded as adaptive; first, because the animal burrows, and is for the most part concealed; and secondly, because its whiteness makes it a more conspicuous object on the sand than it might otherwise be. This condition may, however, be the last term in a series of changes, some of which were distinctly adaptive.

\section{VARIATIONS IN COLOR PATTERNS.}

SPOTTED LOBSTERS.

The spotted lobsters_"calico," or "leopard lobsters," as they are variously called by fishermen-exhibit an interesting and striking coloration, which is somewhat rare. They appear to be occasionally captured, however, all along the coast. An experienced fisherman at Rockland, Maine, said that he usually took one or two of this variety in the course of the season.

There is a well-preserved spotted lobster in the museum of the Peabody Academy of Science, a female with hard shell, $11 \frac{1}{2}$ inches long. The whole upper part of the body is of a light-yellow color, with purplish blue pigments (in the dried shell) so arranged as to give a spotted or marbled appearance. The light-yellow spots on the carapace vary much in size and shape, the largest being half an inch in diameter and of a slightly irregular, rounded contour. The spots are confluent at the hinder end of the carapace, where they form a marked yellowish area. On the sides of the carapace the spots are small and tend to flow together. The "tail" is marbled above with irregular yellow spots, in excess of the darker color. The tail-fan is yellow, beautifully mottled with reddish-purple. The appendages are spotted in the same way, light yellow predominating. The large claws are dark purplish-red above, with obscure spots; but on the under side, they are of the usual bright reddish-orange color, spattered with purple. 
PARIT-COLORED VARIETIES,

Once in a while a lobster is caught which exhibits a remarkably abnormal coloration. A lobster which would weigh about 2 pounds was captured near Long Island, Portland Harbor, about the year 1886. One half of the body was light yellow, clearly defined up to the middle line of the back from the color of the other half, which was bright red. There were no spots on the shell. This specimen was exhibited in Boston, and afterwards sent to Professor Baird.

De Kay mentions a similar case (51). He says:

In June, 1840, I saw in the Fulton Market a lobster which was of two colors, distinctly separated by a medial line from the tip of the rostrum to the middle extremity of the plate of the tail. One side of the body and all the members were of a light sky-blue, and the other of the ustal olivaceous green.

Mr. S. M. Johnson informs me that it is not uncommon to get a lobster in which a part of the body is pale red while the rest is normal in color, and that a few years ago he had a specimen in which this difference in color was marked by the line running through the middle of the back, and that even one-half of each "feeler" was light and the other dark.

Buckland (28) mentions the case of a half "albino" lobster, which he received in May, 1868. He says:

One side of the barrel was blue and the other was white. The blue turned red on boiling, but the white did not. There appeared to be no pigment in the white part of the shell.

Boeck (20, p. 225) says that in 1868 he found a lobster near Haugesund, one half of which was of a greenish-black and the other of a light-orange color, there being a sharp and clearly defined line, which ran lengthwise and divided the shell into two parts of equal area. This closely resembles the odd variations which we have just noticed in the American species.

Lovett (128) has described a number of color variations in lobsters from the island of Jersey. One which is particularly mentioned-a female with eggs-was of a pale lavender color, with a mauve spot on the carapace and with bright blue claws. The usual mottled markings on the sides of the thorax were rather indistinct. He speaks also of having observed a full-grown female with eggs of a pale-reddish color, with bright antennæ.

Carrington and Lovett have described the great chromatic adaptability of the common green crab, Carcinus manas (35).

Boeck says that the European lobster, taken near the mouths of fiords in Norway, is lighter in color than is usual, while farther ont to sea it becomes much darker.

Malard thinks that these peculiar color variations are due to the loss of certain pigments, in consequence of iusufticient light, in the deep grottos or rocky crevices where the lobsters may have lived.

Protective coloration and chromatic adaptability to the immediate environment are common to a large number of the crustacea. It seems to be least observed in the highest representatives, the Brachyura. Accorling to Malard this chromatic adaptation is effected either (1) chemically, by the modification of pigment under the direct action of light, or (2) physiologically, by the action of pigment cells stimulated by light, indirectly through the eyes and central nervous system.

Pouchet has made some interesting observatious (see 1.33) on the variations of color in the common shrimp, Palæmon. It was found to be most variable when 3 to $4 \mathrm{~cm}$. in 
length. When captured by the fishermen they are usually of a rose or delicate lilac color, but lose these tints or become of a light-yellowish hue when kept in vases with white bottoms. In black vases they turn to a deep brown. These effects are produced by the reaction of two kinds of pigments, the cyanic pigments which are generally in a state of solution, and the pigments of the xanthic series (red, orange, and yellow), by the action of the chromatoblasts. Malard states that Jourdain has shown that if the eyes are removed and the animal is kept in darkness, a red color is always obtained.

Certainly, one of the most striking cases of protective coloring met with in the crustacea is that of the inhabitants of the floating islands of sargassum which are encountered in the Gulf Stream or along its borders. This alga is of a dirty yellowishbrown color, often flecked with white, when its floats are incrusted with the bleached skeletons of bryozoa. This appearance is emphasized by the numbers of goose bar. nacles which are attached to the fronds. A small crab which is an important colonist of these islands is brown, with a large snow-white spot on its back; and the shrimp, of which there are several species, are colored in a similar manner, the body being dappled with brown and white.

We must place in another category the gaily dressed shore crab of the West Indies, Gegarcinus ruricola, whose brilliant hues and bizarre coloration are clearly without protective significance. This beautiful crab burrows in the mangrove swamps at about the level of high water, and is very common throughout the Bahama Islands. After a drenching rain the green boughs of the mangrove suddenly blossom out with crabs. Some of them have crimson legs, a dark purple body, with a large yellow spot on each side of the carapace, while in others these colors are reversed. Others again are nearly black, or the carapace is orange or straw color, flecked or marbled with purple, in an endless series of patterns, so that no two are alike. It is possible that this is an example of warning coloration, such as is seen in many gaudy insects, serving to protect them from the assaults of birds and other enemies, or it may be a case of substantive variation, without any vital siguificance.

The colors of deep-sea animals which live in total obscurity can not be of any utility to the animal as a source of protection. The colors may be very brilliant-red, scarlet, orange, rose color, purple, violet, and blue being frequently reported-but they appear to be developed quite independently of the light. It has been shown by experiment with sensitive photographic plates that luminous rays do not penetrate ordinary sea water to a greater depth than 400 meters. In depths of 50 fathoms or more there might be an appreciable amount of light on clear days, but even then, when the water was loaded with sediment and the bottom composed of dark materials, it seems hardly probable that colors would have any protective value whatever.

The normal colors of the lobster, which are spread like a mantle over its whole upper surface, tend undoubtedly to screen its movements while crawling over a weedy or rocky bottom. The absence of all color or a more generous display of bright pigment would make it a more conspicuous object, especially upon sandy bottoms in shallow water, which it is usually careful to avoid in the daytime. The vivid red of the claws appears to be overlaid by a darker pigment in spots, particularly on the upper surface. The under side of the pleon, which rests upon the bottom when the tail is not folded, is very meagerly supplied with pigment, as is usually the case with marine animals which inhabit the bottom. 


\section{Chapter IX.-VARIATIONS IN STRUCTURE.}

Deformities in the adult stages of the higher crustacea center chiefly in the large claws, which are more subject to mutilation than any other parts, owing to their constant use as weapons. We will therefore consider first the variations in these appendages.

\section{NORMAL VARIATIONS IN THE LARGE CLAWS.}

Aristotle (4) says of the claws of the lobster: "In the Astaci alone it is a matter of chance which claw is the larger, and this is in either sex." The difference between the right and left claws is greatest in the small fiddler-crabs where, as in Gelasimus, the large claw, according to Bate, can not reach the mouth, a power which it must have originally possessed.

It seems, as Aristotle remarked, a matter of chance whether the erushing-claw is on the right or left side of the body; but this is not really the case. I have shown that in Alpheus saulcyi, where the large crushing-chela can be recognized even before the animal is hatched, the members of a brood are either right-handed or left-handed, that is, have the crushing-claw on the same side of the body. This seems to be a case of direct inheritance from the pareuts, though not enough data were collected to settle this point. (For a statement of the facts, so far as they are known, see 94, p. 376.)

The large elaw occurs about as frequently upon the right side of the body as upon the left, without distinction of sex, as shown by the following table, embracing 2,433 individuals:

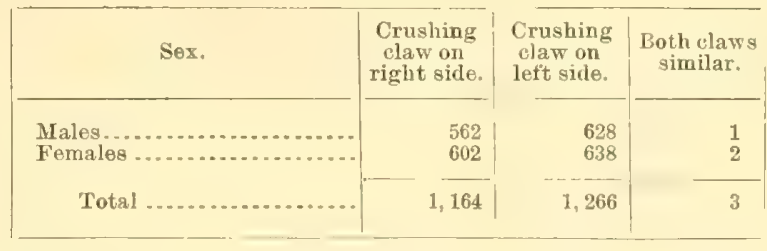

ABNORMAL VARIATIONS IN THE CLAWS.

STMILAR CLAWS DEVELOPED ON BOTH SIDES OF THE BODY.

A variation sometimes occurs in which the normal differentiation of the great claws is wanting. Both claws are similar, developed either for cutting or crushing. In examining over 2,400 lobsters, only 3 were found in which this abnormal variation was present. It is, therefore, undoubtedly rare, and apparently has never been previously described. Before examining these cases in detail it will be best to uotice the normal characteristies of the claws. This description is taken from a femalelength, 11 inches; weight, 24 ounces-with hard shell (compare fig. 20a, plate 15):

Crushing-claw: On right side; seven marginal spines on propodus, third spine (from peripheral end) depressed; a small spine opposite the latter on upper side of propodus. There is a small tubercle on the upper side of propodus, near articulation of dactyl; in a corresponding situation below there are two tubercles, one considerably

' I have heard of a single case reported by a fisherman, where similar crushing-claws were developed on both sides of the body. 
smaller than the other; a small tubercle on upper side of propodus, on outer margin, near carpus. There is considerable variation in the number and prominence of these processes, particularly the marginal ones.

Cutting-claw: Six marginal spines on propodus, second and fifth depressed; other processes present, as in corresponding claw.

ABnorial Variation.-(1) Female; length, 101 inches; hard shell; cuttingclaws on both sides similar; Woods Hole, Massachusetts, March, 1894.

Right cutting-claw: Small tubercles of propodus, near aactyl, wanting.

Left cutting-claw: Transverse scar-like groove on propodus, at level of articulation of dactyl; one small tubercle on upper surface of propodus, near dactyl; two very minute ones below; five marginal spines, third bent inward, rest turned forward and upward.

(2) Female; length, 101 inches; hard shell.

Right cutting-claw: Five marginal inner spines on propodus, third depressed; no small tubercles near joint of dactyl present.

Left cutting claw: A little smaller than right; 5 marginal spines, none depressed; one small tubercle on lower side of propodus near dactyl.

(3) Male; length, 10 inches; hard shell; both claws relatively small, haviug been regenerated; length of propodus, $3 \frac{3}{8}$ inches. (Plate 14, fig. 19, from photograph.)

Right cutting-clau: Seven marginal spines, second and fourth depressed; one small tubercle on under side of propodus, near dactyl.

Left cutting-claw: Five marginal spines, second depressed; one very small tubercle on upper side of propodus near dactyl; two very minute ones below.

There seems to be about as much variation as regards the details here mentioned in normal symmetrical claws as in the abnormal symmetrical ones, and it is probable that in either case the conditions met with are to some extent congenital.

\section{DIVISION AND REPETITION OF APPENDAGES.}

The curions moustrosities which occur in the appendages, particularly in the large claws of the lobster, have attracter the attention of naturalists for a long time. They were noticed by Von Berniz (17) over two hundred years ago, and some good figures of the deformed claws of the crayfish were published by Rösel in 1755 (168). A careful review of crustacean deformities, concerning the lobster in particular, was given by Faxon in 1881. His paper was accompanied by valuable figures and a bibliography (66). The general subject of variation as it affects the appendages of arthropods has been recently treated in a masterly manner by Bateson in his invaluable work on variation. ${ }^{1}$ The variations which concern the crustacea, particularly the decapods, are fully described and illustrated, with references to the abundant literature. Bateson shows that in most of the cases of supposed duplication of limbs in both insects and crustacea the extra parts are double instead of single, as where two dactyls are formed at the extremity of the claw instead of a complete claw consisting of dactyl and propodus. He has also formulated certain principles according to which supernumerary appendages make their appearance in secondary symmetry. If the normal appendage which bears the extra ones is a right leg, "the ne rer of the extra legs is a left and the remoter a right."

\footnotetext{
' Materials for the study of varıation treated with especial regard to discontinuity in the origin of species, by William Bateson, 1894.
} 
The moustrosicies noticed in the chelipeds of the lobster are mainly the result of a secoudary outgrow th from one of the two terminal joints. Rarely the appendage is duplicated or triplicated; a case of the craytish is reported with three extra claws (see bateson, p. 537). In some cases the extra appentages are porfoctly formed, while in others deformation has been carried to excess, resulting in irregular branching processes or grotesque contortions. Injuries to the claws are excessively common, while duplication of parts is rare. Defective or deformed claws, the result of injuries (see figs. 194, 198) in different stages of repair, are met with every day by dealers, while thousands of lobsters may be examined without meeting a single case of repetition or duplication of parts. ${ }^{1}$

If the tips of the claws are snipped off near the articulation of the dactyl, the lost parts are restored (see p. 105) as we have seen at the next molt. This restoration is often perfect, but not always so. The condition seen in fig. 198 might have been caused by a piuch and arrest of growth while the claw was soft (before the last molt), or by the unequal growth from a stump, the end of the propodus haviug been cut off by an enemy just before the shell was cast. In the latter case the member could be only partially restored, and unequal growth would account for the distortion.

The dactyl shown in fig. 194 has probably had a similar history. All such cases are the results of regeneration after injury. This can not be said of such a specimen as that represented by tig. 189, where the dactyl bears upon its inner margiu near the tip a small conical prominence. This is smooth and is separated from the tip of the dactyl by a shallow groove, as if there had been a normal bifureation or division at this point. What the primary cause of such a growth or swellng may be is not known, but it is impossible to suppose it to be the result of injury.

With the appearance of such a simple outgrowth a progressive series of changes seems to take plave with every molt, such as is illustrated by tigs. 189-193, plate 47. With the growth of the animal, the superadded part, whether it be upon dactyl or propodus, seems to be shifted at each molt farther aud farther back upon the claw, aud meantime, in most cases, to undergo fission in a vertical (figs. 190, 191) or somewhat oblique plane (figs. 187, 185). This fission apluarently proceeds until one or both of the supernumer:ury dactyls are entirely separated (figs. 19:, 193). The oplyosing edges of these become gradually toothed, so that each is almost an exact copy of the original (see especially fig. 193, plate 47). According to the principles land down by Bateson, the part which is nearer the original joint corresponds with the appendages on the opposite side-that which is farthest away with those on the same side of the body. This is not strictly true in such a case as that show 1 in fig. 196, where the supernumerary parts do not face each other, and in some cases the repeated part is single, wot double. In fig. 190 a short row of teeth marks the median plane of division aud the opposing surfaces of the incipient finger's are also toothed. In fig. 191 the outgrowth is divided nearly to its base into two secondary processes, each of which resembles the joint of

In 2,657 lobsters captured at Woods Hole, Massachnsetts, from lecember to .June, 1893-94, but one case of repetition or formation of extra parts in the large claw occurred. No account was kept of injuries, but in the months of December and January 7 per cent of all lobsters caught (54 in a total of 725 ) had thrown off one or both claws. (See p. 103.)

A man who had been engaged in the business of canning lobsters for a score of years in Maine told me that he had at one time nearly a bushel of deformed claws, which he had collected in the course of his experience.

$$
\text { F. C. B. } 1895-10
$$


which it is a part. According to my interpretation, such a case as that shown in fig. 193 has gone through phases similar to those shown in figs. 189-191.

In figs. 192 and 197 the conditions are somewhat different, since the superadded dactyl is single. I think there can be no doubt that a progressive division of the propodus takes place in such cases. In fig. 192 the plane of fission in the propodus is marked by spines very much as in fig. 190. There may be a line of median, unpaired spines at the bottom of the groove, and bilaterally symmetrical spines upon its sides. It seems probable that the conditions like those seen in fig. 197 could be derived from such as are met in fig. 192 by the intervention of a single molt.

Faxon describes a very interesting case $(66$, plate 2, fig. 6) in which there appears to be a duplication of the right cheliped down to the meros. The latter is partially divided by a deep groove runniug across its distal end. It seems to me very probable that we have here an illustration of the same process which is seen in figs. 192, 197, only carried a step or two farther. In the former case the fourth joint of the limb is undergoing a process of fission begun nearer the outer extremity, while in the latter the sixth segment is involved. The supernumerary carpus in the case figured by Faxon bears a stump-like segment, which looks like an abortive propodus, corresponding probably to the abortive segment borne on the extremity of the supernumerary branch of the propodus in fig. 197. In the latter case it is an undoubted dactyl, and is smaller and more rudimentary than in fig. 192, where the fission of the propodus has not gone so far. It is thus probable that with the extension of this process, emphasized at each molt, the terminal segments may in some cases, as in those before us, atrophy and disappear, until we have, as in the example cited by Faxon, only an abortive propodus left. Bateson regards this superadded member as double, formed of two compounded parts. This may be so, but the same kind of reasoning would lead us to regard such an incipient member as that seen in fig. 197 as double, consisting potentially of two dactyls and two propodi. The only apparent reason for doing so lies in the supposition that such a superadded part arose as a tubercle or budding growth on some part of the claw, probably in this case on the dactyl, and was potentially a double member from the start, or at least capable of doubling by a process of fission, as we see actually going on in fig. 190. Whatever changes may have taken place precedent to the condition seen in fig. 197, there is no evidence of fission in the extra dactyl unless the two spines $\left(S, S^{1}\right)$ be taken as such.

There seems to be a considerable gap between the condition seen in fig. 193, where three dactyls are present, one of which is free, and that shown in fig. 192, where there is a single process. The latter is bent downward and toward the primary dactyl. Its inner border has a spine $(S)$ like that borne on the normal dactyl, showing this part to belong to the left side. It bears also another spine near its articulation with the propodus $\left(S^{1}\right)$, which might indicate that this toothless appendage was really a double member. (See fig. $197, S, S^{1}$.)

Another good example of repetition of the propodus, with division of the bud, is shown in figs. 187, 188, plate 46, which are from photographs. In this case the bud has grown out obliquely from the under side of the propodus instead of from the margin, as in fig. 190. The continuity of the outer margin is interrupted by a deep groove which divides the bud into perfectly similar parts. In this case the teeth on the inner margins of the supernumerary digits are not opposed. The outer or lowermost, which is usually symmetrical with the normal part, makes here an angle of about $42^{\circ}$ with the normal digit, and the two supernumerary digits make an angle of $12^{\circ}$ with 



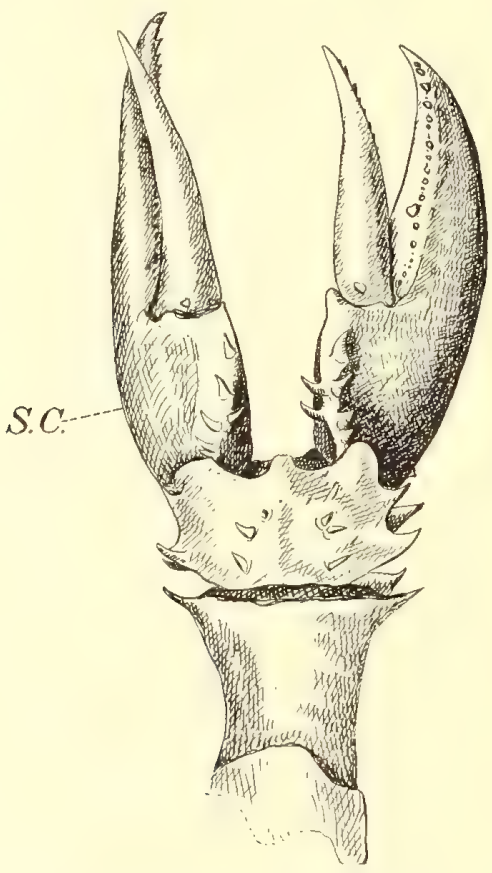

CUT 16.-Double right cutting-claw of female lobster, $11 \frac{1}{2}$ inches long, now in the American Museum of Natural History, New York City. Seen from the anterior side. One-half natural size

S. $O$, supernumerary claw.

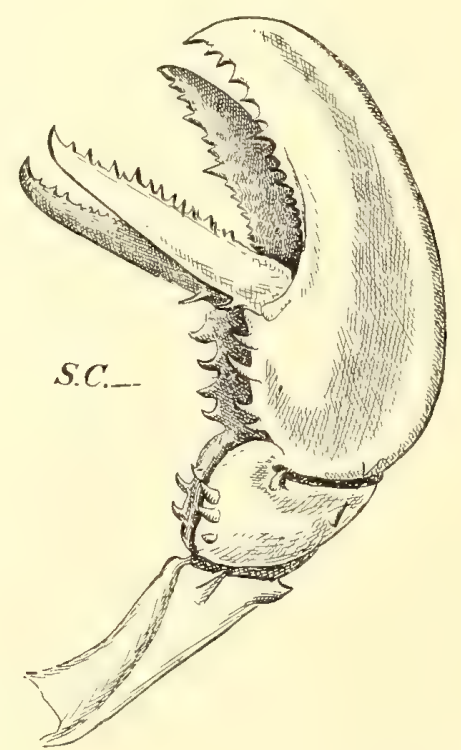

CuT 17.-Donble right cutting-claw of the same lobster, seen from above. One-half natural size.

S. $C$, supermumerary claw. 
each other. The pollux is depressed, so that when the claw is closed it falls almost exactly midway between the nolmal and first superadded digit. The fission is marked on the upper surfice by a distinct groove. The total length of the propodus is about $2 \frac{1}{2}$ inches (13 mm.), so that the lobster was not in all probability over 6 inches long. The size of this elaw as compared with the basal joints of the limb suggests that it has been lately regenerated, and it is unfortunate that this interestiug point can not be determined with certainty.

In fig. 196 a similar monstrosity is seen in the dactyl of the eutting-claw. Here the bifurcating brauch is near the apex. Wach pong is furnished with teeth on the inner side. A trimerous dactyl (fig. 195), one division of which is independent, in the second or third pereioporl presents precisely the same relations which occur in the first pereiopod (fig. 193), and probably they have been produced in the same way.

What is now most needed in clearing up questious in the interpretation of deformities in erustacean appendages is to watch the molting of the animals and to measure and record the change which occurs in the malformed individual at each stage of growth. The abnormal developments seen in figs. 18!-193 probably represent a series of changes such as ordinarily occur in the same individual. What the course of events really is between the conditions represented by figs. 193, 192 is not so clear.

While the true duplication, or even triplication, of limbs or parts of limbs is rare in crustacea, it is occasionally met with; but it is an important fact, which Bateson has emphasized, that "in arthropods and vertebrates such a phenomenon as the representation of one of the appendages by two identical appendages standing in succession is unknown. No right arm is ever succeeded ou the same side of the body by another arm properly formed as a right, and no crustacean has two right legs in succession where one should be."

In the American Museum of Natural History, in New York, there is a specimen of a lobster in which the right cutting-claw is perfectly duplicated from the carpus or fifth joint. I was recently enabled to examine this interesting specimen and to make some drawings of it, which are given in cuts 16,17 , plate $\mathrm{E}$.

The two cutting-claws resemble each other very closely in every detail and are of almost exactly the same size, but each is relatively smaller than normal. The measurements of each cutting-claw are as follows:

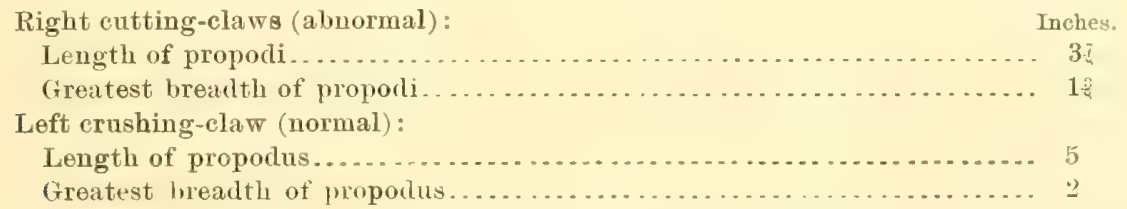

In the primary cutting-claw the dactyi closes normally on the propodus; in the superadded claw ( $S . C_{0}$ ) it is bent upward out of line with the cutting edge of the latter. The symmetry of the two claws extends, with few exceptions, to the spines mpon their cuttiug edges and on the inner margins of the propodi. The carpus of the limb is apparently single, but it has duplicated spines, and a deep groove at its peripheral end shows that it is virtually double. The carpus and meros have beevi twisted through an angle of 900 , so that their posterior surfaces face upward.

This specimen was obtained some years ago from a marketman in New York ('ity. 
Nothing is definitely known about the causes of repetition. It looks at first sight as if the deformities in the appendages of the lobster and other arthropods could be explained as phenomena of regeneration, though in this case there is addition rather than replacement.

We have seen that where the cheliped is thrown off by reflex museular contraction the bud of a new leg forth with appears, and under favorable conditions grows into a perfect limb. The tissues of this limb are developed out of the formed histological elements of the stump. The process of regeneration is begun in this case as a direct result of a loss or injury. The plane of fracture lies between the second and third joints, and all parts peripheral to the second joint are reproduced. Repetition of parts, however, occurs in many insects and vertebrates where no such regeneration of lost appendages is known. However, the power of regeneration, which is present in all organisms, differs rather in degree than in kind, and Weismann has shown that it has probably been developed in many cases as a means of defense and protection to the individual. (See p. 107.)

In the specimen of Palinurus (No. 808, Bateson, originally deseribed by Léger in 1886), where the left penultimate leg bears two supernumerary legs, both of which spring from the basipodite, it certainly looks as if what would have taken place in the case of loss of the original limb-namely, the growth of a new oue from this joint -had happened repeatedly, so that instead of the regeneration of one limb at a time there is the superaddition of two; but where the limb is not cast off the first superadded one is in secondary symmetry and belongs to the opposite side. If such an interpretation will apply to this case, the various other repetitions and abnormal grow ths which arise in more peripheral joints, as upon the sixth and seventh, fall into the same geveral eategory. In the case of the growth of a new limb in consequence of loss, however, all parts which are external to the plane of fracture are reproduced. In the cases of repetition this is not usually the case, as Bateson has shown. The bud which arises on the propodus (as in figs. 187, 190) may by fission give rise to a second propodus, but not usually, if ever, to a dactyl.

It seems as impossible to suppose that such a deformity as that seen in fig. 187 or fig. 189 is congenital as that it is the result of injury. The monstrosities which occur in the embryo, which are considered in another place, are, however, in some cases at least, the result of injury or unfavorable conditions.

Autotomy, or the casting of the claw at the second joint, is probably directly accountable for the rarity of abnormal growths in the limbs of the higher crustacea. It is extremely improbable that any deformity at the extremity of a limb could survive autotomy, but the experiments to settle this iuteresting point have yet to be made. While it would appear that the various deformities which have been described can not be explained as the results of injuries and the attempted regeneration of injured parts, since the limb is usually thrown off in such cases to be completely renewed or it is retained to be completely restored, yet I can not escape the conviction that the problem is in some way directly concerned with that of regeneration. The mechanism by which so complete a structure as a limb is regenerated can not be regarded as simple. As Weismann says, the machinery of a cotton factory can not be made out of a few simple levers. It is probably exceedingly complex, and it is no wonder that the parts do not always work harmoniously, that the thread is sometimes knotted or the product useless. 


\section{VARIATIONS IN OTHER ORGANS.}

\section{ROSTRUM.}

I have met with a single case of bifureated rostrum, a small male, representert in figs. 162, 163. The median groove, which corresponds to an area of absorption in the shell (see p. 88), divides near the apex, each branch going to a terminal spine. Instead of a single spine below the terminal, there are several smaller ones.

In Alphens sancyi the median rostral spine is sometimes wantiug, as in the genus Betæus, of Dana. (See 94, p. 384, plate XxII, fig. 11.)

\section{OVARY。}

Two instances were observed in which the ovarian lobe on one side has suffered division, one that of a small female $(44 \mathrm{~mm}$. long, fig. 131, plate 38 ) in which one of the posterior lobes is involved, the other an adult lobster (fig. 164, plate 42) with similar division of the left anterior lobe.

\section{HERMAPHRODITISM.}

A malformed hermaphrodite lobster, Homarus gammarus, was described and figured by Nicholls in the Philosophical Transactions of the Royal Society of London in 1730 (141). "The specimen," he says, "if split from head to tail, is female on the right side and male on the left side." This was true of both the internal and external organs. A similar case of hermaphroditism has been described by Gissler (rs) in the Phyllopod Eubranchipus vernalis.

La Valette St. George (193) discusses a very interesting case of hermaphroditism which he discovered in the craytish. He found eggs present in the nearly ripe testis of Astacus fluviatilis in July and August. The eggs were placed usually at the periphery of the testis lobe. They were round or oval, $0.06 \mathrm{~mm}$. to $0.015 \mathrm{~mm}$. in diam. eter, and showed the usual constituents of ovarian eggs. They had a larger germinal vesicle than the normal egg, were sometimes inclosed in a follicle, and contained yolk spheres. He asks how the presence of the eggs in the normal testicle is to be explained and gives the following answer:

These eggs are evidently derived from spermatogonia, which have become unfaithful to their original functions. Instead of multiplying by division to form a number of spermatocytes, they have chosen a shorter way, which makes it possible for a single egg to arise from them by simple growth.

Under certain conditions a primitive sperm cell may be converted into an egg cell, and this, he says, furnishes a new proof of the relation of spermatogonia and oogonia. Follicle cells may arise from a spermatogonium, but the latter can never arise from follicle cells.

The spermatogonia, according to La Valette St. George, prodnce, chiefly by mitosis, the spermatocytes, which eventually give rise to the spermatids. Spermatosomes, as well as large follicular nuclei. may be found in the process of degeneration in the testis.

Hermaphroditism has also been described in the lobster by Hermann (89), who, according to La Valette St. George, was the first to prove the presence of hermaphro ditism in the testes of decapods. Hermann discovered in the anterior parts of the testis of the lobster large round or oval cells with granular protoplasm, each pos. sessing a large germinal vesicle with nucleoli. Eight or ten such cells, which were regarded as undoubted eggs, were found in one specimen. In some of the figures given by La Valette St. George the ovum fills nearly the entire lumen of the testis. 


\title{
Chapter X.STRUCTURE AND DEVELOPMENT OF THE REPRODUCTIVE ORGANS.
}

\author{
THE FEMALE REPRODUCTIVE ORGANS.
}

THE OVARY.

In order to understand the structure of the ovary and the changes it undergoes it is necessary to examine this organ at different stages of development and in the various phases of the sexual life of the animal. The external eggs borue on the swimmerets of the female serve as a gauge to determine the age of the developing ovarian ova.

I have already given an account of this organ in my paper on Alpheus (94, see also 90 and 93) and have illustrated the growth of the eggs. Bumpus (30) has also devoted considerable attention to this subject aud has figured certain structural phases of the ovary, but the early development of this organ has not been touched upon and there are important anatomical facts which have not yet been noticed or illustrated. I shall therefore deal with this subject in detail, though in doing so it will be necessary to repeat some facts which are already known.

The time of the year when the ovary becomes mature and the size which the spawning female attains are discussed in other parts of this work.

\section{THE RIPE OVARY.}

The ripe ovary, which I will first describe (plate 36, fig. 123), occupies, as we have seen, the dorsal part of the body cavity. The anterior lobes encirele the stomach, while the hinder ones extend sometmes as far backward as the fifth abdominal somite. The ovarian wall, though often quite thick, is very transparent, and the ripe eggs give it a dark green, beaded appearance. The walls, if mutilated, immediately collapse and the perfectly ripe eggs flow out in a stream.

The structure of a nearly mature ovary is seen in fig. 141, plate 39. Most conspicuous are the massive ova filling the lumen of the thick, tubular wall. Immediately next to the latter are seen very characteristic structures which I shall call ovarian glands $\left(O . G_{0}\right)$. Immature ova of varying size are interspersed among the glands and dip down between the ripe peripheral eggs. These structures, together with irregular blood sinuses $(B l$. S. $)$ and strands or nodules of muscle and connective tissue, make up the substance of this organ.

The glands are folds of follicular epithelium similar in origin to that which encapsules the larger ova. The long axis of the fold is parallel with the ovarian wall. The glandular fold consists of a structureless basement membrane and of columnar epithelial cells (fig. 152, plate 41). The nuclei generally lie at the deeper ends of the cells, the protoplasm of which is decidedly granular, and cell walls are very indistinct after the ordinary methods of treatment. Occasionally a glandular fold is seen (plate 41, fig. 153) which has a very different character from the structure just described. It is expanded into an oval or oblong form, and its epithelial wall appears in a much disordered state. It is highly vesicular, containing numerous vacuoles, which probably represent fat globules $(F . G$.$) ; cell walls are absolutely effaced; nuclei,$ 150 
no longer spheroidal, have become shrunken and scattered about the meshes of a protoplasmic network. There are, besides, globules (fig. 15i, y. s.), probably of an albuminous nature, which resemble spherules of yolk, and lie either in the lumen of the fold or are embedded in the protoplasmic reticulum. They are most abundant in the reticulum, where they sometimes occur as large granular masses. In fig. 14., plate 40, a single large spherule $(y . s$.$) of this kind is seen interpolated between$ the follicular cells. A number of nuclei surround it and, however anomalous its position, the appearance is not artificial. In other cases, where no degenerative processes are at work, the lumina of these folds are filled with a fine granular residue. The intimate relations which these structures bear on the one hand to the vascular sinuses, and on the other to the growing ova, point to their probable function, that of the formation of yolk. If this is the case, it is evident that the ovarian glands can play but a minor role in this process. The massive yolk of the ripe egg is formed for the most part in the protoplasmic reticulum of the egg cell from materials which are drawn directly from the blood. A third source of the yolk is the follicular cells themselves, large masses of which pass into the egg at this stage, where they undergo complete degeneration, as I have pointed out in another paper (9:3,9.1), and shall describe more fully presently.

\section{THE OVARY AFTER OVULATION.}

The appearance of the ovary shortly after egg-laying is represented in plate 38, fig. 136. It has collapsed from its distended condition, and is now of a yellowish-white color, Hecked with green and orange spots. The green bodies are ripe ova which failed to be forced out at the time of the last laying. The ducts are often full of them (compare fig. 119). The orauge specks are the remains of similar eggs left over from the previous ovulation. While the latter have thus been in the ovary for at least two years, they are not yet completely absorbed. The primary membrane of the egg still remains, inclosing a small disorganized residue (fig. 150).

The structure of an ovary at this period is shown in fig. 139, plate 39. The external eggs were in an early stage of yolk segmentation, showing that not more than thirtysix hours had elapsed since the last egg-laying. The ovarian lobe is now a solid mass of tissue, the youngest ova being disposed abont the axis, the older at the periphery. Irregular blood sinuses penetrate to every part, between folds of follicular epithelium. These folds take the form of irregular pouches and represent, as Bumpus has shown (30), invaginations of the ovarian epithelium. This is better seen in Paliuurus, or in the ovary of the adolescent lobster.

The ovarian glands have now attained their greatest prominence, and their relation to the growing eggs is well illustrated in fig. 139, plate 39, and figs. 151, 152, plate 41. In fig. 151, from a horizontal section, the eggs lie in strings, or rather tiers, between the double walls of the epithelial folds, which dip down vertically from the surface of the ovary. This is from a later stage than fig. 15\%, which represents a section through the central or terminal boundary of the fold. It is from the same ovary as fig. 139, where the glands are in the ascendant. The glandular cells have the form of tall columns, the nuclei lying at their deeper ends. Cell boundaries are very vagne, the central ends of the cells merging into what appears as a granular reticulum. The columnar cells, though apparently stopping short at the sides of the egg, are directly contiunous with the less conspicuous cells of the true follicle. This glandular corcum resembles, in section, a narrow bag with an egg pushed into its month. A thin layer 
of follicular cells, however, screens this particular egg (fig. 152) from the lumen of the glandular fold. In some cases, however, I have seen the glandular cells in direct relation with the yolk, with amoboid cells passing into the egg along the line of contact (plate 40, fig. 149). At this point cells are sometimes seen completely engulfed in the food yolk. Their nuclei swell to a somewhat larger size, and then speedily degenerate. Faint ghost-like outlines can be detected for some time; then the chromatin becomes concentrated about the walls of a gradually dwindling vesicle (plate 39, fig. 142, Dg.). Finally the chromatin is reduced to very small stainable fragments. In other cases the chromatin probably breaks up more immediately into a swarm of minute particles, which remain in the interstices of the yolk spheres in the peripheral parts of the egg. The "plasmic vesicles" or vacuoles, which Bumpus (30) has described, are products of the cell degeneration just considered.

Eggs which have been well started on the road of normal grow th suddenly go into a decline and are probably finally absorbed into the blood, somewhat as the follicle cells are couverted into nutriment within the eggs. (See pp. 211-213.) A number of such degenerating ova are seen to the right of fig. 150, plate 41 . They are filled with refractive globules, which are undoubtedly of an albuminous nature.

After the lapse of from ten to fifteen days after ovulation (the external eggs being then in the egg-nauplius stage), the ovarian glands have almost wholly disappeared. The walls of the follicuiar folds, now crowded to the extreme periphery beneath the ovarian wall, are shrunken and crumpled. At a still later period (attached eggs with eye pigment, from four to five weeks old) the glands are reduced to shriveled remnants. Later still, no vestige of them is seen.

STRUCTURE OF THE OVARY AT TIME OF HATCHING OF EXTERNAL EGGS.

When the external eggs are ready to hatch, the ovarian ova have had nearly a year's growth. The appearance of the ovary at this time is shown in fig. 138, plate 38, and its structure in fig. 147, plate 40. It has a characteristic pea-green color, and the largest peripheral ova (fig. 133, plate 38 ) have a diameter which is equal to only onetenth that of the mature eggs. The ovarian wall is thinner than in previous stages, and in the axial portions there are the usual germogenal folds.

Fig. 137 (plate 38) represents the ovary of a lobster taken August 21. An exami nation of the external eggs shows that they are about six weeks old. The ovary was light green, sparingly flecked with yellow. The individual eggs are greenest at the center, which gives the organ a finely dotted appearance. There is no trace of glands.

The ovaries of "paper-shells" taken in July, after having produced a brood and molted during the current season, contain ova which measure fully half the diameter of the mature egg. This shows that after ovulation and again after the hatching of the young-that is, during the first, second, and twelfth, thirteenth, and fourteenth months after egg-extrusion-the ovarian eggs experience their most rapid growth. (See p. 71, and in particular the description of fig. 138, p. 246.)

At a still later period, when the ovarian eggs have been growing for the space of nearly two years, ' and the ova have attained a diameter which is from 80 to 90 per cent that of the ripe egg, the organ has the structure seen in fig. 140, plate 39 . There may be considerable variation, but in the specimen from which this drawing was made (female, taken July 30 ) the ovarian wall is excessively thin and the lumeu is packed full

'This is an estimate based upon the general facts of growth and development of the ovary, and not upon the observation of single individuals during this length of time. 
of eges of fairly uniform size. The stroma of germogenal tissue is redncer to a minimum, and there is no trace of the ovarian glands which subsequently appear (fig. 141).

The anatomy of the ovary and the slow growth of the ovarian egg, which we have followed from the time the new egg's were laik during a period of two years, when the next batch are ready for extrusion, proves conclusively, as I have pointed out in earlier papers (93 and 97), that the breeding season of the lobster is not an anuual one, as had been supposed. (See pp. 70-73.)

We have seen in the foregoing account that the massive yolk of the eggs is produced in three ways: (1) It is manufactured in the protoplasm of the growing ovum from materials absorbed from the blood-the most fruitful sonrce; (2) it is produced by the activity of the ovarian glands; $(3)$ by the direct alssorption of follicular cells.

The fact that parts of the follicular epithelinm becone differentiated into glands at a definite period, and that these later become totally obliterated is certainly remarkable, but I do not see how the phenomena which have been described can receive any other interpretation. The yolk in Peripatus nova-zealandix is described by Lilian Shelflon (180) as arising in part from follicle cells. The latter pass into the egg through the tubular stalk by which this is attached to the ovary, and become converted into yolk. Yolk is said to originate also in the protoplasm of the ovum, as is commonly observed in Arthropods; also from the breaking up of a part of the germinal vesicle, and finally it is produced by certain parts of the ovarian tube itself. The condition ustally found in Platyhelminthes, where there is a permanent yolk-secreting gland, may thus be compared with that of Peripatus and the lobster, where this function is in some measure performed by parts of the follicular epithelium.

\section{THE ORIGIN OF THE OVA.}

The ova arise from nuclei of the germiual epithelium, as I have described in detail in a former work (94). The origin of the primary egg membraue from the follicular cells (tig. 148, plate 40 ) is well known, but it should be remembered that this chitin-like envelope is not completed until after the decay of the ovarian glands. Thus, in the eggs show in tig. 142, plate 39 , and fig. 149 , plate 40 , there is no membranous boundary between the yolk and glandular cells.

Cases of the apparent fusion of young ova, mentioned by Bumpus (30), are oceasionally met with, but it seems to me probable that no real fusion ever oceurs-the impiugement of cell upon cell often seeming, however, to support this idea.

\section{THE METAMORPHOSIS OF THE GERMINAL VESICLE.}

The very young ovum has a large, rapidly growing germinal vesicle or nuclens, as shown in fig. 154. At this stage the cell protoplasm forms a thin peripheral zone having a fine granular appearance in stained sections.

The metamorphosis of the germinal vesicle from this early stage to the perfectly ripe condition is illustrated by figs. 155 to 161 , all of which are drawn to the same scrale. The nucleolus is formed at a very early period (fig. 1.n) and is soon vesiculated (fig. 155). Rarely two or more uucleoli are present (fig. 156); there is usually but one.

The nucleus reaches its largest size (about $\frac{1}{11} \mathrm{~mm}$. in diameter) at the close of the first year after ovulation. It is now regularly oval, its long axes being parallel with the long diameter of the egg (fig. 158). As at an earlier stage, the nucleolus is vesiculated and almost always found lying close to the nuelear membrane, as if it hat fallen of its own weight like a shot in a bag. 
The nuclear membrane is very distinct up to the time when the ovum approaches maturity (figs. 159 and 160), when its outlines have become hazy. In the case illustrated (fig. 140) the long diameter of the mucleus corresponds with the short diameter of the egg. The nucleolus and nuclear fluid have undergone a very marked change. When stained in Kleinenberg's hæmotoxylon, the nucleolus has a hazy, almost homogeneous, appearance, and stains rather feebly, while the karyoplasm is of the same character, but takes the stain more feebly still.

When the eggs are ripe and lie free within the ovary ready for extrusion (fig. 141, plate 39), it is difficult to find the nucleus (partly, no doubt, on account of the great mass of yolk and the difficulty in cutting it). In one case, where I succeeded, what appeared to be the metamorphosed nucleus was a somewhat eccentric island of karyoplasm (fig. 160; for position in ovum, see fig. 141) without membrane or trace of a nucleolus. This vesicle stains uniformly, and has a very fine-grained texture. It has started for the surface of the egg, and in the next stage examined (fig. 161) is in contact with it. In this particular egg, taken from the oviduct of a female shortly after ovulation, the cell is dividing, or giving off a polar body; the nucleus has diminished in size, and no membrane is distinguishable.

THE MOVEMENTS OF THE NUCLEOLUS THROUGH THE ACTION OF GRAVITY.

I havealready pointed out the eccentric position of the nucleolus, which is always observed whenever the immature ovary is sectioned. This was noticed by Bumpus in 1891 , but no explanation of the fact was offered. (30, p. 225.)
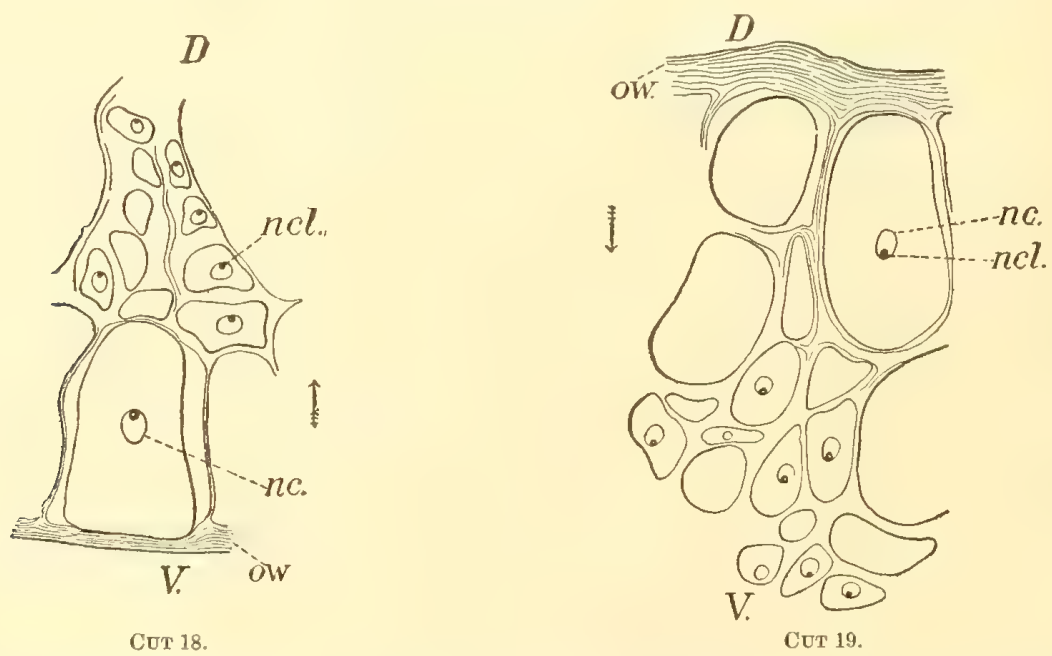

CUT 18.-From transverse section of a part of ovary of lobster, hardened with ventral sile uppermost, to show the effect of gravity upon the nucleolus. From hard-shell lobster which had recently hatched a brood. July $18,1894$.

CuT 19.-From transverse section of a part of same ovary, hardened with dorsal side uppernost, to show the effect of gravity upon the nucleolus. $D$, dorsal surface of ovary; ne, nucleus of ovum; ncl, nucleolus of ovum; ow, ovarian wall; $V$, ventral surface of ovary.

The arrow in each cut shows the direction of the force of gravity.

It seemed very probable that this phenomenon was due to gravity acting directly upon the nucleolus, which was free to move in every part of the nucleus. A few simple experiments immediately proved that this was the case. The ovary of a lobster which had recently hatched a brood was selected and cut into several pieces. These were then hardened in different positions, in Mayer's picro-sulphuric acid, with ventral or 
dorsal side nppermost or in vertical suspeusion. This was repeated, and it invariably followed that the nucleolus fell from its own weight, to the lower side of the nucleus, like a shot within a temnis ball. This is well illustrated in cuts 18 and 19. The latter shows in section a part of the ovary hardened in its natural position, with the dorsal surface uppermost; the mucleoli are here invariably on the lower side, in contact with the nuclear membrane. In 18 , where the part of the ovary was turned bottom side up, the uncleoli are eccentric, but lie against the opposite side of the nucleus. Suspend the ovary and kill the tissue in any position you please, the nucleoli sink like shot in the karyolymph and lie against the lower side of the nucleus. This is true of all but the smallest ova, in which the nucleolus may or may not so readily respond. Such eggs sometimes possess two or more nucleoli (fig. 156).

This phenomenon is a direct result of the structure of the nucleus and of the action of gravity, or else it is an artifact, the result of post-mortem changes. The nucleus consists of karyolymph, in which float granules of chromatin and other substances of but slightly less specific gravity, and a single large nucleolus of greater specific gravity than the surrounding fluids. The chromatophilous substance is distributed in flocculent masses (tigs. 157, 158), which are commonly suspended in the nuclear fluid, but tend to "sink to the bottom" together with the nucleolus. There is no trace whatever of a muclear network in the meshes of which bodies are suspended.

The nucleolus stains very intensely, but is often highly vesiculated, in some cases forming a hollow shell, owing probably to the extraction of soluble matter by some of the reagents used. When the nuclear membrane is strongly contracted over any part of its area (as in fig. 152) it leaves between it and the rest of the egg a regularly definer space, which is partially tilled with a coagulable liquid. This may come partly or wholly from the nucleus.

I have never seen this phenomenon in the eggs of any other animal. If anyone liave doubts about the facts, a very simple experiment like the one herein described will be conviucing. The explanation which I have offered nay, however, be questioned. I regret that the subject of post-mortem change did not come up for cousideration when I was at the seashore. ${ }^{1}$

\section{THE RIPE OVUM.}

The ripe unfertilized ovum is illustrated by figs. 119 and 141. Those which I have examined have been taken from the ovary or ducts a few hours or days after ovulation.

The nucleus was in such cases found at or very near the surface of the egg. In fig. 161, as already mentioned, the nucleus was in karyokinesis. The plane of section passed throngh the equatorial plate, so that the poles lie, in reality, above and below the plane of the paper. This is apparently the division preliminary to the formation of the first polar body. The rest of the egg is composed of yolk disposed in spherules of fairly uniform size. A coagulable liquid is usually gathered at the surface, below the eggshell, where the yolk spheres are here apt to be smaller. There is a single egg membrane (about $\frac{1}{25}-\mathrm{mm}$. in thickness), which is mualtered in the course of the passage of the egg through the oviduct.

${ }^{\prime}$ In regard to this question Professor Bumpus writes me that Bellonci found something very similar in the brain of Squilla, and that this was afterwards explained by Mayer as the result of the action of reagents, the nucleoli migrating from the killing fluids. Here, however, the action of gravity certainly plays a part. 


\section{6 \\ BULLETIN OF THE UNITED STATES FISH COMMISSION.}

THE DEVELOPMENT OF THE REPRODUCTIVE ORGANS.

GENERAL DEVELOPMENT.

In well-advanced embryos taken in January (for stage of development, compare cut 38) a very minute cluster of cells can be detected on either side of the middle line close upon the mesodermic partition which screens the heart from the intestine. These cells are mesoblastic in origin; they possess oval or spherical nuclei which, however, are not conspicuous for their size. At the time the embryo is about to hatch there is less doubt in the identification of the reproductive organ (fig. 116, plate 36). It now consists of a small oval, somewhat flattened mass of cells, lying close upon the mesentery, next to the intestine. It appears to arise as a proliferation of the mesoblast of the mesentery, but at this time is very distinct from it.

Later, in the first and second larval stages, the reproductive organ is a more compact, almost spherical, cell mass (about $\frac{1}{44} \mathrm{~mm}$. in diameter). Its position, close to the anterior end of the heart, but in contact with the mesentery, is well shown in fig. 174, $o v$, plate 43. It is now differentiated into two kinds of cells: (1) Central cells with large nuclei; (2) peripheral cells with much smaller nuclei (fig. 117, plate 36). The latter probably give rise to the ovarian wall, the former to the ova and follicular epithelium. The clearer central cells contain a distinct reticulum in which masses of chromatin are held. The organ is delicately suspended to the side of the mesentery by connective tissue. I did not distinguish the outlines of cells in any part of it.

In as late as the sixth or seventh stages the reproductive organ is still of very small size and not readily seen.

\section{IHE OVARY。}

In a female $44 \mathrm{~mm}$. long (No. 2, table 32) the ovary was of the size shown in fig. 131. I did not observe the ducts, probably because of the poor condition of the specimen when dissected. These were undoubtedly present, since their openings are visible in the eighth stage (fig. 89 , plate $32-N_{0} .3$, table 34 ), when the animal is less than an inch long. This ovary was $15 \mathrm{~mm}$. long, and each lobe was about one-fourth mm. in diameter. The anterior lobes embrace the masticatory stomach, and one of the posterior lobes was branched.

If the condition of the tissue could be trusted-it was preserved in alcohol, considerably diluted-the organ now consisted of a distinct connective tissue wall and an inclosed mass of large cells, which are the ova (fig. 146, plate 40). There was no plaited or folded ovarian epithelium such as we see at a later stage.

In a young female $2 \frac{15}{16}$ inches long the ovary had the size and appearance shown in fig. 132. It is about $40 \mathrm{~mm}$. long and has a diameter of $0.5 \mathrm{~mm}$. It is opaque white.

In a lobster $4 \frac{3}{16}$ inches in length (No. 42, table 20 ) the ovary has the same appearance but is somewhat larger. Its structure is now much more complex than at any of the stages described. It consists of a thin connective tissue envelope and a compact stroma. Folds of epithelium dip down from the surface and penetrate the interior of the organ, thus dividing up the outer portions into radial compartments, in which the larger eggs are seen. These contain large nuclei, with one, two, or more nucleoli. The axis of the ovary lies in a stroma in which all stages in the development of ova can be traced. Karyokinetic figures of dividing cells are not infrequently seen. Blood now penetrates to the ovary by sinuses which come in from the wall along reentrant folds of epithelium. 
TIIE OVIDUC'T.

The oviduct is a straight tube of nearly uniform caliber (figs. 119, 123 od), which opens to the exterior in a hairy papilla on the coxopodite of the third pair of pereiopods. The skin is folded in the mouth of the opening so as to form a valve which prevents the ingress of water. The appearance of the dnct when eggs are passing out is shown in fig. 119. The ovary had collapsed, but these eggs failed of passage.

The structure of the duct is the same throughout. It has a thin wall of museular and connective tissne, and a characteristic epithelium of tall columnar cells. The latter undergo so marked a change at the period of ovulation that there can be little donbt that they have some important function to perform. As shown by a comparison of figs. 167,168 , taken respectively from a lobster just before and just after ovulation, these cells become very greatly elongater and vesicular. One would infer that they secrete a liquid which is poured ont with the eags when they are laid. Whether these cells take any share or not in forming the cement I do not know.

\section{THE SEMINAL RECEPTACLE.}

The sternal pouch of the female was noticed and roughly figured by Nicholls in the Philosophical Transactions of the Royal Society for 1731, but he entertained a wrong notion of its function. His interesting and unique account of this organ is as follows (141):

Between the two last legs and the two legs above them there are two processes, which, from their resembling the nymphe of women, I shall term nymphreform processes. These processes are covered with hair, and unite at their bases without leaving any passage. * * * The two processes, which I have termed nympheform, in the female make a more obtuse angle at the union of their bases, are less hairy, and leave a passage, through which it is probable the ova are emitted, to be affixed to the appendages under the tail.

This remarkable conclusion reached in the last paragraph is unexplained even by the forced comparisons which were employed.

The observation of Nicholls was forgotten, and the structure which he imperfectly described was overlooked until its true function was discovered by Bumpus in $1891(30)$.

The seminal receptacle lies on the under side of the female near the junction of the thorax with the abdomen. (For its position and general appearance see plate $\bar{\tau}$, in which the median slit is clearly showu, and for details, fig. 130, plate 38.) Its paired wing-like processes, the enlarger sterna of the seventh thoracic segment, are tinged with bright blue and form, with a werge-like middle piece belonging to the sterum of the eighth thoracic segment, a somewhat heart-shaped body. There is a median slit with elastic edges, and if these are depressed, as Bumpus remarks, a grayish substance, the spermatic fluid, sometimes oozes out. The middle stemal piece is prolouged inside the chamber into a stout keel-shaped borly strengthened with thick deposits of chitin, which have a yellowish color and horny consistency. This is supported by a pair of irregular rods belonging to the enclophragmal system, which meet on the middle line. If the molted shell of a lobster is examined, in place of a solid, horuy keel, a membranous pouch is found. The solid keel-shaped unass is probably absorbed before a new keel is formed. In the living animal the seminal receptacte is a narrow, irregular cavity. 


\section{THE DEVELOPMENT OF THE SEMINAL RECEPTACLE.}

Development of the seminal receptacle is illustrated by figs. $79,81,89$, and 98 , plates 32 and 33. Fig. 98 is drawn from the molted skin of the fifth larva. The sex is not determinable with certainty, but it is highly probable that this is from a male; the sterna of the sixth to eighth thoracic segments (marked 3-5 in figure) are clearly defined. The sternal processes of the seventh thoracic segment are fused on the middle line, where they are distinctly depressed. The unpaired middle piece is marked as a slight transverse ridge or forwardly directed fold. It is clearly seen in the sternum of the adult male, where it is not so distinctly wedge-shaped or so intimately united with the wing-like sterna of the preceding segment. Three successive stages in the development of the seminal receptacle are shown in figs. 89, 79, and 81, plate 32; they are from young lobsters measuring $21.2 \mathrm{~mm}$. (eighth stage, No. 3, table 34 ), $35 \mathrm{~mm}$, and $52 \mathrm{~mm}$, respectively. If these are compared with the condition in an adult lobster (fig. 130) we observe the following external changes: The sterna of the seventh segment, which are united on the middle line, diverge from their anterior extremities, folming a wide angle. The sternum of the eighth thoracic segment consists of a tougue-shaped fold (fig. 81) and a pair of backwardly diverging rods. The former is constricted off as a single piece, though originally paired, and develops into the wedge-shaped process seen in the adult organ. It grows forward into the narrowing angle made by the wing-like process of the preceding sterna. A secondary cleavage or division of the united sternal pieces of the seventh thoracic segment is now going on, and the cleft thus formed is the permanent opening of the seminal chamber. The latter is formed by the approaching walls of the wing-like folds of the seventh thoracic sternum and tongue-like process derived from the eighth thoracic sternum.

THE MALE REPRODUCTIVE ORGANS.

TESTIS.

Each testis of the lobster is a grayish white sacculated tube consisting of anterior and posterior lobes. There is no union between the organs of opposite sides. The testis of the lobster was figured and described by Milne Edwards, and its structure has been studied by Grobben (83) and Sabatier (173). According to Grobben, it is made up of $(a)$ a capsular membrane, $(b)$ tunica propria, and $(c)$ the spermatogenous epithelium. Underneath the tunica propria a delicate, structureless membrane was seen. The epithelium is differentiated into spermatoblasts, from which spermatozoa are developed, and a syncytium-the Ersatzkeim-from which new spermatoblasts are deriverl. The spermatoblast is regarded as homologous with the egg cell, the Ersatzkeim with the follicular epithelium. A reserve albuminous material is laid down in the spermatoblast for use in the development of the sperm cell.

\section{VAS DEFERENS.}

The vas deferens or seminal duct is shown as it appears in its natural position on one side of tig. 120 and when dissected out on the other side. It consists of three fairly distinct sections: (a) A proximal segment (Zuleitungs-Abschnitt of Grobben), which serves to conduct the sperm from the testis; a very slender tube of uniform caliber, which curls, often in an irregular manner, over the posterior lobe of the gastric gland. This passes very abruptly into the enlarged $(b)$ glandular segment, where the tube bends backward upon itself. It then turns forward again and, in somewhat the form of the 
letter S, passes to the back of the last thoracic leg. The sperm may be traced aloug the course of the tube as a central, milk-white, linear mass of closely packed spermatozoa. In the glandular segment this is surrounded by a transparent, jelly-like substance which is secreted by the glandular epithelial cells (spermatophoral glands) lining this part of the duct. 'This is gradually constricted into the terminal $(c)$ musenlur segment, or ductus cjaculatorius, which ends in a valvular opening. A sphincter or swelling of the muscular layer is seen at the beginning of the ductus ejaculatorius, serving to force out the sperm.

The two distal segments (b,c) were called the penis or "verge" by Milne Edwards and Brocchi, because it was supposed that they were evaginated in copulation. It has been already pointed out that the evagination of these parts is mechanically impossible, a sufficient reason for dismissing this supposition.

The structure of the different sections of the vas deferens is illustrated by plate 37. The planes of section are marked in fig. 120, 1 to 5. As Grobben has already shown (83), the vas deferens is surrounded by a distinct membrane and is composed of a counective tissue wall, inclosing muscles, and a lining epithelinm; the latter gives rise to secretions which mingle with the sperm and surround it with protective envelopes. The connective tissue is fenestrated, abounds in blood channels, and the muscular tissue is disposed into an inner stratum of longitudinal fibers and an outer layer of circular bundles.

At the extreme proximal end of the cluct (fig. 124) the epithelium is apparently stratified and the wall is thin. The tube is filled with a solid mass of ripe sperm $(s p)$ and a surroumding coagulable thid, which is the direct secretion of the epithelial cells. As the glandular segment is approached the epithelium becomes distinctively colummar (fig. 125). The glandular segment (figs. 127, 128) is partly subdivided by the infolding of the epithelium $(f)$. The spermatophores (iu some cases there are $t w 0$ ) are restricted to one chamber and are immediately surrounded by a yellowish secretion $(S p r$.$) , which is probably formed in the proximal segment and stains very feebly in$ carmine. The remainder of the spacious eavity $(a$ and $b$ ) is filled with a less dense coagulable substance which stains freely in carmine. Bodies resembling yolk-spheres can sometimes be seen.

Grobben says that the secretion of the glandular segment of the vas deferens of the crayfish aplears chalky-white in reflected light and consists of swall, shining granules.

In the ductus ejaculatorius (fig. 126) the muscular coats are strongly developed and the epithelium appears to secrete an albuminous, granular substance. The height of the columnar or eylindrical cells varies very much, as Grobben remarks, according as they are squeezed more or less closely together.

The exterual opening of the vas deferens is formed by an invagination of the skin, and according to Grobben is paved with thick cuticle.

\section{SPERMATOPHORES.}

The sperm is ejected from the muscular segment of the vas deferens in the form of spermatophores, which consist of elongated packets of sperm cells, surrounded by gelatinous capsules, the origin of which we have just seen. The spermatophores can be pressed out of the ducts when these are removed from the body. They quickly imbibe water and swell perceptibly when wet with it. The spermatophore is composed of two distinct secretions, as was first pointed out by Grobbeu. According to the 
same investigator, spermatophores were first seen in Eupagurus by Schwammerdam in 1752, and were observed in the Brachyura also by Cavolini in 1792. They were rediscovered by Kölliker in 1841 .

\section{SPERY CELLS.}

The sperm cells of the lobster were apparently seen for the first time by Valentin, in September, 1837 (192), and he gave a brief account of his discovery in the following year. A more accurate account by Kölliker, who also remarked on the apparent immobility of the "rayed cells," appeared in 1843 (109).

The structure and genesis of the spermatozoa of the lobster have been studied with much detail by Grobben (83), Gilson (77), Hermann (89), and wore recently by Sabatier (173).

Each sperm cell (fig. 129, plate 37) consists of a cylindrical and partially hollow column or shaft, surmounted with a rounded dome, on what may be called the superior end. Between the capital and shaft three long, slender processes are given off, making an angle of $120^{\circ}$ with each other. The processes are sharp-pointed, rigid, and very slender. The stiffuess of the rays has led to the erroneous view that the rayed condition represented an immature stage in the maturation of the cell. The sperm cells withdrawn from the spermatic receptacle where they have lain weeks or months are still rayed, although the processes are often broken off or very limp (fig. 129, a). Apropos to this subject Grobben (83) says:

The stiffness of the rays does not prove that these cells are completely immobile. Moreover, the observation of Owsjannikow that the rays sometimes draw themselves in, and certain structures which I have examined, enable me to conclude definitely that these rays are living protoplasm and that they represent amoboid processes, remaining almost in a state of rest. [Compare the observation of Cano quoted on p.49.]

The genesis of the sperm cells from the spermatoblasts has been satisfactorily determined in most particulars, but there are some questions, which concern both this and the structure of the adult sperm cell, which are still undecided. The conclusion of Sabatier that the rayed cells become enucleated in the course of their growth can hardly be accepted. Sabatier has suggested that the stiff rays may serve at first to stick the cells together.

Nothing is definitely known either as to how the spermatophores are conveyed to the seminal receptacle or how the spermatozoa reach the eggs and fertilize them. 


\section{Chapter XI.-THE HABITS OF THE LOBSTER FROM THE TIME OF HATCHING TO THE PERIOD OF MATURITY.}

When the lobster hatches from the egg it is scarcely a third of an inch long. It rises to the surface, where it leads for a number of weeks a free-swimming, larval life, totally unlike that of an adult. After the fifth or sixth molt, its larval locomotor organs having atrophied, it sinks to the bottom, and though now resembling the adult lobster in outward form it is scarcely more than half an inch in length.

The free-swimming habit of the lobster is characteristic of the first five or six stages of its existence. In Vineyard Sound and outlying waters we have taken the swimming stages during the summer months, the latest rapture being a fifth larva on August 28. This period lasts from six to eight weeks, varying slightly with the season and greatly with the individual. It will be convenient to deal with the habits of the larvæ more fully in describing their structure and growth.

From the end of larval life until the later adolescent period the lobster drops ont of sight almost completely. It is a singular fact that the habits of the young lobster, from 1 to 4 inches long, have never been well understood. Many fishermen have never seen a lobster less than 2 or 3 inches in length, although they have fished the greater part of their lives. Lobsters under : inches long pass readily between the slats of the traps and hence are seldom caught. Rarely, however, one is found clinging to some part of the gear and is brought up by accident.

Sars in the course of his studies upon the European lobster, traveled along the coast of Norway from Lurhavn to Bergen, June 19 to August 19, 1875, but was unable to obtain any young lobsters from an inch to a finger's length, and says:

So far as I know, none are found in any museum. I consider it as certain, howerer, that the lobster keeps near the coast also during this stage of development. The reason why they can not be caught with the bottom seraper is partly beeause of their quick movements, and partly from the circumstance that they bide among the alga on the bottom of the sea. (1\%6.)

He says that young lobsters 3 to 4 inches long were the smallest known when he began his studies, and he has nothing to add beyond a description of the first three larvæ.

Spence Bate remarked in 1879 that "common as the European lobster is, it is very remarkable that a very young specimen has, as far as I know, never been met with." 1 He offered a reward for very young lobsters, but never obtained any less than 3 inches long.

Ehreubaum, whose paper was published in 1894, refers to the same uncertainty which has so long enveloped the history of the lobster from the close of its freeswimming life until it reaches a length of 4 inches $(10 \mathrm{~cm}$.). The smallest lobster which had been taken at Heligoland up to that time had attained a length of $4.1 \mathrm{~cm}$. The next largest was $7.8 \mathrm{~cm}$. long. He speaks of a collector who, in the comrse of

' Report of the British Association for the Advancement of Scieuce, Londou.

$$
\text { F. C. B. 1895-11 }
$$


thirty years' experience about Heligoland, had obtained only three lobsters from 3 to $5 \mathrm{~cm}$. long. $(61$, p. 285. $)$

It is evident that the long larval period of the lobster is an important means of securing a transport from the shore and wide distribution up and down the coast by means of the tides and ocean currents. As I shall point out in another place, this transportation is of the utmost importance to the larvæ, since it is in the bays and landlocked channels, where the competition among surface-feeding animals is keenest and destruction of life by animate and imanimate foes by far the greatest.

In consequence of the facts just mentioned, it must often happen that the young lobster settles to the bottom in depths much exceeding 100 fathoms. What does the little animal do on reaching its new abode? It probably begins to travel toward the shore, slowly at first but more rapidly when, in the course of six or eight weeks, it has become $1 \frac{1}{4}$ to $1 \frac{1}{2}$ inches long. Meantime it hides in the crevices of the rocks or conceals itself under stones whenever danger approaches. Having reached the shore, it establishes itself in shallow water at the mouth of some estuary or river on the rocky sides of a bay. It lives under stones, or in stone piles, the tops of which are sometimes left bare at extremely low tides. It can then be found by turning over stones in much exposed situations, often where the water is not over 1 or 2 inches deep, but where at the flood there may be from 3 to 5 feet of water or even more. Sometimes several small lobsters are seen lying under one rock at the same time. While the lobster is very small, $1 \frac{1}{4}$ to $2 \frac{1}{2}$ inches long, it crawls down deep into the piles of loose stones where no enemy can reach it. After attaining a greater length $\rightarrow$ of 3 or 4 inches-the young lobster begins to leave the rock piles and digs for itself a little cave under a stone. From this protection it stealthily crawls forth in search of its prey, and quickly returns when an enemy appears. It may take up its abode in the winding chamber of a deserted eonch shell, or in any hole or niche which promises temporary security.

As the lobster increases in size it grows bolder and retires farther from the shore, although it never loses its instinet for digging and never abandons the usual habit of concealing itself under stones when the necessity arises.

Little is known about the habits of young lobsters in winter, but it is evident that they moust leave the rock piles as soon as ice begins to form, perhaps as early as December in eastern Maine, and move out, as the adults do, into deeper water. The casting up of young lobsters on the beach at Woods Hole, in the latter part of January (see p. 165), proves that they sometimes remain in shallow water even at this season.

The colors of the young lobsters at the time they are from $1 \frac{1}{2}$ to 2 inches or somewhat more in length are very different from those of the adult. This may be seen by comparing figures 39 and 22, which represent, respectively, a young male 1.8 inches long (see No. 22, table 33) and an adult male 10 inches in length. In the young lobster the general cast of color is a russet or light reddish-brown, which is most pronounced on the sides of the body and under surface of the large claws. The borders of the carapace and segments of the body and legs are tinged with light Prussian blue. The upper parts of the body and appendages, especially the first pair of chelipeds, are spattered and marbled with a dull-bluish pigment. The terga of the abdomen have often a fine edging of dull bluish-black.

I am fortunate in being able to present a series of plates to illustrate the adolescent as well as the adult stages of the lobster. The original photograph ${ }^{1}$ are in many cases so perfect that with the aid of a hand lens the finest details in the sculpturing

'These were made by the Edmondson Company, of Cleveland, Ohio. 
of the exoskeleton can be seen. The adolescent forms are all from Casco Bay region, and are described in table 3\%. (See also descriptions of figs. 9-18, plates 8-13.) The smallest (plate 8, fig. 10, No. 1, table 32) is a male, 1.6 inches long. The right cuttingclaw happens to be much under the normal size, since it is in process of regeneration. It would probably have attained its normal size after the next molt. The greater breadth of the "tail" or pleon of the female is not noticeable until at a considerably later period. Other secoudary characteristies, such as the seminal receptacle and first pair of pleopods in both sexes, are not fully developed until the animal has reached the length of about 2 inches.

The most striking characteristic of these adolescent stages, in comparison with the adult form which they so closely resemble, is the large size of the stalked eyes (plates 8-12). The eye is very much compressed laterally, and in size and shape resembles that of Peneus. The eyes of the artult are relatively much smaller. (See table 38.) It is therefore possible that the large size of the eyes in the adolescent stages is an ancestral character. The present lobsters have probably descended from the Erymoid crustacea which inhabited the seas of the Liassic period. "In the latter part of the Jurassic epoch," says Huxley (103), "the Astacine type-that of the modern craytishes-was already distinct from the Homarine type, though both were marine." Hoploparia, which is found in a fossil condition in the Cretaceous and early Tertiary formations, combines the characteristies of Homarus (Astacus in this work) and Nethrops. I have seen nothing but fragments of this genus figured, but in the Eryma leptoductylina of Zittel (20) the eyes are relatively quite large, as we see them in the adolescent lobster at the present time.

Another characteristic of these early stages is the fringe of very long setæe on the caudal fan and the matted tufts of setre abont the ends and toothed edges of the cutting-claw. (See figs. 13-15.)

In a female lobster measuring $3 \frac{2}{5}$ inches in length (No. 22, table 32 ) the general color is a dull reddish brown. The upper parts are spotted and mottled with darker brown: the tips of the claws and projecting spines are generally reddish, as in the adult. A suffusion of light blue is seen, as in younger forms, at the joints of the appendages and on the edges of the carapace and abdominal terga. This coloration closely resembled that of an adult egg-bearing female which I had at the time. A small male (No. 23 , table 32 ) resembled this female very closely in color. The adolescent period is a long one, and the gradual development of the pigments of the adult is correspondingly slow. The history of the development of the color of the adult lobster from that of the larva will be discussed in another place. After this general account of the period of adolescence, I will now add all the notes which I have gathered that throw any light upon this important subject. In tables 32 and 33 the history of 63 immature lobsters, varying from 1.3 to 5.6 inches, is briefly given.

I am indebted to Mr. M. B. Spinney, of Cliffstone, Maine, for a valuable collection of small lobsters from the shores of Casco Bay aud Small Point Harbor, which he has examined with great eare. This collection embraces 36 individuals, 22 of which are males and 14 females. They were captured mostly in October and November. Mr. Spinney found young lobsters firom $3 \frac{1}{2}$ to 4 or more inches long in considerable abundance under small stones, where at an extreme low tide there would be but 1 or 2 inches of water; the smallest lobster were found down among the stone piles, where the stones were four or five tiers deep. They crawl as far as they can into the laby. rinthine passages between the stones, and are here secure from every enemy. 
TABLE 32.- Young lobsters from the vicinity of Casco Bay, Maine.

[Length, 40.3 to $129 \mathrm{~nm}$. or 1.6 to 5.1 inches.]

\begin{tabular}{|c|c|c|c|c|c|}
\hline No. & Sex. & $\begin{array}{l}\text { Length } \\
\text { in mu. }\end{array}$ & Date of capture. & Place of eapture. & Remarks. \\
\hline 1 & Male..... & 40.3 & Oct. 9-19, 1893:... & Casco Bay, Small Point, Me. & Found in stone piles at very low tide; \\
\hline 2 & Female ... & 44 & . . do ............. & $\ldots$ do & Do. \\
\hline 3 & Male..... & 48 & .... do & ....do do $\ldots-\ldots . . . .$. & Do. \\
\hline 4 & ...do ..... & 52.5 & .... do ...... & do ........................... & $\begin{array}{l}\text { Do. } \\
\text { Do. }\end{array}$ \\
\hline $\begin{array}{l}5 \\
6\end{array}$ & $\begin{array}{l}\text { (... do } \\
\ldots \text { do....... }\end{array}$ & $\begin{array}{l}58 \\
62\end{array}$ & Sept, $27,1893 \ldots$. & New Meadows River, 6 miles & Found under stones at very low tide; \\
\hline 7 & Female ... & 64 & Oct. $9-19,1893 \ldots$ & $\begin{array}{l}\text { north of Small Point. } \\
\text { Casco Bay, Small Point..... }\end{array}$ & $\begin{array}{l}\text { tops of stones out of water. } \\
\text { Under stones and in stone piles at } \\
\text { very low tide. }\end{array}$ \\
\hline 8 & Male... & 67 & Sept. 27,1893 . & New Meadows River......... & Do. \\
\hline 9 & Ferale & 68 & & $\begin{array}{l}\text { Basin Bay, east side Mead- } \\
\text { ows River. }\end{array}$ & Do. \\
\hline 111 & ... do ..... & 68 & Aug. 31, 1893.. & Small Point Harbor......... & Do. \\
\hline 11 & Male..... & 69 & $0 \cdot \operatorname{to} 9-19,3893$ & $\ldots$ do $\ldots \ldots \ldots \ldots \ldots \ldots$. & Do. \\
\hline $\begin{array}{l}12 \\
13\end{array}$ & Female... & $\begin{array}{l}71 \\
73\end{array}$ & Aug. 31,1893 & Small Point Harbor (inner & $\begin{array}{l}\text { Do. } \\
\text { Do. }\end{array}$ \\
\hline & & & & harbor). & \\
\hline $\begin{array}{l}14 \\
15\end{array}$ & Malo.... & $\begin{array}{l}74 \\
75\end{array}$ & $\begin{array}{l}\text { Sept. } 26-28,1893 \text {. } \\
\text { Oct. } 9-19,1893 \ldots\end{array}$ & . do do $\ldots . . . . . . . .$. & $\begin{array}{l}\text { Do. } \\
\text { Do. }\end{array}$ \\
\hline 16 & Female. & 75.6 & Sept. $26-28,1893$. & ... do ... & $\begin{array}{l}\text { Do. } \\
\text { Do. }\end{array}$ \\
\hline 17 & Male.... & 81.5 & .....do do.......... & ... do & Just molted; stomach filled with \\
\hline 18 & ....do..... & 83.5 & Oct. 9-19, 1893.. & ... do ..... & Found under stones and in stone \\
\hline 19 & ....do ...... & 84 & .... do & .... do & $\begin{array}{l}\text { Dines tu very low nue. } \\
\text { Do. }\end{array}$ \\
\hline 20 & $\ldots$.... do .... & 85.5 & .....do & .... do & Do. \\
\hline 21 & Fomale ... & 86.5 & -.... do & Be.do ..... & Do. \\
\hline 23 & Male...... & $\begin{array}{l}87 \\
92.3\end{array}$ & Oct. $9-19,189$ & $\begin{array}{l}\text { Basin Bay ......... } \\
\text { Small Point Harbor... }\end{array}$ & $\begin{array}{l}\text { Do. } \\
\text { Do. }\end{array}$ \\
\hline 24 & ... do ..... & 93 & Sept. 1,1893 . & do n............ & Do. \\
\hline 25 & Female... & 93.4 & Sept. 26-28, 1893 . & $\ldots$ do $\ldots \ldots \ldots \ldots \ldots . . . . . .$. & Do. \\
\hline 26 & ....do ..... & 94 & Oct. $7,1893 \ldots$ & $\begin{array}{l}\text { New Meadows River, } 8 \text { miles } \\
\text { E. of Small Point Harbor. }\end{array}$ & $\begin{array}{l}\text { Just molted stomach tilled with } \\
\text { fragments of shells of mollusks, ete. }\end{array}$ \\
\hline 27 & Male... & 95 & & $\begin{array}{l}\text { East side Casco Bay, Phipps- } \\
\text { burg, Me. }\end{array}$ & Under stones. \\
\hline 28 & do do & 101.5 & Sept. 1, $1893 \ldots . .$. & Small Point Harbor......... & Do. \\
\hline $\begin{array}{l}29 \\
30\end{array}$ & Female... & 102,4 & 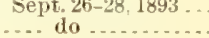 & - m do do & $\begin{array}{l}\text { Do. } \\
\text { Do. }\end{array}$ \\
\hline 31 & Male..... & 104.5 & Oct. $9-19,1893 \ldots$ & ... do & Do. \\
\hline 32 & ... do ..... & 110 & Sept. $26-28,1893$ & . do do ....... & Do. \\
\hline .33 & ....do .... & 112 & & Inner harbor, Suall Point.. & $\begin{array}{l}\text { Under stones; rostrum imperfect; } \\
\text { soft shell. }\end{array}$ \\
\hline 34 & ...do do & 119.5 & & Small Point Harbor......... & Rostrum deficient: soft shell. \\
\hline $\begin{array}{l}35 \\
365\end{array}$ & Female.... & $\begin{array}{l}124 \\
129\end{array}$ & $\begin{array}{l}\text { Sept. } 26-28,1893 \ldots \\
\text { A й. } 31,1893 .\end{array}$ & Inner harbor Small Point & \\
\hline & मून & & & & \\
\hline
\end{tabular}

TABLE 33.- Young lobsters from Vineyard Sound, Massachusetts, in vicinity of Woods Hole. [Length, 35 to $142.8 \mathrm{~mm}$. оr 1.4 to 5.6 inches.]

\begin{tabular}{|c|c|c|c|c|c|}
\hline No. & Sex. & $\begin{array}{l}\text { Leugth } \\
\text { in mim. }\end{array}$ & Dizte of capture. & Place of capture. & Remarks. \\
\hline 1 & Female : & 36 & $\begin{array}{l}\text { Hatehed a bout } \\
\text { Jawe } 20,1893 \text {. }\end{array}$ & Woods Hole ... & $\begin{array}{l}\text { Raised from egg in hatchery of U. S. F. C. } \\
\text { Station. June } 27,1894 \text {, it was } 36 \mathrm{~mm} \text {. long. } \\
\text { It died early in August, } 1894 \text {. }\end{array}$ \\
\hline 2 & ido.... & 39 & Jan $28,1882 \ldots \ldots$ & .... do .......... & \\
\hline 4 & Female. & 41 & ‥do & .... flo & \\
\hline 5 & Male... & 48 & 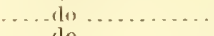 & .... do ..... & \\
\hline $\begin{array}{l}6 \\
7\end{array}$ & ... do .... & $\begin{array}{l}50 \\
52\end{array}$ & 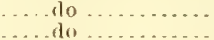 & $\ldots$ do $\ldots . . . . .$. & \\
\hline 8 & Female. & 55.2 & . ndo & .....do ... & \\
\hline 9 & Male.... & 55.5 & . . . d do .......... & .... do fo...... & \\
\hline $\begin{array}{l}10 \\
11\end{array}$ & $\begin{array}{l}\text { Female } \\
\text { Male. }\end{array}$ & $\begin{array}{l}60 \\
66.4\end{array}$ & 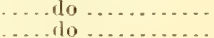 & ... do do ......... & \\
\hline 12 & do & 74.8 & ....dodo & ......do . . & \\
\hline 13 & Fenale & 75 & .... dio ....... & ......do... & \\
\hline $\begin{array}{l}14 \\
15\end{array}$ & $\begin{array}{l}\text { Male... } \\
\text { Female }\end{array}$ & $\begin{array}{l}80.3 \\
83.5\end{array}$ & .... do do... & ...do do ... & \\
\hline 16 & Male... & 83.7 & a do & $\ldots$ do ........... & \\
\hline 17 & Female. & 35 & $\begin{array}{l}\text { I'restrved Dec. } 10 . \\
\text { 1886. }\end{array}$ & n.............. & $\begin{array}{l}\text { Hatched and raised at the U. S. F. C. Sta- } \\
\text { tion, Woods Hole, Mass. }\end{array}$ \\
\hline $\begin{array}{l}18 \\
19\end{array}$ & $\begin{array}{l}\text { Male... } \\
\text { Female }\end{array}$ & $\begin{array}{l}36.3 \\
51.8\end{array}$ & .... do ............ & & $\begin{array}{l}\text { Do. } \\
\text { Do. }\end{array}$ \\
\hline 201 & . do.... & 69.5 & June 1,1891 . & Woods Hole ....... & \\
\hline 21 & . do .... & 74.6 & June 30,1891 . & Woods Hole Harbor. & No. 98 , table 20 \\
\hline $\begin{array}{l}23 \\
23\end{array}$ & Male.... & $\begin{array}{l}47 \\
92\end{array}$ & $\begin{array}{l}\text { July } 18,1891 \ldots \\
\text { July } 22,1890\end{array}$ & Gardo Head & Bronght up in lobster pot. (See plate 26.) \\
\hline 24 & Fernale. & 106.3 & Jung $22,1890 \ldots$ & 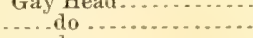 & No. 42 , table 20 . \\
\hline 25 & ...do.... & 107.9 & .... do ........... & ..... do ............... & No. 46 , table 20 . \\
\hline $\begin{array}{l}26 \\
27\end{array}$ & $\ldots$ do..... & $\begin{array}{l}112.8 \\
142.8\end{array}$ & $\begin{array}{l}\text { Aug. } 1892 \\
\text { July } 22.1891 \ldots \ldots . . .\end{array}$ & $\begin{array}{l}\text { Vineyard Sound..... } \\
\text { Wonds Hole Harbor. }\end{array}$ & Dredged by U., S. F. C. ateamer Fish Hawk. \\
\hline & & 19.6. & & & \\
\hline
\end{tabular}


When the lobsters have attained a length of $3 \frac{1}{2}$ or 4 inches they become more bold, leave their burows among the rock piles, and seek the shelter of stones, benenth which they excavate a shallow hole. Here they lie concealed from their cnemies and are realy at all times to strike a blow at the smaller and weaker auimals which pass within the reach of their claws.

The young lobsters enumerated in table 33 were captured in or near Vineyard Sound or raised in the hatchery of the station of the Fish Commission. Fifteen of these (Nos. 2-16) were collected by Mr. Vinal N. Ldwards on Nobska Beach, in Woods Hole, January 25, 1852, after a hard storm, when there had been nuch anchor frost. Mr. Edwards recorded in his journal the tinding also of crabs with eggs, thrown npon the bearh, together with isoporls, holothurians, sea-anemones, and a large number of fish, such as cunners, tautog, hake, sculpins, smelt, flatfish, herring, tomcod, and eels. Mr. Edwards writes that many young lobsters came ashore at the same time on the point of land where the Fish Commission station is now built. Several years ago, when small lobsters were used for bait, he used to find them in comparative abundance, from $1 \frac{1}{2}$ to 3 or 4 inches in length, under stones in shallow water, near Pine Island, on the north side of "The Hole." Some of the stones would be out of the water at low tide. No small lobsters are found in this place or vicinity at the present time. Whether this disappearance is due to the general decrease in the number of lobsters bronght abont by overfishiug or to local changes in the environment, it is difficult to say. Both influences may be at work. It is possible that owing to warmer waters inshore, or to other causes operating in summer, the young lobsters are driven into deeper water, yet they seem to be equally scarce at all seasons. The finding of small lobsters cast up on the beach in the winter shows, as already pointed out, that they sometimes remain at this season in comparatively shallow water.

The inspector of fisheries of Prince Edward Island says (209) that lobsters 2 or 3 inches long "are occasionally washed ashore after storms and have been found alive clinging to the meshes of hoop traps." Lobsters not much over an inch in leugth are also said to have been takeu from the stomachs of codfish. (See p. 120).

An old lobster fisherman, Mr. Thomas Garrett, at Vinal Haven, Maine, whom I have already quoted, informed me that he used to see thonsands of small lobsters in the spring, beginning about the 1st of April. He would find them in sounds in about 20 fathoms of water, on both rocky or sandy bottom. They would ccme up sticking to the lobster pots, often in considerable numbers, and would arerage about $1 \frac{1}{2}$ inches long. He had never seen many lobsters 2 to 3 inches long, probably because they go so readily through the traps.

I made particular inquiries about the occurrence of young lobsters in the lobster pound on Vinal Haven Island. The smallest lobsters canght in the pound in 1893 by seining were about 5 inches long. Half a dozen measuring 8 inches had also been taken. Small lobsters were noticed in the larger of the two lobster pounds at southport, Maine, in March, 1892, and about half a dozen were found from 4 to 6 inches long. In July and August, 1893, thirty or more lobsters were taken, varying from 3 to 6 inches in length. Lobsters 6 to 8 inches long could be taken in the seine. The smaller lobsters were discovered by turniug over rocks, after partially draining the pond. None were seen under 2 inches in length. It is possible that some of these young ones were raised in the pounds, yet it is not certain that this was the case, since they could readily pass between the iron rods of the fence. The older lobsters, which are placed in the pounds in very great numbers, would tend to drive out the smaller ones, whether hatched in these inclosures or not. 
An intelligent lobsterman of Rockland, Maine, said that thousands of small lobsters, an inch long or under, came up on the warps and pots every day whice he was fishing at Hare Island in October and November. The lobsters would tumble off the traps as they came up. He took one of them home and examined it with a hand lens, and said that it had the general form and appearance of a lobster. The bottom in that vicinity was muddy or rocky, and covered with seaweed. He had never seen a 2-inch lobster. The smallest of the young lobsters recorded in table 32 is about an inch and a half long. These, as we have seen, were taken from the rock piles in the fall of the year, and most of the lobsters which are hatched in early summer and survive are more than an inch long by October. Still, this fisherman's observation may be correct, and the lobsters seen by him may represent that period between the sixth larval stage (length $16 \mathrm{~mm}$.) and the smallest of those found in the rock piles.

A small lobster, about $1 \frac{1}{2}$ inches long, was said to have been taken from the shell of a living clam in Rockland Harbor not long ago. This was evidently a case of accidental imprisonment, and the animal may not have been a lobster.

A fisherman at West Jonesport said that he had seen small lobsters brought up on traps which were set on trawls, in deep water outside, in winter.

Mr. Adolph Nielsen, superintendent of the fisheries of Newfoundland, says that small lobsters $1 \frac{1}{2}$ to 2 inches long can be found in shallow water among the "goosegrass" in the latter part of Septem ber, and that he has seen lobsters an inch long in the same situations in the latter part of August and first part of September.

Very few fishermeu among many whom I have consulted can give any definite information about the occurrence of lobsters from 1 to 3 inches long, and probably very few can discriminate between the young of the lobster and many other crustacea. Those who have made any observations agree that such young lobsters are very seldom seen in winter, but are usually found at other times in shallow water, in bays, harbors, or the mouths of rivers, on rocky (rarely muddy) bottom, where they cau be found by turning over stones at low tide. Mr. George E. Cushman, of Cape Elizabeth, Maine, says that lobsters 2 to 4 inches long are found in coves and rivers, in eelgrass, aud on sandy bottom, in from 2 feet to 5 fathoms of water.

Mr. Rathbun, of the United States Fish Commission, informs me that hundreds of lobsters 4 to 6 inches long were captured in the summer of 1880 in Narragansett Bay by the beam trawl. The bottom was sandy, and the water 3 to 4 fathoms in depth.

I think it is plain from the foregoing observations that a large number of the adolescent lobsters over $1 \frac{1}{2}$ inches long seek protected places, such as beds of eelgrass in shallow water, rocky shores of bays, and the mouths of rivers, where shelter from an enemy is always at hand; but it is quite likely that some remain in deeper water.

The habits of this animal are molded by its immediate environment and vary to some extent with the varying elements in the complex of its surroundings.

If we examine the lengths of lobsters described in table 32 we shall find they form a gradually ascending series, so that when we lay off these lengths as ordinates upon a horizontal base line, and construct a curve, the latter forms a slightly undulating ascending line. This means either that the breeding season is indefinite or at least prolonged, or that the young are extraordinarily unequal in their development. The number examined is perhaps too small to enable us to draw any conclusions, but it is a fact, as already shown, that the hatching is not strictly confined to a definite period. Individual variation in size in a state of nature may, moreover, be considerable.

The interesting question of the age of these adolescent lobsters is considered in the chapter on the rate of growth of this animal. 


\section{Chapter XII.-THE HISTORY OF THE LARYAL AND EARLY ADOLESCE.TT PERIODS.}

The transition from the caterpillar to the chrysalis and from this to the winged butterfly or moth is apparently so sudden that it strikes every one with wonder. This is, however, deceptive, since changes in the internal organs go on very slowly. The hard supporting skin of the chrysalis masks the changes which are taking place within. The young erustarean, on the other hand, has a soft cuticle which is readily cast off; it thus changes with every molt aul in most eases acquires very slowly the external form and habits of the adult state. It is therefore possible to follow its metamorphosis step by step. For convenience I shall divide the life-history into three periods-the laval, adolescent, and adult. The larval period will embrace the free-swimming life, during which the animal molts five or six times, and the adolescent state the long interval thereafter before sexual maturity is reached.

The larval history of the lobster is one of exceptional interest and importance, and mist be thoromghly understood before the problem of hatehing and rearing the young can be intelligently discussed, much less solved. I therefore decided, at the beginning of this work, to devote as much attention as possible to this part of the subject. This seemed particularly desirable since the individual larval history had never been traced molt for molt; only four pelagic stages had been described, and the relations of these were not fully understood. Of the later adolescent period (length of animal $\frac{1}{2}$ or $\frac{3}{4}$ inch to $2 \frac{1}{2}$ inches) nothing, as we have just seen, was definitely known.

\section{HISTORICAL NOTES.}

J. V. Thompson, who was first to establish beyond any doubt the important fact that the decapod crustacea underwent a metamorphosis after hatching from the egg, was also the first, so far as I am able to learn, to point out that the European lobster was no exception to this very general rule. His letter (published in 1835) to the editor of the Zoological Journal is dated at Cork, December 16, 1830. A "rough sketch of" the cheliferous member of the larva of the lobster" accompanies this letter. Hesays:

With regard to the marine species, Astacus marinus or Lobster, I can aver that it actually does undergo a metamorphosis, but less in degree than any of the above-mentioned genera (Pagurus, Porcellana, Galathea, Crangon, Palæmon, etc.), consisting in a change from a cheliferous Schizopode to a Decapode; in its first stage being what I would call a modified Zoe with a frontal spine, spatulate tail, and wanting subabdominal fins; in short, such an animal as would never be considered what it really is were it not obtained by hatching the spawn of the Lobster. (189.)

Brightwell (24) gave in 1835 a very imperfect description of the young lobster which he dissected from the egg membranes. He was the first to notice the occurrence of double monsters in this species. (See p. 216.)

The embryo of the European lobster when ready to hatch was described by Rathke in 1840 (159), and a fuller account with figures of the embryo and of some of its appendages appeared in $18+2(160)$. He found lobsters with external eggs in early stages of development at different times of the year-at the end of May in Christiania, in Jume and July at Molde and Christiausund, in September at Gothenburg, and in the tirst half of October in Hamburg. He therefore concluded that lobsters either laid their eggs at different times of the year or that their development was very slow. 
Kröyer also, in 1842 (110), deseribed with drawings the first larva of the lobster. In the following year the paper of Erdl was published on the development of the egg of the lobster (62), in which some good colored drawings of the older embryos are given.

About thirty years later, in 1874, the first circumstantial account of the metamorphosis of the European lobster was published by Professor Sars (175). His studies, however, included only the first three larval stages, and, as he remarked, the changes which these early larvæ undergo, before they reach the adult state, were still unknown. Some comparisons are drawn in this paper between the first larvæ of the European and American species. (For figures of Homarus americanus, see 175, Tab. I, figs. 18-20.)

The first description of the metamorphosis of the American lobster was given by Professor S. I. Smith, in 1872 (182), his fuller paper being published in the following year. He described and figured the first three larval stages and what appeared to be a fourth or fifth stage from specimens obtained in Vineyard Sound, Massachusetts, in the summer of 1871. At that time the United States Fish Commission did not possess the laboratory facilities which afterwards grew out of the labors of Professor Baird, but notwithstanding these drawbacks this work is so carefnlly done that subsequent studies will find little to correct, so far as they deal with the external anatomy of the larvæ described. Professor Smith says that between the third stage and what he called an "early stage of the adult form" "there is possibly an intermediate form. The changes in the whole appearance of the animal have been so much greater than between the first and second or between the second and third larval stages that, although the difference in size is inconsiderable, the whole change did not perhaps take place in one molt."

Professor Ryder, who published a short paper on the metamorphosis of the lobster in 1886 (171), supposed that the first adult-like form of Smith was preceded by four stages, but by only three ecdyses, the first molt (which oceurs at the time of hatching, as Sars (175) had found to take place in the European lobster) having been overlooked. The fact of the case is that the lobster molts four times before reaching the stage in which it resembles so strikingly the adult animal. It is still essentially a larva in habit and structure and swims at the surface, although its earlier natatory organs are reduced to mere rudiments (plate 23).

Figures of the late embryos and of the first larva or its appendages have also been published by Erdl (62), Couch (48), Gerbe, ${ }^{1}$ and Faxon (67), the work of the latter containing drawings by Stimpson and Alexander Agassiz, but it is not necessary to refer to these in detail.

\section{METHODS OF STUDYING THE YOUNG.}

In the course of my studies on the metamorphosis of the lobster I have endeavored to follow the history of individual larvæ. This seems to the inexperienced a very simple matter, but the task is beset with serious difficulties. We may isolate the delicate larva from its natural enemies and place it under the most favorable conditions which we can devise, when new foes immediately spring up or unexpected disasters happen. The larvæ which I studied were in most cases hatched at a known period by the artificial methods now in use. Healthy specimens were then selected and placed,

${ }_{1}^{1}$ The figures of Gerbe are very erude, as reprodnced by Blanchard (19) and Duncan. They are intended to represent the embryo shortly before hatching, the young immediately after hatching, and after the second molt. The original paper of Gerbe I have not seen. 
usually singly, in a 4-gallon glass jar, which was coverer with coarse linen scrim and supplied with running sea water. The mesh of the cloth soon became clogged, thus fouling the water in the jar, which had to be cleansed daily. Under these conditions young lobsters have been kept alive over 100 days and carried through ten molts. The ouly food which they had beside that contained in the water was lobster eggs. These were rarely touched by the very young larva, unless they were floated. Had my stay at the seashore been prolonged some of the young could have been kept alive, I am sure, for an indefinite periou, but other duties calling me away before the close of summer, they usually died from lack of attention.

There is now (August 1, 1894) alive in the hatchery of the Fish Commission station a lobster which was hatched from the ego in June, 1893, and which is, therefore, considerably over a jear old. The length of this lobster is only $36 \mathrm{~mm}$., while three lobsters which were hatched and kept alive until I ecember 10, 1886, being then between five and six months old, measured 35, 36.3, and 51.5 mm., respectively. I mention this fact, now, to show how variable individuals are in their molting or, what amounts to the same thing, in their rate of growth. It is improbable that such a marked variation would oceur in a state of wature, yet it is likely, as I shall later show, that even here variation in individual growth is by no means slight. (See table 34 and p. 97.)

Before describing the structure and habits of the larva we will glance at the condition of the embryo at a late period in embryonic life.

\section{THE EMBRYO IN LATE STAGES OF DEVELOPMENT,}

A photograph of a living lobster with external eggs taken in Cleveland, Ohio, 1)ecember $S, 1593$, is reproducer in plate 7 . A cluster of these eggs, showing how they are attiched to one another aud to the setie of the swimmerets, is illustrated by fig. 25. Drawings of the living egg and of the embryo teased from the egg capsule (figs. 26 to 23) give us some idea of the stage of development reached, in this instance, at the very beginning of winter. Progressive stages of growth in the case of a lobster whose eggs were laid July 1, 1890, aud were begimuing to hatch June 1, 1891, are illustrated by figures in the text. (Plates G to J.)

At the stage shown in fig. 27 the bright green yolk occupies nearly one entire hemisphere of the egg. This massive store of food, at the expense of which the organs of the body are gradually (leveloped, becomes reduced at the time of hatching (fig. ‘9, plate 18) to a mere remnant within the stomach of the larva, and often undergoes changes in color, at the last stage becoming a dull yellowish-brown. The paired compound eyes have already become most conspicuous, both on account of their size aud color. The pigment area, which has a peculiar contour, is almost black when light is transmitted or when retlected, except at a certain angle. It then glistens with great brilliancy, owing probably to the interference of light in the thin peripheral pignentlayer. Bright red chromatophores are distributed in a characteristic manner on the appendages, particularly on their basal segments and along the sides of the carapace. The yolk is divided by couspicnous dorsal and lateral indentations, corresponding to the folds of the digestive tract and its diverticula, which gradually inclose it.

During the course of development the ova increase considerably in size and, losing their original globular form, become distinctly oval or oblong. 
Peculiar concretions are developed in the intestine of the embryo when 5 or 6 weeks old, as shown in figure 233, plate 51, and persist up to the time of hatching (fig. 30, pl. 18). They were noticed as early as 1843 by Erdl (62). We see them to better advantage in a section of the intestine of a much older embryo, as in figure $253, P$. There is great variation in both the size and shape of these bodies, but they consist of a stainable, apparently structureless core, surrounded by a nonstainable substance. The latter has distinet concentrie striæ and resembles the eyst of a parasite. A concretion teased from the intestine of a similar embryo is illustrated in figure 256.

In the living animal they have a white lustrous appearance, and are quite conspicnous, moving to and fro with the peristaltic contractions of the intestine. On the suspicion that they might be of a parasitic origin I submitted them to Dr. Stiles of the United States Bureau of Animal Industry. He has kindly examined them, and concludes, so far as it was possible to reach a conclusion from the material at command, that the bodies in question were nonparasitic. In this event it is probable that they are the frecal residue of the egg yolk which undergoes digestion in the course of embryonic life. The animal is entirely rid of them soon after hatching.

\section{THE HATCHING OF THE LARVA.}

A lobster in the act of hatching is represented in fig. 29 , plate 18 , and one teased from the egg in fig. 30. The embryo at this time is inclosed by three membranes, namely: (1) the outer or secondary egg membrane; (2) the primary egg membrane, improperly called the chorion; (3) a larval membrane, which is seen inclosing, like a glove, the various appendages in fig. 30. These are better shown in a much distended condition in cut 20 , plate $\mathrm{F}$. In this case, however, the innermost cuticle is not the larval membrane, but an earlier embryonic molt, which is absorbed long before the time of hatehing is reached.

When burst by internal pressure the secondary egg membrane splits (in the vertical longitudinal plane of the embryo) into two halves like the cotyledons of a bean, and is drawn off in most cases over the head by the strand or stalk with which it is continuous. It is a thick, translucent bag of a yellowish-brown tint, slightly elastic and easily torn. It completely separates from the underiying membrane, except at one point, that beneath the stalk of attachment. Here it adheres to the primary membrane, which has now become reduced by distention into an exceedingly delicate pellicle. In this particular case (fig. 29) it was whole, until ruptured by needles (just above eyes), and thus completely inclosed the exposed parts of the embryo. When the outer membrane of attachment bursts, it contracts and usually drags the delicate inner cuticle away with it. The embryo thus slips out in the condition shown in fig. 30 .

This is a very critical period in the life of the artificially hatched lobster. If it is healthy it soon molts, the swimming hairs are rapidly evaginated, and it emerges into what may be properly called the first locomotor larval stage. If less fortunate, it lies on its back for hours, struggling to get clear of some part of its larval covering. The failure to pass this molt is the cause of death to many embryos which have been reared successfully up to this point in the hatching jar. 
THE FIRST STAGE.

When the lobster has sucessfully aseaped from the egg capsule, and shaken itself free from its larval cuticle, it emerges as a fiee-swimming animal, rising to the surfare, where it remains until its pelagie nfe is over. A sketch of one of these young lobsters is represented in plate 19, and a lateral view is given in plate 20.

The animal is but little over a thrir of an mch long. The average length of 15 specimens was $7.84 \mathrm{~mm}$, the extremes being 7.50 and $8.03 \mathrm{~mm}$.

The body is segmented as in the adult form, the most striking characteristics being the euormons compound eyes, the conspienous rostral spine, the spatulate telson, and the biramous swimming appendages, which, from their resemblance to the permaneut swimming organs of the Schizopods, have given to this and the two succeeding forms the name of "Schizopod larve." Functional appentages are wanting only in the abdominal segments, where, however, very small buds of the adult swimmerets can be seen beneath the cuticle, in the secoud, third, fourth, and fifth abdominal somites.

The cuticle of the larval lobster is now as translucent as glass, and the organs of the body-the heart and blood vessels, the alimentary tract, and rudimentary gillsare seen with great clearuess. The green food yolk has disappeared entirely, or is reduced to a mere remnant, now more yellow than green, in the masticatory stomach. Perhaps the most conspicuous internal organ is the yellowish-brown liver, or gastric gland, the form of which ou either side of the body, resembles a cluster of grapes.

\section{VARIATIONS IN COLOR.}

The color of the larval lobster is produced, as we have already seen, by a bhe pigment dissolved in the blood plasma and by chromatophores which lie in the dermal layer of the skin, besides the pigment cells of the eyes. The distribution of the chro. matophores is very characteristic and it is to these that the brilliant colors of the larvæ are largely due. (See plate 19.) The pigment which they secrete is of two kinds, bright vermilion and yellow. The red cells are the larger and play the most prominent role. The expausion and contraction of the chromatophores, by which the animal becomes brightly colored or pale, ordinarily requires from ten to fifteen minutes when stimulated by pressure. The ehromatophores are distributed in the region of the carapace, along its sides, and in front of the cervical groove. When they are contracted the auimal is pale blue aud very translucent; when expanded the red cells give it a very decided color. Larva when struggling on the bottom to get free from their old cuticle or when crippled in any way are usually red, a commonly recognized symptom of weakness. This, however, does not seem to be an infallible sign. Larvæ which were placed in a pool out of doors on a bright day in June became red in a few hours while swimming at the surface in apparent vigor. (See p. 188.)

Both the blue pigment of the blood and the yellow and red pigment of the chromatophores are lipochromogens, which are couverted into lipochromes under the influence of alcohol and other reagents (sce pp. 135-136). The stomach and liver are sometimes bright red, which recalls an observation by MacMuun (132), who concluder from spectroscopic evidence that in the lobster (Homarus gammarus) the enterochlorophyll of the liver might be carried to the hypodermis and couverted into a liposhrome. 


\section{HABITS.}

The habits of young lobsters differ but little during the various "stages" of their free-swimming life, which is spent near the surface. Their pugnacious instinct is undoubtedly strongest immediately after hatching, when their activity in killing and devouring one another invariably attracts the notice of the spectator and forms an insurmountable barrier to raising them in small aquaria. Like the young of most pelagic organisms, they can not bear crowding, either in vertical or horizontal limits. As Weldon and Fowler (201) have remarked:

They must, if they are to thrive, have a large superficial range, as well as a considerable depth of water in which they may sink when such conditions as light and heat demand it.

In swimming the larvæ use both the exopodites of the thoracic limbs, by the beating movements of which they are impelled upward and forward, and the abdomen, by the contraction of which, with its broad telson-plate, they dart rapidly backward. Each thoracic limb consists of a short stalk, with two diverging branches, the outer branch, which serves as an oar, being flattened and fringed with long feathered hairs. The oars or exopodites work independently of the inner branches, which are mainly prehensile organs, and alone give rise to the adult limb. The exopodites atrophy and disappear completely after the fifth stage. In the common swimming or floating position at the surface the thorax is usually held in a horizontal position, with bent abdomen. In rising the head is inclined dowuward, often with the "tail" uppermost. When too weak to keep at the surface, they vacillate over the bottom, standing on their head, as if probing for food, which, however, is not the case.

The larvæ appear to be quite hardy under certain conditions. Thus I have kept them alive, and apparently healthy, in small flat dishes of sea water, without change, for from one to four days at a time, or until they molted to the second stage.

The time which elapses between two successive molts varies, as at all subsequent stages, with the supply of food and general condition of the animal. In the larvæ which I had under observation the first stage lasts from one to four or five days, the healthier ones molting in the shorter period.

\section{THE SECOND STAGE.}

All the larvæ of this stage which I have examined were raised from the egg. The average length in forty-seven cases was $9.2 \mathrm{~mm}$., the extremes being 8.3 to $10.2 \mathrm{~mm}$. It is evident that some of these were undersized, and the measurement of this stage given by Professor Smith, 10.6, is greater than any which I have observed. His specimens were all taken by the towing net, and if the number examined was sufficiently large it would indicate that under natural conditions a greater size is attained.

A profile view of the second larva is given in plate 21. This is drawn to the same scale as the first larva on plate 20 , and illustrates the increase in size effected at the second molt. All parts are now much larger, excepting the swimming thoracic appendages, which have grown but little. The swimmerets, visible as buds below the cuticle of the first larva, have now grown out on the second to fifth abdominal somites, and the rudiments of the last pair of appendages can be seen beneath the skin at the proximal end of the telson plate (fig. 102, plate 34 ).

The habits of the second larva differ in no respect from those of the first, and in color the two stages are very similar. In transparent larvæ, with contracted chroma- 
tophores, great variety may be produced by the color of the gastrie gland, which is often orange or some cast of yellow, and by the contents of the alimentary tract, which shows plainly throngh the body walls. Bright green pigment now appears for the tirst time upon the dorsal surface of the carapace and upon the tergal surfaces of the first five abdominal somites.

As in the first stage, the larva thrive only on one another when kept in close quar. ter's. I have often watched one of these larvie as it attacked another which appeared to be its equal in size and strength. The aggressive lobster usually tried to seize his fellow by the small of the back or between the carapace and abdomen, using for weapous the walking appendiges, chiefly the first three pairs. He was soon astride the back of his victim, and dragged him to the bottom of the jar, where he began to devour him.

The second larval stage lasts from two to five days.

THE THIRD STAGE.

The average length of the third larva in seventy-nine individuals examined was $11.1 \mathrm{~mm}$., the extremes being 10 to $12 \mathrm{~mm}$.

The third larva resembles the preceding stages very closely in habits. Strueturally, it differs but little from the second larva. (Compare plates 21 and 22 .) The outer branches of the thoracic legs are still the principal swimming orgaus. However, the last pair of abdominal appendages, which form the outer blades of the tail-fin, are ready for service, and the swimmerets are fringed with short setre. The large claws, which were already conspicuous, are relatively much larger.

COLOR.

The third larva resembles the preceding stages closely in color. When the chromatophores cluse the animal is quite pale, as was the case with one which 1 examined in the act of molting. As a rule, the color is enhanced by this stimulus. When this specimen was examined with the microscope it was seen that the red chromatophores were contracted so as to resemble small dots or stipple marks. The yellow pigment cells were more irregular.

When this transparent, almost colorless, larva is placed in a dish with others the contrast is very striking. The colored form, in which the pigment cells are expanded, is a rich, deep brown, varied with a vivid yellowish-green. The appendages are for the most part reddish-brown, excepting the terminal parts of the smaller ones, such as the exopodites and endopodites of the pleopods and the Hagella of the antenuie, which are bluish. The large chelie are in deep redilish-brown. The same color occurs sparingly on the sides of the carapace and ou the lateral and ventral surfaces of the abdomen. The hinder parts of the carapace are tou'hed with brigint yellowish-green, as are the third, fourth, and fifth terga of the abdomen. These intense metallic colors greatly resemble those of the fourth larva. In reflected light a whitish pigment is seen in the lateral eye, which is strongly iridescent, as in the earlier larvæ.

One larva (10.8 mm. long) has the thorax and upper half of the abdomen greenish. blue; abdomen reddish below; tail-fan rendish; red pigment cells occur on the appendages and on the sides of the branchiostegites, as in the earlier stages.

In another, examined in the act of molting, on July 3 , the colors were very bright. Especially noticeable were the metallic green spots on the fourth and tifth ablominal segiwents. 
Another larva (11 mm. Iong) has colors similar to the first just described: Large chele reddish-brown; lower half of the abdomen, caudal fan, and sixth abdominal segment of same color; carapace yellowish-green, rather less trausparent than in earlier stages; bright peacock-green with yellowish tinge on the terga of the fourth and fifth abdominal segments; considerable blue at the joints of the appendages (probably because the cuticle is here thimner) and in different parts of the body. It must be remembered that the transparency of the larva is now determined in an important degree by the greater or less time which has elapsed since the last molt-that is, by the greater or less proximity to the ecdysis which is to follow. The old cuticle becomes partially opaque as soon as any lime is deposited in it, which happens at about this period.

The third larval stage lasts from two to eight days.

\section{THE FOURTH STAGE.}

The young larva ${ }^{1}$ emerges from its fourth molt into a form which bears such a striking resemblance to the adult lobster that an intervening stage between this and the preceding was supposed to exist; but such is not the case. A dorsal view, colored to life, of one of these larvæ is represented by plate 23 . The swimming branches of its thoracic legs have been abruptly shed, or rather have been reduced to functionless stumps (plate 31, figs. 74,75). It still swims at the surface, with greater agility and speed than at any former stage, and is still virtually a larva, although it has the adult locomotor organs.

It swims rapidly forward by means of the swimmerets, and darts backward with quick jerks of the abdomen, "frequently jumping out of the water in this way," as Professor Smith says, "like shrimp, which their movements in the water much resemble" (182). As they move forward they hold the large chela extended straight in front of the head; when disturbed they raise the chelæe to defend themselves like an adult lobster.

It has the larval rostrum and the large antennal scale or exopodite, and the first abdominal somite is without trace of appendages.

The average length of 64 larvæ was $12.6 \mathrm{~mm}$., or about half an inch, the extremes being 11 and $14 \mathrm{~mm}$.

COLOR.

The range of variation in color is now very great. A typical color pattern is represented in plate 23. Occasionally, even at this period, a larva is very light-colored and its trausparency is nearly equal to that of the third larva.

The cast of color may be (1) yellow and red; (2) red; (3) green; (4) green and reddish-brown. In the first case the carapace is light yellow, translucent, and sprinkled with red chromatophores. The abdomen and large chelie are reddish-brown, and there is a quadrilateral yellowish-green area on the terga of the fourth and fifth abdominal segments. In the red individuals the animal is bright red, especially on the abdomen and large chelæ. The carapace is yellowish, spotted with red, and the abdomen is marked in the way just described. In the green variation, the whole animal is bright

The use of the word "larva" for the fourth and fifth stages is not without objection, but it is perhaps better than the phrase "adult-like form." It is very probable, as I have shown, that the foung lobster may remain at the surface of the ocean, even after the sixth molt. It will be nost convenient, however, to define the larval period of the animal by the duration of its pelagic life, which is practically at a close by the end of the fifth stage. 
green. Bright yellow-green areas are noticeable on the ablominal terga as before, and upon the hinder portion of the carapace. There is some brown pigment on the large chelo and tail-fan. In the fourth variety (fig. 36), the abdomen and chelse are rich reddish-brown, with light peacock-green on the terga of the abdominal rings, as is commonly seen, and on the carapace next to the abdomen. The rest of the carapace is greenish-brown. In this and all earlier stages the color of the carapace is partly due to that of the interual organs, especially to the alimentary tract and gastric glands.

The following notes illustrate the changes which individual larva undergo, with reference to molting and surrounding conditions. A fourth larva raised from the egg, when examined on July 13, was decidedily bluish. The whole animal was quite trans. lucent, the heart and yellowish "liver" showing plainly through the shell. The claws and body were sky-blue, due, as in the first larva, to the blood pigment. The brown and yellow chromatophores were contracter to such an extent as to have no appreciable effect upon the general color pattern. Two days later the carapace was grenish and the chelre dark brown. On July 17 the colors were deeper; on the 19th the general cast of color was dark bluish-green; reddish-brown on the abdomen and chelæ. On July 21, when the animal was nearly ready to molt, the carapare was bluish-green, the abdomen and chelæe brownish-red. Four days later. July 25, this animal molted to the fifth stage. The fifth larva was dark olive, tinged with brown on the abdomen and chelat.

A larva which molted July 11 to the fourth stage was pale, and apparently almost devoid of pigment. The internal organs were plainly visible. There was a delicate wash of brown on the abdomen, tail-fan, and chelæe. The microscope showed that the closed chromatophores were very small.

Another larva, $13.1 \mathrm{~mm}$. long, which was raised from the egg, had on July 6 the usual mixture of brown and green pigments. On July 15 the animal was very dark brown, excepting the carapace, which had a metallic green Iuster. The large chelse are tipped with white or cream color, and there is a large light patch on the outer side of the hinder end of the exopodite of the uropod. Fainter and smaller whitish areas oceur on the plenra of the first abdominal ring. This larva molted about August 3 to the fifth stage; color, reddish-brown.

Rarely is a larva seen which is reddish-orange, the blue and brown pigments being almost completely obseured. The pigments of the eye are similar to those of the earlier stages.

In a larva of $14 \mathrm{~mm}$. long, observed July 25 , the carapace was of the usual greenishbrown cast, with three light-greenish spots ou each side-a very small spot behind the eye, a smaller one below this, and a larger oue farther back below the cervical groove. These are the first traces of very characteristic areas, which I shall call "tendon marks," upon the skeleton of all later stages, and mark the places where certain muscles are attached to the integument. The siguificance of these color changes will be considered later on. (See p. 135.)

A fourth larva, which was caught at the surface near the Fish Commission wharf on a very bright day (July 25, 1891), was similar in color to some of those already described. The thorax was green, brightest posteriorly; the chelie and abdomen dark redlish-brown; a brilliant light-green area appeared on the tergum of the third and fourth abdominal segments.

On August 10 I examined a number of lobsters in the fourth, fifth, and sixth stages, which had been kept in glass, jars and fed upon meat. Many of these were so 
completely covered with foreign matter that they could hardly swim, some lying upon their backs on the bottom of the aquarium. Colonies of zoothamnium-like protozoa were clustered over all their appendages. The setæe were loaded with sediment filled with bacteria, diatoms, and infusoria. This illustrates the fate which awaits the larvæ of all crustacea, when crowded in small aquaria.

The fourth larval stage lasted (in the average of nine individuals, which were raised from the egg) 13 days and varied from 10 to 19 days.

THE FIFTH STAGE.

In fifteen individuals known to have molted five times, the average length was $14.2 \mathrm{~mm}$., and the extremes 13.4 and $15 \mathrm{~mm}$.

There are no external marks by which the fifth stage can be distinguished from the fourth or even from the sixth stage with any degree of precision, at least by the unaided eye (fig. 31, plate 18). Neither the size nor color changes can be invariably relied upon. Microscopical examination, however, shows that the rudiments of the swimming exopodites, which could be readily detected in the fourth larva, have now become still more reduced, while in the sixth stage they have completely disappeared.

The following notes illustrate the changes of color which are observed in larvæ passing from the fourth to the fifth and sixth stages. On July 7 a fourth larva (No. 35, table 34) showed the typical colors, reddish-brown and various tints of green. When observed eight days later the color was dark maroon. The fifth molt occurred about July 17 (length, $14.8 \mathrm{~mm}$.). The color was then greenish-brown; the large chelæ reddish-brown, tipped with cream color, most marked upon the propodi. As in some fourth larvæ, there is a terminal light spot on the exopodite of the uropod. Faint light spots are also seen on the sides of the abdominal segments. There are, moreover, two very prominent, white, discoidal areas on the carapace corresponding to the insertions of muscles, as already pointed out.

The following measurements of this larva will give a clearer idea of the length of some of the parts and of their increase after the molt:

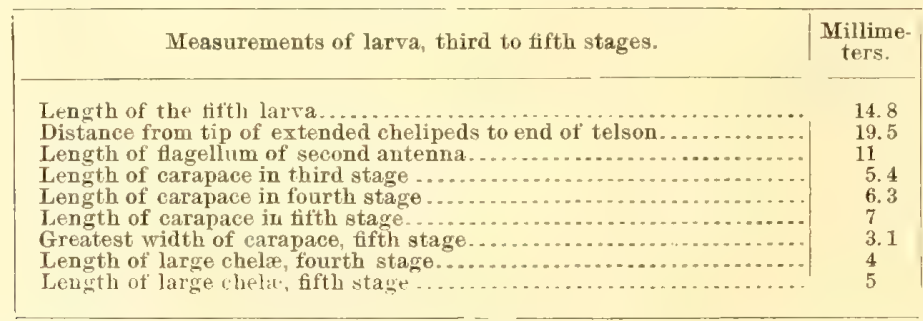

Another larva raised from the third stage (No. 12, table 34) is olive-green, with the characteristic white marks very faint on the carapace. The large chelæ are yellowish-green, due to the presence of blue and yellow chromatophores.

In the case of a fifth larva reared in an aquarium the colors resemble those of the sixth stage, represented in plate 25 . The white spots on the carapace have the disposition shown in fig. 37 , plate 24 . The third pair of maxillipeds are tipped with white.

No noticeable differentiation can be detected in the large claws unless occasioned by loss and subsequent growth or by injury to one of the members. It often happens 


\section{'ut stayfs.}

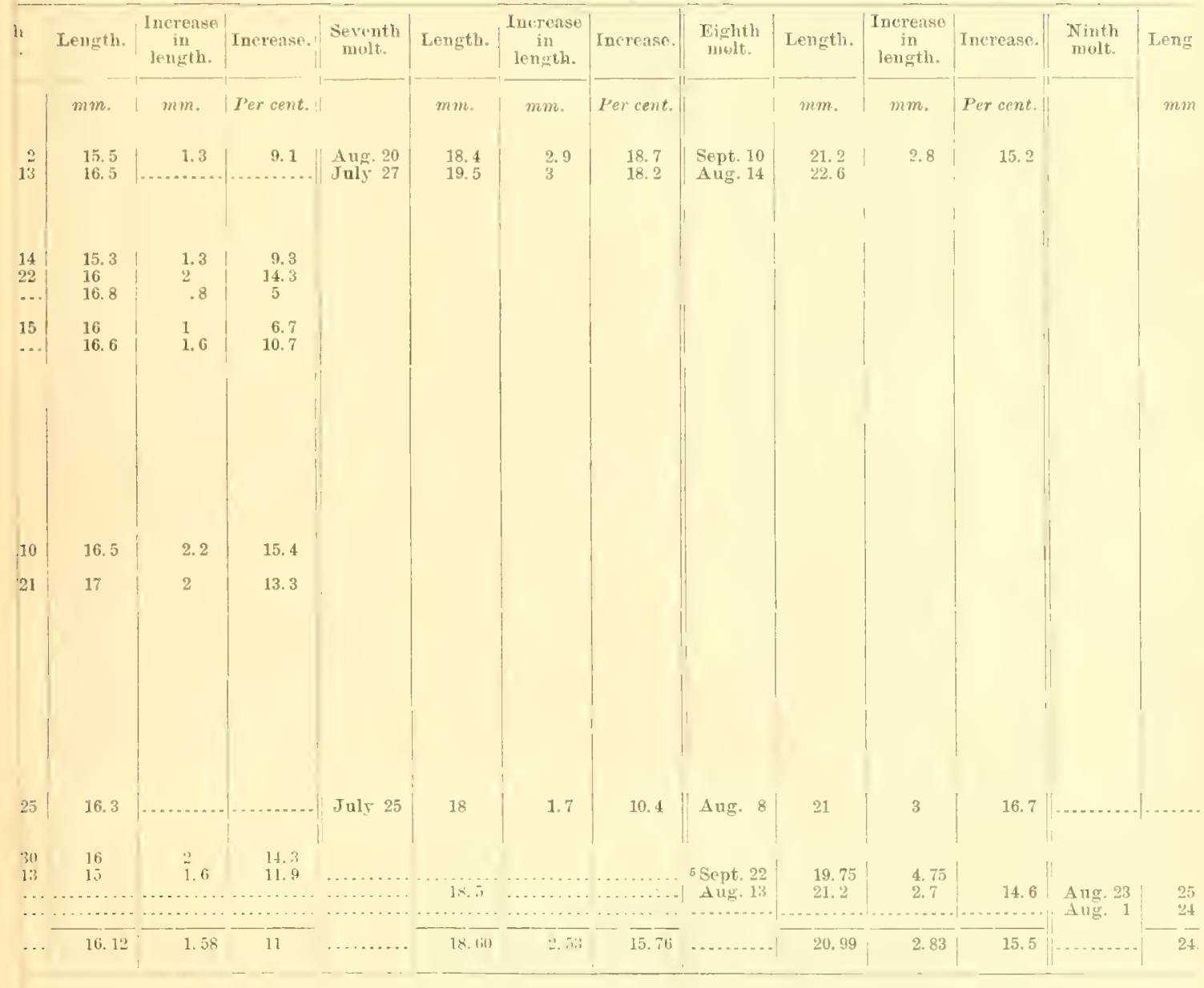



TABLE 34.-Record of molts of larval and adolescent stages.

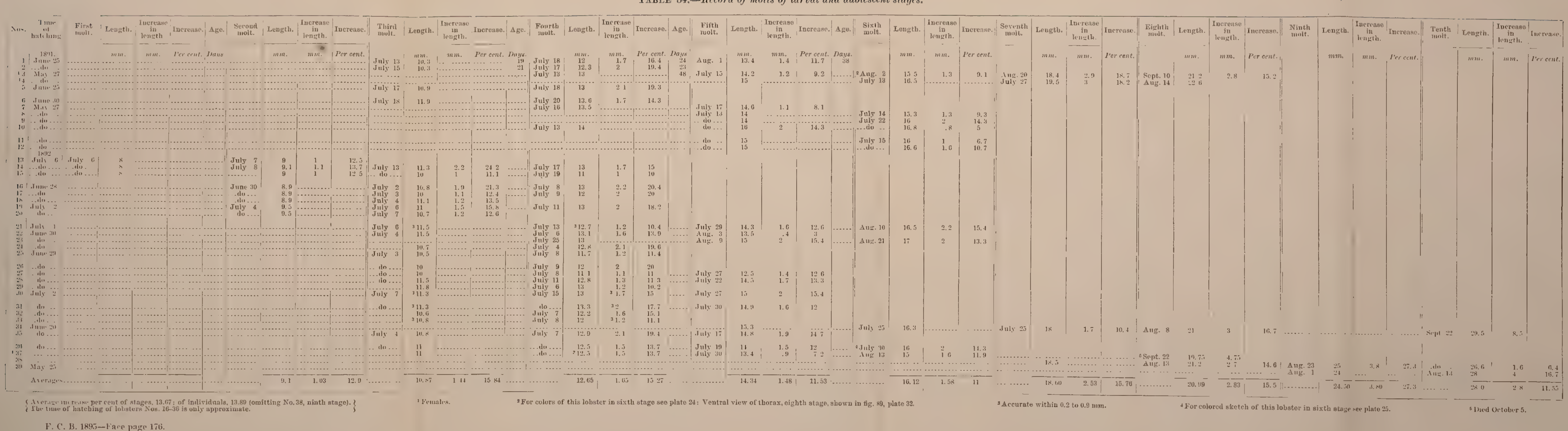



that the dacty! is bent upward as much as forty degroes away from the propodus, so that the cutting edges meet but imperfectly.

Larva No. 36, table 34, was nearly ready to molt to the fifth stage on July 17 . It was of an opaque greenish-brown color, the claws deep brown. The carapace had a duil, bluish luster when strong light was reflected from it, a well-recognized mark of the molting state.

Two days later it was in the fifth stage. The carapace and upper surfaces of the abdomen were now greenish brown. The white tendon mark on the side of the carapace below the cervical groove was very prominent. The light areas on the first abdominal ring and upon the uropods were rather faint, and the chela, as usual, were tipped with cream color.

The remarkable "death-feigning habit," which I shall diseuss later, was developed in this larva to an unusual degree. I coloned drawing of this lobster after the sixth molt, which occurred about $\mathbf{J u l y} 30$, is represented in plate 25.

The fifth larval stage lasted in five observed cases from 11 to 18 days.

FHE SIXTH STAGE.

The average length of five lobsters known to have molted six times was $16 \mathrm{~mm}_{\text {. }}$, the extremes being 15 and $17 \mathrm{~mm}$.

I have already referred to the color of this stage, which is represented in an individual raised from the egg on plate 25. The general cast of color of the upper parts is often dark green or greenish-brown, and the "tendon-marks" on the carapace have now become rery conspicnous. Equally characteristic are the snow-white pleura of the first abdominal ring.

A dorsal view of another lobster of this stage is given on plate 24. The coloring is from the sixth stage of larva No. 3, table 34. The whole animal is of a reddish. chocolate color, agaiust which the white spots contrast very sharply. In the cervical groove there is a narrow transverse white area, a large white spot on the distal extremity of the meros of the cheliped, in addition to those already mentioned and the flattened rostrum is conspicuous for its absence of color, being but faintly tinger with green.

A young lobster captured with the tow net in Woods Hole Harbor in the daytime, August 23, 1890, resembles the sixth stage, already described. The length of the lobster was $16.5 \mathrm{~mm}$. (For record of the capture of other lobster's in sixth stage, see table on p. 187.)

The individual color-changes which these lobster's undergo were well illustrated in a specimen, $16 \mathrm{~mm}$. long, captured in the net July 34,1890 . When first taken it was bright bluish-green, excepting a slight amount of brownish pigment visible on some of the appendages. This lobster was accidentally left over night in a glass dish of water on my work-table. In the morning it had a decided reddish-brown color and was very weak. One is reminded of the similar but more striking ehange in color which the remarkable little lizard Anolis princeps, of the Southeru States, undergoes when it is suddenly stimulated.

Larva have also been captured in the tow, from 15 to $16 \mathrm{~mm}$. long, which resembled more nearly the fourth stage in color, but undoubtedly belouged to the fifth and sixth stages.

$$
\text { F. C. B. 1895-12 }
$$


A young lobster about six weeks old, raised from the egg, and probably in the sixth stage, was light brownish-olive on the upper surface, the chelæ being more decidedly brown. The under surface of the body was almost colorless. The usual cream-colored or white spots occurred on the carapace and appendages and the terminal spines of the abdominal pleura were whitish. The large claws, which show no special differentiation, are held together in front of the animal as it swims forward. When suddenly disturbed, the young lobster opens its elaws, spreads wide its armlike chelipeds, at the same time raising itself into a threatening attitude, ready to receive or strike a blow. The iridescent pigment of the eyes is no longer visible. Some measurements of parts of this lobster are as follows:

\begin{tabular}{|c|c|}
\hline Areasurements. & $\begin{array}{l}\text { Millime } \\
\text { ters. }\end{array}$ \\
\hline 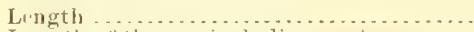 & \\
\hline Lendth of thoras, ineluding rostrum. & 8 \\
\hline Greatest width of thorax............. & 4 \\
\hline Leneth of antemnary flagellum....... & 11 \\
\hline Length of propodus of large chela.... & 5.5 \\
\hline
\end{tabular}

Lobsters in the fifth stage, which are raised in aquaria, swim less at the surface than in preceding stages, going frequently to the bottom of the jars for their food, and it is during this and partly in the sixth stage that the pelagic life of the lobster comes to an end. It then sinks to the bottom and leads an entirely new life. Its larval characters have completely disappeared, and buds of the modified appendages of the first abdominal segment have begun to grow out. In locomotion and general habits it resembles the adult animal closely, but the final adult condition is only attained after a loug series of molts, which require, in all probability, from four to five years.

The sixth stage lasted (in three cases observed) 9, 14, and 18 days, respectively.

SEVENTH STAGE.

The seventh stage can not be distinguished by any known characteristics from that which immediately precedes and follows. Unless one has wateher and recorded the molts, it is impossible to say at this or a later period through just how many ecdyses the animal has actually passed. The larval stages merge insensibly into those of the adolescent period, and these pass as gradually into those of the adult, so it will be more profitable to follow the history of individual lobsters from this period onward rather than to attempt to describe stages which have no marked distinguishing characters.

In table 34 I have recorded the molts of thirty-nine young lobsters raised during the summers of 1891 and 1892. The increase at each ecdysis and the increase per cent (that is, the ratio between the actual increase and the former length) are also given. Many of the adolescent lobsters, which it should be understood are the remnant of a much larger number which I attempted to raise, died shortly after the last recorded molt. Some, however, were living when I was obliged to leave Woods Hole, at the middle or latter part of August, and doubtless could have been reared had they received the necessary care. The life-history, as illustrated in table 34, has been followed from the time of hatching to the tenth stage or ecdysis, when the animal is over an inch long and about three months old.

We have considered in detail at the close of Chapter III the bearings of these observations upon the rate of growth in the lobster. 


\section{DESCRIPTION OF SMALL LOBSTERS}

The number of molts or the rapidity of growth is a question which now assumes special interest and, as I shall eventually show, it is subject to considerable individual variation.

Two young lobsters after the seveuth molt measured 18.4 and $19.5 \mathrm{~mm}$. (Nos. 1, 2, table 35 ) and remained in this stage 21 and 18 days respectively.

Lobster No. 1 (table 35). - The first of these was raised from the fourth stage. Its color in the sixth stage is represented on plate 24. The animal after the seventh molt was light brown, tinged with green, when observed on Angust 20. It exhibited the "death-feigniug habit" in a very marked degree. This lobster molted for the eighth time on September 10, and died the day following, when it measured $21.2 \mathrm{~mm}$. It was hatched about May 27, and was therefore 107 days old.

Lobster No. 2 (table 35). - This young female lobster had just molted when first examined on July 13, and was then withont doubt in the sixth stage. In color it closely resembled fig. 37 , plate 24 . It molted for the seventh time on July 27 , when it attained a length of $19.5 \mathrm{~mm}$. The color at this time was but little changed, being a deep chocolate above, with the tendon marks on the carapace equally prominent.

The triangular rostrum is somewhat narrower. The "finger" of the large claw and the outer branch of the tail-fan are cream-colored. The latter, as in the sixth stage, carries a very long fringe of set:e, which becomes characteristic of the adolescent period. These setre are about two-thirds the length of the uropod. The left cheliped, which was thrown off at the time of the sixth molt, had grown ont again, so that after the seventh eedysis the length of the new appendage was about seven-tenths of that on the opposite side. The length of the right chela was $6.5 \mathrm{~mm}$.; of the left, $4.5 \mathrm{~mm}$.

The stalked eyes are now very large and continue to grow relatively faster than the rest of the body until they attain great prominence in the adolescent stages, as already described.

The first pair of abdominal appendages are present as small buds, and after the next molt their size is not greatly increased.

After the eighth molt (August 14, length $22.6 \mathrm{~mm}$.) there was but little noticeable change in color. The general cast is still brown, with a bluish green tinge on the carapace. The length of the fringing setæ of tail fan- $1 \frac{1}{2} \mathrm{~mm}$.-nearly equals that of the telson. The median sternal spines are present on the second to fifth abdominal somites, and have a bluish color.

Lobster No. 3 (table 35).-This young female lobster was raised from the egg and placed under observation when in the third stage, July 4, 1892. At this time it was $11 \mathrm{~mm}$. long. It molted to the sixth stage ou August 13, and when I finally left Woous Hole on the 23d of this mouth there had been no notew orthy change. When examined on September 22, by Dr. E. A. Andrews, it had attained the length of $19.65 \mathrm{~mm}$. It is therefore highly probable that only one intervening molt had ocenred and that this happened late in August or early in the following month. It died before another ectysis, on the 5th of October, when it was about 105 days old, having molted eight times.

Lobster No. 4 (table 35).-When this lobster came under systematic observation, on the 25th of July, it was in the sixth stage and $16.3 \mathrm{~mm}$ long. Au account of its ecdyses, which were carefully watched, one occurring on that very day while in a dish upon my table, will be given in another place. (See p. 183.) 
Before molting the animal was of a dark umber color and very sluggish. Immediately after this ecdysis (the seventh in number) the whole body was translucent, the general color being reddish-brown, with a slight greenish tinge on the carapace. The large claws were a bright terra-cotta color. There was a prominent whitish crescentic spotimmediately behind the cervical groove and the three characteristic tendon marks on each side of the carapace were as prominent as in the sixth stage. (Compare plate 24.) The pleura of the first abdominal somite were snow-white, and the uropods of the tail-fan were tipped with cream color.

The lobster after the seventh molt keeps steadily upon the bottom, in walking over which it uses chiefly the last three pairs of thoracic legs. The large claws and smaller chelate legs next to them are extender forward in front of the head, although the latter appendages are occasionally used for locomotion. A very slight differentiation in the large chelæ is noticed, but in the eighth stage the difference is marked. At about the time of the seventh ecdysis the right antennary flagellum was lost; eight days later it appeared, in the process of regeneration, as a short spiral coil; this continued to grow, and after the eighth molt, which occurred on the 8th of August-an interval of two weeks from the last-it was about its normal size.

At the seventh stage pigment has been deposited below the enamel layer of the cuticle in an amount which, though at first very slight, increases with every molt, and the color pattern becomes more and more complex. In the eighth stage the general color is deep reddish-brown, with olive tints. The characteristic tendon marks and cream-colored spots are present. There is a dorsal light-green mediau stripe on the carapace, very much narrower than when first seen in the fourth stage.

This lobster had undergone no appreciable change by the 23d of August, but when next examined, September 22, it measured $29.5 \mathrm{~mm}$. In the interval of thirty days it had undoubtedly molted twice and was in the tenth stage. The first abdominal somite has very delicate, white appendages, which are distinctly two-jointed and raised from the surface to a nearly vertical position.

Lobster No. 5 (table 35).-This lobster was hatched about May 25, and when isolated, on August 1, it measured $24 \mathrm{~mm}$. It was probably in the ninth stage and was about 67 days old. The general color was dark green, touched with brown; large chelæ olive-brown, reddening toward the extremities, with glistening white tips; the under side was a tint lighter. The uropods and telson are whitish, bordered with reddish-brown. The contents of the intestine can be seen through the slightly transIucent shell. Tendon marks on the carapace are prominent, as in the other cases described.

Some measurements of this lobster are as follows:

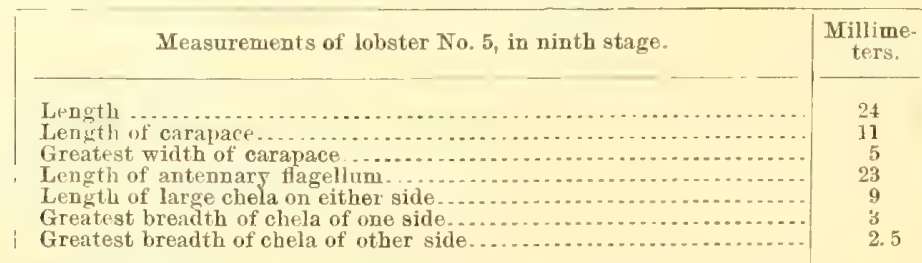

In the smaller of the two claws the extremities are nearly straight; in the larger the "fingers" are more bent, and each bears a large tubercle at about the middle of the occludent margius. 
The animal hides among the stones at the bottom of the aquariun, and behaves in most respects like an adult animal. The eyes are dull brownish-black, without iridescence.

When examined again on Angust 13 this lobster had molted, now for the tenth time, and was $28 \mathrm{~mm}$. long. The general color was dark brownish-green, with reddish-brown on the large chelipeds, as before. The white or light color of the pleura of the first abdominal segment and tail-fan is obseured or has disapperred. The shell pigments are now more abundant, and the cuticle has lost its translucency in consequence.

The following measurements illustrate the growth of some of the parts:

\begin{tabular}{|c|c|c|c|}
\hline $\begin{array}{l}\text { Measurements of lobster No, 5, in tenth } \\
\text { stage. }\end{array}$ & $\begin{array}{l}\text { Millime- } \\
\text { ters. }\end{array}$ & $\begin{array}{c}\text { Measurements of lobster No.5, in tenth } \\
\text { stage. }\end{array}$ & $\begin{array}{l}\text { Millime } \\
\text { ters. }\end{array}$ \\
\hline Length.. & 28 & Length of cutting chela. & 11 \\
\hline Length of carap & 13 & Greatest breadth of eutting che & 3 \\
\hline Greatest width of carapa & 6.4 & Leugth of dactyl of cutting chela. & 5. 7 \\
\hline Length from tips of extended cheli- & & Length of telson .................... & 4 \\
\hline peds to end of telson. . . . & 34 & Breadth of telson & 3.3 \\
\hline Length of antennary Hagellum. & 25 & Length of terminal fringe of bairs. & 2 \\
\hline Length of antemnal exe & 5.5 & Greatest width of abdomen at second & \\
\hline Length of er & 10.5 & somite $\ldots \ldots$ & 5 \\
\hline Greatest breadth of crushing chela... & 3.5 & Length of rostrum. . . . . . . . . . . & 4 \\
\hline Length of dactyl of crushing chela... & 5 & Breadth of rostrum at base ... & 2 \\
\hline
\end{tabular}

Lobster No. 6 (table 35). - This was the only survivor out of a considerable number of lobsters hatehed early in the season of 1892, and when first examined-about the first week in August-measured $18.5 \mathrm{~mm}$., and was probably in the seventh stage. At this time a slight difference in the large claws could be detected, which increased with subsequent molts. There is nothing noteworthy in which this young lobster differed from those already described. (See No. 38, table 34.)

Lobster No. 1 (table 33). - I have referred to this young female lobster, which was hatched about June 20, 1893, and was alive when I left Woods Hole, August 6, 1894. It was therefore 412 days old, and allowing it to have attainerl the length of $28 \mathrm{~mm}$. at the tenth molt-the average length of three individuals known to have reached this stage-it must have molted thirteen times, which I am confident is not far from the truth. It is probable that no molts occurred during the winter, the last two recorded having taken place May 21 and June 18, 1894.

The brilliant color is now wholly due to the pigments of the shell, which is no longer transparent, and the color pattern is so complicated that it almost baftles (leserip)tion. The body is light umber, freely speckled and mottled with darker shades. The appendages are redilish-brown and slightly trausluecht. Small light areas or suffusions are scattered over the body. The tendon marks on the carapace corresponding to those seen in the fifth and sixth stages are prominent, that below the cervical groove being over a millimeter in diameter. The pleura of the first abdominal ring are snowy white. The free edges of the segments of the body and appendages are bright blue. The large chelæ are tipped with white. The openings of the oviducts are clearly seen and the copulatory pouch is not yet elosed. The color of the appendages on the under side is light reddish-brown. The tail-fan is of the same hue edged with deep red. The elaws, which are tufted with setse at their tips, show remarkably little differentiation. The eyes have a dark-purplish pigment and have acquired the characteristic large size and prominence of the adolescent stages. 
The following measurements show the proportions of some of the parts:

\begin{tabular}{|c|c|c|c|}
\hline Measurements. & $\begin{array}{c}\text { Millime- } \\
\text { ter's. }\end{array}$ & Measurements. & $\begin{array}{l}\text { Millime- } \\
\text { ters. }\end{array}$ \\
\hline 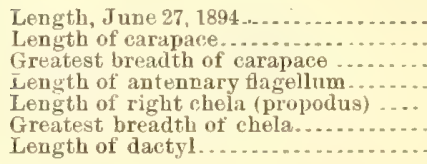 & $\begin{array}{l}36 \\
16.5 \\
7.9 \\
33 \\
13.5 \\
4 \\
7\end{array}$ & 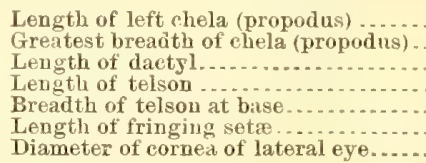 & $\begin{array}{l}13 \\
3.6 \\
7.8 \\
5 \\
4.1 \\
2 \\
2\end{array}$ \\
\hline
\end{tabular}

This lobster was kept in a small glass aquarium, and fed with clams and with lobster and cod eggs. It was undoubtedly undersized for its age, having molted about tifteen times.

The three lobsters raised in 1886 , which on December 10 measured $35,36.3$, and $51.8 \mathrm{~mm}$., respectively (Nos. 7, 8, 9, table 35), had probably molted twelve times in the first two instances and fifteen times in the last.

Lobster No. 10 (table 35).-When this young lobster was brought up accidentally on a lobster pot in Woods Hole Harbor July 18, 1891, it measured only $47 \mathrm{~mm}$. (See colored drawing, plate 26.) If it was hatched in the summer season it must have been a little over a year old, and it is very probable that in this case also there had been fifteen molts.

The youngest lobsters taken in Casco Bay, Maine, October, 1893 (Nos. 1, 2, table 32 , were doubtless hatched in the previous June, and were therefore about 16 weeks old. They had probably passed from thirteen to fourteen molts.

It is, therefore, clear that the young lobster varies very considerably in its rate of growth, whether under artificial or natural conditions. In a state of nature the young lobsters hatched in June are probably from 2 to 3 inches long when 1 year old. (See pp. 96-99.)

I will now add a tabular statement of the successive molts of the adolescent lobsters, whose development has just been considered. Further details of their history are given in table 34 .

TABLE 35.-Successive molts of young lobsters and their measurements in millimeters.

\begin{tabular}{|c|c|c|c|c|c|c|c|c|c|c|c|c|c|c|c|c|c|}
\hline \multirow{2}{*}{ No, of lobster. } & \multicolumn{15}{|c|}{ Number of molt. } & \multirow{2}{*}{$\begin{array}{l}\text { Date of } \\
\text { last } \\
\text { measure- } \\
\text { ment. }\end{array}$} & \multirow{2}{*}{$\begin{array}{l}\text { Age in } \\
\text { days. }\end{array}$} \\
\hline & 1 & 2 & 3 & 4 & 5 & 6 & 7 & 8 & 9 & 10 & 11 & 12 & 13 & 14 & 15 & & \\
\hline 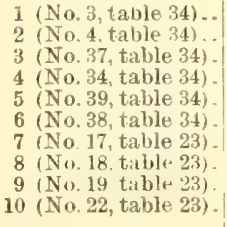 & |- & ... & 11 & $\begin{array}{l}15 \\
12.5 \\
\cdots \ldots\end{array}$ & $\begin{array}{l}14.2 \\
13.4 \\
\ldots \ldots\end{array}$ & $\begin{array}{l}15.5 \\
16.5 \\
15 \\
16.3 \\
\ldots \ldots\end{array}$ & $\begin{array}{c}18.4 \\
19.5 \\
217.05 \\
18 \\
18.5\end{array}$ & $\begin{array}{l}21.2 \\
22.6 \\
19.75 \\
21 \\
21.2\end{array}$ & $\mid \begin{array}{r}\cdots \\
\cdots \\
225 \\
24 \\
25\end{array}$ & $\begin{array}{l}29.5 \\
28 \\
26.6 \\
\cdots \ldots . . \\
\cdots \ldots . .\end{array}$ & & $\begin{array}{l}235 \\
236.3 \\
\ldots . . .\end{array}$ & $\begin{array}{c}\cdots \\
\cdots \\
\cdots\end{array}$ & $\begin{array}{l}\cdots \\
\cdots \\
\cdots \\
\cdots \\
\cdots \\
\cdots \\
\cdots \\
\cdots \\
\cdots \\
\cdots\end{array}$ & 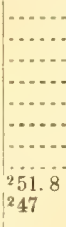 & $\begin{array}{l}\text { Sept. } 11 \\
\text { Aug. } 14 \\
\text { Oct. } 5 \\
\text { Sept. } 22 \\
\text { Aug. } 13 \\
\text { Sept. } 22 \\
\text { Dec. } 10 \\
\text { Jlo..... } \\
\text { July } 18\end{array}$ & $\begin{array}{r}107 \\
79 \\
105 \\
94 \\
80 \\
294 \\
2173 \\
2173 \\
2173 \\
2390\end{array}$ \\
\hline
\end{tabular}

1 Approximate.

2 Number of molts, length, or age estimated.

THE MOLTING OF THE EMBRYO AND LARVA.

The first cuticular structure formed in the egg is a delicate blastodermic rembrane, which appears in the later stages of yolk segmentation and has often been erroneously considered to belong primarily to the ovum. It becomes so firmly glued 
to the primary egg-membrane that any attempt at its removal almost inevitably results in stripping off the blastoderm with it. It is, however, soon absorbed, or at least detacher, so that in the early egg-nauplius stages the shelling of the egg is quite au easy matter, yet when the egg-nauplius is fully developed the inuer layer of the capsule invariably sticks to the tips of the antennr, which are usually torn off with its complete remoral.

At a stage closely following the egg-namplins the embryo is inclosed by three distinct membranes. I think it probable that the delicate inner cuticle, which can now be removed by the aid of hot water without injury to the parts, is a distinct structure from the blastodermic membrane just mentioned. The appendages at this time are gloved with a cuticular molt, evidently distinct from that which comes off with the egg. capsule when the animal is hatched. When eye pigment is formed these envelopes are very easily demonstrated, as seen in cut 20, plate F, where they have been distended by the prolonged action of picro-sulphuric acid. Up to this time it is therefore probable that at least three embryonic molts have occurred. Others follow during the long embryonic life, and, as I have already shown, when the animal is about to hateh it is inclosed in a cuticular molt which must be shed before it can enter upon its larval career.

In the second molt, preceding the second larval stage, the delicate shell is cast entire, the only break being, as in the later stages, along the margins of the inuer fold of the carapace-that is, in the epimeral region of the branchial cavities and next the abdomen. The shed cuticula is transparent, colorless, and flexible, and contains little ol no lime. The abdomen is usually withdrawn last, as is the case in adult life.

The cast shell at the fourth molt, which precedes the fourth stage, contains a little lime, but no pigment. The fifth ecdysis, which ushers in the fifth stage, is more noteworthy. A larva of this period molted in a glass dish on my table in the forenoon of July 13, 1892, and was soon attacked by others in the dish and killed. The carapace is gradually elevated from behind, and the animal escapes throngh the opening thus formed. The calcareous shell, which is of a beautiful light-blue color, retains its shape perfectly. The carapace, as early as the fourth stage, has a characteristic areolation (see figs. 113 and 115, plate 35) and is covered with short setre. There is a wide median stripe or band of absorption which branches into the cervical groove ou either side and widens at the rostrum. The carapace can be easily split along this thin unpigmented area.

The ecdysis of a lobster in the sixth stage, the color of which has already been described (No. 34, table 34), was observed under similar eircumstances. On the 8th of August this lobster molted again while I was watching it. At about 9.30 a. m., when first examiued, the abdomen was drawn away from the thorax, showing a distended pink membrane which connects these parts of the shell. Fifteen minutes later the carapace was elevated, the pressure of the inclosed body swelling ont the membranes slowly. At 10.24 a. m. the young lobster turned over on its side and in three minutes was out of its shell, about an hour having elapsed from the moment when the process, already begun, was observed. The eyes and cephalo-thoracic appendages are withdrawn first, and when these are free the animal slips away from the old shell, the abdomen coming out last, as in the arlult lobster.

The color of the cast shell is blue, with some green and brown pigment on the tergal surfaces. Pigment is now gradually deposited in the outer calcified layer of the 
shell, which soon becomes wholly responsible for the color of the animal. The dorsal median stripe of the carapace is much narrower than when first observed in the fourth stage (fig. 115), and the areas of absorption of lime salts from the lower segments (meros and ischium) of the large chelipeds are clearly outlined. The molting and growth of the adult animal are fully discussed in Chapter III.

\section{COLOR VARIATIONS IN THE YOUNG LOBSTER.}

In the description of the larval stages just given I have purposely dwelt upon the color changes which the young animal undergoes. This is intended to supplement the previous observations upon the color variations of the adult. To sum up these detailed accounts, we find that the color of the first four larval stages is subject to considerable individual variation, due to the transpareney of the shell and the contractility of the chromatophores which lie beneath it. In the first larva the pigment cells are relatively few, and respond to the slightest stimulus. With the growth of the animal they become very numerous, more differentiated, and so commingled that a very varied color pattern results. It is probable that in these stages their chief rôle is a physiological one. A transparent and almost colorless larva swimming at the surface of the ocean would undoubtedly be safer than a brilliantly colored one, but the indiscriminate destruction of these larvæ is so great, both on the part of animate ${ }^{1}$ and inanimate foes, that such protection would count for little. That it really counts for nothing $1 \mathrm{~s}$ shown by the fact that the fourth larva (also a pelagie animal) is almost invariably richly colored and is far more conspicuous at the surface than it would be if colorless. Again, it is not likely that larvæ know any such thing as fear, and the chromatophores appear to expand under any unusual stimulus.

The color variations of the larva are the expression of physical and chemical changes taking place in the body, as the result, for the most part, of physiological conditions. Some of these changes are sudden or discontiumous, and have no adaptive or protective significance.

After the fourth molt pigment begins to appear in the chitinous shell and a complicated color pattern is gradually produced which, as I have already shown, has, in all probability, a protective value. This happens when the young animal has given up its pelagic life and lives upon the sea bottom, having essentially the characters of the full-grown mature form.

The color variations of the adult are discussed in Chapter vIII.

\section{THE DEATH-FEIGNING HABIT.}

It was a matter of no little surprise to find that young lobsters in the fourth and fifth stages sometimes exhibit in a striking degree the remarkable phenomenon known as "feigning death." It is not strictly a habit, since it does not appear in all larvæ. Some display it upon the least provocation, the greater number but seldom or not at all. I have observed the same thing in a lobster over a year old, but have seen no trace of it in the adult.

A young lobster to which I have already referred (No. 36, table 34) when examined two days after the fifth molt showed this peculiarity in a typical way. When stroked lightly with the finger it would immediately stiffen, and lie stretched ont at the bottom

' Such as herring, mackerel, and menhaden, which from their peculiar habits of straining wate for food can hardly fail to be great destroyers of crustacean larvæ. (See note ou menhaden, p. 122.) 
of the dish, on its side or back, as if paralyzed. Its appearance is now, however, very different from that of a dead animal. The large chelipeds are stretehen forward in front of the head, and tho other thoracie legs are drawn after them and held close together with their tips pointing forward. It usually remained in this position from a quarter of a minute to a minute, when it would slowly orient itself and begin to move about, in a short time becoming very active. This lobster on one occasion remained in this stiffened, apparently paralyzed condition for the space of eight minutes, and would have continned in it a longer time still had it not been aroused.

While lying at the bottom of the dish in this state, a convulsive movement of the swimmerets was detected and a twitching of varions muscles over the body. The appendages sometimes quivered, as if the muscles were in tetanic contraction. The chelipeds and other walking legs remained perfectly rigid. When the animal finally recovered, the thoracic appendages were gradually relaxed and, putting itself in a defensive attitude, it slowly swam off.

If water is squirted at it with a pipette it will sometimes roll over and immediately straighten out as if dead. When disturbed and treated roughly with the finger or a penholder, it stiffens in the same way; the abdomen is bent up slightly; all the appendages are straightened out; the swimmerets are beut backward and can be seen to quiver; the beating of the scaphognathite does not cease.

I have no doubt that this phenomenon is strictly analogous to the "shamming death" of insects, but it is neither a habit nor an instinct. It is, perhaps, the raw material, so to speak, out of which useful instincts are developed in some animals. According to Darwin, there is great variation in the degree in which this instinct is manifested in insects. He observed "a most perfect series, even within the same genus (Curculio and Chrysomela), fiom species which feign only for a second and sometimes imperfectly, still moving their antennæ (as with some Histers), and which will not feigu a second time however much irritated, to other species which, according to De Geer, may be cruelly roasted at a slow fire, without the slightest movement-to others, again, which will long remain motionless, as much as twenty-three minutes, as I find with Chrysomela spartii." In seventeen differeut species which he observed, including an Iulns, a Spider, and Oniscus, "both poor and first-rate shammers," he found that "in no one instance was the attitude exactly the same, and in several instances the attitudes of the feigners and of the really dead were as unlike as they possibly could be." 1

Romanes, in his Mental Evolution in Animals, has treated the subject of feigning: death very fully, and has collected some very interesting facts. Two observations upon the crustacea are quoted, one of Bingley upon the "common crab, which, when it apprehends danger, will lie as if dead, waiting for an opportunity to sink itself into the sand, keeping only its eyes above it," and one by Preyer, who is said to have made crayfish "stand upou their hearls while in the hypnotic state"! Romanes agrees with Preyer in attributing the shamming death in insects to "kataplexy," or mesmerie sleep (in many cases the physiological effect of fear), but gives some remarkable cases among vertebrates in which it seems almost equally probable that there is intentional purpose to deceive.

The "shamming dead" in insects and crustacea which leads simply to quiescence, and thus to their becoming conspicuous in the presence of their enemies, had been

"Chapter on Instinct written for The Origin of Species. See Appendix to Meutal Erolution in Animals, by George Jobn Romanes, p. 364. 
intensified, as Darwin believed, through the agency of natural selection. It is evident that no such instinct could thus arise in pelagic animals, where the cessation of the natural movements through hypnotic or other influences would lead to vertical down. ward motion by the action of gravity, unless such movements were of decided benefit.

It may be significant that the phenomenon is seen for the first time in the lobster when it is about ready to sink to the bottom and assume the adult habits. I have not examined a sufficiently large number of the adolescent lobsters, from $1_{2}^{\frac{1}{2}}$ to 3 inches long, to say how commonly they exhibit this peculiarity. I believe, however, that it is in this ease a sporadie phenomenon, which has not at present become a habit. It is not easy to see, moreover, how, in the environment of these animals, where so many of their enemies are scavengers or omnivorous, it could be of much service to its possessor when finally established on the bottom.

\section{THE FOOD OF THE LARVA.}

The food of the larval lobster must necessarily consist for the most part of minute pelagic organisms, such as copepods and crustacean larvæ. When watched in confinement they may now and then be seen giving chase to copepods, sometimes larger than themselves, and often without success.

The young lobster, however, shows little diserimination in its food. It seems to snap up almost any moving object, living or dead, which it is able to seize and swallow. Thus I have found in the stomachs of the older larvæ vegetable fibers, the seale of a moth or butterfly, and fine grauules of sand.

On June 17, 1893, I examined the stomachs of a number of larvæ (raised in aquaria) 13 to $14 \mathrm{~mm}$. long, probably in the fourth and fifth stages, aud found them to contain the following substances: (1) diatoms in abundance, chiefly Navieula and the long tangled ribbons of Tabelaria; (2) remains of crustacea, probably parts of young lobsters; (3) bacteria in large numbers; (4) cotton and linen fibers and parts of algæ; (5) amorphous matter, with sand grains. The sediment of the jar contained the same species of diatoms in abundance, and anorphous débris similar to that found in the stomach and intestine.

The stomach of a larva captured in Vineyard Sound August 12 (length $15 \mathrm{~mm}$. ) contained the following organisms: (1) parts of crustacea; (2) diatoms; (3) shreds of algæ. In another young lobster taken at the same time (length $17 \mathrm{~mm}$.) there were (1) parts of erustacea, (2) large numbers of diatoms, (3) filaments of green algæ and thin sheets or shreds of vegetable tissue, (4) the scale of a lepidopterous insect, (5) bacteria, (6) amorphous matter in large masses.

Messrs. Weldon and Fowler (201) came to the following conclusions after experimenting with different kinds of food which were thought might be acceptable to the larve:

It was definitely concluded from these experiments that whatever food is ased must be floating in the condition of small particles at a short distance below the surface, $i . e_{\text {. }}$, in the same position as the natural pelagic food of the larvie of the sea, whether this consist of Copepoda, other Decapod larvi, trochospheres, fish ova, or other members of the pelagic fauna. As to the other two forms of food tried, the Noctilucæ were apparently eater, the shrimp larvæ (Mysis stage) certainly were attacked, and from the fact that the young lobsters attack and devour each other it is probable that Decapod larvæ form at any rate part of the usual food. The contents of a tow net taken near the Eddystone on August 6, which held a young lobster, consisted chiefly of Megalops anil Mysis stages of Decapoda. 
The yolk of hard-boiled eggs, crushed erab, boiled liver, tow-net material, noctilucx, copepoda, and live shrimp larvir, were all partially, but mone absolutely, successful as a food supply.

The self-destructiveness of the young lobsters when too closely crowded in arparia bas already been referred to. When one lobster attacks another under these conditions the pursuer usually endeavors to get astride of his victim and uip into the abdomen at its junction with the carapace with its sharp-pointed prehensile legs. When the object is too heavy to float, such as the egg or larva of the lobster, they frequently go to the bottom; but if the animal is healths it will be usually seen swimming about the aquarium dragging its prey with it and feeding upon it as it goes.

\section{HELIOTROPISM OF LARVAL LOBSTERS.}

During the past six summers which I have spent at Woods Hole, 1889-1894, I have been struck with the scarcity of the larve of the lobster in the waters of Vineyard Sound. The tow net has been frequently used both by day and night, and I have made many unsuccessful trips in search of young lobsters in the season when one would expect them to be common. Thus, on July 11, 1891, I towed all around Gay Head, a mile beyond the Devils Bridge buoy, and in Vineyard sound. We found only copepods, sagitta, young fish, and fish eggs. The day was bright and the water had been calm for two days. The prevailing winds had been from the northeast. At Menemsha we obtained one lobster with eggs hatehing ont, but the fishermen reported that very few lobsters with old eggs were then taken; that is to say, the hatehing season was about over.

I had a similar experience on July 16. The water was smooth; the wind had been southwesterly for four or five days. There was very little surface material, a few barnacles, megalops and sagittas.

The following is a list of all the lobsters taken at the surface of the ocean during the six seasons mentioned-the capture was made in the daytime unless otherwise stated:

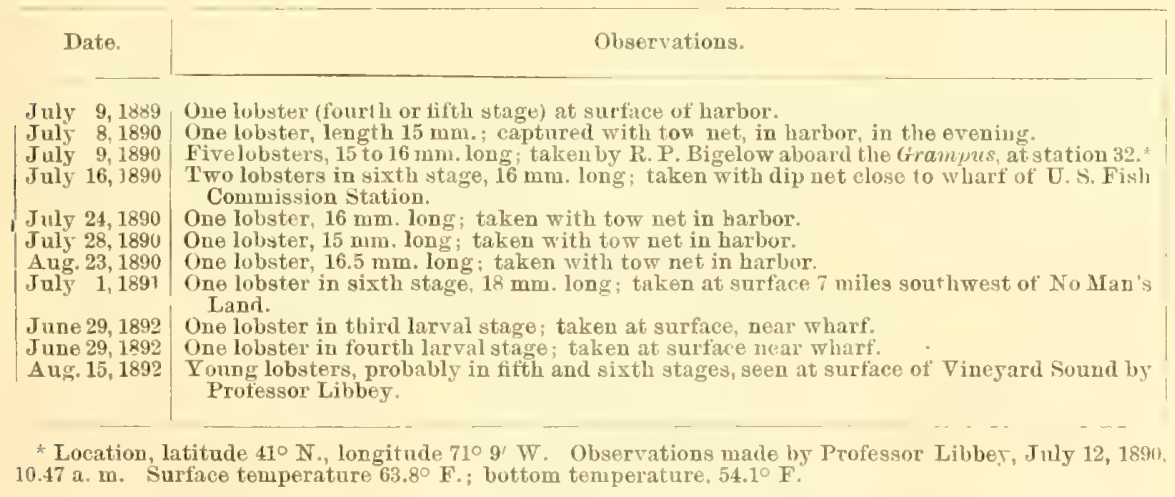

Larve in the first stage have been taken in Vineyard Sound as early as June 3. Lobsters in the fourth stage were captured by Vinal N. Edwards, August 12, 1887. Young lobsters (stages not determined) were also taken by him in Woods Hole IIarbor, Vineyard Sound, and in the vicinity of Gay Head, in the month of July, 1888. 
Surface towing was done at the following places in the same year without obtaining any lobsters: August 1, 17, and 18, Vineyard Sound; August 23, off Cuttyhunk; Angust 27, 30, 31, Woods Hole Harbor.

Professor S. I. Smith says of the young lobsters which he obtained in Vineyard Sound in the summer of 1871, that numerous specimens "were mostly taken at the surface in the daytime, either with the towing or hand net" (182). Of the older pelagic stages he says:

They appear to live a large part of the time at the surface, as in the earlier stages, and were often seen swimming about among the surface animals. They were frequently taken from the 8 th to the 28 th of July, and very likely occur much later.

We know that lobsters are now far less abundant around the Elizabeth Islands than they were twenty years ago, and we should expect to find that the young had diminished in a proportionate degree. Millions of larvæ, however, must still be hatched in Vineyard Sound and adjacent waters every year. What then becomes of them? I believe that they are eaten up by surface-feeding animals, principally fish, or meet their death from indiscriminate causes. The tides tend to disperse the young over a wide area, thus carrying them to and from the shores. Horizontal distribution alone would not account for the extreme scareity of the young in Vineyard Sound at the present time. If, however, there were a corresponding vertical distribution, the conclusion which we have reached would not be warranted. It thus becomes a matter of much interest to determine the heliotropism of the larva, or the law which governs their vertical movements in the water.

The results of my observations and experiments with larvæ lead me to conclude that the young, free-swimming lobster usually displays what Loeb has called positive heliotropism (125) - that is, it tends to swim toward the light or near the surface in the daytime. The conclusion therefore which we stated above, that the absence or extreme scarcity of young lobsters in a region where the adults still abound is due to their destruction, is supported by experimental testimony. The bearing of this fact upon the artificial propagation of lobsters I have discussed in an earlier paper (see 97).

I will add a few notes upon the experiments which were made to test the heliotropism of these larvæ.

Experiment 1.-On June 27, 1894, I placed about 25,000 young lobsters, in the first larval stage, in the observation pool at the Fish Commission Station, to wateh their behavior. The sun was intermittently obscured by clouds during the greater part of the forenoon. When liberated, the larvæ formed a large eluster near the surface, where they remained for a short time. Then all went down to a distance of from 1 to 2 feet, some apparently reaching the bottom, a distance of 3 feet more. A lot of small

'With reference to this subject, Professor Smith has kindly written in detail substantially as follows: "All the larvæ captured in Vineyard Sound and neighborhood in 1871, on which my papers were based, were taken in the 'daytime.' My notes usually give only 'day,' or 'evening' for time of eapture, but the larvæ of my first and second stages, taken July 1, are marked 'forenoon.' Since 1871 I have many records of first and second stages taken in the 'day' and, as far as I can find now, only two cases of capture in the 'evening,' and one of these cases was when the electric light was used in the water to attract the surface forms. The young in the adult form [equivalent to fourth and possibly fifth and sixth stages described in this work] were, however, often taken in the evening and were almost always attracted by the electric light. In my experience the young of the adult form were much more frequently taken at the surface than the larvæ." 
cunners then made theil appearance and snapped up the larva right and left. Two hours later the lobsters were diffused over the whole surfice of the pool, a large number of them swimuing close to the surface. The paler larva, with chromatophores contracted, can not be easily distinguished at a distance of a few feet, but when one of their eyes is turned at the right angle it glows, like a minute electric spark, with a greenish light. At 1 p. m. the surface on the lee side of the pool swarmed with larva. Oceasionally one could be seen to attack and drag another down. They swim about aimlessly with considerable rapidity, now rising or falling, aud changing their direction frequently. The majority had now become quite red. Later in the aftermoon nearly all had disappeared, having been swept out by the tide or destroyed by the cumers and other tish in the pool.

Experiment 2.-On July 13, 1894, I placed a number of larvæ, mostly in the first stage, in a glass dish, next to the window in the hatehery. The larvi immediately gathered on the side of the dish nearest the window. Turn the dish slowly through an angle of 150 degrees, and the lobsters invariably flock toward the source of light. This may be repeated indefinitely, but always with the same result.

Experiment 3. A box was made with blackened sides, so that when a glass jar was set in it vertically, with its upjer end exposed, ligh could enter ouly from above. When larva were placed in this, the stronger always rose toward the source of light into the illuminated zone. Some, however, apparently the weaker ones, remained below.

Experiment 4.-A light-proof box was then constructed with sliding lid aud eud, so that a long, closed jar could be laid in it horizontally. When the lid was removed, the larva swam up to the surface in different parts of the jar. When the diffused or direct suulight was admitted only at the end the larvie invariably thocked toward the illuminated end and remained there. If any lagged bebind, it was because they were too weak to swim.

These simple experinents ${ }^{1}$ seem to show conclusively that under ordinary circum. stances the larva of the lobster are positively heliotropic. I made no experimentson the effects of changing the temperature courlitious. The temperature of the water used was the same as that of the water lunning through the aquaria, or about $1^{\circ}$ higher than the water temperature of the harbor (see table 2).

The second experiment was tried in the summer of 1893 with the reverse result, the lobsters swimming away from the sounce of light, showing possibly that under certain couditions the larvie are negatively heliotropic (97, 1).8:). This experiment is, however, the least trustworthy of all, since there are always cross lights in a room and the conditious are consequently changing. Professor Ryder found that under similar circumstances the larvæ gathered on the side nearest the source of light ${ }^{2}$ (172).

The general conclusion reached, that larva swim up to the surface during the daytime and stay there, probably sinking at uight aud rising again with the approach of light on the following day, is supported by the record of the capture of larva which I have already given. The taking of larve at uight seems to be the exception; their capture by day the rule.

${ }^{1}$ In the course of these experiments I had the advantage of consulting with Professor Loeb, to whose researches our knowledge of heliotropism in animals is very largely due.

"He also says: "At night, or if light is shut off", the young lobsters go to the bottom of the tanks; and it seems they mag then be most actively engaged in feeding if food is placed within their reach." 
The following notes illustrate the difficulty of raising the young of the lobster in close quarters. Old eggs were always placed in the jars, but even when the water was agitated so that these were floated, the young invariably preferred to feed on one another. The death rate, however, is due in part to other causes besides cannibalism.

On July 2d, 1893, 130 larvæ in the second stage were placed in a 4-gallon jar and supplied with rumning water. On July 3d, 108 were alive; on July 4th, 96 ; July 5th, 89,3 of these in the third stage ; on July 6th, 63 were alive, 47 of these having molted for the third time. In the course of four days 48 per cent had succumbed.

On July 1st, 100 second larvæ were placed in a hatching jar. On July 2d, 82 were living; July $3 \mathrm{~d}, 73$; July 4th, 64,2 of these having molted to the second stage; and on July 5 th, 50 were alive, 24 in the third stage. The third larvæ, 26 in all, were left in this jar, and on July 6 th 24 were alive; on the following day only 6.

Jume 29th, 1893, I placed 12 lobsters in the first larval stage in four flat glass dishes (3 to a dish). I3y the 1st of July 10 were alive, 4 in the second stage; on July 5 th 7 were liring, all in the second stage, and July 6th 1 second larva only was alive.

July 6th I placed 6 first larvæ in two flat dishes (3 to a dish) with lohster eggs for food. Each lobster was $8 \mathrm{~mm}$. long. On July 7th 2 in one dish were alive, both in second stage and devouring the remaining larva; no change in the other dish. On the 9th, at 9 a. m., 4 were alive, 3 in the third stage and 1 in the first.

I placed 4 third larvæ in a hatehing jar on the 7th of July. All were living on the 13th, and on the 15 th 3 were alive, having molted to the fourth stage. The smallest had been attacked by the rest and its thoracic legs were eaten off. I left 2 fourth larva in the jar, both of which were in the fifth stage on the 27 th of the month.

\section{THE EFFECT OF INCREASED TEMPERATURE ON THE RATE OF DEVELOPMENT OF THE LARV Æ.}

The following experiment is interesting in showing how the rate of development is affected by raising the temperature:

July 1st, 1893, I placed 100 first larvæ of the lobster in a hatching jar, with food, and heated the water by means of a block-tin coil to $74^{\circ} \mathrm{F}$. The water in the aquaria at this time registered $66.9^{\circ}$ and that of the harbor $66^{\circ}$.

July 2d, 9 o'clock a. m., 56 were alive. Some were weak and lying on their backs at the bottom, an easy prey of the strong.

July $3 d, 9.30$ a. m., 56 alive, not looking healthy, many with air bubbles in branchial cavities; temperature raised to $78^{\circ}$.

July 4 th, 41 alive, 28 in second stage, 13 in third stage.

July 5th, 24 alive; left third larvæ, 18 in all, in jar.

July 6 th, 7 alive; temperature of water $80^{\circ}$

Jaly 7th, all living, another in fourth stage; left 6 thircl larva in jar.

July 8th, all alive, 3 molted to fourth stage. One fourth larva had one blind eye; the eye was small and pigment deficient. All left in jar.

July 11th, all alive, 4 in fourth stage, 2 in third stage.

July 13th, all alive; no change; temperature 79०; left 3 larva in fourth stage in jar.

July 15th, 2 alive.

July 17th, both living; temperature $79^{\circ}$.

July 19th, both living; temperature $78^{\circ}$.

July 21st, both living; temperature $75^{\circ}$.

July 30 th, one alive; temperature $78^{\circ}$.

August 2d, one alive, in fifth stage (length $13 \mathrm{~mm}$.); temperature $79^{\circ}$.

August 5th, last one dead.

We see that with a rise in temperature of from 7 to 13 degrees the third molt was passed in about 5 days, which is not far from the average age of these larvæ reared 
under the usnal conditions. The fourth stage was reached when the larva was 9 to 11 days old, the average age under normal conditions being about 13 days. The only fifth larva reared was from 33 to 34 days old, which is nearly twice the age of this larva living under the usual temperature conditions. If the larvæ had been less crowded in the early part of the experiment, and if the temperature of the water had been raised very gradually, without fluctuations, it is possible that the results might have been more favorable than they proved to be under the circumstances. This would require considerable care and close watching, but the experiment, as performed, seems to demonstrate the impracticability of making such attempts.

The development of the embryo can be hastened by artificially raising the temperature, but it is not certain that any advantage would attend the practice. Bumpus suggests (:30) that if the young were hatched by artificially raising the temperature of the water during the cold months of the year, and were then liberated into the ocean, they would be certain to escape the attacks of many summer enemies. This is undoubtedly true, but it is almost equally certain that ihe young lobsters would enconnter new enemies in winter and that indiscriminate destruction, which must be very great at any time, would then be enhanced.

\section{THE DEVELOPMENT AND MORPHOLOGY OF THE BODY AND APPENDAGES.}

It was my original intention to trace in detail the development of the form of the body and its appendages, but I have not been able to devote as much time as I had wished to this subject. With this in view, however, I have given a pictorial history of the development of the most important parts, which will be found chiefly on plates $27-35$.

Professor Smith has already described the tegumentary appendages of the first three larva and the "early stages of the adult form," which, as I have shown, comprehend the fourth, fifth, and in some cases the sixth stages. In describing these I shall avoid repetition as far as possible, and pay most attention to those parts upon which few or no observations have been made.

THE BODY.

The carapace.-The carapace arises in the embryo as folds of the ectoderm, the lateral and posterior parts being the first to appear (cut 34 and fig. 234). In the first larva it has the form shown in fig. 110, plate 35. It is somewhat gibbous behind, and is armed in fiont with three down wrdly directed procenses, a median, slender, sharppointed rostrum, and two lateral teetb. There is also a keel-like process ou the middle line near the base of the rostrum. The latter is nearly as long as the rest of the carapace. The position of the future cervical fold or groove is very faintly marked. In the second and third larval stages the rostrum becomes expanded horizontally into a thin plate with toothed margins, but increases very little in length (figs. 109, 111, 112).

In the fourth larva (figs. 113, 115, plate 35) the cervical groove is well developed; the rostrum is a thin, triangular plate, bordered with spines and plumose setæ. The terminal spine is usually bifid at its apex, carinate below, and turned slightly upward. The length of the rostrum is now but little more than one-third that of the entire carapace. The anterior lateral spines are much reduced. Tendon marks now make their appearance, but are more prononnced in the fifth and sixth stages (fig. 114). Areas of absorption, correspouding to the median longitudinal stripe, the "welt" and lateral 
bright blue areas of the carapace of the adult lobster are clearly seen. The fine trans. verse hair line, just above the cervical groove, behind the second antenna, can also be detected. The cross-shaped figure seen on the npper surface is formed by the wide median absorption area and the cervical groove with which it is continuous on either side. Besides the fringing hairs, the whole surface is covered with short setre which correspond in some measure at least to the hair pores of the adult carapace. In certain cases some of these changes, as in the relative lengths of the rostrum and anterior lateral spines, are far less marked. The anterior median carina is not prominent after the third stage.

The carapace of the fifth stage is illustrated in fig. 114. The characteristic tendon marks, which have been described, are very conspicuous. The rostrum is narrower and in the sixth stage is about one-fourth the length of the entire carapace.

In a young lobster $35 \mathrm{~mm}$. long, which had molted about twelve times, the shape and areolation of the carapace were very similar to that of the adult.

The abdominal segments. - In the first larva (plate 20) the abdomen has its full number of segments. The first is unarmed and partially covered by the carapace. The second, third, fourth, and fifth somites bear early a prominent median spine, which projects upward and backward from the posterior end of the tergum. Each of these segments also bears upon either side a long, sharply pointed pleural spine, which projects backward.

The median spines, of which the last two are the longest, are gradually reduced during subsequent stages and finally disappear at the fourth molt. Meantime the pleural spines become shorter, shift their position slightly, and in the fourth larva point downward.

The disappearance of the median dorsal spines is, however, not uniform, but subject to considerable variation, as shown by the following observations upon eleven larvæ in the second and third stages.

TABLE 36.-Tariation in time of disappearance of the median tergal spines of the larval abdomen.

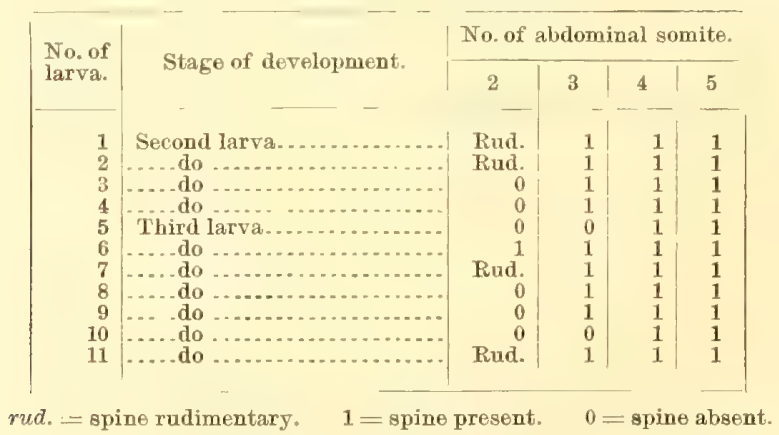

We see by the preceding table that the median spine of the second abdominal segment may entirely disappear at the second molt or persist in either a rudimentary or perfect condition even after the third ecdysis, while the spine of the third somite, though usually present, is sometimes absent in the third stage. (Nos. 5, 10.)

The sixth abdominal somite bears at its posterior margin a pair of dorsal spines on either side of the middle line. These curve backward over the telson, and are much smaller than the median spines (fig. 33, plate 20). They disappear at the fourth molt. 
The respiratory organs.-In the adult lobster there are twenty pairs of gills, one of which, belonging to the second pair of maxillipels, is rulimentary. There are 6 podobranchier, 10 arthobranchier, and 1 plemobranchie, distributed according to the following table:

TABLE 37.- Branchial formula.

\begin{tabular}{|c|c|c|c|c|c|}
\hline \multirow{2}{*}{ Thoracic segments and appendages. } & \multirow{2}{*}{$\begin{array}{c}\text { Podo- } \\
\text { brauchise. }\end{array}$} & \multicolumn{2}{|c|}{ Arthrobranchiso. } & \multirow{2}{*}{$\begin{array}{l}\text { Pleuro- } \\
\text { branchieo. }\end{array}$} & \multirow{2}{*}{ Totals. } \\
\hline & & Anterior. & Posterior. & & \\
\hline 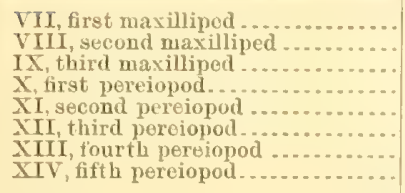 & $\begin{array}{l}0 \text { (ep.). } \\
1 \text { rud.(ep.). } \\
1 \text { (ep.). } \\
1 \text { (ep.). } \\
1 \text { (ep.). } \\
1 \text { (ep.). } \\
1 \text { (ep.). } \\
0\end{array}$ & $\begin{array}{l}0 \\
0 \\
1 \\
1 \\
1 \\
1 \\
1 \\
0\end{array}$ & $\begin{array}{l}0 \\
0 \\
1 \\
1 \\
1 \\
1 \\
1 \\
0\end{array}$ & $\begin{array}{l}0 \\
0 \\
0 \\
0 \\
1 \\
1 \\
1 \\
1\end{array}$ & $\begin{array}{l}0 \text { (ep.). } \\
1 \text { rud. (ep.). } \\
3 \text { (op.). } \\
3 \text { (ep.). } \\
4 \text { (ep.). } \\
4 \text { (ep.). } \\
4 \text { (ep.). } \\
1 \text { ( }\end{array}$ \\
\hline Total .... & $6(\mathrm{ep})$. & 5 & 5 & 4 & 20 (1 rud.). \\
\hline
\end{tabular}

The first larva has no rudiment of a podobranchia in the eighth somite, but all the other branchice are represented. The podobrauchic of the following segments are very small and are partially exposed, together with their reniform epinodites. In the second larva the podobranchic are covered by the carapace (plate 21 ) and the branchial formula is complete (fig. 101, plate 34).

The gills are developed in the embryo as simple folds or pouches in the body wall. 'They belong to the trichobranchiate type, the respiratory surface being gralually increased by growth of the multiserial branchial filaments.

In the fourth larva (fig. 106, plate 34) the podobranchia carries four rows of filaments, and the mastigobranchia, or epipodite proper, is a long, tapering, hairy plate.

\section{THE VISUAL ORGANS AND APPENDAGES.}

The ocellus.-The median eye, which is present in the first larva, is situated at the apex of a prominent median papilla, between the paired eyes and antenmules. It is marked by a pear-shaped mass of dark pigment. It disappears in the course of larval life, and no trace of it can be seen in the adult. The ocellus was observed by Sars (175) in the first larva of Homarus gammarus.

The paired eyes.-The compound or lateral eyes originate in the embryo as diskshaped thickenings of ectoderm, and do not become lobate until a relatively late period (euts. 27-34). ${ }^{2}$ In the summer eggs eye-pigment is developed when the embryo is about 27 days old. It then appear's as a thin line or crescent-shaped area, when seen from the surface. The eye-spot increases gradually in size, and its characteristic shape affords a convenient gange to measure the embryonic development. (I'late J.)

In the first larva the eye is relatively very large. It is dorso-ventrally compressed or flattened, as in the embryo and in all subsequent stages. The stalks are proportionally shorter than in the fourth larva, and since they nearly meet in the middle line in front of the brain, they are practically sessile and immobile.

I For an account of the development of the Decapod gill see 94, p. 392, figs. 193, 230-233.

${ }^{2}$ The structure and development of the compound eyes of the lobster have been carefully worked out by Parker (149). 
The following measurements show the greatest diameter of the eye and the length of the eye-stalk, as compared with the length of the body, in the first and fourth larvie, in a lobster $58 \mathrm{~mm}$. long (No. 5, table 32) and in an adult male:

TABLE 38.

\begin{tabular}{|c|c|c|c|c|}
\hline Measurements. & $\begin{array}{l}\text { First } \\
\text { larva. }\end{array}$ & $\begin{array}{l}\text { Fourth } \\
\text { larva. }\end{array}$ & $\begin{array}{c}\text { No. } 5 \\
\text { table } 32 .\end{array}$ & $\begin{array}{l}\text { Ardult } \\
\text { male. }\end{array}$ \\
\hline 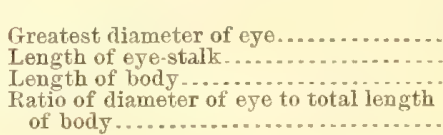 & $\begin{array}{l}m m . \\
0.74 \\
.92 \\
8 \\
.092\end{array}$ & $\begin{array}{r}m i n . \\
0.8 \\
1.2 \\
14.5 \\
.055\end{array}$ & $\begin{array}{l}m m . \\
3 \\
3.3 \\
58 \\
\quad .052\end{array}$ & $\begin{array}{l}\mathrm{mm} . \\
7 \\
10 \\
264 \\
.026\end{array}$ \\
\hline
\end{tabular}

The diameter of the eye, expressed in terms of the total length of the body, is much greater in the first than in the fourth larva, but is relatively twice as great in the latter stage or in a lobster 2 iuches long as in the adult condition. (See p. 163.)

Labrum and metastoma.-Both the upper lip and paired metastoma have in the first larval stage (fir. 54, plate 28) the general form and appearance which they finally possess. The surfaces of the latter abound in setæ. What look like setæoceur also on the labrum, but none are present in the adult organ. (See p. 133.)

First antenna.-The first antenna is a simple appendage up to the time of hatching. In an embryo about four months old (fig. 107, plate 35, and fig. 27, plate 17) it is tipped with short setæe and shows no trace of segmentation. When the embryo is five weeks old the first antenna has the appearance shown in figure $6 \%$. In the first larva this appendage is no longer simple, as described and figured by Smith (182), but the inner, secondary flagellum (plate 27 , fig. 40) is present, though a small rudiment, and bears at its apex a single plumose seta. When the stalk is examined from the under side we can detect traces of segmentation into three parts, but on the upper surface the proximal cuticular fold only can be seen. The appendage terminates in a small bunch of setæ, one of which is conspicuous for its length. It is possible that in some cases the flagellum is not liberated until after the second molt, as described by Professor Smith, but none such were observed. These appendages are immobile in the first larval stage.

The superficial changes which take place in this appendage during the first five larval periods are illustrated in plate 27 , and will not be described in detail.

In the second larva the segmentation of the stalk into three joints is sharply defined and the flagella show faint constrictions. The clusters of olfactory setæ, which increase in length and number with every molt, are developed during the first larval period and appear full-fledged immediately after the second molt.

The auditory pit becomes prominent after the third stage. In the fourth larva (fig. $43, a u$ ) it is a wide and shallow, -shaped depression, marked with brown pigment cells, bordered with short setx, and containing a few otoliths or grauules of sand. In the fifth larva (fig. 44) the closure of the anditory sac has already begun. The pit is filled with otoliths and the irregular orifice is guarded by short, feathery setre. The constriction of the opening continues until in the adult state it becomes a small pore, into which it is barely possible to insert the point of a pin.

The first antenna of the European lobster, as represented by Sars (175, tab. I, fig. 4), agrees essentially with that of Homarus americanus, but the secondary Hagellum 
is more rudimentary. The antennular nerve was traced by Sars toward the end of the appendage, where it appeared to divide into two branches.

Second antema.-The outer anteuna of the first larva (fig. 45, plate 27) consists of three parts, which are represented in the adult (fig. 118)-a two-jointed stalk, a segmented endopolite, and a scale-like exopodite, terminating in a sharp tooth and bordered on its inner margin with long plumose hairs.

This is the first of the naupliar appendages to become bilobed (cut 30). In an embryo four months old, fig. 108 (compare fig. 77 ), the cuticular molt shows the traces of only a few terminal setae on either branch.

The progressive changes in the second antenna during the first five larval periods (figs. 45-49) consist mainly in the reduction of the scale and its feathered setie, in the rapid growth and segmentation of the slender endopodite, and differentiation of the latter into stalk and flagellum proper, and in changes in the stalk or protopodite. In the fourth larva (fig. 48) the first segment (coxa) ${ }^{1}$ of the latter bears a prominent tubercle (already conspicuons in the third stage), on which the duct of the excretory organ opens, while the second segment or basis is divided by oblique constrictions into three parts, as in the adult lobster. The extermal division bears, next the articulation of the scale, a stout spine which grows with the gradual rednction of the exoporlite until it finally nearly equals the latter in length. The terminal sete of the flagellum are rapidly reduced and are barely recognizable in the third larva.

The mandibles.-The jaws of the first larva (fig. 54) consist of a stout basal portion, with toothed, indurated, coronal surfaces, meeting on the middle line opposite the mouth, and of a slender, three-jointed palpus, which terminated in the specimen fig. ured in a single strong seta. The cutting elges are asymmetrical, and at the anterior angle there is a stont, variously toothed process which is separated from the rest of the coronal surface by a deep groove. As Professor Smith observed, this is most prominent on the left side.

In the third larva the asymmetry of the coronal surfaces is even more striking, particularly in the toothed process on the outer side at the anterior end. On the left side this forms a widely overlapping fold, which carries three sharp teeth. The process of the right side is smaller, but had also three teeth in the specimen examined.

In the fourth larva the maudible is deeply cleft by a wide groove, as in the adult (figs. 55-5i), and the brush-like palpus folds over the cutting margin into the fossa.

In the fifth stage the mandibles are still asymmetrical, and the teeth are no longer sharp but tubercular, the smaller being at the posterior angle. The stout-toothed process of the first larva remains as a blunt tubercle on the left side, where it was most prominent, but has disappeared from the right side.

First maxilla.-The metamorphosis of this appendage from the larval to the adult condition is relatively very slight. It consists in the first larva (fig. 51) of coxa, basis, and a one-jointed endopodite. All are armed at their extremities with setic of various kinds-slender, sensory hairs on the outer segment, a double row of stout masticatory teeth on the basis, and a cluster of less regular, distinctly serrated, stiff bristles at the extremity of the coxa.

1 The following abbreviations for the segments of the decapod limb will be used: (1) coxa $=$ coxopodite; (2) basis = basipodite; (3) ischium =ischiopodite; (4) meros=meropodite ; (5) carpus = carpodite; (6) propodus = propodite; (7) dactyl $=$ dactylopodite. 
In the fourth stage (fig. 61) the endopodite is two-jointed, and is tipped with two nonplumose setæ. A few hairs occur at the distal articulation on the inner side and a larger number at the base on the outer side. The other branches have more of the configuration and character of the adult state.

In the fifth stage (fig. 62) the terminal segment of the endopodite is folded back toward the basal joint and bent somewhat as in the adult. The imner margin of the proximal segment has scatteriug setre, and those on the outer side near the base now form a dense bunch, most of which are feathered. The tegumental glands, which later are so abundant in the foliaceous parts of the maxillæ, can now be distinctly seen in at least the basis.

Second maxilla.-The structure of the second maxilla of the first larva is repre sented by fig. 60, plate 29. It consists of two biramous lobes, the coxa and basis, the respiratory plate or "bailer" and median endopodite. The masticatory setæare sometimes jointed and but sparsely plumose. The long sensory seta of the endopodite is also marked by transverse constrictions and has a few lateral hairs, while the fringing setæe of the scaphognathite are all plumose and of nearly equal length. The posterior lobe is the wider and somewhat spatula-shaped, and this difference is emphasized after the second molt. Minor changes which occur in the course of the three following molts concern chiefly the endopodite and the conformation of the mouth parts to the mandibles and of the scaphognathite to the branchial cavity.

First maxillipeds.-In the first larva these appendages have the form shown in fig. 58 , and if this is compared with the condition met with in the fourth stage (fig. 59) we find that the principal changes concern the two-jointed exdopodite and the flagelliform exopodite. In the fourth larva the latter is bordered on both inner and outer margins with plumose hairs. The setæ on both protopodite and eadopodite are more numerous, and in the latter branch are much reduced. The respiratory epipodite is relatively a little larger.

Second maxillipeds.-In passing through the first four molts the second pair of maxillipeds undergo but minor changes (figs. 63, 64, plate 30 ). The exopodite becomes segmented, flagelliform, and setigerous. The segments of the endoporlite, particularly their inner margins, become more densely studded with setæ, many of which are serrated. A rudimentary podobranchia is developed. The natural position of the appendages in the first three larval stages is shown in plates 20-22.

Third maxillipeds.-In the early larval stages (plates 20-22) these appendages are usually directed forward and bent into nearly a right angle at the third articulation from the extremity. In the first larva (fig. 69) the distal ends of the three terminal segments (dactyl, propodus, meros) are armed with stont setæ, some of which are serrated, while the inner margins only of the proximal divisions are setigerous. The exopodite reaches beyond the middle of the fifth segment, and is an important swim. ming organ during the first three larval stages.

The right third maxilliped of the fourth larva is shown in its natural form and position in fig. 65. The appendage is still partially bent upon itself, as in the first larva, but the proximal half (first to fourth segments) has been twisted through an angle of $90^{\circ}$, until what were the inner and outer margins have come to lie in a vertical plane. The proximal joints are trihedral, and what now forms the inner, upper margin has developed a row of stout, rather sharp teeth, which are very prominent in the adult. The podobranchia, which is rudimentary in the first stage, is now well developed. 
The pereiopods.-The general structure of the pereiopods is shown in the various plates illustrating the larval and adolescent history. For a considerable period before the time of hatching the great chelipeds can be distinguished by their size. At the time of hatehing all have prominent podobranchice and long exopodites. After the tirst molt the swimming hairs and setir which garnish the endopodites are rapidly er aginated. Tlea first three pairs of pereiopods are subchelate. After the fourth molt (fig. 67, plate 30) the exopodites are reduced to rudiments and leave no trace in the sixth stage.

The first pereiopods.-In the first larva (fig. 66) the first pair of pereiopods or large cheliperls are nouprehensile, armed with stout, seattering setat, of which those seen on the inner margins of the meros and ischium are the representatives of stout spurs which are developed in the fourth larva. Both propodus and dactyl end in a strong, nearly straight spine, which in the latter joint is conspicuous for its length.

Antotomy of the large chelipeds occurs in the fourth larva, but fusion of the basis and ischinm is not effected until at least after the fifth stage (plate 33, fig. 96, and plate 30 , fig. 67).

In the second, third, and fourth stages the prehensile claw is gradually developed (plates $20-23$ ). In the third and fourth larve the opposed margins of the large claws are distimetly toothed, and the latter end in incurved, horny tips.

There is usually butvery little or no difference in the size of the large chelæ until after the seventh molt. Iu the sixth stage the extremities are already provided with numerons tufts of sensory setre (compare plates 23-25). In the later adolescent stages, when the differentiation of the large clars is complete, these tufts are mostly confined to the cutting claws, where they form a dense mat over the toothed margins and extremity of the propodus (plates 10-12).

The differentiation of the chelæ for crushing and cutting is a gradual process, but is fairly well established in a young lobster 30 to $40 \mathrm{~mm}$. in length (plate 8). It rarely happens that both claws are similar in the adult stages (see Chapter IX).

Second and third pereiopods. - The structure of these appendages, which agree, except in size, is illustrated by fig. 73. In the fourth larva (fig. 74) the chelate structure is pronounced and the exopodite is a rudiment.

Fourth and fifth pereiopods.-The dactyl of these appendages in the first larva (fig. 70, plate 31) ends in a very long, nearly straight spiue, while the propodus bears a characteristic cluster of setre close to its articulation with the dactyl.

In later stages (fig. 76, plate 31) the terminal spine becomes reduced and the terminal cluster of serrated setæ on the propodus is then very conspicuous. In the fifth larva the constriction at the proximal end of the ischinm is clearly defined and the exopodite has disappeared except as a mieroscopic rudiment (not shown in fig. 76).

The pleopods.-The second, third, fourth, and fifth pairs of abdominal limbs are visible as buds beneath the cuticle of the first larva and emerge after the second molt (plates 20,21).

The sixth pair of pleopods, which form with the telson the tail-fan, are seen as rudiments through the cuticula of the second larva aud are released with the third molt.

\section{THE DEVELOPMENT OF THE FIRST PAIR OF PLEOPODS.}

No accurate observations have been made upon the development of the first pair of abdominal limbs, which are specially modifien in the two sexes. They are the last appendages to appear, aud their growth aud differentiation are very gradual. In the 
fifth stage they are represented by small rounded tubercles (fig. 78, plate 32). At this time there are no exterual characters by which the sex of the individual can be determined with certainty.

In the sixth stage (fig. 95, plate 33; lobster No. III, table 39) this appendage consisted of a swall bud $(0.1 \mathrm{~mm}$. long); after the seventh molt (larva $18 \mathrm{~mm}$. long) its length was doubled (tig. 83).

In lobster No. VI (table 39) this appendage in the eighth stage (larva $19.75 \mathrm{~mm}$. long) was a simple bud of about the same dimensions (fig. 80).

In another young lobster, probably a male in the eighth stage (length, $19.3 \mathrm{~mm}$., fig. 90), the appeudages of the first abdominal somite are similar to those of the seventh and eighth stages just referred to.

In another case, that of a lobster in sixth stage (No. II, table 39, fig. 84, plate 32 , length of lobster $16 \mathrm{~mm}$.), this appendage was about equal in size to those just described. In still another lobster (No. vI, table 39), which was followed from the fourth stage onward through four molts, this appendage is a little larger and is partially segmented (fig. 85, plate 32) in the eighth stage. The under surface of the thorax of this lobster is shown in fig. 89 , plate 32 , where the openings of the oviducts are clearly seen, thus determining the sex.

In a young female $35 \mathrm{~mm}$. long (No. x, table 39) this appendage measures $2 \mathrm{~mm}$. and is composed of two joints (with possibly a small coxal segment) of about equal length (fig. 86). The distal joint is constricted into a number of smaller segments and bears a few very minute setæ. When the female is 2 inches long the first pair of abdominal limbs have attained the length of only $3 \mathrm{~mm}$. (fig. 88, plate 32 ). The appendage is exceedingly sleuder and, as in earlier stages, is deroid of pigment. The peripheral segment is multiarticulate and is fringed with fine, short hairs.

In a male $36.3 \mathrm{~mm}$. long (No. XI, table 39 ) the appendage, though very minute (2.3 mm. in length), has the same shape as in the adult. It consists of a two-jointed protopodite, a minute coxa and long basis, and a grooved distal segment (fig. 87). In a lobster but little larger (No. Xir, table 39), length $40.3 \mathrm{~mm}$., the appendages of the first abdominal somite are similar, but a trifle longer. As shown in the drawing of the under side of the thorax of this lobster (fig. 91, plate 32), they nearly meet on the middle line.

We see that the appendage of the first abdominal ring may assert itself either in the sixth, seventh, or eighth stages. The buds are developed on the posterior margin of the sternum of the first abdominal somite, and in the early period of their growth lie facing each other, transverse to the long axis of the animal (fig. 95, plate 33). These minute delicate appendages do not at first show any trace of pigment. After segmenting into two joints the appendage becomes elevated from the surface of the somite into a nearly vertical position.

The sex can be determined as early as the eighth stage, but not, as Professor Ryder supposed, by the appearance of the appendages of the first abdominal ring. At this stage these vary from 0.20 to $0.27 \mathrm{~mm}$. in length, and may or may not be segmented into two joints (figs. 80, 85,90). It is only by the openings of the sexual ducts that the sex can be distinguished at the eighth stage. The under surface of a female in the eighth stage (21.2 mm. long, No. VII, table 39) is shown in fig. 89, plate 32. The openings of the oviducts were discernible, and the development of the sterna of the last and penultimate thoracic segments which enter into the formation of the seminal receptacle is slightly different from the conditions seen in the male. 
The sex can not be determined by the abdominal appendages alone until after the tenth cnolt. In two lobsters, 35 and $36.3 \mathrm{~mm}$. loug respectively (Nos. $\mathrm{x}, \mathrm{XI}$, table 39 ), which siad probably molted twelve times, we have no dificulty in deciding fom the structure of the abdominal appendages (represented by figs. $s 6, s i$ ) that the first is a female, the last a inale.

The gradual growth of the appendages of the first abdominal somite is illustrated in table 39. In a lobster 2 inches long (51.8 mm.) these have a leugth of about an eighth of an inch (or $3 \mathrm{~mm}$.).

TABLE 39.-Progressive stages in the development of the appendages of the first abdominal somite.

\begin{tabular}{|c|c|c|c|c|c|c|}
\hline No. & Number in tables. & $\begin{array}{l}\text { No. of } \\
\text { molt. }\end{array}$ & $\begin{array}{l}\text { Length } \\
\text { of lob. } \\
\text { ster. }\end{array}$ & $\begin{array}{l}\text { Length of } \\
\text { first ab- } \\
\text { dominal } \\
\text { appendage. }\end{array}$ & Sex. & Remarks. \\
\hline 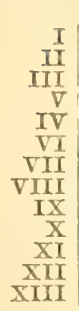 & 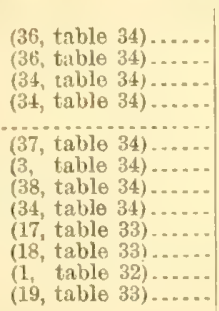 & $\begin{array}{r}5 \\
6 \\
6 \\
7 \\
8 \\
8 \\
8 \\
10 \\
10 \\
312 \\
312 \\
3 . . .\end{array}$ & $\begin{array}{l}m m . \\
14 \\
16 \\
16.3 \\
18 \\
19.3 \\
19.75 \\
21.2 \\
26.6 \\
29.50 \\
35 \\
36.3 \\
40.3 \\
51.8\end{array}$ & $\begin{array}{c}m m . \\
20.11 \\
.27 \\
2.10 \\
.2 \\
.27 \\
.2 \\
.25 \\
31.5 \\
32 \\
2 \\
2.30 \\
2.60 \\
3.04\end{array}$ & 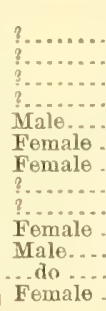 & $\begin{array}{l}\text { See fig. } 78 \text {, plate } 32 . \\
\text { See fig. } 84 \text {, plate } 32 . \\
\text { See fig. } 82 \text {, plate } 32 . \\
\text { See fig. } 83 \text {, plate } 32 \text { (bud without joints). } \\
\text { See fig. } 90 \text {, plate } 32 \text {. } \\
\text { See fig. } 80 \text {, plate } 32 \text {. } \\
\text { See figs. } 85 \text { and } 89 \text {, plate } 32 \text {. } \\
\text { Appendage not segmented. } \\
\text { Appendage consists of two minute joints. } \\
\text { See fig. } 86, \text { plate } 32 \text {. } \\
\text { See fig. } 87 \text {, plate } 32 \text {. } \\
\text { See fig. } 91 \text {, plate } 32 . \\
\text { See fig. } 88 \text { plate } 32 .\end{array}$ \\
\hline
\end{tabular}

Second, third, fourth, and fifth pleopods. - The condition of these appendages in the second, third, and fourth larval stages is illustrated by figs.93,91 and 97, plate 33. Each appendage cousists in the second larva of a stalk with the blade-like endopodite and exopodite. Rudimentary fringing setæ are developed after the third molt, but the appeudage is but little longer and otherwise unchanged. In the fourth larva (fig. 97) the uatatory appendages come immediately into use. The long fringing setre grow out and the limb itself is almost double its former size.

The telson and "tail-fan."-The flat telson of the older embryos is deeply cleft into two lobes (fig. 72), which bear on their free terminal elges short interlocking set:e. The bifucate condition of the embryonic telson, which recalls very forcibly that of a protozoea and is probably the remnant of a former larval condition, is retained up to the time of hatching and is lost only with the molt preceding the first larval stage.

After the first molt the telson appears as a broad, triangular plate (plate 19, and plate 34, fig. 103) joined immovably to the abdomen and admirably adapted for swimming. By the aid of this paddle the animal darts rapidly backward with every Hexion of the abdomen. The dorsal surface of the plate is convex, and its posterior margin is incurved and armed with spines and stout plumose setæ, as shown in the drawing:

The sixth pair of ablominal appendages, which, as already mentioned, are clearly outlined beneath the cuticle of the second larva (fig. 102, become broad lamellar paddles in the third stage (fig. 104), aud in the fourth larva nearly equal the telson in length (fig. 105). The outer lamella is jointed at its posterior end and bears on its upper surface, near the line of the articulation, a short median tooth, as in the adult state. After the fourth molt the caudal-fun is rery similar to that of the adult. The telson is 
a quadrangular plate, about two-thirds as broad as long, with an even convex margin bordered with long fringing sete at its hinder end. The median spine has disappeared and the long lateral spines are reduced to short, stout teeth.

In the later adolescent stages the fringing setre of the caudal-fan become greatly elongated until they nearly equal the telson in length. The adult telson is somewhat spatula-shaped and about as broad as long at its base.

\section{THE METAMORPHOSIS OF HOMARUS GAMMARUS}

Sars studied the first three larval stages of the European lobster in specimens which he collecterl at the surface of the ocean. He saw enough to convince him that they were at this time an easy prey to fish, swimming birds, and to ocean currents which swept them into unfavorable places (175).

At Espevaer, a fishing-place on the coast of Norway, his attention was directed to large numbers of lobster larvæ, which were there "packed together with an enormous mass of Calanides (a kind of herring) and other species of pelagic animals, upon which swarms of herring and birds were feeding."

The abbreviation of the metamorphosis has been carried a little further in Homarus gammarus than in the American species. The young of the two forms apparently agree in color, but are very dissimilar in size. According to Sars, the first three larvæ of the European lobster measure 10,14, and 17 to $18 \mathrm{~mm}$., respectively. If these measurements are representative, the first larva of this species is larger than the second larva of Homarus americanus, and the third larva larger than the sixth stage. (See table 25 .)

The color of the third larva, according to Sars, is a mixture of yellow-red or brown and blue-green, and at this stage the integument has lost much of its transparency.

The carapace, the large chelipeds, and abdomen in the first larva of the European species have reached a stage of development which corresponds very nearly to the second larval stage of the American form. This is best illustrated by the rostrum, large chelæ, and telson. The second somite of the abdomen is devoid of the median spine, which, as we have seen (table 36), usually disappears in the American form with the second molt. Sars says that even in the first stage the anlage of the uropods can be discerned beneath the cuticle. These appendages, however, are not released until after the third molt, as in our lobster.

\section{THE SHORTENING OF THE METAMORPHOSIS IN THE LOBSTER.}

I have diseussed in my work on the development of Alpheus $(94, \mathrm{p} .380)$ the abbreviation of the larval period in Crustacea, and described the remarkable examples of this phenomenon which the study of the Alphei revealed. We will now consider the case of the lobster a little more closely than it was possible to do at that time. What is the cause of the suppression of the zoea stage in the metarnorphosis of this animal?

We can not doubt that this is a secondary phenomenon which has appeared in comparatively recent times, and that some of the immediate ancestors of the lobster went through the long metamorphosis after hatching, as the majority of Decapods do to-day. It is equally certain that something in the environment of these animals has called forth this change. Why should the lobster be better off with a short metamor- 
phosis than the common blue crab (Callinectes hastetus) or common shrimp (Crangon vulgaris) in both of which the larval life is prolonged? The only clew to an answer lies in the study of the habits and economy of these animals. The course which the larval development finally assumes in any species is a compromise between several conflicting paths. A wide surface distribution is necessary for the continuance of certain animals, but in order to secure this the larval period must be extended. On the other hand, a long life at the surface would be death to many species.

Natural selection is operative at all stages of development, and is effective in increasing the chances of survival mainly in two distinst ways: (1) Either by increasing the number of ova or young produced, or (2) by shortening the path of development. In the latter "ase the number of eggs is diminished and the size of the egg increased.

The crab and shrimp have adopted the former course and the lobster has followed the latter. A lobster $10 \frac{1}{2}$ inches long lays, upon the average, 11,000 eggs, each of which is about $1.9 \mathrm{~mm}$. in diameter, while Callinectes produces, according to S. I. Smith (18f), 4,500,000 eggs, each having a diameter of only $0.28 \mathrm{~mm}$. Thus the crab, though much the smaller animal, lays over four hundred times as many eggs. With the same number of eggs as the lobster and a long larval life, the erab could not survive. The lobster lives in deeper water than the erab and is probably more sensitive to changes in temperature. The larval period lasts from 5 to 8 weeks; that of Callinectes probably longer, but this is not known. Any further shortening of the development of the lobster would lead to a considerable reduction in the number of eggs, and if the metamorphosis were lost completely so that the animal left the egg in what now corresponds to its sixth or seventh stage the conditions of life would be very unfavorable for the young, on account of the sedentary habits of the adults. The adolescent lobsters (being thus concentrated in a relatively small area) would fall in vast numbers the prey of fish and crustacea, especially to members of their own speries, before they could establish themselves securely in their retreats along the rocky shores. (See Chapter XI).

The advantage of a larval life lies in securing distribution, in this case an absolute necessity, over wide areas up and down the coast, and at the same time in the immediate transportation of the young from the shore out of reach of many enemies. This being true, why, it may be asked, has the larval development been shortened at all? This has been brought about, in all probability, because of the general slowuess which characterizes the whole period of development and because of the great destruction which is wrought upon the pelagic larva even under the most favorable conditions.

It is very interesting to notice, as I have already mentioned (p. 200), that abbreviation in development is carried a step farther in the European species.

It is a well-known law that a fresh-water life tends to shorten the development of animals, and this may be due to the fact that the seasonal changes of temperature are far greater and more abrupt in inland waters than in the ocean.

A life in deep water tends also to shorten development and eliminate the larval period. Where deep-water forms at the present day have an indirect development, it is possible that the problem is complicated by other conditions or that the bathic habit has been acquired in comparatively recent times. 


\section{Chapter XIII.-THE EMBRYOLOGY OF THE LOBSTER.}

I shall not attempt to give a detailed account of the embryonic history of the lobster, although for several seasons I have spent much time both in collecting and preparing material for this purpose. I will offer only a few notes on the early phases of development, and, to lend continuity to the whole, will sketch briefly the changes in external form which the embryo undergoes.

Early embryologists, Rathke in particular, to whom reference has already been made (160), examined the older embryos of the lobster or dissected them from the egg membranes, but the only paper of this period which attempts to deal directly with the embryology of the animal is that of Erdl (62), published in 1843. Erdl treats of the laying of the eggs and the fastening of them to the appendages of the mother; of the nature of the laid egg and of the external anatomy of the older embryos; but his work was done before the modern methods of microscopical research had been discovered. This pioneer observer was thus greatly handicapped and his results are now of but little value.

Smith figured and described the external anatomy of a well-advanced embryo from a lobster captured May 2, 1872, at New London, Connecticut (182). This stage nearly corresponds to that shown in cut 38.

In September, 1891, a paper on the Embryology of the Lobster, by Bumpus, appeared, in which the early stages, to the close of the egg nauplius period, are carefully described and illustrated by very accurate and beautiful drawings (30).

A short account of my earliest studies appeared in 1890 (91), and this was followed by additional notes in May, 1891 (92), in 1893 (96), 1894 (97), and 1895 (100).

\section{NORMAL DEVELOPMENT.}

\section{THE MATURATION AND SEGMENTATION OF THE EGG.}

In the section on the growth of the germinal vesicle I have described the only stage in the maturation of the egg which has been directly observed (p. 154, plate 42, fig. 161), where the germinal vesicle has approached the surface and is undergoing indirect division, being overtaken in the metakinetic stage. As already stated, it is evident that in this particular egg the germinal vesicle was about to give off a polar body.

Bumpus, who was the first to detect polar bodies in the egg of the lobster, gives the following account of them:

They are present in many eggs, and appear to be attached at no special point of the vitellus, so far as the flattened area is concerned, being sometimes within it and sometimes without. It may be, however, that I have only seen them in secondary positions; for in some cases they seemed to move freely about within the egg membrane. They were not observed in process of formation, nor were they invariably present. Before the blastula is formed they disappear. (30)

I was unable to satisfy myself that the polar cells could be distinguished with certainty, and so have not figured them. It is difficult to detect such minute bodies in so large and so opaque an object as the egg of the lobster, and owing to mechanical causes, possibly through the emission of the polar bodies themselves, minute spherical globules of food yolk are set free and float in the fluid which underlies the eggshell. A 202 
single globule of yolk is practically colorless, and as I have never detected the polar bodies in stained sections I can not affirm that the small particles which seened to auswer to their assumed appearance were not detached globules of yolk. In ovarian eggs which had failed to pass out of the body at the time of ovulation I have seen what looked like polar corpuseles, but here, although the nucleus of the ovum was at the surface, the observation could not be confirmed by histological analysis. The position of the nucleus in such cases seems to point to the extrusion of the polar cells under normal conditions, while the eggs are within the ovary or its ducts.

I have already described and figured the eg of the shrimp, Stenopus hispidus, in which two cells and a single polar body can be distinguished in sections (95, fig. 1, plate 6). One cell lies at the surface, and very near it in the space beneath the yolk and shell a spherical mass of deeply staining chromatin, corresponding in size with the nucleus of the superficial cell. It is probable that the latter represents the germinal vesicle after one division, and that the deeper lying cell is the uale pronucleus. (Compare 94, description of plate, p. 474.)

\section{TIE EXTERNAL PIENOMENA OF SEGMENTATION.}

A colored sketch of the fresh egg's of the lobster is given in fig.24, plate 17 . These were laid in an aquarium, and when examined August 11, 1893, were closely adherent and could be separated ouly with difficulty. The fresh egg is spherical, oblong, or somewhat irregular in form, and measures about $\frac{1}{16}$ inch in diameter. (See p.55.) It has in appearance a fine granular texture all over, owing to the miform distribution aud charicter of the yolk spherules, aud the shell lings the egg closely in all its parts.

An early sign of development is the flattening of a part of the surface of the yolk and the consequent elevation of the shell over this area. A liquid, in which a granular substance is sometimes feebly developed while the egg is still fresh, is pressed out of the yolk and fills the free space between it and the shell. This flattened area marks the animal pole of the egg and is very characteristic. The surface of the orum is often flecked with light spots due to the irregular grouping and perhaps looser ar'angement of the yolk spherules. Light Hecks, three to four in umber, but of different character, now appear in the depressed area (fig.215). These are cells which are approaching the surface, and their nuclei can now be seen shimmering through the green yolk.

The phases which immediately follow are represented in figs. 216, 217, and 218, which were drawn from the same egg at successive stages of development. The cells approach nearer to the surface, multiply by indirect division, diffuse about the animal pole, aud bring ou the superficial segmentation of the yolk iuto hillocks as seen in protile in fig. 218. The drawing shown in fig. 216 was made at $10.30 \mathrm{a} . \mathrm{m}$. At the animal pole there are seen two double rows of cells, 8 in each double row, or 16 in all. These are arranged in pairs-four pairs of daughter cells in each double row-the products of recent division. This egg appears in profile in fig. 218. The yolk is now in contact with the shell over less than half its area, but the yolk hillocks appear about the animal pole only. At 10.55 a. m., 25 minutes later, 20 cells could be detected. At 12 m., or 65 minntes later, this egg had the appearance shown in fig. 21\%. The segments or yolk hillocks were then farther apart. This process continued until the entire surface of the yolk was segmented.

Opposite sides of the same egg in mhich that conditiou was already realized are represented in figs. 219 and 220. The fonmer shows the animal pole, the latter the 
vegetative. At about $9.30 \mathrm{p}$. m., when I began these drawings, the nuclei were in karyokinesis; at 10 p. m. nearly all were in the diaster stage (as represented here); at 10.10 p. m. superficial furrows began to appear, separating the daughter cells in the region of the animal pole. At $10.15 \mathrm{p}$. m. cell cleavage was completed. The cells on the opposite side of the egg lagged somewhat behind the others, the cleavage furrows in that region being completed about 5 minutes later. The yolk segments, both before and after division, were wedged rather closely together and were now polygonal in outline over the greater part of the egg. At 11 p. m. this egg had the appearance represented in fig. 221, when seen from the animal pole. The yolk segments or hillocks now protruded, becoming very convex, and the whole egg took on a beantiful mulberry-like appearance, the segments which were visible to the naked eye being dark green with whitish protoplasmic caps or centers. At $1 \mathrm{a} . \mathrm{m}$. or $22_{4}^{3}$ hours after the last cleavage period was completed, the segments flattened down, and by mutual pressure assumed a polygonal form, the energy which had been stored up during the interval being now directed to do the work of the next cleavage.

A similar phase is illustrated by cuts 23,24 , plate $G$, the former showing the vegetative pole. When these drawings were made, at $12.55 \mathrm{p} . \mathrm{m}$., the nuclei were mostly in the diaster stage of division, and in 70 minutes cleavage furrows were beginning to appear.

An egg in a stage quite similar to that seen in fig. 221 is represented in fig. 222. When first observed, at 10 a. m., from thirty-six to forty segments were visible over that half of the egg corresponding to the animal pole. At 10.55 the nuclei were in active division. At 11.30, when the drawing was completed, cell-cleavage furrows were beginning to appear, and in 20 minutes the segmentation was completed over the greater part of the surface. At $12 \mathrm{~m}$. (30 minutes from the time cell-cleavage became visible, and 65 minutes from the beginning of karyokinesis) the process was complete and the segments bad begun to swell. The egg in this phase is represented by fig. 223. At 2.45 p. m. active karyokinesis again began, and at 6.25 , or in less than 4 hours, division of the segments was again completed. This phase of the segmentation lasted nearly four times as long as the former period. The drawing of it (fig. 224) was made at $9 \mathrm{p} . \mathrm{m}$., and represents the side including the vegetative pole. (See figs. 218, 219, and 220.) The polygonal cells, near the central part of the area represented, were the last products of this segmentation.

The time occupied in cell division is illustrated by another egg, which was under observation $7 \frac{1}{2}$ hours $(10.55 \mathrm{a} . \mathrm{m}$. to $6.25 \mathrm{p} . \mathrm{m}$.). It was of about the same age as the egg shown in fig. 222. At 10.55 a. $m$. the nuclei were in the diaster or metakinetic stage of division. At 11.40 a. m., or 45 minutes later, cell division or segmentation was completed. At 1 p. m., 80 minutes later, the superficial furrows were very definite and the protoplasmic cap of each segment was more distinct when examined in reflected light. At $2.45 \mathrm{p} . \mathrm{m} ., 105$ minutes later, or nearly 4 hours from the beginning of the last period of segmentation, the segments were closely crowded and nuclei were agaiu in active division. (Stage of the equatorial plate.) At 4.15 p. m., $1 \frac{1}{2}$ hours later, cleavage amphiasters were formed, but no furrows. At 6.25 p. m., 2 hours and 10 minutes later, or 3 hours and 40 minutes from the time of appearance of the equatorial plate, segmentation was completed. Here the total segmentation period lasted about 6 hours and 45 minutes, of which 2 hours and 20 minutes were spent in quiescence and 4 hours and 25 minutes in activity. 



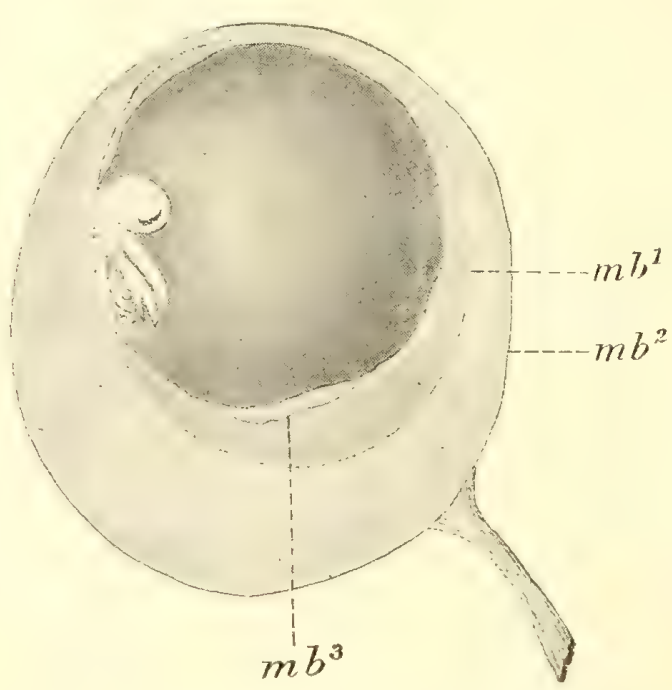

CUT 20.-Egg embryo, showing membranes abnormally distended after prolonged immersion in piero-nitric acid. 29 diameters.

$m b$, primary egg-membrane, formed in ovary. $m b^{2}$, secondary eggmembrane, prolonged into the stalk of attachment, formed by the cement glands. $m b^{3}$, cuticular molt of embryo.

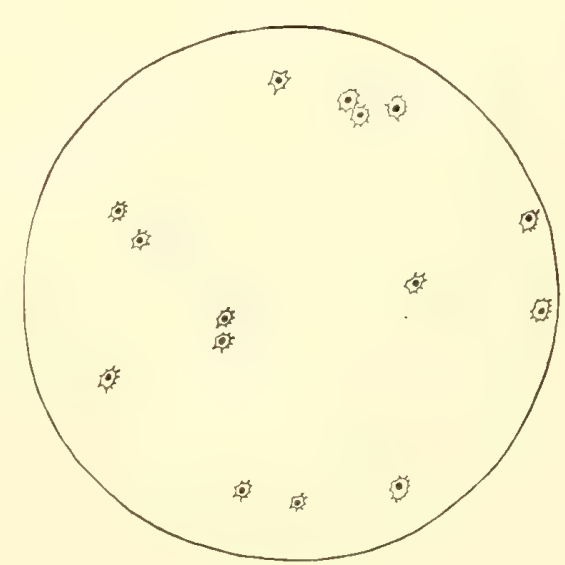

CoT 21.-Projection of an egg witb 15 yolk-cells, all near the surface or approaching it.

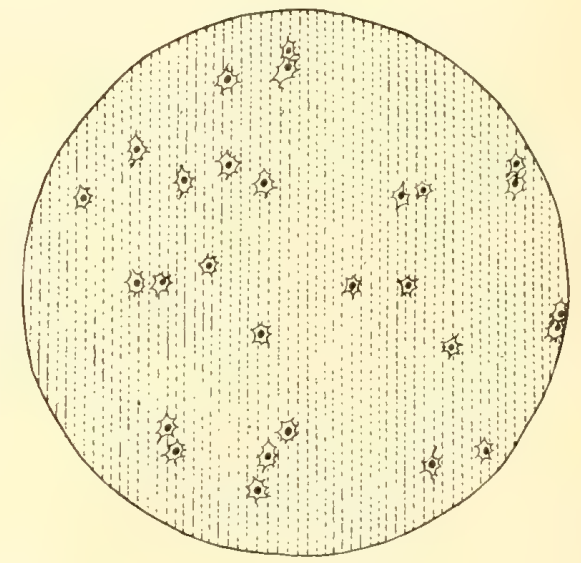

Cut 22--Projection of an egg with 28 yolk-cells, 3 in karyokinesis-mostly near the surface.

In these cuts the yolk-cells only are showu. Sections are represented by dotted lines in cut 22. 
About 110 cells are present in the egg shown in fig. 223, and not far from 220 in the next phase (fig. 2't). The lack of uniformity in cell division which was present in the eirlier stages now entirely disappears. In other words, the individual rhythms of the component cells of the embryo appear to be in harmony.

At the next and following divisions (fig. 225) the protoplasm approaches nearer and nearer the surface, and the animal and vegetative poles are no longer distinguishable. A surface view of an egg intermediate between the stages shown in figs.

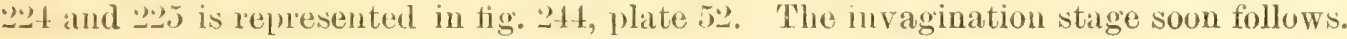

\section{INTERNAL CHANGES IN SEGIENTAIION.}

The histological changes which take place in development up to the beginning of the invagination stage will now be considered.

The segmentation nucleus in a single egg, from a batch which I obtained on August 1, was very eccentric in position, and in appearance resembled the germinal vesicle of the unextruded egg. The nucleus was spherical and lay in a spherical island of granular protoplasm. The nuclear membrane mas very delicate, and could hardly be demonstrated in sectious, while the chromatin had a rather coarse granular appearance.

The first division takes place near the center of the egg, and the products move away from each other. In two eggs examined, each of which contained two nuclei (possibly the pronuclei), one uncleus in each case lay nearer the center and the other nearer the surface. The nuclei are relatively small, and after a few divisions become very much smaller. Each is surrounded by a rayed body of protoplasm, in some cases (as in fig. "2t9) the rays being exceedingly mumerous aud delicate, reaching far out among the yolk-spheres. In an egg which was cut into 56 sections, the first two cells appeared in the twenty-fourth and thirtieth sections, respectively. In each case the nuclens was spherical, aud the cell protoplasm formed a compact oval islaud, giving offi no long characteristic pseuclopodia, as are seen in fig. "2:3s. In another case, where the egg was cut into 64 sections, one cell appeared in the thirty-first and its sister cell in the thirty-ninth section of the series, the latter being in process of division.

In the second and third segmentations which follow, producing four and eight cells, the products separate and migrate toward the surface. The greater number teud to move toward the side of the egg corresponding to the animal pole, where the yolk is first segmented (figs. 215-218, plate 50).

In an egg containing nineteen cells, with yolk undivided, eight were in various stages of karyokinesis. Some cells were nearer, others farther from the surface, the majority being about midway between the center and periphery, in different parts of the egg.

In another egg, where the segmentation of the superficial yolk was completed, just thirty cells or yolk pyramids were present. (See figs. 219 and 220 ; a section of the egg is represented in fig. 2t2.) The constrictions of the yolk are not simply superficial, but cleavage planes often reach balfway down to the center of the egg. The nucleus with its rayed protoplasm lies toward the center of the convex face of each segment, but is still separated from the surface of the egg by a considerable layer of yolk. The entire protoplasm is thrs distributed among the yolk segments, none of it remaining in the undivided yolk mass. In surface views the nuclei can be seen shining through the thin stratum of yolk which lies between them and the surfite. Sometimes a segment is partly overgrown by the surrounding cells and squeezed below 
the surface, as in fig. 238, but this must not be mistaken for one of the phagocytes or yolk cells, which are formed in an entirely different manner.

Karyokinetic figures, which are clearly seen in all dividing nuclei, show that up to this time the plane of cell division is radial, for all cells at least which have approached as near the surface as those shown in fig.242. A little later than this, fig. 224, plate 50, and fig. 244, plate 52, when over 200 cells were present, phagocytes or yolk cells suddenly appear. One egg showed, when sectioned, the following condition:

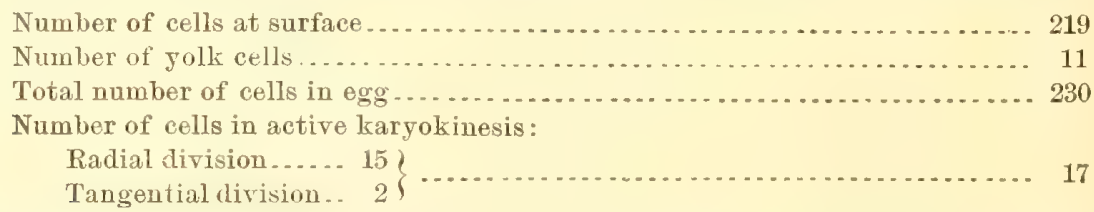

The yolk cells are in various stages of migration from the surface to the depths of the egg. Four have reached points about midway between the surface and center, and one of these is in the metakinetic stage of division. They originate by the tangential division of a certain number of the peripheral cells and by the multiplication of yolk cells thus formed. The peripheral cells at this time are not quite in contact with the surface of the egg, but are separated from it by a thin layer of yolk spherules. When a peripheral cell divides in a horizontal or tangential plane, the central daughter cell migrates into the great yolk mass, filling the egg, while the other remains at the surface and forms a part of the primitive blastoderm. The process is illustrated in figs. 236 and 243 , the latter showing the formation of a yolk cell near the surface, and also the division of a yolk cell already formed.

\section{THE INVAGINATION STAGE.}

After a stage similar to that shown in fig. 225 is reached the peripheral cells continue to divide in radial planes, and their protoplasm soon bounds the surface of the egg. Cell division becomes more rapid over one side of the egg, possibly that corresponding to the animal pole, but this was not finally determined. An area of rapid proliferation is thus distinctly marked off, and in the midst an invagination of superficial cells occurs. This begins by the in-wandering of a few cells, which is followed by the multiplication of those thus immersed in the common food stock, and by the siuking in of a small area of the blastoderm about this point. In an ovate egg, like that shown in fig. 227 , the invaginate area lies toward one of the poles.

The depression is at tirst very shallow, but increases considerably in depth and becomes a well-defined circular pit. Later it elongates transversely (cut 26), and in abnormal cases a deep gutter is formed. The character of this depression is indeed subject to great variation. The pit at the surface lasts from four to five days, when, after becoming elongated into a slightly triangular slit, by the ingrowth of the sides, it completely disappears.

In an egg in which there is a distinct patch of cells marking the area of invagination, but where the depression is very slight or has entirely disappeared, the embryonic area which lies in front of the point of invagination is marked by a wonderful activity among the superficial cells. This is illustrated in fig. 252, plate 54. About the point of invagination there is a mass of several hundred cells, from which migration into the yolk has taken place. Many of the cells, both at and below the surface, 


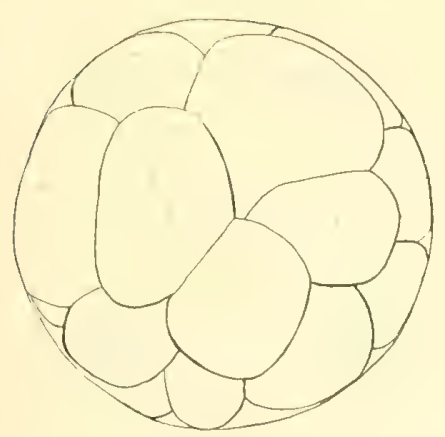

CUT 23.-Egg with about 32 yolk segments present, seen from regetative pole. A bout twenty-eight hours after fertilization. At $12.05 \mathrm{p}$. $\mathrm{m}$. the nuclei were diriding, and at 2.05 p. $m$. corresponding segmentation furrows in the yolk lial appeared. 29 diameters.

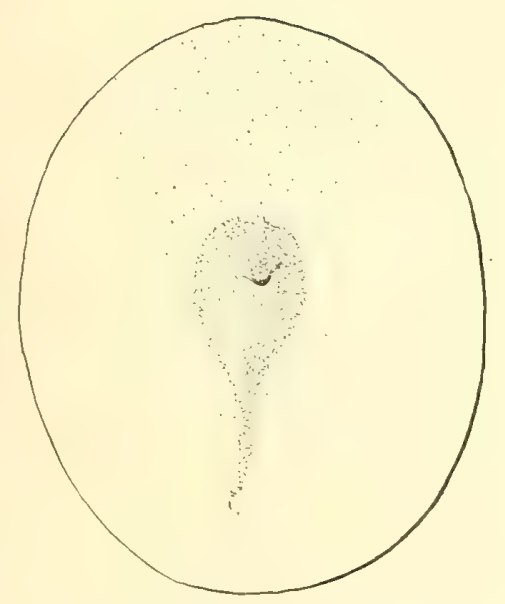

Cur 25. - Surface view of embryo 8 dass old in invagination stage, showing pit at surtace, embryonic area, and mass of in-wandering cells which penetrate deeply into the rolk. These appear now as a dense pear-shaped clond when seen through the superficial parts. $29 \mathrm{di}$ ameters. From No. 3 (1), table 18, July 9, 1890.

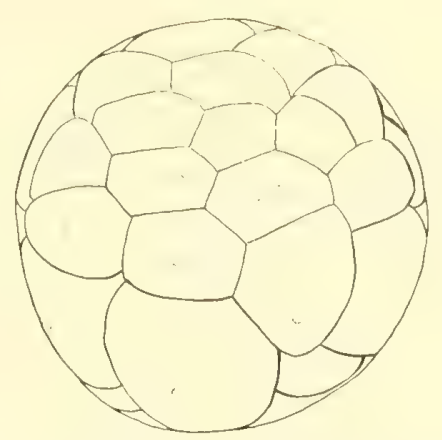

Cut 24.-Reverse side of same egg, showing divided nuclei at the animal pole. Drawings from living egg. 29 diameters.

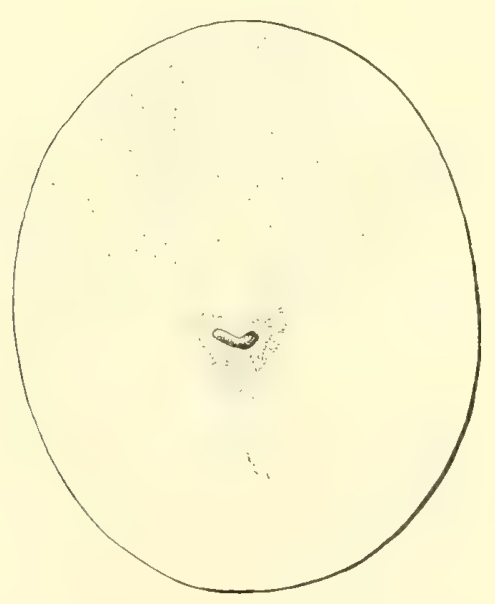

Cor 26.-Surface rier of egg in mragination stage. Pit very distinct, transversely elongated, showing tendency to become horseshoe-shaped. 29 diameters. Embryo about 8 days old. August 12, 1892. 

are in various stages of division, as shown by the clearly defined karyokinetic ligues. The surface of the egg at the sicles, but particularly in front of this area, presents a striking, and, for a transitory period, a very characteristic appearance. The nuclei are grouped in pairs, in short strings, or in clusters or nests of a dozen or more. In many cases these nuclei are breaking down and giving" rise to the "plasma vesicles" and "chromatin nebulie" of Bumpus (30). The degenerating chromatin of these distupted cells still reacts vigorously upon the staining fluids, and appears as a ('omled mass of fine particles ( $6 . \mathrm{g} .237,0 \mathrm{~g}$.) which in time becomes more diffused and scattered amid the adjacent yolk granules (fig. 241). The pairs or chains of cells arise by the usual process of indirect division in radial planes.

The cell nests, as illustrated in fig. 245 , plate 52, are the result of a multiple karyokinesis, and are formed immediately by either one or two divisions from a single cell $\left(y n^{\prime}\right)$. Since the active phase of this process lasts but a brief interval, it is not surpising that it usually escapes attention. In this egg, nests of nuclei are very abundant at the sides and immediately behind the regiou of ingrowth, and oceur, as is well shown in fig. 245 , both at the immediate surface $(c n)$ and below it. In most cases a yolk ball is formed with very definite outlines, its size depending upon the amount of protoplasm which it contains. The yolk ball is strictly analogous to the superficial yolk-bearing cell and to the yolk pyramid. The superficial cell, which is a direct descendant of the enormous yolk segment or pyramid, has this peculiarity in the lobster: By the time a distinct blastodermic envelope is formed it tends to become distinctly separated from the rest of the egg. A definite stratum of cells is thus formed consisting of yolkladen discoidal or columnar cells. (See figs. 251 and 255, ec.)

The appearance of the cell nest or cluster in a restiug condition is shown in figs. 245 and 247 . The yolk immediately surrounding it is usually, but not always, segmented into spherical masses. Upon the side of the egg, opposite the embryo nuclei are far less numerous and very uniformly distributed. No cell nests or evidence of active division are seen.

It will probably be found that, whenever clusters or nests of nuclei appear in the blastoderm or other parts of the embryo of Arthropods, they are the result of multiple cell division. Some time ago I suggested $(9 \dot{t}, \mathrm{p} .425)$ that this would account for the nuclear cluster's which Reichenbach has figured in the large endodermal cells which form the lining of the mesenteron in Astacus, and which he supposed were dne to a process of direct division (163). Both in this case and in the lobster the division is attended by the dissolution of some of the chromatin.

The histology of the embryo during the invagiuation period is illustrated by figs. 246, 251, 254. At a very early stag'e a few cells break with the surface and migrate a short ray into the egg. A depression about the point of ingrowth soon appears, and the cells, being bathed with untriment, multiply rapidly until the coudition illustrated in fig. 251 is reached. They here form at the surface a definite layer of prismatic elements, each containing a quautity of yolk with definite boundaries. It should be noticen also that the nuclei of the in-waudering cells are often inclosed in spherieal masses of yolk.

The histological processes which occul at this period vary considerably in different embryos. Thus in fig. 246 we see a stage of development very similar to that of fig. 252, but a little earlier. In the former (fig. 246) the cells about the area of invagination have multiplien until they form a large cluster at the bottom of the pit. A syncytium is formed, aud the protoplasm of the ontermost cells lies at the surface, while the neighboring yolk is thrown into long, tapering segments. Some of these 
invaginated cells have wandered a short way only into the egg. Now, if we examine the peripheral cell envelope, we find abundant evidence of cell division over the side of the egg where the embryo proper is soon to be built up. Nests of nuclei, often surprisingly large and numerous, are now and then seen in the midst of a spherical mass of yolk either at the surface or just below it. Isolated cells, though few in number, also occur, scattered through the peripheral parts of the yolk at this stage. What is their origin? They can not be referred to invaginate cells, since none of these have yet wandered to remote parts. Furthermore, these cells tend, not to seatter, but to migrate in a body. They may be the descendants of the primary yolk cells or migrants from the peripheral cell envelope, or may originate in both these ways.

At the time of invagination the egg of Alpheus is very similar to that of the lobster in its histological relations. The main difference which is apparent to the eye is in the larger size or greater amount of food yolk in the latter. I have described and figured the invagination stage of Alpheus in some detail in my work on the embryology of this crustacean $(94, p, 400$, plate XXXI). In this species the primary yolk cells persist and mingle with the wandering cells derived from the invagination. An egg of Alpheus saulcyi in the invagination stage contains about 460 cells, of which 8 per cent-exactly 37 were found in two separate eggs-are primary yolk cells $(94, \mathrm{p}$. 432, table 1). These yolk cells do not appear to be much more numerous in the larger egg of the lobster (see cuts 21 and 22, showing eggs with 15 and 28 yolk cells respectively), but in this animal they degenerate faster than in Alpheus, so that at the invagination period very few are left. On the other hand the occurrence in the lobster at this time of nests of nuclei within the yolk ball, which lies just below the surface or some times almost in contact with it, points to migration of cells from the surface after the invagination stage. In any case most, if not all, such cells degenerate and disappear.

In an older embryo, represented in fig. 254, the pit in the invagination area is considerably enlarged, and below this a solid wedge-shaped column of cells is seen advancing straight down into the yolk or bending slightly toward the hinder end of the embryo. This mass of cells forms what has been called the thoracic-abdominal plate. It here gives rise in part to a mass of cells which migrate into the yolk and eventually form mesodermic and endodermic structures. I shall call this cell-mass the mesendoderm. Regarding these cells we notice in particular the peculiar association of the cytoplasm with the yolk, the psendopodia by which they worm their way among the yolk spherules like so many amoebr, the evidence of cell multiplication and of the degeneration or breaking down of cells.

Signs of cell degeneration are also present in a striking degree over the embryonic area of the egg. The surface cells form a single tier of short prismatic elements loaded with yolk, while beneath them we see a thin cloud of fine chromatin particles. These are mostly the remains of cells which have migrated thither from the mesendodermic mass, and possibly in part also of cells which have wandered from the surface.

The embryo at a little later period has the appearance shown in plate 53. The ingrowing plug of cells has a rounded, somewhat pear-shaped outline when seen from above, the stem end of the pear pointing backward and dowuward into the yolk. The embryonic area of the egg presents a beautiful mosaic of cells, among which karyokinetic figures are abundant. The dividing planes of these cells are always radial-that is, parallel with a radius drawn from the center to the surface of the egg, but make auy angle with a line drawn upon the surface of the egg, such as that 


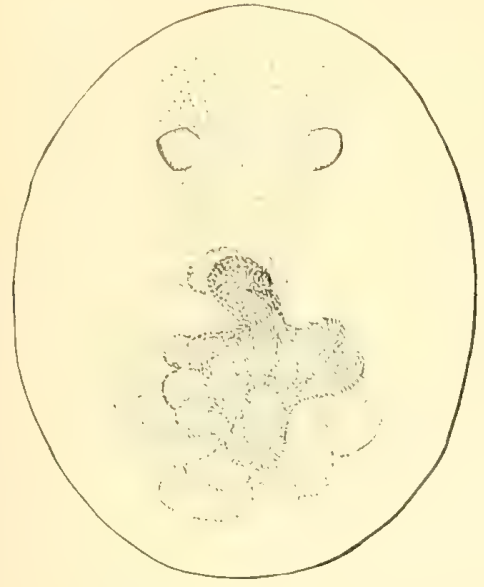

Cur 27-_urface view of embryo, showing buts of first pair of antenure and clouds of in-wandering cells. The lattor extend in great cumulus-like folds and surround large masses of yolk with thin lajers of cells. Embryo about 9 dass old. Augusi, 6, 1891.29 diameters.

In cuts 25-33 the eggs were tixed with hot water and Mayer's piero-sulphuric acid, and stained in Kleinenberg's hrmotoxylon or Grenacher's borax-carmine.

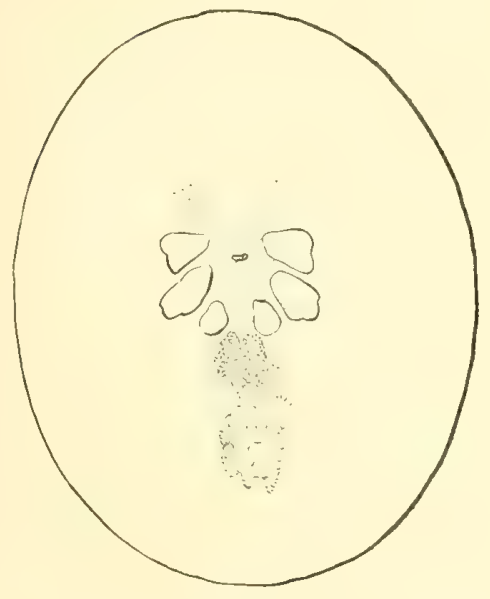

CoT 29.-Surface view of early egg nauplins embryo, showing buds of the first and second antennze and the mandibles. Mouth or opening of stomodrum distinct; in-wandering cells beneath the thoracic abdominal plate sharled dark. The yolk-rells are still further circumscribed to outward appearance, haring wandered far into the egg. Optic disks more clearly $\mathrm{de}$ fined. Enubryo about 10 days old. 29 diameters.

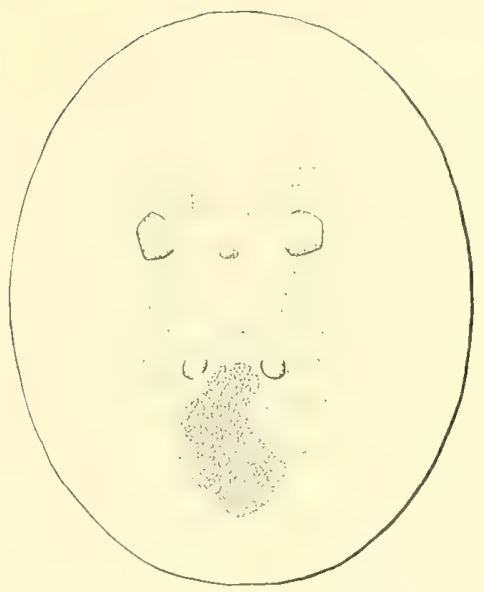

Cut 28. -Surface view of embryo, show. ing buds of first pair of antenne and of mandibles. The stomodreum is present in form of a small transverse pit, on the level of a line drawn through the posterior margins of the antennary buds. The outlines of the masses of yolk-cells appear much more circumscribed than in the earlie stage shown in eut 27. Embryo 9 to 10 days old. August 5, 1891. 29 diameters.

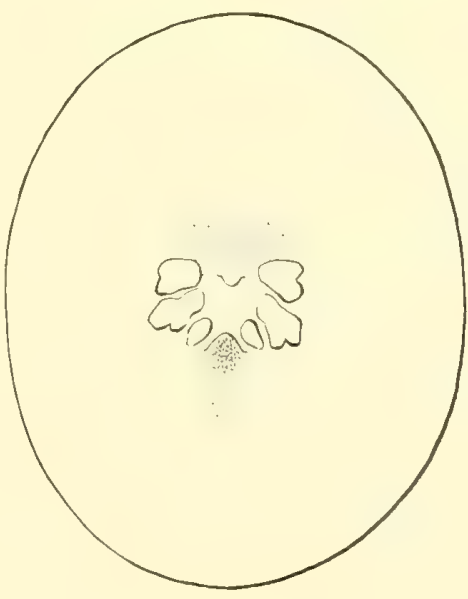

CuT 30.-Surface view of egr namplius, slightly older than that shown in cut 29; second anteunæ bifid; labrum and thoracic abdominal folr present; embryo abont 11 days old. July 12. 29 diameters.

In cuts 25-30 surface-cells are roughly indicated only in the immediate region of the embryo. 




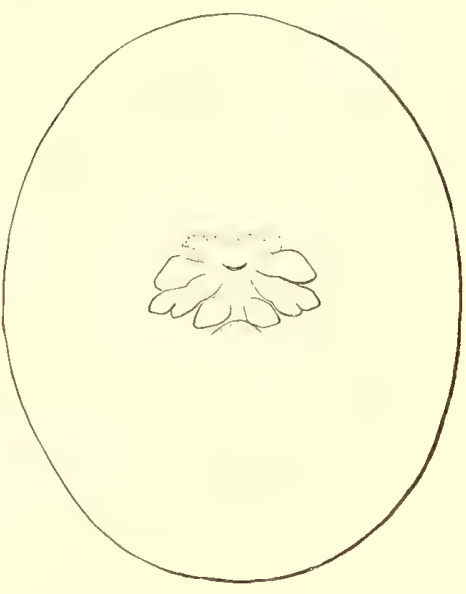

Cut 31.-Surface riew of egg nanplius, showing thoracic abdominal fold. The mouth, as in cut 30 , is sereened by the lab rum, and the optic disks are more sharply defined; second antennæ forked; embryo about 12 days old. 29 diameters.

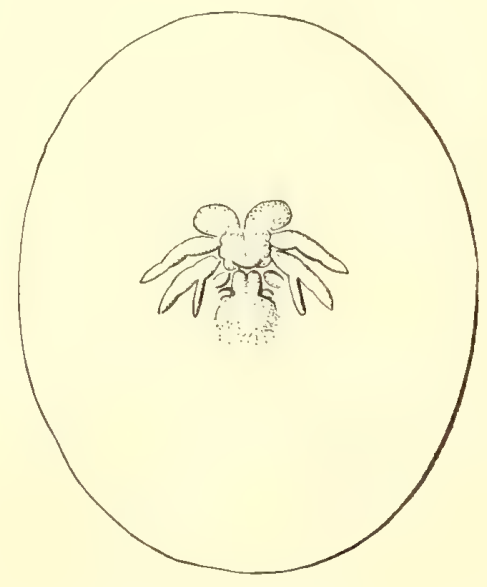

CuT 33. - Surface view of embryo with first maxilla budded; embryo 16 to 18 days old. August 5. 29 diameters.

In cuts $31-38$ there is little attempt to show more than the form of the embryo. The series $\mathrm{G}$ to $\mathrm{J}$ represents the progres sive derelopment of the summer eggs. Compare the Rate of Development, pp. 55 to 57 , and table 18.

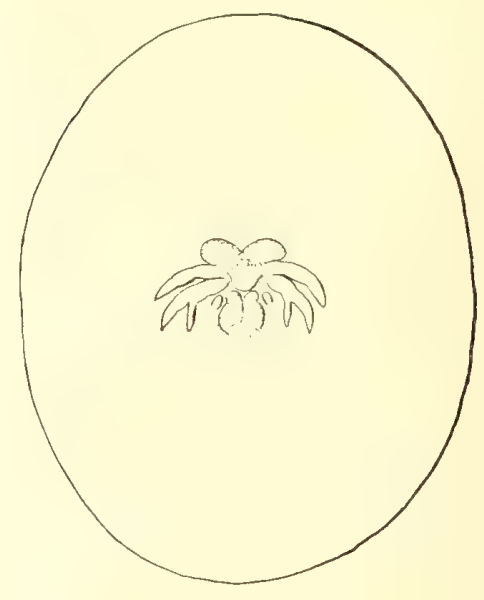

CuT 32.-Surface view of egg nauplius, showing parts much more concentrated than in earlier stages. Antenna exhibit traces of segmentation, and the second antenno have a slender inner branch. The abdomen is bifid at its extremity, which nearly touches the labrum; optic disk lobular; embryo 14 to 16 days old. August 14. 29 diameters.

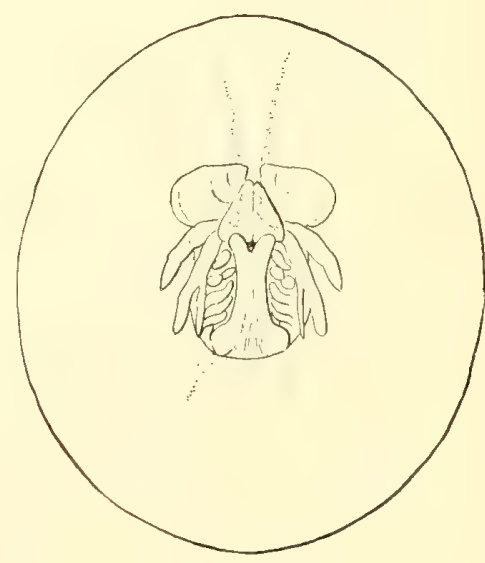

CUT 34.-Surface view of embryo, showing 5 pairs of post-mandibular appendages The antennæ have grown obliquely backward until they come to lie nearly parallel with the abdomen. The telson. which is now distinctly forked, partially overlaps the brain. Eye-pigment not yet apparent. Nearly same stage as 3 (5), table 18; alout 21 days old. From egg killed in Perenyi fluid, Angust 15, 1893. 29 diaweters. 
through the longitudinal median axis. There is no tendency to form radial strings or concentric circles of cells with reference to a given center at the surface, such as lieichenbach (163) has described in the erayfish, a fact already noticed by Bumpus (30). Diffused clonds or islands of chromatin particles, the wrecks of cell colonies, lie strewn over the embryonic area, particularly in its forward part. These are for the most part immediately below the ectoderm. The opposite side of this egg shows nothing particularly noteworthy aud has not been figured. The nuclei are more seattered, cell division is less frequent, and clouds of chromatin grauules are much less extensive.

The internal structure of a little older embryo is illustrated by fig. 255 , plate 54 . The most noticeable changes are the great spread of the mesendoderm which, like a cloud of dense smoke from an engine, rises up aud trails backward into the depths of the yolk with many rounded summits; the columnar form of the ectodermic cells-most pronounced in the region of the optic disks-and the swarm of degenerating particles which underlie these regious. Sticking to the basal ends of the prismatic cells, numerous amcboid elements can also be seen. How do they originate? They must come either from the mesendoderm or from the ectoderm. That some of them migrate forward from the region of the thoracic-ablominal plate there can be $n o$ doubt, and it seems almost equally certain that some come from the surface cells. The position of the nuclei of the peripheral cells frequently points to the theory that some of them are crowded below the surface by mutual pressure. On the other hand it is sometimes, but not always, the case that the boundaries of the ectodermic cells are clearly defined. The ectoderm still consists of a single cell stratum. The ectodermic nucleus is suspended in the middle of the cell, cytoplasm filling the peripheral and deutoplasm the central ends. Mesendoderm cells also travel backward and sideways from the thoracic-abdominal plate and settle down upon the ectoderm. The cells which migrate into the depths of the egg and form the cumulus-like mass have this peculiaritythey form a connected syneytial mass; their nuclei are small and of irregular shapes. On the other hand amoboid cells below the embryonic area frequently possess large spherical nuclei.

\section{LATER STAGES IN EMBRYONIC DEVELOPMENT.}

The development of the external form of the embryo is illustrated by cuts 27 to 38 and by plate s̃1. The mesendoderm cells play an important rôle at the time the appendages are budding. In surface views they become less and less conspicuous, until in the late egg nauplius (cuts 31,32 ) they have passed out of sight into the deeper parts of the egg.

The appendages make their appearance in the following order: (1) First antenn: (2) mandibles, (3) second antennæ, (4) first maxillæ, and the remaining thoracic appendages in regular succession. They are all formed by the folling of the body wall or ectoderm, and contain solid yolk cores, until these are absorbed and replaced in part by the mesodermic cells which migrate into them. The second antenua soon becomes bifid and bilobed at its apex (cuts 30-32), the inver branch representing the future long tlagellum of this appendage. The first antenna remain single until just before the time of batching, when the inner branch or Hagellum begins to grow out from the inner lower surface of the primary stalk. The optic disks are tlat areas of rapid cell division. 
The relative position of the mouth and antennæ is illustrated by cuts 28 and 29 . I will add the account given in my paper on the development of Alpheus, where the lobster was also included, since it applies to the higher erustacea generally:

Before the first antennæ are folded, whan they are distinguished as dense patehes of cells, some eggs show the primitive mouth as a minute circular pit, lying nearly on a line drawn between the centers of these proliferating cell areas, but, so far as my observation goes, never distinctly in front of them. The relative positions of the mouth and first pair of antennæ shift very rapidly during the early period of their growth, before the fully developed egg-nauplius stage. The pit elongates and becomes a transverse furrow, and by the time the first pair of antennæ are clearly marked off as rounded buds, and before the second pair are raised into folds, the mouth is on a line with the first of these appendages. When the second antennæ are elevated into folds the mouth is behind the buds of the first pair, or on a line drawn between their posterior margins (94, p. 412).

At a stage before the appearance of eye pigment, represented in fig. 232, plate 51, a diffuse but conspicuous patch of ectodermic cells is developed, similar to what I have already described in Alpheus $(94, \mathrm{p} .414)$. In case the egg is oblong this patch lies at one pole about $90^{\circ}$ behind the embryo.

A stage just previous to the appearance of eye-pigment is seen in fig. 234. The forked telson now covers the labrum and is reaching up in front of the brain.

The relation between the age and size of the embryo under normal conditionsthe eggs having been laid in summer-may be seen by comparing cuts 23-38 with table 18. Most of these are from the same batch of eggs.

Eye pigment is developed in about four weeks, and the rate of growth of the embryo can thenceforward be gauged by the increase of the pigmented area (cuts $35-38$ ).

At a stage before the concentration of the embryo has begun, a little earlier than that shown in cut 29, Bumpus (30) has described and figured what has the appearance of a rudimentary pair of preoral appendages. These are elongated folds lying parallel with the convex border of the optic lobe, and separated from it by a slight furrow only. They are very transitory, disappearing completely after a brief interval. They can be seen in some of my preparations, but are not shown in the drawings.

\section{HISTORY OF THE YOLK CELLS.}

In my paper on the development of Alpheus I have devoted a chapter to the "Origin and history of wandering cells in Alpheus," and I have little doubt that what is said there of Alpheus is generally true of the lobster and of most decapoda.

In Alpheus, as in the lobster, a certain number of cells, 30 to 40, are budded off from the blastosphere, and form what I have called the primary yolk cells. Wandering cells, or those which enter the yolk and move about in it, have a triple origin, namely, from the blastoderm, the invaginated cells, and the ventral plate. It should also be added that both the process of multiplication by indirect cell division and that of dissolution or degeneration of protoplasm take place simultaneously in the wandering cells.

During the egg-nauplius period there is a rapid diminution of the wandering cells, due to cell disintegration and emigration to those parts of the embryo where mesoblastic organs are being laid down. The history of the wandering cells in Alphens is largely the history of the early development of the mesoblast and entoblast. The endoderm makes its appearance as a distinct cell layer during the egg-nauplius period, and takes the form of a narrow sheet of rather large cells, between the yolk and the rudimentary heart, near the body wall. In the space corresponding to the heart, blood corpuscles can already be detected, besides scattered mesoblast cells. Both the latter and the entoblast are derived from the wandering cells which come out of the yolk (91, p. 408). 


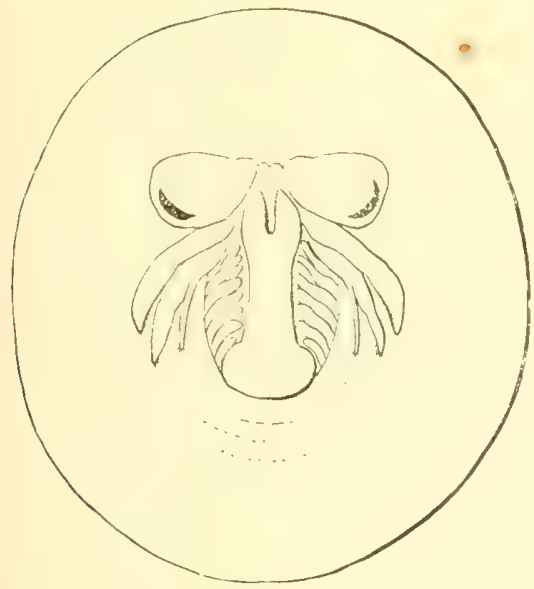

C.T 35. - Surface riew of embryo with eye-pigment in form of crescent, as seen from the surface. Telson orerlaps brain. Embryo about 26 days old. From series No. 3, table 18, July 26, $12 \mathrm{~m}$. Cuts 35-38 drawn from eygos fixed with picro-sulphuriv acil. Outline of egg a little under size. 29 diameters.

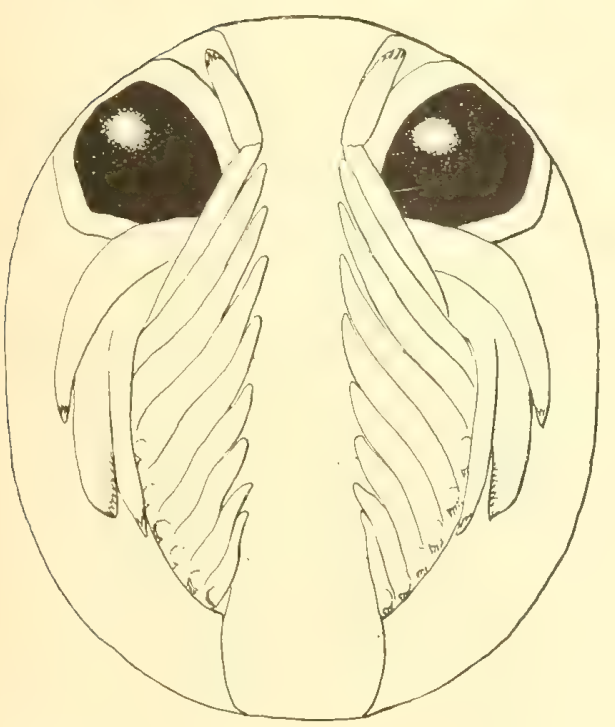

Cut 37.-Embryo 122 days old. Area of eye-pigment rounded or irregularly oval in outline. From No, 3 (13). table 18. November 1. 29 diameters.

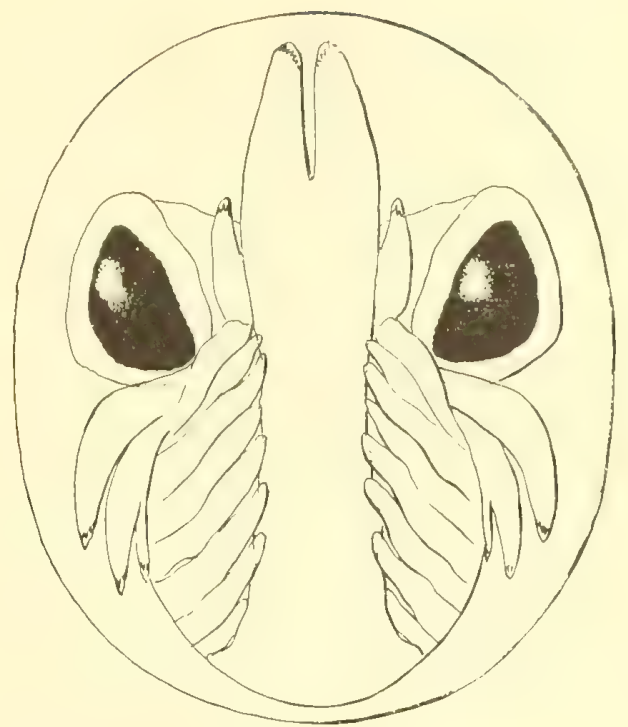

Cut 36.-Embryo61 daysold. Area of eye-pigment senı circular. Telson hehind brain. From No, 3 (11), table 18, September 1. 29 diameters.

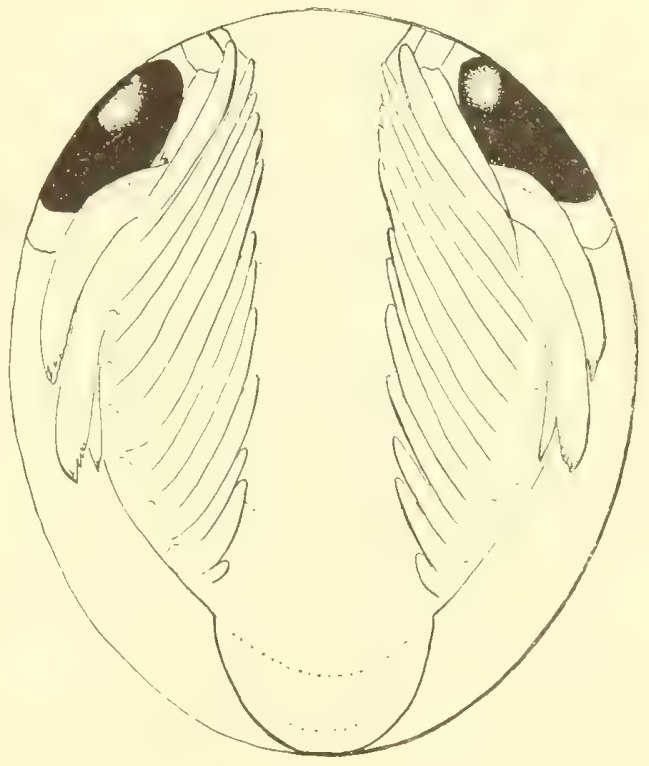

CoT 38.-Embryo 211 days old. Area of eye-pigment irregular, somewhat oval or rounded in outliue. From No. 3 (16), table 18, Februars 1. 29 liameters. 

In the lobster there appears to be this difference, in that the primary yolk cells are for the most part, if not wholly, disintegrated before invagination occurs, and take no part in development. This can not be shown to be the case in Alpheus.

I have spoken of the formation of the primary yolk cells by tangential division, in Alphens and other forms, as a process of delamination, on the ground that they represented a primitive endoderm, and that the egg with primary yolk cells corresponds to the planula stage of coelenterates. I first called attention to this mode of origin of yolk cells in decapod crustacea in my paper on $A l p h e u s(9.1, p .400)$, and found that in the lobster they arose by transverse division from the blastospherie cells or firom the peripheral cell layer (since there is no true blastosphere in this egg). The budding of these cells, moreover, begins before the outwardly migrating cells have reached the surface and completely surrounded the yolk. The regularity with which this process oceurs "in such typical forms as Alpheus and Homarus argues," as I remarked in an earlier paper, "for its presence in allied species where it has possibly been overlooked." A precisely similar origin aud speedy dissolution of yolk cells has been recently described in Gebia by Butschinsky (31). It seems that there can be no doubt that the formation of yolk cells at this early period is the last trace of a process which was once of importance, but the rôle which they play now must be an exceedingly minor one. I have never fonnd more than 28 of these cells in the large egg of the lobster (cut 22). Here, while it may be admitted that they are phagocytes or yolk digesters, the impression which they make upon this large mass of material is insignificant, aud they are themselves soon disintegrated and become a part of the general food stock. It is possible that they are the remains of a primitive hypoblast, that they once played a more important part as digesters of the yolk than they do at present, and that this function was usurped by the mesendoderm formed at the time of invagination. The term transverse fission iustear of delamination should, however, be used in speaking of this process (94, see pp. 400 and 419), since no true delamination occurs and nothing certain is known about the origin and meaning of this process in the decapod crustacea.

\section{DEGENERATION OF CELLS.}

I have discussed the subject of cell degeneration in my paper on Alpheus (94, pp. 425-431) and need not refer to the facts again in detail (see figs. 237, 240, 241, plate 52). The degeneration of cells in the ovary has already been mentioned (p.152). In the embryo this breaking down and absorption of cells into the common yolk mass is first seen in the primary yolk cells, and afterwards in the mesendoderm, where it soon becomes one of the most striking, and at the same time most puzzling, of all the varied phenomena presented by the developing embryo. If we examine a longitudinal section of the egg nauplius of the lobster, we find not a few chromatin balls, but a meteoric swarm of granulated bodies and naked chromatin grains coextensive with the embryo and reaching a considerable distance into the yolk amid the seattered mesodermic cells, but perhaps most abundant, as in Alpheus, in the neighborhood of the stomodrum. A long, nebulous train of yolk spherules and granules extends forward a considerable distance in front of the month and is especially marked in the region of the optic disks. The labrum and the folds of the appendages which contain solid yolk cores abound also in these peculiar granulated bodies. They occur in less numbers in connection with the mesendoderm cells, which have at this stage traveled through the greater part of the egg and form a series of irregular sacs filled with yolk. These yolk masses, with their surrounding sheet or advancing column of cells, corre- 
spond to the endoderm sae of the crayfish. In the latter the peculiar cell fragments also oceur.

If one now examines very thin sections under high powers, he finds that the granules and the granulated bodies correspond in general to the structures found in Alpheus. The chromatin grains appear sometimes as naked masses in the yolk, and stain either very intensely or faintly. They are often vesiculated-that is, they appear as hollow shells (fig. 241). Under favorable conditions it is easy to demonstrate the fact that these bodies surround particles of yolk, and occasionally they have a crescentic shape, when they seem to be enwrapping a yolk spherule (fig. 240, plate 52) (94, p. 427). I have shown that the "secondary mesoderm cells" described in the crayfish by Reichenbach (163) are undoubtedly products of degeneration which are afterwards absorbed in the yolk. In this species the endodermic cells which are loaded with yolk probably divide by multiple karyokinesis, producing nuclear nests or clusters, some of which in time undergo degeneration. The naked balls of chromatin which are found in these cells are probably formed in situ, though they unquestionably shift their position in the egg.

In a species of Cambarus, which I studied at a stage when five pairs of appendages were present, the endodermal nucleus was surrounded by a thin layer of protoplasm, which worked its way amid the yolk so as to practicaliy surround a pyramidal mass. This strongly recalls the serpentiue manner in which the cells ereep through the yolk in the egg of the lobster.

Later, when nine pairs of appendages are represented, the endodermal cells have nearly reached the ectoderm. The yolk within the confines of the ectoderm has an irregular, pyramidal, or radial cleavage. Centrally it blends with a serum-like fluid, in which occasional granules or balls of chromatin are suspended. Small spherical bodies containing a single chromatin ball, or several balls, oceur not only in the yolk underneath the ectoderm and in the vicinity of the endodermal nuclei, but also in the central yolk of the endoderm sae at various levels below the endodermal nuclei. This is a point of some interest in connection with the fate of these bodies. They wander not only peripherally but centrally. ${ }^{1}$ Rarely we meet one which is three or four times the average size, having a small chromatin spherule in its center. These latter become absorbed and gradually disappear (94, p. 428).

As I have already shown, the plasmic vesicles described by Bumpus (30) in the ovarian egg are mesodermic cells in the process of degeneration. (For the origin and history of these bodies see p. 152.)

Later, according to Bumpus, the plasmic vacuoles are represented by chromatin granules scattered about in the peripheral parts of the yolk.

In the early cleavage stages Bumpus says that the plasma cells are still represented by chromatin grains, which "are no longer confined to the periphery, however, but have advanced toward the center and formed an indefinite ring" (30). In the specimens of eggs in the early cleavage stages which I have studied-stained chiefly in Kleinenberg's hæmatoxylon solution-I have never been able to detect any degenerative products whatever. They appear to have been completely absorbed or converted into yolk before this time.

In a still later period, when the $U$-shaped embryonic area is differentiated, "the plasma vacuoles," according to Bumpus, "are represented by chromatin nebulie, which

${ }^{1}$ The movement of these bodies is probably due wholly to extraneous mechanical causes 
generally underlie the triangnlar and $U$-shaped areas" and are "found as small clouds between and also outside the limits of the embryonal tract." Ho says further that "chromatin grains, as was seen in the surface view, are most abundant where ectodermal cells are most ummerous." No inference is drawn fom this, but plainly the true one is not that the larger collection of endoderm cells are centers of cell degener. ation, but that the mesoblastic cells attach themselves to those parts of the embryonic ectoblast which are growing the fastest, and by their own dissolution give rise to the "chromatin nebulie."

Bumpus does not explain the origiu and fate of the chromatiu particles which he accurately figures, but remarks that "structures comparable with the chromatiu grains of the plasma cells are neither mentioned nor figured by Reichenbach, though the so-called 'serum' may represent the region of their activity." Further on it is said that "future comparison may prove these," the" "secondary mesoderm cells," of Reichenbach "to be the same as the plasmid vacuoles and their chromatin grains;" and again, "I have been unable to find in Homarus preparations that throw any direct light on the so-called "secondary mesoderm."'

I have shown (94) that the "secondary mesoderm cells" are not cells at all, but the prodnets of cell degeneration, aud that in their origin and final destiny they bear the closest resemblance to the "chromatin nebulre" of the lobster.

\section{ABNORMAL DEVELOPMENT.}

\section{SEGMENTATION OF THE EGG.}

In every batch of segmenting lobster eggs one is sure to meet with many irregular forms, and in some cases the greater number appear to be abnormal. Nuclei can be detected at the surface of many of the segments, and if the egg is treated with Pereuyi's fluid or with au acid the dark-green segments and their nuclei contrast very strongly with a milk-white coagulable substance in which they seem to be embedded. Some eggs, which were laid by a lobster on August 23, after a captivity of eight weeks in a small aquarium, were light-colored, but were normally fixed to the abdomen, and were fertile, although the segmentation was exceptionally irregular. Sections of these eggs showed an irregular distribution of cells both at the surface and throughout the yolk. In some places cells appear to have been carried below the surface by overgrowth, and afterwards to have multiplied in the yolk.

Eggs which are otherwise regularly segmented may contain a large superficial mass of undivided yolk, as in fig. 226 , plate 50. Here is a very large mass of yolk about the pole of the egg-a similar one lay near it on the opposite side-and a considerable number of smaller segments. When this egg is sectioned it is found that the large yolk masses are nearly devoid of protoplasm, while the smaller segments contain each a nucleus which shows traces of degeneration. There is no nuclear membrane, and the chromatin has assumed a very irregular form.

It is common to find eggs with yolk unseguented with the exception of one or more small balls at the surface. Sometimes a siugle large segment is seen, looking as if it had been pinched off, and in this and in many other cases it is evident that the egg has in some way received harsh treatment.

In one egg, rather more anomalous than usual, there was a single small spherical segment at one of the poles of the elongated egg, while the remainder of the yolk was 
undivided. A single nucleus was visible in the small segment, but the egg in reality contained six cells, five lying in the unsegmented yolk.

It would be interesting to know how many of the irregularly segmented cells eventually attain a normal condition. It seems probable that very many of them do, judging from the fact that the number of abnormal eggs which later appear when the nauplius stage is reached is much smaller, yet there is no evidence that any of the eggs are lost.

THE INVAGINATION AND EGG-NAUPLIUS STAGES.

I will now speak of some interesting variations which oceur during the invagination period and immediately after it.

Instead of the normal ingrowth of cells from the surface into the yolk and the sinking in of others to form a small circular pit, there is what appears at the surface as a deep transverse invagination. This is sometimes a loug crescent-shaped or irregular transverse fissure, as in the egg of which cut 40 represents a median longitudinal section.

In other cases, in which the processes of development have gone further, there is formed an irregular, oval, or circular disk of cells in connection with the invagination, as shown in fig. 229, plate 51. Here there is a well-defined rim on one side, while upon the other the structure seems to blend with the yolk. In a further-developed stage in the same process I find that the egg has often a well-defined, sometimes round, and very irregular cireumvallate disk of cells. The cells within the vallum are densely crowded, and the presence of numerous karyokinetic figures shows that at times cell division may become rapid. Below the surface, both within and without the vallum, the granular masses of chromatin bear abundant testimony to the degeneration of living protoplasm which is taking place in the yolk. The columnar aspect of the marginal cells of the disk can be plainly seen. The way in which this condition is reached is illustrated by cuts 39 and 40. By the ingrowth (or infolding in consequence of unequal growth) of some of the superficial or ectoblastic cells into the massive ball of yolk, a tongue-shaped or island-like patch of cells is formed, on which the embryo proper is subsequently marked off (figs. 228 to 231 ).

The egg-nauplius may arise in a depressed central part of the disk, as in fig. 231, or upon its margins, figs. $228,230$.

We will now glance at the histology of some of the abnormal embryos. Cut 40 shows a median longitudinal section through one of the earlier stages described. When the egg was examined from the surface a transverse irregular fissure was seen, corresponding to the pit $(P i t)$ where the sheet of cells dips below the surface. We see from a study of this egg that a considerable stratum of cells, including the invaginate area, has grown into the yolk, and that its edges are folded upon themselves. In this case one side of the disk, corresponding to the anterior end of the embryo, is at the surface, while the opposite side is deeply embedded in the yolk. Numerous cells have budded off from this cell plate, particularly at its posterior end, where they multiply rapidly and move about freely in the yolk, like the normal mesendodermic cells. Like the latter, they move chiefly in a posterior direction into the deeper parts of the yolk. Many of these wandering cells are moreover already in process of degeneration. It looks as if there was a migration of cells from the surface behind the cell plate, but the appearances may be in this respect deceptive. The yolk flows over the engulfed cells, but I find in my preparations no new superficial layer of ectoderm established. 
Cut 39 represents a median longitudinal section through the embryo shown in fig. 2:30, plate.j1. Here the entire embryo is immersed in the yolk or in at thin coagulable, fluid derived from it, through which it can be seen, while the cell plate touches the surface in a narrow, bow-shaped area, but dips below again at its peripheral margiu. The cell plate beyond the confines of the thoracicabdominal process and appendages of the embryo consists of a single layer of very large cubical or columnar elements gorged with yolk. In front and behind, the edges of this sheet unite to form a cul-desac, so that the whole structure resembles in form a flattened bag, which is partially buried in the yolk, with which it communicates by the opening or mouth of the sae below. The edges of the plate are curled over in the yolk, like one of the limbs of

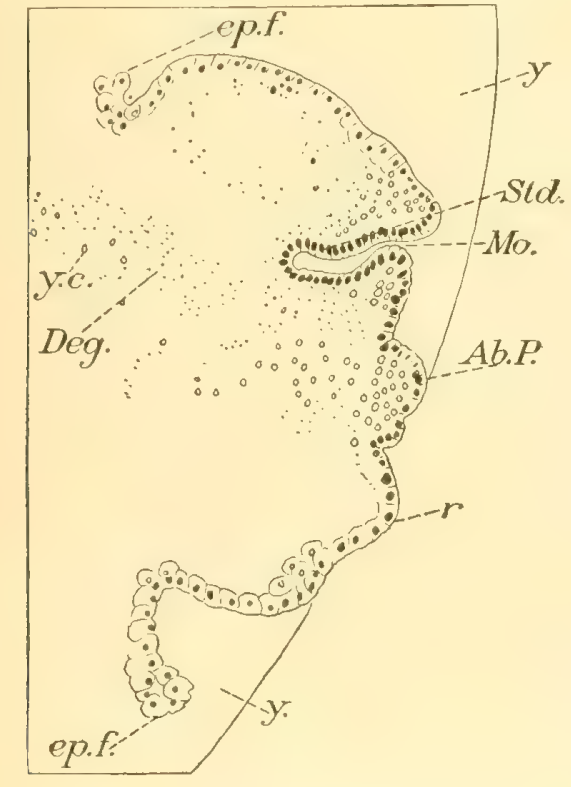

Cut 39.-Median longitudinal section through abnormal embryo shown in fig. 230, plate 51. Fixed with picro-sulphuric acid, stained iu Kleimenberg's
brematoxylon, August 9,1892 .

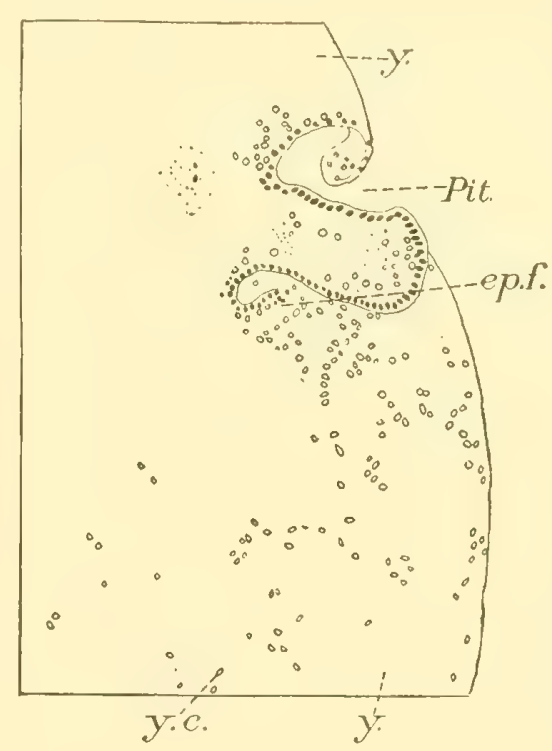

CoT 40.- Sagittal section through abnormal embryo in early stage of derelopment. Fixed in picro-sulphuric acid, stained in Kleinenberg's

AbP. thoracic-abdominal process. Deg., egenerating cells. ep.f., ingrowing fold of surface-epithelium. Mo, noouth of stomodrum. Pit, pit forued by ingrowing fold. $r$, outward fold of surface epithelium. $y . c$, scattered cells in yolk. $y$, food-yolk, abnormally covering embryo in cut 39 .

the letter S. In other respects the histology of this egg-nauplius embryo resembles that of a normal form, except in perhaps a great preponderance of degenerating cells. In the embryo, the surface view of which is shown in fig. 228, plate 51, essentially the same conditions are seen. These abnormal embryos which bave just been described are clue in all probability to a disturbance of the normal mechanical conditions under which the egg usually develops. It is quite probable that they could be artificially produced, but no experiments have yet been made in this direction.

I have noticed another interesting abnormal variation in the invagination stage. (See 91). At a period nearly corresponding to that shown in fig. 255, plate 54, there is a large irregular eavity or several communicating cavities in the depths of the egg. This chamber contains very little yolk, and its wall is composed of cells which srasp the 
yolk by long pseudopodia. The surface of the wall next the cavity is densely studded with nuclei. This irregular cavity is undoubtedly formed by a folding of the embryonic area, brought about by unequal growth, like the cases already described, and morphologically lies outside the embryo. This is probably the same as the structure referred to by Bumpus (30, p. 238). It has nothing to do primarily with either the endoderm or the alimentary tract.

It seems quite probable that many of the abnormal stages already described may eventually attain to a normal growth and development, but this is not certain.

\section{DOUBLE MONSTERS IN OVUM AND LARVA.}

Brightwell, who gave a description of the young of the European lobster (Homarus gammarus), in 1835, was the first to notice double monsters in this species. He says: "Two specimens of the young which appeared double were found, being strongly united in the head" (24). In 1886 the first particular account of these monstrosities was given by Ryder (171), who describes four types of fusion among the free-swimming stages. It is to his kindness that I am indebted for the opportunity of examining the six abnormal larvæ which he described, two of which I have figured.

It seemed worth while to trace, if possible, the history of these abnormal larvæ back to their early embryonic stages, but although I examined many eggs from many individuals, I found only three monstrosities of this kind. The earliest is in the invagination stage, corresponding to that shown on plate 53. It has the appearance of a normal egg, except that instead of a single invagination there are two areas of ingrowth. The axes of these two embryos appeared to be inclined to each other at an angle of about $135^{\circ}$, and they were separated by considerably more than one-third the circumference of the egg. The posterior ends of these embryos are the nearest together, as with the others which I have observed. There is no cellular union of the embryos in the yolk, but they meet in a common peripheral layer of cells, the nuclei of which are now widely scattered, except in the immediate embryonic areas.

The next youngest stage obtained was the egg-nauplius, which I have reproduced in fig. 235, plate 51. The two embryos are similar in every respect and lie almost exactly opposite each other. The thoracic-abdominal plate of one embryo is joined to that of the other by a long train of cells which extends through the yolk just below the surface. These have the general character of migrating mesendodermic cells, and some have already passed into the depths of the egg.

In a little older double egg-nauplius the long axes of the two embryos make an angle of about $160^{\circ}$ with each other. Their posterior extremities are apposed and, as in the first instance, separated by about one-third the eircumference of the egg. It is probable that had the two latter monsters been allowed to develop they would have appeared, when ready to hatch, as if fused, back to back, like the fourth type described by Ryder, in which four eyes were developed, two to each embryo, two distinct sets of mouth parts, and biramous locomotor appendages. As Ryder remarks: "This relation of two perfectly formed embryos in the same lobster egg is exactly the reverse of that which is observed in vertebrates" (171).

In the first type of larva described by Ryder there are no eyes; the cephalothoraces are fused completely, both laterally and anteriorly, and the separate abdomens diverge at a wide angle. In his second type (fig. 200) there is a single median eye on the line of fusion of the cephalo-thoraces. The abdomens diverge at a very wide angle, and, as seen in the drawing, there is a fusion of the first pair of antennæ. 
This shows that parts of the embryo ou the middle line, including the ocellus, liave disappeared, and that the large median pigment spot is beyond question the last trace of the fused compound eyes.

In fig. 199, which illustrates the third type described by Ryder, the cephalothoraces are fused laterally and anteriorly; there is no median eye, but a pair of compound eyes, the right of which is the right eye of the right embryo and the left the left eye of the left. The stomachs are fused on the middle line, but there is no apparent union of the antenna or mouth parts. Behind the stomach the parts are all double.

It is evident that the causes which have produced the monsters with a single pair of compound eyes (fig. 199) are of exactly the same nature as those which have produced the monster with a single median pigment spot. In the latter case their action has been more prolonged. It is also evident that these abnormal larva have been derived from embryos like those which I have described. There is, however, this noticeable distinction: In the abnormal embryos the posterior ends of the bodies are apposed and united, while in the larve the anterior ends are united, the posterior parts being widely divergent. It seems to me probable that the apposition and union of the tail ends of the embryo do not last long, and never involve anything more thau the cells in the yolk; that two distinct thoracic-abdominal processes and two distinct tail folds are formed, which begin to diverge at an early period. Along with these changes a process of fusion apparently takes place between the anterior parts of the two embryos, which are at first entirely separate and distinct, excepting for the yolk and peripheral cells (ectoderm) which unite them.

The fusion of parts does not take "place coincidently with the process of gastrulation," as Ryder suggested, and does not begin to show practical results until after the egg-nauplius stage. In regard to the way in which the different degrees of fusion have beeu brought about, Ryder applies the rule adopted by Rauber for the interpretation of fish embryos-that the degree and manner of fusion is "determined by the width of the augle at which the embryonic axes were primarily iuclined to each other." This principle probably applies to the double monsters produced from the lobster's egg, but the process of fusion seems to me to be something entirely distinct from the concrescence seen in the parts of the normal embrvo. We have to do here with the fusion of two embryos which are practically distinct from the first.

\section{NOTE ON THE DEVELOPMENT OF CAMBARUS.}

I receired through the kindness of Professor J. F. Reighard, in the fall of 1893, a large number of crayfish of the species Cambarus immunis. They were taken from a pond in Ann Arbor, Michigan, on the 16th of November, when ice was just begiuning to form. Many of the females.were already "in berry," and most of the eggs were in a very early stage of development, some, without segmentation of the yolk, having been recently laid. Several were in the egg-nauplius stage, and the oldest which I examined corresponded to Stage $\Pi$ of Reichenbach (163), having all the thoracic appeudages, and the folded abdomen had grown forward so that it nearly tonched the labrum.

The eggs carried by each female are relatively very large $(1.5 \mathrm{~mm}$. in diameter) and few in number. They are of a light or sometimes rather dark coffee-brown, and appear to be insecurely fixed to the swimmerets, being liable to drop off or become detached, especially when several animals are kept together. The species is hardy 
and will thrive in confinement, although, as Professor Reighard remarks, the eggs do not fare so well.

The early phases of segmentation of the protoplasm and yolk correspond very closely to what has been described in the lobster. The protoplasm divides, and its products migrate toward a limited area of the surface of the egg, which becomes the animal pole. This lies usually, if not always, somewhere between the stalk of attachment and the opposite surface of the egg.

In one egg which I studied three small whitish spots could be seen glistening through the brown yolk. These, which were some distance apart, marked the first cells to reach the surface and initiate the segmentation of the yolk. In another egg, which had 27 cells visible at the surface, the shell was raised or distended over that hemisphere containing the animal pole. This distention of the membrane is not, however, so uniformly restricted to this part of the egg as is the case with the lobster, nor were the large yolk hillocks, so characteristic of the latter, discernible here. The cells are now visible to the naked eye as white dots.

Other eggs are seen in which 40 or more cells could be detected lying rather near together and covering nearly half the egg, while the rest of the surface is without trace of protoplasm.

The process of migration from depths of the yolk and division of those cells which have reached or nearly reached the surface continues until the whole superficies of the egg is dotted with cells, 80 or more in number. What corresponds to the animal pole can now be faintly distinguished where the cells are somewhat thicker or closer together. No segmentation of the superficial yolk has yet taken place, although the latter is apparently raised slightly about each cell.

As cell division proceeds, the number of surface cells becomes very greatly increased until 400 or more are visible. The egg then appears to be very nearly uniformly segmented at the surface, and in certain phases of "rest" has the usual beaded appearance. This is a late "yolk-pyramid" stage.

The invagination stage soon follows, and a very distinct round pit appears at the surface, very much in external appearance like the corresponding phase of the lobster's egg, excepting that the invaginate cavity is larger.

An invagination of a different character sometimes occurs which is probably abnormal. A round, very symmetrical depression is seen in the midst of the cells corresponding to the animal pole. The depression is shallow, and at its bottom three or more cells ean be seen looking as if they had been pushed below the surface at this point. The cells bordering this depression are sometimes arranged very uniformly. A similar pit was seen in the midst of the cells of the animal pole before they had spread over the entire yolk. In this case it was plainly abnormal.

I have not yet studied all the phases of the external segmentation of Cambarus by means of sections, but from what has already been seen it is clear that it follows in all essential details the course of events which have been described in the lobster. 


\section{Chapter XIV.-SUMMARY OF OBSERVATIONS.}

\section{GENERAL RETIEW OF THE LIFE-HISTORY OF THE LOBSTER.}

I will now give a brief summary of the most important observations which have been detailed in this work, emphasizing in particnlar those facts which bear upon the problem of the artificial propagation of the lobster.

(1) Distribution. - The geographical range of the lobster covers abont 20 degrees of north latitude, from the thirty-fitth to the fifty-second parallel, and includes a strip) of the Atlantic Ocean 1,300 miles long and from 30 to 50 miles wide. Its vertical distribution varies from 1 to upward of 100 fathoms. The most northern point at which its capture has been recorded is Henley Harbor, Labrador; the most southern point, the coast of North Carolina. The fishery ras begun on the coast of Massachusetts and gradually extended northward. Consequently, at present the lobster is most abundant and attains the greatest size in the northerly part of its range, in eastern Maine, and in the northern maritime provinces of Canada.

(2) There is great diversity in the character of the environment which explains in some measure the many variations which occur in the habits of the animal, as in the time and frequency of molting, in egg-laying, in the hatching of the young, and in the rate of growth.

(3) The lobster displays a considerable rlegree of intelligence and possesses organs to which the various senses of the higher animals have been ascribed. The tactile sense is diffused over the whole body, and the dead shell is perforated by innumerable minute pores which are capable of transmitting stimuli to sensitive cells lying in the delicate skin below. It has the sense of smell and of taste, but it is doubtful if the so-called auditory organs are really ears.

(4) The sea-bottom is the natural abode of the lobster in the adult state, and it never leaves it and never forsakes the water unless obliged to do so.

(5) Migrations.-No coastwise migrations are known to occur, but large numbers of lobsters move to and from deep water in fall and spring. This bathic migration varies in accordance with the character of the coast and nature of the bottom. It is influenced by the temperature of the ocean, by the abundance of food, and to some extent by the molting and breeding habits.

(6) Many lobsters remain in the relatively shallow and cold waters of harbors throughout the winter, but at this season they are found only upon rocky bottoms, where food is most abundant. One may search for them in other situations, as on a weedy or muddy bottom, during the winter season in vain.

(7) Influence of temperature.-The optimum temperature of the lobster is about $55^{\circ} \mathrm{F}$. When the temperature of the sea marks $50^{\circ}$ to $55^{\circ}$ in spring (May at Woods Hole) large numbers of lobsters begin to creep nearer the shores, and when again in the fall (October at Woods Hole) the temperature is wear this point, they have already begun the outward movement.

(8) In severe winters lobsters are either driven into deeper water or, if living in harbors, seek protection by burrowing in the mud when this is available. This sometimes happeus when a sudden lowering of the temperature arises from any canse, and always when the animals are confined in pounds. In such cases a prolonged cold spell may prove fatal (see p. 26). The lobster is practically excluded from the coast of Labrador east of the Straits of Belle Isle by the Arctic current and lingering ice. 
(9) The adult lobster is essentially a nocturnal animal, being far more active by night than in the day. The reverse is true in the larval period, when the habits are entirely different.

(10) Burrowing habits.-The lobster is a great burrower in the sea-bottom. This habit is developed to an extraordinary degree in pounds or inclosures, at all seasons, and is practiced, though less regularly, under other cireumstances: (Compare para. graph 8.) The holes, some of which are 2 to 3 feet long, are solely for protection and are never used while the animal is molting. In the construction of the holes the large claws are used, and possibly the tail-fan. The lobster almost always enters its burrow tail first.

(11) Food.-The adult lobster feeds chiefly upon fish, dead or alive, and upon invertebrates. It also takes a small quantity of vegetable food, such as algæ and eelgrass. Fragments of dead shells, coarse sand, and small gravelstones are also swallowed. The former yield lime, which is absorbed and finally laid down in the skeleton. Many small fish which inhabit the bottom fall a prey to the sharp eutting-claw of the lobster, which it uses with great skill and dispateh. The larger lobsters prey invariably upon the smaller or weaker ones when they can.

(12) The food is seized, torn, and crushed by the large claws, and then taken up by the appendages about the mouth (maxillipeds, maxillæ, and mandibles), by which it is successively torn and chopped fine, when this is possible. While the animal is eating, a stream of fine particles is passed into the mouth, thence to the gastric mill or masticatory stomach. Here the food is ground and the fluid or digestible parts are strained into the small delicate intestine from which they are absorbed. The indigestible refuse is regurgitated from the stomach-bag.

(13) Impregnation.-In copulation the female receives the sperm from the male in packets or spermatophores, which are deposited in an exterual chamber, the seminal receptacle. This is a blue, heart-shaped structure, situated on the under side of the body, between the bases of the fourth pair of legs counting from the large claw-bearing appendages. It opens to the exterior by a median slit with elastic edges, which can be easily pressed apart.

(14) The male does not discriminate the sexual condition of the female, which may be impregnated at any time. It is, however, probable that copulation takes place most commonly it spring. The sperm retains its vitality for a long time, in some cases for at least several months before it is used.

(15) Egg laying.-Much confusion has existed concerning the time when the eggs are laid. This has resulted chiefly from the fact that the eggs are carried by the females for the space of from ten to eleven months before they are hatched. About 80 per cent of the spawning females lay their eggs at a definite season in the summer months, chiefly July and August. The remainder, about 20 per cent of the whole number, extrude eggs at other seasons-in the fall and winter certainly, and possibly also in the spring.

(16) In the western end of Vineyard Sound and the region about Woods Hole the greater number of eggs are extruded during the latter part of July and the first half of August. The summer spawning of each year lasts about six weeks, and fluctuates from year to year backward and forward through an interval of about a fortnight.

(17) This variation in the time of the production of the eggs is due to the fact that the ovarian ova require at least two years of growth before they are ready for 
extrusion. Anything which affects the vital coudition of the adult female will thus affect the time of spawning.

(18) The spawning season in the middle and eastern districts of Maine is abont two weeks later than in Vineyard Sound. In 1893, 71 per cent of the eggs which were examined from the coast of Maine were extruded during the first half of Angust.

(19) At Woods Hole, Massachusetts, 168 egg-beariug lobsters were captured from December 1, 1893, to June 30, 1894. Out of this number 44, or 25.6 per cent, bore eggs which had been laid outside of the summer months, chiefly in the fall. A lobster captured at Matinieus Island, Maine, February 4,1893 , with the yolk unsegmented, and therefore in a very early stage, is mentioned in table 13, No. 20. Similar captures recorded in tables 12 and 13 show that the laying of eggs in fall and winter is not rare.

(20) Lobsters laid eggs in confinement only twice during the six summers which I spent at Woods Hole, although ripe females were frequently placed in the aquaria. When kept uuder these conditions, or even in floating-boxes outside, the eggs are usually not laid, but are absorbed directly from the ovary.

(21) Law of production of eggs. - The law of the production of eggs may be expressed arithmetically as follows: The numbers of eggs produced at each reproductive period vary in "geometrical series, while the lengths of the lobsters producing these eggs vary in an arithmetical series. A lobster 8 inches long produces about 5,000 eggs. According to this law, a lobster 10 inches long would produce 10,000 , a 12-inch lobster 20,000, a 14-inch lobster 40,000. An examination of table 15, in which the number of eggs borne by orer 4,100 lobsters is tabulated, shows that this law holds good up to the fourth term. When a lobster attains a length of 14 to 16 inches this high standard of production ceases to be maintained. A 17-inch lobster produces about 63,000 eggs.

(22) The largest number of eggs recorded for a single lobster is 97,440. In one case the lobster was 15 inches long and in another 16 inches. In neither was the animal able to fold its tail on avcount of the large number of its eggs. This suggests that the rudimentary condition of the swimmerets on the first abdominal somite in the female is necessary for the protection of the eggs. The egg-bearing female goes about with the tail folded. This would be impossible if these appendages were of the usual size and carried the usual number of eggs.

(23) The average weight of a 102 -inch female lobster with eggs is $1_{4}^{3}$ pounds, the eggs weighing about 2 ounces. A 15-inch lobster, which weighs upward of 4 pounds, sometimes carries a burden of a pound of eggs. The number of fresh eggs in a fluid. ounce is about 6,440 , and they weigh about 1 ounce avoirdupois.

(24) Incubation period.-The period of incubation for the summer eggs at Woods Hole is from 10 to 11 months, in one case lasting 335 days, from July 1, 1890, to June 1, 1891, when the young were just beginning to hatch out.

(„5) The general range of the hatching period of summer eggs at Woods Hole is from May 15 to July 15. The greater number are hatched in June.

(26) The hatching of a single brood lasts in some cases over a week, owing to the slightly unequal rate of development of individual eggs.

(27) The period of incubation of the summer eggs varies with the temperature of the water. In Newfoundland the hatching period is said to be from three to six weeks later than at Woods Hole (15th or 20th of July to the 20th of August).

(28) The hatching period also varies with the time of egg-laying. Thus the hatching of young lobsters has been observed in November in Newfoundland and Woods Hole, and in February at Gloucester, Massachusetts. 
(29) Time of sexual maturity.-Female lobsters become sexually mature when from 8 to 12 inches long. The majority of all $10 \frac{1}{2}$-inch female lobsters are mature. In 100 dissections recorded in table 20,25 females were found, from $9 \frac{5}{16}$ to 12 inches long, which had never laid eggs, but in 8 of these the ovaries were nearly ripe. Of the 17 immature, 6 were $10 \frac{1}{2}$ inches or over in length, and in most cases the ovaries would not have become mature for two years.

(30) Frequency of spawning.-The lobster does not spawn oftener than once in two years. The spawning interval is probably a biennial one, one set of eggs (summer eggs) being laid in July or August (at Woods Hole), and the following set in two years from that time. One has only to examine the ovary of a lobster (see fig. 138, plate 38) which has just hatched a brood-that is, one year from the time of the last spawning-to be convinced that annual spawning is an anatomical impossibility. The conclusion reached from a study of the growth of the eggs is confirmed by the percentage of egg-bearing females captured during the fall and winter. I have shown that conclusions deduced from statistics of this kind are often erroneous, especially when observations have been made in a single locality. When the results of the catch in the harbor of Woods Hole and off No Mans Land were averaged it was found that about one-half of the adult females had external eggs, which accords with the view that the spawning interval is a biennial one.

(31) Relative abundance of the sexes.-The relative number of males and females varies considerably in certain localities, as at No Mans Land, May, 1894 (table 22), especially in places affected by the inshore migrations, where the males seem to take the lead. In other places the number of the sexes is about equally divided; this would always be true if our observations were extended over a sufficient period and area.

(32) Molting.-By far the greater number of lobsters molt during the months of June, July, August, and September, but there is no month in which soft lobsters may not be caught. The male probably inolts oftener than the female, which would accord with the larger proportion of soft male lobsters captured and with the greater size attained by the male.

(33) Molting lobsters are more often taken on sandy or weedy than on rocky bottoms.

(34) In preparation for the molt organic matter is absorbed from the shell, making it very brittle. Mineral salts are also extracted from certain definite areas of the carapace and chelipeds, an essential condition for the safe passage of the molt.

(35) In molting, the carapace is raised up behind and the body is drawn out through the opening thus made between carapace and abdomen. Normally, the shell comes off entire, and there is no break in any of the membranes except that between the carapace and the rest of the body. The flesh of the large claws is drawn through the narrow openings of the joints of the limb by the elasticity of the muscles and previous removal of blood from the extremity. This difficult process is also aided by the absorption of lime from certain joints of the old shell.

(36) The lining of the alimentary tract is molted, and the gastroliths which are left in the stomach are eventually dissolved. The gastrolith is a specialized part of the lining of the stomach. It is formed in a gastrolithic sac, which is an organ of excretion. It agrees in chemical composition with the rest of the shell, excepting in the greater proportion of calcium salts. The view that the function of the gastroliths is to supply the molting lobster with an immediate supply of lime for the hardening of its soft shell must be abandoned. The gastroliths more probably represent a mass of lime which 
has been excreted in the course of absorption of mineral salts from certain areas of the shell. The subsequent assimilation of these bodies thus becomes of secondary importance. It was foum that small lobsters ( 3 to $4 \frac{1}{2}$ inches long) filled their stomachs with fragments of dearl shells of mollusks and erustacea, probably for the purpose of obtaining an immediate and abundant supply of lime for hardening the skeleton.

(37) Hardening of the new shell.-From six to eight weeks are necessary under ordinary conditions to produce an shell which is as hard as the one cast off, and lobsters destined for the market are in better condition in from ten to twelve weeks after molting.

(38) Rate of growth.-From the data at hand we conclude that the rate of growth varies considerably with the individual and its surroundings. The length of the young lobster when it hatches from the egg is about $7.84 \mathrm{~mm}$., and the increase in length at each molt is about 15.3 per cent. The lobster molts from 14 to 17 times during the first year. A $10 \frac{1}{2}$-inch lobster has molted from 25 to 26 times, and is abont 5 years old.

(33) Regeneration of parts.-All the appendages are capable of regeneration, the time required for this process depending upon the time of the accident with respect to the molting period and on the temperature of the water and the abundance of food. Defensive mutilation or autotomy is perfectly developed only in the large chelipeds.

(40) Size.-The greatest size attained by lobsters is about 25 pounds. This conclusiou is reached after the examination of skeletons of large lobsters in museums and comparing them with the measurements of large lobsters of known weight. Most accounts of the weights of these animals are unreliable.

$(41)$ The weight does not bear a constant relation to the length, owing to the occasional loss of the appendages. The large chelipeds alone contribute from one-quarter to one-half the weight of the entire animal, and in giants like the Belfast lobster the weight of the large chelipeds is more than two-thirds that of the entire body. The weight is also subject to great variation in consequence of the molt, when a heavy shell is exchanged for a much lighter one.

(42) The adult male is as a rule heavier than the adult female of the same length, and this difference increases with age in favor of the male.

(43) The egg-bearing females with eggs removed weigh less than the female lobster of the same length without external eggs.

(44) Enemies.-Every predaceous fish which feeds upon the bottom may be an enemy of the lobster. The cod is one of the most destructive to small lobsters, after the larval stages are passed.

(45) Tegumental glands.-Besides the hair pores, the shell is perforated by innumerable minute pore canals which lead into tegumental glands situated in the soft skin. Each gland has a capillary duct of its own which opens by a pore canal at the surface of the shell, aud each has one or two peculiar cells which resemble nerve or ganglion cells. These organs are found widely diffused over the surface of the body, aud they also occur in the walls of the oesophagus and intestine. It is probable that those in the swimmerets of the female secrete the cement by which the eggs are glued to the body, and that iu some parts of the body, as in the labrum, they have a secondary sensory function, and are the organs of taste, but this is uncertain.

(46) Color.-The color variations of the lobster, some of which, like the red, blue, and cream colored types, are nonadaptive, and this is also true of the remarkable color 
variations in the larvæ and older stages. The normal coloration of the lobster has, however, a protective significance.

(47) Abnormal variations.-Normally the large claws are differentiated for either cutting or erushing the food, but a rare variation occurs in which the same type of claw is developed on both sides of the body. The large crushing-claw may be either upon the right or left side of the body, but this is a question of heredity, and it is probable that all the young of a brood have the larger claw developed on the same side.

(48) Repetition of parts.--The large chelipeds of the lobster are especially liable to secondary ontgrowths, which undergo a peculiar fission, giving rise to what appears at first sight as a double claw. It is usually a double part rather than a double appendage, although duplicate limbs occasionally occur.

(49) Structure of ovary. - When the ovary is ripe it is of a dark-green color and can be dimly seen through the membrane between the carapace and "tail." If the wall of such an ovary is ent the eggs immediately flow out in a stream. The eggs if immature invariably adhere together or to the substance of the ovary.

(50) After ovulation the ovary is collapsed, of an opaque white color flecked with green spots, ripe eggs which were left behind-or yellow spots, the remaius of similar eggs from the last reproductive period. The presence of degenerate eggs thus proves that the animal has already become sexually mature and has previously laid eggs. The ovaries of lobsters which have never before produced eggs have a uniform tintyellow, pink, gray, or green-and are unmistakable. (For histology of the organs, see Chapter $\mathbf{x}$.)

(51) Development of ova.-The eggs are developed from mesodermic cells of the ovarian stoma, and the massive food yolk is derived from three sources: (1) From the protoplasm of the cells destined to become eggs; (2) from the degeneration of follicle cells, and (3) from the ovarian glands.

(52) When the lobster hatches, its reproductive organ is a minute cluster of cells $\frac{1}{44} \mathrm{~mm}$. in diameter, and in the case of the female it takes from four to five years for the organ to reach maturity.

(53) The sperm cells are probably motile in the final stage of their history, but nothing is known either as to how the spermatophores are conveyed to the seminal receptacles or how the spermatozoa reach the eggs and fertilize them.

(54) Young.-The lobster hatches from the egg as a pelagic free-swimming larva. It lives at the surface of the ocean from six to eight weeks, when, after having molted five or six times, it goes to the bottom and appears in habit and general structure like a very small adult animal. After reaching the bottom it travels toward the shore and establishes itself in rock piles in harbors and at the mouths of rivers, where it remains until driven out by ice. At very low tide they can be found by digging away the loose stones. The smallest, from 1 to 3 inches long, go down deep among the loose stones, where they are secure from every enemy. When they reach the length of $3 \frac{1}{2}$ to 4 inches they become bolder, leave their burrows in the rock piles, and seek the shelter of stones, beneath which they excavate a shallow hole. Young lobsters are also found in eelgrass and on sandy bottom in shallow water.

(55) At the time of hatching, the egg membranes burst into two halves and are drawn off over the head. At about the same time the little lobster sheds its entire cuticle; the plumose hairs which garnish its appendages are evaginated and, leaving its mother, it swims up to the surface. The first larva has long rowing exopodites on its thoracic appendages, and a six-jointed abdomen with spatulate telson. At the second 
molt rudimentary abdominal appendages appear on the second to fifth aludominal somites, inclusive, and the branchial formula is completed.

(56) At the fourth molt it loses the use of its larval swimming organs, but still remains at the surface, propelling itself forward by its swimmerets and backward by flexion of the ablomen. It is now from three to four weeks old, is half an inch long, and has characteristic colors.

(57) After the fifth molt is passed the young lobster still swims at the surface, though it is possible that some leave it duming this stage. When the sixth stage is reached, age five to six or eight weeks, length about three-fourths of an inch, it remains at the surface for a time at least, but goes to the bottom to stay before the seventh molt is passed. At the sixth molt all trace of the larval swimming organs is lost.

(58) The molts follow each other at rather short intervals, and during the first year of life, supposing the animal to have been hatched ju June, the lobster molts from fourteen to seventeen times and attains a length of from 2 to 3 inches. The main facts of the subsequent life-history need not be repeated.

(59) The problem of artificial propagation of the lobster will be solved when means are devised by which the larvie after hatching can be reared in large inclosures until the fifth or sixth stage, when they are able to take care of themselves.

(60) Food of larve.-The food of the larval lobster consists of minute pelagic organisms of all kinds. They show little discrimination at this time, snapping up auy floating objects not too large for them to manage.

(61) Heliotropism of larve.-In the pelagic stages the young lobsters are positively heliotropic, rising to the surface in the daytime and staying there, and going down at night. This habit is not invariable, but the capture of the young by day is the rule, by night the exception.

(62) Survical of larw.-Great destruction is wrought upon the free-swimming stages by both animate and inanimate enemies. A survival of 2 in every 10,000 larve hatched would maintain the species at an equilibrium, and the destruction of the young under the present conditions of the fishery is probably even greater than this implies. (For a discussion of this subject see No. 97 of Bibliography.)

(63) The general scarcity of the young in the hatching season in places known to abound in lobsters is due (1) to their wide horizontal distribution, and (2) to their destruction.

(64) The whole course of development and later grewth is slow. The slow larval development secures the necessary transportation from the shores and wide horizontal distribution, which is absolutely necessary for the life of the species. An abbreviated metamorphosis such as is found in this animal appears to be a compromise between a still longer development which the animal would have to go through if the egg possessed less yolk, and the limitations to protoplasmic activity which are imposed by the temperature of the North Atlantic Ocean.

For the facts pertaining to the development of the embryo the reader must refer to Chapter XII, and for details and the discussion of general questions to the body of the work. 


\section{Appendix I.-PREPARATION OF THE EGGS.}

The eggs of the lobster may be easily prepared for the study of the external surface in the following way: The fresh eggs are to be placed in either fresh or salt water, which is heated to near the boiling point, until the green pigment coloring the yolk is permaneutly converted into bright red lipochrome (see p. 137). They should then be transferred to cold water and shelled under the dissecting microscope. The eggshell when distended slightly with water may be removed by means of very fine-pointed forceps, nipping the shell and holding it with one pair of forceps while the shell is ruptured and the egg carefully released with the other pair.

There are two periods in the course of development when it is difficult to remove the shell without injury to the embryo. These are at the close of segmentation, when the blastoderm secretes a fine membrane, which becomes soldered to the shell so that when the latter is removed the blastoderm itself is torn away; and, secondly, either during the egg-nauplius stage or shortly after it. In the early egg-nauplius two membranes can be removed, an outer thick one, the eggshell (composed of the primary and secondary egg membranes), and an inner cuticle, the secreted product of the embryo. This last usually sticks to the tips of the antennæ, the second pair in particular, and carries them with it when it is removed. It sometimes happens that the entire embryo is thus stripped off.

After shelling, the eggs should be placed at once in Mayer's concentrated picrosulphuric acid, and left from two to three hours. They may be then transferred to 70 per cent and finally to 80 per cent alcohol, and the latter should of course be changed nntil all trace of the yellow salt is removed.

I have frequently made use of 70 per cent alcohol instead of water in making up the picro-sulphuric acid solution, and it is usually successful. I used it with excellent results ten years ago in studying the eggs of Alphens, but the aqueous solution is perhaps better on the whole. I have tried a great variety of killing and fixing reagents, but none are to be compared for reliability with picro-sulphuric acid in the concentrated form.

The eggs are stained by placing them in a vial of borax-carmine for the space of two to three minutes or longer, just long enough to stain the surface cells only. The diffuse stain must then be thoroughly removed by acidulated alcohol until the eggs have a light-yellow color, the nuclei of surface cells only being stained red. Turpentine is one of the best clearing reagents, none of the essential oils im common use-oil of cloves, origanum, thyme, or bergamot-offering any appreciable advantage over it.

Clearing requires but a few minutes, and while it is in progress the eggs should be placed in a solid watch glass with turpentine, and examined under a dissecting microscope. With a very small and thin knife they may be cut into halves in any desired plane. It is better to roll the egg under the knife edge, and thus eut into the surface all the way round before pressing the knife through the egg. The eggs cut like cheese at first, but later become brittle and are very apt to break if left in turpentine for too long a time. It is thus best to place a few at a time in the clearing fluid, and cut them at once. 
In the treatment of these eggs I have profited by the experience and arlvice of my frieud Dr. William Patten, whose method of mounting the ova of Arthopods, ${ }^{1}$ and orienting them for the microtome, which I have essentially followed, leaves little to bo desired. A cell is made of strips of cardboard of the desired thickness, and the respective hemispheres of each egg are fixed in place by a small drop of concentrated Schallibaum's fixative. The cell may be flooded with turpentiue while the process of fixation is going on, and when drained thick balsam is added and the cover glass is afterwards applied. In this way the most perfect and beautiful preparations can be made.

Eggs are hardened in the same way, when the object is to cut them into sections. They may be suceessfully embedded in either paraffin or celloidin. Bumpus has described his successful use of the latter reagent, which he heartily recommends." This method is undoubtedly the surest although the most laborious to pursue. I have obtained excellent sections of the early and late stages of development by the paraffin method, and for the older embryos it is certainly preferable. Turpentine and all the essential oils soon harden the yolk so that it firmly resists the knife. The eggs should therefore be allowed to remain in the clearing fluid for the shortest possible time ouly, and then thoroughly saturated with paraffin. The method which Patten has given for orientation can hardly fail to meet with success.

\section{Appendix II.-COMPOSITION OF THE SHELL AND GASTROLITHS OF THE LOBSTER.}

[By Albert W. Smith, Ph. D., Associate Professor of Chemistry in the Case School of Applied Science.]

The analyses of the shell of the lobster were made from four distinct individuals, taken at Woods Hole, Massachusetts (Nos. 1 to 4 in the table below), and were selected with reference to the molting period. The deseription of the shells and lobsters from which they were taken is as follows:

No. 1. Hard-shell female with external eggs, August 3, 1894.

No. 2. A hard-shell female lobster near the point of egg-laying; length, 11 inches; July 16, 1894. The ovarian eggs of this lobster were mostly absorbed. (See p. 48.)

No. 3. From a female near the point of molting; length, 10 inches; August 2, 1894. (The gastroliths of this "shedder" are described on p. 89, and their chemical analysis is given in No. $3 a$ of the following table.)

No. 4. The molted shell of a male 11 inches loug. (See No. 2, table 24, and p. 89.)

The gastroliths subjected to analysis have the following history:

No. $0 a$ is taken fresh from the gastrolithic sac of a "shedder." (For drawing of this gastrolith separated into its constituent spicules see fig. 165, plate 42.)

No. $3 a$ is from lobster No. 3 of this table, taken fresh from the gastrolithic sae of the animal shortly before it was ready to molt.

No. $4 a$ is from the lobster which east off shell No. 4 of this table, taken from the stomach of the animal when soft and preserved in alcohol. (For drawings of this gastrolith see cut 8, plate C; for description of lobster No. 2, table 24.)

1 Orienting Small Objects for Sectioning, and "Fixiug" them, when Monnted in Celis. (Ameriean Naturalist, vol. 28, pp. 360-362, 1894.)

${ }^{2}$ American Naturalist, vol, 26, pp. 80-81, 1892 
Table showing composition of the shell and gastroliths of the lobster.

\begin{tabular}{|c|c|c|c|c|c|c|c|}
\hline \multirow{2}{*}{ Composition-air dried. } & \multicolumn{4}{|c|}{ Carapace. } & \multicolumn{3}{|c|}{ Gastroliths. } \\
\hline & 1. & 2. & 3. & 4. & $0 a$. & $3 a$. & $4 a$. \\
\hline 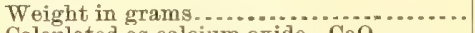 & 11.87 & 21.51 & 8.48 & 9.12 & 1.37 & & 3.96 \\
\hline Calculated as calcium oxide-CaO. & 22.87 & 23.11 & 24.94 & 30.41 & 45.85 & 49.14 & 50.82 \\
\hline Magnesium oxide-MgO ........... & 3.18 & 1.14 & 1. 61 & 1. 30 & 0.30 & 0.40 & 0.48 \\
\hline Aluminum oxide $-\mathrm{Al}_{2} \mathrm{O}_{3}-\left(\mathrm{Fe}_{2} \mathrm{O}_{3}\right) \ldots$ & 0.68 & 2.04 & 1. 04 & 1. 36 & 0.20 & 0.04 & 0.06 \\
\hline Sodium oxide $-\mathrm{Na}_{2} \mathrm{O} \ldots \ldots \ldots \ldots$ & 0.89 & 1. 06 & 1. 35 & 1.67 & 1.09 & 1. 34 & 0.55 \\
\hline Silica- $\mathrm{SiO}_{2} \ldots \ldots \ldots$ & 0.14 & 0.29 & 0.08 & 0.46 & 0.10 & 0.06 & 0.08 \\
\hline Phosphoric anhydride- $\mathrm{P}_{2} \mathrm{O}_{5}$ - & 3.53 & 3.81 & 5. 12 & 4. 36 & 4. 43 & 4. 16 & 5.12 \\
\hline Sulphuric anhydride- $\mathrm{SO}_{3} \ldots \ldots \ldots$ & 0.34 & 0.31 & 0.58 & 0.40 & 0.07 & 0.08 & 0.35 \\
\hline Carbonic dioxide $-\mathrm{CO}_{2} \ldots \ldots \ldots \ldots \ldots$ & 21.20 & 17. 05 & 17. 70 & 23.00 & 37.00 & 37.10 & 35.00 \\
\hline $\begin{array}{l}\text { Water at } 100^{\circ} \mathrm{C}-\mathrm{H}_{2} \mathrm{O} \ldots \ldots \\
\text { Calculated as calciun carbonate-Caco }\end{array}$ & & $\begin{array}{r}7.40 \\
32.83\end{array}$ & & & & & $\begin{array}{r}3.50 \\
78\end{array}$ \\
\hline Calcium phosphate $-\mathrm{Ca}_{3}\left(\mathrm{PO}_{4}\right)_{2} \ldots \ldots$ & $\begin{array}{r}45.08 \\
7.70\end{array}$ & $\begin{array}{r}32.83 \\
8.32\end{array}$ & $\begin{array}{l}32.95 \\
11.18\end{array}$ & $\begin{array}{r}44.60 \\
9.52\end{array}$ & $\begin{array}{r}7.44 \\
9.67\end{array}$ & $\begin{array}{r}78.87 \\
9.08\end{array}$ & $\begin{array}{l}78.46 \\
11.18\end{array}$ \\
\hline Calcium sulphate-CaSO ............ & 0.58 & 0.53 & 0.99 & 0.68 & 0.12 & 0.14 & 0.59 \\
\hline Magnesium carbonate- $\mathrm{MgCO}_{3} \ldots \ldots \ldots$ & 3.50 & 2. 39 & 3.38 & 2.73 & 0.63 & 0.84 & 1.01 \\
\hline Sodium carbonate $-\mathrm{Na}_{2} \mathrm{CO}_{3} \ldots \ldots \ldots \ldots$ & 1. 51 & 1.80 & 2.31 & 2.85 & 1.87 & 2.28 & 0.93 \\
\hline Alumina, $\mathrm{Al}_{2} \mathrm{O}_{3}-\left(\mathrm{Fe}_{2} \mathrm{O}_{3}\right) \ldots \ldots \ldots$ & 0.68 & 2.04 & 1.04 & 1. 36 & 0.20 & 0.04 & 0.06 \\
\hline Silica- $\mathrm{SiO}_{2} \ldots \ldots \ldots \ldots$ & 0.14 & 0.29 & 0.08 & 0,46 & 0.10 & 0.06 & 0.08 \\
\hline 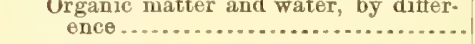 & 42.21 & 51.80 & 48.09 & 37.80 & 14.97 & 8.69 & 7. 69 \\
\hline
\end{tabular}

As will be seen by reference to the table the principal part of the mineral structure in the carapace is made up of carbonate of calcium, with some considerable proportion of calcium phosphate and of magnesium compounds. The gastroliths differ in being much more largely mineral, and in consisting almost entirely of carbonate and phosphate of calcium. All of the specimens contained iron, its quantity being so small that it was not thought advisable to make a separation of it from the aluminum. A minute proportion of potassium also was present in every case, but its quantity was so small that it was detected with difficulty by the spectroscope in the separated alkali salts.

No successful determination of the quantity of chitin in the carapace was attained, and no separation of any of the other organic constituents was attempted. The total quantity of organic matter and water is reported as the difference between the sum of the calculated percentages of inorganic salts and 100 .

The portion of the shell subjected to analysis was taken in each case from the carapace, from the part bounded by the cervical groove in front and the branchiocardiac groove above. 


\section{Appendix III.-BIBLI0GRAPHY.}

In the following bibliography the literature of the lobster, especially that relating to its habits aud development, will be found to be fairly complete. All papers possessing scientific or historical interest to which reference is made, though some of them are of minor importance, have been included.

Since, in my chapter on the embryology of this species, I have not entered into the comparative development of the crustacea, it has been necessary to refer to but few general works, and all physiological papers have been omitted when not in the direction of my studies.

1. Abbott, C. C. Are the "chimneys" of burrowing crayfish designed? Amer. Nat., vol, xviI, pp. 1157-1158. Phila,, 1884.

2. Aldrovandi, Ulyssis. A. U. philosophi et medici Bononiensis; de reliquis animalibus exsanguibus libri quatuor, post mortem eius editi: Nempe de mollibus, erustaceis, testaceis, et zoophytis. De astaco. Cap. III, p. 108. 1st ed., fol. Bononiæ, 1606.

3. Andrews, E. A. Autotomy in the crab. American Naturalist, vol. 24, pp. 138-142, figs. 1-4 (pl. vI). Philadelphia, 1890.

4. Aristotle. On the parts of animals. Transl, by W. Ogle. London, 1882.

5. Atwood, N. E. On the habits and geographical distribution of the common lobster. Proc. Bost. Soc. Nat. Hist., vol. x, pp. 11-12. Boston, 1866.

6. v. Baer, K. E. Ueber die sogenannte Erneuerung des Magens der Krebse u. die Bedeutung der Krebssteine. Archiv f. Anat., Physiol, ete. Ed. by Johannes Müller. Pp. 510-523. Berlin, 1834.

7. Baker, H. A letter from Mr. Baker to the president, concerning the stones called crab's eyes, etc. Phil. Trans. Roy. Soc. (abridged), vol. x, part II, pp. 876-879, for year 1750. London, 1756.

8. Baster, J. Opuscula subseciva. De astacis, tom. II, lib. 1, tab. 1. Harlemi, 1762.

9. Bate, C. Spence. Notes on Crustacea. Ann. and Mag. of Nat. Hist., 2d ser., vol, viI, pp. 297-300, 1 pl. 1849.

10. Bate, C. Spence. Report of the committee appointer to explore the marine fauna and flora of the south coast of Devon and Cornwall. No. 2. Rept. Brit. Ass. Adv. Sci., 1867, pp. 275-287, pls. I-III. London, 1868.

11. Bate, C. Spence. Report on the present state of our knowledge of the Crustacea. Part III. Rept. Brit. Ass. Adv. Sei., 1877, pp. 36-55. London, 1878.

12. Bate, C. Spence. Report on the present state of our knowledge of the Crustacea. Rept. Brit. Ass. Adv. Sci., pp. 193-209, pls. V-VII. London, 1879.

13. Bate, C. Spence. Report on the present state of our knowledge of the Crustacea. Part V. Rept. Brit. Ass. Adv. Sci., 1880, pp. 230-242. London, 1880.

14. Bell, Thomas. A history of the British Stalk-eyed Crustacea. Pp. I-LXvi+1-386. London, 1853.

15. Belon. De aquatilibus. 1553.

16. Bergh, R. S. Beiträge zur Eıbryologie der Crustaceen. I. Zur Bildungsgeschichte des Keimstreifens von Mysis. Zool. Jahrb., Bd. vi, pp. 491-528, Taf. 26-29. Jena, 1893.

17. Berniz, Martinus Bernhardus. Chela astaci marini monstrosa. Miscellanea curiosa medicophysica Academiæ naturæ curiosorum, annus secundus, Observatio C, p. 174 (fig.). 1671.

18. Lo Bianco, Salvatore. Notizie biologische riguardanti specialmente il periodo di maturità sessuale degli animali del golfo di Napoli. Mitth. zool. Stat. zu Neapel, Bd. vir, pp. $385-440$. 1888. 
19. Blanchard, Émile. Métamorphoses, mœurs et instincts des insectes. Paris, 1868. The transformations of insects, by Martin P. Duncan (London and New York, 1870) is essentially a translation of this work.

20. Boeck, Axel. Om det norske Hummerfiske og dets Historie. Tidsskrift for Fiskeri, 3die Aargangs. Kjöbenhavn, 1868-1869. Transl. in Rept. of U. S. Com. of Fish and Fisheries, part III, 1873-1875, pp. 223-258. Washipgton, 1876.

21. Bouchard-Chantraux. Crustacés du Boulonnais. 1833.

22. Braun, Max. Ueber die histologischen Vorgänge bei der Häutung von Astacus fuviatilis. Arbeit. ans dem zoologisch-zootomischen Inst. in Würzburg, Bd. II, pp. 121-166, Taf. VIII-1X. 1875.

23. Braun, Maz. Zur Kenntniss des Vorkommens der Speichel- und Kittdrüsen bei den Decapoden. Arbeit. aus dem zoologisch-zootomischen Inst. in Würzburg, Bd. III, pp. 472-479, Taf. 21. 1876-77.

24. Brightwell, T. Description of the young of the common lobster, with observations relative to the questions of the occurrence and non-occurrence of transformations in crustaceous animals. Loudon's Mag. Nat. Hist., ete., first series, vol. vIII, pp. 482-486. 1835.

25. Brocchi, P. Recherches sur les organes génitaux mâles des crustacés décapodes. Reprinted from Ann. des sci. nat., 6e série, pp. 1-132, pls. 13-19. Paris, 1875.

26. Brook, George. Notes on the reproduction of lost parts in the lobster (Homarus vulgaris). Proc. Roy. Physical Soc., session cxvr, pp. 370-385, pl. Xvil (figs. 1-5). 1887.

26 $\frac{1}{2}$. Brooks, W. K. The habits and metamorphosis of Gonodactylus chiragra. (Being chap. III of the fourth memoir of vol. $V$ of the Proceedings of the Nat. Acad. of Sciences, entitled "The Embryology and Metamorphosis of the Macroura," by W. K. Brooks and F. H. Herrick.) Pp. 353-360, with 4 plates. Washington, 1892.

27. Brown, Patrick. The civil and natural history of Jamaica. Fol., copper pls. London, 1789.

28. Buckland, Frank; Walpole, Spencer, et al. Reports on the crab and lobster fisheries of England and Wales, of Scotland and Ireland. Pp. I-XXII +I-XXVI $+\mathrm{I}-\mathrm{IV}+1-80$, with appendices, pls. 1-8. London, 1877.

29. Buckland, Frank, Report on the fisheries of Norfolk, especially erabs, lobsters, herrings, and broads. Presented by Her Majesty's command. Ordered by the House of Commons to be printed. Aug. 11, 1875.

30. Bumpus, Hermon Carey. The embryology of the American lobster. Jour. of Morph., vol. v, pp. 215-262, pls. XIV-XIX. 1891.

31. Butschinsky, P. Zur Entwicklungsgeschichte von Gebia litoralis. Zool. Anz., 17. Jhg., No. 452, pp. 253-256. July 16, 1894. Translated in Ann. Nat. Hist., (6), vol. xv, pp. 677-678.

32. Cano, G. Morfologia dell' apparecchio sessuale femminile, glandole del cemento e fecondazione nei crostacei decapodi. Mittheil. Zool. Stn. Neapel, Bd. IX, pp.503-532, Taf. 17. 1891.

33. Cano, G. Sviluppo dei portunidi. Morfologia dei portunidi e corystoidei. Memoria estratta del toma. viII, serie $3^{\text {a }}$, No. 6, della Società italiana delle scienze, pp. 1-30, tav. I-III. Napoli, 1893.

34. Carpenter, William. Report on the microscopic structure of shells. Part II, Rept. Brit. Ass, for Adv. Sei., 1847, pp. 93-134, pls. I-Xx. London, 1848.

35. Carrington, John T., and Lovett, Edward. Notes and observations on British Stalk-eyed Crustacea. The Zoologist, third series, vol. vi, pp. 9-15 (continued). London, 1882.

36. Cavolini. Memoria sulla generazione dei pesci e dei granchi. Napoli, 1787.

37. Chantran, S. Observations sur l'histoire naturelle des écrevisses. Compt. Rend., t. 69, pp. 43-45. Paris, 1870.

38. Chantran, S. Nouvelles observations sur le développement des écrevisses. Compt. Rend., t. 73, pp. 220-221. Paris, 1871.

39. Chantran, S. Sur la fécondation des écrevisses. Compt. Rend., t. 74, pp. 201-202. Paris, 1872.

40. Chantran, S. Expériences sur la régénération des yeux chez les écrevisses. Compt. Rend., t.76, pp. 240-241. Paris, 1873.

41. Chantran, S. Observations sur la formation des pierres chez les écrevisses. Compt. Rend., t. 78, pp. 655-657. Paris, 1874.

42. Chantran, $\mathbf{S}$. Sur le mécanisme de la dissolution intra-stomacale des concrétions gastriques des écrevisses. Compt. Rend., t. 79, pp. 1230-1231. Paris, 1874.

43. Coste. (Report of work of Gerbe.) Faits pour servir à l'histoire de la fécondation chez les crustacés. Compt. Rend., t. 56, p. 432 . Paris, 1858.

44. Coste. Etude sur les mœurs et sur la génération d'un certain nombre d'animaux marins. Compt. Rend., t. 47, pp. 45-50. Paris, 1858. 
45. Couch, Jonathan. Observations on some circumstauces attending the process of exuviation in shrimps and lolsters. Mag. Zool. and Bot., vol. I, pp. 170-173. 1837.

Translation of same. Bemerkungen uber den Iläutuugsprocess der Krebse und Krabben. Archiv f. Naturgesch, vou Wiegmanu, Jahrg, 4, Bd. I, pp. 337-342. 1838.

46. Couch, Jonathan. On the process of exuviation and growth in erabs and lobsters, and other British species of stalk-eyed crustacean animals. Eleventh Ann. Report Royal Cornwall Polytechuic Society, 1843, pp. 1-15. London, 1843.

47. Couch, Jonathan. A particular description of some circumstauces hitherto little known connected witl the process of exuviation in the common odiblecrab. (With plates.) Aun. Report Royal Cornwall Polytechuic Society, 1858, pp. 39-45, pls. 1-3. London, 1858.

48. Couch, R. Q. On the metamorphosis of the Decapod Crustaceans. Eloventh Annual Report of the Royal Cornwall Polytechnic Society, 1843, pp. 28-43, pl. x. London, 1843.

49. Coues, Elliott. Notes on the natural history of Fort Macon, North Carolima, and vicinity. (No. 2.) Proc. Acad. Nat. Sci. Phila., 1871, pp. 120-148. Philadelphia, 1871.

50. Dalyell, John Graham. The powers of the Creator displayed in the Creation. London, 1827.

51. De Kay, James E. Zoology of Now York, or the New York fauma. Part Vi, Crustacea, pp. 23-25, pl. xrI, figs. 52, 53. Albany, 1844.

52. Desmarest, Anselme G. Considérations générales sur la classe des crustacés. i825.

53. Dulk. Chemische Untersuchungen eines Mageninhalts von Krebsen, die sich eben gehautet haben. Archiv f. Anat., Physiol., etc., J. Miiller, Jahrg. 1834, pp. 523-5̌27. Berlin, 1834.

54. Dulk. Chemische Untersuchungen der Krebssteine. Archiv fiir Anat., Physiol., etc., ed. by Johannes Müller, pp. 428-430. Berlin, $183 \check{.}$.

55. Du Tertre, Jean Baptiste. Histoire Générale des Antilles habituées par les Fravழ̧ois. T. I-III. T. II, Hist. Nat. Paris, 1667-71. The first edition of this work, in which natural history received much less attention, was published in one volume in 1654 under the title Histoire Générale des Îsles des S. Christophe, de la Guadeloupe, de la Martinique, et autres dans l'Amérique.

56. Duvar, J. H. Report on lobster fishery of Prince Edrard Island, in annual report of the department of fisheries, Dominion of Canada. App. No.6, p. 240. 1884.

57. Duvernoy. Deuxième fragment sur les organes de génération de divers animaux. Des organes extérieurs de fécondation dans les crustacés décapodes. Compt. Rend., t. 31, pp. 342-348. Paris, 1850.

58. Edwards, H. Milne. Histoire naturelle des crustacés. Vols. 1-3, with atlas. Paris, 1834-1840.

59. Edwards, H. Milne. Observations sur la structure et les fonctions de quelques zoophytes mollusques et crustacés des côtes de la France. Ann. des Sci. Nat., $2^{\text {e }}$ série, t. 18, pp. 321-350, pls. 10-15. 1842.

60. Edwards, H. Milne. Leçons sur la physiologie et l'anatomie comparée de l'homme et des animaux. T. IX. Paris, 1870.

61. Ehrenbaum, Ernst. Der Helgolander Hummer, ein Gegenstand deutscher Fischerei. Wissensch. Meeresuntersuch., herausg. von der Kommission zur Untersuch. der deutschen Meere in Kiel u. der biologischen Anstalt auf Helgoland. Neue Folge, Bd. I, s. 277-300. Kiel u. Leipzig, 1894.

62. Erdl, M. P. Entwicklung des Hummereies von den ersten Veränderungen im Dotter an bis zur Reife des Embryo. 8. I-X + 11-40, Taf. I-IV. Müuchen, 1843.

63. Fabricius, Otho. Fauna Grœnlandica, etc. Pp. I-xvI + 1-452, 1 pl. Hafnire et Lipsiæ. 1780.

64. Fabricius, J. Ch. Entomologia systematica. Tom. II. 1792-94.

65. Fabricius, J. Ch. Supplementum entomologire systematica. 1798.

66. Faxon, Walter. On some crustacean deformities. Bull. of the Mus. Comp. Zool. at Harvard College, vol. viII, No. 13, pp. 257-274; pl. I, figs.1-17; pl. II, figs. 1-9. Cambridge, Mass., 1881.

67. Faxon, Walter. Selections from embryological monographs, compiled by Alexander Agassiz Walter Faxon, and E. L. Mark. I. Crustacea. Mem. Mus. Comp. Zoology, vol. rx, No. 1, $14 \mathrm{pl}$, with descriptions. Drawings of Homarus, pl. xII, figs. 11-17. Cambridge, July, 1882.

68. Faxon, Walter. A revision of the Astacidæ. Part I. The genera Cambarus and Astacus. Mem. Mus. Comp. Zool., vol. x, No.4, pp. 1-186+I-VI, pls. I-X. Cambridge, August, 1885.

69. Foettinger, Alexandre. Recherches sur l'organisation de Histriobdella homari, P.-J. Van Beneden, rapportée aux Archiannélides. Arch. de Biol., t. v, pp. 435-516, pls, xxv-xxx, 1884. See also Van Beneden. Bull. de l'Acad. Roy. de Belgique, t. xx, p. 63, 1853. A later account, with plates, in memoirs of the same Academy, t. XxxIV, 1858. 
70. Fraiche, Félix. Guide pratique de l’ostréiculteur et procédés d'élevage et de multiplication des races marines comestibles. Transl. by H. J. Rice, in Rept. of the Commissioner of Fish and Fisheries for 1880, pt. vir, pp.753-824. Washington, 1883.

71. Fredericq, Léon. Nouvelles recherches sur l'autotomie chez le crabe. Archives de biologie, t. XII, pp. 169-197, figs 1-6. Paris, 1892.

72. Garman, S. Report on the lobster. Rept. of the Massachusetts commissioners of inland fisheries and game for 1891, pp. 60-61. 1892.

73. Garman, S. Lobster Reproduction. Zool. Anz., No. 467, pp. 38-40, February 4, 1895. (For a review of this article see No. 101 of this bibliography.)

74. Geoffroy, le jeune. Observations sur les écrevisses de rivière (August 23, 1709). Hist. de l'Acad. Roy. des Sciences, 1709, pp. 309-314. Paris, 1711.

75. Gesneri, Conradi. Medici Tigurini historiæ animalium, lib. III, qui est de piscinm et aquatilium animantium natura. De Astaco, pp. 113-121. Tiguri, 1553.

76. Gesner, Conrad. Fischbuch. Trans. from original into German by Conrad Forer. Franckfurt, 1598.

77. Gilson, G. Etude comparée de la spermatogénèse chez les arthropodes. Recueil La Cellule, t. I and II, 1st and $2 d$ fasicles. Crustacea, pp. 140-310, pls. 8-14. Louvain, 1886.

78. Gissler, C. F. Description of a hermaphroditic Phyllopod Crustacean (Eubranchipus). American Naturalist, vol. xv, pp. 136-139, figs. 1-3. Philadelphia, 1881.

79. Goode, G. Brown. The food-fishes of the United States. Pt. III of Section I. Natural history of usefiul aquatie animals, in the fisheries and fishery industries of the United States. Washington, 1884 .

80. Goodsir, H. D. S. A short account of the mode of reproduction of lost parts in the Crustacea. Ann. and Mag. of Nat. Hist., vol. XII, p. 67. London, 1844.

The following is an abstract of the same: On the reproduction of lost parts in the Crustacea. Rept. Brit. Ass. Adv. Sci., 1844, p. 68. London, 1845.

81. Gosse, P. H. On the sloughing of the Spider Crab. Ann. and Mag. of Nat. Hist, second ser. vol. $x$, pp. 210-212. London, 1852.

82. Gouriet, E. De quelques caractères extérieurs qui différencient les sexes chez l'écrevisse fluviatile. Compt. Rend. Acad. des Sei., t. 75, p. 841. Paris, 1872.

83. Grobben, C. Beiträge zur Kenntniss der männlichen Geschlechtsorgane der Dekapoden, nebst vergleichenden Bemerkungen über die dex ủbrigen Thoræeostraken. Arbeit. aus dem Zoologischen Inst. der Universität Wien u. der zoolog. Station in Triest, Bd. 1, pp. 1-94, Taf. I-VI. 1878.

84. Gulland, P. Lovell. The sense of touch in Astacus. Proc. Roy. Phys. Soc. Edinburgh, vol. IX, pt. I, pp.151-179, pls. VIII, IX. London, 1886.

85. Hagen, Hermann A. Monograph of the North American Astacidæ. Ill. Cat. of the Mus. of Comp. Zool. Harvard Coll., No. III (vol. II of Mem. of Mus. of Comp. Zool.), pp. I-VIII+ 1-112. pls. I-XI. Cambridge, 1870.

86. Heller, Camil. Ueber einen weissen Flusskrebs. Verhandlgn d. zool.-bot. Gesellsch in Wien, Bd. 8. Verhandlgn des zool.-bot. Vereines, viII, pp. 83-84. Wien, 1858.

87. Heller, Camil. Die Crustaceen des südlichen Europa. Crustacea Podophthalmia, pp. 1-336+I-VI. Taf. I-X. Wien, 1863.

88. Herbst, J. F. W. Versuch einer Naturgeschichte der Krabben u. Krebse, nebst einer systematischen Beschreibung ihrer versehiedenen Arten. Bde. I-rr. Berlin u. Stralsund, 1790-1804.

89. Hermann, G. Notes sur la structure et le développement des spermatozoides chez les Décapodes. Bull. Scientif. de la France, etc., t. Xxir, 1890

90. Herrick, Francis H. Notes on the embryology of Alpheus and other Crustacea and on the development of the compound eye. Johns Hopkins University Cireulars, vol. IX, No. 54, pp.42-44. Baltimore, 1886. Note on development of the ovarian eggs of the lobster.

91. Herrick, Francis H. The development of the American lobster, Homanus americanus. Johns Hopkins Univer. Cire, vol. Ix, No. 80, pp. 67-68. Baltimore, 1890. See also Zool. Anz. for 1891, pp. 133-137, and pp. 145-149, figs. 1-6.

92. Herrick, Francis $\boldsymbol{H}$. Notes on the habits and larval stages of the American lobster. Johns Hopkins Univ. Cire., vol. x, No. 88, pp. 97-98, May, 1891. Baltimore.

93. Herrick, Francis $\mathbf{H}$. The reproductive organs and early stages of development of the American lobster. Johns Hopkins Univ. Circ, vol. x, No. 88, pp. 98-101, May, 1891. Baltimore, 1891. 
94. Herrick, Francis H. Alphens: A study in the developmont of Crustacea. (Boing chap. $\mathrm{V}$ of the fourth memoir of vol. $V$ of the Proceedings of the Nat. Acad. of Sciences, entitled "The Embryology and Metamorphosis of the Macroura," by W. K. Brooks and F. H. Herrick.) Pp. 370-463+, with 38 pls. Washington, 1892.

95. Herrick, Francis H. The life history of Stenopus. Chap. II of the above memoir.

96. Herrick, Francis H. Cement glands and origin of egg-membranes in the loloster. Johns Hopkins University Circ., vol. xr, No.106, p.103. Baltimore, 1893.

97. Herrick, Francis H. The habits and development of the lobster and their bearing upon its artificial propagation. Paper presented at the World's Fisheries Congress, Chicago, 1893. Art. 12, Bull. U.S. Fish Commission for 1893, pp. 75-86. Washington, 1894.

98. Herrick, Francis H. The reproduction of the lobster. Zool. Anz., No. 454, Aug. 13. 1894, pp. 289-292. Leipzig, 1894. Also in the Zoologist, vol. 18, pp. 413-417. London, 1894.

99. Herrick, Francis H. The Lobster. Johnson's Universal Cyclopædia, vol, v, pp. 31.7-318. New York, 1894.

100. Herrick, Francis $\mathbf{H}$. Notes on the biology of the lobster. Science, n. S., vol. I, No. 10, March 8, pp. 263-266. See also Science, n. \&., vol. I, No. 14, p. 382. New York, 1895.

101. Herrick, Francis H. The Reproduction of the Lobster. Zool. Anz., No. 477, pp. 226-228, June 10, 1895. (Review of paper by S. Garman, No. 73 of this bibliography.)

102. Huxley, T. H. On the classification and distribution of the crayfishes. Proc. Zool. Soc. London, pp. 752-788. London, 1878 .

103. Huxley, T. H. An introduction to the study of zoology, illustrated by the crayfish. Inter. Sci. Ser., pp. I-XIV, 1-362. New York, 1880.

104. Hyatt, Alpheus. Moulting of the lobster, Homarus americanus. Proc. Bost. Soc. Nat. Hist., vol. XXI, pp. 83-90, 1880-1882. Boston, 1883.

105. Irvine and Woodhead. Secretion of carbonate of lime by animals. Part II. Proc. Roy. Soc. Edinb., vol. for 1888-1889, pp. 324-354.

106. Jones, Th. Rymer. On the moulting process in the crayfish. Ann. of Nat. Hist. or Mag. of Zool., Bot., and Geol., vol. IV, pp.141-143. 1840. Abs. from General outlines of the animal kingdom, part VIr, Sept., 1839.

Reriews of the same: Ueber die Häutung der Krebse. Frorieps Notizen, Bd. 12, No. 248, pp. 83-85, 1839, and Ueber das Häuten des Krebses.

Isis, ed. by Oken, 1844, Heft I-XI, pp. 912-913. Leipzig, 1844.

107. Jonstonus, Johannes. Historia naturalis de exsanguibus aquaticus, 1650. De piscibus et cetis, lib. v. Tab. II, fig. 2. Amstelodami, 1657.

108. Kalm, Peter. Travels into North America; containing its natural history and a circumstantial account of its plantations and agriculture in general, with the eivil, ecclesiastical, and commercial state of the country. The manners of the inhabitants and several curious and important remarks on various subjects. Transl. by John Reinhold Forster. Vols, I-III. Warrington, 1770 .

109. Kölliker, Albert. Beiträge zur Kenutniss der Geschlechtsverhältnisse und der Samenflissigkeit wirbelloser Thiere, nebst einem Versuch über das Wesen und die Bedeutung der sog. Samenthiere. Berlin, 1841.

For translation of the above, see: Observations pour servir à l'histoire des organes sexuels et du liquide séminal des Crustacés et des Cirrhipèdes. Ann. des Sci. Nat., 2e sér., t. 19, pp. 335-350, pls. 9-13.

110. Kröyer, Henrik. Monografisk Fremstilling af Slaegten Hippolyte's Nordiske Arter. Med Bidrag til Dekapodermes Udviklingshistorie. Diet Kongelige Danske Videnskabernes Selskabs naturvidenskabelige og mathematiske Afhandlinger. Niende Deel. Pl. VI, figs. 133-144. Kjöbenhavn, 1842.

111. Lafresnaye, F. de. Observations sur l'accouplement du crabe commun de nos côtes. Rev. Zool. de la Soc. Cuvier, pp. 279-282. 1848.

112. Laguesse. L'écrevisse nouvellement éclose. Jour. de 1'Anat, et de la Physiol., ann. 27, pp. 503-514, pl. Xxi. Paris, 1891.

113. de Lamarck, J. B. P. A. Histoire naturelle des animaux sans vertebres. 3e éd. Bruxelles, 1837-1839. (1st ed., 1815-1832.)

114. Lang, Arnold. Text-book of comparative anatomy, transl. by H. M. and M. Bernard. Part I. London, 1891. 
115. Latreille. Le règne animal, Cuvier. T. IV. Crustacés. 2e Łd. Paris, 1829.

116. Lavelle. Recherches d'anatomie microscopique sur le test des crustacés décapodes, Ann. des Sci. Nat., 3e sér., Zoologie, t. 7, pp. 352-377, pl. 7, figs. 10-12. Paris, 1847.

117. Leach. Paper in George Samonelle's The Entomologist's Useful Compendium; or, an Introduction to the Knowledge of British Insects, ete. London, 1819.

118. Lemoine, Victor. Recherches pour servir à l'histoire des systèmes nerveux musculaire et glandulaire de l'écrevisse. Parts I-II. Ann. des Sci. Nat,, 5e sér., Zool. et Paléontol., t. IX, pp. 99-280, pl. 6-11. Paris, 1868.

The same: Troisième partie. Ann. Sci. Nat., Zool. et Paléontol., t. x, pp. 5-54. Paris, 1868.

119. Iereboullet, A. Note sur les variétés rouge et bleue de l'écrevisse fluviatile. Compt. Reud., t. 33, pp. 376-379. Paris, 1851.

120. Lereboullet, A. Recherches sur le mode de fixation des oufs aux fausses pattes abdominales đans les écrevisses. Ann. des Sci. Nat., 4ér., t. 14, pp. 359-378, 1 plate. 1860.

See also the earlier paper: De la manière dont les ceufs des écrevisses s'attachent aux fausses pattes abdominales. L'Institut, t. xxr, No. 998, p. 64.1853.

121. Leydig, Franz. Untersuchungen zur Anatomie and Histologie der Thiere. Pp. 1-174, pls. I-Vru. Bonn, 1883.

122. Leydig, Franz. Zelle und Gewebe, nene Beiträge zur Histologie des Thierkörpers. Pp. I-VI, 1-220, Taf. I-VI. Bonn, 1885 .

123. Linné, C. Fauna suecica. Editio altera. Stockholmiæ, 1761.

124. Linné, C. Systema naturæ. Edit. XII, 1766.

125. Loeb, Jacques. Ueber kinstliche Umwandlung positiv heliotropischer Thiere in negativ heliotropische und umgekehrt. Archiv f. d. ges. Phys., Bd. 54, pp. 81-108, figs. 1-6. Bonn, 1893.

126. Loeb, Jacques. Weitere Untersuchungen über den Heliotropismus der Thiere u. seine Uebereinstimmung mit den Heliotropismus bei Thieren, Archiv f. d. ges. Phyø., Bd. 47, pp. 391-416, Taf. IX. Bonn, 1890.

127. Loeb, Jacques. On the influence of light on the periodical depth-migrations of pelagic animals. Bull. U. S. Fish Comm. for 1893, vol. XII, pp. 66-68. Washington, 1894.

128. Lovett, Edward. Abnormal color of common lobster. The Zoologist, $3 d$ ser., vol. virI, p. 491. London, 1884.

129. Lovett, Edward. Notes and observations on British stalk-eyed Crustacea. The Zoologist, 3d ser., vol. Ix, pp. 100-104. London, 1885.

130. Lucas, H. Exploration scientifique de l'Algérie. Crustacés. 1849.

131. MacMunn, C. A. On the chromatology of the blood of some invertebrates. Quart. Journ. Mie. Sci., new ser., vol. xxv, pp. 469-499, pls. 33, 34. London, 1885.

132. MacMunn, C. A. Contributions to animal chromatology. Quart. Journ. Mic. Sci, new ser., vol. xxx, pp. 51-96, pl. 6. London, 1890.

133. Malard, A. E. Influence de la lumière sux la coloration des Crustacés. Bull. de la Société Philomathique de Paris, 8e sér., t. IV, No. 1, pp. 24-30. Paris, 1892.

134. Martin, M. J. Sur un spécimen blanchâtre de homard. Bull. de la Société Philomathíque de Paris, 8e sér., t. IV, No. 1, pp. 17-19. Paris, 1892.

135. Mather, Fred. The lobster. The Aquarium, vol. III, No. 30, pp. 89-92. Brooklyn, N. Y., 1894.

136. Mather, Fred. What we know of the lobster. Scientific American Supplement, Feb. 10, 1894; also in Bull. U. S. Fish Comm. for 1893, pp. 281-286. Washington, 1894.

137. Mayer, Paul. Carcinologische Mittheilungen. Mittheil. aus der zoolog. Stat. zu Neapel. Bd. I. $\oint$ IV. Die Seheerenschwielen von Heterograpsus Tucasii, pp. 51-53, figs. 1-4. (Describes and figures amylum-like inclusions in connective tissue.) Leipzig, 1879.

138. Mayer, Paul. Zur Entwicklungsgeschichte der Dekapoden. Jenaisehe Zeit. Naturwiss., Bd. XI, pp. 188-269, Taf. XIII-Xv. 1877.

139. Müller, Otho Fredric. Prodromus. Hafniæ, 1776.

140. Nebeski, Otmar. Beitrüge zur Kenntniss der Amphipoden der Adria. Arbeit. aus dem zool. Inst. der Universität Wien, Bd. III, pp. 1-52, Taf. I-IV. Wien, 1880.

141. Nicholls, F. An account of the hermaphrodite lobster presented to the Royal Society on Thursday, May 7, by Mr. Fisher, of Newgate Market, examined and dissected, pursuant to an order of the society. Phil. Trans. Roy. Soc. of London, vol. Xxxvi, No. 413, pp. 290-294, figs. 1-4, 1729-1730. London, 1731.

Abridgment, vol. viI, pt, m, pp. 421-423, pls. II, rV. 1734. 
142. Oesteriein, Friedrich. Ueber den Magen des Flusskrebses. Miiller's Archiv für Anat, und Physiol., pp. 387-444, Taf. xiI. 1840.

143. Olivier. Encyclopédio méthodique. Hist. Nat. Insectes, t. virr. 1811.

144. Packard, A. S. A list of animals dredged near Caribou Islaud, southern Labrador, during July and August, 1860. The Cauadian Naturalist and Geologist, vol. vur, No, 6, art. xxvIn, pp. 401-429. Montreal, 1863.

145. Packard, A. S. Observations on the glacial phenomena of Labrador and Maine, with a view of the recent invertebrate fauna of Labrador. Memoirs of the Boston Soc. of Nat. Hist., vol. r, part II, pp. 210-303, pls. 7-8. Boston, 1867.

146. Packard, A. S. The history of the lobster. Review of paper by S. I. Smith. Am. Nat., vol. VIII, pp. 414-417. 1874.

147. Packard, A. S. The molting of the lobster, Am. Nat., vol, xx, p. 173. 1886.

148. Packard, Alpheus Spring. The Labrador eoast. New York, 1891.

149. Parker, G. H. The histology and development of the eye iu the lobster. Bull, of the Museum of Comparative Zoology, vol. xx, No. 1, pp. 1-60, pls. I-IV. May, 1890.

150. Patten, William. On the morphology and physiology of the brain aud sense organs of Limulus. Quart. Journ. Mic. Sci., vol. 35, n. s., pp. 1-96, I-VI, pls. 1-5. London, 1894.

151. Pennant, Thomas. Article on lobsters, containing letter by Travis. (See ref. No. 191.) British Zoology, vol. Iv, pp. 8-19. London, 1777.

152. Pontoppidans, Erich. Versuch einer natiirlichen Historie von Norwegen. Kopenhagen, 1753. Danish edit., Kiöbenhavn, 1752-1754.

153. Portius, Iucas Antoine. Sur les parties de la génération des écrevisses d'eau douce. Collection Académique, t. IV, de la partie étrangère. Observation XIX, pp. 127-136, pls. III-IV. Paris, 1757.

154. Putnam, F.W. On some of the habits of the blind crawfish, Cambarus pellucidus, and the reproduction of lost parts. Proc. Bost. Soc. Nat. Hist., vol. xviII, pp. 16-19. Boston, 1875.

155. Rathbun, Richard. The fisheries and fishery industries of the United States. Prepared through the cooperation of the Commissioner of Fisheries and the Superintendent of the Tenth Census, by George Brown Goode. Section I, Natural history of the useful aquatic animals; Part V, Crustaceans, worms, radiates, and sponges, by Richard Rathbun; pp. 759-850. Washington, 1887.

156. Rathbun, Richard. The crab, lobster, crayfish, rock lobster, shrimp, and prawn fisheries. In the fisheries and fishery industries of the United States. Section V, History and methods of the fisheries, vol, II, pt. XXI, pp. 627-810. Washington, 1887.

157. Rathbun, Richard. The transplanting of lobsters to the Pacific coast of the United States. Bull. U. S. Fish Comm., vol. virI, for 1888, pp. 453-472. Washington, 1890.

158. Rathbun, Richard. Notes on lobster enlture. Bull. U. S. Fish Comm., vol. vi, pp. 17-32. Washington, 1886.

159. Rathke, Heinrich. Zur Entwickelungsgeschichte der Dekapoden. Wiegmann's Archir für Naturgeschichte, Bd. vi, 1, pp. 241-249, 1840.

160. Rathke, Heinrich. Beiträge zur vergleichenden Anatomie u. Physiologie. Reisebemerkungen aus Skandinavien. Neuste Schriften der Naturforschenden Gesellschaft in Danzig, Bd. III-II. Zur Entwickelungsgeschichte der Dekapoden, 1, Astacus marinus. pp. 23-29, Taf. II, figs. 11-21. 1842.

161. Réaumur. Sur les diverses reproductions qui se font dans les écrevisses, les omars, les crabes, etc., et entre autre sur celles de leurs jambes et de leurs écailles. Mém. de l'Acad. Roy. des Sci., pp. 226-245, pl. 12. Paris, 1712.

162. Réaumur. Additions aux observations sur la mue des écrevisses, données dans les mémoires de 1712. Hist. de l'dead. Roy. des Sciences, pp. 263-27t, 1 plate. Paris, 1719.

Summary of the same, Sur la mue des écrevisses. Hist. de l'Acad. Roy. des Sci., 1718, pp. 22-24. Paris, 1719.

163. Reichenbach, Heinrich. Studien zur Entwickelungsgeschichte des Flusskrebses. Abhandl. Senckenbergischen Naturforsch. Gesellsch., Bd. 14, pp. 1-138, 1-6, Taf. I-XIV, Ia-IV $a$, Ivb. Frankfurt a. M., 1886.

164. Richard, Jul. Sur quelques cas de monstruosité observés chez les erustacés décapodes. Ann. Sci. Nat. (7), Zool., t. 15, No. ㄱ, pp. 99-107, 4 figrs., 1893. 
165. Risso, Histoire naturelle des crustacés des environs de Nice. 1816.

166. Risso. Histoire naturelle de l'Europe méridionale. Tom. v. 1826.

167. Rondelet, Guil. Libri de piscibus marinis, in quibus veræ piscium effigies expressie sunt, ete. 1554.

168. Rösel, August Johann, von Rosenhof. Der monatlich herausgegebenen Insecten-Belustigung drittex Theil. Der Flusskrebs hiesiges Landes, mit seinem merkwärdigen Eigenschafften. Pp. 305-328, Tab. LIV-LIX. Núrnberg, 1755.

169. Rösel, August Johann, von Rosenhof. Fernere Beschreibung des hiesigen Flusskrebses und seiner merkwiirdigen Eigenschafften. Der monatlich herausgegebenen Insecten-Belustigung dritter Theil, pp. 329-350. Deformed claws, Tab. LX, figs. 28, 29, and Tab. LXI, figs. $30-33$. Nurnberg, 1755.

170. Rougement. Anatomie des organes génitaux de l'Astacus fuviatilis et physiologio de la génération de ce crustacé. Bull. de la Soc. des Sci. Nat. de Neuchâtel, p. Ix, pp. 400-402. Neuchâtel, 1879.

171. Ryder, J. A. The metamorphosis of the American lobster, Homarus americanus, H. Milne Edwards. American Naturalist, vol. xx, pp. 739-742. 1886.

172. Ryder, J. A. Hatching, rearing, and transplanting lobsters. Science, vol. viI, pp. 517-519. New York, 1886.

173. Sabatier, Armand, De la spermatogenèse chez les crustacés décapodes. Travaux de l'Institut de zoologie de Montpellier et de la Station maritime de Cette. Pp. 1-394, pls. I-X. Montpellier and Paris, 1893.

174. Salter, S. J. A. On the monlting of the common lobster (Homarus vulgaris) and the shore erab (Carcinus manas). Journ. Proc. Linn. Soc. London, vol. 4, pp. 30-35. London, 1860.

175. Sars, G. O. On Hummerens postembryonale Udvikling. Selskabs Forhandlinger, pp. 1-28, tab. I-II. Christiania, 1874.

176. Sars, G. O. Reports made to the Department of the Interior of investigations of the salt-water fisheries of Norway during the years 1874-1877. (Indberetninger til Departmentet for det Indre fra Professor Dr. G. O. Sars om de afham i Aarene 1874-1877 anstillede Undersögelser vedkommende Saltvandsfiskerierne, Christiana, 1878.) Translated by Herman Jacobson; report of U. S. Fish Commission for 1877, pp. 663-705. Washington, 1879.

177. Say, Thomas. An account of the Crustacea of the United States. Jour. Acad. Nat. Hist., vol. I, pt. 1, pp. 155-169 (Astacus), 235-253, 316-319, 374-401, 423-459, with appendix, observations, and notes. Philadelphia, 1817.

178. Schmidt, Carl. Contributions to the comparative physiology of the invertebrate animals, being a physiologico-chemical investigation. Sci. Memoirs, ed. by Rich. Taylor, vol. v, pt. XVI, pp. 1-43. London, 1852.

179. Seba, Albertus. Loeupletissimi rerum naturalium thesauri accurata descriptio et iconibus artificiosissimis expressio per universam physices historiam. T. III, tab. XvII, No. 3. Copper-plate figure of lobster, called Astacus marinus Americanus. Amstelædami, 1758.

180. Sheldon, Lilian. The maturation of the ovum in the Cape and New Zealand species of Peripatus. Quart. Journ. Mic. Sci., n. s., vol. XXX, pp. 1-30, pls. I-III. London, 1890.

181. Smith, A. C. Notes on the lobster, Homarus americanus. Bull. U. S. Fish Commission, vol. v, pp. 121-125. 1885.

182. Smith, Sidney I. The early stages of the American lobster (Homarus americanus, Edwards). Trans. Conn. Acad. Sci., vol. II, pt. 2, pp. 351-381, pls. XIV-xvıI, figs. 1-4. New Haven, 1873. Earlier papers in Am. Journ. Sci. and Arts, 3d ser., vol. II, pp. 401-406, 1 pl., June, 1872, and in Rept. U. S. Fish Commissioner of Fish and Fisheries on the condition of the sea fisheries of the southern coast of New England in 1871 and 1872, pp. 522-537. Washington, 1873.

183. Smith, Sidney I. Review of the marine Crustacea of Labrador. Proc. U. S. Nat. Mus., vol. vi, for 1883, pp. 223-232. Washington, 1884.

184. Smith, Sidney I. Report on the Decapod Crustacea of the Albatross dredgings off the east coast of the United States during the summer and autumn of 1884. Ann. Rept. of the Commissioner of Fish and Fisheries for 1885, pp. 605-705, pls. I-xx. Washington, 1886.

185. Stearns, W. A. The Labrador fisheries. Bull. U. S. Fish Commission, vol. v, pp. 6-27. 1885.

186. Stebbing, Thomas R. R. A history of Crustacea, recent Malacostraca. Int. Sci. Ser., vol. Lxxi. New York, 1893.

187. Soubeiran, Léone. Sur l'histoire naturelle et Yéducation des écrevisses. Compt. Rend., t. 60, pp. 1249-1250. Paris, 1865. 
188. Tarr, Ralph S. Habits of burrowing erayfishes in the United States. Nature, vol. $\mathrm{xxx}, \mathrm{pp}$. 127-128, figs. 1-2. 1884 .

189. Thompson, J. V. Letter in the Zoological Journal. Vol. V, May, 1829-1834. London, 1835.

190. Thompson, William. The Crustacea of Ireland. Ann. and Mag. of Nat. Hist., vol. XI, pp. 102-111. Second article. London, 1843.

191. Travis. Letter dated Scarborough, 25th October, 1768. Quoted in article on lobster by Thomas Pennant (see ref. No. 151). Pennant's British Zoology, vol. IV, pp. 10-13. London, 1777.

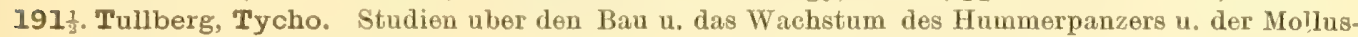
kenschalen. Kongl. Svenska Vetenskaps-Akademiens handlinger. Bd. 19, No. 3, 8. 57, 12 taf. Stockholm, 1882.

192. Valentin, G. Repertorium für Anatomie u. Physiologie. Die Fortschritte der Physiologie im Jahre 1837, Bd. III, p. 188. 1838.

193. St. George, v. la Valette. Ueber innere Zwitterbildung beim Flusskrebs. Archiv für mikroscopische Anatomie, Bd. 39, pp. 504-524, Taf. XxI. Bonn, 1892.

194. Van Beneden. Bull. de l'Acad. Roy. de Belgique, t. XxxviI, pp, 444-456. 1869. Deseribes Gregarine found in intestine of lobster. See, also, Quart. Jour. Mic. Sei., vol. x, 1870. For reference to other work, see No. 69.

195. Van der Hoeven, J. E. Handbook of zoology. Transl. from 2 d Dutch ed. by Rev. Wm. Clark. 2 vols. Cambridge, Eng., 1856.

196. Verrill, A. E. Report upon the invertebrste animals of Vineyard Sound and the adjacent waters, with an account of the physical characters of the region. Rept. of the United States Fish Conmissioner for 1871-72, pp. 295-778, pls. I-Xxxvm, with descriptions. Washington, 1873.

197. Vitzou, Alexandre-Nicolas. Recherches sur la strueture et la formation des téguments chen les Crustacés Décapodes. Archiv. de Zool. Expér. et Générale, t. x, pp. 451-576, pls. XxiIxxvir. Paris, 1882.

198. Ward, Fenry B. On the parasites of the lake fish. Trans. Am. Mic. Soc., vol. Xv, pp. $173-182$. Washington, 1894. Describes a distoma found encysted in Cambarus propinquus.

199. Warrington, Robert. Observations on the natural history and habits of the common prawn, Palcmon serratus. Ann. and Mag. of Nat. Hist., 2d ser., vol. Xv, pp. 247-52. 1857.

200. Weeden, Wm. B. Economic and social history of New England-1620-1789, vols. I, II. See vol. II, p. 540, quotation from Proc. M. H. S., pp. 112, 113. Cambridge, Mass., 1890.

201. Weldon, and Fowler, G. H. Notes on recent experiments relating to the growth and rearing of food-fish at the laboratory. I. The rearing of lobster larvæ. Jour. Marine Biol. Ass. of United Kingdom, new series, vol. I, No.4, pp. 367-375. London, Nov., 1890.

202. Wheildon, Wm, H. The lobster (Homarus americanus). The extent of the fishery; the spawning season; food of the lobster; shedding of shell; legislation on the fishery. Proc. A. A. A. S., vol. xxI, pp. 133-141. 1875.

203. White, Adam. A popular history of British Crustacea. See Astacus, p. 101. London, 1857.

204. Whitman, C. O. The seat of formative and regenerative energy. Jour. of Morphol., vol. II, pp. 27-50. Boston, 1889 .

205. Williamson, W. C. On some histological features in the shells of the crustacea. Quart. Journ. Mic. Sei., vol. 8, pp. 35-47, pl. III, 1860.

206. Wilson, E. B. Amphioxus and the Mosaic theory of development. Jour. of Morphol., vol. viII, pp. 579-638, pls. Xxix-Xxxvir. Boston, 1893.

207. Wood, W. M. Transplanting lobsters to the Chesapeake-Experiments upon the temperature they can endure. Bull. U. S. Fish Comm., 1885, vol. v, pp. 31-32. Washington, 1885.

208. Zittel, Karl A. Handbuch der Palæontologie, 1 Abth. II Bd. Mollusca u. Arthropoda. München u. Leipzig, 1881-1885.

209. Fisheries statements, 1880. Supplement No.2 to eleventh annual report to minister of marine and fisheries. Appendix No. II, report of J. H. Duvar, inspector of fisheries for the Province of Prince Edward Island, for 1880. Lobsters, p. 231. Ottawa, 1881.

210. Fisheries statements for the year 1882. Supplement No.2 to the fifteenth annual report of the department of marine and fisheries for the year 1882. Ottawa, 1883.

211. Annual report of the department of fisheries, Dominion of Canada, for 1888. Ottawa, 1889.

212. The cultivation of lobsters. Practical Magazine, vol. 2, pp. 258-259. London, 1873.

213. Review of the reports by Buckland and Spencer on the lobster, crab, and oyster fisheries of Great Britain. Quarterly Review, vol. 144, art, vi, pp. 249-262. 1877. 


\section{Appendix IV.-DESCRIPTION OF PLATES.}

\section{Plate 1.}

Fig. 1. The Belfast lobster. Dorsal view of male lobster, eaptured at Belfast, Maine, May 6, 1891. Living weight a little over 23 pounds. From photograph of skeleton. Original in possession of the author. For detailed measurements see table 30, No.1. A little less than one-fourth natural size.

\section{Plate 2.}

Fig. 2. Ventral view of large lobster shown in plate 1.

Fig. 3. Ventral view of small lobster for comparison with fig. 2. Egg-bearing female; length 97 inches; weight about 1 i pounds. Most of the eggs which were attached to the abdomen have been removed.

Both figures reproduced from photograph. About one-fourth natural size.

\section{Plate 3.}

Fig.4. Profile view of living red lobster. Female, length 11 용 inches; weight about 2 pounds. Captured near Mount Desert, Maine. From photograph from life, April 10, 1894. For colored drawing of this lobster see plate 16, fig. 21. A little over one-half natural size.

\section{Plate 4.}

Fig.5. Adult male lobster, dorsal view. Length $12 \frac{1}{16}$ inches; weight 2 pounds 14 onnces. From photograph from life, December 8, 1893. A little under one-half natural size. Membrane between thorax and abdomen unnaturally distended.

This Iobster, with those represented by the three following plates, figs. 5-8, was captured at Woods Hole, Massachusetts, December, 1893, and sent alive to Cleveland, Ohio.

\section{Plate 5.}

Fig. 6. Adult male. Ventral view of lobster shown in plate 4. From photograph from life. A little under one-half natural size.

\section{Plate 6.}

Fig. 7. Adult female lobster with external eggs, dorsal view. Length $11_{16}$ inches; weight 1 pound 13 ounces. From photograph from life. A little over one-half natural size.

Plate 7.

Fig. 8. Adult female. Ventral view of lobster shown in plate 6. The dark-green egga attached to the swimmerets under the tail are very clearly seen. A colored sketch of one of these eggs, showing the contained embryo, and a cluster of eggs from the swimmerets are represented by figs. 25,26 , plate 17 . One-half natural size.

A lobster of this size produces on the average about 19,000 eggs. The seminal receptacle is seen between the bases of the third and fourth pairs of walking legs. Compare this with the organ as it appears in the immature lobster shown in plate 11. 
Plate 8 ,

Fig. 9. Immature female lobster, dorsal view; length $44 \mathrm{~mm}$. (1.73 inchos). From photograph, life-o size. Casco Bay, Maine, October, 1893. See table 32, No.2, for further details.

This and the immature or adolescent lobsters represented by plates. 8-13, figs. 9-18, were collected in Casco Bay, Maine, in Small Point Harbor and vicinity, from August 31 to October 19,1893. The photographs were all made from the alcoholic specimens. They are described in table 32, pp. 163-165. All are life-size.

Fig. 10. Immatruemale lobster'; length $40.3 \mathrm{~mm}$. (1.59 inches). See No. 1, table 32. The right cuttingclaw is smaller than is normal, due to the fact that it has been recently cast off and is now only partially restored. (See Chapter IV.)

Fig. 11. Immature female lobster; length $64 \mathrm{~mm}$. (2.5 inches). No. 7 , table 32.

Fig. 12. Immature male lobster; length 58 mm. (2.28 inches). No. 5, table 32.

\section{Plate 9.}

Fig. 13. Immature female Iobster; length $75.6 \mathrm{~mm}$. (2.98 inches). No. 16, table 32. The right cuttingclaw is smaller than normal. See fig. 10, pl. 8, with description given above. From photograph; life-size.

Fig. 14. Immature male lobster; length 67 mm. (2.64 inches). No.8, table 32. From photograph; life-size.

Plate 10.

Fig. 15. Immature female lobster; dorsal view; length 86.5 mm. (3.41 inches). No.21, table 32 . From photograph; life-size.

Plate 11.

Fig. 16. Ventral view of immature female lobster shown in plate 10. Length $86.5 \mathrm{~mm}$. (3.41 inches). No.21, table 32. From photograph; life-size. The seminal receptacle is seen between the third pair of walking legs. The normal rudimentary condition of the first pair of swimmerets is also well shown. Compare with plate 7.

\section{Plate 12.}

Fig. 17. Immature male lobster; length $92.3 \mathrm{~mm}$. (3.64 inches). No. 23, table 32. From photograph; life-size.

Plate 13.

Fig. 18. Immature male lobster; lengìn $110 \mathrm{~mm}$. (4.34 inches). No.32, table 32. From photograph; Iife-size.

\section{Plate 14.}

Fig. 19. Male lobster showing abnormal, symmetrical development in large claws. Instead of the usual differentiation of the great claws, one for crushing, the other for cutting (well shown in fig. 6, pl. 5), both are here similar and belong to the cutting type. Length 10 inches; taken at Woods Hole, Massachusetts. See p. 144. From photograph from alcoholic specimen; about four-fifths life size.

\section{Plate 15.}

Fig. 20. Right erushing-claw of lobster, probably a male, preserved in the museum of the Peabody Academy of Science, Salem, Massachusetts: Estimated weight of live lobster, abont 25 pounds; weight of skeleton of claw (including the fifth joint or carpus), the parts shown in the drawing, 16: ounces. Natural size.

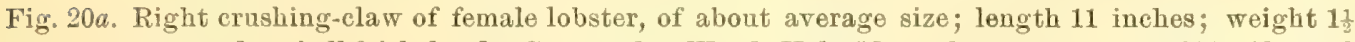
pounds; shell fairly hard. Captured at Woods Hole, Massachusetts, July 24, 1894. Natural size.

This drawing of the claw of a lobster of average size, placed by the side of the mammoth specimen for the sake of comparison, shows more forcibly than words or figures can the great difference in size which may exist between adults of the same species. Both drawings are life-size, and to insure accuracy their outlines were carefully traced from the objects themselves. The living weight of the smaller claw (including the entire limb) was about 10 ounces, that of the larger about 10 pounds. (See p. 115.) 
Plate 16.

- Fig. 21. Red female lobster, colored from life. Length 11: inches; weight about 2 pounds. Captured in the vicinity of Mount Desert, Maine, April, 1894. An examination of the reproductive organs showed that the lobster had not yet reached sexual maturity. For photograph of this lobster see plate 3. A trifle under one-half life-size.

Fig. 22. Adult male lobster, colored from life. Length 10 inches; weight about $1_{\frac{1}{2}}$ pounds; shell moderately hard. Woods Hole, Massachusetts, August 14, 1891. About two-thirds life-size.

Plate 17.

Fig. 23. Eggs of lobster showing an unusual color variation. Drawn from life. The embryo was somewhat past the egg-nauplius stage. The lobster, which was 12 inches long and weighed 2 pounds 5 ounces, was captured at Woods Hole, Massachusetts, December 4, 1893, and sent to me alive. These eggs turned a very light salmon-color when boiled, Six times natural size.

Fig. 24. Cluster of fresh eggs of lobster, colored from life. Laid in aquarium at the United States Fish Commission station, Woods Hole, Massachusetts. Drawn August 11, 1893. When first examined the eggs were closely adherent, and the glue which bound them together was very soft. The ovary of the lobster was examined on August 17; it was of small size, and contained but few unextruded eggs, which were partially absorbed. About 6 times natural size.

Fig. 25. Cluster of egg embryos from swimmerets of female shown in plate 7. Drawn from life December 7, 1893 The entire mass of eggs are attached to each other and to the setre or hairs of the swimming feet, as shown in the drawing. A single detached seta with a number of eggs glued to it is here represented. About 13 times natural size.

Fig. 26. Profile view of embryo released from eggshell; taken from a cluster like that in fig. 25. Drawing made December 12, 1893, after killing the embryos with hot water. Embryos from the same lobster (see fig. 8) lived eight days in damp seaweed, in a cool room, and could apparently have been kept alive under the same conditions for a much longer time. Enlarged 33 times.

Fig. 27. Side view of embryo, as seen through the transparent shell. Drawn and colored from life. Eggs from same batch as those shown in fig. 25; female represented by plate 7 . The conspicuous green yolk, which is restricted to the upper half of the egg, fills the cavity of the mid-gut. This eventually forms the "liver" or gastric glands, the anterior lobes of which are clearly seen in fig. 28. The clear space to the right (on the lower side in fig. 28) represents the heart. Below it the intestine joins the mid-gut. The eye is shown as it appears in reflected light in fig. 27, as in transmitted light in fig, 28. (See p. 169.) Enlarged 33 times.

Fig. 28. Dorsal view of embryo shown in fig. 27. Enlarged 33 times.

Plate 18.

Fig. 29. Lobster hatching. Drawn from life July 5, 1891. The membrane of attachment (secondary egg membrane) has split along the middle line and is being drawn off over the head. The inner part of the shell (primary egg membrane or "chorion") invested the embryo as an exceedingly delicate, transparent membrane, and was ruptured (above the eyes) by needles in order to show it. When the outer membrane is borne away it usually drags the delicate inner one with it. Enlarged 33 times.

Fig. 30. Lateral view of a lobster, teased from an egg which was about ready to hatch, to show the embryonic cuticle which must be shed before the first swimming larval stage is reached. The healthy embryo sheds this skin either at the time of its escape from the eggshell or very soon after it. The intestinal concretions are clearly seen in both this and the preceding figures. The pigment cells of the skin and other details are purposely omitted. Drawn from life. Enlarged about 33 times.

Fig. 31. Profile view of lobster in fifth stage. General color reddish-brown. Pigmentation of skin not represented. Rudimentary exopodites of thoracic appendages present. Length 16 mm. July 2, 1891. Enlarged 9 times. 
Plate 19 .

Fig. 32. First swimming stage of the lobster, usually called the first larva or the first schizopod stage. Dorsal view. Drawn from life July 3, 1890. The bright vermilion pigment cells or chromatophores of the skin are here expanded under stimulation. Under some conditions they contract, and the animal becomes very pale-blue, in consequence of the blood pigment. The stomach-bag on the middle line behind the eyes, the lobes of the yellow "liver" on either side of this, the heart behind the stomach, and the intestine passing beneath this from the stomach to the hinder end of the body, are clearly discerned through the transparent shell. The yellow cast of color is rather too pronounced, especially in the abdomen. For color of eyes, see p. 169, and fig, 27. Length about $7.8 \mathrm{~mm}$. ( $\frac{3}{10}$ inch). Enlarged 22 times.

\section{Plate 20.}

Fig. 33. Profile view of the first larva of the lobster. Length about $8 \mathrm{~mm}$. July 22, 1891. The transparency of these larve is often very great, and many of the organs, such as the heart, gills, and alimentary tract, are seen with great clearness through the shell. (Compare fig. 32.) The "liver" or gastric gland, usually of a golden-yellow color and resembling a cluster of grapes, is the most voluminous and conspicuous of the internal organs. The shading by stipple in this and the two following plates is purely conventional, no attempt being made to represent the pigmented skin. Eularged 30 times.

\section{Plate 21.}

Fig. 34. Second larra; profile view; drawn to the same scale as fig. 33. The second larval stage is preceded by the second molt. Beside the striking increase iu size in all the parts of the body, the most important changes are the growth of the autenuze and the appearance of rudimentary legs or swimmerets on the under side of the abdomen-upou the second to fifth somites, inclusive. Length about $9 \mathrm{~mm} .(0.35 \mathrm{inch})$. Eularged 30 times.

\section{Plate 22.}

Fig. 35. Third larva; lateral viow. Drawn July 15, 1891. The principal changes which are emphasized at the third molt concern the antenna, the grow th of the thoracic appendages, chiefly seen in the large claws, and the aequisition of the last pair of abdominal appendages, which, with the telson, constitute a very important locomotor organ, the propeller or tail fan. Length $11.1 \mathrm{~mm}$. (0.44 inch), Enlarged 22 times.

PLATE 23.

Fig. 36. Fourth larva; dorsal view. Length $14.6 \mathrm{~mm}$. Drawn and colored from life August 7, 1891. This represents the average normal color of this stage, yet, as will be seen in Chapter XII, this is subject to considerable variation. The brilliant peacock-green or intense yellow-green spots upon the carapace and abdominal segments are characteristic of this period, but it is difficult to represent these pigments in their natural glow and purity. Enlarged $10 \frac{1}{2}$ times.

\section{Plate 24.}

Fig. 37. Sixth stage; dorsal view. Outline from a young lobster $15.3 \mathrm{~mm}$. iong, July 14, 1891; coloring from lobster No. 3 , table 34, in sixth stage raised from fourth larva; length $15.5 \mathrm{~mm}$. Enlarged 8,30 times.

\section{Plate 25.}

Fig. 38. Young lobster in sixth stage; profile view. Raised from the egg; lobster No. 36, table 34. Length $16 \mathrm{~mm}$. Drawn and colored from life July 30, 1892. The white spots or tendonmarks on the carapace are very characteristic of this period. They are somewhat less prominent in the fifth stage. The fifth stage usually resembles the sixth very closely, particularly in color. Enlarged $11 \frac{1}{2}$ times. 
Plate 26.

Fig. 39. Young, immature lobster; male. Length $47 \mathrm{~mm}$. Drawn and colored from nature July 18, 1891. This animal was injured and brought up by accident in a lobster pot in Woods Hole Harbor. (No. 22, table 33.) Enlarged 2\% times.

Plate 27.

[The stage or molt to which each drawing belongs is shown by roman numerals on plates 27 to 35. ]

Fig. 40. Right first antenna of first Iarva, from below. The inner branch or flagellum of this appendage is now present as a very small unsegmented rudiment, which grows out of the primary stalk from its under side toward the middle line. 36 times natural size.

Fig. 41. Left first antenna of second larva, from below. Segmentation of flagellum of exopodite not yet visible, or but faintly marked; endopodite tipped with one long and one or two short set:; shows slight traces of segmentation. Nine bunches of olfactory setæ present, 4 to 6 in a bunch, distributed in two longitudinal rows. 36 times natural size.

Fig. 42. Left first antenna of third larva, from below. Segmentation of flagella more marked. Onter and inner branches separated by pressure. 36 times natural size.

Fig. 43. Left first antenna of fourth larva, from above, Masses of brown pigment are seen in the auditory chamber. Segmentation of parts very distinct. au, auditory organ. 36 times natural size.

Fig. 44. Left first antenna of fifth stage, from below. Lobster No. 3, table 34. Parts shown in natural position. 36 times natural size.

Fig. 45. Right first and second antenuæ of first larva, from above. Inner edge of exopodite of first antenna bears a fringe of 22 to 23 plumose setæ. 36 times natural size.

Fig. 46. Right second antenna of second larva, from above. 36 times natural size.

Fig. 47. Left second antenna of third larva, from above. 36 times natural size.

Fig. 48. Left second antenua of fourth Iarva, from below. Flagellum divided into 40 segments. 36 times natural size.

Fig. 49. Proximal portion of left first and second antennæ of lobster in fifth stage, seen from below. Lobster No. 28, table 34. Drawn without pressure. gr, papilla on which green gland opens. 36 times natural size.

Plate 28.

Fig. 50. Left first and second antennæ of fifth larva, as seen from above. From lobster No. 28, table 34. 36 times natural size.

Fig. 51. Right first maxilla of first larva, from anterior face. 153 times natural size.

Fig. 52. Terminal joint of left fifth pereiopod of first larva from anterior side. 50 times natural size.

Fig. 53. Tip of endopodite of first maxilla of first larva. 45 times natural size.

Fig. 54. Front view of mouth and surrounding parts-labrum, metastoma, and nuandibles-of first larva. Dark-red chromatophores occur on the mandibles and labrum. The mandibular palp sometimes carries two setæ at its tip. 154 times natural size.

Fig. 55. Right mandible of fourth larva, from behind, showing groove and cutting edge. 36 times natural size.

Fig. 56. Left mandible of fourth larva, from outer side. Hard, chitinous part next to cutting edges, bluish steel color. 50 times natural size.

Fig. 57. Mandibles of fifth larva, from anterior side. Drawu from the molted shell of lobster No. 23, table. 34, August 10, 1892. Leugth of larva before molt $13 \mathrm{~mm}$. 36 times natural size.

\section{Plate 29,}

Fig. 58. Left first maxilliped of first larva, from the inner side. 125 times natural size.

Fig. 59. Left first maxilliped of fourth larva, from outer side, showing tegumental glands in secoud segment (basis). 52 times natural size.

Fig. 60. Right second maxilla of first larva, from outer side. 153 times natural size.

Fig. 61. Right first maxilla of fourth larva, from inner side. 52 times natural size.

Fig. 62. Right first maxilla of fifth larva, from outer side, showing tegumental glands in second segment (basis). Drawn without pressure, From lobster No. 27, table 34. 50 times natural size. 
Plate 30.

Fig: 63. Left second maxilliped of first larva, from anterior face. Epipodite is developed on basis; no distinct podobranchia. 50 times natural size.

Fig. 6t. Left second maxilliped of fourth larva, from anterior face. Podobranchia present, but rudimentary as in the adult. 36 times natural size.

Fig. 65. Right third maxilliped of fourth larva, from dorsal surface, natural position. 22 times natural size.

lig. 66. Left first pereiopod of first larva, from below. 'The arthrobranchire which issue from the membranes between the body and appendage, and are sometimes torn off with the latter, are also shown in fig.65. 52 times natural size.

Fig. 67. Left tirst pereiopod of fourth larva, from below. The small tubercles of the chelæ are scarcely visible in this position. The exopodite (compare fig. 66), now a short rudiment at the base of the appendage, does not entirely disappear until the fifth molt. 22 times natural size.

Fig. 68. Part of left third maxilliped of fourth larva, from below, showing serrated inner margin of third segment. 22 times natural size.

Fig. 69. Left third maxilliped of first larva, from above. 50 times natural size.

\section{Plate 31}

Fig. 70. Left fourth pereiopor of first larva, from above. 50 times natural size.

Fig. 71. Serrated spine from propodus of left second pereiopod of fourth larva. 153 times natural size.

Fig. 72. Telson of embryo with eye pigment, July 26. Piero-sulphuric acid preparation; teased from egg in glycerin. 22 times natural size.

Fig. 73. Right second pereiopod of first larva, from the side. 50 times natural size.

Fig. 7t. Left second pereiopod of fourth larva, from above. 22 times natural size.

l.ig. 75. Left fifth pereiopod of fourth larva, from above. 22 times natural size.

Fig. 76. Left fourth pereiopod of fifth larva, from above. The podobranchia with epipodite, the arthrobranchire and the pleurobranchia are here shown. 30 times natural size.

Fig. 77. Antenn of embryo, the telson of which is shown in fig. 72. 22 times natural size.

\section{Plate 32}

Fig. 78. Bud of first left abdominal appendage of fifth larva; length of larva 14 mm. Drawn from molted shell of lobster No.36, table 34. July 30, 1892. 63 times natural size.

Fig. 79. Seminal receptacle of female. Lobster No. 17, table 33. Length of lobster $35 \mathrm{~mm}, 14$ times natural size.

Fig. 80. Left first abdominal appendage of lobster No. 37, table 34; eighth stage; length $19.75 \mathrm{~mm}$. (0.78 inch); raised from egg. 63 times natural size.

Fig. 81. Ventral view of young female lobster; length $51.8 \mathrm{~mm} .(2.04$ inches); No. 19, table 33 . The seminal receptacle is here shown in process of development. Compare with plate 11. 5.3 times natural size.

Fig. 82. Left first abdominal appendage of the sixth stage of development. From lobster No. 34, table 34. Drawn from molted shell. Length of lobster in sixth stage $16.3 \mathrm{~mm} .63$ times natural size.

Fig. 83. Left first abdominal appendage of lobster No. 34, table 34, in seventh stage. Length of lobster $18 \mathrm{~mm}$. ( 0.71 inch), 63 times natural size.

Fig. 84. Left first abdominal appendage of lobster in sixth stage. No. 36, table 34; length of lobster 16 mm. 63 times natural size.

Fig. 85. Left first abdominal appendage of female in eighth stage. Lobster No. 3, table 34. Length of lobster $21.2 \mathrm{~mm}$. Appendage segmented into two parts. For ventral view of thorax of this lobster see fig. 89. 63 times natural size.

Fig. 86. Left first abdominal appendage of female. Lobster No. 17, table 33. Length of lobster 35 mm. (1.39 inches). 14 times natural size.

Fig. 87. Left first abdominal appendage of male. No. 18, table 33. Length of lobster $36.3 \mathrm{~mm}$. (1.43 inches). 14 times natural size.

Fig. 88. Left first abdominal appendage of female. No. 19, table 33. Length of lobster $51.8 \mathrm{~mm}$. (2.03 inches). For seminal receptacle of this lobster see fig. 81.14 times natural size. 
Fig. 89. Ventral view of female lobster in eighth stage. From lobster No. 3, table 34. Length of lobster $21.2 \mathrm{~mm} .(0.83 \mathrm{nch})$. For first abdominal appendage of this lobster, see fig. 85 ; for color in sixth stage, see pl. 24. 5.3 times natural size.

Fig. 90. Left first abdominal appendage of young male. Length of lobster $19.3 \mathrm{~mm}$. $(0.76$ inch) erghth stage. August 14, 1892. 63 times natural size.

Fig. 91. Ventral view of young male. No. 1, table 32. Length of lobster 40.3 mm. (1.59 inches.) 3.5 times natural size.

\section{Plate 33.}

Fig. 92. Left cheliped of fourth larva (No. 23, table 34 ) in process of regeneration from stump, seen. from below. Length of larva $13 \mathrm{~mm}$. Drawn from molted shell of fourth larval stage August 9, 1893. $X$, plane of fracture. 1-7, segments of limb. 22 times natural size.

Fig. 93. Left tourth pleopod of second larva, from outer face. 95 times natural size.

Fig. 94. Left second pleopod of third larva, from outer face. 36 times natural size.

Fig. 95. First abdominal segment of shell of lobster No. 34, table 34, in sixth stage, seen from behind. Raised from egg, and followed from third larval stage. Length of lobster $16.3 \mathrm{~mm}$. A colored drawing of this lobster is given in fig. 38, plate 25, and a drawing of the first abdominal appendage in fig. 82. 16 times natural size.

Fig. 96. Left cheliped of molted shell of fifth larva, seen from above. Regenerated from the condition shown in fig. 92 after the interrention of a single molt. $X$, plane of fracture. $1-4$, segments of limb. 22 times natural size.

Fig. 97. Left second pleopod of fourth larva, from anterior face. end, endopodite. 36 times natural size.

Fig. 98. Sterna of the last three thoracic somites of fifth larva. From No. 36, table 34. Length of lobster $14 \mathrm{~mm}$.; sex doubtful. July 30,1892 . 47 times natural size.

Fig. 99. Left fourth pereiopod of fourth larva, in process of regeneration. No. 23, table 34. Length $13 \mathrm{~mm}$. 1-7, segments of limb. 22 times natural size.

Fig. 100. Right second antenna of lobster in seventh stage, in process of regeneration, seen from above. No. 34, table 34. Drawn from molted shell, August 8, 1892. 22 times natural size.

\section{Plate 34.}

Fig. 101. Respiratory organs of second larva, from left side, 8-14, appendages of corresponding somites of body. 36 times natural size.

Fig. 102. Telson of second larva, from above. 36 times natural size.

Fig. 103. Telson of first larva, from above. 50 times natural size.

Fig. 104 Caudal fan of third larva, from below. 36 times natural size.

Fig. 105. Caudal fan of fourth larva, from above. Alcohol-glycerin preparation. Setæall plumose. 30 times natural size.

Fig. 106. Podobranchia of left second pereiopod of lobster, probably in fourth stage, from inner side. The gill now carries four rows of branchial filaments. 36 times natural size.

\section{Plate 35.}

Fig. 107. Left first antenna of the embryo shown in figs. 27, 28, plate 17. Frontal view. 63 times natural size.

Fig. 108. Right second antenna of the same embryo, from below. 63 times natural size.

Fig. 109. Rostrum of second larva, from above. 37 times natural size.

Fig. 110. Profile view of carapace of first larra. 13 times natural size.

Fig. 111. Profile view of carapace of second larva. 13 times natural size.

Fig. 112. Profile view of carapace of third larva. 13 times natural size.

Fig. 113. Profile view of carapace of fourth larva. From molt, July 15. Dorsal view of same given in fig. 115. The entire outer surface is now studded with short setæe. 13 times natural size.

Fig. 114. Profile view of carapace of fifth larva, showing tendon marks. General color of larva brownish-green; carapace brown. 6 times natural size.

Fig. 115. Dorsal view of carapace of fourth larva, from molted shell. Profile view of same is given in fig. 113. The median area of absorption is now a loroad band which widens in the rostral regions and unites with the cervical groove on either side to form a oross-shaped figure. 13 times natural size. 
Plate 36.

Fig. 116. Section of reproductive organ of embryo near time of hatching. 513 times natural size.

Fig. 117. Section of right reproductive organ of first larva. R. O., reproductive organ. 513 times natural size.

Fig. 118. Right second antenna of an adult female lobster, orergrown with alga (chiefly Olva and Laminaria), seen from above. Length of lobster about 10\% inches Taken from lobster pound at Viual Haven Island, Maine, Augnst 26, 1893. Two-thirds natural size.

Fig. 119. Oviduet and part of ovarian lobe from left side, showing a row of nnextruded eggs in duct. Length of female about 10 inches. External eggs in yolk segmentation. Woors Hole, Massachusetts, August 3, 1894. od, ovidnet. Two-thirds natural size.

Fig. 120. Reproductive organs of adult male lobster from above. Dnet of testis in natural position on right side, dissected out on the left. Dotted lines (1 to 5) mark planes of section of the vas deferens and refer to figures on plate 37. a, proximal segment; $b$, glandular segment; $e$, ductus ejaculatorius; in, intestine; $g g$, gastric glaud. Two-thirds natural size.

Fig. 121. Disk-shaped concretion, probably containing glycogen, from maxilla; cracked by pressure. 133 times natural size.

Fig. 122. Large granular cell from first maxilliped, probably glycogenons in function. August 17, 1893. 733 times natural size.

Fig. 123. Reproductive organs of adult female dissected out, viewerl from above; ovary nearly ripe. Length of lobster 10 s inches. No. 77, table 20. August 21, 1890. od, oviduct. Twothirds natural size.

\section{Plate 37.}

Fig. 124. Transverse section of proximal end of vas deferens of adult lobster. Plane of section marked " 1 " in fig. 120. Duct filled with sperm; lining-epithelium consists of" small flat cells. This and figs 125-128 are from the same organ and illustrate the anatomy of the different parts of the male duct. $\quad s p$, sperm cells; $m b$, connective tissue sheath of duct. 36 times natural size.

Fig. 125. Transverse section of vas deferens of adult lobster. Plane of section marked " 2 " in fig. 120. ep, epithelial lining of duct. 36 times natural size.

Fig. 126. Transverse section of vas deferens of adult lobster, showing thick muscniar walls. Plane of section marked " 4 " in fig. 120. c. mu, circular museles; $l$. mu, longitudinal muscles; Bl. S., blood sinus. 36 times natural size.

Fig. 127. Part of transverse section of vas deferens, in plane marked " 5 " in fig. 120. bm, basement membrane; c. $m u$, eircular muscles; ep, epithelial lining constituting the spermatophoral glands; l. mu, longitudinal muscles; $m b$, membranons sheath. 190 times natural size.

Fig. 128. Part of transverse section of vas deferens through glandular portion, in plane marked " 3 ," fig. 120, showing spermatophores, contained sperm and glandular lining-epithelium. The gelatinous spermatophore is a secretion of the latter. $a, b$, compartments of duct; $f$, inward fold of epithelium of duct; $S p$, sperm; $S p r$, inner gelatinous substance of spermatophore. 36 times natural size.

Fig. 129. Ripe sperm cells: $b$, $c$, from the vas deferens of an adult male and $a$, from the seminal receptacie of a female. About 550 times natural size.

Plate 38.

Fig. 130. Seminal receptacle of adult female, from above. Natural size.

Fig. 131. Ovaries of immature lobster, seen from above. Length of lobster $44 \mathrm{~mm}$. (1.73 inches). Length of orary $15 \mathrm{~mm}$; ; diameter of lobe $\frac{1}{4} \mathrm{~mm}$. From No.2, table 32. Color opaque white. Oviducts, though undoubtedly present, not seen in dissection. Natural size.

Fig. 132. Ovaries of immature lobster, seen from above. Length of lobster $74.5 \mathrm{~mm}$. (215 inches). Length of ovary $41 \mathrm{~mm}$; d diameter of lobe $1 \mathrm{~mm}$. From No. 98, table 20. Natural size.

Fig. 133. Egg teased from fresh ovary shown in fig. 138. Represents relative size of ovarian eggs one year older than those shown in fig. 134. 44 times natural size.

Fig. 134. Ova teased from fresh ovary shown in fig. 136. Drawn to same scale as fig. 133. This illustrates the size at the time of egg-laying of the immature eggs which are to form the next generation, and which will be ready for extrusion two years hence. One year later they attain the relative size shown in fig. 133 . 44 times natural size.

Fig. 135. Ova teased from fresh ovary shown in fig. 137. The difference in relative size between these eggs and those shown in fig. 134 represents a growth of about six weeks in summer. 44 times natural size. 
Fig. 136. Orary immediately after egg laying, seen from below. From lobster No. 52, table 20. The oviducts are filled with unextruded eggs; a few of these ova are also seen in the ovaries. Immature eggs from this ovary are shown in fig. 134. The yellow flecks are the remains of unextruded eggs of a former egg generation; that is, they have been in the ovary two years at least. Drawn in natural size and color from life. July 28, 1891.

Fig. 137. Ovary of lobster No. 87, table 20, bearing external eggs. The latter have been laid about six weeks (date of laying about July 10). The ovarian eggs possess a dark-green core and lighter periphery. At the period of ovulation they are colorless, as shown in figs. 134 and 136. August 21, 1891. Drawn in natural size from life.

Fig. 138. Ovary of female which has recently hatched a brood. Taken July 30, 1831. For description of lobster see No. 95, table 20. The pea-green color is characteristic of the ovary at this time. The contained eggs, one of which is shown in fig. 133, are approximately one vear old. The difference in relative size between the ova shown in figs. 133 and 134 thus represents a year's growth, while the relative difference in size between the ova shown in figs. 134 and 135 represents only six weeks of summer growth.

We thus see that a generation of ovarian ova grow very rapidly during the first summer following the last ovulation. They then enter upon a period of quiescence, growing but slowly, like the external embryos during the succeeding winter. The second summer following ovulation is marked by a second period of rapid growth, followed in turn by a second period of quiescence during the succeeding winter. At the beginning of the third summer after ovulation this generation of eggs is ready for extrusion. That the spawning periols are thus two years apart is a valid inference drawn from the study of the anatomy of the reproductive organs. Yellow spots mark as before the remains of degenerate eggs which failed of emission at the last reproductive period. The characteristic condition of the ovary shown in this drawing proves that annual breeding is an impossibjlity. Drawn in natural size and color from life.

\section{Plate 39.}

Fig. 139. Part of transverse section of ovary of lobster, No. 52, table 20, with external eggs in early segmentation, the ova having been laid about thirty-six hours. The peculiar glandular organs are now seen in the peripheral parts of the lobes. $O . G$., ovarian gland; $O . W$. wall of ovary. 36 times natural size.

Fig. 140. Part of transverse section of ovary of lobster No. 94, table 20. Glands absent; ovaries approaching maturity. 36 times natural size.

Fig. 141. Part of transverse section of nearly ripe ovary, from lobster No. 75, table 20. August 19, 1890. The nucleus or germinal vesicle is shown in one of the nearly ripe eggs. (For more detailed drawing of nucleus, see fig. 160.) Bl. S., blood sinus; $C t$, nodule of connective tissue. O. G., ovarian gland 22 times natural size.

Fig. 142. Part of transverse section of ovary of lobster No. 52, table 20, showing follicle cells which have wandered into the egg and are undergoing degeneration. $D g$, vesiculated masses of chromatin, the fragments of degenerated cells; $B l$. S., blood sinus containing blood cells. 457 times natural size.

Fig. 143. Part of transverse section of ovary, the same as in fig. 141, showing the gland-like organs. $B l . S_{.,}$blood sinus (dotted line should be continued across gland). 211 times natural size.

Plate 40.

Fig. 144. Right pleopod of adult female lobster, seen from posterior surface. Drawn from alcoholic preparation, with eamera and dissecting microscope, the cuticle being removed from one side to show distribution of cement glands in swimmerets. 4 times natural size.

Fig. 145. Fold of glandular epithelium from transverse section of ovary of lobster No. 75, table 20 From same as fig. 141. ys, body resembling yolk spherule. 190 times natural size.

Fig. 146. Transverse section of lobe of ovary shown in fig. 131, plate 38 . From No.2, table 32.67 times natural size.

Fig. 147. Part of transverse section of ovarian lobe from a lobster with external eggs near the point of hatehing. The condition of this ovary closely corresponds to that shown in fig. 138. June $30,1890 . \quad B 7$. S., blood sinus. 36 times natural size. 
Fig. 148. Part of transverse section of ovary of lobster No. 51, table 20, showing the inner or primary egr membrane (shaded dark), and the follicular epithelium by which it is sccreted. 137 . S., blood sinus. 211 times natural size.

Fig. 149. Part of transverse section of ovary of lobster No. 52, table 20, showing part of an egg and follicular cells in contact with it. Those which have wandered iuto the yolk afterwards degenerate. The external eggs borne by this lobster were in an early stage of segmentation. f. c., follicle cells immersed in the yolk. 211 times natural size.

\section{Plate 41.}

Fig. 150. Degenerating cells from the ovary of lobster No.76, table 20. The larger body to the left is the remains of what was once a mature egg, which having failed of emission at the time of egg-laying has sufiered degeneration. The tough egg membrane seems to defy complete absorption. To the unaided eye such an egg appears as a yellow fleck, if visible at all (see fig. 136). 540 times natural size.

Fig. 151. Part of horizontal section of ovary from lobster No.76, table 20, showing ora inclosed in folds of follicular epithelium. This ovary was slit open along the mid-dorsal line, pinned out, hardened, and sectioned in longitudinal, horizontal planes. 67 times natural size.

Fig. 152. Part of transverse section of ovary of lobster No.52, table 20, showing the developing ovum and its relation to the folds of glandular epithelium. Remnants of degenerating cells can be detected in this egg. (See figs. 139 and 149.) B. M., basement membrane; BI.S., blood sinus; $G . E .$, glandular epithelium. 281 times natural size.

Fig. 153. Glandular epithelium from transverse section of ovary of lobster No, 75, table 20. F. G., vacuoles, probably representing fatty globules which have been rewoved in the process of preparing the tissue for sectioning; $y s$, bodies resembling yolk spherule. 253 times natural size.

PLATE 42.

Fig. 154. Ovum in early stage of growth, from ovary of lobster No. 52, table 20. Diameter of egg $\frac{3}{33} \mathrm{~mm}$., of uucleus $\frac{1}{62} \mathrm{~mm}$. 353 times natural size.

Fig. 155. Young ovum from same ovary as the last. Diameter of egg $\frac{1}{19} \mathrm{~mm}$, of nucleus $\frac{1}{35} \mathrm{~mm} .353$ times natural size.

Fig. 156. Young ovum from same ovary as the last. This nueleus contains two nucleoli. Diameter of egg $1_{2} \mathrm{~mm}$., of nucleus $\frac{1}{2} \mathrm{~mm}$. 353 times natural size.

Fig. 157. Young ovum from same ovary as the last. Diameter of egg a little over $\frac{1}{12}$ mm., of nucleus $\frac{1}{15} \mathrm{~mm}$. 353 times natural size.

Fig. 158. Nucleus of ovum from transverse section of ovary of lobster with external eggs about to hatch. From same as fig. 147. Diameter of egg 70 mua, of nucleus $\frac{1}{11}$ mm. 353 times natural size.

Fig. 159. Nucleus of ovum from nearly ripe ovary of lobster No. 94, table 20. See fig. 140 for ovarian section. Diameter of egg $1 \frac{1}{8} \mathrm{~mm}$., of nucleus $\frac{1}{2} \mathrm{~mm}$. 353 times natural size.

Fig. 160. Nucleus of ovum from ovary of lobster No. 75, table 20. For ovarian section and position of nucleus, see fig. 141. Ovary ripe. Diameter of egg $1 \frac{2}{3}$ m., of nucleus $\frac{1}{21}$ mm. 353 times natural size.

Fig. 161. Nucleus of egg in process of emitting polar cells. From section of unextruded egg taken from the oviduct. Diameter of $\operatorname{egg} 1.31 \mathrm{~mm}$., of nucleus $\frac{x}{40} \mathrm{~mm}$. The nucleus is in process of karyokinesis and lies close to the surface of the egg. The axis of the nuclear spindle appears somewhat oblique to the surface. July 28, 1891. 353 times natural size.

Fig. 162. Bifurcated rostrum of lolster taken at Woods Hole, Massachusetts. Dorsal view. Tw0thirds natural size.

Fig. 163. Profile view of the same. Two-thirds natural size.

Fig. 164. Ovaries of lobster, from below, showing bifurcation in left anterior lobe. Ovary light goldenyellow color. Ova very immature. May 19, 1892. Two-thirds natural size.

Fig. 165. Part of gastrolith, separated into its constituent spicules, taken fresh from the wall of the stomach of a lobster nearly ready to molt. For chemical analysis, see No. Oa of table, Appendix II. Compare cut 8, plate C. The broad flattened spicule at the lower righthand corner of the drawing is from the peripheral convex margin of the gastrolith. 5.3 times natural size. 
Plate 43.

Fig. 166. Bud of right fourth pereiopod in process of regeneration from young lobster probably in fourth stage. August 3, 1893. 47 times natural size.

Fig. 167. Part of transverse section of oviduet of lobster, with ovary nearly ripe. July 25, 1893. 270 times natural size.

Fig. 168. Part of transverse section of oriduct of lobster, with external eggs in early yolk segmentation. For a drawing of this ovary see fig. 119, plate 36. August 3, 1894. 270 times natural size.

Fig. 169. Longitudinal section of first, second, and third segments of right first pereiopod of young lobster in sixth stage. Plane of section shown in cut 15. Length of lobster $18 \mathrm{~mm}$. The right cheliped of this lobster was regenerated between the molts of the fifth and sixth stages. When the animal was preserved, Angust 17, 1893, the right regenerated cheliped was slightly smaller and more translucent than the left. No rudimentary tissue out of which the new limb is differentiated can be detected in the series of sections through plane of fracture. $x y$, plane of fracture; 1, 2, 3, segments of limb. About 47 times natural size.

Fig. 170. Internal surface of cuticle of second joint (basis) of first maxilla macerated in Béla Haller's fluid, showing chitinous tubules of tegumental glands, and characteristic rosettes of what appears to be calcareous matter. From male lobster 10 inches long. July 31, 1893.140 times natural size.

Fig. 171. Part of section of gastrolithic plate from female lobster with hard shell. August 10, 1893. Shown in its natural position in wall of stomach, in fig. 183. Fixed in picro-sulphuric acid; stained in borax-carmine; embedded in celloidin. GP., cuticular portion of gastrolithic plate. The demarcation between the layers is not so sharp as shown in the drawing. 171 times natural size.

Fig. 172. Section of left first pereiopod of lobster 9 inches long, in process of regeneration. At $a$ a mass of large disk-shaped coneretions, probably of a glycogenous nature, is seen. Compare figs. 121 and 122. The blackened margins of cuticle on either side of appendage represent the remains of clotted blood on surface of the stump. About 6 times natural size.

Fig. 173. Section of bud of right first (crushing) cheliped of adult male Iobster, showing the columnar epithelium, the new cuticle, blood sinuses, and connective tissue. Fixed in picro-sulphuric acid; stained in Ehrlich-Biondi mixture; embedded in celloidin. August 9, 1892. 47 times natural size.

Fig. 174. Part of longitudinal section of first larva through heart (Ft. ) and right rudimentary reproductive organ $(o v)$, eutting also intestine (in) and gastric glands ( $g g)$. 67 times natural size.

Plate 44.

Fig. 175. Right fourth pereiopod of adult lobster in process of regeneration, from below. Color, bright coral red. Two thirds natural size.

Fig. 176. Stump of right first pereiopod of adult lobster in course of regeneration, from below. Bud and surface of scar dull white. August 9, 1892. Two-thirds natural size.

Fig. 177. Surface view of membrane between old and new shells of molting lobster. This membrane is conspicuons at the time of shedding. It is noncellular, but is marked by the cell impressions of the chitinogenous epithelium. 733 times natural size.

Fig. 178. Right second pereiopod of adult male in process of regeneration, from below. New appendage reddish, tinged with blue at the joints. August 4, 1892. Two-thirds natural size.

Fig. 179. Left second antenna of adult lobster in process of regeneration, from above. June 30, 1892. Two-thirds natural size.

Fig. 180. Antenn of the Isopod, Ligea oceanica, from above; that of the left side in the course of regeneration. Beaufort, North Carolina, June, 1885. 4.7 times natural size.

Fig. 1 $\times 1$. Regenerating left antenna of the same, showing the new flagellum inclosed in the exoskeleton of the joint, which serves as a brood pouch. 16 times uatural size.

Fig. 182. Left first cheliper of adult lobster in process of regeneration, seen from the inner and anterior side. Color, bright red, bluish at joints; cuticle thrown into thin creases. Longitudinal axis of body in direction of arrow. 5.3 times natural size.

Fig. 183. Profile view of masticatory stomach of lobster, showing gastrolithic plate, for the structure of which see fig. 171, plate 43. Lobster with hard shell, approaching the molting time August 10, 1893. Two-thirds natural size. 
Fig. 184. Profile view of masticatory stomach of male lobster 7.5 inches long. Nearly ready to molt, showing gastrolith in place in the wall of stomach. For drawings of the gastrolith as it appears when it is dissected out and separates into its constituent spicules, see fig. 165, plate 42. Two-thirds natural size.

\section{PLATES $45 a$ and $45 b$.}

Fig. 185. Molted shell of lobster shown in fig. 186. No.1, table 24. This represents the size of the lobster before the molt. Length $5 \frac{1}{2}$ inches. Natural size.

Fig. 186. The soft lobster, shortly after the shell shown in fig. 185 was cast off. Length, $6 \frac{1}{2}$ inches. Natural size. These drawings show the average increase in size which is effected by a single molt 'see Chapter III).

\section{Plate 46.}

Fig. 1Ki. Left cheliped of lolster, from below, showing budding and repetition of parts in propodus or sixth joint.

Fig. 188. Same as fig. 187, seen from above. Both figures from photographs, and both natural size,

\section{Plate 47.}

Fig. 189. Part of right erushing-chela of female lobster, 11 inches long, seen from above, showing budding of dactyl. Woods Hole, Massachusetts, July 13, 1894. Two-thirds natural size.

Fig. 190. Propodus of left crushing-claw, from below. This and figs. 191-196 are from specimens in Peabody Academy of Science, Salem, Massachusetts, all from adult lobsters. Two-thirds natural size.

Fig. 191. Left erushing-claw, seen from above. Outgrowth from dactyl in horizontal plane; dactyl closes under propodus. Two-thirds natural size.

Fig. 192. Left crushing-chela, from above. Secondary dactyl bent downward slightly; no teeth; dactyl laterally compressed. $S$, spine of dactyl in primary symmetry; $S^{\prime}$, spine of dactyl in secondary symmetry. This supernumerary appendage probabls represents two dactyls fused together. Two-thirds natural size.

Fig. 193. Right cutting-chela, from below. Fingers bent up; dactyls articulate at joint with propodus; primary dactyl and one of the adjacent secondary dactyl united. S, supernumerary dactyl in primary symmetry. Two-thirds natural size.

Fig. 194. Dactyl of left cutting-claw, seen from below. It is bent horizontally upon itself, into an angle of about $80^{\circ}$, this being probably due to irregular growth in the regeneration of a lost part. Two-thirds natural size.

Fig. 195. Chela of second or third pereiopod, from below, showing two supernumeræry dactyls. Two-thirds uatural size.

Fig. 196. Right dactyl of cutting-chela, seen from outer side. Bifurcating branches bear teeth, which are not, however, apposed. Two-thirds natural size.

\section{Plate 48}

Fig. 197. Deformed right cutting-claw. Accessory appendage bent downward from horizontal plane about 50. The small terminal joint of the superadded part probably represents two dactyls fused together. $S$, spine of dactyl in primary symmetry; $S^{1}$, spine of dactyl in secondary symmetry. Two-thirds natural size.

Fig. 198. Right eutting-claw. Propodus apparently deformed by the irregular growth produced in the regeneration of a lost part. Two-thirds natural size.

Fig. 199. Double monster of first larra of lobster. Raised at Fish Commiøsion station, Woods Hole, Massachusetts, by Professor J. A. Ryder; seen from above. 13 times natural size.

Fig. 200. Double monster of first larva of lobster, from Professor J. A. Ryder. Fusion of the organs at the anterior extremity has been carried to such a degree that the compound eyes are now represented by a small median spot of pigment. 13 times natural size.

\section{Plate 49}

Fig. 201. Gland-cell from tegumental gland of second maxilla. Macerated in Béla Haller's fluid for several days, and stained in methyl green. 733 times natural size.

Fig. 202. Gland-cell from same preparation as fig. 201. 733 times natural size. 
Fig. 203. Part of macerated tegumental gland from metastoma. Compare also fig. 214. From female with ripe ovaries. Angust 9, 1893. Stained in methyl green. Central cell takes on deepest stain. gd.c, gland-cell; $R$, central reticulated body; s.c, ganglion cell. 773 times natural size.

Fig. 204. Cell from macerated tegumental gland of first maxilla. Stained in methyl green. 773 times natural size.

Fig. 205. Gland-cell from same preparation as fig. 204. 773 times natural size.

Fig. 206. Cell from macerated tegumeutal gland of abdominal appendage of female before egg extrusion. Ovaries nearly ripe. Attenuated, central end of cell very refractive, Small bodies, apparently accessory nuclei, are present in cell. 773 times natural size.

Fig. 207. Same preparation as last, rolled under cover-slip and seen from opposite side. 773 times natural size.

Fig. 208. Tegumental gland from metastoma of female with ripe ovaries. Macerated three days in Béla Haller's fluid and stained in methyl green. The duct $(d)$ of the gland could be seen to open directly into a small central chamber, as in fig. 212. 513 times natural size.

Fig. 209. Gland-cell from tegumental gland of abdominal appendage of female, which had recently laid eggs in an aquarium at the United States Fish Commission station, Woods Hole, Massachusetts. Macerated in Béla Haller's flnid. August 14, 1893. 773 times natural size.

Fig. 210. Tegumental gland from abdominal appendage of female lobster $10 \frac{1}{2}$ inches long, preparing to molt. Chromic acid preparation, stained in the Ehrlich-Biondi anilin mixture. Picrosulphuric acid gives same result. Cells apparently shrunken, transparent, non-grauular; nuclei clear. August 17, 1893. 513 times natural size.

Fig. 211. Tegumental gland from abdominal appendage of female after ovulation. External eggs in yolk segmentation. Central ends of glaud-cells are filled with dark zymogen granules. Nucleus of gland-cell stains green, that of central cell alwass red, in the Ebrlich-Biondi mixture. August, 1893. gd.e, gland-cell; s.c, ganglion enll. 513 times natural size.

Fig. 212. Section of tegumental gland from abdominal appendage of female lobster with mature ovaries. Central part of gland has a bluish clouded appearance. Nuclei may be green or red according to the degree with which the stain is extracted. Stained in the EhrlichBiondi mixture. August 4, 1893. $d$, duct of gland; $n$, nerve-supplying gland; $R$, central reticulated body. 513 times natural size.

Fig. 213. Gland-cells from same preparation as figs. 204, 205. Central ends of cells attenuated, and strongly refractive. 773 times natural size.

Fig. 214. Macerated tegumental gland from metastoma of female, showing the central reticulated body, gland-cells, ganglion cell, and duct of gland. From female with ripe ovaries. $d$, duct of gland; $R$, reticulated body. 773 times natural size.

\section{Plate 50.}

Fig. 215. Egg before jolk has segmented. The whitish spots are due to the presence of cells which are approaching the surface on one side of the egg. The yolk is later massed up about these in hillocks, as in fig. 218. 29 times natural size.

Fig. 216. Surface view of egg with 16 cells present near the surface, two double rows of eight cells each." The cells have just divided. This drawing was made at 10.30 p. m. ; at 10.55 p. m. 20 cells could be discerned near the surface. 29 times natural size.

Fig. 217. Same egg as fig. 216; drawing made $1 \frac{1}{2}$ hours later (12 p. m.), showing the cells more diffused orer the surface. 29 times natural size.

Fig. 218. Same egg as in figs. 216 and 217; rolled to show animal pole and yolk hillocks in profile. Drawing made at 10.55 p. m., when 20 yolk elevations had been formed. On the outskirts of these, other cells can be seen lyiug below the surface and destined soon to become the centers of new hillocks. 29 times natural size.

Fig. 219. Surface view of egg showing yolk segments in active division; 10.15 p. m., segmentation furrows complete. This side of egg corresponds to the side shown with yolk billocks in profile, in fig. 218. Nuclei all dividing at 10 p. m.; at 10.10 p. m., furrows began to appear, separating cells. Same egg as shown in fig. 220. 29 times natural size.

Fig. 220. Reverse side of egg shown in fig. 219, corresponding to the right side of the egg shown in fig. 218, opposite the yolk hillocks. When drawn at $9.30 \mathrm{p} . \mathrm{m}$., nuclei, were invisilule; at $10 \mathrm{p} . \mathrm{m}$. they were very distinct and in diaster phase; at $10.15 \mathrm{p} . \mathrm{m}$. segmentation furrows completed. 29 times natural size. 


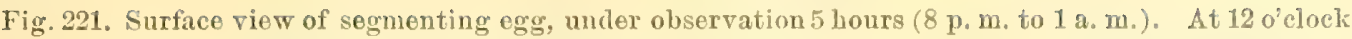
the segments shown in the drawing were very convex at surface, stauding far apart as if the egg were breaking up. At $1 \mathrm{a} . \mathrm{m}$. the segments were closer together and nuclei wero about to divide again. Drawing made at 11 p.m., after completion of division. 29 times natural size.

Fig. 222. Surface view of segmonting egg. Drawing begun at $11 \mathrm{a.m}$; ; when completed, half an hour later, the nuclei had divided and segmentation furrows were making their appearance. 29 times natural size.

Fig. 223. Surface view of same egg, drawn at $12 \mathrm{~m}$. Division of cells mostly completed. 29 times natural size.

Fig. 224. Surface view of same egg as in figs. 222 and 223, at 9 p. mo, in advanced stage of segmentation. At 2.45 p. m. nuclei were dividing; at 6.45 p. m., when exanined, division was completed. Drawing made at 9 p. m. 29 times natural size.

Fig. 225. Surface view of egg in advanced stage of yolk segnentation. Free-hand drawing. 29 times natural size.

Fis. 226. Surface view of egg in abnormal yolk segmentation, showing a larger yolk mass at the lower part of the figure and a number of smaller regular segments. A similar large yolk mass oceurs on the opposite side of the egg next to the one shown in the drawing. 29 times natural size.

\section{Plate 51.}

Fig. 227. Surface view of egg in invagination stage. August 3, 11.30 a. m. 29 times natural size.

Fig. 228. Surface view of abnormal embryo in egg-nauplius stage. August 10. 29 times uatural size.

Fig. 229. Surface view of abnormal embryo. August 8. 29 times natural size.

Fig. 230. Surface view of abnormal embryo in egg-nauplius stage. $P$, cells approaching surface; $r$, outward fold of surface epithelium; y, yolk. Angust 9. 29 times natural size.

Fig. 231. Surface view of abnormal embryo in egg-nauplius stage. August 8. 29 times natural size.

Fig. 232. Lateral view of embryo, showing large white patch behind abdomen. August 5. 29 times natural size.

Fig. 233. Lateral view of embryo about 5 weeks old, showing lateral fold of carapace covering the antenns, the heart $(H t$.$) , the intestine containing characteristic concretions (P)$, the telson $(T)$ overlapping brain and optic lobes, and the lateral indentations of the yolk corresponding to divisions of the midgut. July 29. 48 times natural size.

Fig. 234. Surface view of embryo about 25 days old, showing the large optic lobes of cephalo-thoracic appendages. The telson touches the brain, and the crescentic fold of the carapace extends forward as far as the first maxillipeds. August 3, 1892. 29 times natural size.

Fig. 235. Lateral view of double monster in egg-nauplius stage, August 13. 29 times uatural size.

\section{Plate 52.}

Fig. 236. Part of transverse section of egg in stage between that shown in figs. 224 and 225, yolk cells $(y$ c) being formed by tangeutial division. About 70 times natural size.

Fig. 237. Part of longitudinal section of egg in egg-nauplius stage, showing degenerating cell $(D g)$. 457 times natural size.

Fig. 238. Part of section of segmenting egg, showing cell migrating from surface. July 31.40 times natural size.

Fig. 239. Section of segmenting egg, showiug yolk cell near center. July 31. 40 times natural size.

Fig. 240. Degenerating cells from same preparation as shown in fig. 237. y 8, bodies resembling yolk spherules. 457 times natural size.

Fig. 241. Vesiculated masses of chromatin $(D g)$ undergoing degeneration in the yolk. From transverse section of early egg-embryo. July 18. 457 times natural size.

Fig. 242. Section of segmenting egg. Drawn July 31,4 p. m.; 34 cells present. 40 times natural size.

Fig. 243. Section of egg in late segmentation, showing formation of yolk cells and division of these in yolk. August 1. s c, cell at surface undergoing tangential division; y c, yolk cell in process of division. 40 times natural size.

Fig. 244. Surface view of egg in late segmentation of yolk. July 11. Fixed in Perenyi's thid. About 50 times natural size. 
Fig. 245. Part of transverse section, showing multiple karyokinesis and formation of nests of nuclei. Stage like that shown in fig. 252. Part of section behind and to one side of invagination area. Same series as fig. 241. c n, cell nest at surface; $y n$, cell nest in yolk; $y n^{\prime}$, cell in multiple karyokinesis, situated in yolk ball. 457 times natural size.

Fig. 246. Part of transverse section through embryo in invagination stage. in, area of invagination. 211 times natural size.

Fig. 247. Part of section of egg to show nest of nuclei at surface. 211 times natural size.

Fig. 248. From section through embryo in invagination stage, showing multiple karyokinesis and formation of nuclear nests at surface, like that shown in fig. 247. 211 times natural size.

Fig. 249. Part of section of egg containing two nuclei, this one near surface. 285 times natural size.

Plate 53.

Fig. 250. Surface view of embryo in invagination stage. The embryonic area of this egg lies in front of the shallow pit. Cells are most numerous immediately in front of this depression and about the extreme anterior margins of the exposed surface. The rapid proliferation of cells in these regions gives rise on the one hand to the thoracic-abdominal plate, and to the optic disks on the other. Karyokinetic figures of dividing cells are seen scattered over the entire surface of the egg. The equatorial plate is in each case vertical, and may make any angle with the longitudinal axis of the embryo, or with a ine drawn through any proliferating center. Numerous granules, the products of cell degeneration, are commonly seen. The reverse side of this egg shows nothing peculiar. Nvelei are there less numerous, and the superficial cells are larger. Flecks or clouds of granules, floating: in the yolk below the surface, are seen here and there with no regularity. The nuclei over most of the surface, excepting those at the extreme periphery, were drawn by aid of the camera lucida, as were the cell outlines in the more central parts. From a picrosulphurie acid preparation, stained in borax carmine, the egg cut in two, and the hemispheres mounted in balsam. August 6, 1892. 500 times natural size.

Plate 54.

Fig. 251. Part of transverse section throngh area of invagination (in), showing columnar surface cells (ec) filled with yolk and invaginate cells, lying between and within solk masses. Some of the latter cells just below the surface are undergoing degeneration; some in the deepest parts of the egg are creeping with their long pseudopodia between the yolk spherules. These play the part of phagocytes and also contribute to the tissues of the embryo. 360 times natural size.

Fig. 252. Surface view of embryo in region of invaginate area, showing clusters of cells at surface, produced by inultiple karyokinesis. $A$, anterior; $P$, posterior end of egg; Deg, degeneratinc cells; $e \alpha$, embryonic area; In, area of invagination; $y n$, cell nest, produced by multiple karyokinesis. 89 times natural size.

Fig. 253. Part of longitudinal section of intestine of embryo in a late stage of development, showing concretions in the lumen of the organ. $b m$, basement membrane; $e p$, intestinal epithelium; $p$, intestinal coneretion. 360 times natural size.

Fig. 254. Part of transverst section through invaginate area of an earlier stage than last, showing in-wandering masses of cells. $A$, anterior; $P$, posterior; $I n$, pit of invagination; $y c$, invaginate cells. 89 times natural size.

Fig. 255. Part of longitudinal section through area of invagination, showing the advancing cumuli of cells, which are pressing into the deeper parts of the egg and investing large masses of yolk. The distinctly columnar superficial cells, gorged with yolk, are also shown. In the embryonic area these become very tall, and beneath them there are clouds of disorganized chromatin granules, the remains of degenerated cells. $A$, anterior; $P$, posterior; Deg, degenerating cells; ec, ectoderm; Mes-ent, mesendoderm; In, pit of invagination; $O D$, optic disc. 89 times naturaī size.

Fig. 256. Concretion from intestine of an embryo which was nearly ready to hatch. Teased from picro-sulphuric acid preparation and mounted in glycerin. 360 times natural size. 


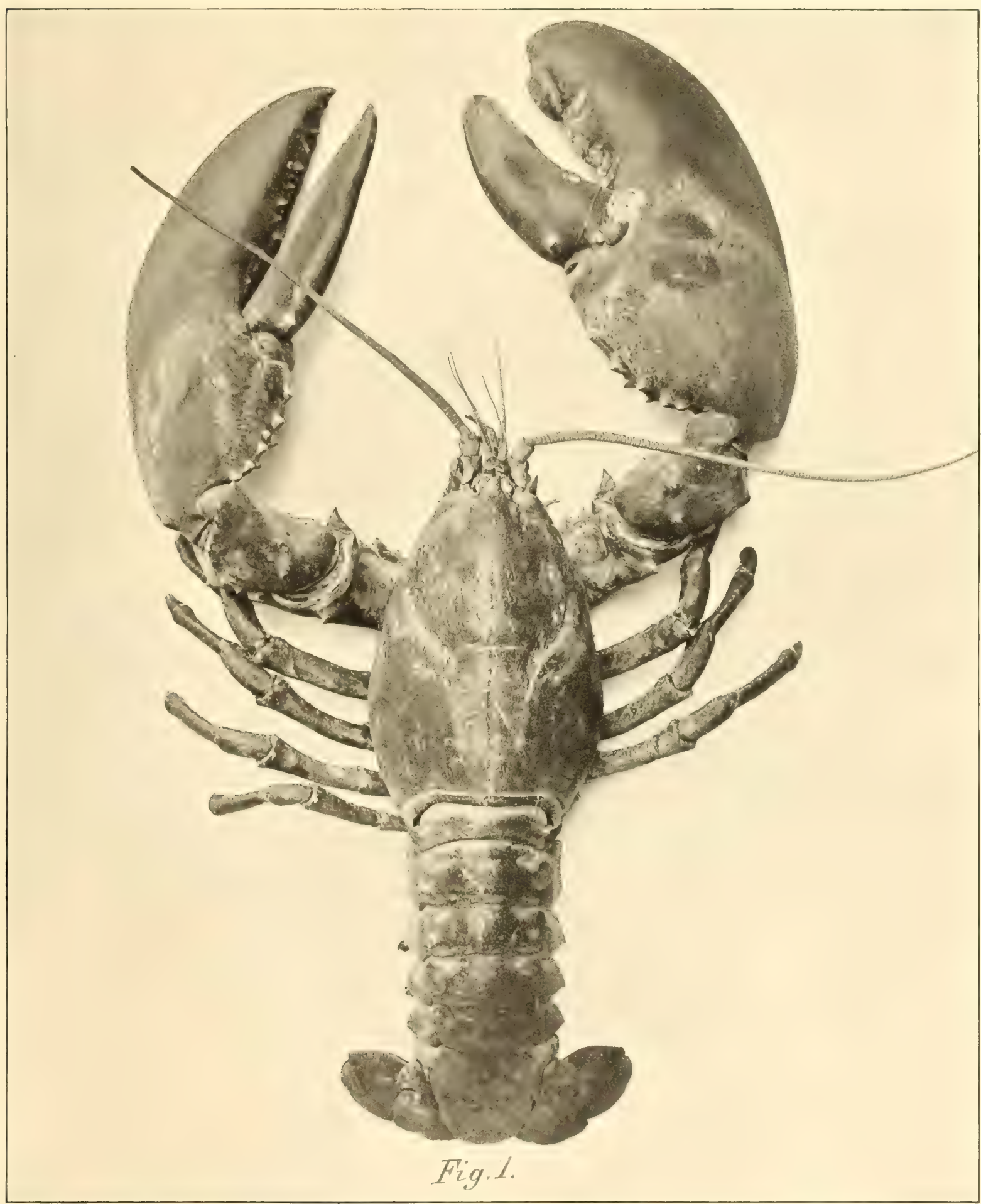

From photograph.

MALE LOBSTER. Weight, 23 pounds 



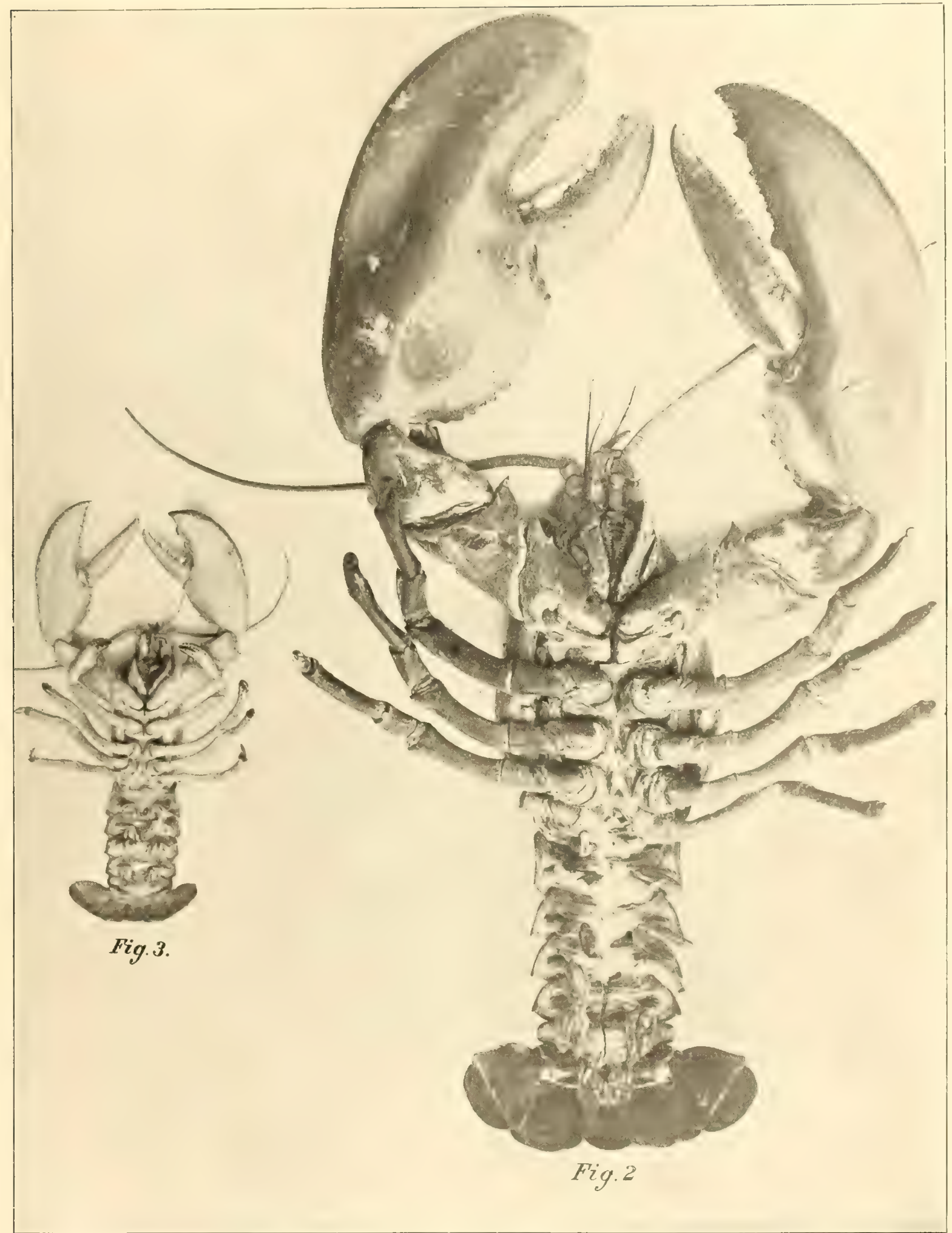

From photograph.

VENTRAL VIEW OF MALE LOBSTER. Weight, 23 pounds.

VENTRAL VIEW OF FEMALE LOBSTER. Weight, $1 \frac{1}{2}$ pounds. 



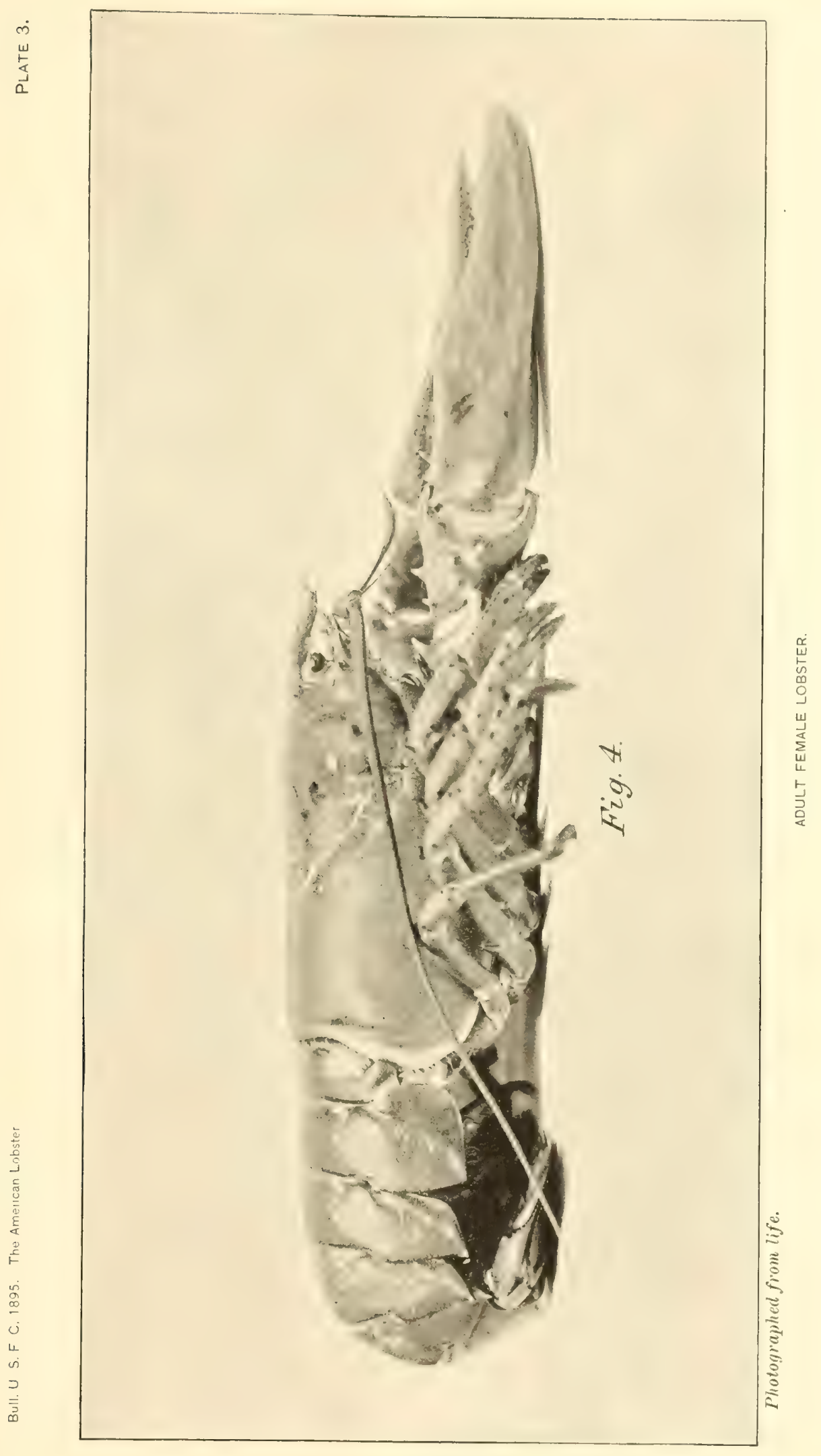




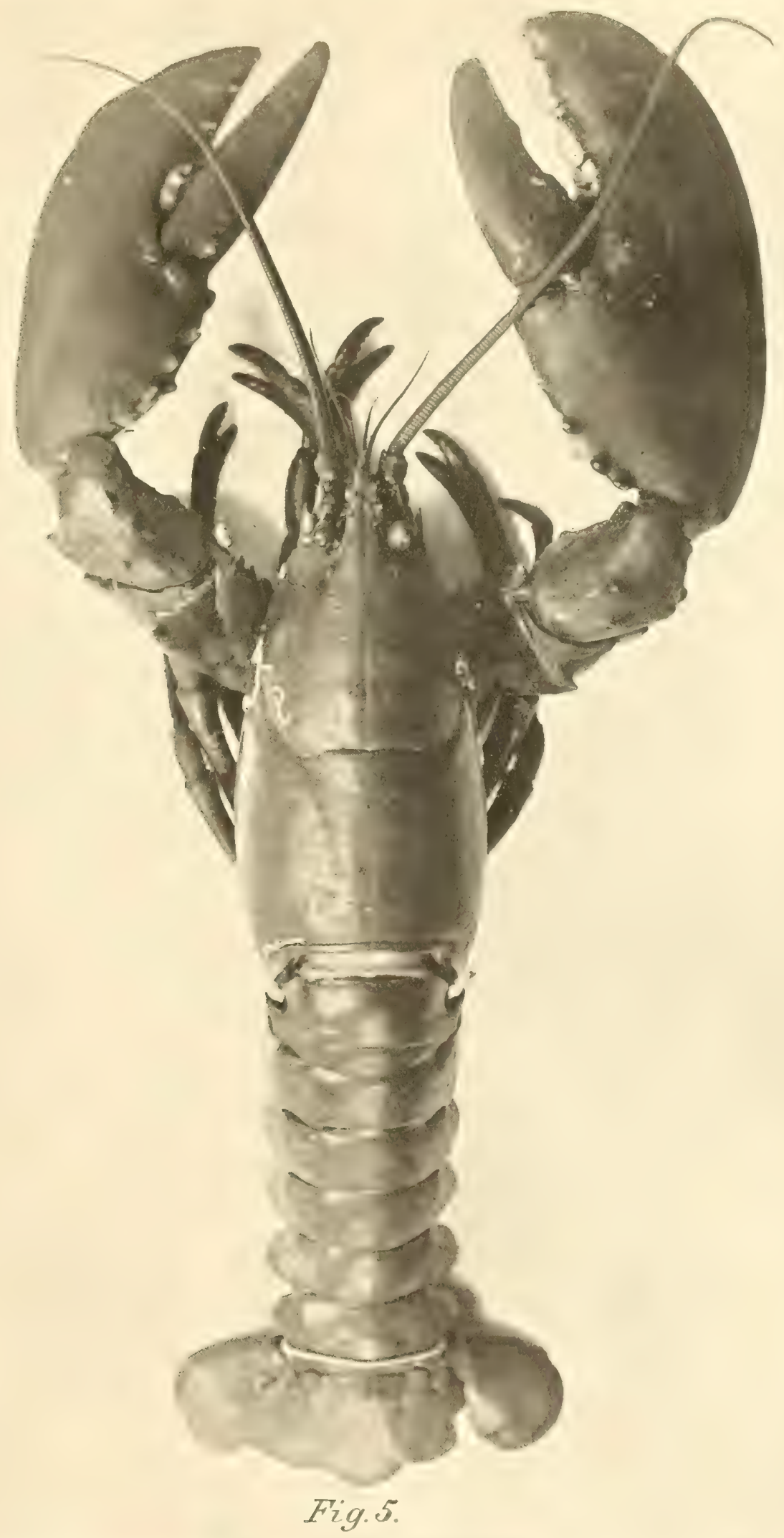

Photographed fiom life. 



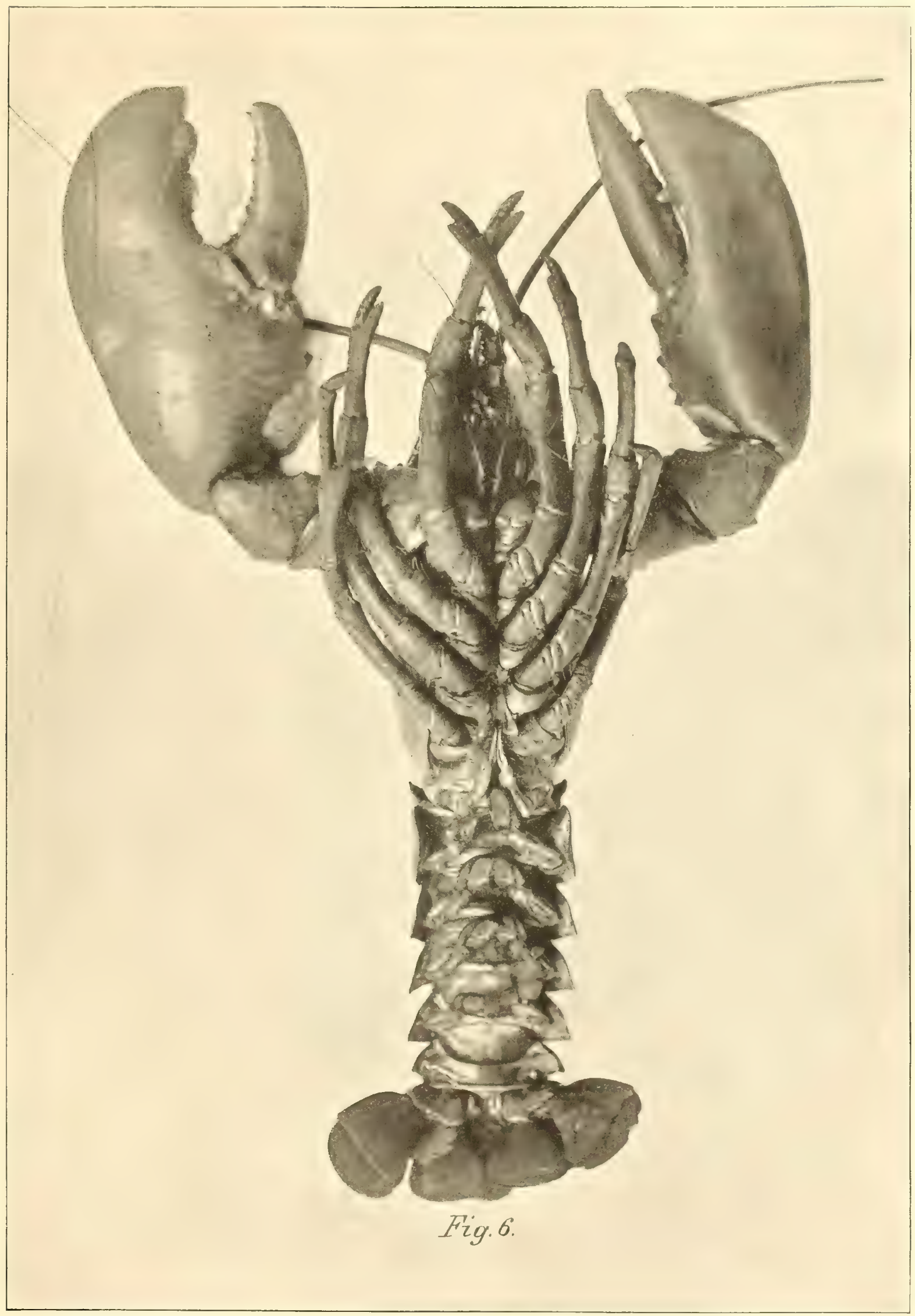





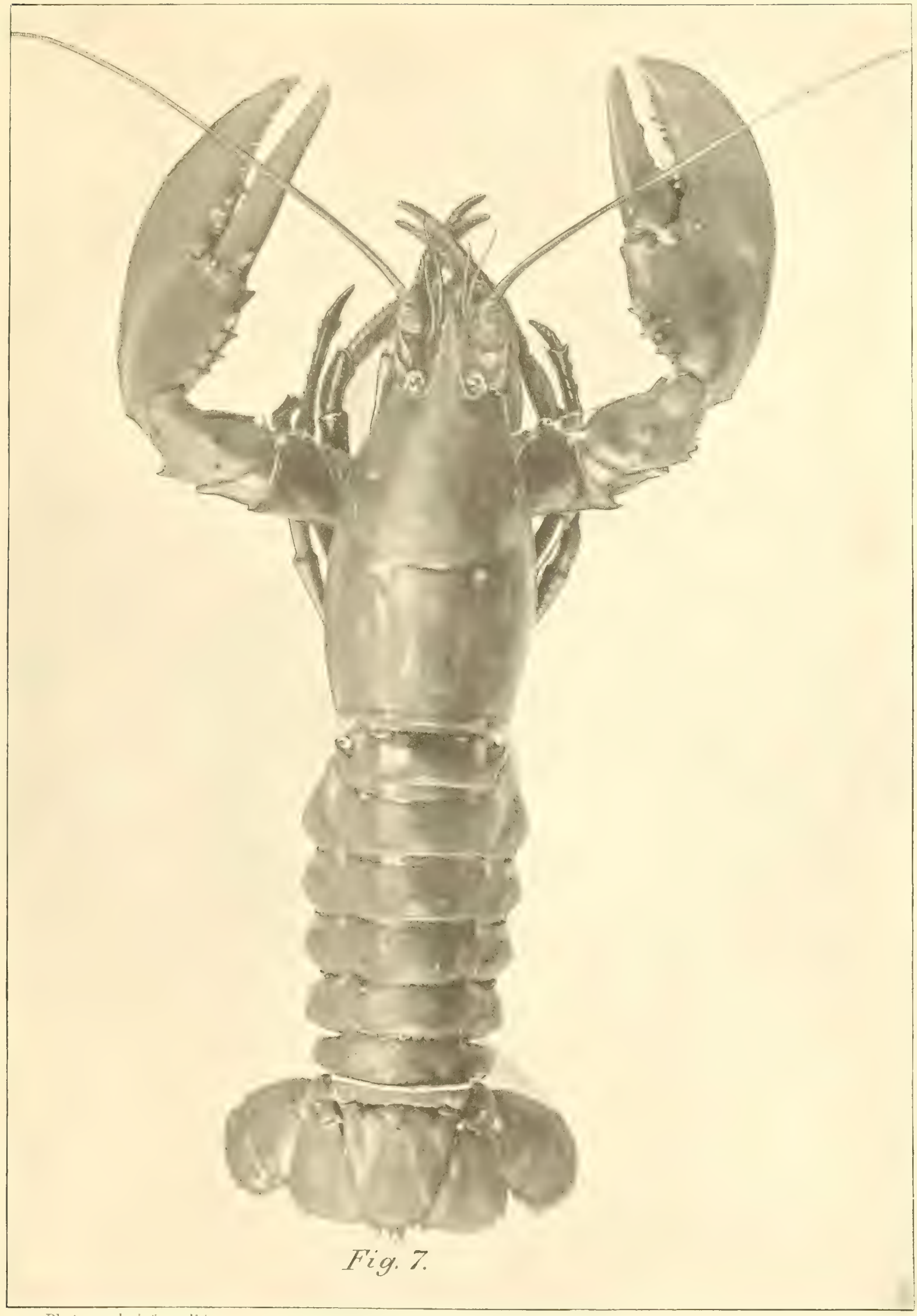

Photographed from life. 



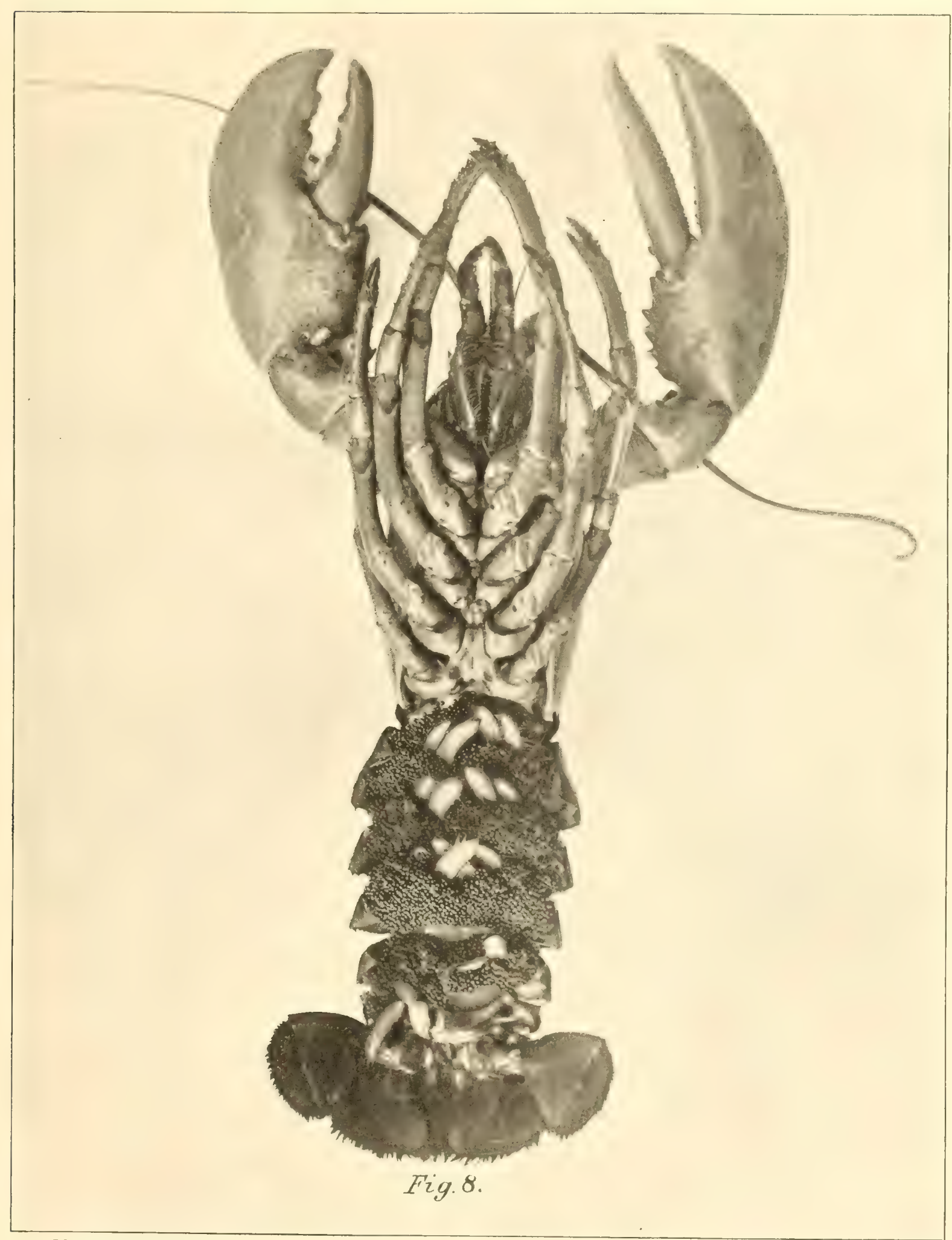

Photographed from life.

ADULT FEMALE LOBSTER WITH EXTERNAL EGGS. Ventral view. 



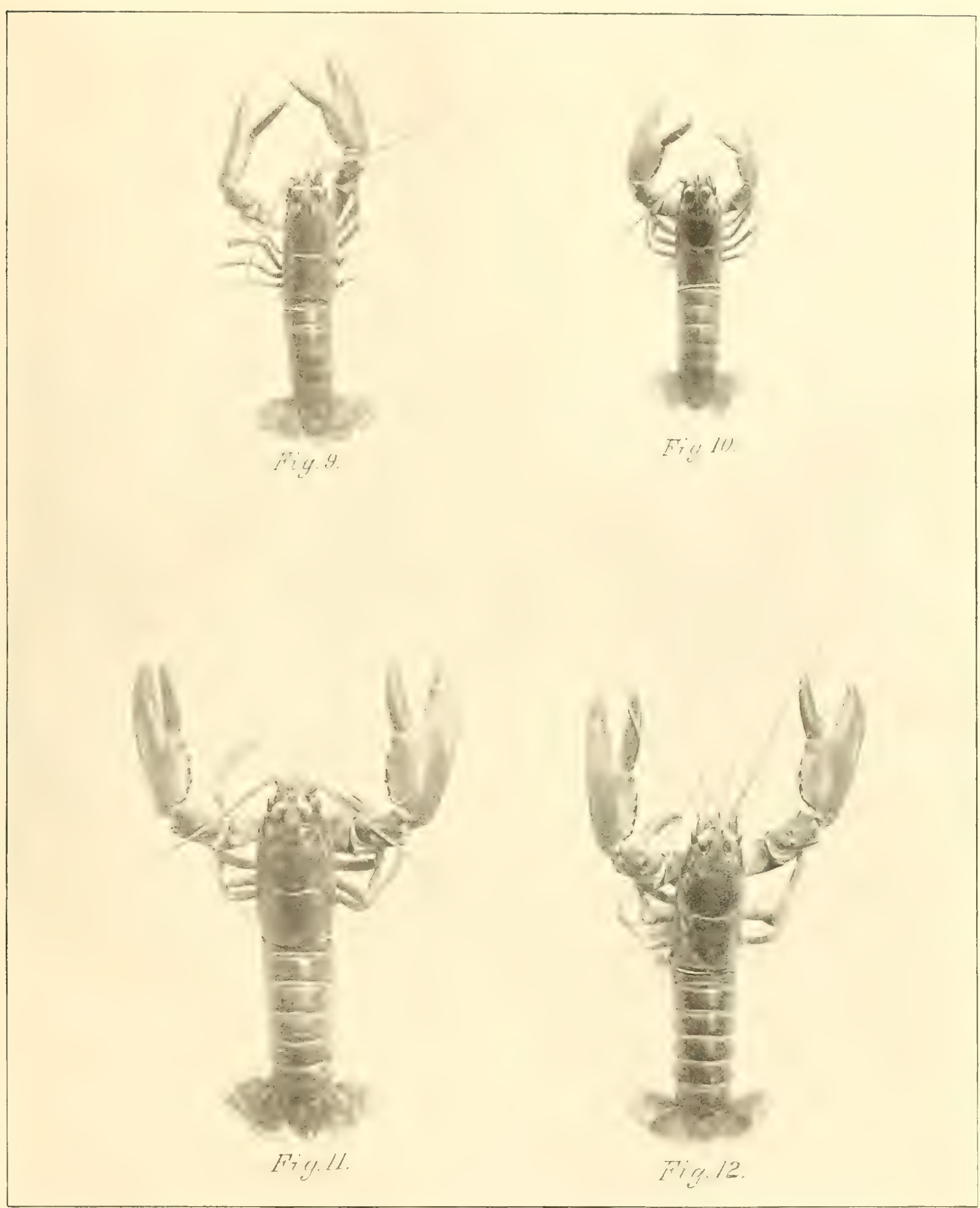

From photograph.

Females. Males.

IMMATURE LOBSTERS. Natural size. 



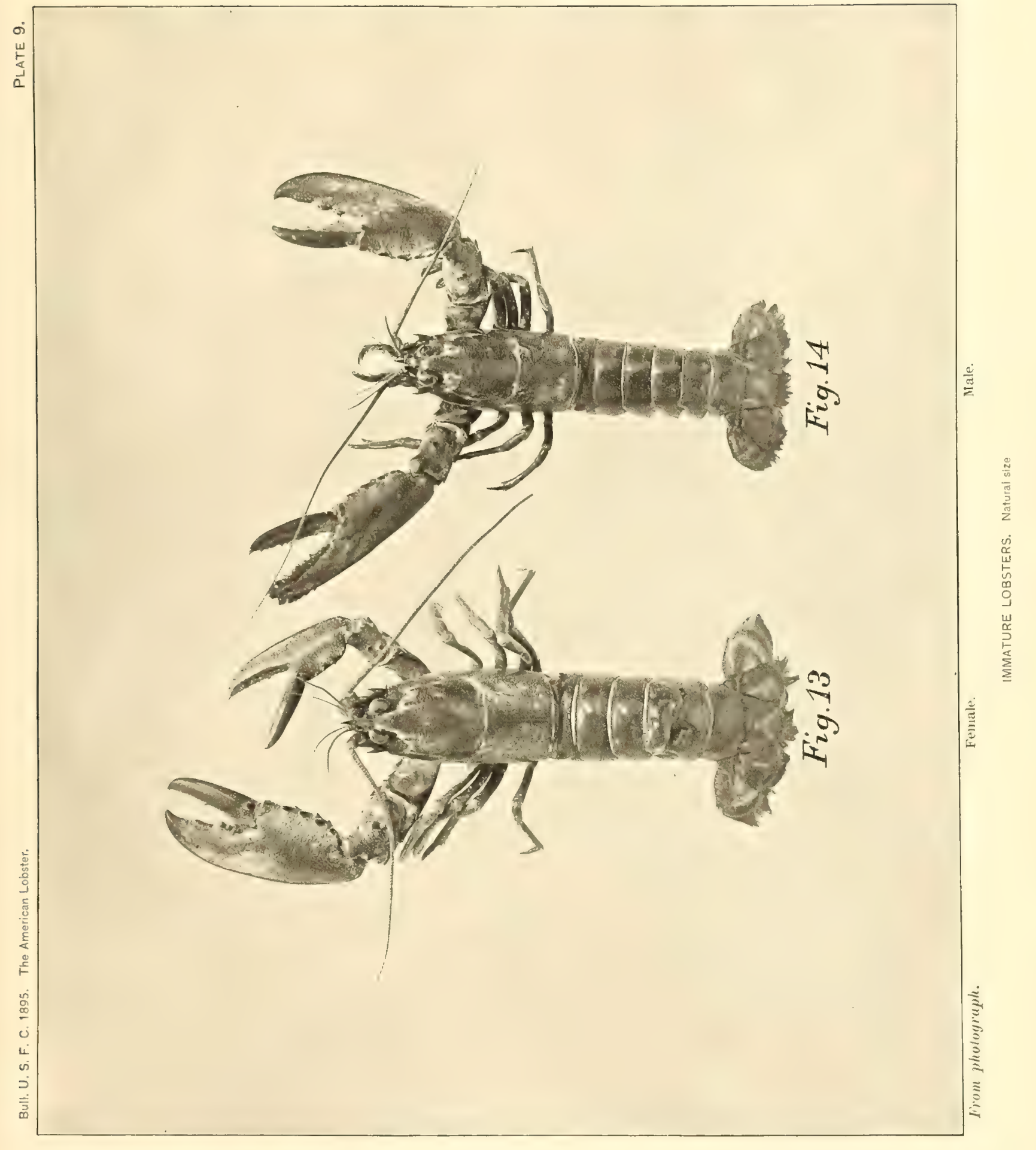





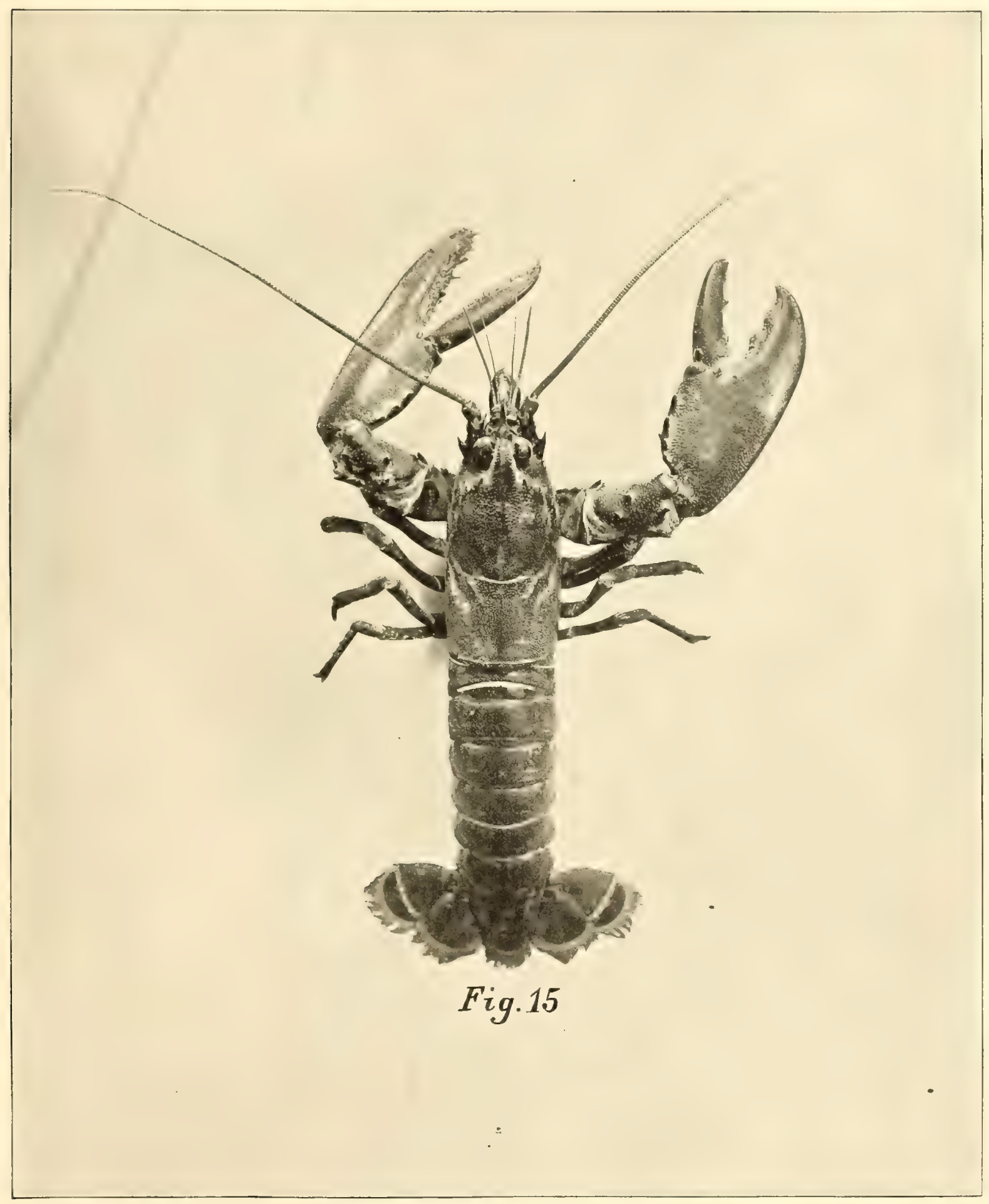

From photograph.

IMMATURE FEMALE LOBSTER. Natural size. Dorsal view. 



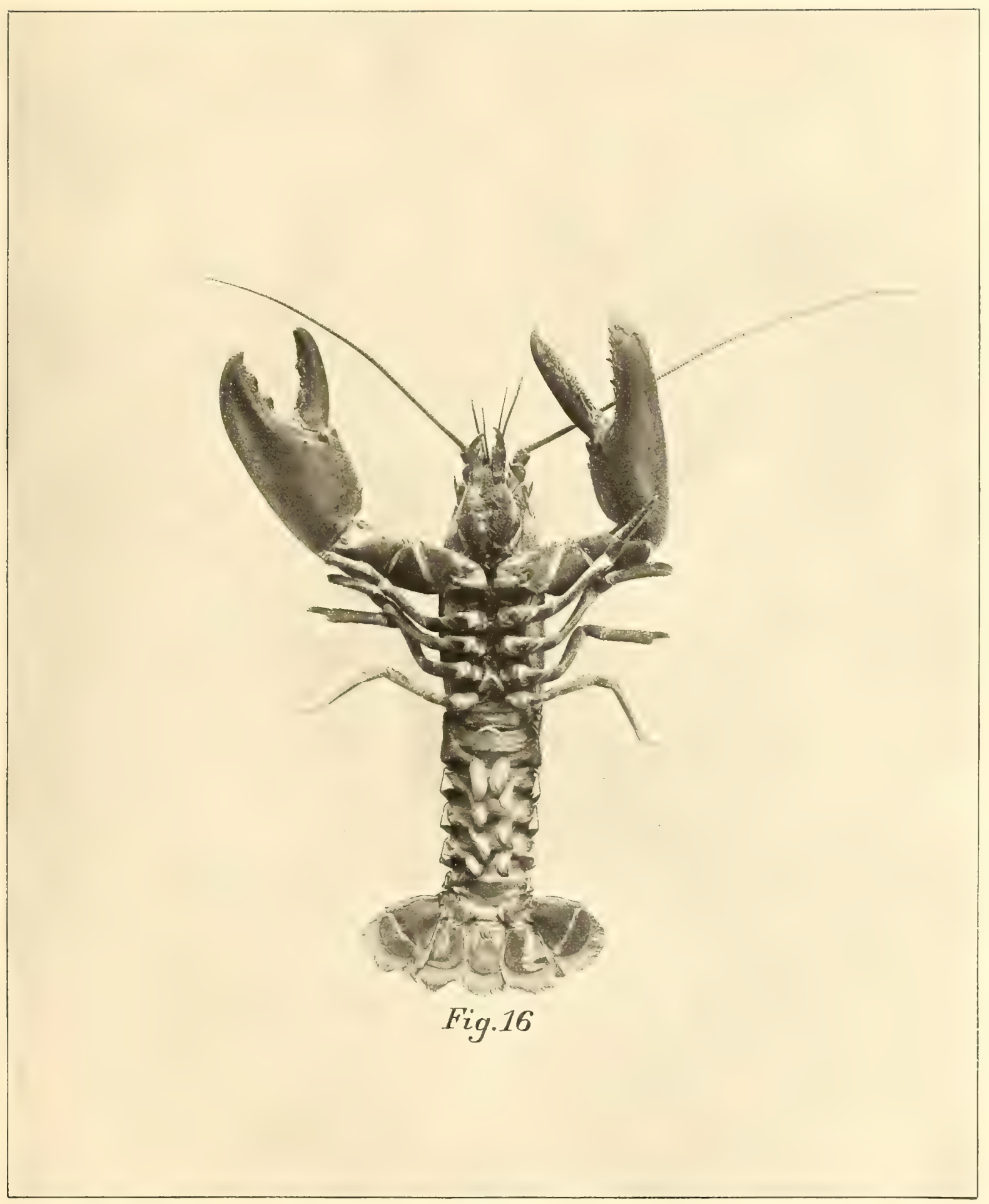

From photograph. 



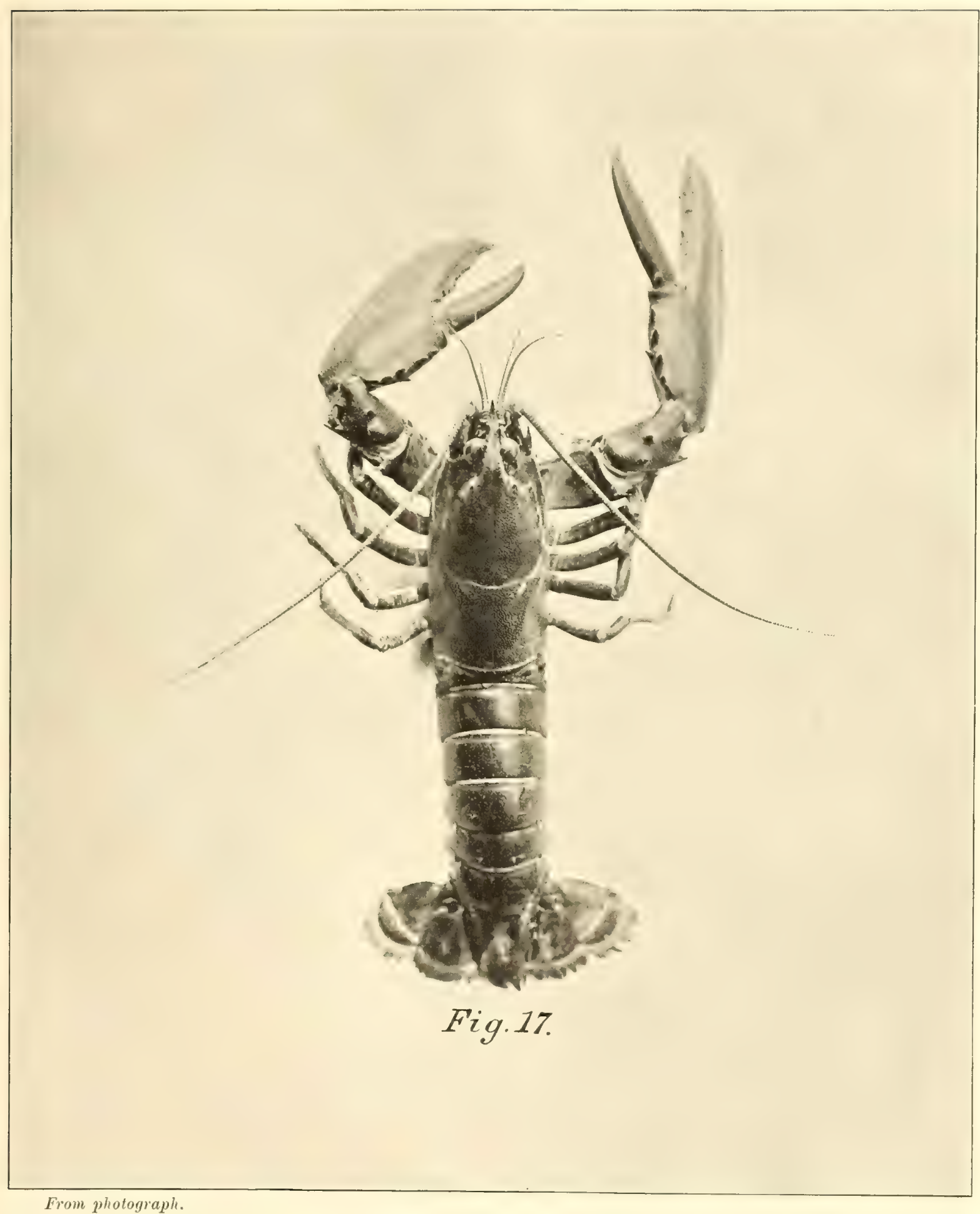

IMMATURE MALE LOBSTER. Natural size. 



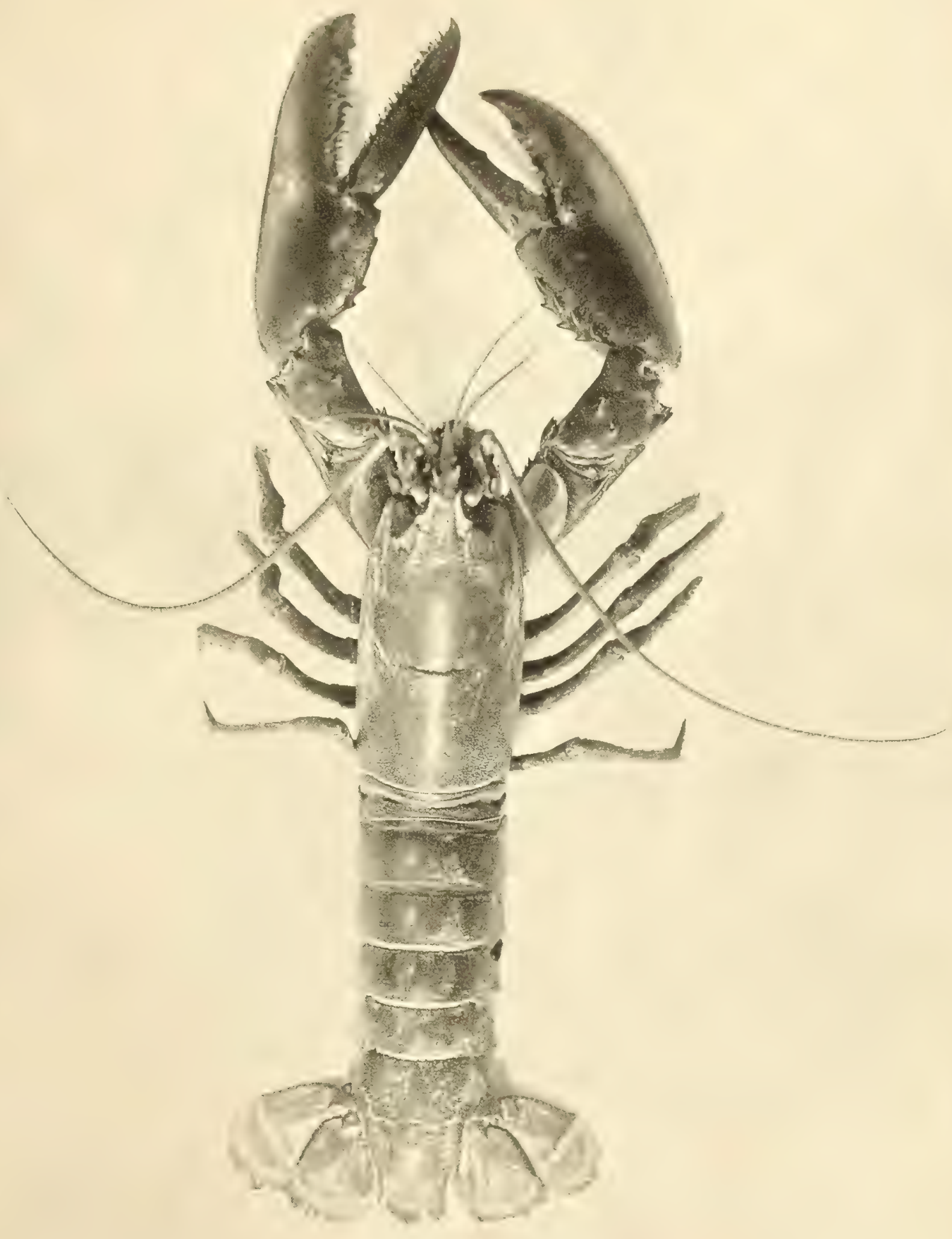

Fig. 18 . 



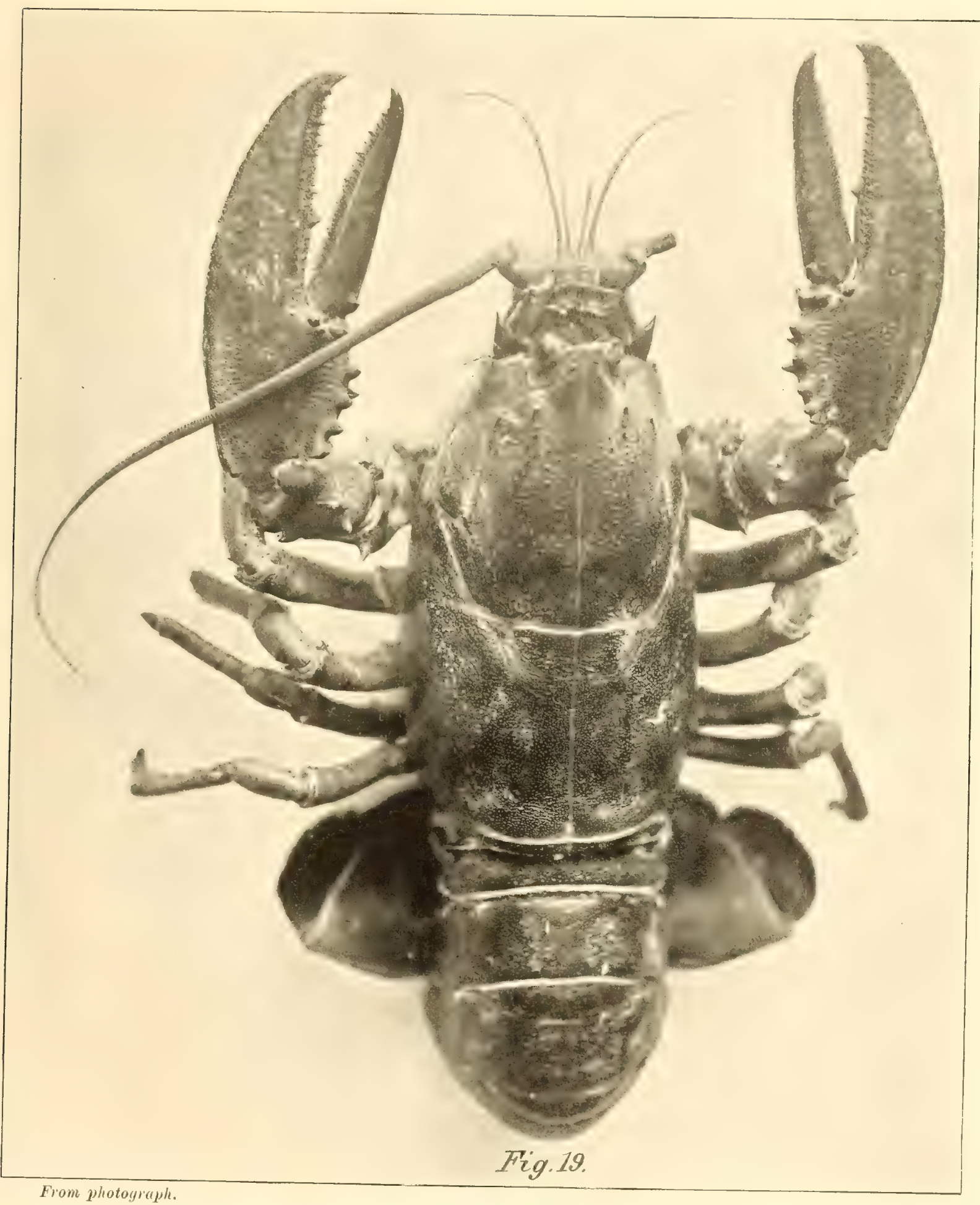

ADULT MALE LOBSTER WITH ABNORMAL SYMMETRY IN LARGE CLAWS. 



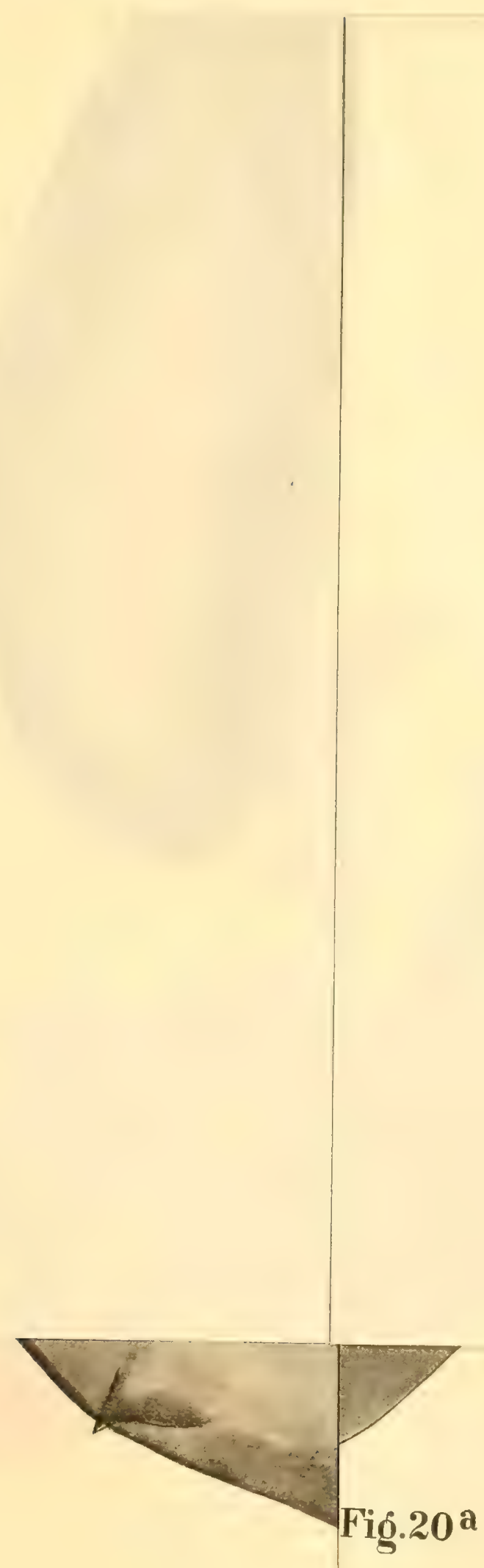

F. H. Herrick ad nat. del. 



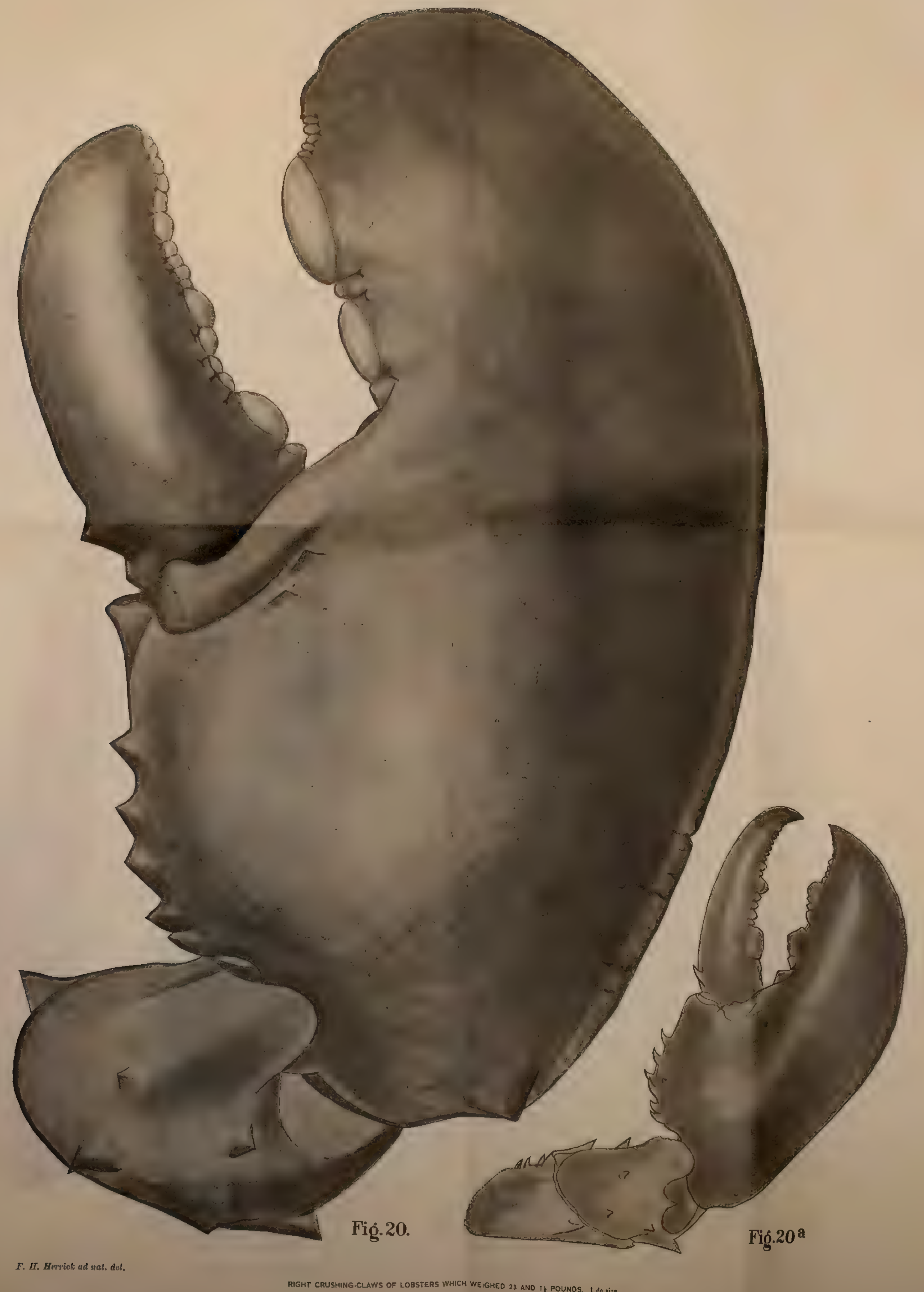




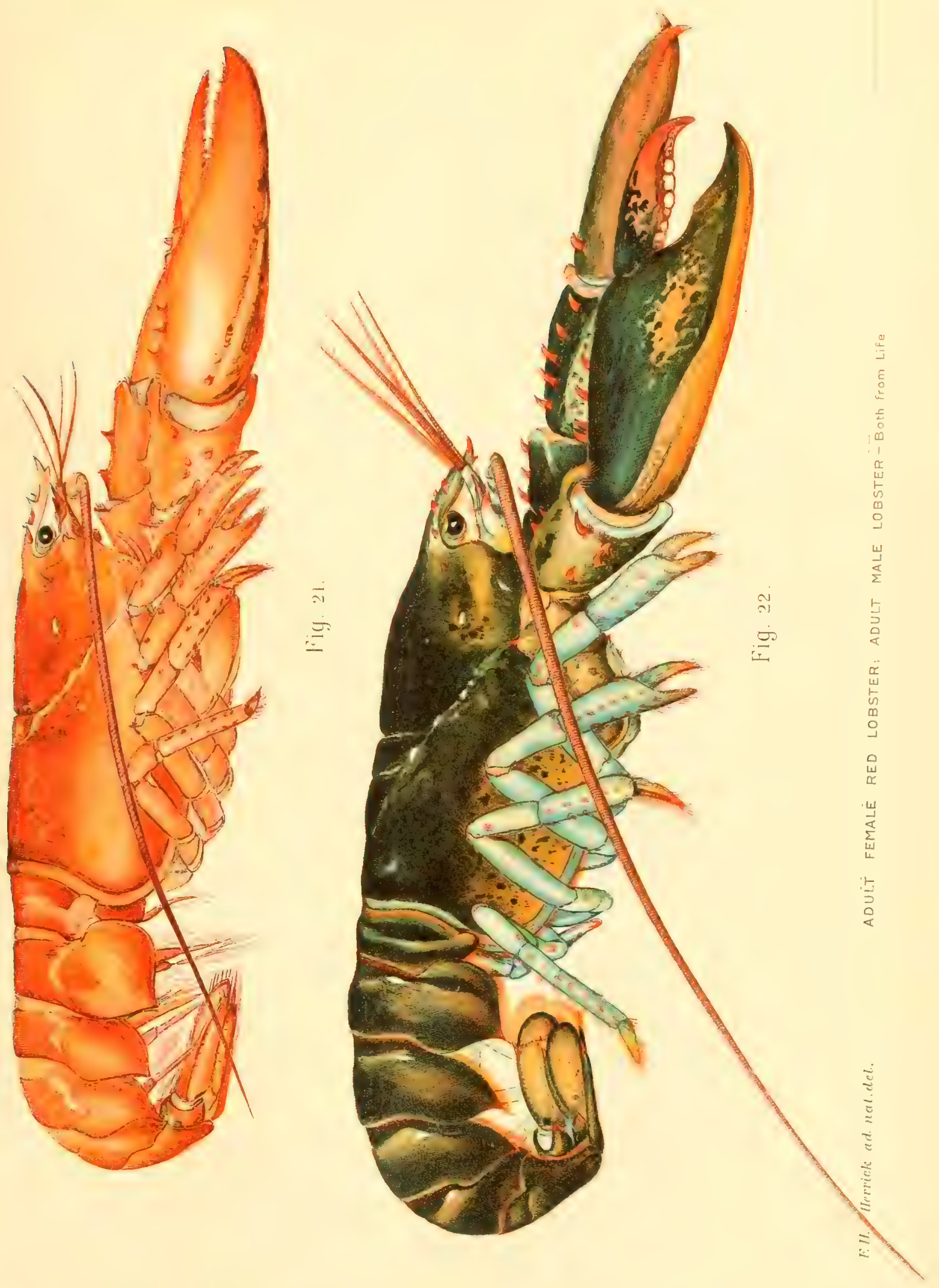


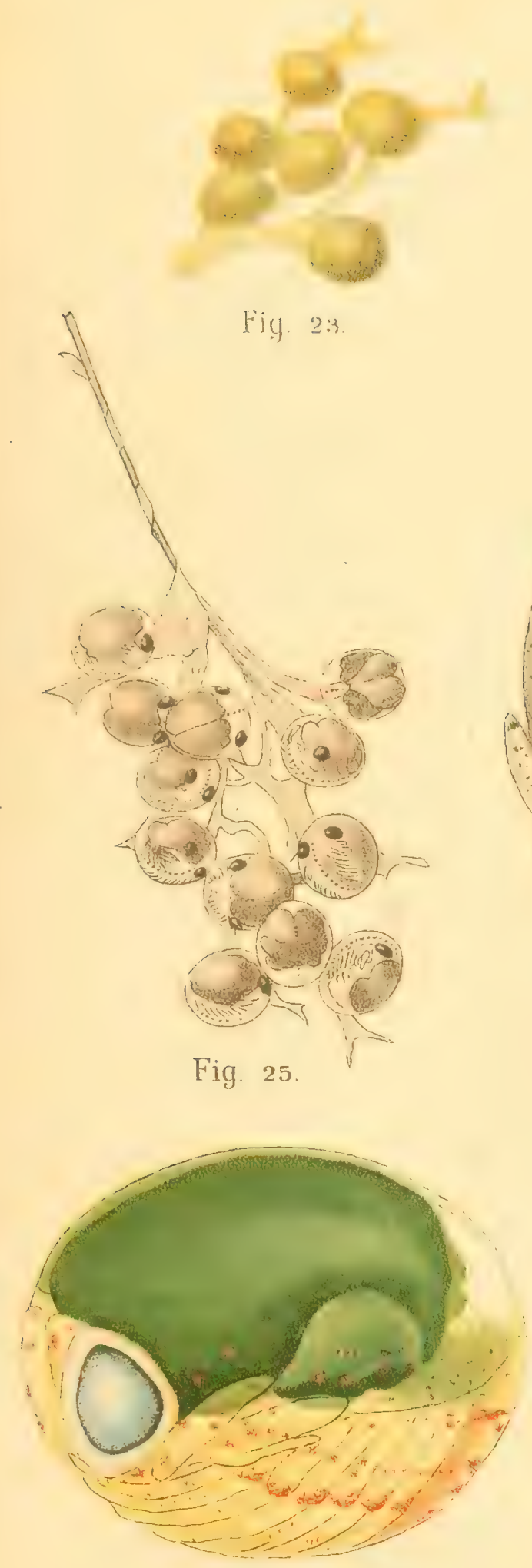

Fig. 27.

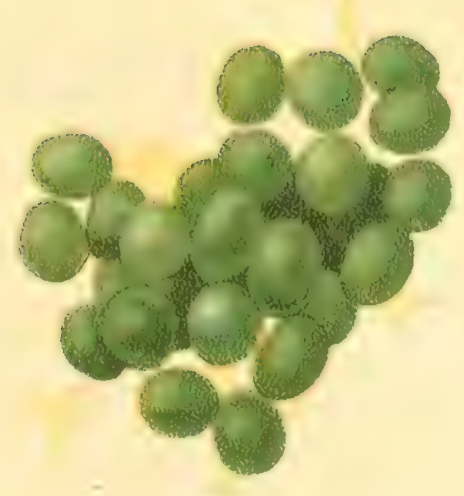

Fig. 24

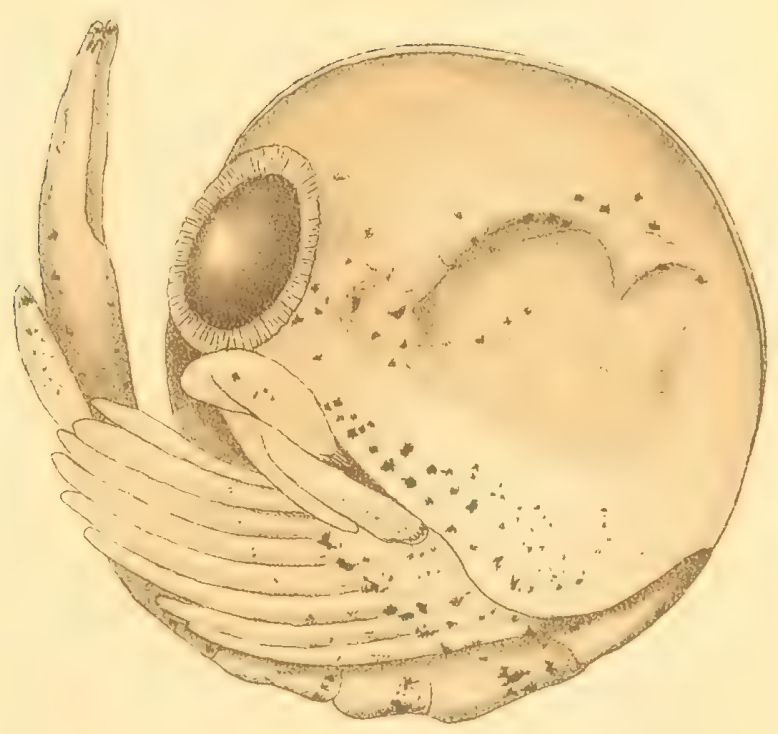

Fig. 26

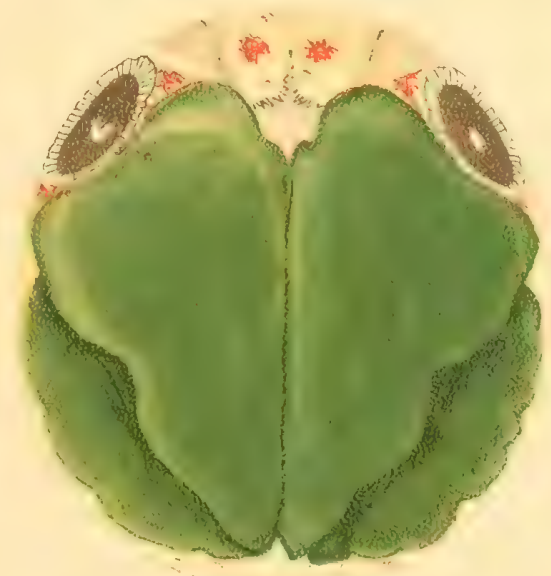

Fig. 28 .

F. H. Herriek ad nat del. 



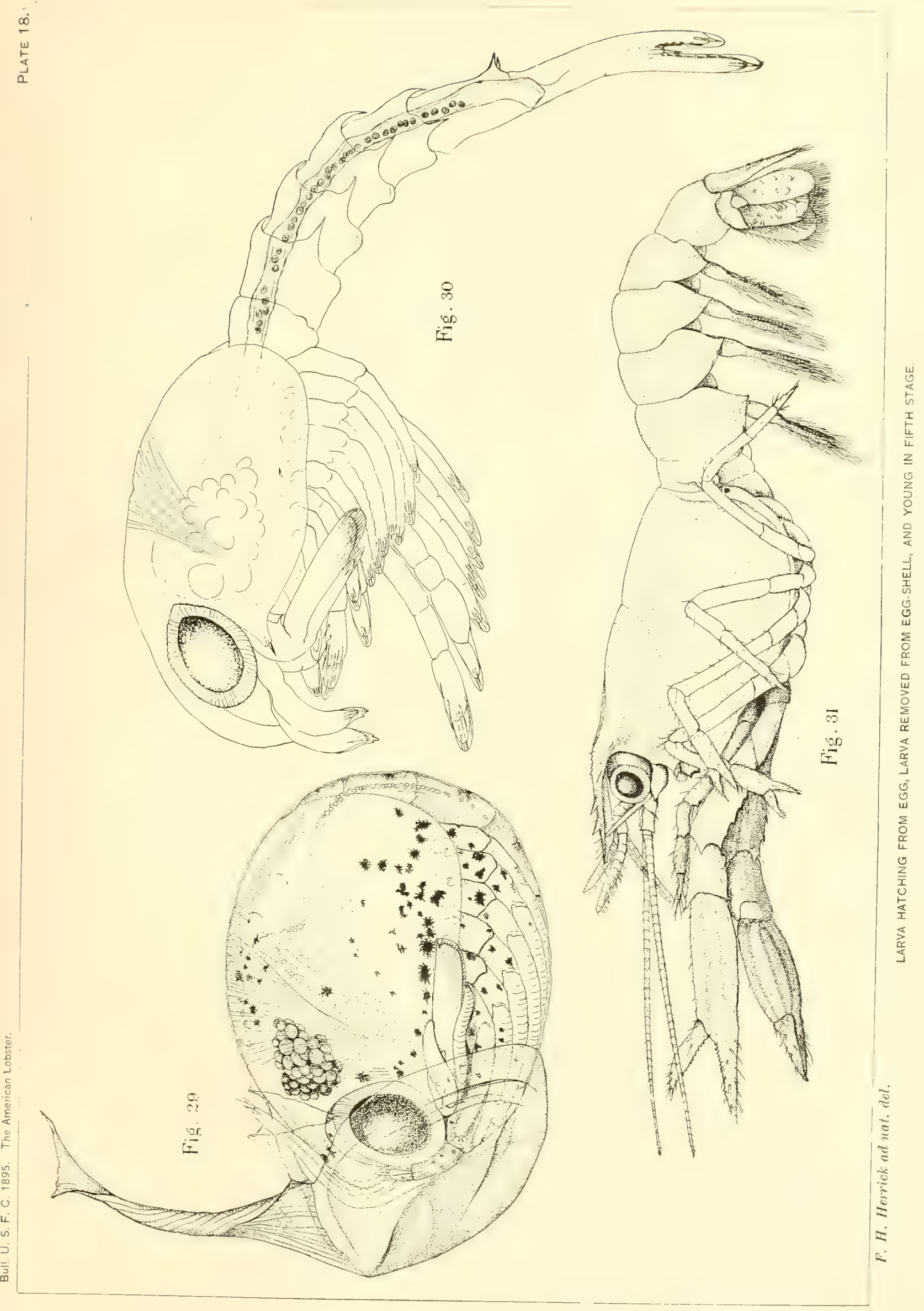





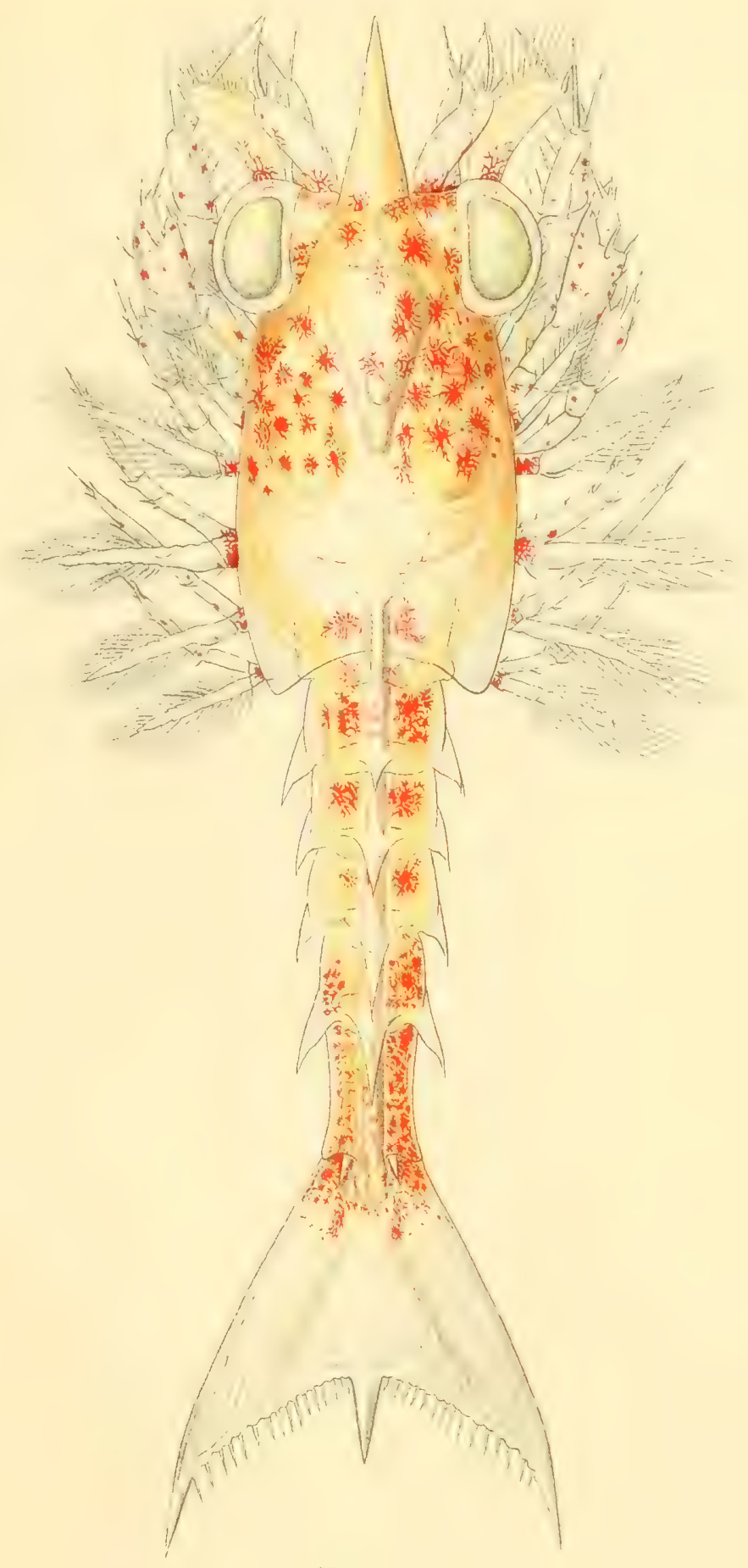

Fig. 32. 



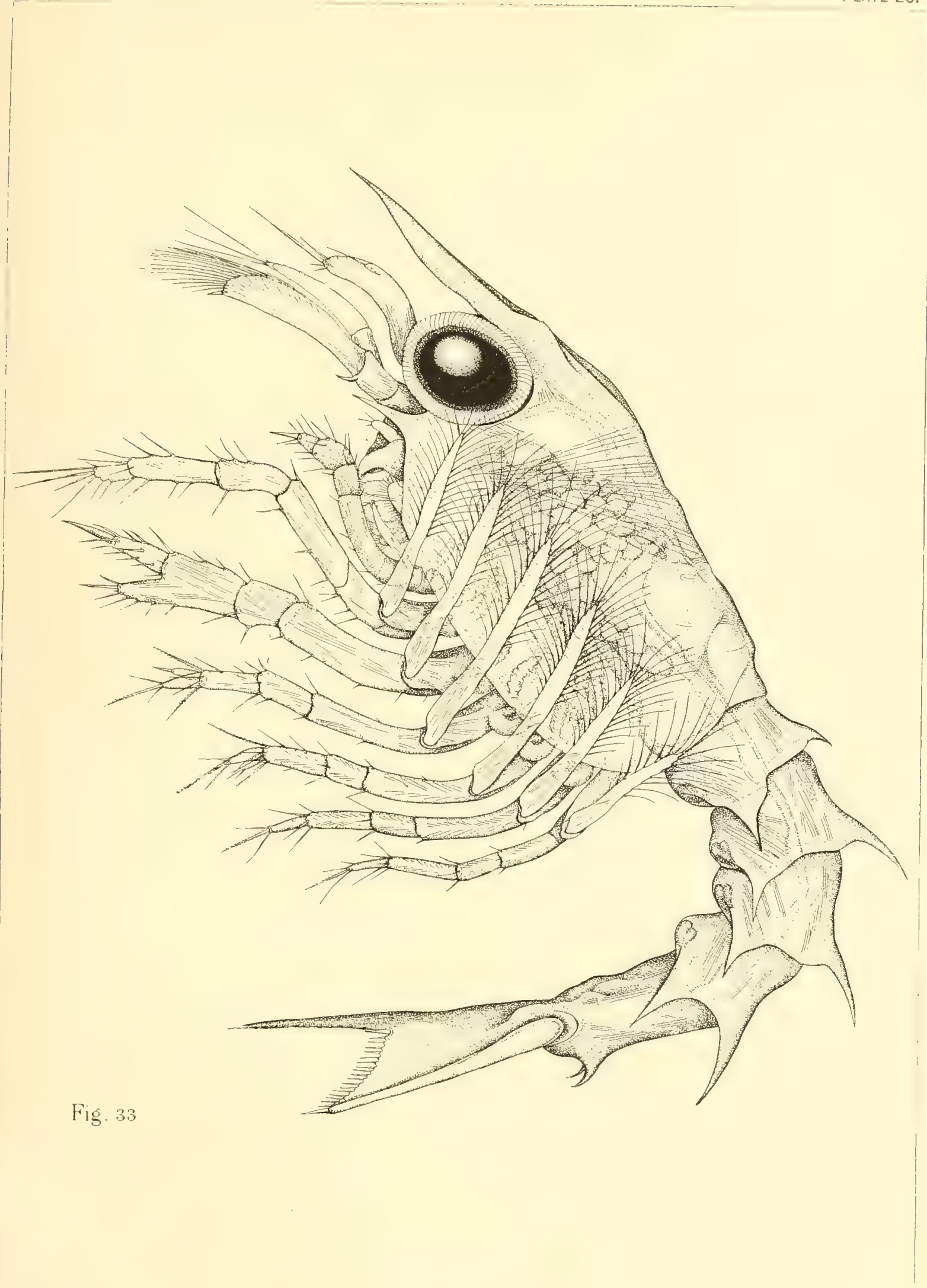





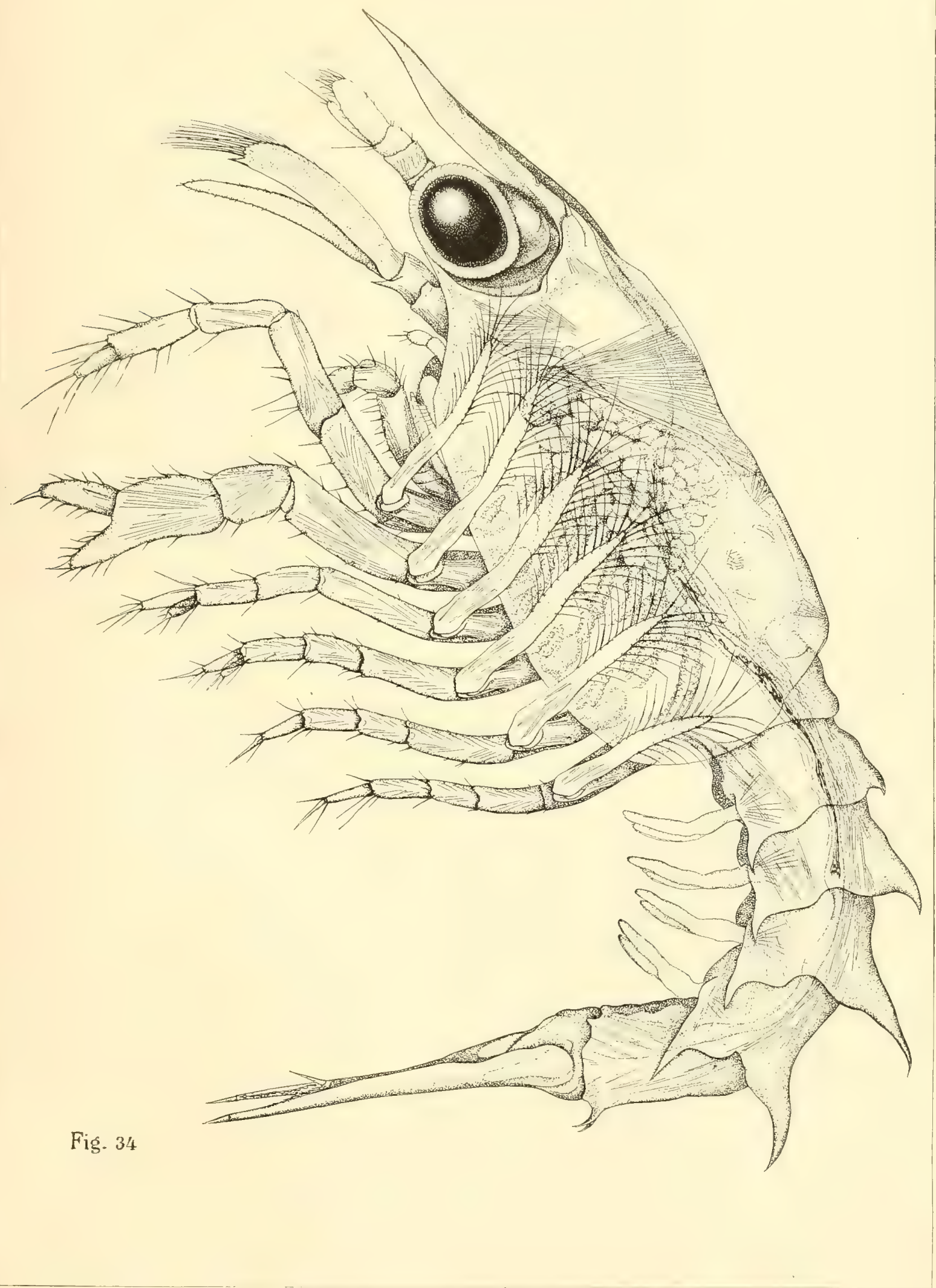

F. H. Herrichi ad nat del. 



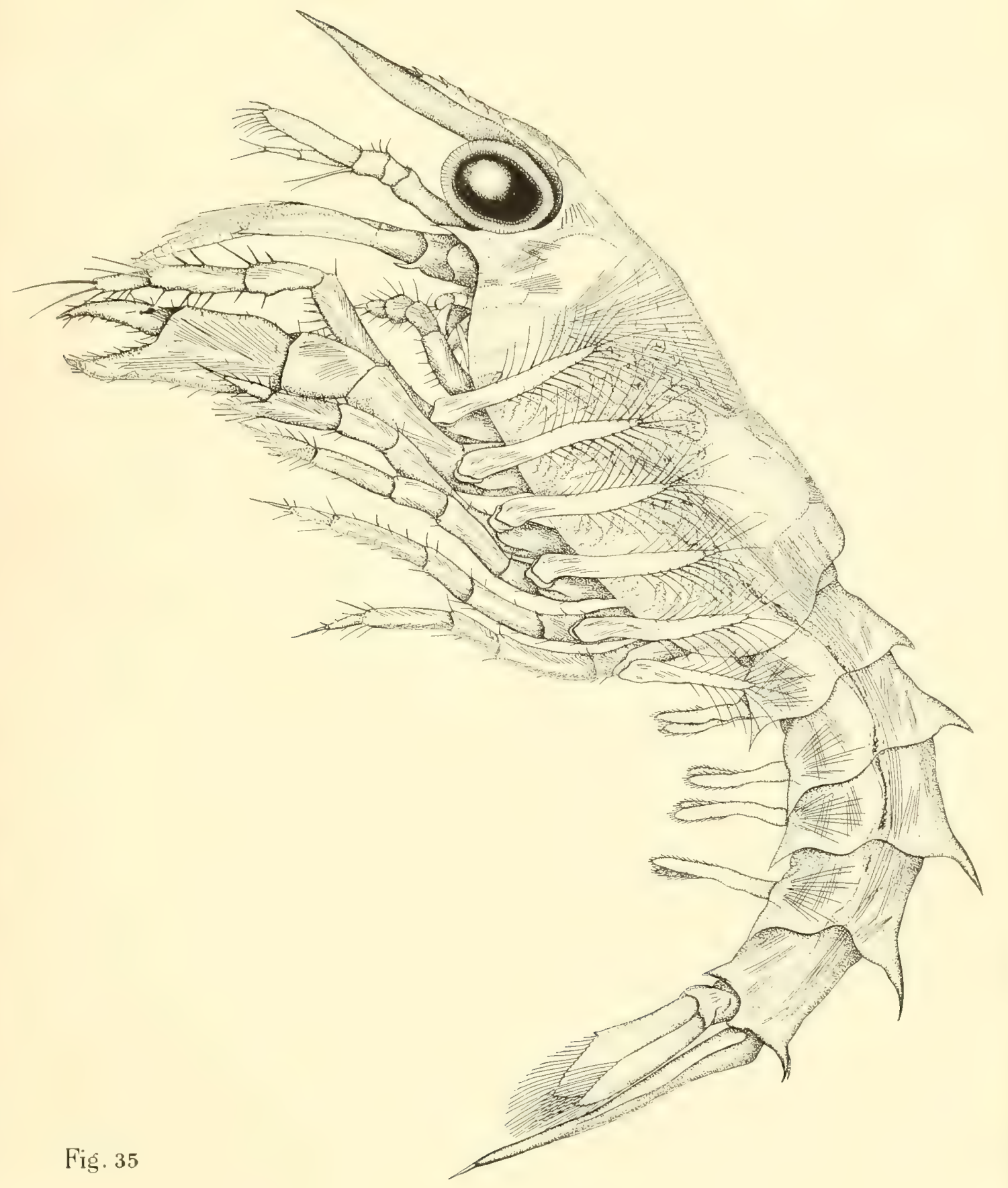





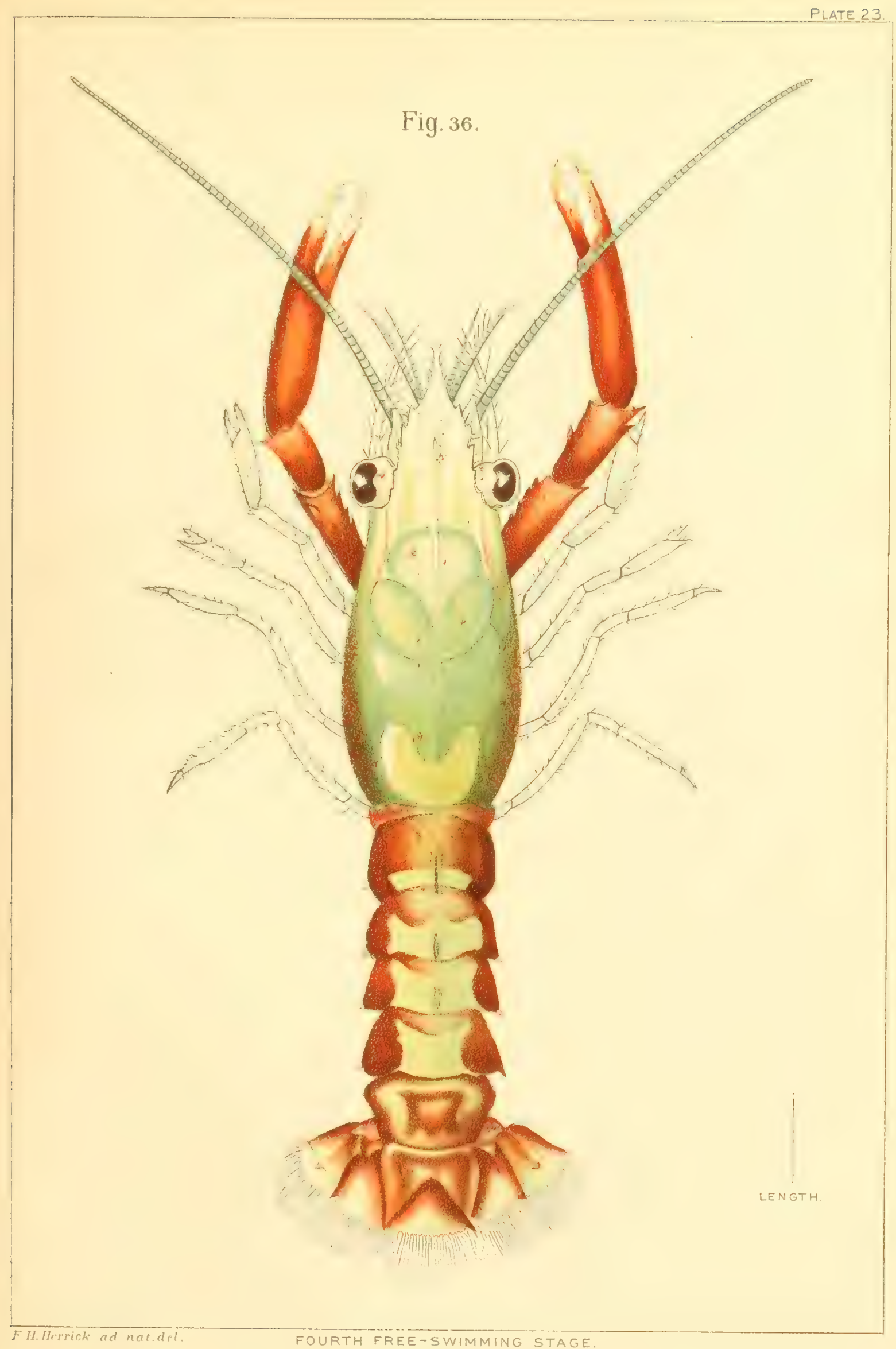



Fig. 37

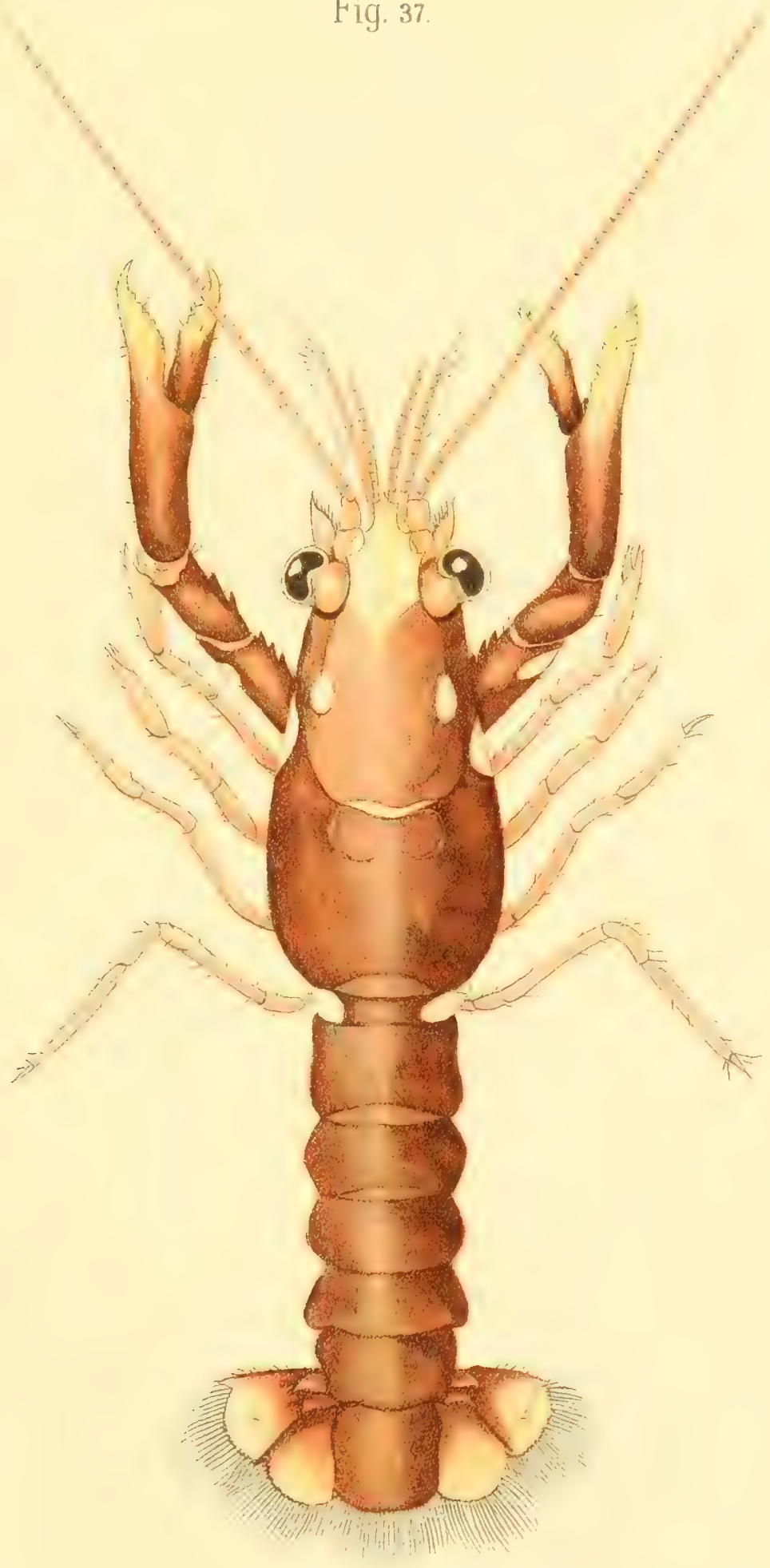





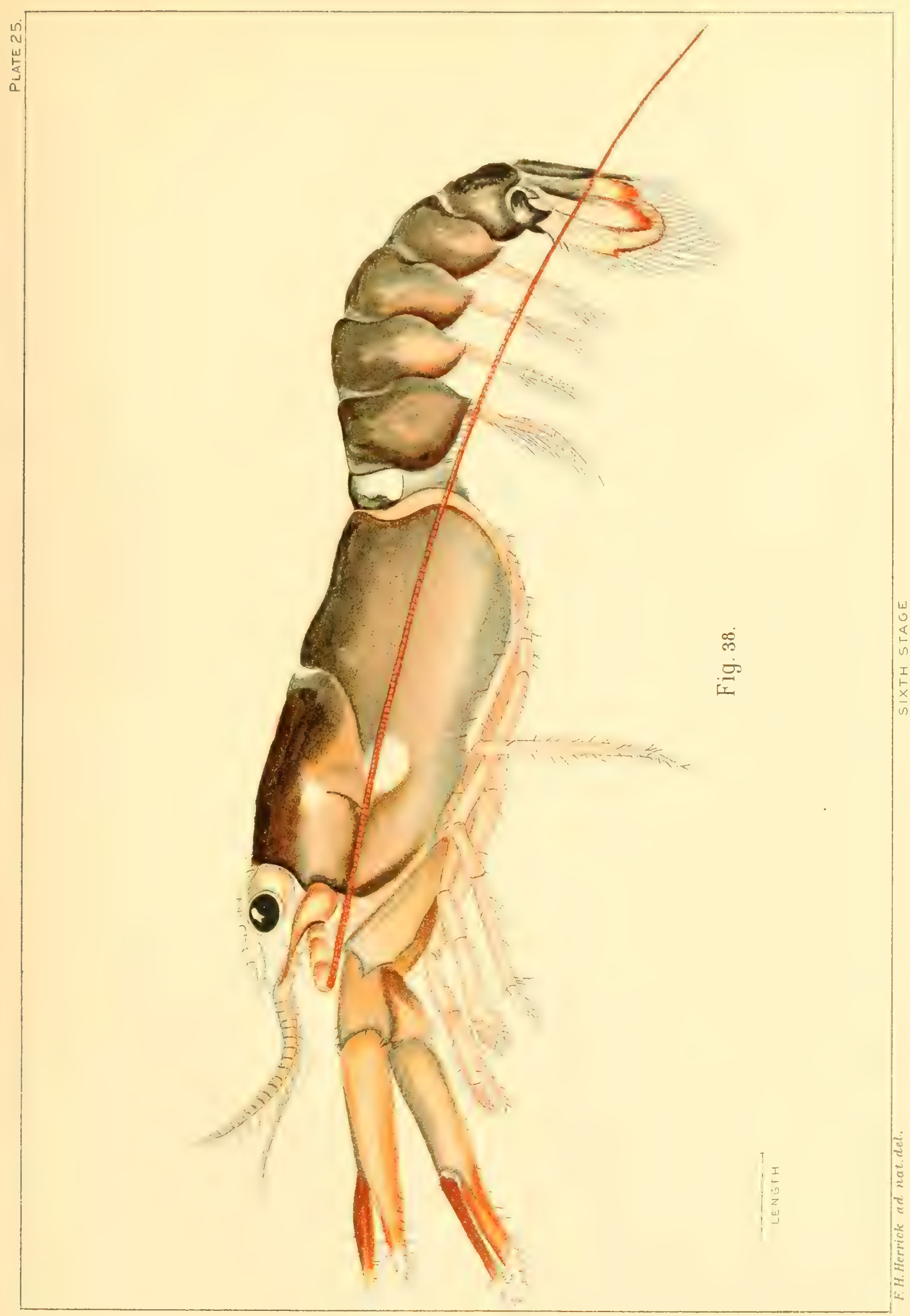





$$
\text { l }
$$




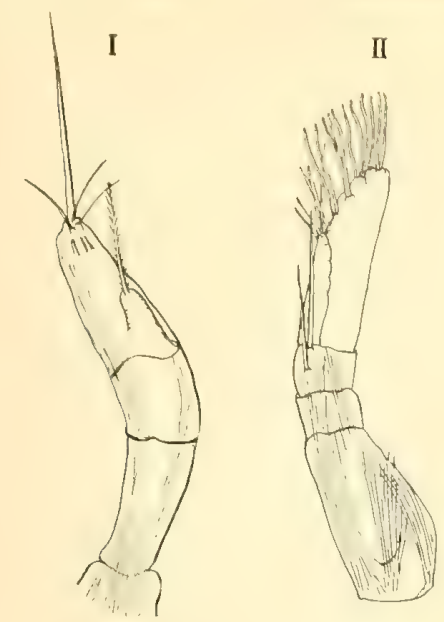

Fis. 40

Fig. 41

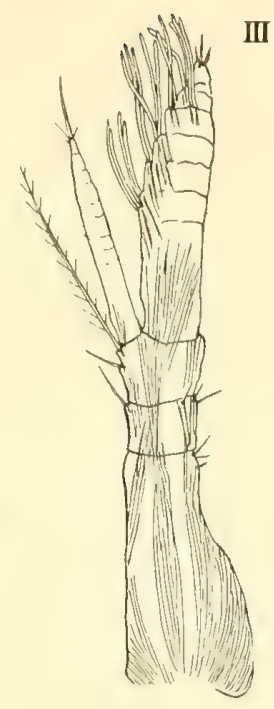

Fig. 42
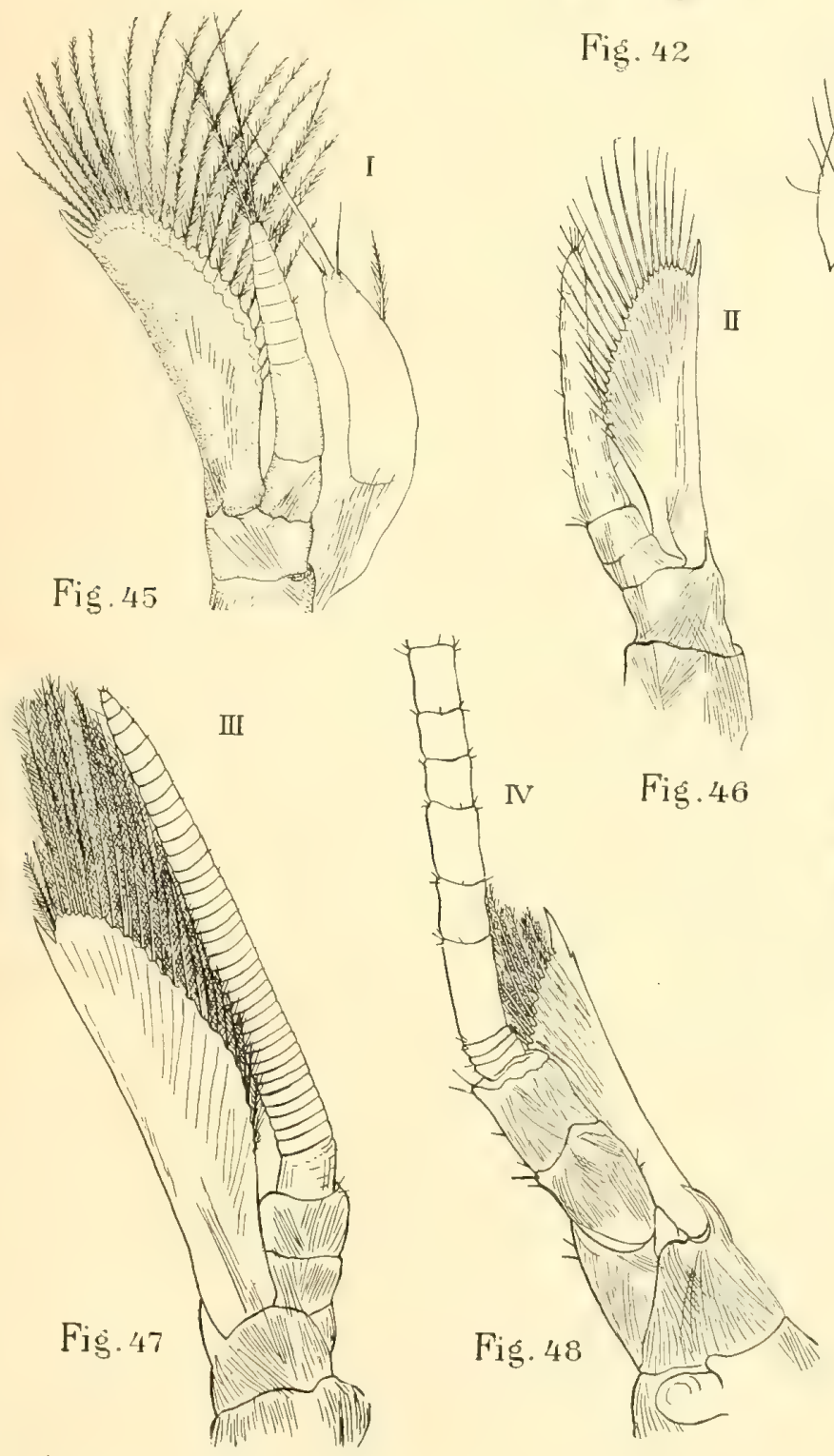
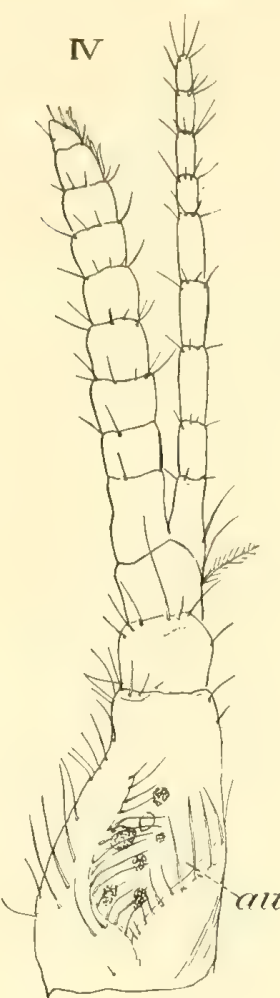

Fig. 43
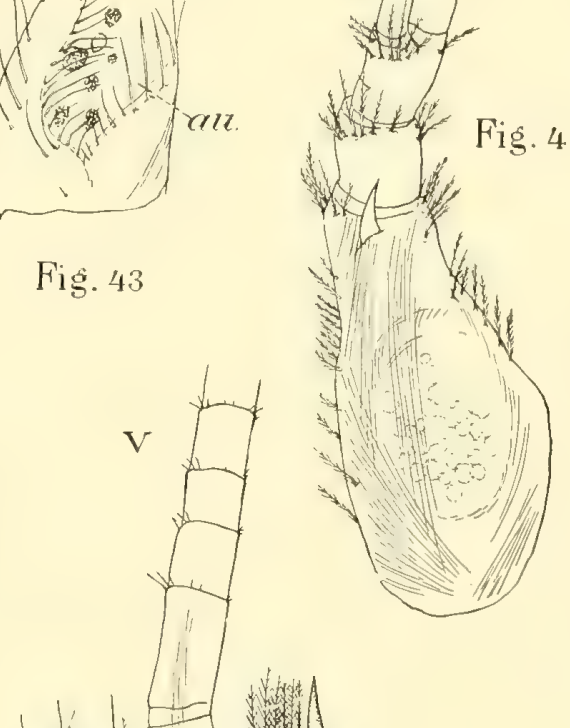
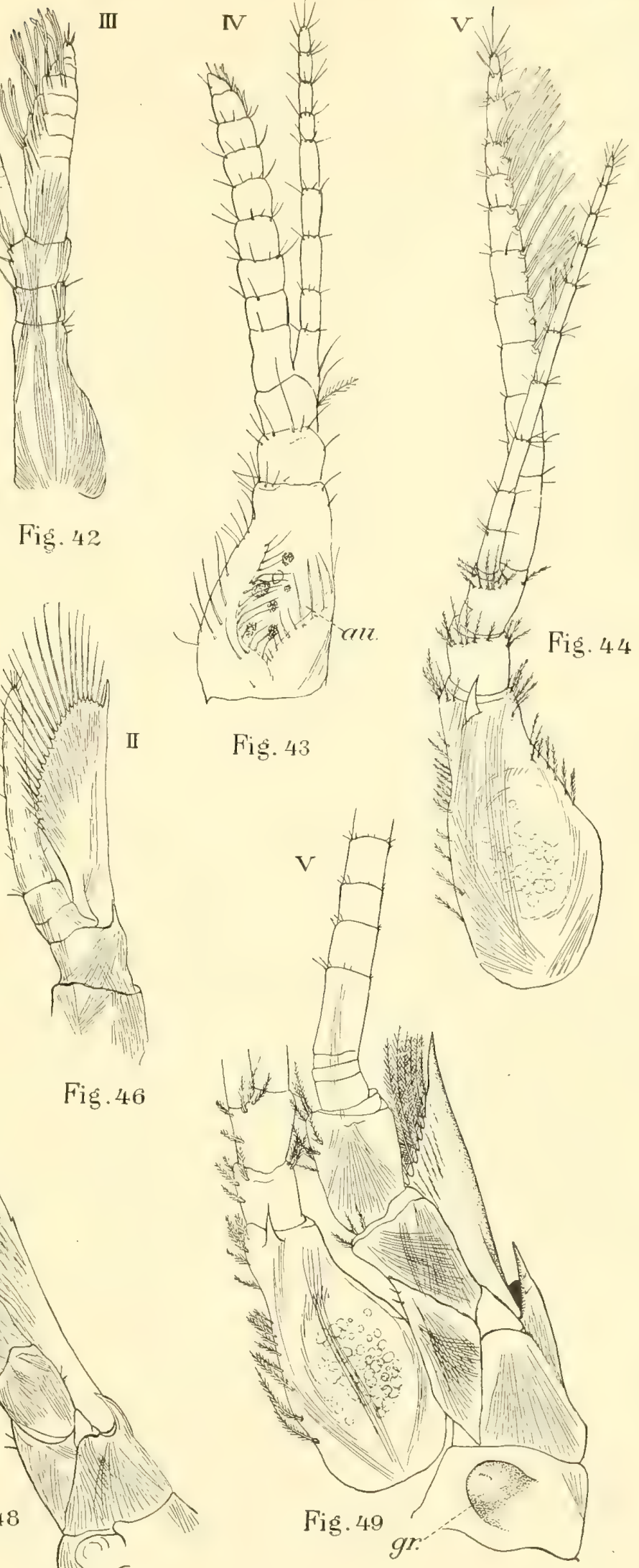

F. H. Herrich ad nat. del. 



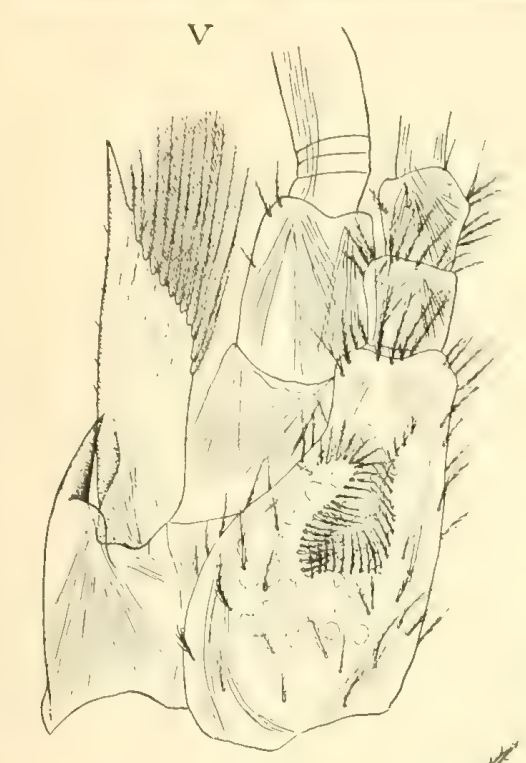

Fig. 50
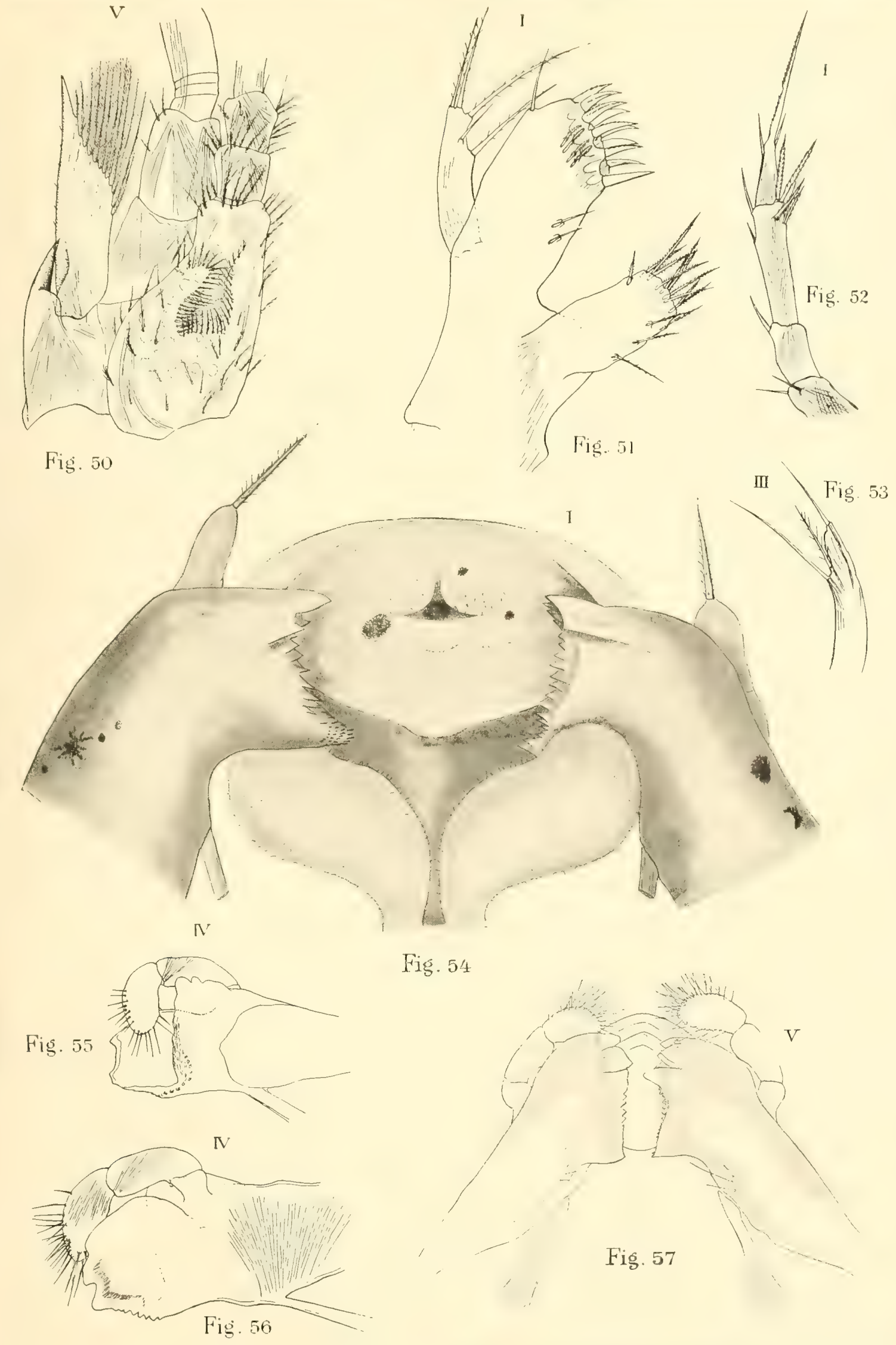

Fig. 54

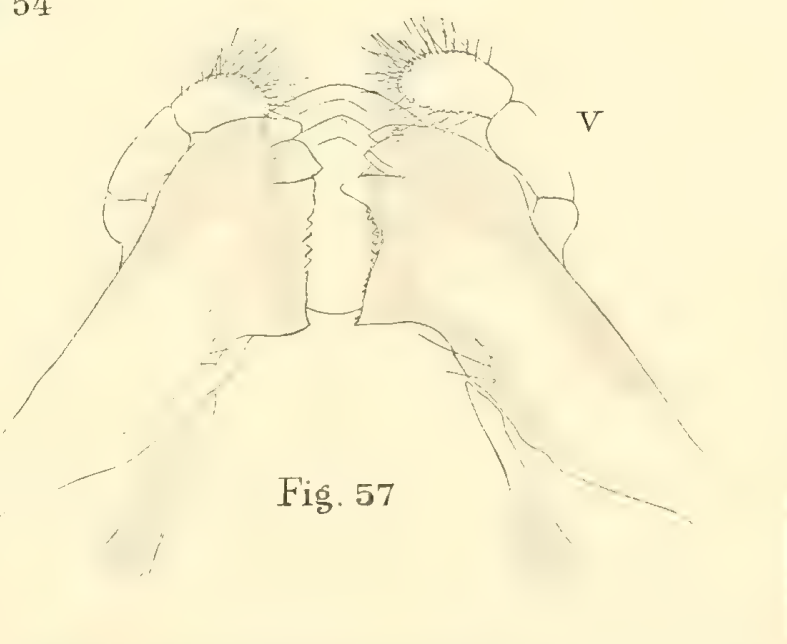

F. H. Herrick ad nat. det. 



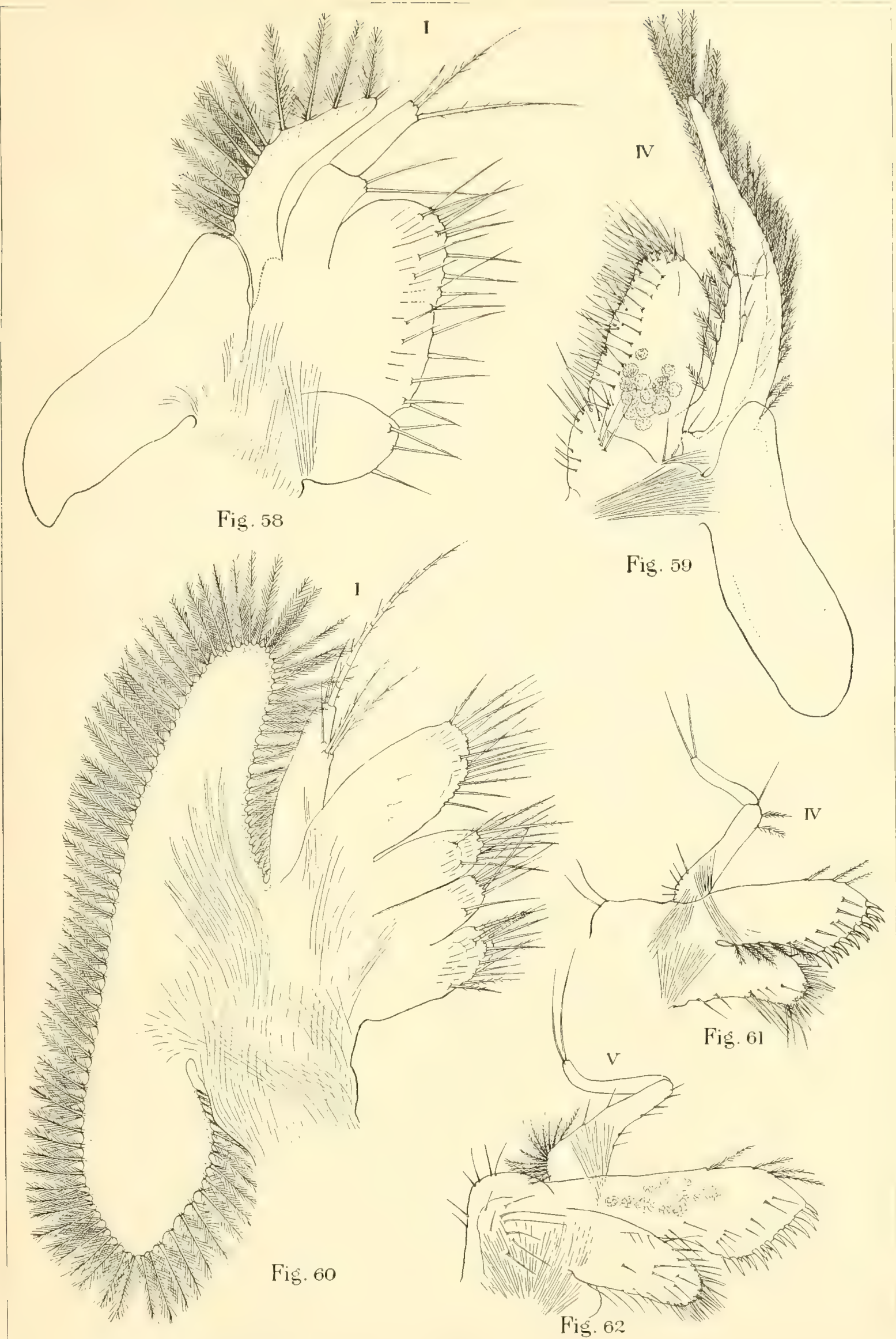

F. H. Herrich ad nat. del. 



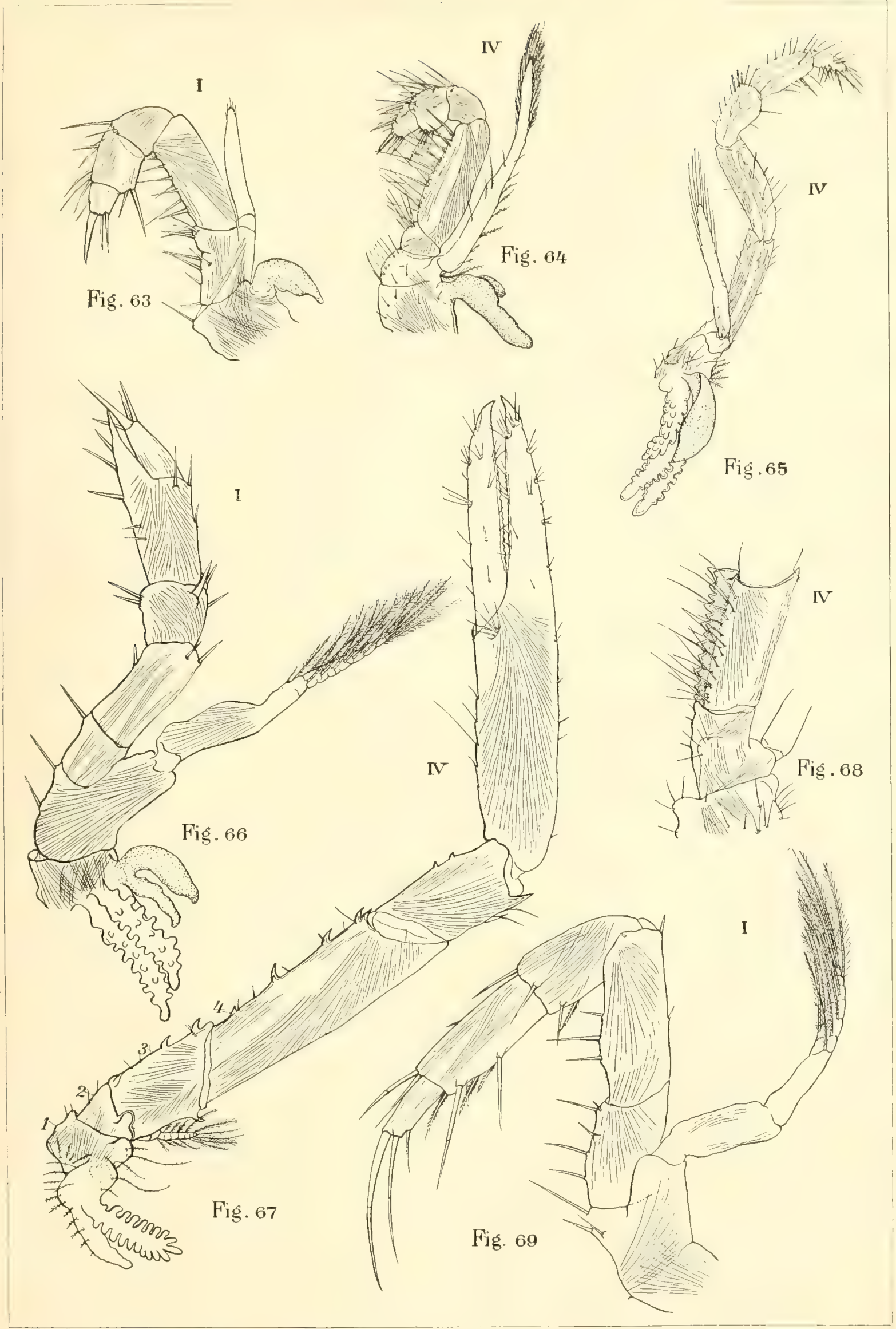

F. H. Herrick ad nat. del. 



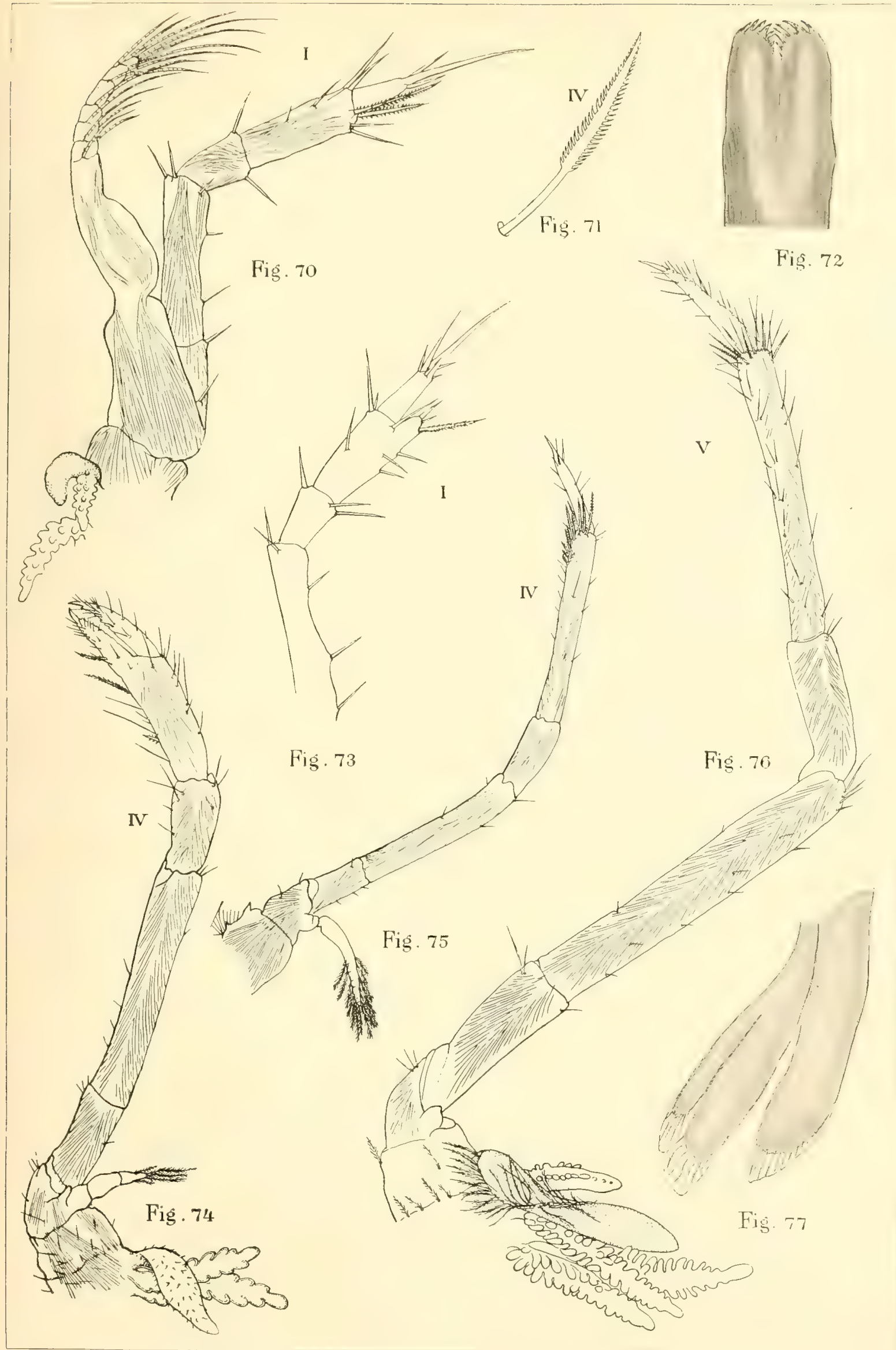

F. H. Herrick ad nat, del. 



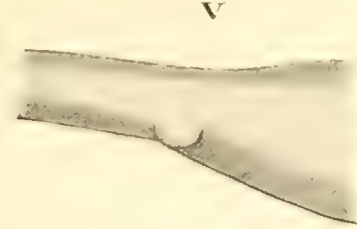

Fis. 78

VT

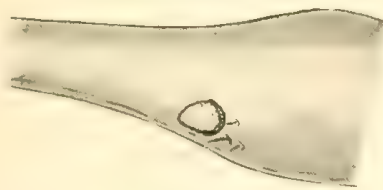

Fis. 82

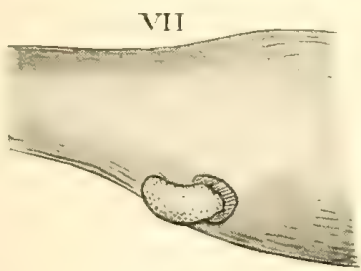

Fig. 83

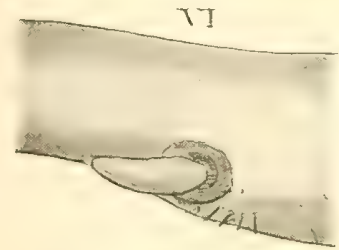

Fig. 84

Q ITII

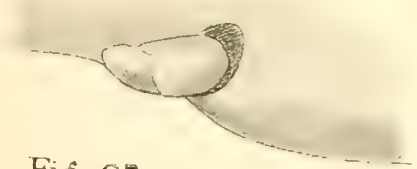

Fis. 85

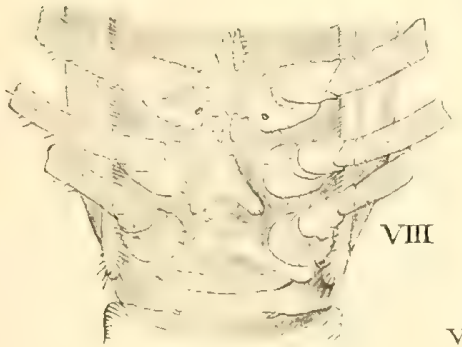

Fig. 89
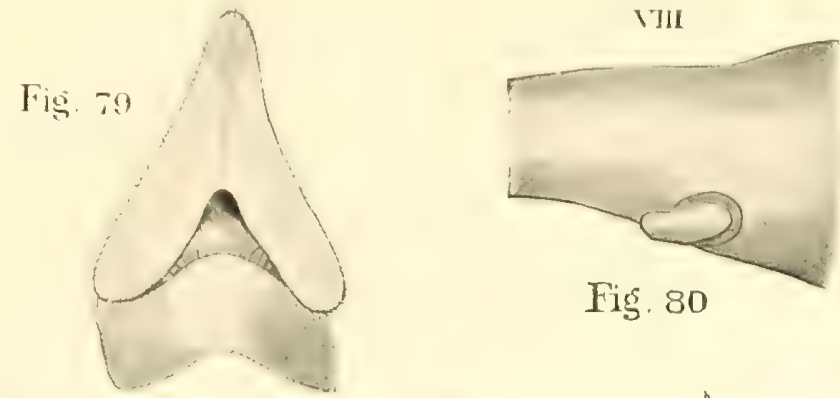

Fig. 80
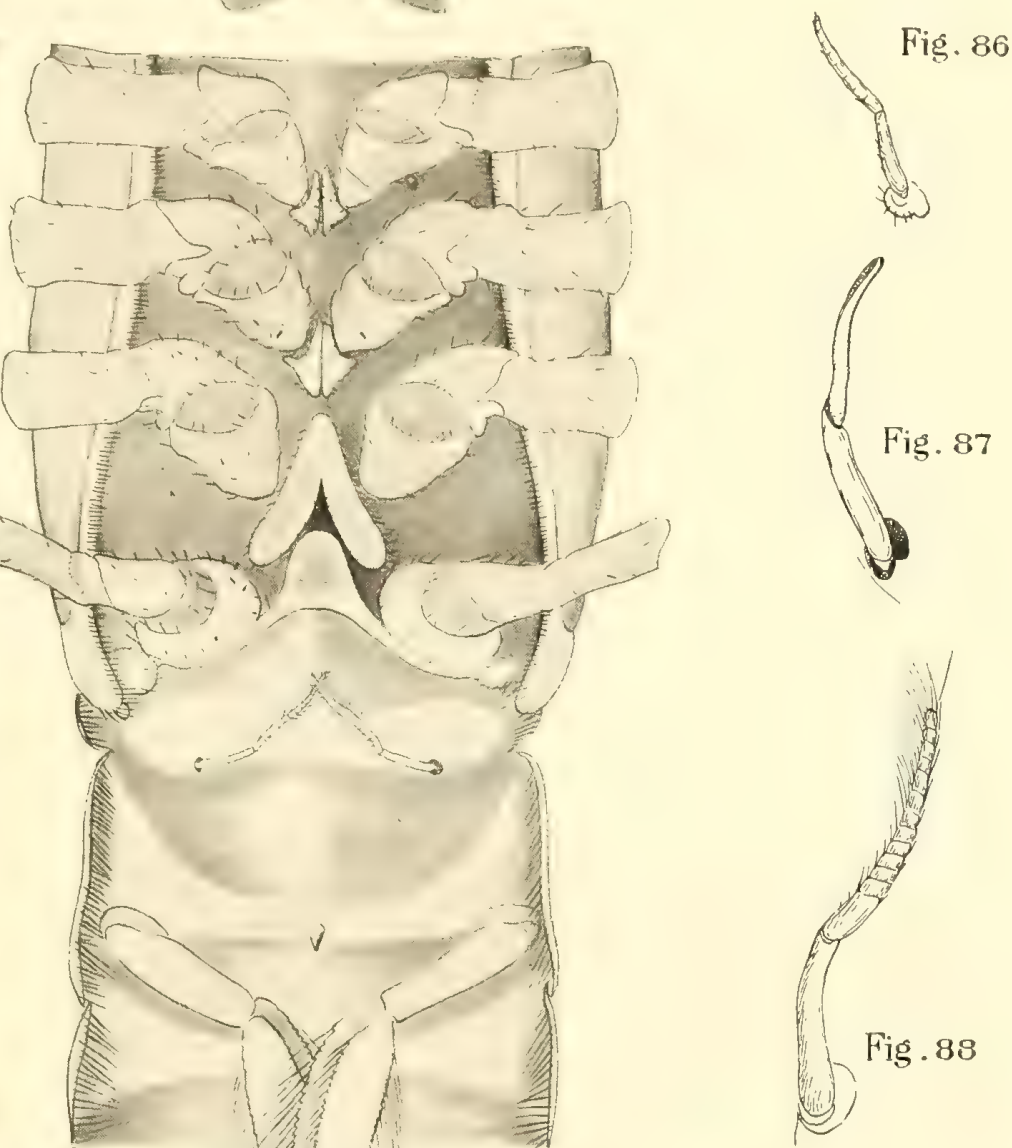

Fig̉. 81
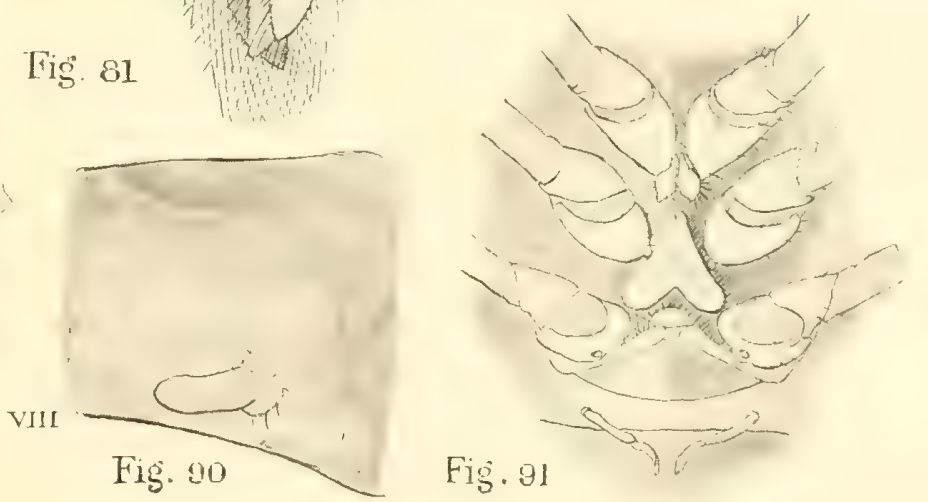

F. H. Herrick ad nat. del.

DEVELOPMENT OF FIRST PAIR OF ABDOMINAL APPENDAGES AND SEMINAL RECEPTACLE. 



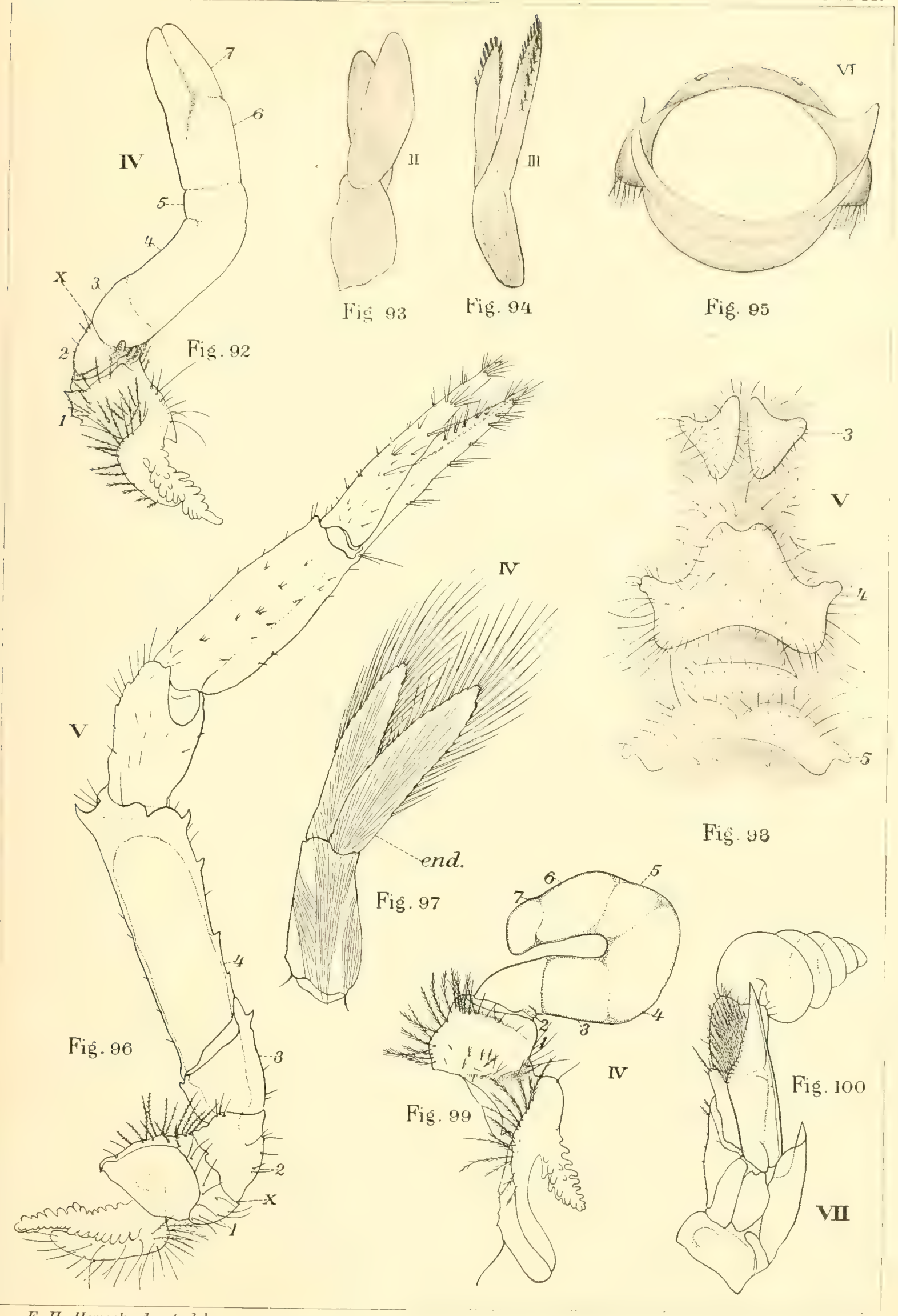

F. H. Hemoli ad nat. del. 



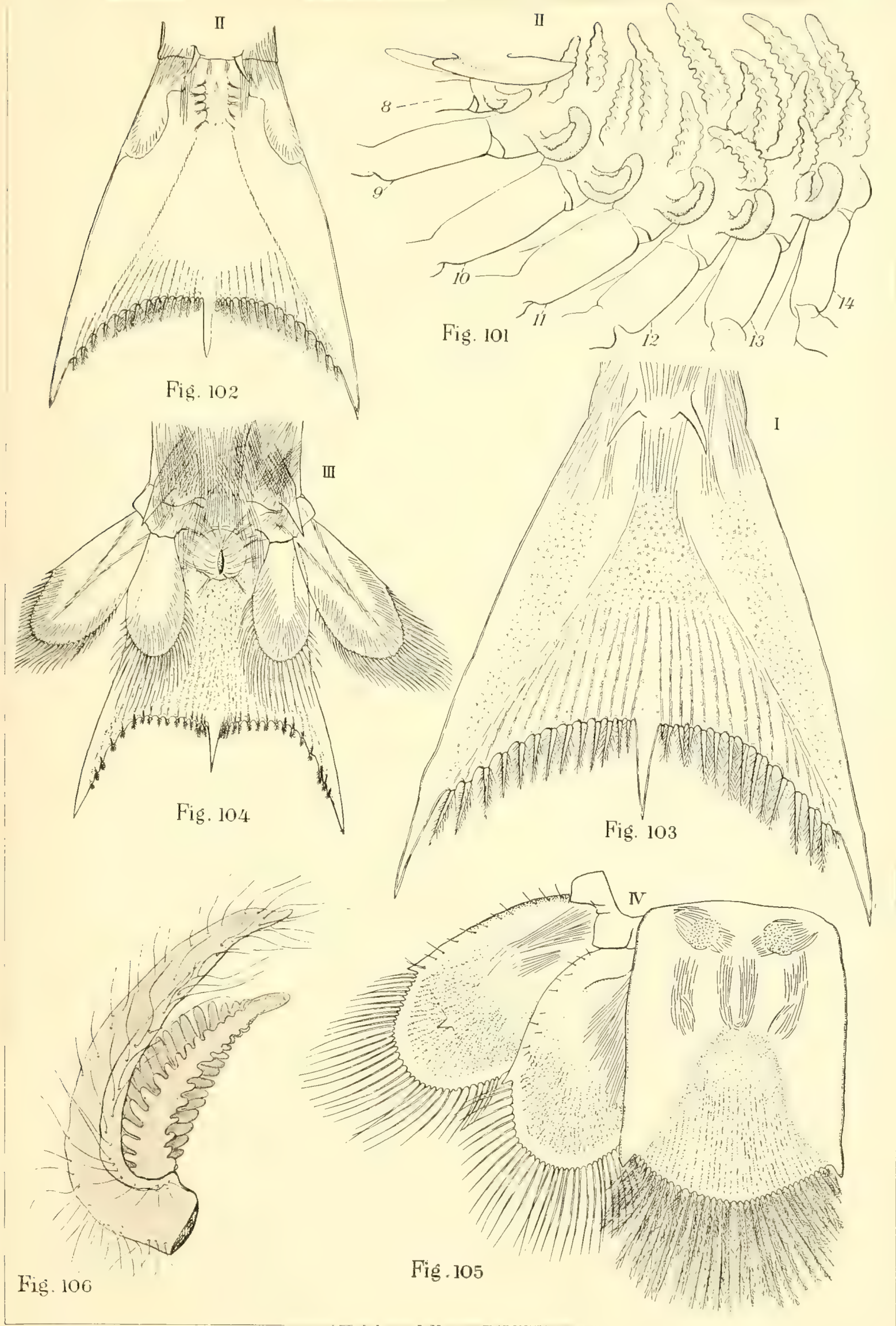

F. H. Herrick ad nat. del. 



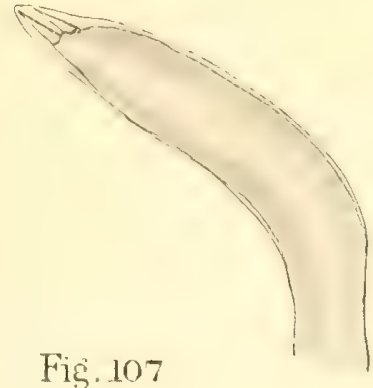

Fig. 107

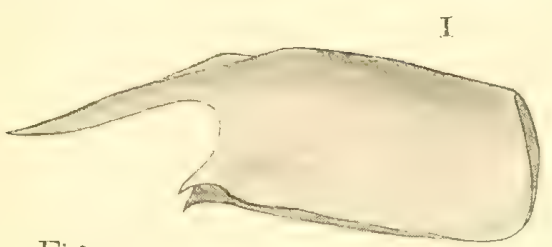

Fig. 110

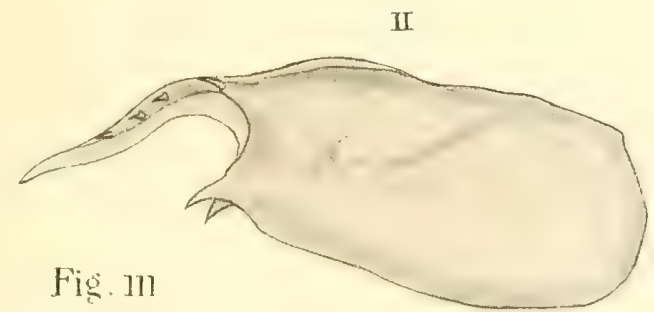

Fig. 111

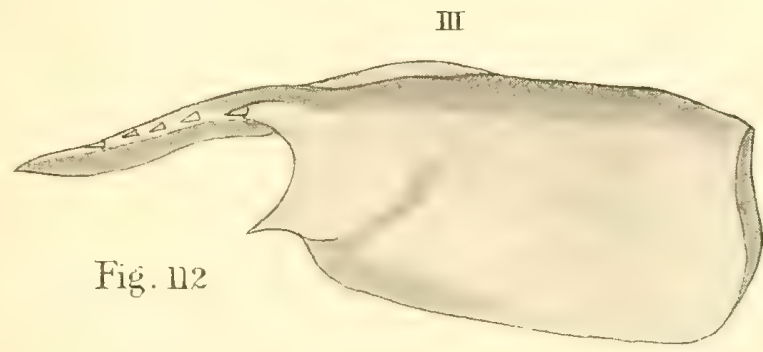

IV

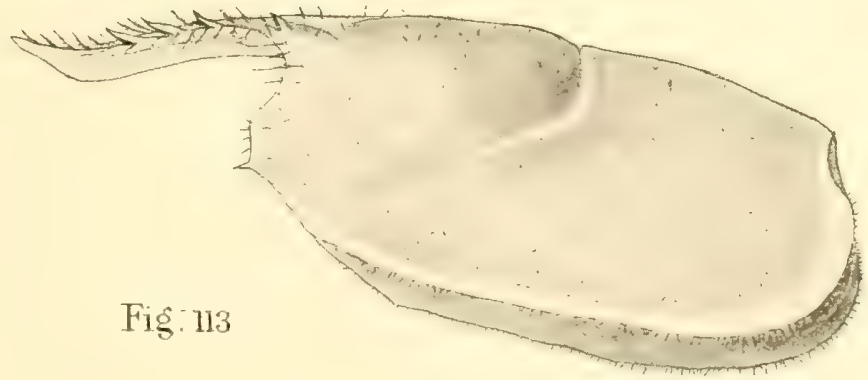

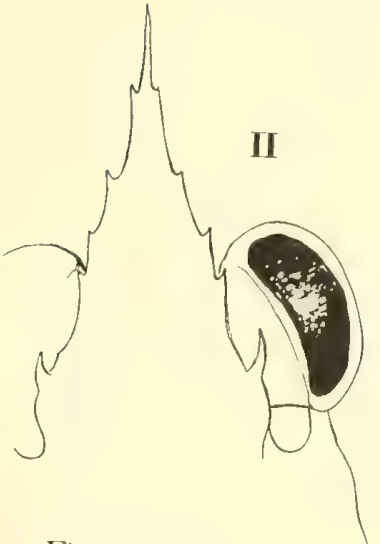

Fig. 109
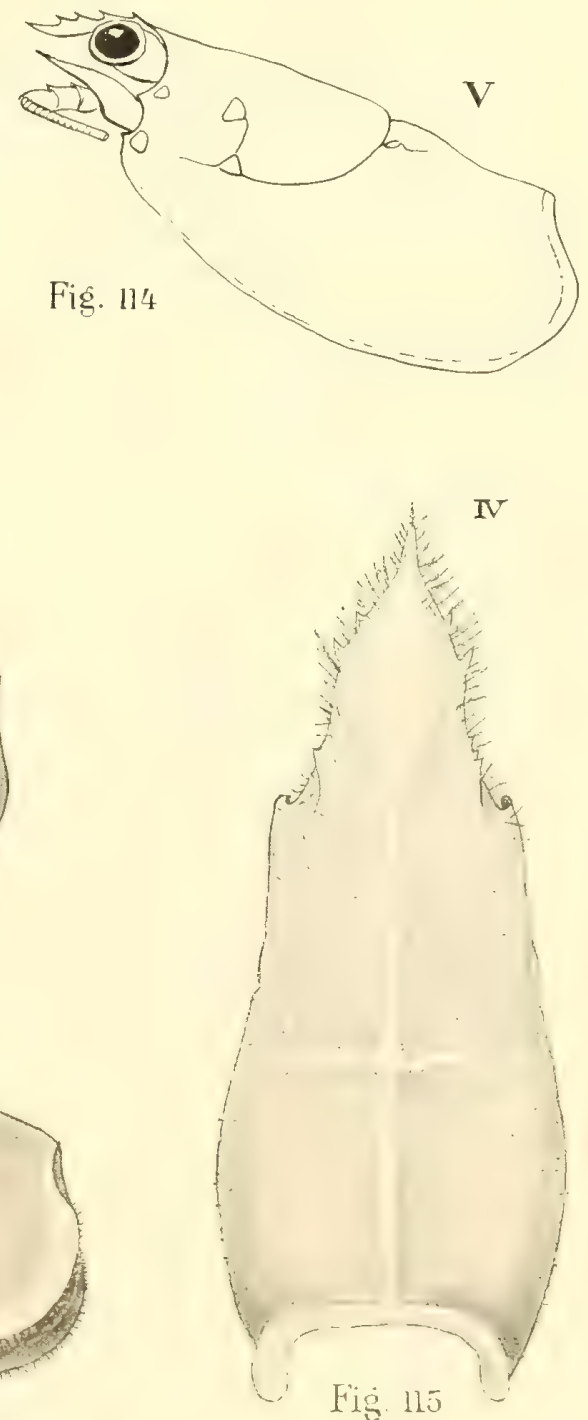

Fig. 116

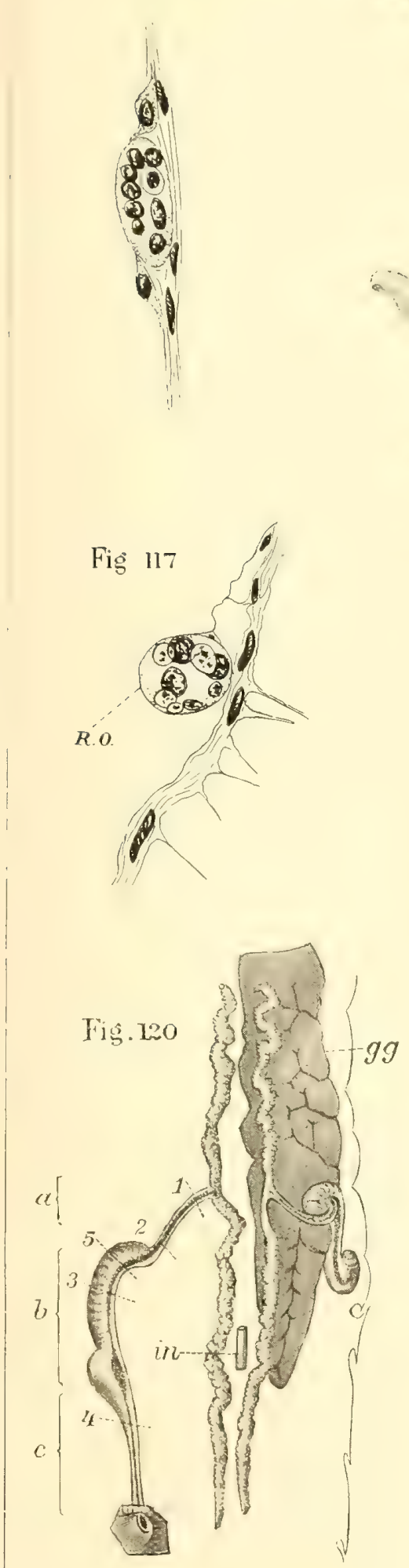

Fig. 118

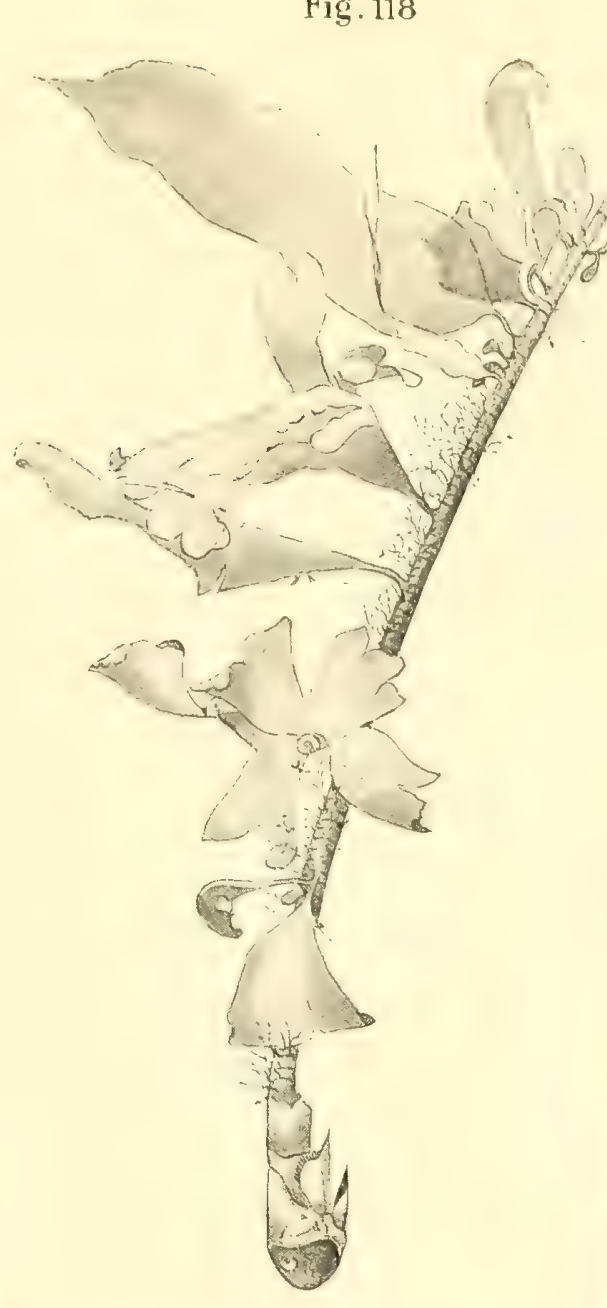

Hig. 119
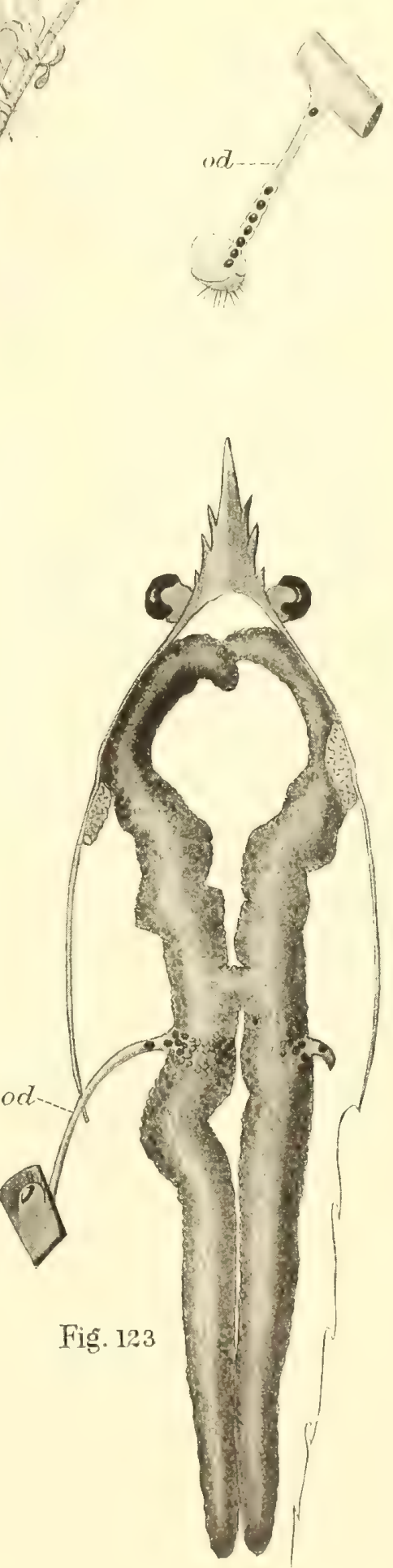

F. H. Herrick ad nat. del. 



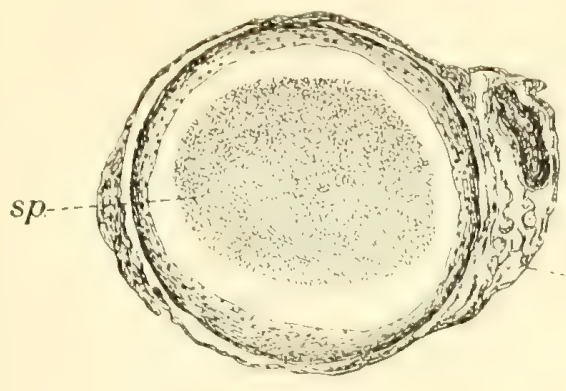

Fig. 124

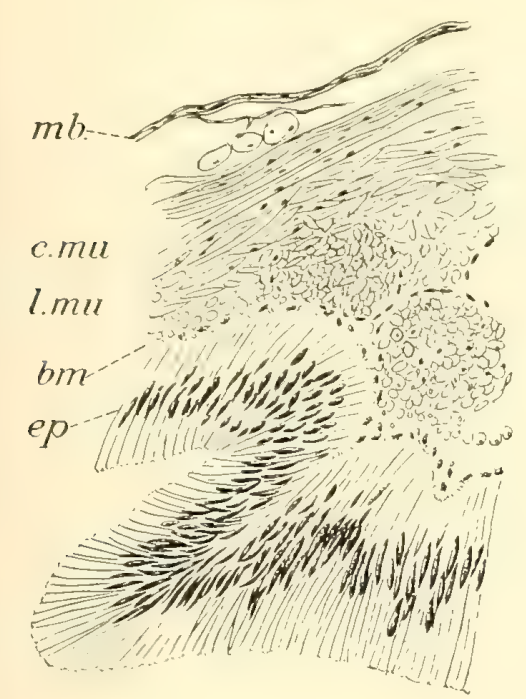

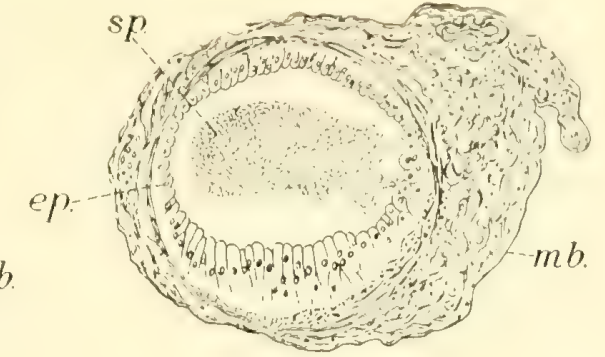

Fig. 125

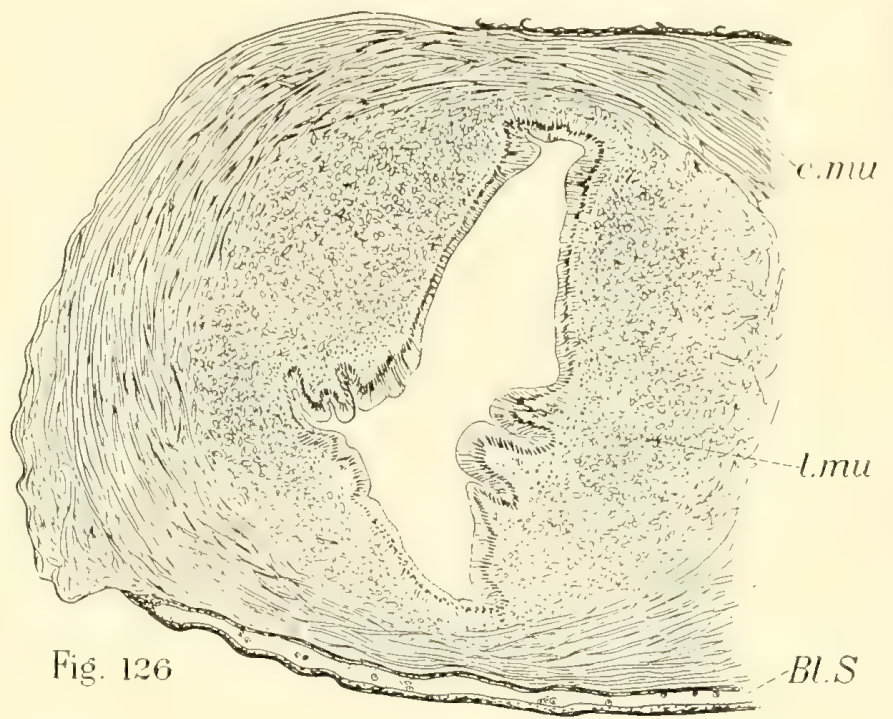

Fig. 127
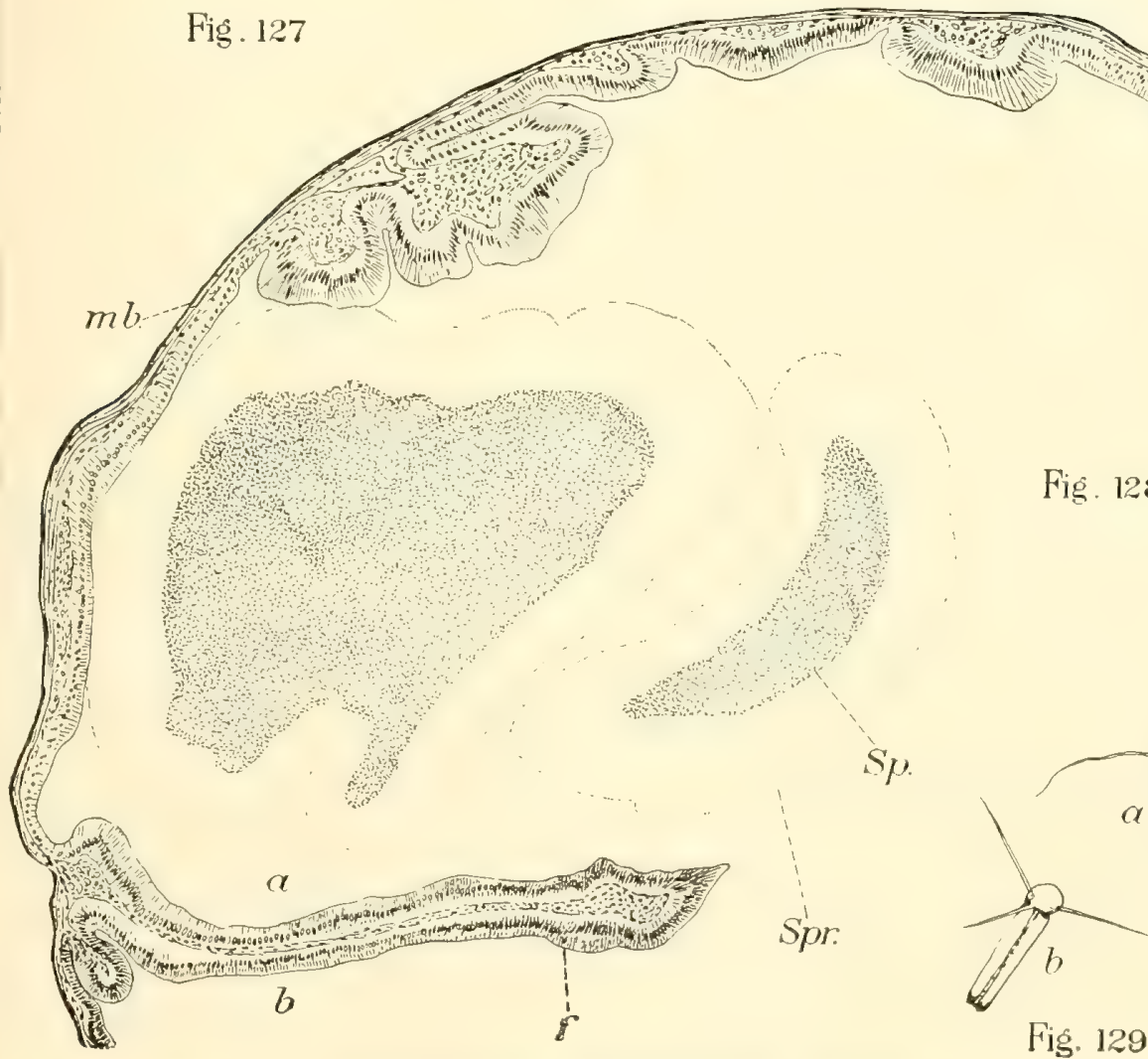

Spr.

Fig. 128

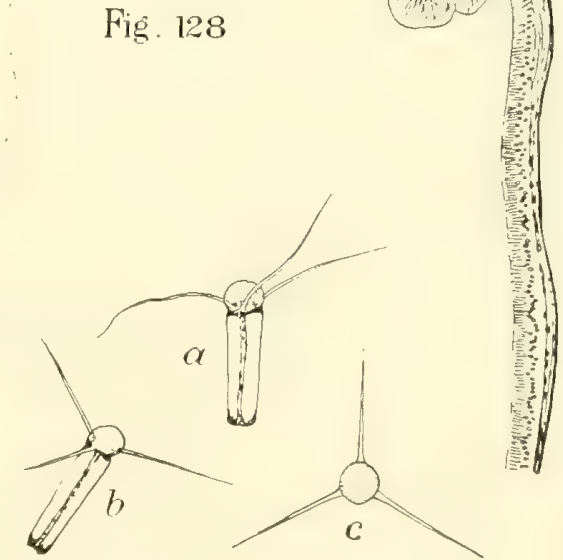

Fig, 129

F. H. Herrick ad nat. del. 



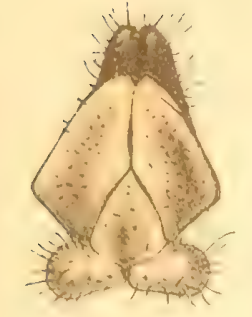

Fig. 130

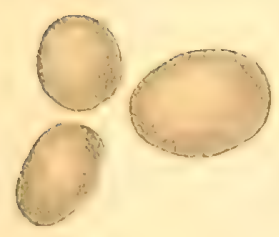

Fig. 134.

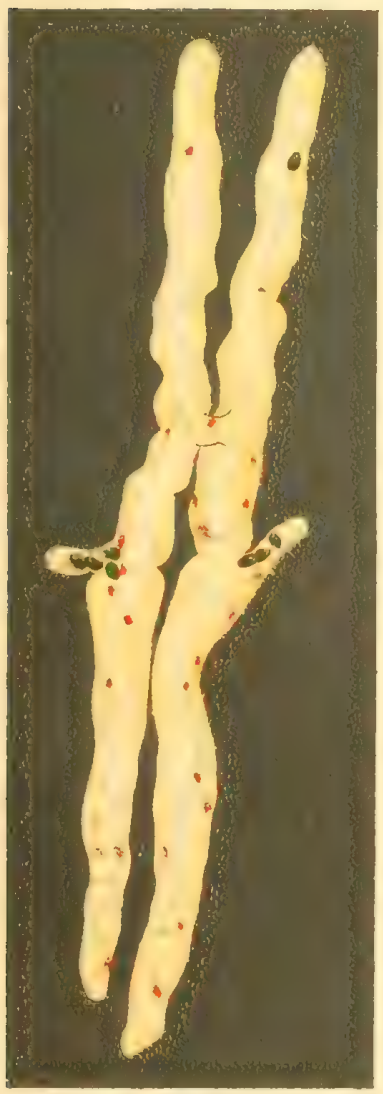

Fig. 136.

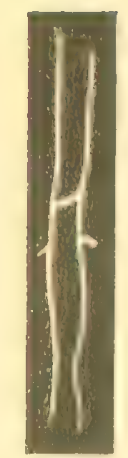

Fig. 132

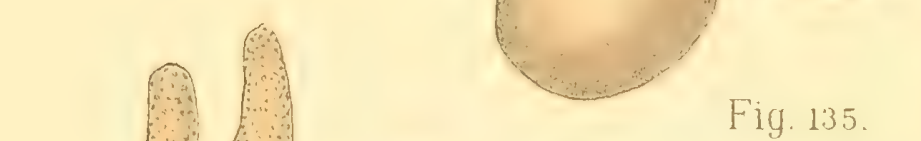

Fig. 135

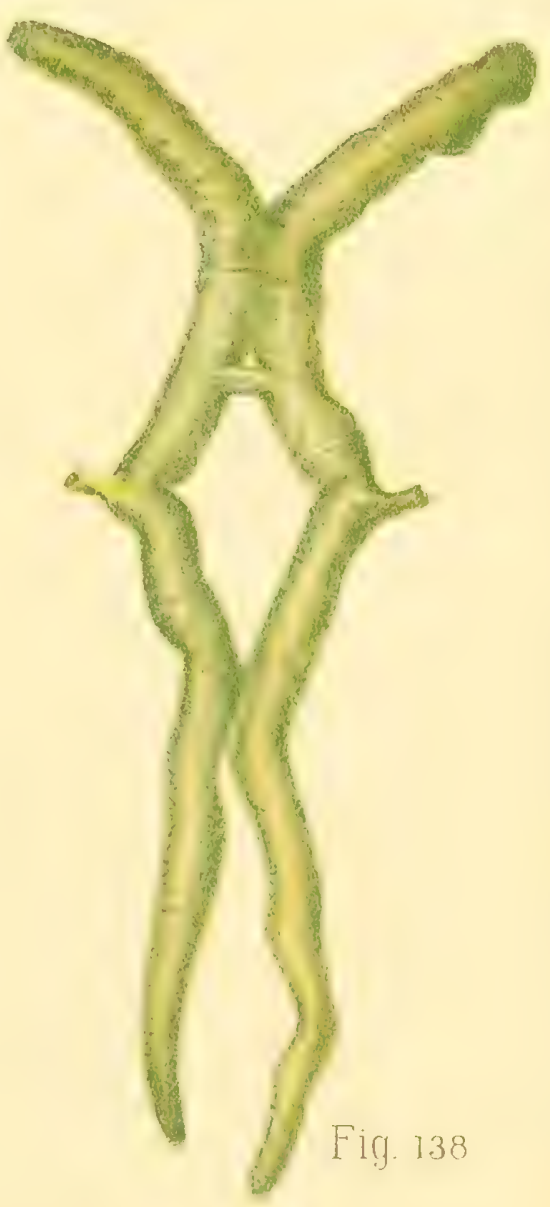

Fig. 137

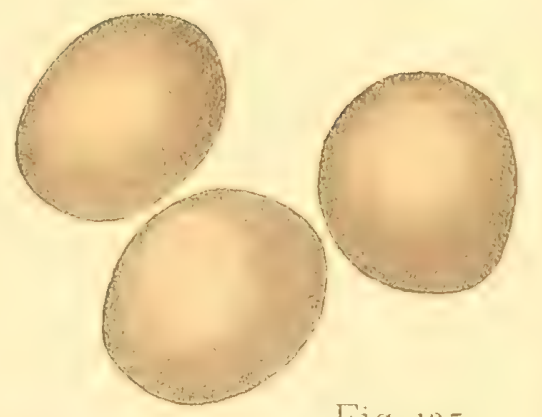

Fig. 133

Fig. 131
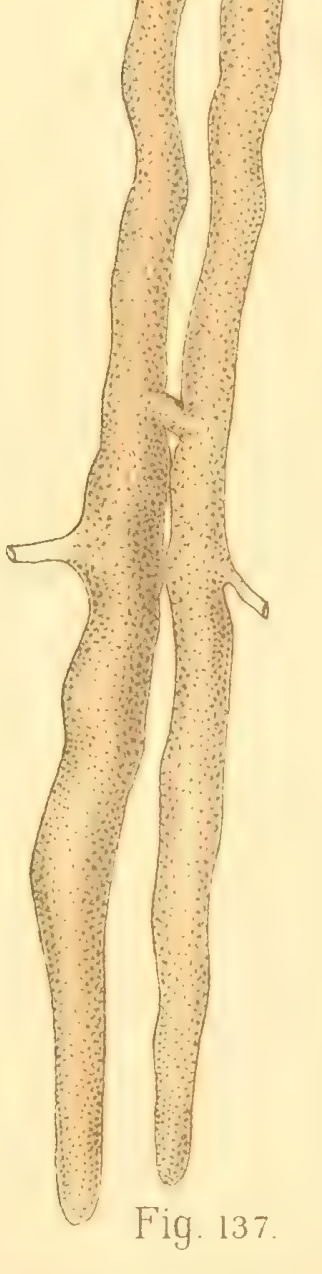


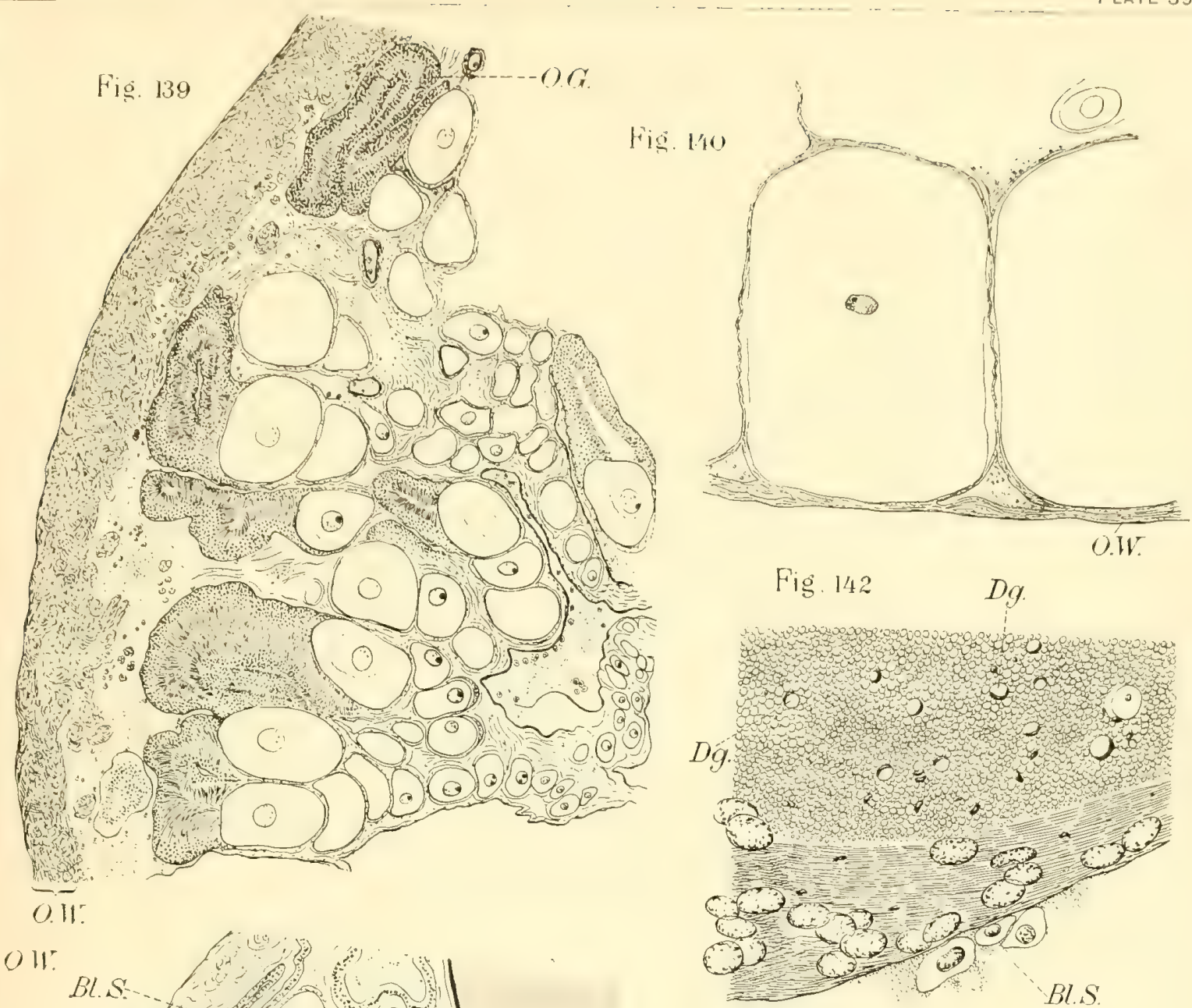

Fig. 142

$D y$

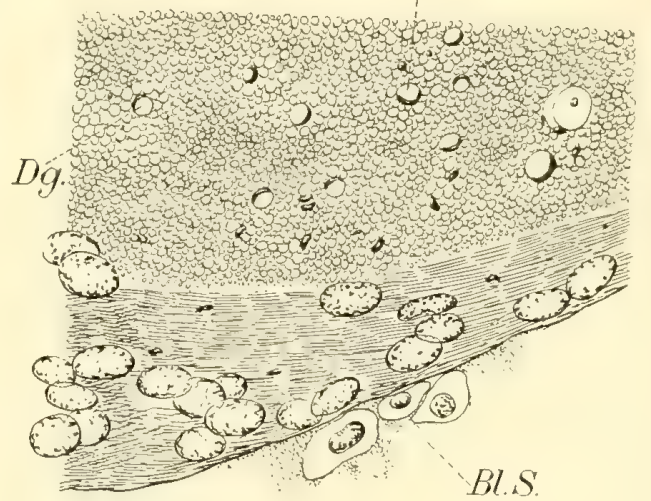

Fig. 141 a
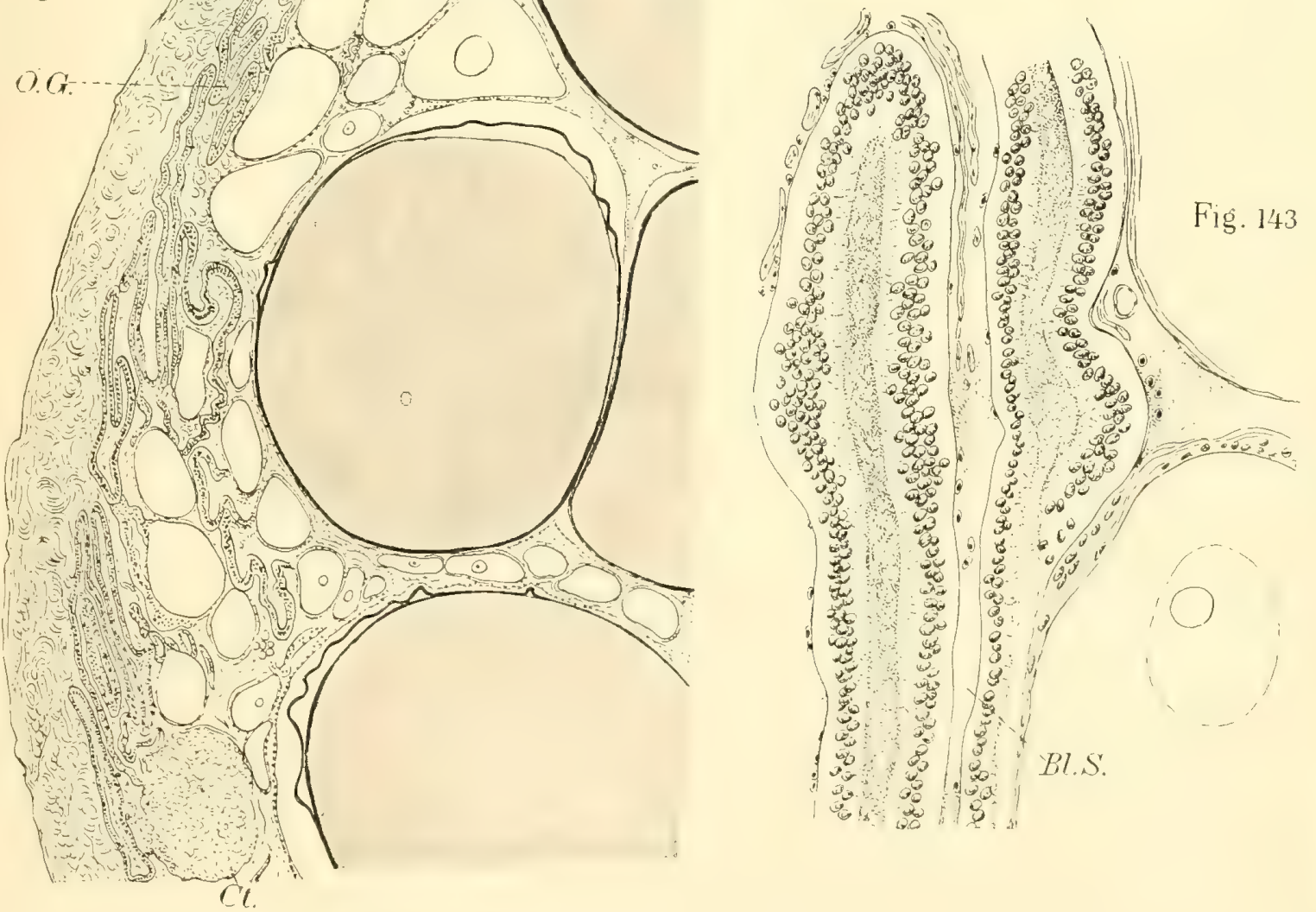

F. H. Herrick ad nat, del. 



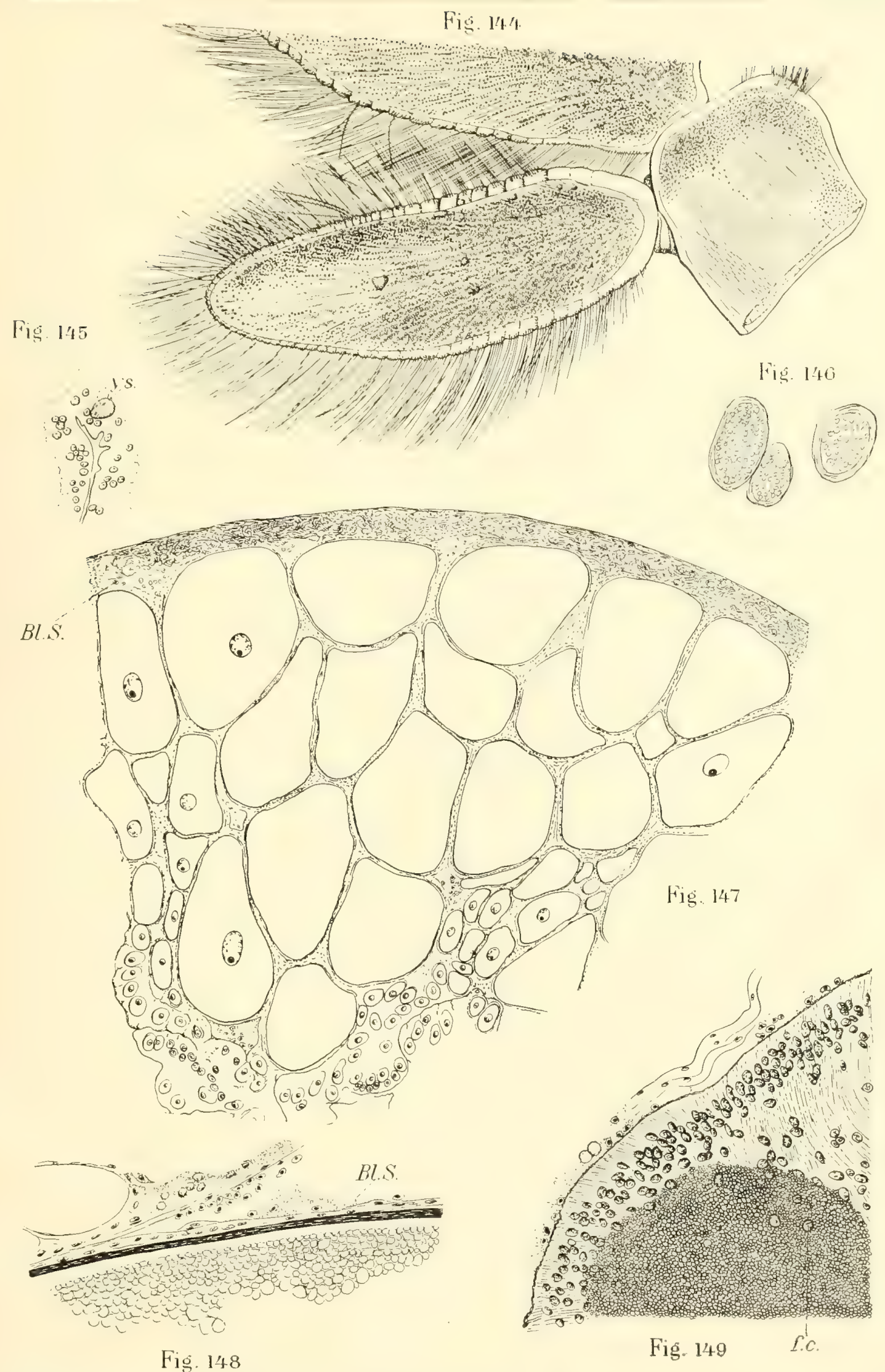

F. H. Herrick ad nat. del. 



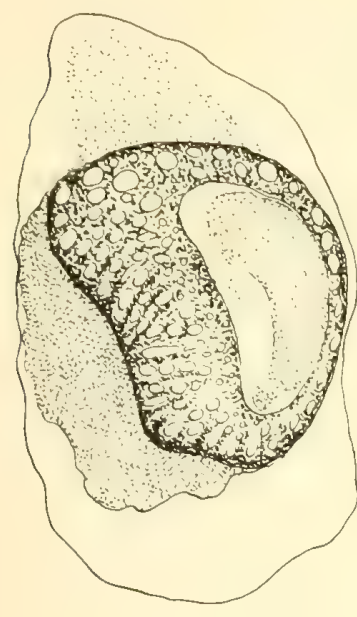

Fig. 150
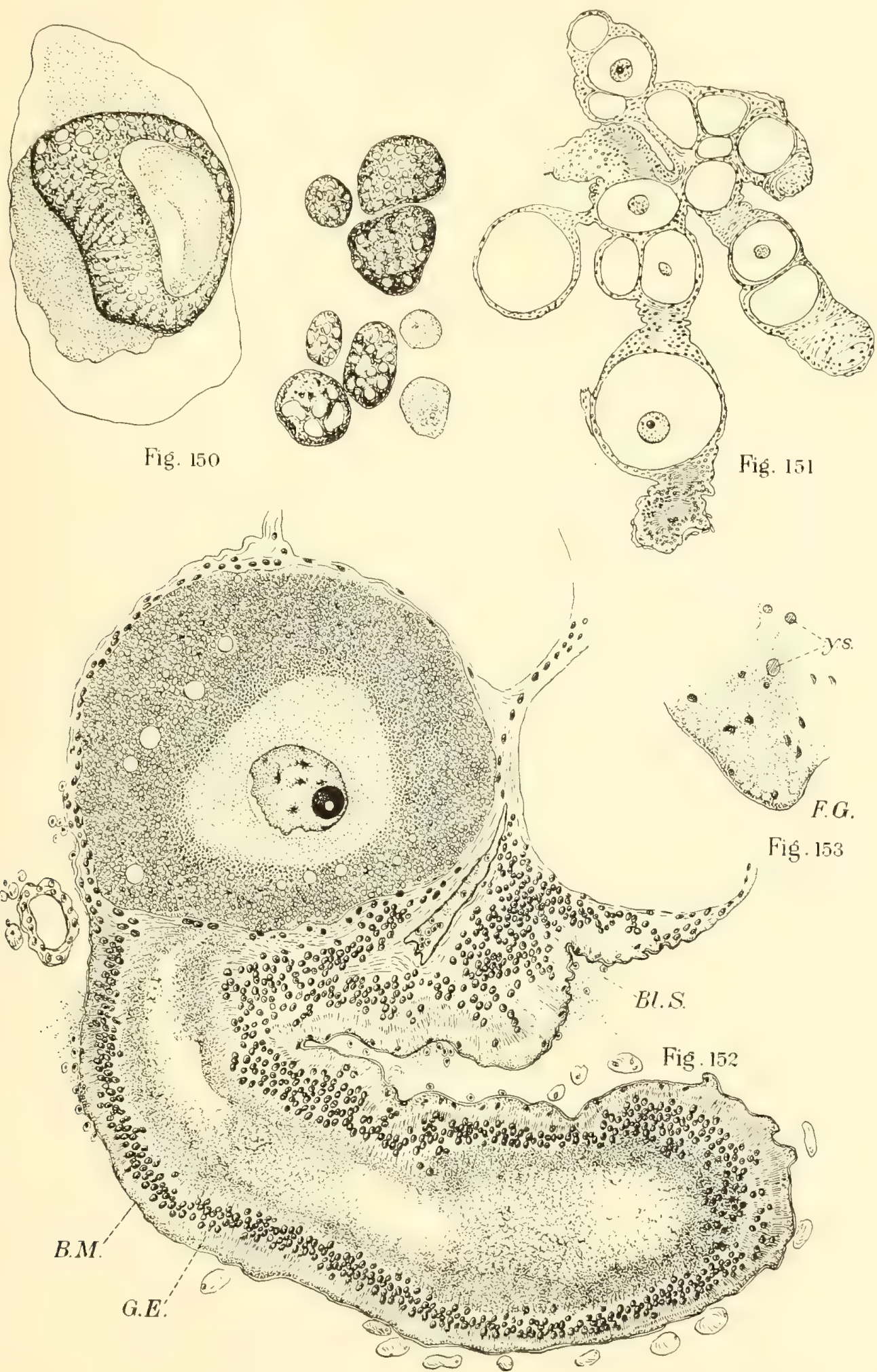

F. H. Herrick ad nat. del. 



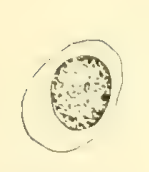

Fis. 154

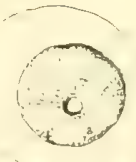

$17 \mathrm{sis} .155$

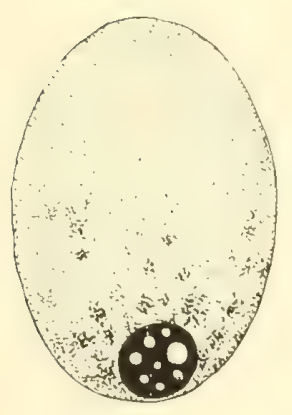

Fig. 158

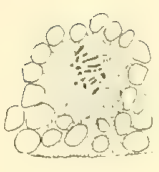

Fig. 16]

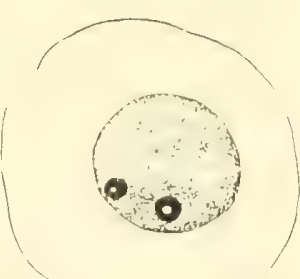

Fig. 156

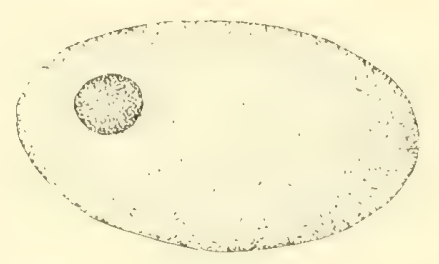

Fig. 159

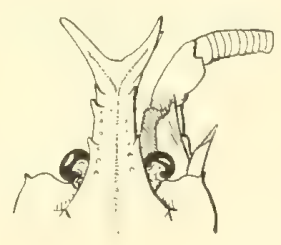

Fig 162

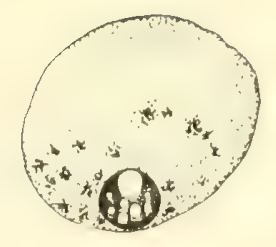

Fig. 157

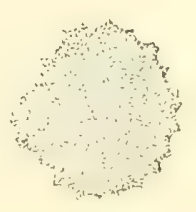

Fig. 160

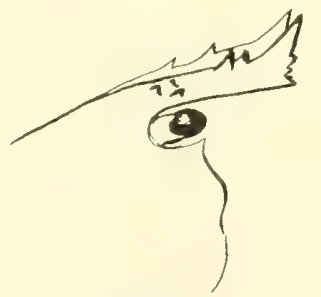

Fig. 163

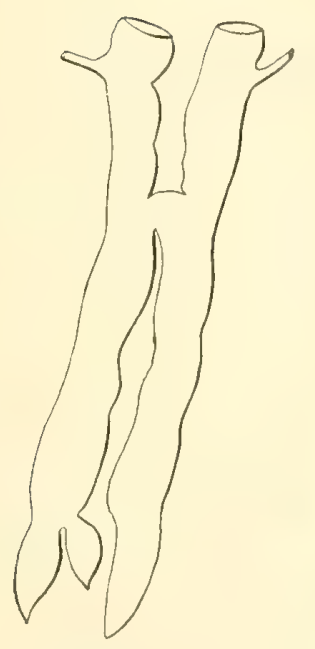

Fig. 164

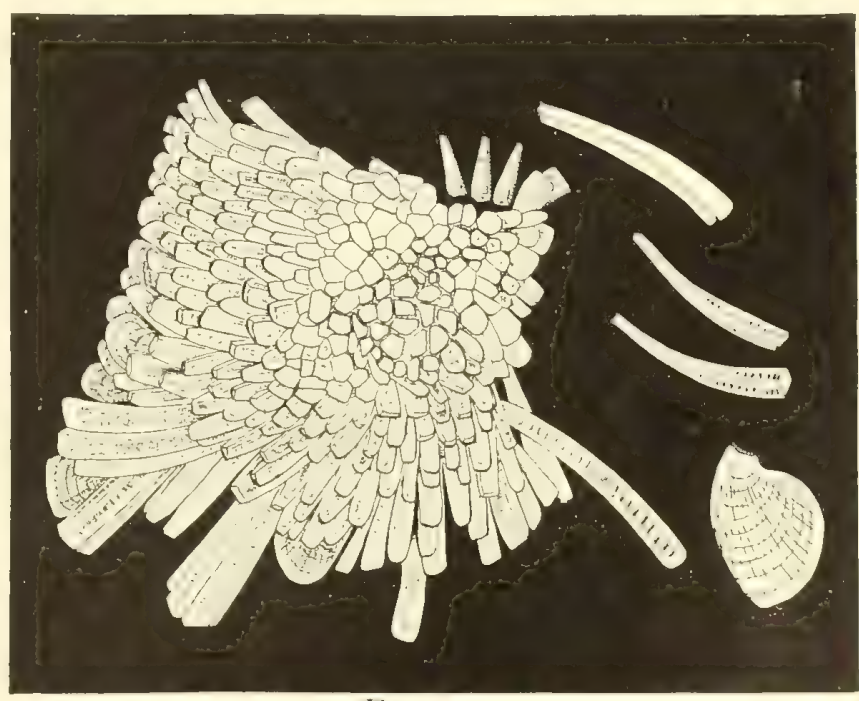

Fig. 165 

Fig. 166

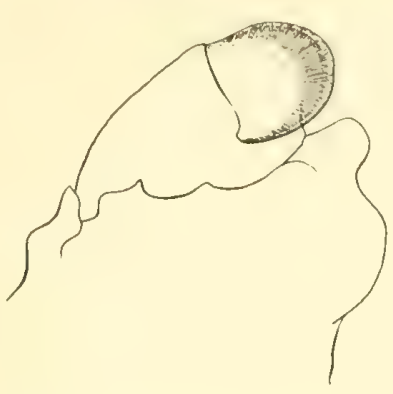

Fig. 167

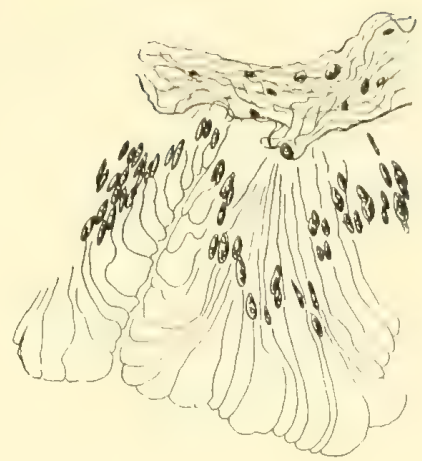

Fig. 168

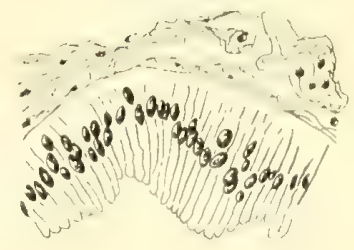

Fig. 169

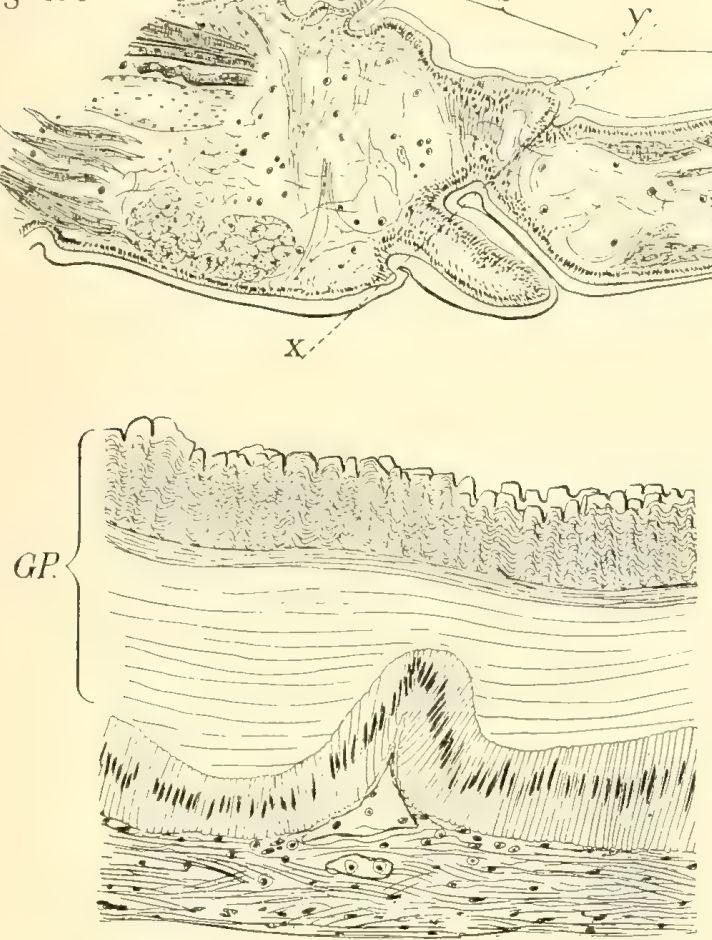

Fig. 171

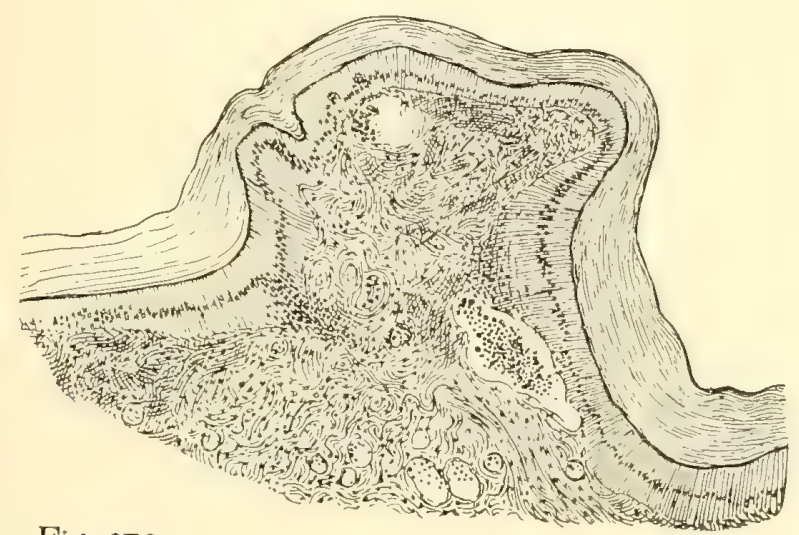

Fig. 173

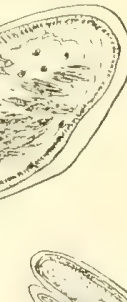

Fig. 170
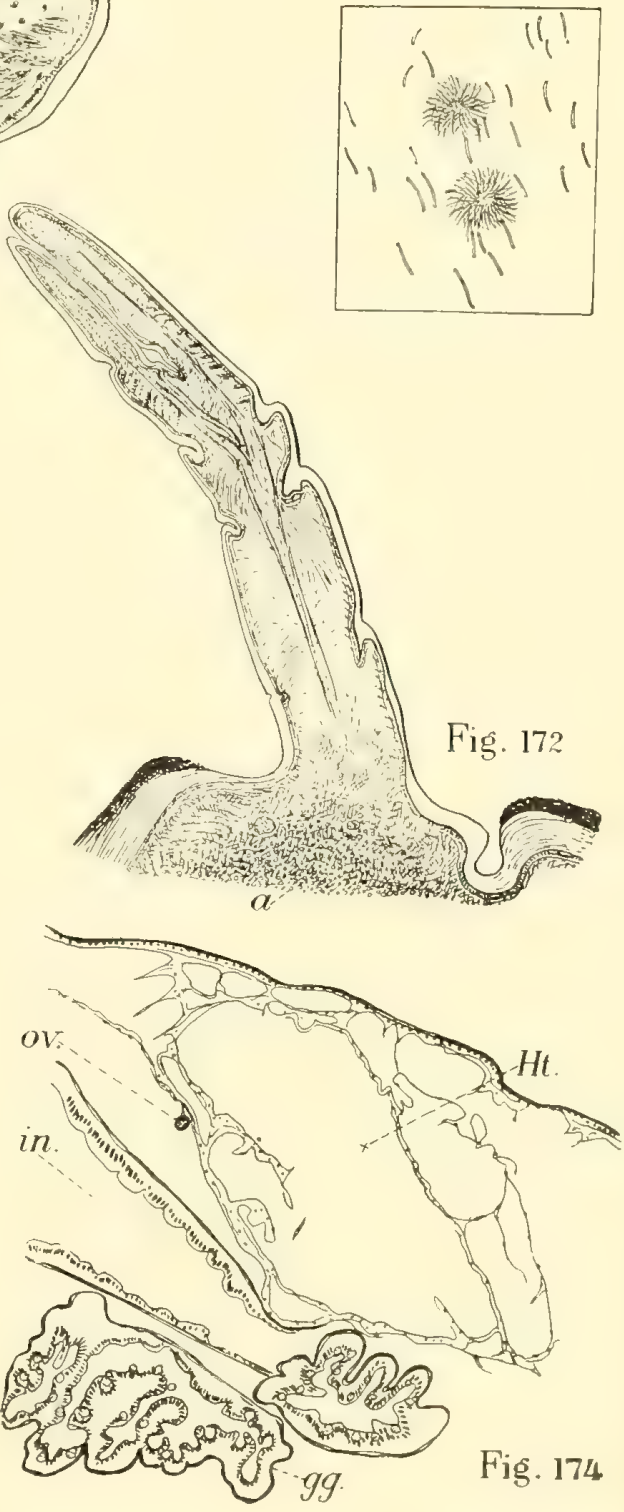

F. H. Herrick ad nat. det. 

Fig. 175

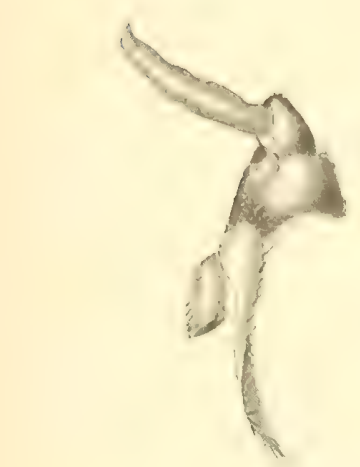

Fig. 176

Fig. 177
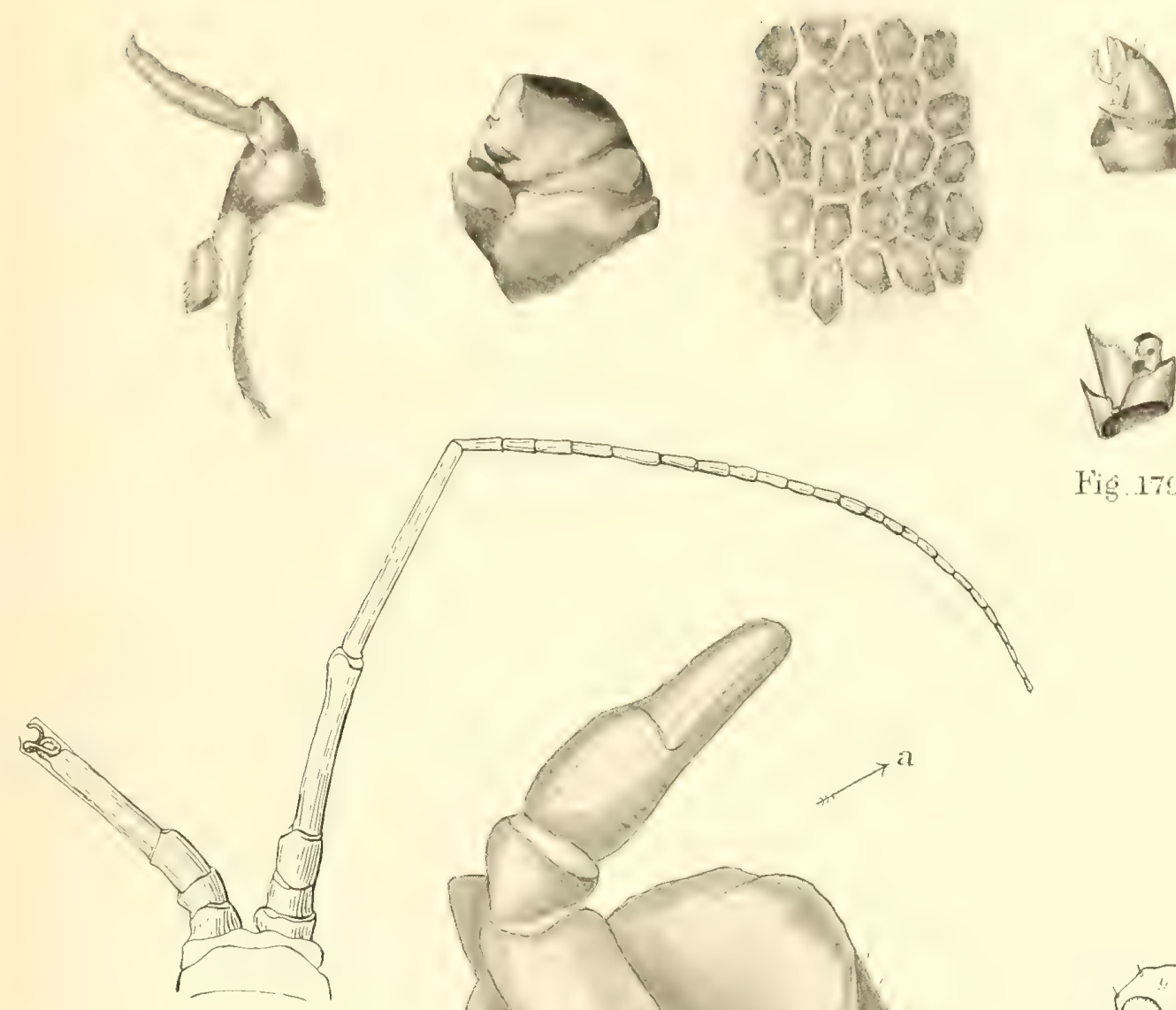

Fig. 180

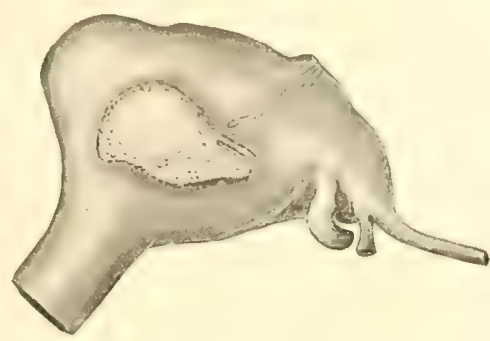

Fig. 183

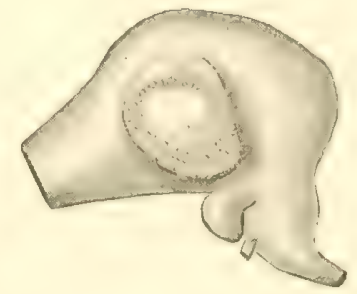

Fig. 184
Fig. 178

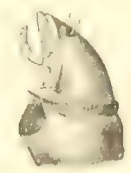

Fig 179

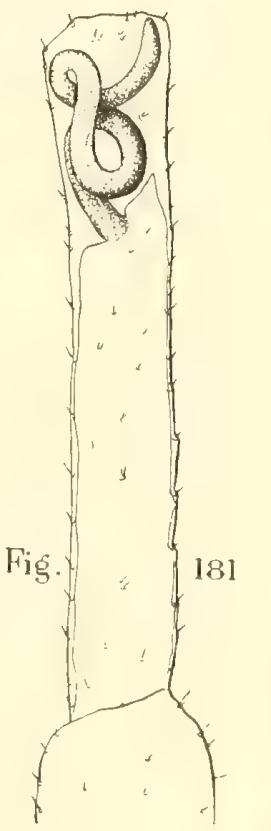

F. H. Herrick ad nat. del. 




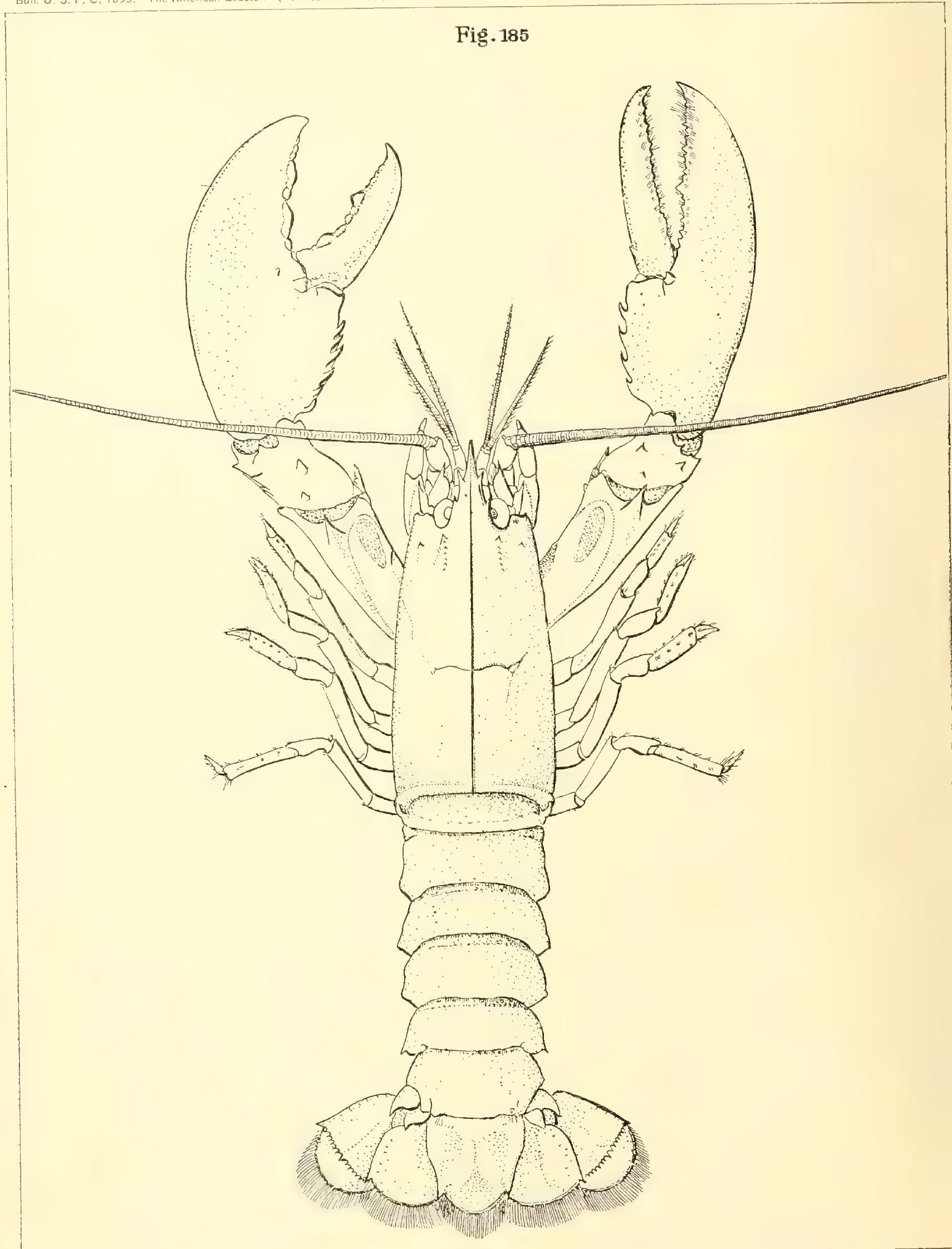

F. H. Herrick ad nat. del. 
Fiß. 186

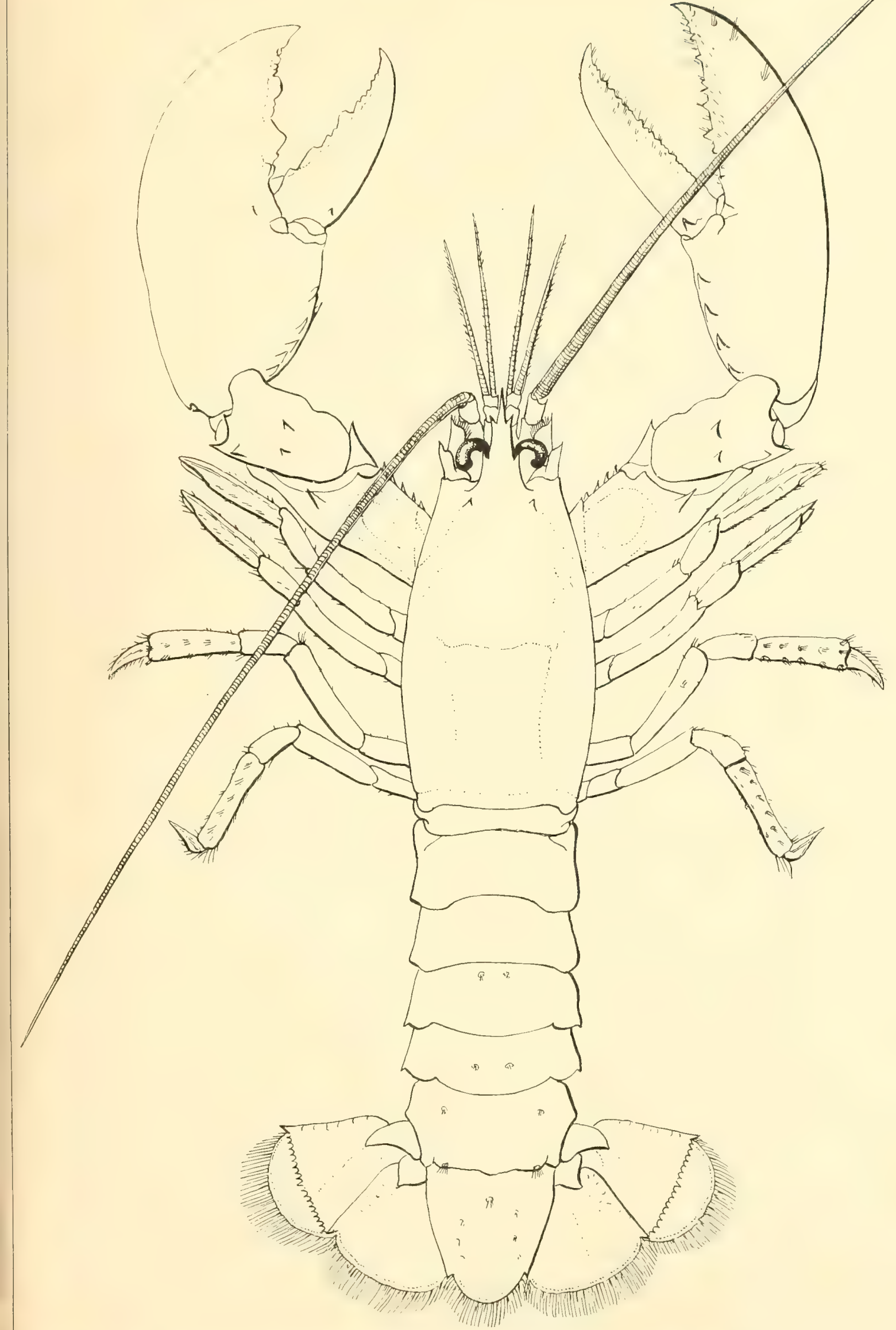

F. H. Herrick ad nat. del. 



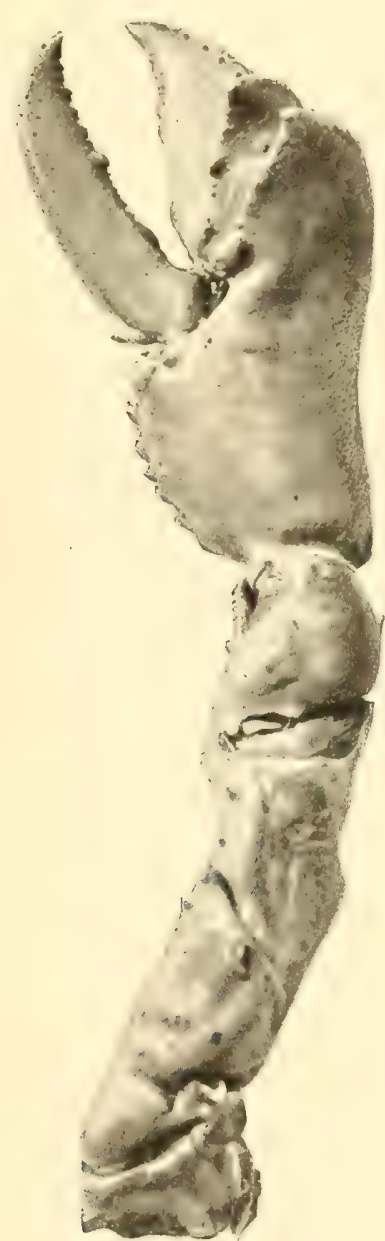

Fig. 187.

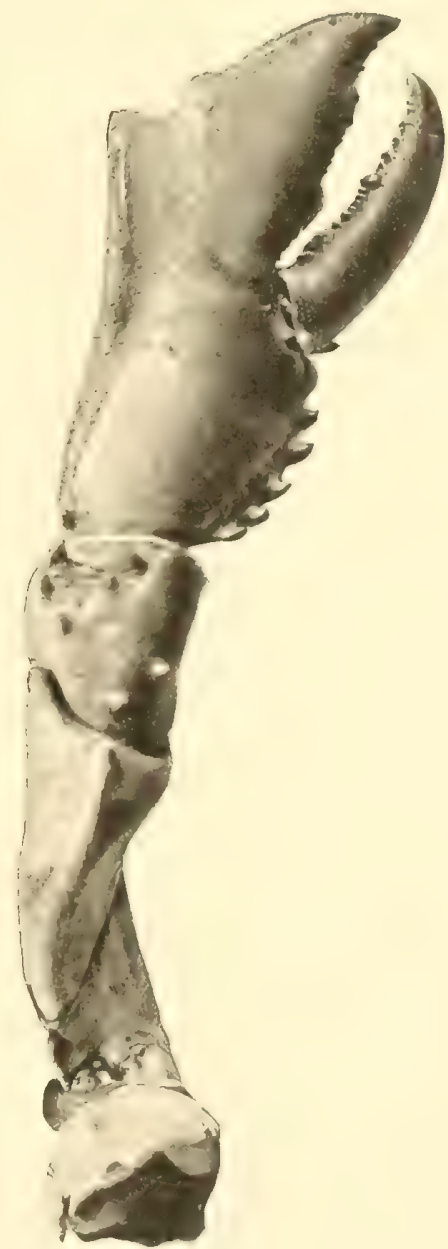

Fig. 188. 


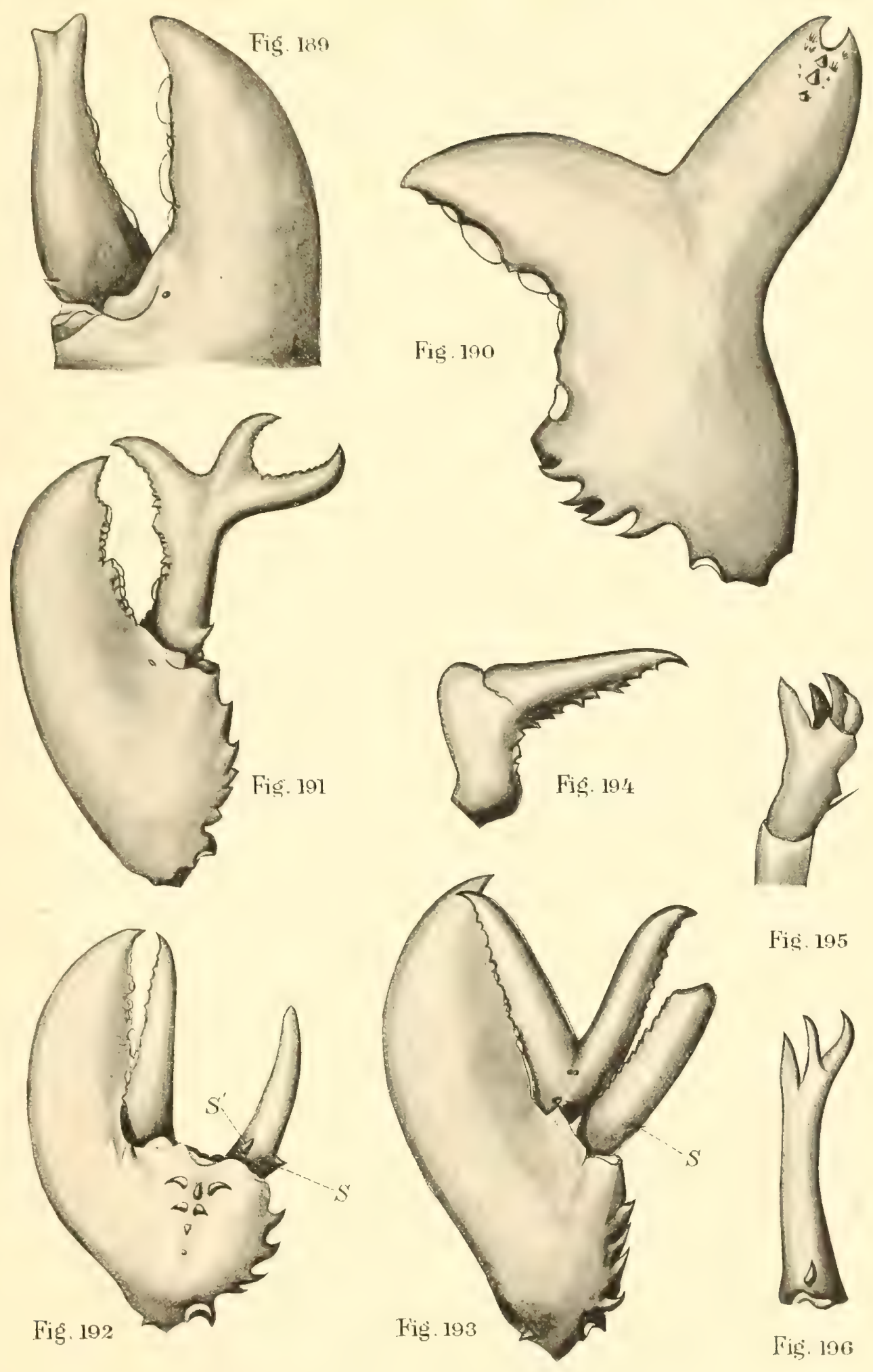


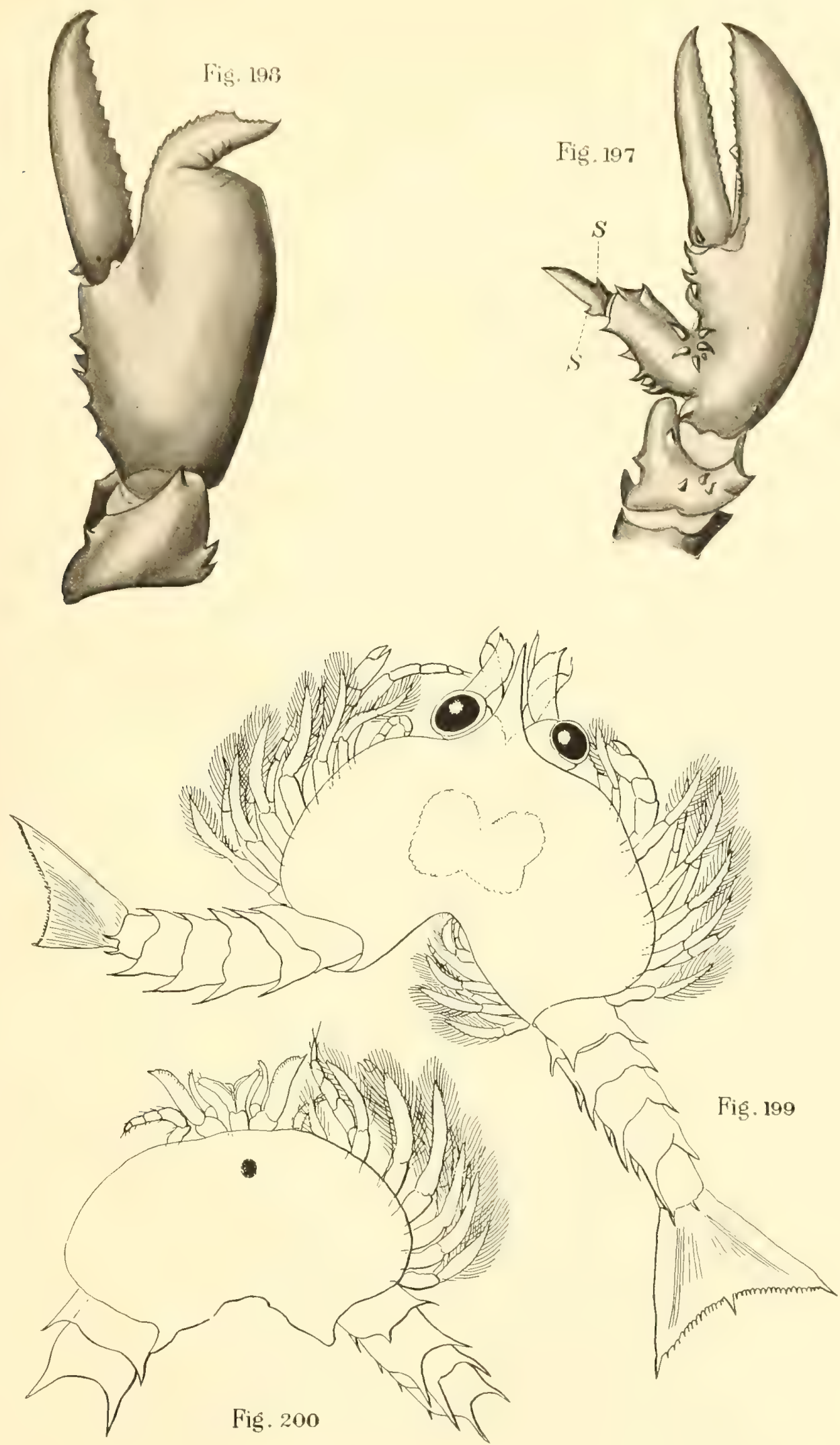

Fig. $201 \quad$ Fig. 202

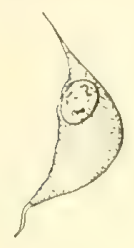

Fig. 206

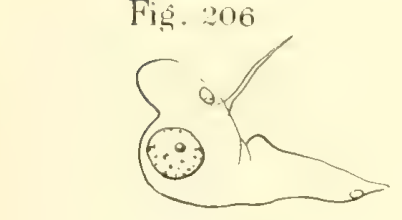

Fig. 207
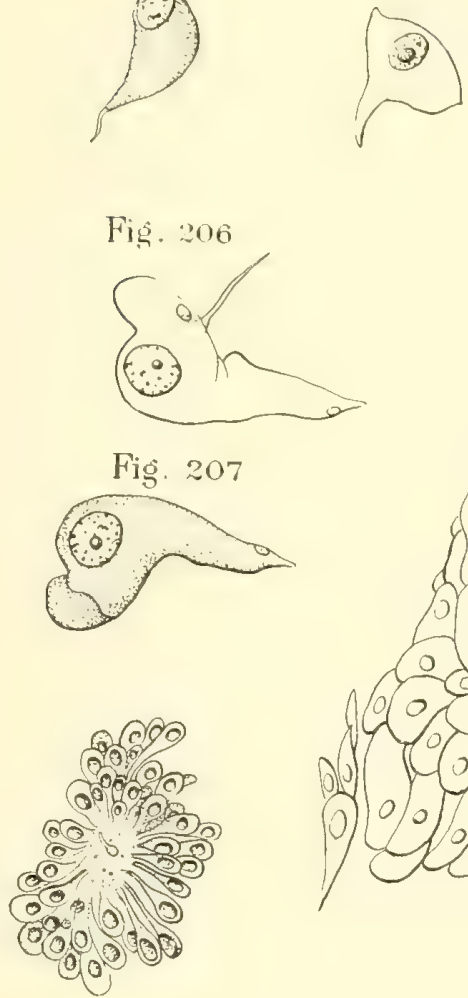

Fig. 208
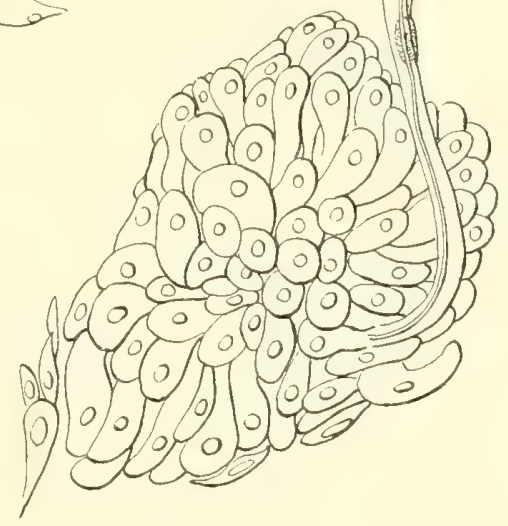

Fig. 210

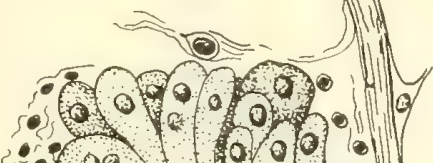

so 00

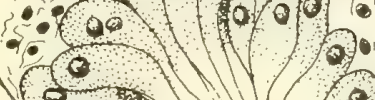

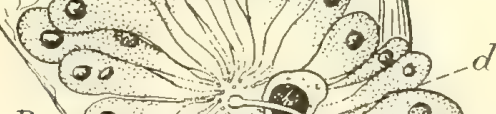

$R-(2-3)=0$
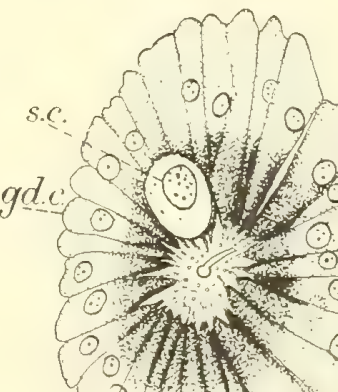

(1)

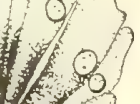

Fig. 203

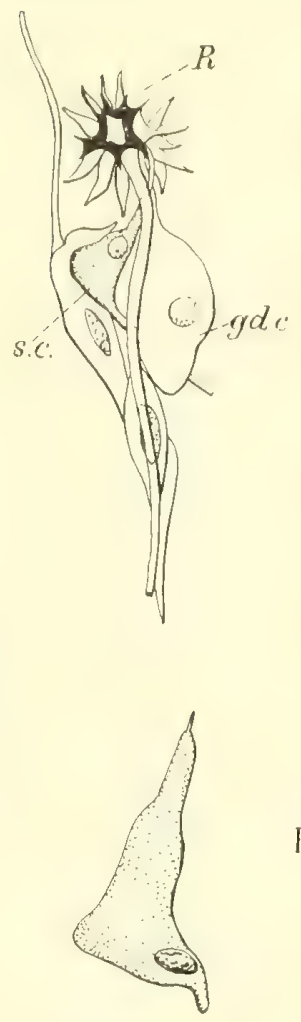

Fig. 204

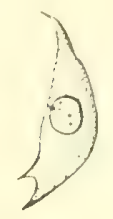

Fig. 209

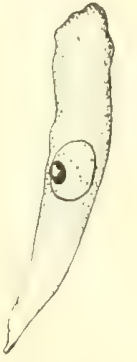

Fis. 205

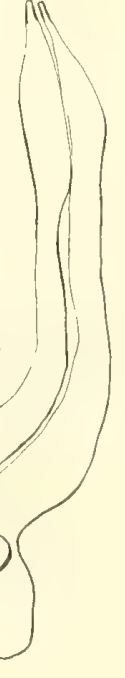

Fig. 211

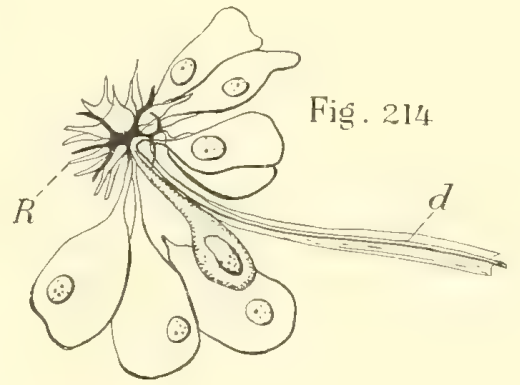





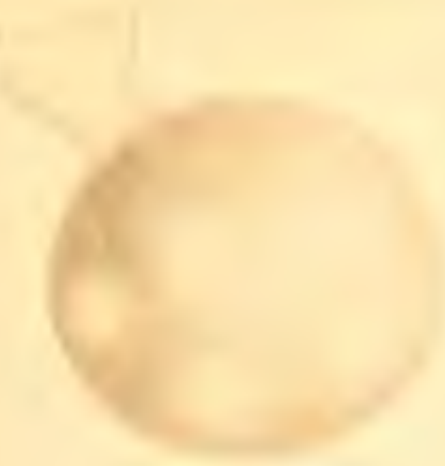

$14+19$

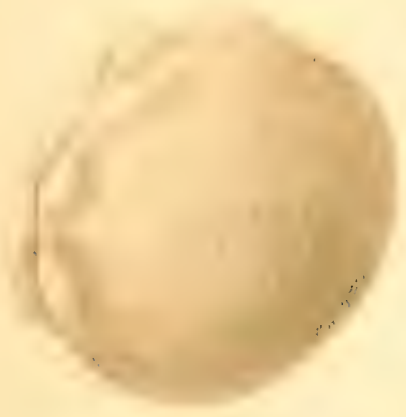

$\operatorname{lin}_{\mathrm{j}}, \cdots$

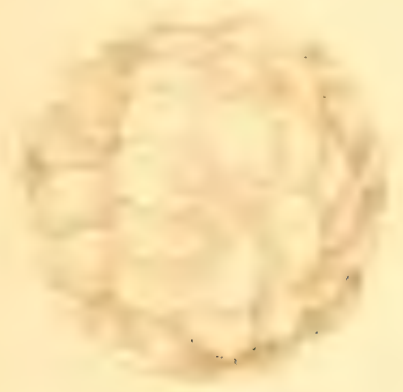

Hej 221

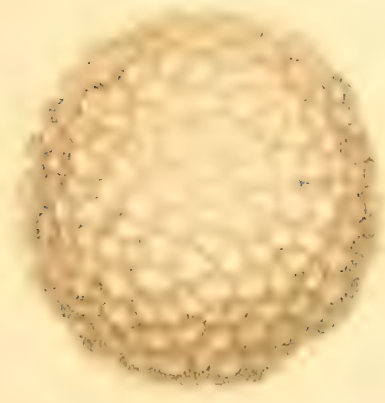

Fig. 224.

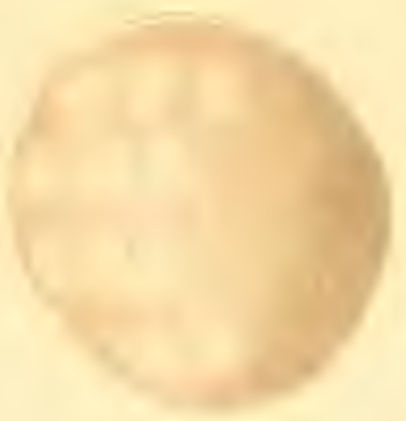

a.......

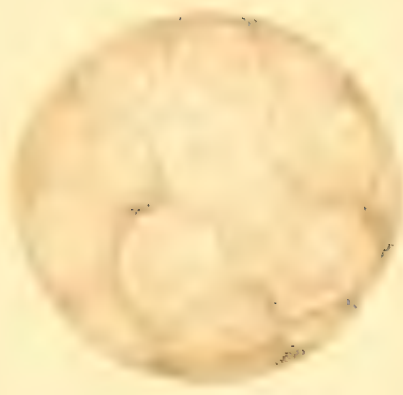

$\lim , \therefore$

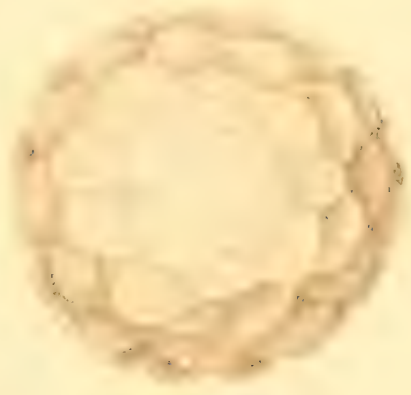

Iir. $\therefore 2$

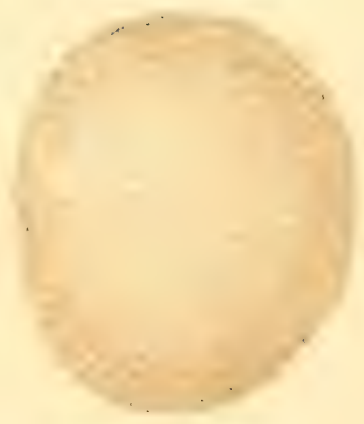

Fia. 225.

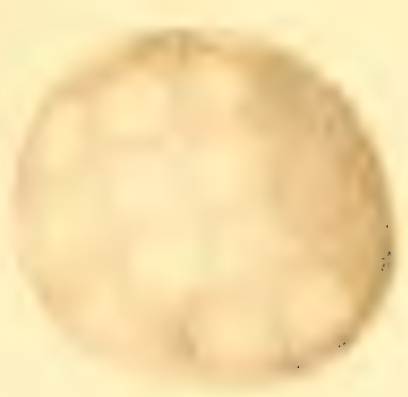

$11, \ldots$

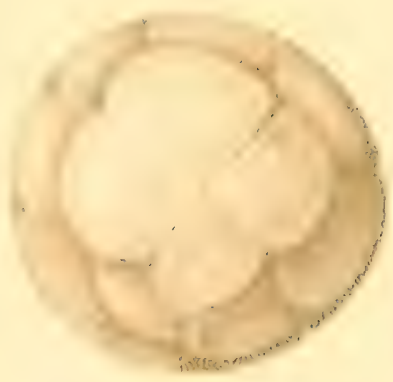

in: $\ldots$...

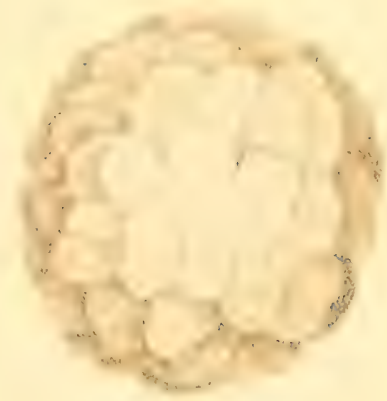

I: $\quad \cdots$

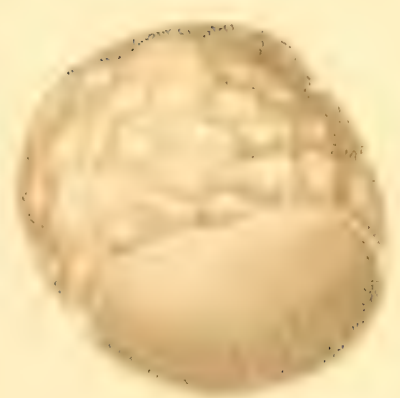

lig. 226 


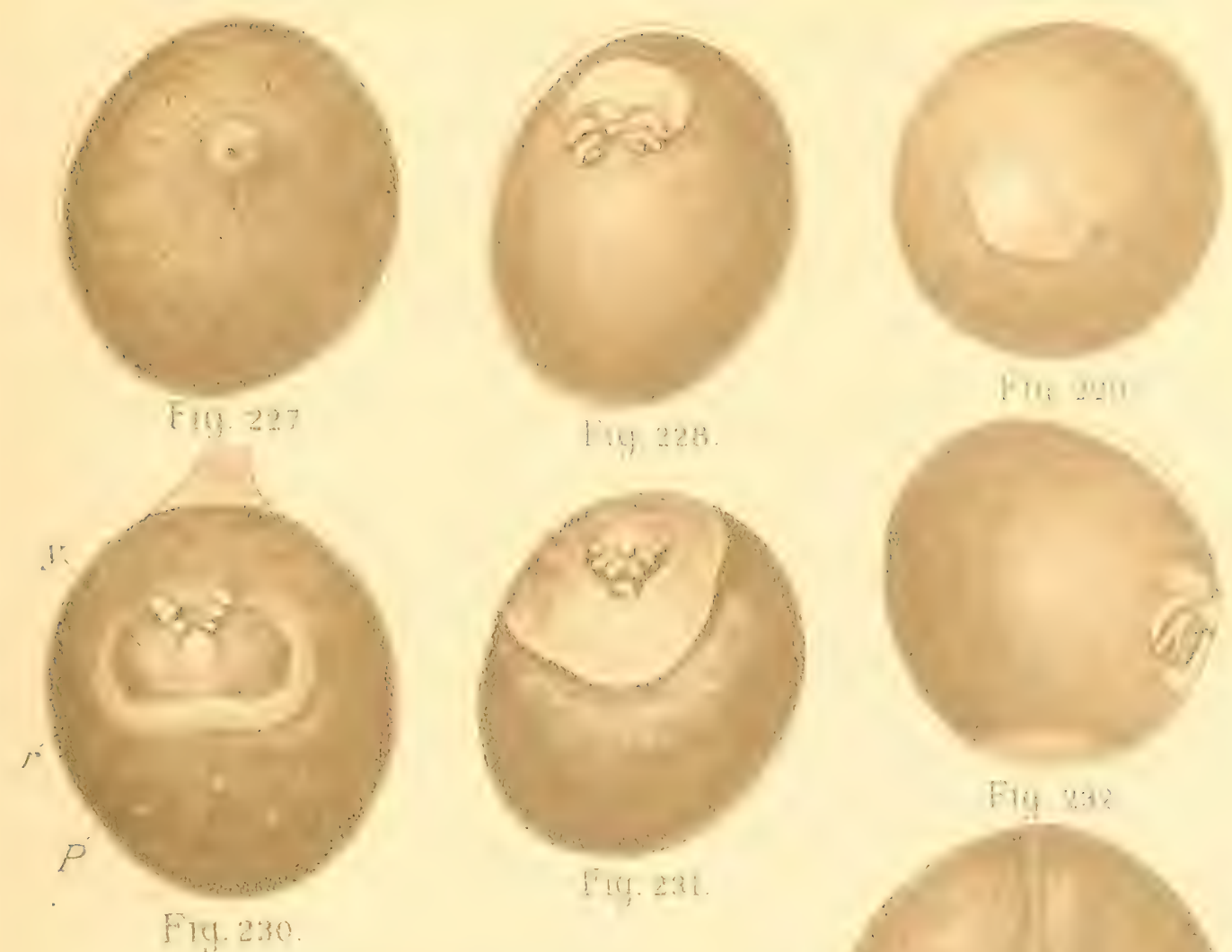

P11: $\cdots .11$

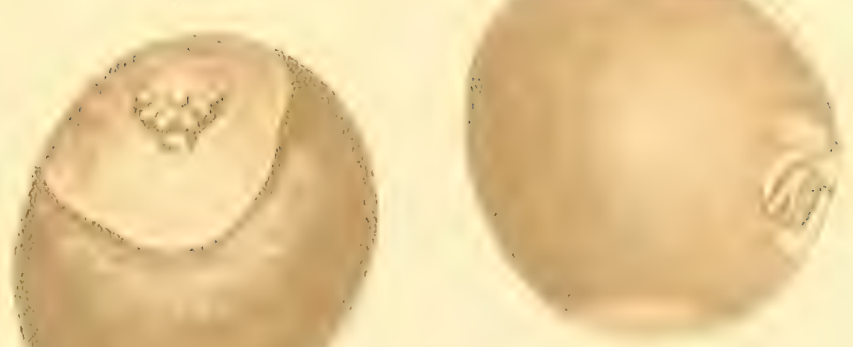

Fig 8:1:
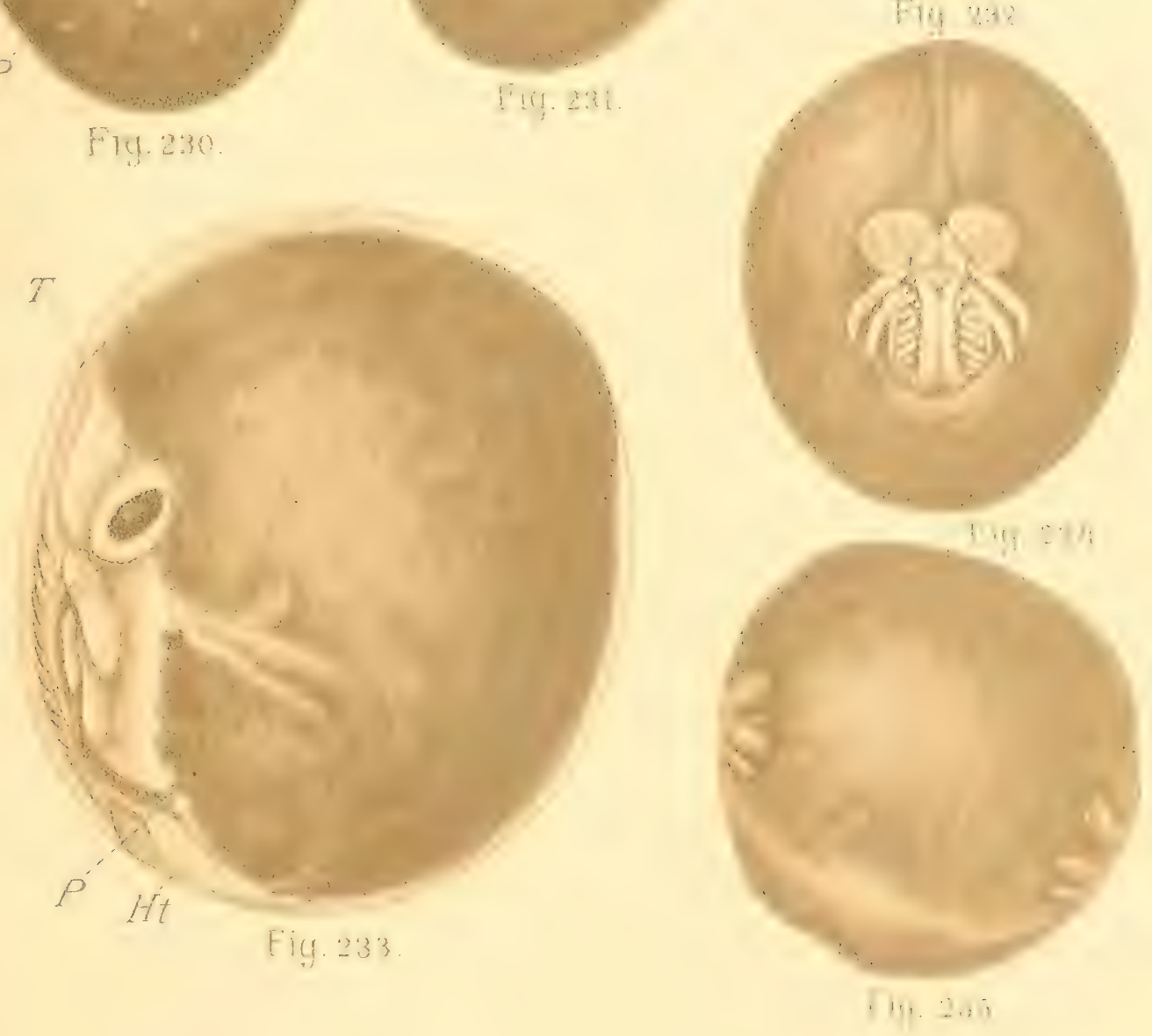


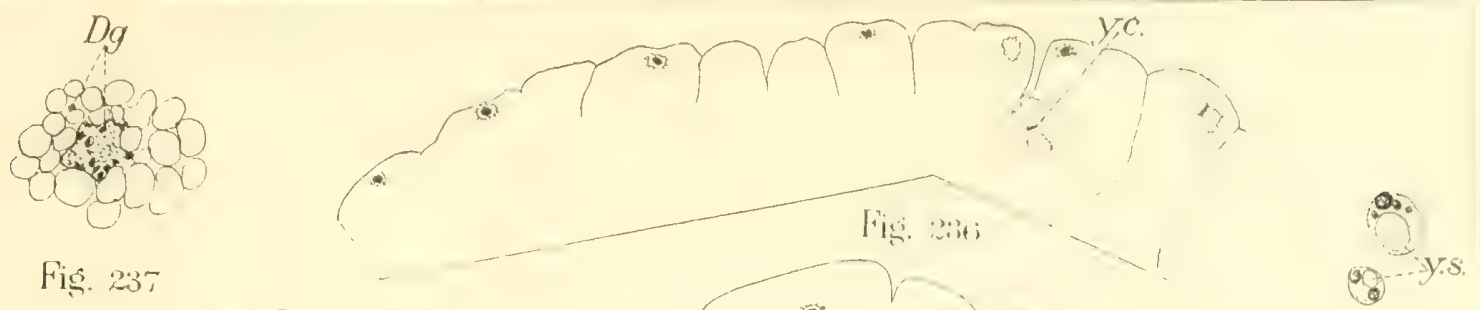

Fis. 237

Fig. 238
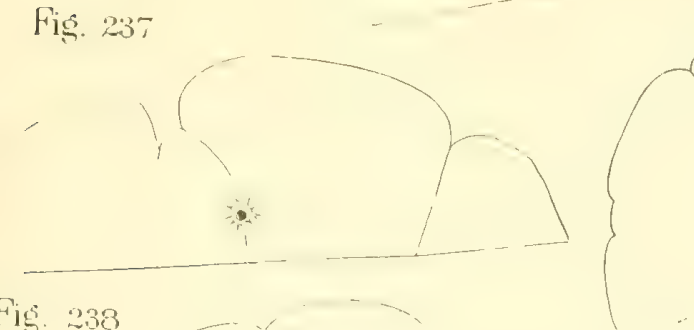

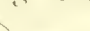

Fig. 240

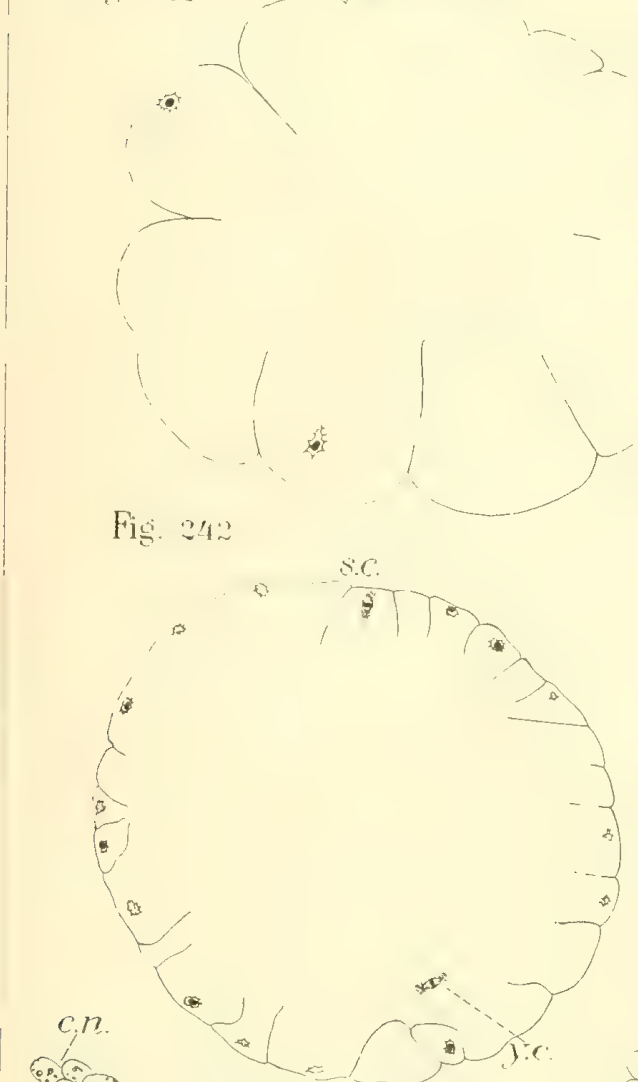

iिi-200000 Fig. 24:

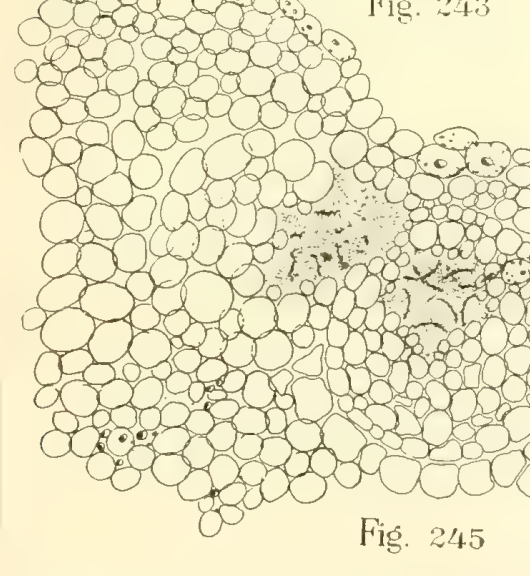

Fig. 245

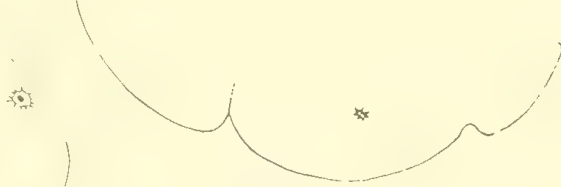

Fis. :30

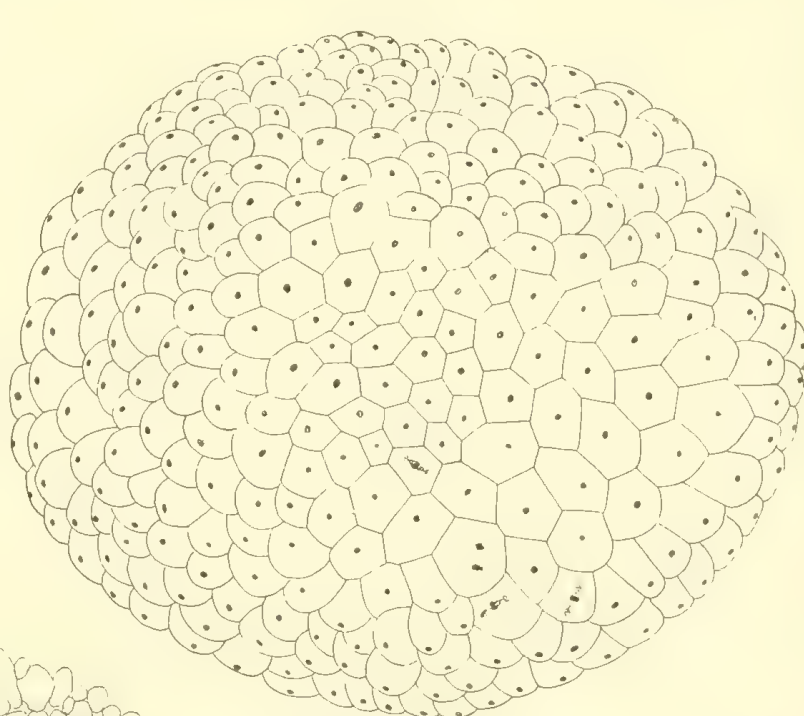

Fig. ':'t'

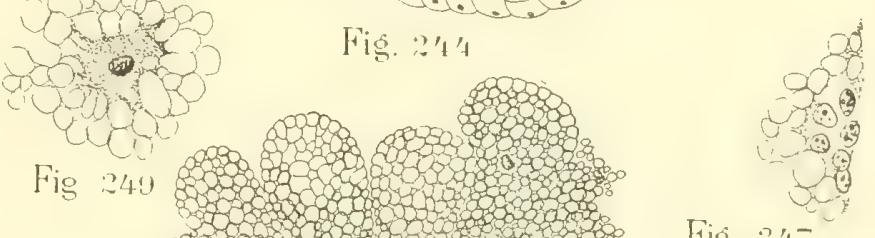

Fig 249

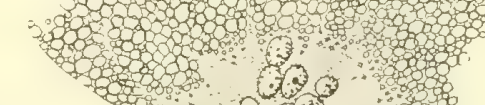

Fijg. 297

\section{(5)}

Fis. 248

F. H. Herrick ad nat. del. 



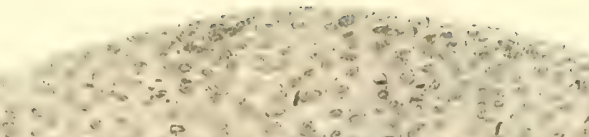

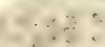

$=\ldots$

\section{$\therefore \ldots$}

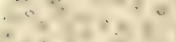

is 3

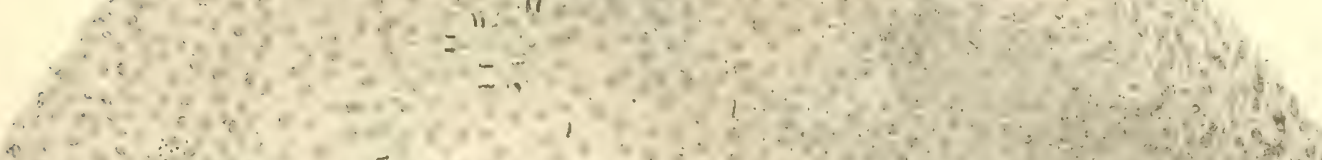

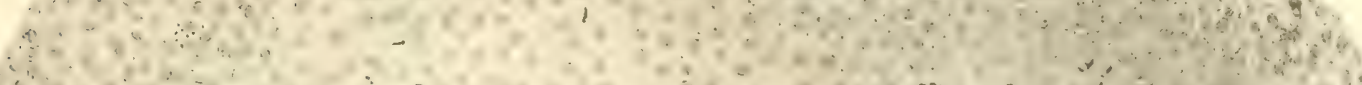

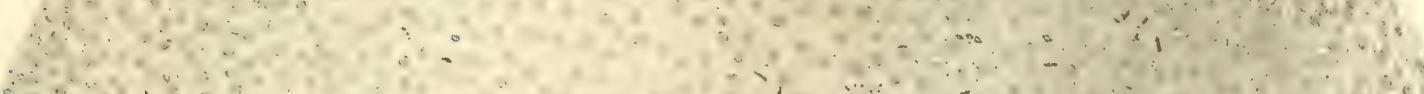

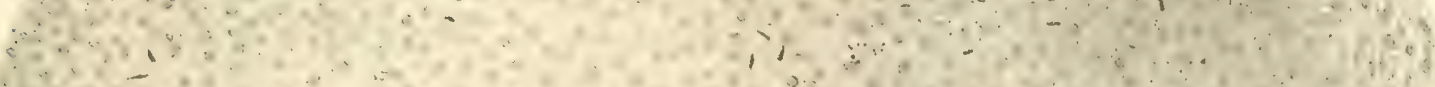

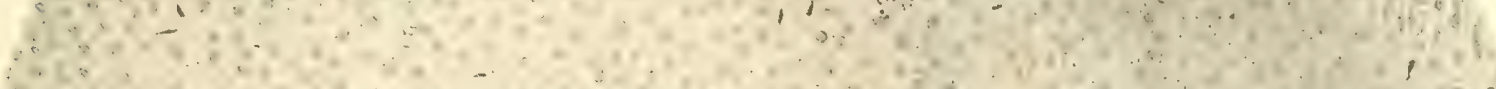

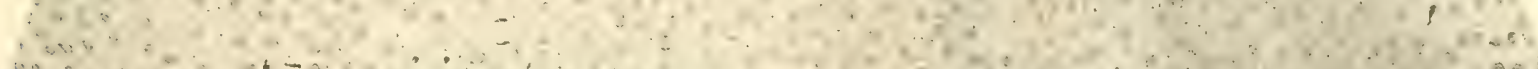

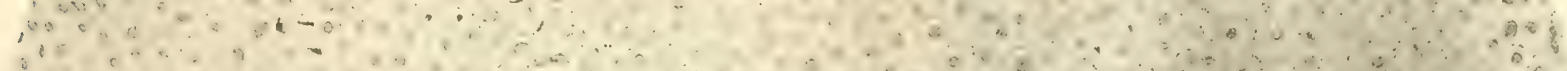

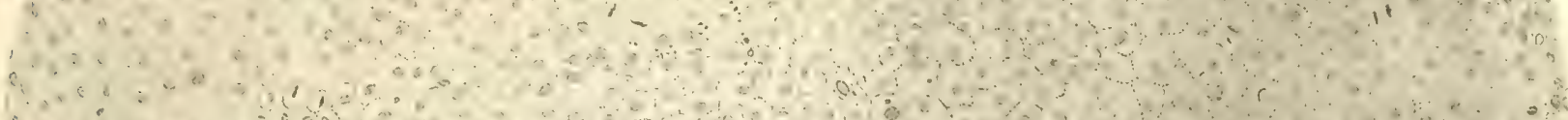
$40^{6}$ o o

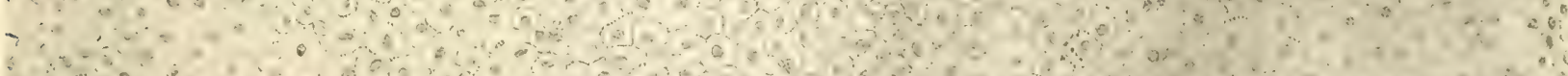

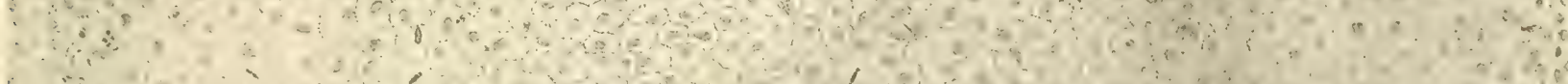
a

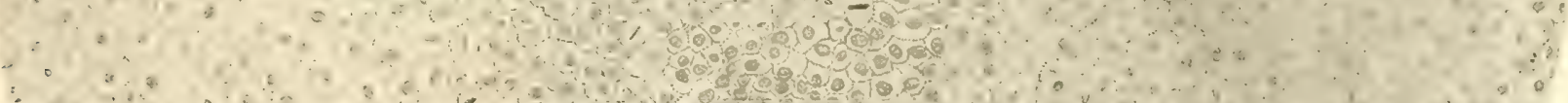

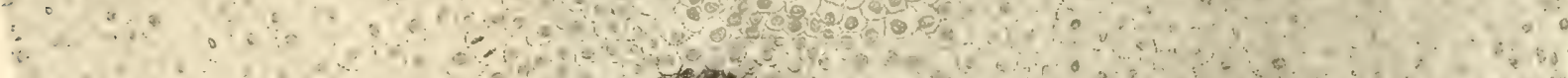

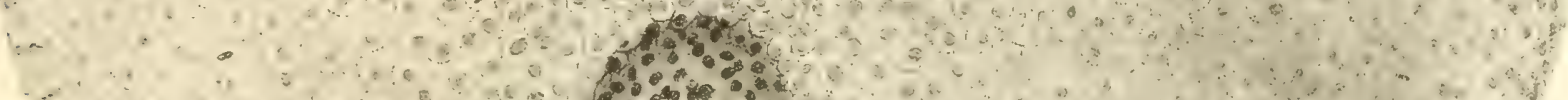

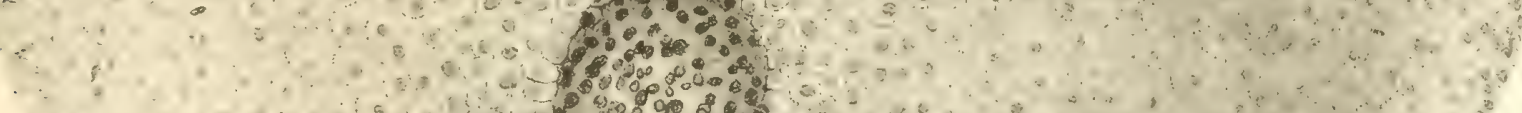

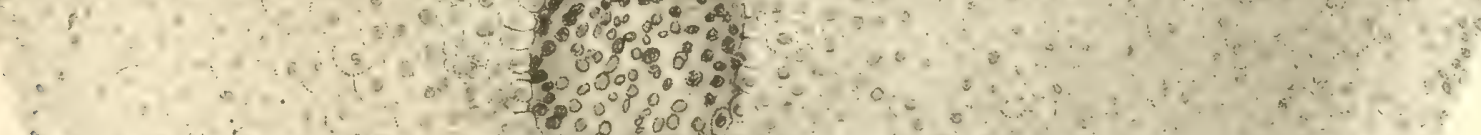

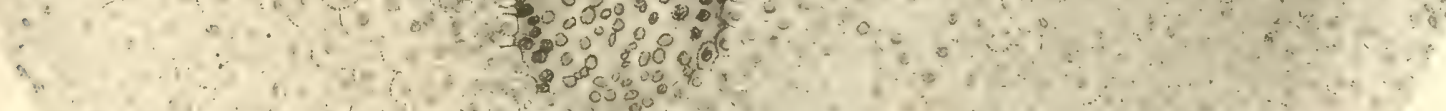

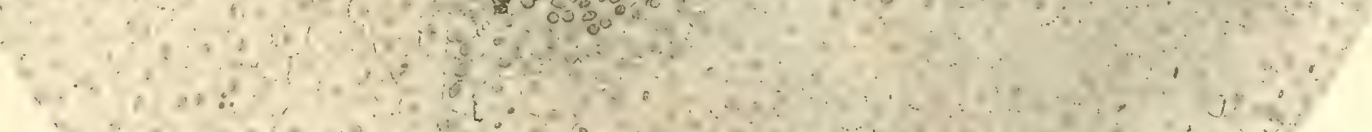

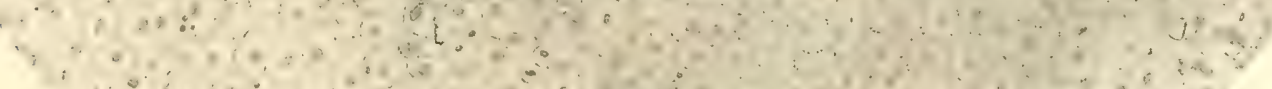

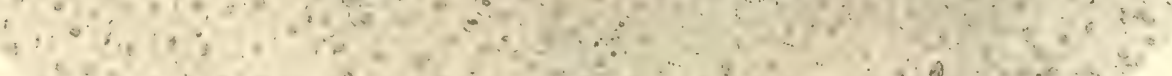

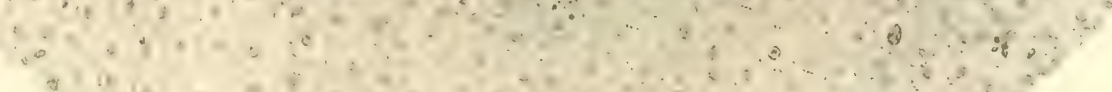

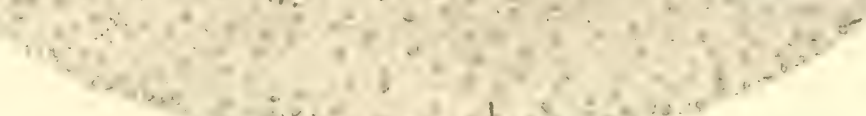

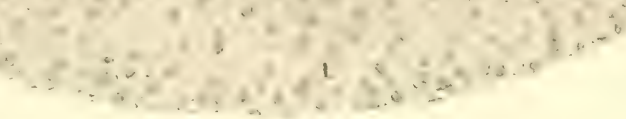

\section{Fig. 250}

F. H. Herrick ad nat, det. 



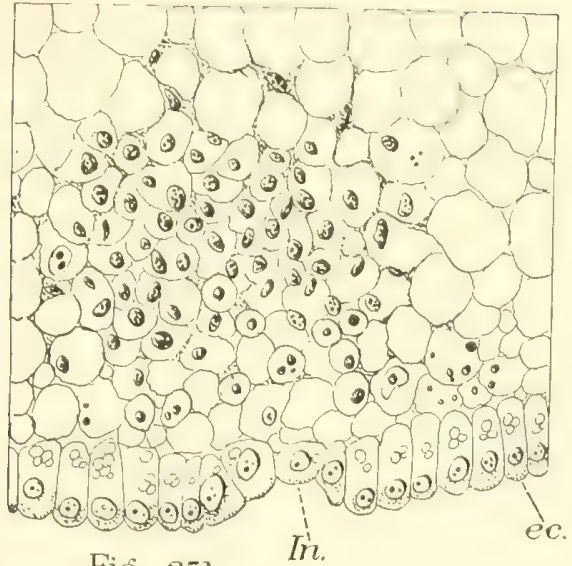

Fis. 251

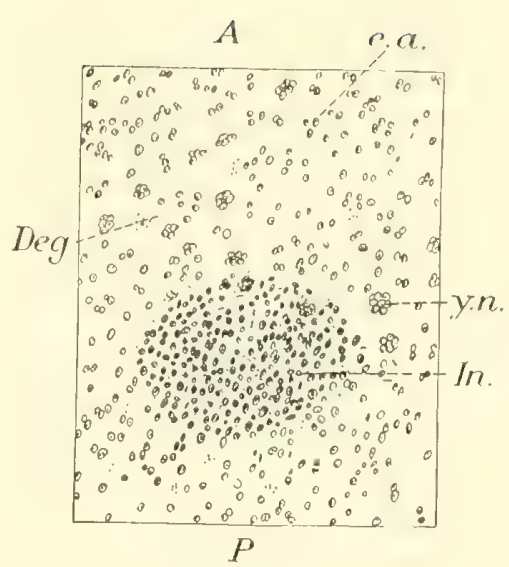

Fig. 25:
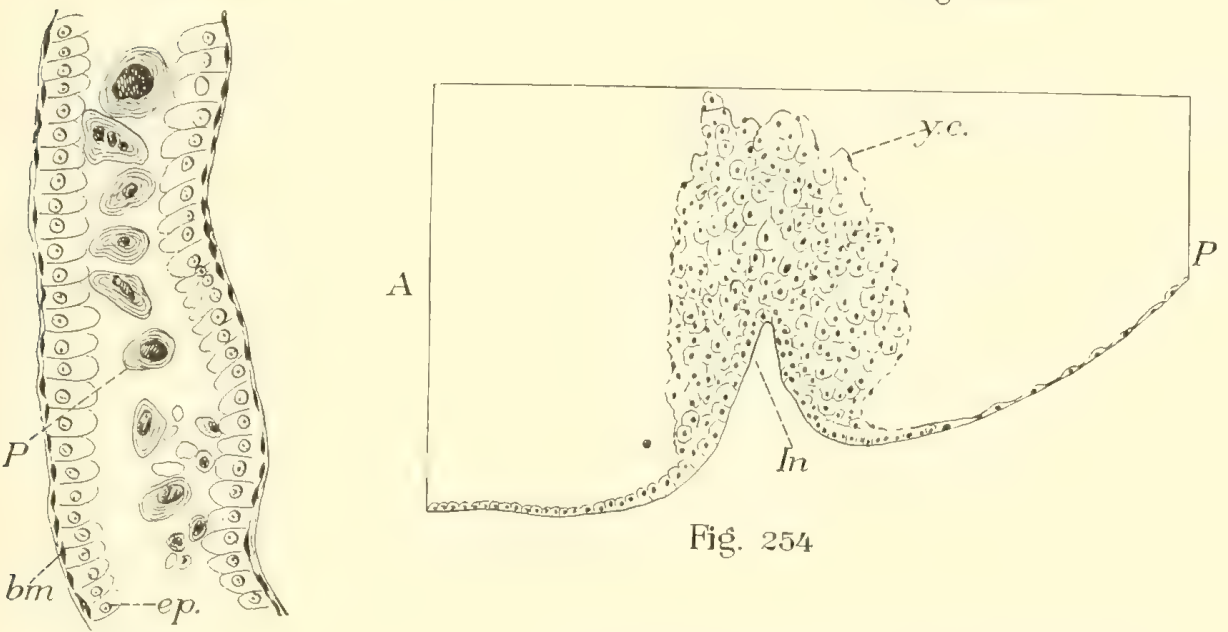

Fig. 254

Fig. 253

A

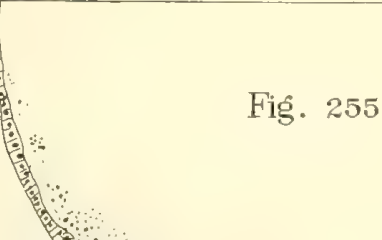

F. H. Herrick ad nat. det. 


$$
\beta^{6 .} 2^{30^{3 *}}
$$







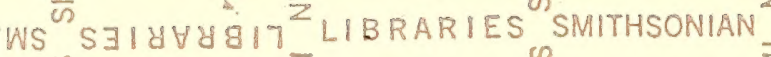
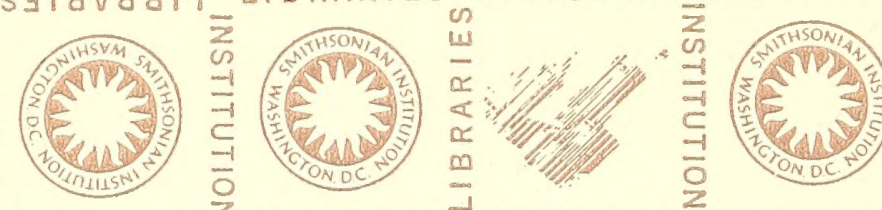

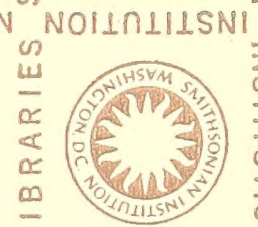
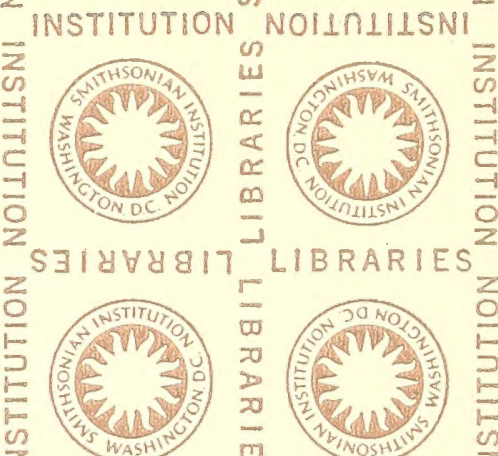

Z

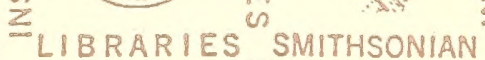

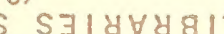

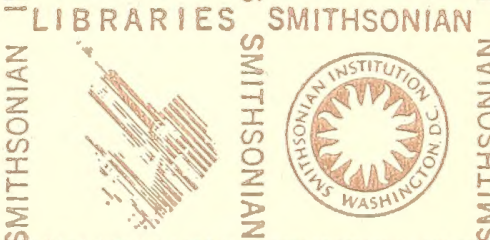

$\sum_{\text {NOILIIISNI }}$

INSTITUTION
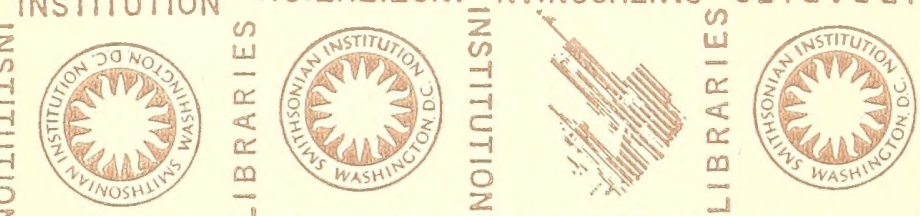

LIBRARIES SMITHSONIAN
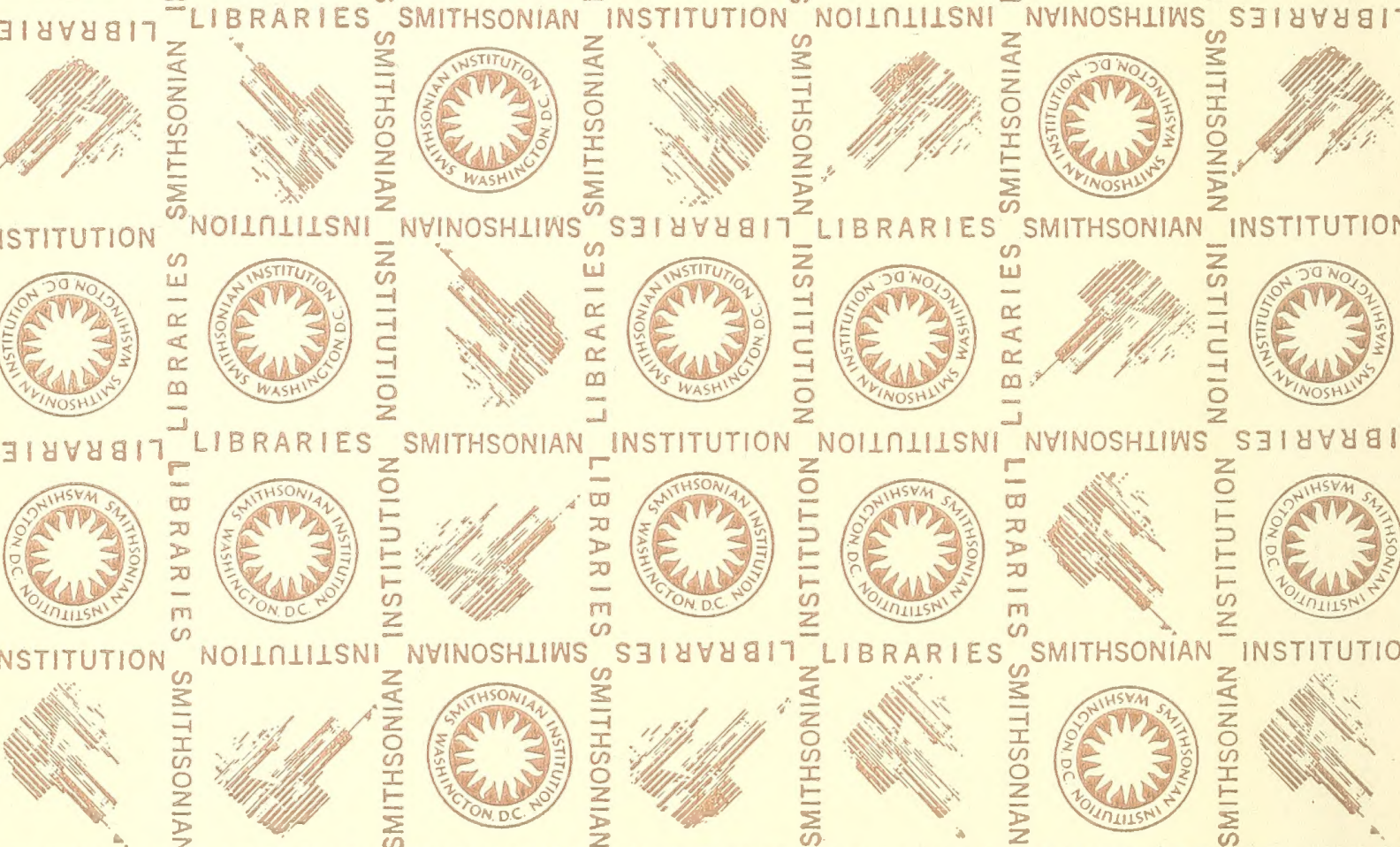

NYINOSHIIWS
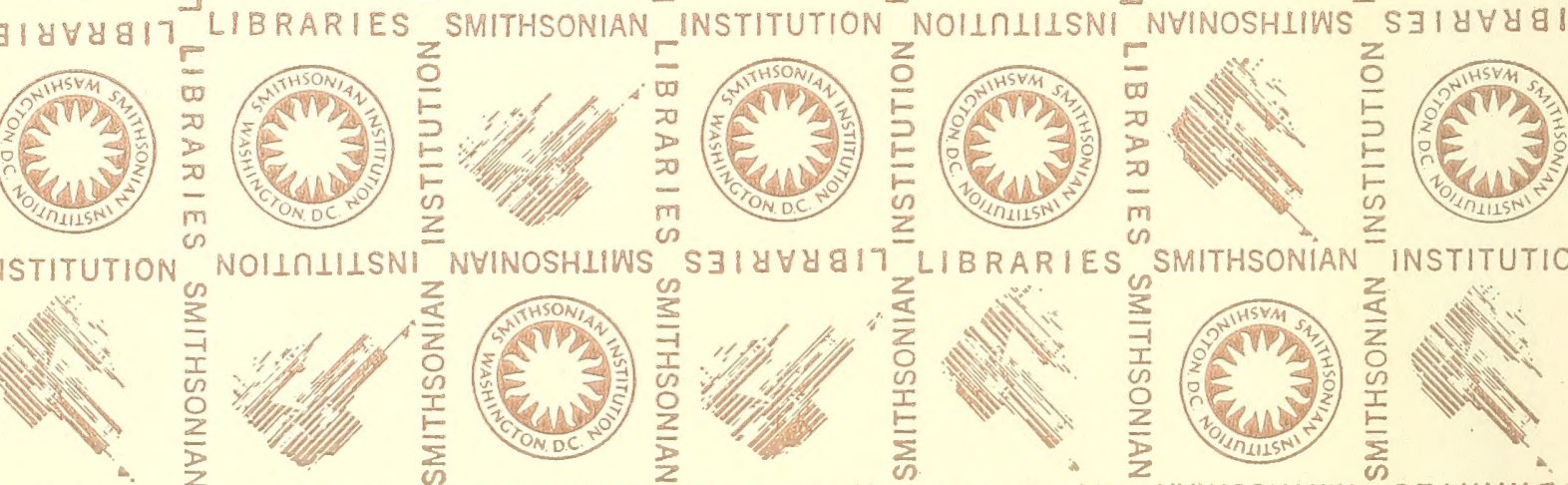

$5714 \forall 4817$
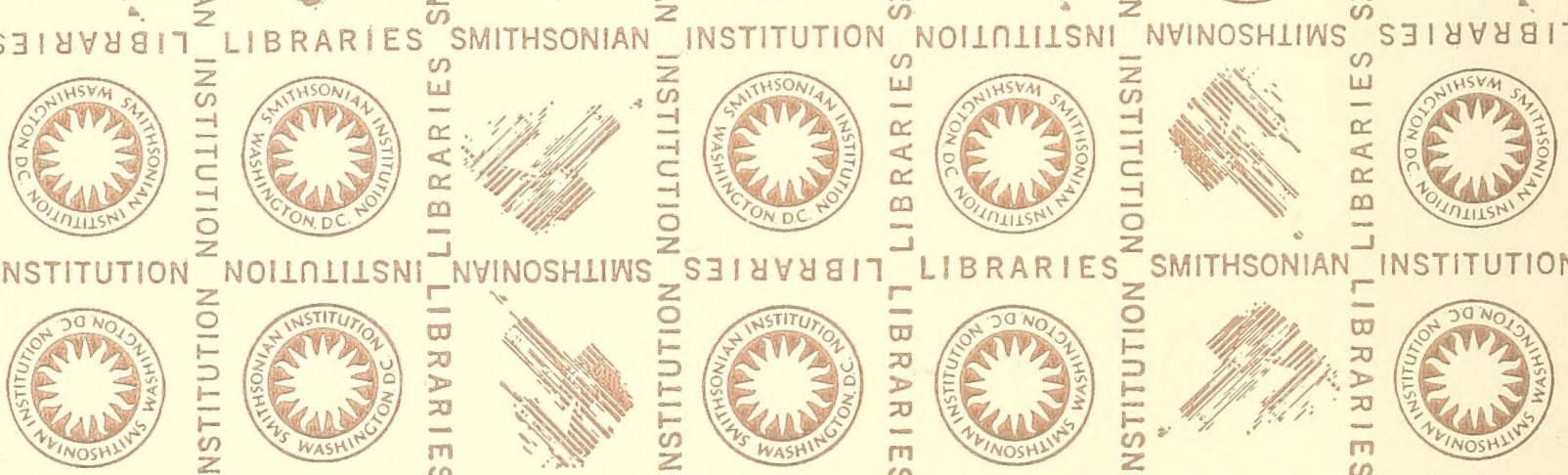

(1)

- Listaries

SMITHSONIAN

ASTITUTION NOIINIIISNI
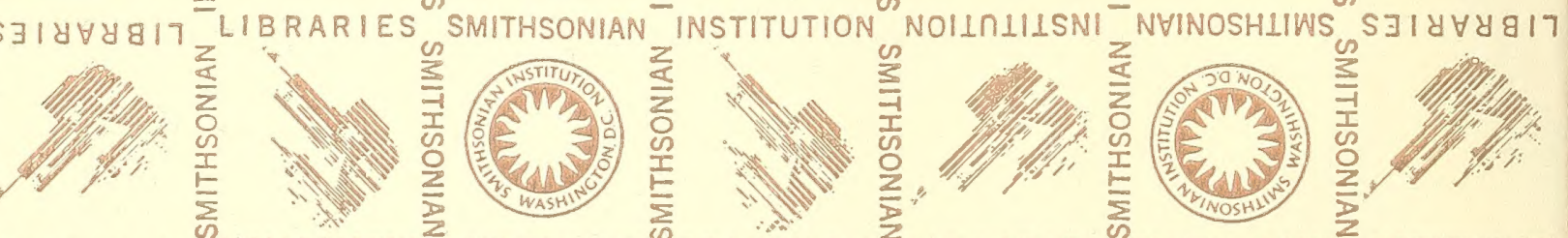

inSTITUTION

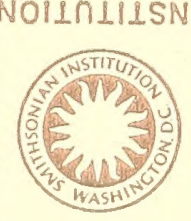

$\overline{2}$
$\frac{1}{1}$
-1
$\frac{1}{0}$
$\frac{1}{2}$
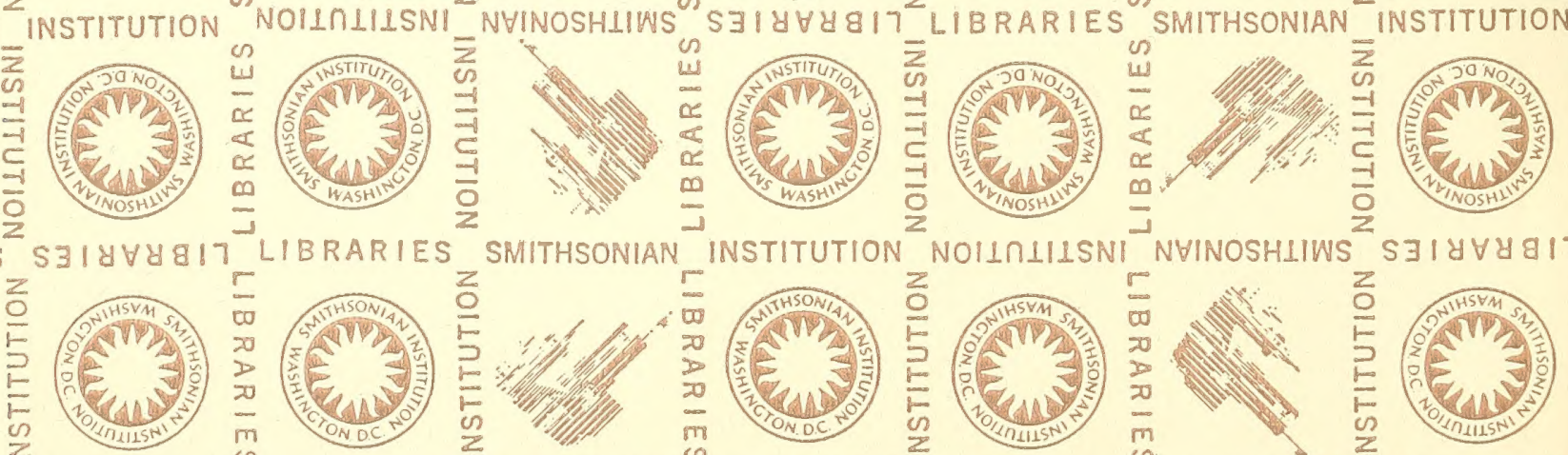

NOILIIISNI NBINOSHIIWS

S318Y8G17 LIBRARIES SMITHSONIAN INSTITUTION 
